Tesis Doctoral.

\title{
Análisis y catalogación de la obra de Carles Santos.
}

\author{
Autor: Joaquín Ortells Agramunt
}

Director: Dr. Antoni Ripollés Mansilla

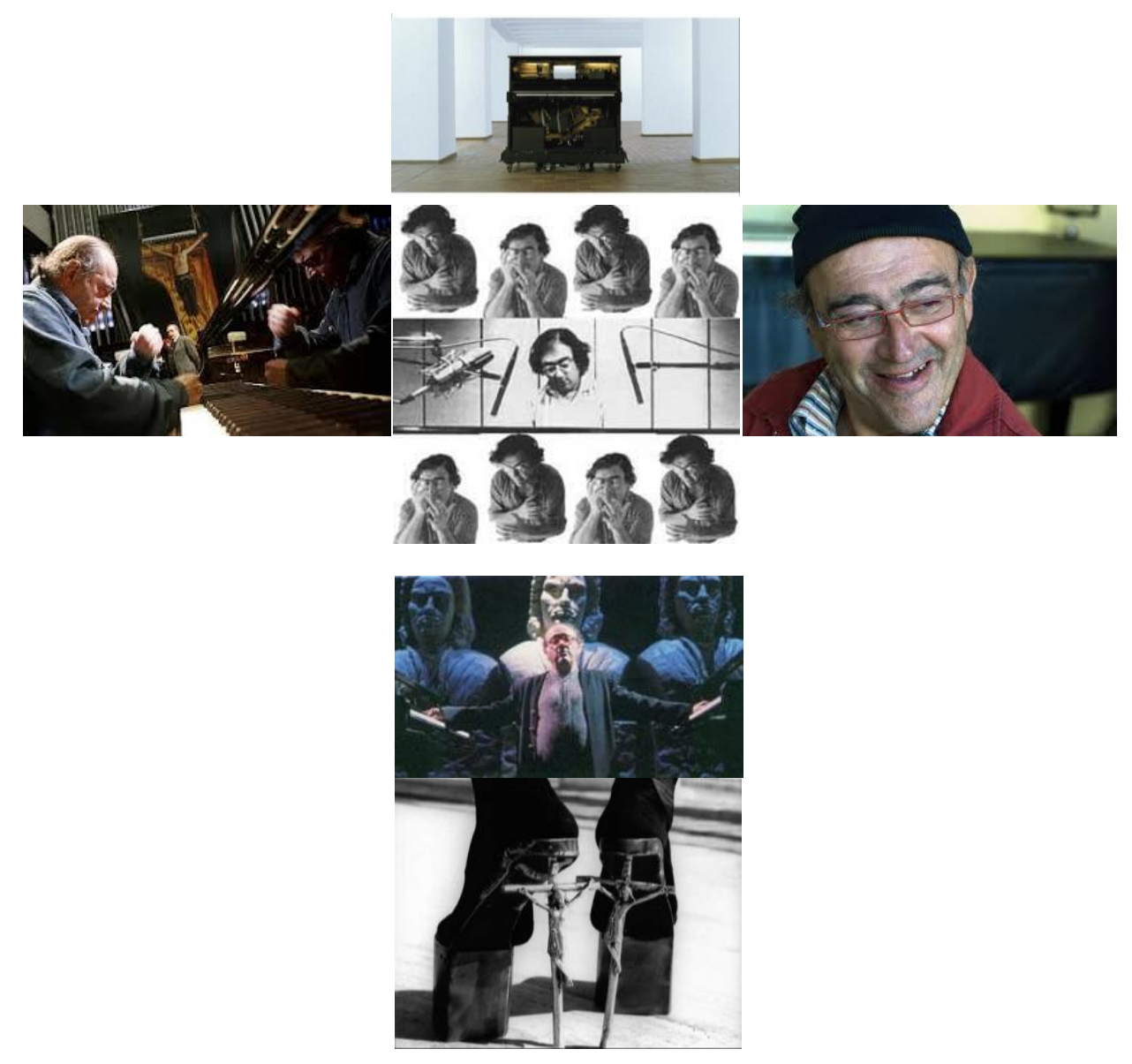

Castellón, julio - 2015

Universitat Jaume I

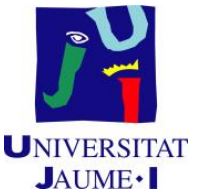



Tesis Doctoral.

\section{Análisis y catalogación de la obra de Carles Santos.}

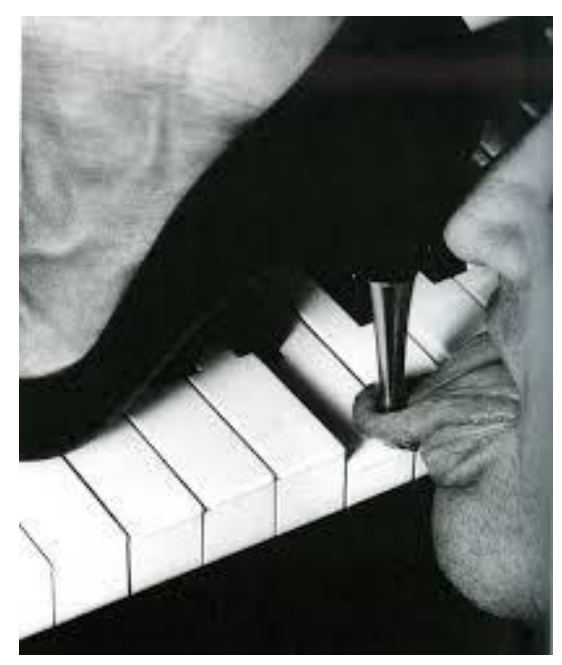

Autor: Joaquín Ortells Agramunt.

Director: Dr. Antoni Ripollés Mansilla.

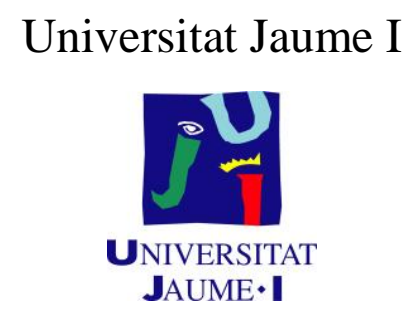



A Mari, Carmen y Quim. 



\section{Agradecimientos:}

Para comenzar este trabajo desearía escribir unas palabras de agradecimiento a las personas que me han ayudado a realizarlo. Sin su paciencia, dedicación o consejos, hubiese sido imposible llevar a termino lo aquí expuesto. Sin duda olvidaré a alguien. Ruego no lo tengan a mal.

A mi mujer Mari y mis hijos Carmen y Quim. Al Dr Toni Ripollés. A Nati Romeu. A Carles Santos.

A mis hermanas, Rosa y Elisa y a sus familias por la inestimable ayuda que me han brindado.

A todos aquellos amigos que me han apoyado y animado a seguir.

Y a mis padres, que siempre me inculcaron el amor al esfuerzo y al trabajo bien hecho y me apoyaron en este agradable camino que es la música. 



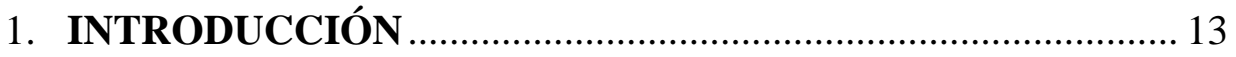

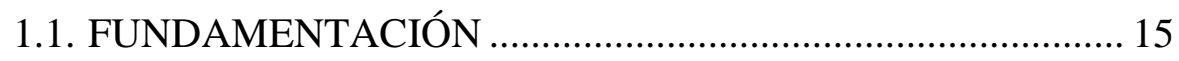

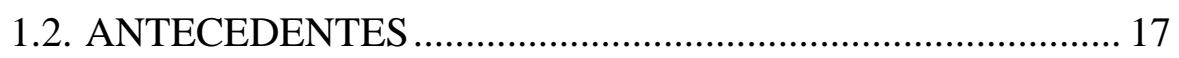

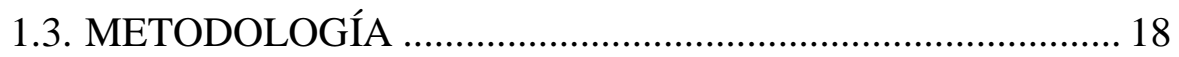

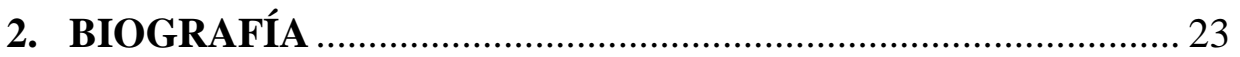

2.1. INFANCIA Y ADOLESCENCIA (1940-1954) ........................ 25

2.2. PARÍS Y SUIZA (1954-1958) …………………………....... 26

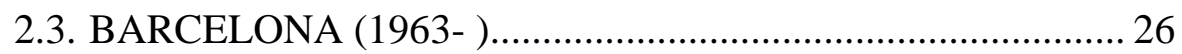

2.4. NUEVA YORK (1968-1981)...................................................... 30

2.5. RECONOCIMIENTOS Y PREMIOS …………………........... 30

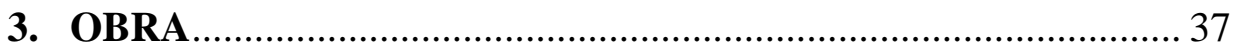

3.1. ANÁLISIS DE LA OBRA............................................................ 39

3.1.1. Estructuras y fraseo ...................................................... 42

3.1.2. Armonía ……………………………………….......... 43

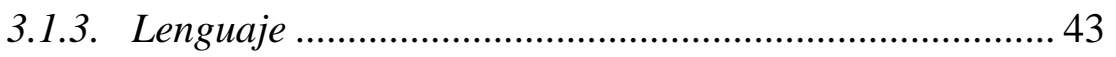

3.1.3.1.Experimento pedagógico ............................................ 44

3.1.3.2.Estudio interpretativo ……………………………..... 49

a.- Claves ................................................................. 52

b.- Medida................................................................ 52

c.- Compás................................................................ 53

d.- Dinámica ………………………………………. 53

e.- Agógica ………………………………………..... 54

f.- Signos de repetición ................................................. 56

g.- Alteraciones.......................................................... 58

h.- Improvisaciones ……………………………….... 59

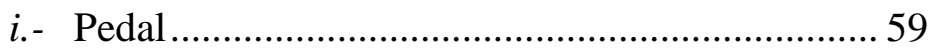

3.1.4. Instrumentaciones ............................................................ 59

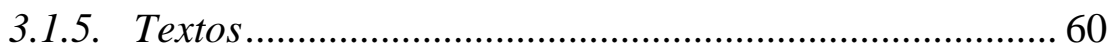

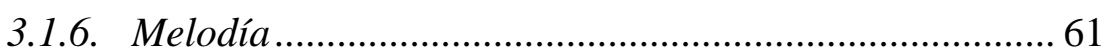

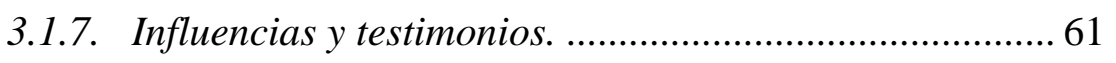

3.2. CATALOGACIÓN SISTEMÁTICA..................................................... 63

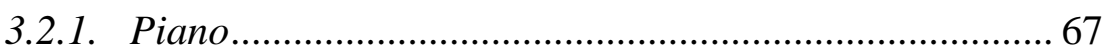




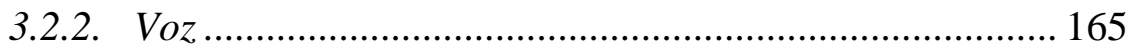

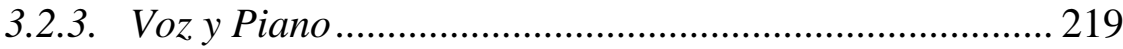

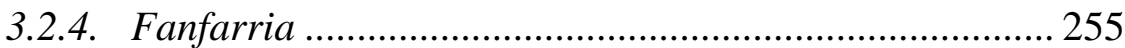

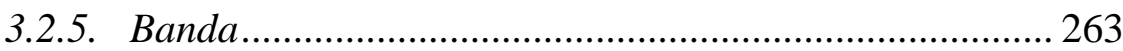

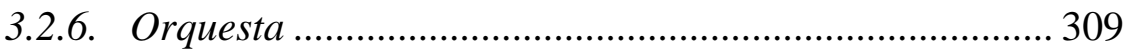

3.2.7. Grupos de Cuerda ...................................................... 317

3.2.7.1. Piano y Violín ............................................................ 319

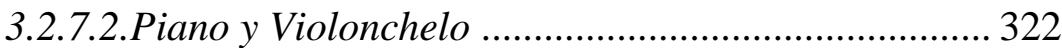

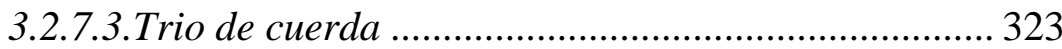

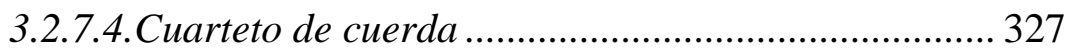

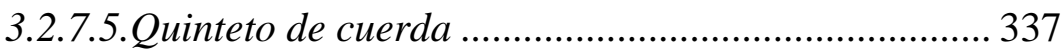

3.2.8. Obra escénica .............................................................. 341

3.2.8.1.Acciones Musicales.................................................. 405

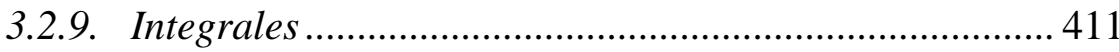

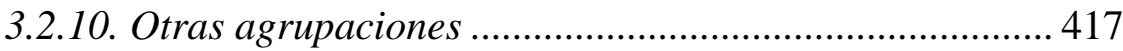

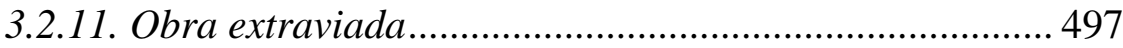

3.2.12. Coincidencias .................................................................. 503

3.3. CATALOGACIÓN ALFABÉTICA …..................................... 509

3.4. CATALOGACIÓN CRONOLÓGICA ……............................... 519

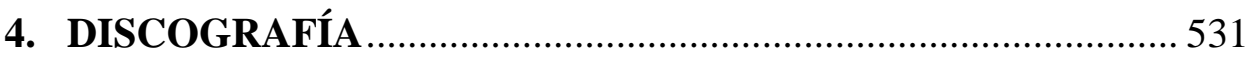

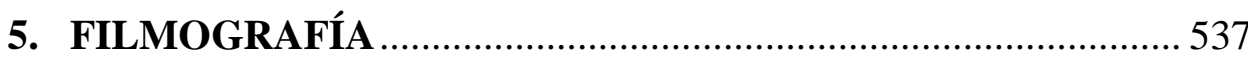

5.1. LARGOMETRAJES DE CINE ….......................................... 539

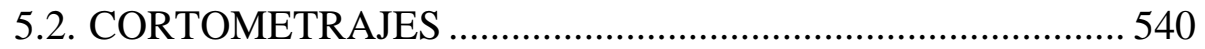

5.3. COMO REALIZADOR …................................................... 542

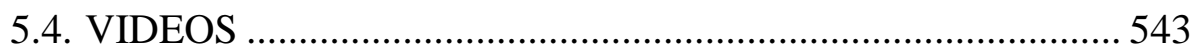

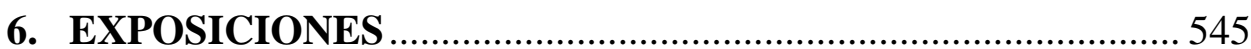

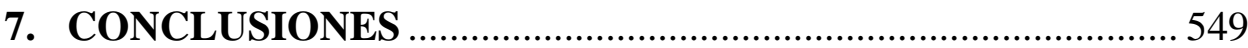

8. FUTURAS LÍNEAS DE INVESTIGACIÓN ............................. 555

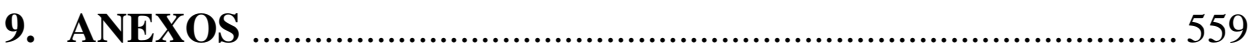

9.1. ENTREVISTAS PERSONALES Y TESTIMONIOS

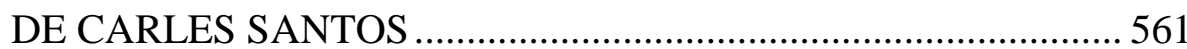

9.2. APÉNDICE DOCUMENTAL (en disco compacto) .................564

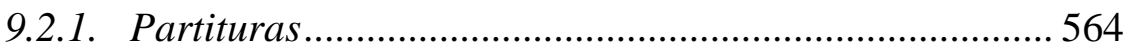

9.2.2. Carteles, fotografías y programas ............................... 564 


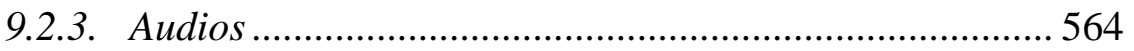

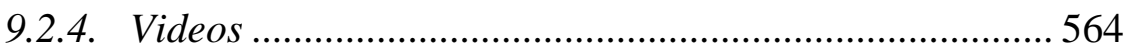

9.2.5. Videos Experimento pedagógico .................................... 564

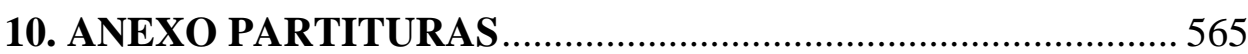

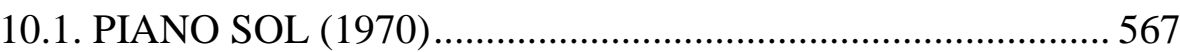

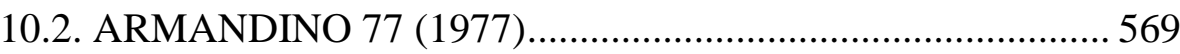

10.3. TO-CA-TI-CO-TO-TA-TA (1978) ........................................ 571

10.4. OCTAVI I LIDIA (1979) .......................................................... 573

10.5. ARROSEGANT EL PIANO (1980) ....................................... 574

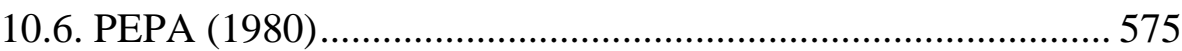

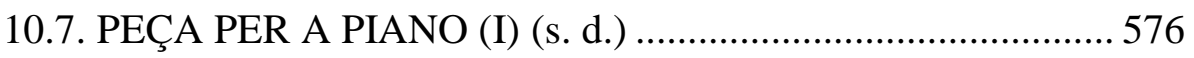

10.8. BUJARALOZ BY NIGHT (1984) ........................................ 579

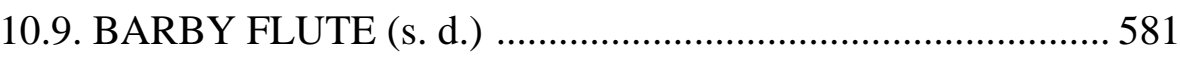

10.10. BUSCA LA PERDIU (1986?) ............................................... 583

10.11.PIANO A 4 MANS (s. d.) ..................................................... 584

10.12. MORELLAR MORELLA (Desfile) (2011) ......................... 586

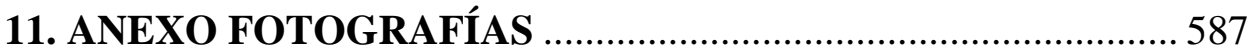

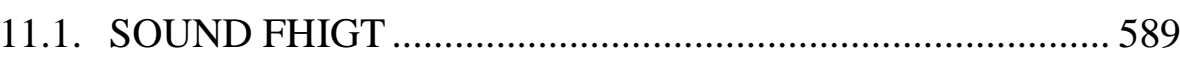

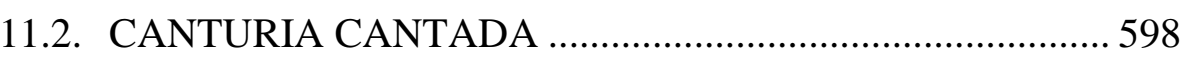

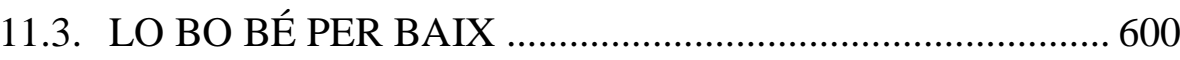

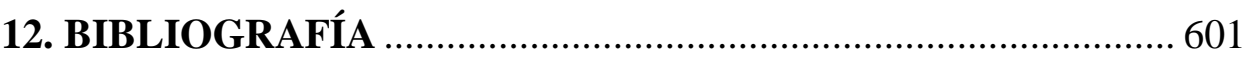

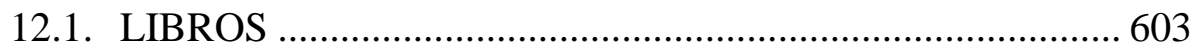

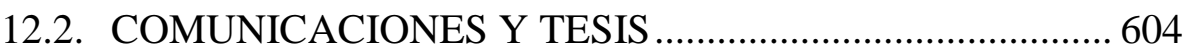

12.3. REVISTAS Y CATÁLOGOS IMPRESOS ............................ 605

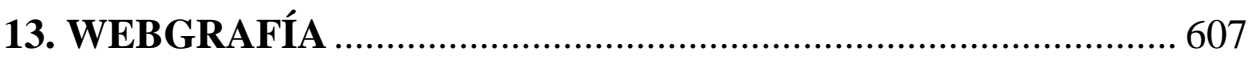





\section{ABREVIARURAS}

A.: contralto (voz).

arc.: [número de] archivador.

B.: bajo (voz).

C. S.: Carles Santos.

G.: [número de archivador] grande.

pizz.: pizzicatto

S.: soprano (voz).

SGAE: Sociedad General de Autores y Editores

s. d.: $\sin$ datar, sin fecha.

s. l.: sin localizador, sin [número de archivador] asignado.

s. reg.: sin registro conocido.

T.: tenor (voz). 

1.- Introducción 
"Soc el que soc i faig el que faig",

"La meva primera arrel es Brossa. La primera senyal arriba amb ell",2

\subsection{FUNDAMENTACIÓN}

El motivo por el cual vinculé este trabajo de investigación a la figura y obra del compositor castellonense Carles Santos Ventura, aduce a una serie de motivos que paso a exponer a continuación, no sin antes remarcar que Carles Santos es el compositor castellonense más influyente del último cuarto del siglo $\mathrm{XX}$ y del principio del siglo XXI.

El 24 de febrero de 2009 se firmó un acuerdo de colaboración entre la Universidad Jaume I de Castellón y la Fundación Caixa Vinarós, con el fin de documentar el patrimonio musical que esta Fundación posee en la localidad castellonense de Vinarós. Este acuerdo fue propuesto y promovido por el Área de Música del Departamento de Educación de esta Universidad y más concretamente por el Doctor, D. Antonio Ripollés Mansilla. En base a este proyecto, la inauguración del nuevo Paraninfo de la Universidad, el 16 de octubre de 2009, contó con la representación de una de las obras escénico-musicales de Carles Santos, en versión concierto: L'adeu de Lucrecia Borgia, con texto de Joan Francesc Mira. Para ello se contó con la inestimable ayuda de la Jove Orquesta Sinfònica de Castelló, con su titular Sergio Alapont al frente, de las corales, Veus de Cambra de Vila-real, Acadèmica d'Orfeu de Castelló, Grups Veus Música Viva de Nules, Orfeó Universitari Jaume I y un elenco de 4 cantantes de reconocido prestigio. Asimismo, este proyecto de colaboración ya había dado sus frutos puesto que otros trabajos de investigación y tesis doctorales, habían surgido de este binomio.

Por otra parte, desde el Área de Música del Departamento de Educación de la Facultad de Ciencias Humanas y Sociales de la Universidad Jaume I de Castelló, se creó un grupo de investigación con el nombre Patrimoni Musical de Castelló, cuya finalidad es recoger y documentar, a través del proyecto de investigación, Catalogación, edición crítica i registro de patrimonio musical de Castellón, toda la obra musical de los diversos compositores castellonenses que, a lo largo de la historia, han enriquecido el patrimonio

\footnotetext{
${ }^{1}$ García, J. M. y Rom, M. (1982): Finestra Santos. Ed. Cine-Club Assiciació d'Enginyers Industrials de Catalunya. Barcelona, p.9

${ }^{2}$ Ibid. p. 16
} 
cultural de esta provincia y que, por diversos motivos, o bien han quedado en el olvido o bien no se han dado las circunstancias apropiadas para revisar su trabajo.

En este proyecto hay diversas líneas de investigación, entre las cuales se encuentra la que enmarca esta tesis, a la cual me ha llevado mi experiencia desde diversos campos de la música:

$>$ la composición musical y los distintos premios obtenidos a través de estas composiciones;

$>$ la dirección musical y montaje de más de 300 conciertos bajo el prisma de la dirección de orquesta y banda;

$>$ el análisis formal, estilístico y musicológico de todos y cada uno de los proyectos musicales emprendidos;

$>$ las transcripciones, instrumentaciones, adaptaciones y arreglos realizados;

$>$ la participación como miembro del jurado en diversos certámenes y concursos musicales;

todo ello desde mi formación académica como Musicólogo, Director de Orquesta y Profesor de Composición, Armonía y Contrapunto, a lo largo de 30 años de dedicación a los mismos. Ante la propuesta del Dr. Antoni Ripollés, de documentar la obra del compositor de Vinaròs, Carles Santos Ventura, no pude más que agradecerle la confianza depositada en mi persona y en mi experiencia y aceptarlo como un reto único. Puesto que parte de la obra del compositor se encontraba en depósito en la Fundación Caixa Vinarós y se tenía localizada otra gran parte de su obra en otras dependencias de esta Fundación, se me planteó la posibilidad de analizar y catalogar dicha obra con la finalidad de que quedara reflejada y catalogada como patrimonio musical de la Fundación y a disposición de todos los castellonenses, músicos y musicólogos que quisieran acercarse a ella.

En un principio se catalogó aquello que se encontraba en las dependencias de la Fundación, en la calle Socors, $n^{\circ} 64$ (antigua Casa Membrillera) y que ya estaba agrupado por títulos. En una segunda etapa, se catalogó el material del que no se disponía de reseñas y que se debía vincular, o bien a obras ya catalogadas, o bien a obras por catalogar o, en todo caso, como material u obras propias o apuntes. En una tercera etapa, se ha catalogado el material que se encontraba en las dependencias anexas de la Fundación, que antes he mencionado y que ya se encuentran junto a todo el material, en el archivo que la Fundación posee en la cuarta planta del edificio, en el Auditorio que lleva por nombre el del autor a catalogar, Carles Santos. Por último, se ha 
realizado un trabajo de búsqueda y posterior análisis y catalogación, de toda aquella obra del autor que ha sido encontrada, o bien en las dependencias personales de Carles Santos, o bien en archivos ajenos a la Fundación. A esto debo añadir que en transcurso de esta investigación han sido muy frecuentes mis contactos personales con el compositor, en la sede de la Fundación, donde acude a diario a trabajar, o en su propia casa, y de estos contactos ha salido mucha información importante que me ha ayudado a la catalogación de su obra, al mismo tiempo que personalmente he podido admirar y disfrutar de la compañía de un ser excepcional, tanto musical como humanamente, hasta el punto de surgir un respeto mutuo entre ambos y, creo adivinar, una sincera amistad. Extractos de todos estos encuentros, con sus consiguientes preguntas y respuestas, dudas y aclaraciones, comentarios y consejos, se exponen en el Anexo 9.1

\subsection{ANTECEDENTES}

Como se verá a lo largo de este trabajo, el acercamiento a la obra de Carles Santos nunca ha resultado fácil. Y no ha sido por su lenguaje musical, por su estilo o por la negativa del autor, sino más bien por el poco apego que este ha tenido de todo aquello material y con ello se incluyen sus partituras. Su manera de componer, perfeccionista donde las haya, le ha permitido no depender de estas partituras para sus conciertos, acciones musicales o algunos espectáculos. Solamente en aquellas composiciones en las que confluyen una serie de factores muy determinados (la estructura formal férrea de la composición, la participación de un grupo grande de instrumentistas, la intervención de Josep Puértolas como arreglista o instrumentador y la dedicación de Nati Romeu por recopilar sus partituras), los materiales, originales o no, se encontraban localizados.

De este modo, los trabajos realizados hasta el momento de la obra de Santos, se basan principalmente en datos biográficos, en el análisis estilístico y estructural de sus espectáculos escénicos o en el análisis auditivo y estilístico de sus composiciones, en base a comentarios del propio autor o de personas vinculadas a él o a su obra, así como a su virtuosismo instrumental como intérprete. No se había podido entrar en detalles propiamente musicales, por la carencia de las partituras de sus composiciones.

En los trabajos realizados con anterioridad sobre Carles Santos, García i Rom, en su libro Finestra Santos $^{3}$, realizan un acercamiento a la estética de Santos en base a

\footnotetext{
${ }^{3}$ García, J. M. y Rom, M. (1982): Finestra Santos. Ed. Cine-Club Assiciació d'Enginyers Industrials de Catalunya. Barcelona
} 
entrevistas y comentarios del autor, sin citar ninguna fuente musical. Josep Ruvira hace un análisis exhaustivo de la estética musical, de los argumentos de sus obras escénicas, que incluyen textos representativos de las mismas y un estudio biográfico de su vida en su libro El caso Santos $^{4}$, argumentos en los que profundiza, bajo un prisma estético, en su libro Los desafíos artísticos de Carles Santos ${ }^{5}$ y Manuel Guerrero realiza una catalogación sistemática de los estrenos de la obra del autor, una recopilación de opiniones de artistas vinculados a Santos, así como una exposición representativa de imágenes vinculadas a sus espectáculos escénicos y a sus exposiciones, en el libro Carles Santos: Visca el Piano ${ }^{6}$. Asimismo, información biográfica del autor la encontramos en los libros Història de la Música Catalana, Valenciana i Balear (Vol. $\mathrm{X})^{7}$, Diccionario de la Música Valenciana. (Vol. II) ${ }^{8}$, The New Grove Dictionary of Music and Musicians. (Vol. XXII) $)^{9}$, y en el Diccionario de la Música Valenciana $(I I)^{10}$, entre otros. Pero en ninguno de estos trabajos, el hilo conductor han sido sus partituras. Es por ello que se hacía necesario realizar un trabajo de investigación en base a lo más primordial de un compositor, sus partituras. Y a partir de ellas y de su análisis, catalogar toda la obra de Santos, como cualquier músico.

\subsection{METODOLOGÍA}

"L'obra inclasificable, multidisciplinar i admirable de Carles Santos, prodü̈da al llarg de més de 35 anys, és encara avui, en gran part, desconeguda. Pianista, compositor, artista conceptual, performer, director musical i teatral, director i guionista de films, artifex d'espais escènics $i$ d'impactants imatges visuals i d'objectes per als seus espectacles... ",11

En base a esta premisa, que considero totalmente cierta tal y como me sumergía en la obra de Santos, la metodología empleada para realizar este trabajo está basada en el

\footnotetext{
${ }^{4}$ Ruvira, J. (1996): El caso Santos. Valencia, Mà d'obra.

${ }^{5}$ Ruvira, J. (2008): Los desafíos artísticos de Carles Santos. Valencia, Institució Alfons el Magnànim.

${ }^{6}$ Guerrero, M. (2006): Carles Santos. Visca el Piano!. Fundació Joan Miró. Barcelona, p 13.

${ }^{7}$ Aviñoa, X. (2003): Història de la Música Catalana, Valenciana i Balear (Vol. X). Barcelona. Edicions 62. ISBN 84-297-5329-X.

${ }^{8}$ Galbis López, V. (2006): Diccionario de la Música Valenciana. (Vol. II). Iberautor Promociones Culturales S. R. L. Madrid. ISBN 84-8048-707-0, p. 414-418.

${ }^{9}$ MacMillan Publishers Ltd. (2000): The New Grove Dictionary of Music and Musicians. (Vol. XXII). Reino Unido

${ }^{10}$ Fundación Autor-ICCMU-Institut Valencià de la Música (Ed.), (2006): Diccionario de la Música Valenciana (II). Valencia. España. ISBN 84-8048-706-2.

${ }^{11}$ Guerrero, M. (2006): Carles Santos. Visca el Piano!. Fundació Joan Miró. Barcelona, p 13.
} 
análisis directo de las partituras del autor. Estas se encuentran en la Fundación Caixa Vinarós, sita en la calle Socors, $\mathrm{n}^{\circ} 64$ de Vinaròs (Castellón).

Muchas han sido las dificultades encontradas a la hora de catalogar la obra de Santos. Ya no digo de analizar, puesto que la labor musical de la lectura de sus partituras, es un hecho del que tengo cierta experiencia. Y la personal manera de escribir la música en sus manuscritos, me ha sido clarificada, tanto por el autor como por la audición contrastada de sus obras (de aquellas de las que se ha podido encontrar grabaciones), frente a las mismas partituras. Y de esta personal manera de escritura musical, se ha creído conveniente, para posteriores estudios y ejecuciones de su obra, realizar una exposición con ejemplos concretos y clarificadores en el apartado "Estudio interpretativo". Pero por sus connotaciones artísticas particulares, la catalogación, como se argumentará posteriormente, ha tenido que adaptarse a estas características, puesto que ninguna de las que constan como referentes, puede adaptarse a sus obras, de modo general. La dificultad radica, principalmente, en la imposibilidad de separar, en la obra de Santos, la parte musical de la que no lo es (textos, escenografía, fotografía, vestuario, adaptaciones, exposiciones, arte en acción, etc.). Y dado que el análisis viene dado de sus partituras musicales, en ellas no están reflejados todos los demás elementos que comprenden su obra. Los estudios musicológicos al uso, realizados de la obra musical de los compositores, siguen el hilo conductor de sus manuscritos, cada uno de los cuales vinculado a un título y a una forma musical determinada. Pero nombrando a Josep Ruvira: ${ }^{12}$

\begin{abstract}
"El carácter anticonservacionista e incluso descuidado, de Santos, hace que esa labor (la catalogación) se asemeje más a la limpieza doméstica que a la práctica del documentalismo. Ningún narcisismo surgido de Santos ha intentado poner orden a esa acumulación de productos. [...] En todos los rincones de su casa y de su memoria aparecen nuevas cosas y cuando se tiene la sensación de tenerlo todo controlado, surgen textos olvidados, detalles que cobran importancia y, además, las nuevas creaciones que impiden un cierre de su estudio. De la observación de todas estas cosas se generan nuevas preguntas. Más preguntas que respuestas pueden quedar al final de este texto"
\end{abstract}

En el caso de la obra musical de Santos, se debe cambiar el enfoque, dada su concepción multidisciplinar del arte. Su obra como conjunto, está reflejada en los guiones que sirven de base para sus actuaciones; pero estos no constan en la mayoría de

\footnotetext{
${ }^{12}$ Ruvira, J. (1996): El caso Santos. Valencia, Mà d'obra. Pág. 10
} 
sus obras $y$, aun existiendo, sufren transformaciones en cada una de sus representaciones, atendiendo a las necesidades del momento.

Se han contrastado, los títulos y referencias del autor en las tapas de sus manuscritos, con el análisis de la música escrita en su interior, cotejado con grabaciones existentes, títulos registrados en programas de mano y, lo más importante, con las referencias que de estas obras ha dado el propio autor. Así pues, nos atenemos a una fuente directa para su catalogación.

Por otra parte se ha contrastado esta información, con el registro de obras del autor que consta en la SGAE.

Aun así, existen diferencias entre títulos, instrumentaciones y grabaciones y esto es debido, principalmente a seis causas:

1. El autor titula sus manuscritos con referencias a personas que lo interpretarán, personas a las que va dedicada la composición o que de alguna manera, forman parte de la acción de la obra. Este título se modifica a posteriori o, incluso, una misma obra puede aparecer con títulos distintos (por ejemplo Joan Font, Sevilla o Marrajo, son tres títulos distintos para una misma composición. Olvido es la música de violín de su espectáculo Roni, que interpretará Olvido Lanza). Se puede tener un acceso directo a los distintos títulos utilizados para una misma composición en el apartado "Coincidencias"

2. El autor reutiliza su música para acciones o conciertos determinados, modificando su nombre, su estructura o título, en acciones musicales ${ }^{13}$ posteriores.

3. En una parte de su obra, el autor no considera título para una composición determinada, bien sea por tratarse de una ampliación de una obra ya existente (No al no) o por no sentir la necesidad de hacerlo, en cuyo caso, solamente Santos conoce para qué ocasión o espectáculo, se compuso ese fragmento u obra musical.

4. El autor titula sus conciertos de forma personalizada, con lo cual, existen referencias bibliográficas o en medios de comunicación que no se corresponden con los títulos de sus obras y llevan a confusión.

\footnotetext{
${ }^{13}$ El concepto de Acción Musical, que define la obra de Santos en su conjunto, es acuñado por Joan Brossa en las notas al programa de mano del estreno del "Concert Irregular", al Teatro Romea de Barcelona, el 7 de octubre de 1968. Este término, no obstante, se atribuye al músico norteamericano John Cage, que con sus ideas planteó una música formalmente abierta en contraposición a las formas cerradas (con número de opus) (Michels, 1992:549).
} 
5. Sobre todo en su obra instrumental, el autor utiliza la improvisación como un recurso innato, tanto en base a la música escrita, para el instrumento sobre la cual se desarrolla, como añadiendo otros recursos instrumentales, como la voz.

6. Los títulos que constan en las tapas difieren de los utilizados en su registro en la SGAE.

Por otra parte, la datación de las obras, en algunos casos ha sido imposible, debido a varias razones:

1. Las fechas que constan como registro de las obras en la SGAE, son posteriores a las fechas de su composición o estreno.

2. Los primeros manuscritos originales de sus obras, han desaparecido en muchas ocasiones y las referencias que se tienen de estas obras, dependen de otros manuscritos posteriores que el autor ha tenido que volver a escribir. Dado que generalmente escribe en blocs de escritura musical, y estos han ido modificando su portada a lo largo de estos años, es habitual encontrar los manuscritos de una obra estrenada en la década de los 80 en blocs de la década de los 90 .

Dada la extensión y complejidad del trabajo del autor, debo señalar una serie de indicaciones:

Se ha atendido a sus instrumentaciones como referencia para la catalogación, independientemente que varias partes de una obra (integral) tengan instrumentaciones distintas, puesto que, partes instrumentales de esta integral son reutilizadas en otras obras o espectáculos o bien han sido modificadas o alteradas para que funcionen como elementos con personalidad propia dentro de sus conciertos.

Su obra la he dividido en varios géneros:

Obra pianística: aquella que está dirigida exclusivamente para el piano, bien sea en piezas de pequeño formato o en formato concierto. En algunas grabaciones puede aparecer la voz como elemento novedoso, aunque consideramos estas intervenciones vocales como improvisaciones ${ }^{14}$.

> Obra vocal: aquella que está dirigida exclusivamente para la voz, bien sea solista, en coro o ambas. La voz puede tener tratamientos diversos como el

\footnotetext{
${ }^{14}$ Ver el apartado 4 de la página anterior.
} 
canto, el recitado, la dramatización, onomatopeyas, o textos inventados y originales del autor. Puede incluir piezas de pequeño o de gran formato.

> Obra para Voz y Piano: Aquella que está dirigida para el piano y la voz, exclusivamente, aunque el tratamiento de esta pueda ser diverso (coro, solista, ambas, canto, recitado, etc.). Puede incluir piezas de pequeño o de gran formato.

Obra instrumental: aquella que está dirigida para agrupaciones instrumentales de cualquier tipo, incluyan estas o no, la participación esporádica o testimonial de la voz humana, bien de carácter solista o coral, o de instrumentos ajenos a estas agrupaciones, como instrumentos tradicionales. Se ha dividido en:

- Obras para Fanfarria.

- Obras para Banda.

○ Obras para Orquesta.

- Grupos de cuerda.

> Otras agrupaciones: aquella que va dirigida a cualquier formación no incluida en las anteriores. Desde dúos instrumentales de pequeño formato a obras que contienen diversas masas instrumentales o vocales distintas, con o sin solistas.

$>$ Obra escénica: aquella que requiere siempre de una escenografía para su representación. Se incluyen aquí sus óperas y también lo que se conoce como acciones musicales.

- Acciones musicales ${ }^{15}$ : Espectáculos con o sin puesta en escena, que no cuentan solamente con el contenido musical, sino que se plantea, junto a este, alguna representación artística conjunta (danza, filmografía, exposición, performance, etc. $)^{16}$. En muchas ocasiones, la música utilizada en estas acciones musicales, es música ya catalogada o música improvisada por el autor.

Asimismo, se incluyen dos apartados para sus integrales y para su obra extraviada.

\footnotetext{
${ }^{15}$ Testimonio del autor: "La finalidad de las acciones musicales es la visualización de la música. La importancia que da el teatro o el resto de artes a los detalles musicales no existen en las interpretaciones musicales, propiamente dichas. Una buena iluminación, utilizar elementos que ayuden a la expresividad de la música hacia el público, desproveer a la música de elementos que enturbien su interpretación (como la aparición del reloj del solista, en un primer plano del mismo, en una retransmisión de un concierto), son la base de un buen y profesional trabajo. Lo que intento es tener en cuenta todos estos detalles."

${ }^{16}$ John Cage, el músico que acuñó el término, es asimismo el padre de la denominada indeterminación, tendencia musical que aboga por la libertad de ejecución al mismo tiempo que defiende la unión e interdisciplinaridad entre las artes.
} 
2.- Biografía 


\section{BIOGRAFÍA}

“Els elements que son les coordenades de la meua vida son el meu llit, la meua barca i el meu piano" ${ }^{, 17}$

\subsection{INFANCIA Y ADOLESCENCIA (1940-1954)}

Hijo único de Ricardo Santos Ramos y Elena Ventura Riuhet, Carles Santos Ventura nace en Vinaròs (Castelló) el 1 de julio de 1940. Su temprana vocación musical viene dada por su padre y, sobre todo, por su tío Pepe Santos (farmaceutico y pianista, fue el que encauzó los primeros pasos al piano de Carles Santos), ambos fundadores y miembros de la Sociedad de Conciertos de Vinaròs, aunque como indica el compositor, "jo no tinc vocació musical". Comienza sus estudios en su Vinaròs natal de la mano de su tío Pepe y de la profesora Cinta Esbrí. A los cinco años tocaba el piano de forma más que correcta. De hecho, gana diversos Premios como interprete en su infancia y su adolescencia:

$>$ Premio Jaen.

$>$ Premio de L'Institut Francais.

En 1950 se traslada a Barcelona para seguir sus estudios musicales en el Conservatorio Superior de Música del Liceu de Barcelona, donde recibe clase de los profesores Teresa Grafia (piano) y Bussons (Armonía y contrapunto), entre otros. En 1954 se Gradúa en la especialidad de Piano, en dicho Conservatorio, obteniendo el Premio Fin de Carrera en la especialidad. Su formación pianística es, como el autor indica, europea.

"La formació es molt dura, rígida",18

Esta rigidez en su aprendizaje le ha supuesto un grado de virtuosismo que ha impregnado toda su obra y la devoción hacia esta rigidez academicista queda reflejada en su amor por Bach y la interpretación diaria que de sus obras realiza al piano, como estudio. Hasta tal punto de "[..] considerarle el más bachiano de los compositores españoles de finales del s. XX" (Galvis, 2006) ${ }^{19}$. Asimismo, la vertiente pedagógica de esta formación y sus desencuentros con ella, marcaron su quehacer, utilizándola, tal vez,

\footnotetext{
${ }^{17}$ Ruvira, J. (1996): El caso Santos. Valencia, Mà d'obra. Pág. 26

${ }^{18}$ García, J. M. y Rom, M. (1982): Finestra Santos. Ed. Cine-Club Assiciació d'Enginyers Industrials de Catalunya. Barcelona, p.13

${ }^{19}$ Galbis López, V. (2006): Diccionario de la Música Valenciana. (Vol. II). Iberautor

Promociones Culturales S. R. L. Madrid. ISBN 84-8048-707-0, p. 414-4148.
} 
como revulsivo para su creatividad desbordante. Prueba del recuerdo de esta formación la encontramos en su película El pianista i el Conservatori (1977).

Su primer concierto público data de 1950, a la edad de 10 años, en su Vinaròs natal, interpretando obras de Bach, Mozart, Schumann, Chopin y Albeniz. A los 13 años, en 1954, realiza su primer concierto como solista en la Sociedad de Conciertos de Vinaròs. Fue presentado por el Canónigo Vicent García Julve ${ }^{20}$.

\subsection{PARÍS Y SUIZA (1954-1958)}

Continúa sus estudios en París en 1954 en el L’Eccole Normal, durante 6 meses, después de obtener el Premio de L'Institut Francais, antes mencionado. Los maestros que se encargan de su formación son Jacques Février, Casadesús, Magda Tagliaferro y Margaret Long ${ }^{21}$.

Poco después se inician sus estancias en Suiza, en navidades y durante el verano, como alumno de Harry Datymer en le Chaux de Fonds ${ }^{22}$. Estas estancias se prolongarían durante 2 ó 3 años. Como indica Rom (1982: 14), estas estancias en París y Suiza le hacen recibir información de la música de Webern, Schomberg, Bartok o Cage, comenzando a interpretar obras de estos compositores.

En 1961 comienza su carrera como interprete de piano interpretando obras de Bartók, Schönberg y Webern. Durante el mismo periodo realiza el Servicio Militar en Castellón, en el Regimiento Tetuan $n^{\circ} 14$. Al final del mismo fue nombrado Director de la Banda Militar del Regimiento, tras el fallecimiento de su titular.

Con 23 años se traslada definitivamente a Barcelona.

\subsection{BARCELONA (1963- )}

En el año 1963, Santos es invitado a participar en un grupo de cámara que debía interpretar música de Robert Gerard y Joaquim Homs dentro del grupo Música Oberta, sección musical del Club 49, fundado en 1949, con la idea de dinamizar la actividad

\footnotetext{
${ }^{20}$ Vicent Gancía Julve fue el primero en poner sobre el atril de un joven Santos, partituras de música contemporánea de Webern (op. 27), Schomberg (op. 14) o Berg (op. 1), después de su estancia en Zurich, gracias a una beca.

${ }^{21}$ Galbis López, V. (2006): Diccionario de la Música Valenciana. (Vol. II). Iberautor

Promociones Culturales S. R. L. Madrid. ISBN 84-8048-707-0, p. 414-418

${ }^{22} \mathrm{Id}$.
} 
cultural de vanguardia en Barcelona. A partir de este momento, su colaboración con Josep Maria Mestres-Quadreny fue en aumento. En 1970 se desactiva el Club 49 y en 1976 crea, junto a Josep Maria Mestres-Quadreny, el Grup Instrumental Català (GIC) ${ }^{23}$, con sede en la Fundación Miró de Barcelona, actuando como director del mismo. El Grupo se disuelve en 1979.

En 1966 conoce a Joan Brossa, al participar como pianista en el espectáculo Suite Bufa (1966), de Mestres-Quadreny y del propio Brossa. Posteriormente participa en el film No compteu amb els dits (1967). Estas colaboraciones con Brossa son el germen de una relación que desemboca en una sincera amistad y que influye notablemente en su carrera profesional, sobre todo en el apartado teatral. Posteriormente se pone en escena Concert Irregular (1968), con música del propio Santos y textos de Brossa, con la participación de la mezzosoprano Anna Ricci y actuando como director, el cineasta Pere Portabella.

Es este uno de sus espectáculos teatrales más significativos y que más relevancia tiene en su carrera. Estrenado en St. Paul de Vence, a la Fundación Maeght, dentro de los actos conmemorativos del 75 aniversario de Joan Miró, de él indica Portabella:

“L'obra estava pensada per ell (per Santos), i ell mateix interpretava el seu paper. La seua activitat posterior musical parteix d'aquí, aquest treball Intel.ligent sobre ell mateix [...], que ha anat desenvolupant fins avui en dia",24

En el mismo sentido, Joan Brossa escribe:

"Santos es una mica fill del "Concert Irregular,",25

Su relación con Pere Portabella comienza en 1966, de la mano de Brossa ${ }^{26}$. Con él entabla una fructífera relación profesional que comienza con el film Nocturn 29 (1968) y se prolonga hasta nuestros días. De hecho y a partir de 1970, con el film CuadecucVampir, Santos es el autor de todas las bandas sonoras de los films de Portabella. Esta relación le hace registrarse como miembro y socio de la SGAE, en la que posee derecho

\footnotetext{
23 Allí toma contacto con el violinista Josep Puértolas, autor de gran parte de las instrumentaciones de la obra de Santos.

${ }^{24}$ García, J. M. y Rom, M.: Finestra S. (1982: 27)

${ }^{25}$ Ibid: p. 31

${ }^{26}$ Guerrero, M. (2006): Carles Santos. Visca el Piano!. Fundació Joan Miró. Barcelona, p.74.
} 
a voto. Santos bebió de la experiencia de Portabella en el lenguaje del cine y lo incluyó posteriormente en sus espectáculos.

Entre 1969 y 1975, Santos colabora con el fotógrafo y director de cine francés, Clovis Prévost $^{27}$, director de la sección de cinema de la Galería Maeght. Esta colaboración le acerca al conocimiento del proceso de trabajo de artistas como Tapies, Miró o Chillida, entre otros.

En 1970 vuelve a Nueva York, residiendo en la ciudad durante casi un año.

En 1971 vende el piano y se dedica, durante 3 años, a teorizar sobre la práctica del $\operatorname{arte}^{28}$, después de tomar contacto con los movimientos conceptuales de la época ${ }^{29}$. Participa activamente en movimientos políticos, que le lleva a ser encarcelado en la cárcel Modelo el 28/10/1973, junto a 113 participantes en la Comissió Permanent de l'Asamblea de Catalunya a la Iglesia de Santa María Medianera, de Barcelona ${ }^{30}$. En 1974 vuelve al piano, realizando su primer concierto en agosto de ese mismo año en la Universidad Catalana de Verano de Prada de Conflent.

En 1975 graba su primer disco, interpretando obras de John Cage, Anton Webern y Karlheinz Stockhausen.

En 1976 se forma el Grup Instrumental Catalá, con sede y patrocinio en la Fundación Miró, del que es director hasta 1979.

Desde 1978, solamente interpreta sus propias composiciones. ${ }^{31}$. El 14 de mayo del mismo año interpreta un concierto en solitario al Carnegie Recital Hall de Nueva York.

En 1980, durante una estancia en Nueva York, participa en el 12th Internacional Sound Poetry Festival. El 14 de marzo de 1981, en el ring del Bobby Gleason Gym, realiza, junto al compositor norteamericano Charlie Morrow, una de sus performances más sonadas, el espectáculo Sound Fight, un combate musical. Asimismo y durante esta

\footnotetext{
${ }^{27}$ Ibid., p.13.

${ }^{28}$ Escribió un texto teórico, posteriormente asumido por el colectivo del Grup de Treball, en el que especifica lo que es para él, la práctica del arte. El mismo dice: "La materialización de las obras conceptuales se puede realizar de muchas formas: se utilizan los films, la fotografía, la página dactilografiada, envíos postales, acciones corporales, etc. Sirviéndose de todo esto como soporte o documentación de una idea que propone un proceso de realización mental a compartir con los espectadores-lectores de unos resultados que no están previstos o determinados en la propuesta inicial". La acción musical posterior a este texto, "Informació d'Art Concepte", realizada a Banyotes en 1973, dará paso a la creación del Grup de Treball. De esta Acción Musical quedan documentos, como el presentado en esta página.

${ }^{29}$ García, J. M. y Rom, M.: Finestra S. (1982: 18 a 20 y 45 a 68)

${ }^{30}$ De este hecho queda la "Cançó dels 113" con música de Santos y texto de la canción "Pescador de Vilanova"

${ }^{31}$ García, J. M. y Rom, M.: Finestra S. (1982: 20)
} 
estancia, graba su disco Voice-tracks (1981). A su vuelta a Barcelona, graba su segundo disco, con música propia, Piano-.tracks (1984).

El principio de la década de los 80 representa un acercamiento a los espacios teatrales por parte de Santos. Una prueba de ello es su espectáculo escénico Beethoven, si tanco la tapa... què passa? (1983), inicio de sus muchos espectáculos escénicos y hoy parcialmente perdida, al igual que Té xina, la fina petxina de Xina (1984) o La boqueta amplificada (1985).

De sus obras de las décadas de los 60, 70 y principios de los 80 no existen casi testimonios y muy pocas obras a catalogar.

"L'apego a les coses materials, en aquell moment, era inexistent. No l'hi donavem importància. Gran part de les obres es quedaben al damunt dels faristols o en el pis llogat quan l'abandonabe'm"

Algunos de los materiales catalogados en este trabajo, sobre obras de estas décadas, se corresponden con reescrituras del autor. Es por ello que, como se ha citado anteriormente, los manuscritos existentes son contemporáneos al estreno de estas obras. Según Josep Lluís i Falcó, ${ }^{32}$ durante las décadas de los 70 y 80, y producido por el Institut del Cinema Català, puso música a numerosos documentales del Noticiari de Barcelona.

A partir de 1985 inicia su relación profesional con Marielena Roqué Su primera obra conjunta fue Argamchulla, Argamchulla Gallac (1985). Esta relación significa, para la obra de Santos, según Guerrero (2006), un cambio:

"L'estètica dels espectacles de Santos canvia radicalment amb la riqueza cromàtica i els materials sensuals que incorpora en el vestuari i en els elements escènics ",33

Esta relación desemboca en la creación de la Compañía Carles Santos en 1995, actuando este, a partir de ahora, como autor, compositor y director de su obra, en teatros y festivales internacionales. Su debut es el espectáculo L'esplèndida vergonya del fet mal fet.

\footnotetext{
${ }^{32}$ Lluís i Falcó, J. (2011): Carles Santos. S. reg. s. reg. Recuperado de: http://usuarios.multimania.es/compositores/csantos00.html. (4 de septiembre de 2011)

${ }^{33}$ García, J. M. y Rom, M.: Finestra S. (1982: 31)
} 
Durante este tiempo (18 años), Santos y Roqué, con una compañía independiente, han estrenado 14 espectáculos originales de gran complejidad.

\subsection{NUEVA YORK (1968-1981)}

En 1968 se traslada a EE. UU. gracias a una beca de estudios de Fundación Juan March $^{34}$, donde toma contacto, durante seis meses, con la vanguardia musical estadounidense, con los músicos próximos al movimiento Fluxus ${ }^{35}$ y con los compositores minimalistas, y muy especialmente con el compositor John Cage. De este último sería un importante intérprete de sus obras durante la década de los 70. En 1970 vuelve a residir en esta ciudad durante un año y en 1980 vuelve a Nueva York. En abril de ese año participa en el 12th Internacio-nal Sound Poetry Festival de Nueva York, y al año siguiente edita su primer disco LP con mú-sica propia, Voicetracks(1981). El 14 de marzo de 1981, en el ring del Bobby Gleason Gym, realiza una de sus performances más sonadas, el espectáculo Sound Fight, un com-bate musical con el compositor norteamerica-no Charlie Morrow. Esta sería su última estancia prolongada en Nueva York.

\subsection{RECONOCIMIENTOS Y PREMIOS}

En 1986 recibe la beca Deustcher Akademischer de Berlín y se desplaza a esta ciudad, como compositor residente. En este mismo año recibe el Premio Alé Vinarosenc de su ciudad natal, otorgado por la Fundación Caixa de Vinaròs.

El 7 de mayo de 2003 es nombrado Hijo Predilecto de su ciudad natal, Vinaròs. ${ }^{36}$

En el año 2006 el Ayuntamiento de Vinaròs le concedió como reconocimiento a su trayectoria artística su nombre a una calle del municipio en la que reside actualmente.

Es Artista Residente del Teatre Lliure de Catalunya desde 2001.

\footnotetext{
${ }^{34}$ Ruvira, J. (2008): Los desafíos artísticos de Carles Santos. Valencia, Institució Alfons el Magnànim, p.25

${ }^{35}$ Red internacional de artistas, compositores y diseñadores, conocidos por mezclar diferentes medios artísticos y disciplinas en la década de 1960. Sus orígenes se encuentran en muchos de los conceptos explorados por el compositor estadounidense, John Cage (1912-1992) en la década de los 50. Posteriormente, el artista lituano, George Maciunas (1931-1978) organizó el evento de Fluxus en la Galeria AG en Nueva Cork, en 1961 y los primeros festivales en Europa en 1962.

${ }^{36}$ Guerrero, M. (2006): Carles Santos. Visca el Piano!. Fundació Joan Miró. Barcelona, p.476
} 
En mayo de 2009 decide ceder toda su obra a la Funadación Caixa Vinarós con el fin de tener la seguridad de su guarda, al mismo tiempo que queda a disposición de quien pueda hacer uso de ella.

Ha actuado en los principales festivales internacionales ${ }^{37}$ :

Akademie der Künste, Berlín (1987)

$>$ Internationales Sommer Theater Festival, Hamburg. (13-14 julio 1990)

$>$ Edimburgo Internacional Festival (23-25 agosto 1996; 28-30 agosto 1998; 21-23 agosto 2001; 24 agosto 2002; 27-30 agosto 2004)

$>$ Brighton Festival (23 mayo 1999)

Salisbury Festival (25-26 mayo 1999)

> Aotomme de Paris (13-24 octubre 1994; 22-26 noviembre 1996)

$>$ Exit Créteil-Paris (3-6 diciembre 2003)

$>$ Festival de Thèâtre - Thèâtre de Bayonne. (16 oct 1993)

$>$ Festival de Strasbourg

$>$ Festival della Parola, Venecia. (5 julio 1997)

$>$ Festival ETI-Roma (6-7 octubre 1998)

> Festival Internacional de Buenos Aires (Septiembre 1999)

$>$ Wintermusic de Karlsruhe (1982)

> Festival Música Nova de Santos (Brasil),

$>$ Foro Internacional de Nueva Música (México)

$>$ Music Theatre Festival de Londres

$>$ New Music America 83 de Washington

$>$ XLV Bienal de Venecia - Teatro Fundamenta Nuove, Venecia. (10 junio 1993)

$>$ Festival de Otoño de Madrid (1-2 octubre 1993; 4-6 octubre 1996; 15 -17 noviembre 2002; 14-17 octubre 2004)

$>$ Teatre Nacional de Catalunya $(2002,2003)$

$>$ Festival de Théâtre des Amériques-Montréal (29 mayo-1 junio 1993)

$>$ Ars Musica Festival de Bruselas (5 marzo 2005)

$>$ Belfast Festival - Stranmilis College Theatre. (27-28 noviembre 1998; 2-4 noviembre 2000)

\footnotetext{
${ }^{37}$ Guerrero, M. (2006): Carles Santos. Visca el Piano!. Fundació Joan Miró. Barcelona.
} 
Festival Internacional de Teatro - Teatro Isabel la Católica, Granada. (16-17 mayo 1992; 13-14 mayo 1995)

entre otros.

Ha recibido numerosos premios y condecoraciones: ${ }^{38}$

> Premio Nacional de Composición de la Generalidad de Cataluña (1990)

Premio Daniel Montorio de la SGAE (1992)

$>$ Premio FAD Sebastià Gasch (1992)

$>$ Premio del Festival Altaveu de Sant Boi de Llobregat (1993)

> Premio Ciudad de Barcelona de la Música (1994)

> Premio de Música de la revista El temps (1996)

$>$ Premio Ciudad de Barcelona a la Proyección Internacional (1997)

$>$ Premio de la crítica por La Pantera Imperial (1998)

$>$ Medalla FAD (1998)

> Premio de la Crítica d'Or al mejor espectáculo por La Pantera Imperial (1998)

$>$ Premio Herald Angel del Edimburg International Festival por La Pantera Imperial (1998)

$>$ Creu de Sant Jordi (1999)

$>$ Premio de la Crítica al mejor espectáculo musical por Ricardo y Elena (2000)

$>$ Premio FAD Sebastià Gasch de Honor (2000)

$>$ Premi Nacional de Teatre (2001)

> Premio de las Artes Escénicas de la Generalitat Valenciana (2001)

> Premio Importante del Diario Levante (2001)

$>$ Miquelet d'Honor de la Societat Coral el Micalet de València (2005)

> Medalla de Oro del Círculo de Bellas Artes (2006)

> Medalla d'Or de la Universidad Jaume I de Castelló (2009)

> Premio Carles Salvador del Colectivo Maestrat Viu (2015)

Medalla de la Universidat de València (2015)

\footnotetext{
${ }^{38}$ Oliveres, M. (2011): [Manager artística/Carles Santos]. S. reg. s. reg. Recuperado de: http://www.martaoliveres.com/pagina.asp?0=3\&1=371838\&3=47366. (4 de septiembre de 2011)
} 
En cuanto a los Premios Max recibidos por sus espectáculos escénicos, la lista es la siguiente:

> 2000: Millor Composició Musical per Hamlet

> 2001: Millor Composició Musical per Ricard i Elena

> 2001: Millor Direcció Musical per Ricard i Elena

> 2002: Millor Direcció Musical per La pantera imperial

> 2003: Millor Composició Musical per Sama Samaruck Suck Suck

> 2003: Millor Direcció Musical per Sama Samaruck Suck Suck

> 2005: Millor Espectàcle Musical per El Compositor, la cantant, el cuiner i la pecadora

> 2005: Millor Composició Musical per El Compositor, la cantant, el cuiner i la pecadora

> 2005: Millor Direcció Musical per El Compositor, la cantant, el cuiner i la pecadora

> 2007: Millor Composició Musical per La meua filla sóc jo

> 2007: Millor Direcció Musical per La meua filla sóc jo

> 2009: Millor Composició Musical per Tirant lo Blanc

2009: Millor Director Musical per Tirant lo Blanc

> 2011 Millor Composició Musical per La lucha libre vuelve al Price

La importancia que le da a los premios es relativa puesto que tal como comenta el propio Santos:

"[...] No tengo ninguno en mi casa porque no he podido recogerlos. Me produce satisfacción pero no noto que después pase nada. Yo sigo con mi ritmo habitual. En cuanto a los premios tanto los grandes como los pequeñitos los tienen mis amigos.[...]". ${ }^{39}$

En cuanto a su obra escénica, sus títulos son los siguientes ${ }^{40}$ :

> 1980, L'Aperitiu. (Estrenada el 22/06/80 al Teatre Romea de Barcelona)

$>$ 1981, Visca el piano. (Estrenada el 12/11/81 al Musée d'Art Moderne de la Ville de París)

\footnotetext{
${ }^{39} \mathrm{http}: / / \mathrm{www} . \mathrm{madridteatro.eu/teatr/entrevistas/entrevista059.htm}$

${ }^{40}$ Carles Santos Ventura, (1 de junio de 2015). En Wikipedia. Recuperado el 20 de julio de 2015 de http://ca.wikipedia.org/wiki/Carles Santos Ventura.
} 
$>$ 1982, Què no donaria jo per una miqueta de sol. (Estrenada el 12/11/81 al Musée d'Art Moderne de la Ville de París)

$>$ 1982, Beethoven, si tanco la tapa... què passa?. (Representada a la Plaça del Rei de Barcelona durante las fiestas de la Mercé (1982), "en un espectacle obert que abarrotà la plaça...,"41

$>$ 1983, Té fina la fina petxina de Xina?. (Estrenada el 24/04/84 al Teatre Regina de Barcelona)

$>$ 1985, Cavaret Voltaire. (Estrenada el 15/05/85)

$>$ 1985, La boqueta amplificada. (Estrenada el 21/05/85 al Teatre de l'Aliança del Poble Nou de Barcelona)

$>$ 1985, Roma. (Estrenada al Teatre Comtal de Barcelona)

$>$ 1985, Arganchulla, Arganchulla Gallac. (Encargo de l'Akademie der Künste de Berlin)

> 1986, Crèdit tonal. (Estrenada el 14/05/86 al Palau de la Música Catalana de Barcelona)

> 1986, Misericòrdia Ubach. (Estrenada el 27/10/86 al Teatre Poliorama de Barcelona)

$>$ 1988, Belmonte. (Estrenada el 4/11/88)

$>$ 1989, Tramuntana Tremens. (Estrenada el 30/11/89 al Mercat de les Flors de Barcelona)

> 1991, La grenya de Pasqual Picanya. (Estrenada el 12/04/91 al Teatre Adrià Gual de Barcelona)

$>$ 1992, Asdrúbila. (Estrenada el 20/07/92 al Teatre Tívoli de Barcelona para los Juegos Olímpicos de Barcelona)

$>$ 1995, L'esplèndida vergonya del fet mal fet. (Estrenada el 04/04/95 al Mercat de les Flors de Barcelona)

$>$ 1996, Figasantos-fagotrop: missatge al contestador, soparem a les nou. (Estrenada el 18/04/96 al Teatre Poliorama de Barcelona)

> 1997, La Pantera Imperial. (Estrenada el 30/05/97 a la Künstlerhaus Mousonturm de Frankfurt)

$>$ 2000, Ricardo i Elena. (Estrenada el 15/03/00 al TNC de Barcelona)

\footnotetext{
${ }^{41}$ García, J. M. y Rom, M. (1982): Finestra Santos. Ed. Cine-Club Assiciació d'Enginyers Industrials de Catalunya. Barcelona, p.5
} 
2000, El Barbero de Sevilla (direcció escènica). (Estrenada el 4/08/2000 al XIV Festival Castell de Peralada)

> 2001, L'adeu de Lucrecia Borgia. (Estrenada el 3/02/2001 al Palau de la Música de València, en el $500^{\circ}$ aniversario de la Universidad de València)

> 2002, Sama Samaruck, Samaruck Suck Suck (Ópera circo). (Estrenada en La Villete París el 26 de abril de 2002)

$>$ 2003, Lisístrata. (estrenada al Teatre de Mérida). (Estrenada el 7 de junio de 2003 en la II Bienal de València, en la Nave Sagunto)

$>$ 2003, El compositor, la cantant, el cuiner i la pecadora. (Estrenada en el TNC de Barcelona el 4 de noviembre de 2003)

> 2005, La meua filla soc jo. (Estrenada el 19 de mayo de 2005 al Teatre Lluire de Barcelona)

$>$ 2006, El fervor de la perseverancia.

$>$ 2006, Visca el piano. (exposición itirenante) ${ }^{42}$

$>$ 2007, Tirant lo Blanc. (Estrenada en la Feria de Fráncfort (Alemania))

> 2008, Brossalobrossotdebrossat. (Estrenada el 8/5/2008 en el Teatre Lliure de Barcelona)

> 2010, Chicha Montenegro Gallery. (Estrenada el 1/10/2010 en el Teatre Municipal de Girona, en el marco del Temporada Alta - Festival de tardor de Catalunya - Girona/Salt.)

$>$ 2011, Schubernacles humits. (Estrenada el, 19/11/2011 en el Festival Temporada Alta de Girona).

> 2012, El Gran Teatro del Mundo. (Estrenada el, 10/11/2012 en Friburgo).

${ }^{42}$ Experimentaclub. (sin fecha). Carles Santos. Madrid. S. reg. Recuperado de:

http://www.experimentaclub.com/data/carles santos/index.htm. (20 de julio de 2015) 
3.- Obra 


\section{OBRA}

\subsection{ANÁLISIS DE LA OBRA.}

Piano, voz, escenario y el resto de las artes. Para Carles Santos son elementos muchas veces indivisibles y a la vez complementarios. Pero todos ellos parten de la misma base: el piano. El piano y Santos. Santos y el piano. Como escribe Josep Ruvira ${ }^{43}$, a palabras textuales del autor:

\footnotetext{
"Yo quiero serle fiel a mi piano. [...] tener un buen instrumento en casa (...) te obliga a vivir con él en una auténtica relación de pareja. No debe perderse esa relación, visceral, fisica, sensual, erótica e incluso pornográfica"
}

Su obra es una obra viva para el intérprete. Puede ser modificada, alterada y combinada, dependiendo de la situación temporal en que se encuentre. Es una obra abierta que requiere, muchas veces, de la musicalidad del intérprete para su ejecución.

Los fragmentos repetidos libremente; la velocidad de ejecución que se adapta a la acústica del momento; la métrica de sus obras, no definida con exactitud y que debe adaptarse a la acústica, al público y a la sensibilidad del intérprete en ese momento; su utilización interpretativa para magnificar otro tipo de arte que se ejecuta a la par que la música, en momentos determinados. Son todos ellos elementos que hacen de esta producción musical un mundo en constante movimiento y progreso.

El lenguaje de la obra de Santos se ha catalogado de minimalista ${ }^{4445}$. Después de observar con detenimiento sus partituras no cabe otra reflexión que poner en duda tal afirmación.

Las distintas definiciones de Música minimalista nos dicen lo siguiente:

\footnotetext{
${ }^{43}$ Ruvira, J. (1996): El caso Santos. Valencia, Mà d'obra. Pág. 26

${ }^{44}$ La primera obra surge en Estados Unidos en el año 1958, siendo un trío de cuerdas compuesta por La Monte Young. Sin embargo, durante un buen tiempo este estilo se identifica bajo música experimental y no es hasta el año 1968 que surge la palabra "Minimalista" utilizada por Michael Nyman para describir el álbum The great Digest de Cornelius Cardew. Los compositores calificados de minimalistas son Terry Riley, Steve Reich, Philip Glass y el propio La Monte Young.

45 Tom Johnson lo califica como "minimalista romántico" y el propio autor se califica como "minimalista apasionado"
} 
[...] es un género [...] que empezó a ser creada en los años 1960 basada en la armonía consonante, en pulsos constantes, en lo estático o en las lentas transformaciones, a menudo en la reiteración de las frases musicales en pequeñas unidades como figuras, motivos y células. $^{46}$

La música minimalista es una categoría extendida y diversificada que incluye, por definición, toda la música que funcione a partir de materiales limitados o mínimos; las obras que utilizan solamente algunas notas, solamente algunas palabras, o bien las obras escritas para instrumentos muy limitados, como címbalos antiguos, ruedas de bicicleta o vasos de güisqui.

Tom Johnson (del Vocabulaire de la musique contemporaine, p. 91, editado por Minerve en 1992, ISBN: 2-86931-058-7)

El minimalismo se basa (su composición) en la repetición del material más básico de una obra, sea éste rítmico, melódico,... junto a otras características: vuelta a la tonalidad, simplificación de las formas, empleo privilegiado de los elementos de percusión, etc.

Pablo Vázquez Gómez. Guionista y articulista. www.filomusica.com/filo25/grana.html.

Aunque Santos fuera un destacado interprete de la música de Steve Reich (uno de los más destacados músicos minimalistas), esto no implica que sus composiciones siguieran la pauta marcada por él. Su lenguaje evoluciona, no se modifica; esta evolución se observa en su escritura manuscrita (no se trata del simple añadido o supresión de notas, sino del desarrollo del discurso musical) y además depende del momento en que es interpretado.

\begin{abstract}
"La mayoría de sus obras vocales (así como también algunas pianísticas) están estructuradas mediante aquello que puede ser denominado "expanding of incremental repetition" (desarrollo de la repetición progresiva) [...] de manera que las series repetidas son gradualmente desarrolladas [...]. Emplea muchos tipos de elementos que van desde notas cantadas y cortas melodías, hasta alaridos, llantos y gritos guturales, pasando por diferentes fonemas, sílabas y efectos realizados con la boca. Su voz presenta una amplia extensión de ataques y de registros que son cantados en falseto pero que muestran una claridad que parece la normal de un contratenor.. "47
\end{abstract}

Asimismo y tal como escribiera uno de los autores más consagrados del minimalismo musical, Michael Nyman:

\footnotetext{
${ }^{46}$ Música minimalista (5 de junio de 2015). En Wikipedia. Recuperado el 20 de julio de 2015 de: http://es.wikipedia.org/wiki/M\%C3\%BAsica minimalista (20 de julio de 2015)
} 
"el minimalismo hoy en día ya no existe, desapareció cuando los respectivos fundadores fueron cediendo el paso o cuando abandonaron su dedicación exclusiva para probar con otros estilos (caso deRiley), o dedicarse a un campo musical diferente. Por lo tanto, hoy puede que muchos músicos sigan experimentando con la estructura minimal, pero no son lo que en aquellos tiempos fue el auténtico sonido minimalista”,

Muchos han sido los adjetivos empleados para clasificar la obra de Santos: conceptualismo, minimalismo, músicas repetitivas americanas, etc. Tal y como destaca Josep Ruvira $^{48}$ :

A lo largo de la existencia de estas corrientes de la música americana, [...] pueden distinguirse tres etapas diferentes: la primera [...] años 50, [...] proponen la introducción de la indeterminación, anulando barreras entre el orden y el desorden, lo azaroso y lo controlado, [...]; la segunda, correspondiente a las décadas de los 60-70, está marcada por la música repetitiva, [...] basada en el concepto artístico minimalista, [renunciando] a las funciones formales de la tradición clásica. [...] Por último [...] la integración de recursos tanto de la música seria tradicional como los provenientes de la contemporánea, pop, músicas étnicas, etc. De todos estos momentos, Carles Santos participa de una manera más o menos consciente.

Es por ello que tanta dificultad entraña la catalogación de la obra de Santos. Se podría adelantar que el minimalismo está más patente en sus obras para piano o voz; que la indeterminación forma parte de toda su obra en general, aunque muy vinculado a sus acciones musicales o sus espectáculos escénicos (exceptuando sus óperas); que el respeto por las formas y estructuras clásicas está presente en todas sus obras y que la integración de recursos es recurrente en toda su obra. Pero afirmar esto categóricamente, es errar en la catalogación de su obra. La indeterminación y la improvisación, o como mejor se puede expresar, la adaptación de la obra al momento de su interpretación, es lo que mejor define la obra de Santos.

En cuanto a la utilización de los diferentes componentes del lenguaje musical, se observa lo siguiente:

\footnotetext{
${ }^{47}$ Mac Low, Jackson (1981): Voice Tracks, New York.

${ }^{48}$ Ruvira, J. (1996): El caso Santos. Valencia, Mà d'obra. Pág. 80 y 81.
} 


\subsubsection{ESTRUCTURAS Y FRASEO:}

Las estructuras formales en las obras de Santos se apartan de las concepciones clásicas y/o estipuladas, sin renunciar por ello, a la importancia que este elemento musical tiene en la concepción de la obra. Las estructuras o repeticiones de motivos en grupos de 4 son muy habituales en sus obras. Esto les confiere una solidez impresionante. Tanto en las formas menores (obras para piano o voz) como en sus formas mayores (óperas y espectáculos escénicos).

La escritura de Santos, en sus manuscritos es muy personal:

$\checkmark$ Utiliza, habitualmente, blocs de escritura musical para sus manuscritos. Estos son de tamaño A4, apaisados, con tapas amarillas y de 30 páginas.

$\checkmark$ En las hojas de estos blocs, solamente escribe en las páginas impares, dejando las páginas pares (o reversos) para anotaciones o cambios. En caso de que lo escrito en estas páginas tenga validez, numera las mismas con la misma cifra de la página anterior y un Bis.

$\checkmark$ Cada grupo o motivo es escrito en un pentagrama o sistema, por separado.

$\checkmark$ Las repeticiones no se señalan habitualmente como tales, sino con doble barra divisoria al final del motivo a repetir.

$\checkmark$ No suele utilizar el signo de clave en sus manuscritos. En este caso, se sobreentiende que "la música escrita está en clave de sol". 49

$\checkmark$ Las figuras musicales no son empleadas como tales, sobre todo en aquellas obras con un componente de improvisación. Las plicas o los valores conceptuales, desaparecen. La manera de interpretar este lenguaje está desarrollada en el apartado Interpretación Musical del lenguaje de Carles Santos.

$\checkmark$ En contadas ocasiones sus manuscritos incluyes referencias a la dinámica a emplear.

$\checkmark$ Tampoco son habituales las indicaciones agógicas.

$\checkmark$ No suele utilizar el signo de compás al principio de sus composiciones, aunque se averigua por las líneas divisorias.

$\checkmark$ Modifica sus composiciones adaptándolas al elemento escénico que las acompaña. Estas modificaciones suele realizarlas en fotocopias de sus manuscritos, no directamente en estos.

\footnotetext{
${ }^{49}$ Testimonio oral del autor.
} 


\subsubsection{ARMONÍA:}

La concepción armónica en las obras de Carles Santos es difícilmente clasificable, dentro de los parámetros establecidos.

“Utilizo la armonía como soporte para la creación de sensaciones. No sigo una pauta establecida y no tengo reparo en conjugar armonía clásica con clusters si con ello puedo expresar lo que siento. Para mí la alternancia tonalismo/atonalismo es natural, ya no constituye una pelea. "50

Si hablamos de su evolución armónica, en sus primeras obras posee una concepción más clásica de la armonía, muy cercana al romanticismo y, hasta cierto punto, contrapuntística, puesto que la armonía surge de la misma melodía. Dado que en estos principios, la música para piano es mayoritaria en sus composiciones, gran parte de sus obras están impregnadas de armonías tonales. Aunque siempre existen excepciones, como la Serie 3-C para piano, con un lenguaje armónico más cercano a la atonalidad. Incluso en aquellas obras en las que rinde homenaje a J. S. Bach, el lenguaje armónico es modal.

En una segunda etapa, su lenguaje armónico se vuelve más atrevido, con la utilización de clusters, que en muchas ocasiones "disfrazan” una concepción melódica más tonal. En gran parte de sus obras, el uso modal que hace de la armonía es más que evidente. Mayoritariamente, y sobre todo en sus obras escénicas, el lenguaje armónico está a disposición de la expresividad, mezclando todo tipo de lenguajes armónicos con la única finalidad de hacer llegar al público su expresión.

\subsubsection{LENGUAJE:}

Dos son los autores que marcan la obra de Santos: Juan Sebastián Bach ${ }^{51}$ (“cada día comienzo mis ejercicios al piano interpretando música de Bach") y Giacomo Rossini.

Del primero toma la fluidez de su discurso musical, la técnica pianística ("me gusta más como suena Bach al piano que al clave,52), y la estructura formal. Del segundo su lirismo y simpleza musical.

\footnotetext{
${ }^{50}$ Testimonio oral del autor.

${ }^{51}$ Ruvira, J. (2008): Los desafíos artísticos de Carles Santos. Valencia, Institució Alfons el Magnànim, p.22
} 
De ahí que el lenguaje de Santos esté impregnado de un virtuosismo, tanto instrumental como vocal, muy acentuado. Este virtuosismo siempre está a disposición de la expresividad y, muchas veces, de la línea melódica, que se destaca de todo el entramado musical de su obra. Y esta línea melódica es, mayoritariamente, clara como en las obras clásicas y repetitiva, semejante a la música minimalista.

Además se debe citar a su maestro, John Cage. No como un elemento formador de sus estructuras, sino como elemento formador de sus concepciones artísticas, generalmente no musicales.

\subsubsection{1.- EXPERIMENTO PEDAGÓGICO.}

"Mi música morirá conmigo",53

En las conversaciones mantenidas con Carles Santos a lo largo de la realización de este trabajo, en varias ocasiones se ha comentado su personal manera de escribir la música en sus manuscritos. Y en cada una de estas ocasiones, el autor argumentaba que, puesto que esta música estaba pensada para ser interpretada por él mismo, se sentía cómodo con esta forma de escribir y no necesitaba ningún elemento más que aquellos que constaban en sus manuscritos. Ante la pregunta de qué pasaría si esta música se diese a interpretar a otros pianistas, sin más referencias que las que constaban en sus manuscritos, el autor aducía que no creía esto probable, puesto que no confiaba en que esta música pudiese interesar a otros intérpretes. Y por otra parte, siempre ha mantenido que, en caso de editarse, esta edición debería respetar la forma de escritura que consta en estos manuscritos. Ante estas afirmaciones, surgieron dos cuestiones que consideramos de interés en este trabajo:

$\checkmark$ En primer lugar, se debería realizar un análisis de lenguaje y escritura musical del autor, con la finalidad de acercar este, sin modificar su aspecto, a la idea que el autor defiende en sus interpretaciones. Esto comportaba elaborar una serie de pautas interpretativas ante la escritura personal del autor que permitiese, a otros intérpretes, defender sus obras con el máximo rigor posible, atendiendo a las características estéticas que Santos defiende en sus obras, al mismo tiempo que dejara a estos intérpretes, la libertad de ejecución que el autor defiende en sus

\footnotetext{
${ }^{52}$ Guerrero, M. (2006): Carles Santos. Visca el Piano!. Fundació Joan Miró. Barcelona, p.399

${ }^{53}$ Testimonio oral del autor
} 
ideales y justifica en sus grabaciones, siempre desde el máximo respeto hacia su obra. Para ello se debería ofrecer a estos intérpretes la posibilidad de ejecutar alguna de las obras pianísticas de Santos. Se desconocía, hasta el momento, la reacción de los intérpretes ante una partitura "diferente" en cuanto a sus elementos constitutivos de escritura musical, teniendo como premisa, no ofrecer ningún tipo de información sobre la misma, y esperar que estos aplicasen su criterio musical para resolver los problemas interpretativos que fuesen surgiendo.

$\checkmark$ Por otra parte, y dado el carácter libre que el autor imprime en sus interpretaciones, se plantea la posibilidad de incluir estas obras en el repertorio pedagógico de las enseñanzas oficiales, otorgando a estas el papel de nexo de unión entre la técnica y la improvisación interpretativa. Este campo, que no ha sido trabajado en los conservatorios españoles, plantea un nuevo reto en las enseñanzas musicales. De entrada, no se tienen referencias en cuanto a su idoneidad atendiendo a las opiniones de los profesores y los alumnos. Por tanto se plantean una serie de cuestiones: ¿pueden los alumnos de piano sacar conclusiones positivas de la interpretación de las obras de Santos? ¿Se encuentran cómodos en el rol de intérpretes "libres"?. El trabajo e interpretación de estas obras ¿llena un vacío pedagógico que no está representado por las obras incluidas en los currículos de las enseñanzas musicales?

Para contestar estas preguntas se realizó un experimento interpretativo, contando con la colaboración del Conservatorio Profesional de Música Francisco Tárrega de Castellón, en concreto del profesor titular de la especialidad de piano y conocedor de la obra de Santos al ser interprete de su música en algunos de sus espectáculos, Dr. Oscar Campos Micó. El mismo consistía en ofrecer a 4 alumnos de Grado Profesional ${ }^{54}$ y al Dr. Campos, dos partituras manuscritas de Santos, para su estudio y posterior ejecución y grabación. Al finalizar las distintas ejecuciones de las piezas los alumnos debían comentar las dificultades encontradas y su opinión sobre las mismas. Se partió de dos premisas: eliminar el título de las piezas y no dar ninguna información sobre ningún aspecto de las mismas. Estas premisas también se aplicaron al profesor. Las piezas elegidas para el experimento fueron Bujaraloz by night y Piano a 4 mans.

\footnotetext{
${ }^{54}$ Ester Botet ( $\left.3^{\circ} \mathrm{GP}\right)$, Marc Martí (4a GP), Laura Villalva ( $\left.3^{\circ} \mathrm{GP}\right)$ y María Adelina ( $\left.3^{\circ} \mathrm{GP}\right)$.
} 
Durante 4 semanas los alumnos trabajaron con el Dr. Campos las piezas, de forma individual la primera y por parejas (piano a 4 manos), la segunda. Al finalizar este periodo, se grabaron en video las interpretaciones de las mismas, se comentaron las dificultades encontradas, las novedades aportadas por estas partituras y se organizó un debate sobre las opiniones de los intérpretes. Posteriormente, se comentaron los aspectos básicos de ejecución a tener en cuenta y se volvieron a interpretar las mismas, volviendo al debate anterior, pero ahora con conocimiento de los criterios interpretativos básicos.

Algunas de las preguntas que surgieron al serles entregadas las partituras fueron las siguientes:

"Como debemos interpretar esta obra?"

Por lo que respecta a la obra Bujaraloz by night, comentar que al finalizar las interpretaciones se realizaron una serie de preguntas como:

Diferencias que encuentras entre esta partitura y una convencional.

Todos argumentan la falta de compás, de medida, la carencia de plicas o de alteraciones. Cabe destacar opiniones como que ven una obra más libre que una convencional y por ello con más criterio de decisión para el intérprete que no para el compositor.

Te ha supuesto un motivo de duda la carencia de elementos de lenguaje musical en la partitura?

○ $\mathrm{Si}$, en un principio, por ver "tantas notas sueltas", pero al ir comprendiéndola, estas dudas desaparecen. La falta de información de un principio desaparece al trabajar la obra ya que esta información va implícita en la misma.

○ No. Todo lo contrario ya que "al no tener un profesor que me dijera como he de hacerlo, me he sentido mucho más libre".

Te has encontrado más atada o más libre, en cuanto a la interpretación, con respecto a una partitura convencional?

Más libre.

Has variado las interpretaciones día a día y si es así en base a qué criterios?

○ No.

- Si, poco a poco he moldeado la obra en base a mi criterio.

○ "La he interpretado como me ha nacido".

Modificarías la interpretación trabajada ante una audición con público?

No. Es como una marca personal que yo aporto a la obra. 
Ves interesante la inclusión de obras con lenguajes diferentes a los convencionales en los planes de estudio?

$\mathrm{Si}$, la mayoría, excepto una alumna que prefería la escritura convencional y dirigida interpretativamente, por el profesorado.

Qué pueden aportarte?

Más expresividad interpretativa que viene dada por la mayor libertad que sugiere este lenguaje.

Comentarios personales

- La interpretación de esta obra ha sido una experiencia provechosa por la novedad.

○ "Me he sentido muy cómoda interpretando esta obra, con respecto a las obras de los periodos barroco, clásico o romántico. No se parece a nada a lo interpretado hasta este momento por mí."

○ "La he visto como una improvisación".

○ "La toques como la toques, siempre suena bien"

A todos les ha interesado conocer al autor. De hecho, una de las alumnas la atribuyó al profesor, Dr. Campos, en un principio.

Los propios alumnos, al no tener ninguna referencia interpretativa, ni por parte de la partitura ni tampoco de su profesor, sacaron una serie de conclusiones previas, con anterioridad a la interpretación de la obra. Estas conclusiones, que afectan a la manera de tocarla, si bien fueron dispares y muy personales, mantienen una serie de puntos en común. Estos puntos en común mantienen cierta direccionalidad paralela a las interpretaciones del autor, aunque existen discrepancias llamativas a estas interpretaciones. Es por ello por lo que se ha pensado en realizar un estudio interpretativo de la escritura de Santos, que permita las futuras ejecuciones rigurosas de sus obras. De las referencias adoptadas por los alumnos ante el estudio previo y posterior ejecución de la obra se deduce que:

$\checkmark$ La velocidad es bastante uniforme en las cuatro.

$\checkmark$ El rigor en el tempo no existe en ninguna.

$\checkmark$ Cada uno de los fragmentos es interpretado una sola vez.

$\checkmark$ Existe una pequeña pausa entre cada uno de los fragmentos escritos.

$\checkmark$ Las notas expuestas entre paréntesis por el autor, han sido una de las diferencias interpretativas, ya que cada alumno ha mantenido un criterio con ellas: desde 
considerarlas las más importantes del discurso musical, pasando por no considerarlas diferentes a las demás hasta no considerarlas y por tanto no ejecutarlas.

$\checkmark$ Ocurre lo mismo con las notas encercadas.

$\checkmark$ La utilización del pedal es completamente libre y diferente en cada ejecución. Se ha utilizado el pedal ligado a la armonía intrínseca, a las frases o sistemas expuestos en la partitura o de una forma completamente libre.

Por lo que respecta a la obra Piano a 4 mans, mayoritariamente coinciden las ideas expuestas anteriormente, aunque con unas significativas diferencias:

La medida se ha racionalizado con la finalidad de facilitar la interpretación y el ajuste de las dos pianistas.

Los comentarios ante la ejecución de esta obra difieren con respecto a la obra anterior. A las alumnas no les ha parecido cómoda la escritura de la misma, han tenido que poner en valores las notas escritas y, ante estos valores, han ido modificando la línea melódica pero no esos valores, aunque por otra parte, siguen coincidiendo en la libertad interpretativa, "es como si la hubiésemos compuesto nosotras". Coinciden en la diferencia del lenguaje, en cuanto a las disonancias expuestas, con respecto a la obra anterior.

Si bien las semejanzas interpretativas de la primera de las obras, entre los distintos alumnos o profesor, e incluso en la versión del propio autor, son evidentes, la interpretación de la obra Piano a 4 mans dista mucho de ser la que realiza Santos. Y esta diferencia radica en una falta de información básica, que es la manera de sentarse los ejecutantes. Las alumnas se han sentado al piano de manera convencional. Por tanto, una de ellas interpretaba los dos pentagramas superiores (en clave de sol) al sentarse a la derecha, y la otra, los dos inferiores (en clave de fa). Ello ha afectado a la ejecución ya que en algunos momentos, el cruce de manos o el poco espacio disponible entre manos implica un trabajo extra. La correcta distribución espacial de los ejecutantes en esta obra, es atípica. Deben sentarse uno detrás de otro. Con ello, el que se encuentra sentado delante, más cerca del teclado, interpreta los dos pentagramas centrales y el segundo, sentado detrás y por tanto más alejado del teclado, interpreta los dos pentagramas exteriores. De esta manera, los problemas de ejecución desaparecen. Pero hace falta esta información a los ejecutantes. Es por ello que se cree necesario un estudio interpretativo de las obras de Santos, atendiendo a su escritura y a las connotaciones particulares de cada obra. Este estudio será expuesto a continuación. 
De este trabajo interpretativo y posterior debate de deducen las siguientes ideas:

$\checkmark$ Los alumnos se sienten cómodos trabajando obras con libertad interpretativa.

$\checkmark$ Esta libertad permite aligerar la carga lectiva que supone el temario de Piano.

$\checkmark$ A los alumnos les ofrece una motivación extra que repercute positivamente en el resto del temario.

$\checkmark$ El componente de "improvisación" y libertad que ofrecen estas obras no lo encuentran en ninguna de las referidas en el temario.

$\checkmark$ Ven muy positivo contar con repertorio de este tipo, por varios factores:

○ por la parte de novedad de contenidos,

○ novedad en el análisis y conocimiento de nuevos lenguajes de escritura,

○ el trabajo de interpretación que proporcionan estas obras, ante el trabajo técnico que predomina en el resto de obras del curso.

Es por ello que, después de la realización de este experimento, se deduce que la obra pianística de Carles Santos es muy válida, tanto para ser interpretada por otros pianistas como para ser incluida en los temarios de las enseñanzas musicales en España. Abrir nuevos horizontes a los futuros pianistas y aprender a ser crítico y tener personalidad en las interpretaciones son dos de los objetivos que se plantean en estas enseñanzas. Y las obras de Santos cumplen estos objetivos, como ha quedado demostrado.

Este experimento y sus resultados, están incluidos en el Anexo 9.2.4. de esta tesis.

\subsubsection{2.- ESTUDIO INTERPRETATIVO}

Que el lenguaje es un elemento vivo en constante evolución queda patente en todas las partes del mundo y en todos los momentos de la historia. Bien sea por necesidad, por intromisión de otras lenguas o por adaptación a los nuevos medios (léase papel sobre pergamino o pantallas táctiles sobre papel, en los últimos tiempos), las pequeñas modificaciones de este se van asentando en los usuarios convirtiéndose en norma a lo largo del tiempo. Esto no quita que este lenguaje tenga una serie de variantes geográficas, que si bien son evidentes, no impiden la comprensión del mismo a mayor escala. Además, esta evolución permanente requiere de continuas revisiones por parte de los organismos pertinentes, que posteriormente informan de los cambios adoptados a través de los medios oficiales. 
En algunas ocasiones, estas modificaciones aparecen a través de un único canal y cabe preguntarse si han de ser o no aceptadas. La nueva utilización del lenguaje en aplicaciones como wasap ha creado controversia en los organismos oficiales y en la opinión de la gente. Estas opiniones dispares sobre si daña o no el lenguaje, quedan resumidas en las palabras de José Antonio Pascual"55: "no la dañan, son formatos distintos". 56

En el caso del lenguaje musical, no existe una Academia que regule estos cambios, sino Tratados Teóricos personales, que presentan estas modificaciones adoptadas por los compositores. Pero al igual que ocurre con las nuevas tecnologías, estos cambios son, hoy en día, más habituales y personales y, si bien la información que podemos tener sobre ellos es más global gracias a estas nuevas tecnologías, sigue habiendo un vacío en este aspecto (que podría ser el punto de partida de un nuevo trabajo de investigación) y en muchas ocasiones esta falta de información perjudica la interpretación de una serie de obras.

Con la aparición de la imprenta musical, a principios del siglo XVI, se unificó la escritura musical. A partir de aquí, y con la finalidad de hacerla más precisa, se incorporaron elementos nuevos, aceptados por todos, que regulan más la correcta interpretación. Es lo que atestigua Ana María Locatelli ${ }^{57}$ en palabras de Jacques Chailley, que la denomina "notation orthochronique". Pero incluso esta notación es imprecisa. De ahí que los profesores de los conservatorios sigan enseñando detalles de fraseo, agógica o dinámica, entre otros, a sus alumnos. Si además tenemos en cuenta detalles como la libertad interpretativa que algunos compositores dejan a los ejecutantes (léase Santos ${ }^{58}$ ) en menor o mayor medida (Bussoni llega a una aleatoriedad gráfica total), se puede comprender la imprecisión del lenguaje musical.

Esta imprecisión puede ser involuntaria o voluntaria. En el caso de Carles Santos, es voluntaria. Pate de la premisa de la libertad de ejecución y la adaptabilidad de esta a las circunstancias que rodean dicha interpretación: lugar, público, estado anímico, etc. Pero por otra parte, la carencia de recursos mínimos de la "notation orthochronique" o la

\footnotetext{
${ }^{55}$ José Antonio Pascual, (Salamanca, 1942) es vicedirector de la Real Academia Española de la Lengua (RAE).

${ }^{56} \mathrm{http}: / /$ www.lavanguardia.com/cultura/20130307/54368078967/entrevista-jose-antoniopascual-rae-whatsapp.html

${ }^{57}$ Locatelli de Pergamo, A. Ma . (1973): La notación de la música contemporánea. Buenos Aires, Ricordi Americana S.A.E.C.

58 "La interpretación, como en gran parte de mis obras, se deja al instinto musical del intérprete y a las características del momento y lugar de la interpretación". Testimonio oral del autor.
} 
adaptabilidad de esta notación a su particularidad, hace que sus manuscritos carezcan de una base interpretativa, que se ha visto reflejada en el experimento anterior.

Carles Santos siempre ha manifestado públicamente que la edición de su obra debe realizarse de acuerdo a la escritura en sus manuscritos y no ha de modificarse nada de lo allí expuesto. La ejecución de sus obras a partir de estos manuscritos deja muy abierta la puerta a dudas o incluso, como se ha demostrado en su pieza Piano a 4 mans, a la imposibilidad de su ejecución, sin unas mínimas pautas.

En vista de todos estos condicionantes, se ha creído conveniente realizar un estudio interpretativo que de luz a esta particular escritura musical.

La carencia de recursos escritos, en los manuscritos de Santos, va menguando a través del tiempo. Así, sus primeras obras, sobre todo las escritas para el piano, poseen menos elementos de la "notation orthochronique" que las últimas. A través del tiempo, el autor va incorporando elementos de notación a sus manuscritos, que por tanto ofrecen más información interpretativa que los primeros.

La evolución en la escritura manuscrita de Santos es evidente. Las primeras obras, escritas en las décadas de los 70 y 80 del pasado siglo, carecen, en su mayoría de elementos tales como claves, compás, medida, agógica, dinámica o signos de repetición. A partir de 1990, aproximadamente, comienza a utilizar con más asiduidad las claves y la medida, aunque el elemento del compás, ligado invariablemente a la medida, debe adivinarse. Las últimas obras ya contienen la mayoría de los elementos (siguen faltando, en ocasiones, los elementos de agógica, dinámica o signos de repetición).

A continuación se pasa a presentar algunas de las particularidades de esta escritura, y a valorar y explicar la aproximación a una correcta ejecución, siempre desde las premisas de libertad y rigor, que impregnan las ejecuciones de Santos. 


\section{a.- Claves:}

En gran parte de los manuscritos de Santos, sobre todo de sus apuntes y obras para piano, el autor omite las claves al principio del primer pentagrama y por consiguiente, de todos los demás. En este caso, se debe pensar que ambos pentagramas están escritos en clave de sol.

\begin{tabular}{|l|l|l|l|l|}
\hline Busca la Perdiu, 1986?, (archivador 16) & Manuscrito \\
\hline Peça per a piano (VIII), s. d. (archivador 16) & Manuscrito \\
\hline
\end{tabular}

\section{b.- Medida:}

Se encuentra, en gran parte de los manuscritos de Santos, una escritura musical "ortocrónica" que carece de elementos como las plicas, los corchetes, las barras o el blanqueo de las notas. En este caso, la medida es libre. De entrada no existen notas más largas o más cortas. Las fluctuaciones de medida de los distintos sonidos escritos, son a libertad del intérprete.

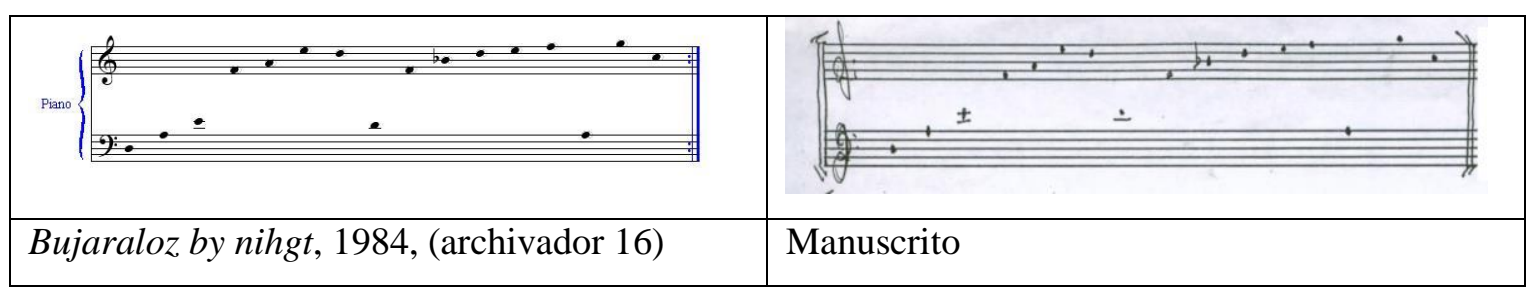




\section{c.- Compás:}

La carencia de la escritura del compás en sus manuscritos es otro de los recursos recurrentes en Santos. La carencia del mismo no significa libertad en la acentuación ya que sí existen las líneas divisorias. En la mayoría de estos manuscritos, si existe la medida de las notas escritas. Se debe tener en cuenta la reunión de las figuras en grupos unidos por barras para concretar el compás utilizado por el autor. Además los cambios de compás son frecuentes.

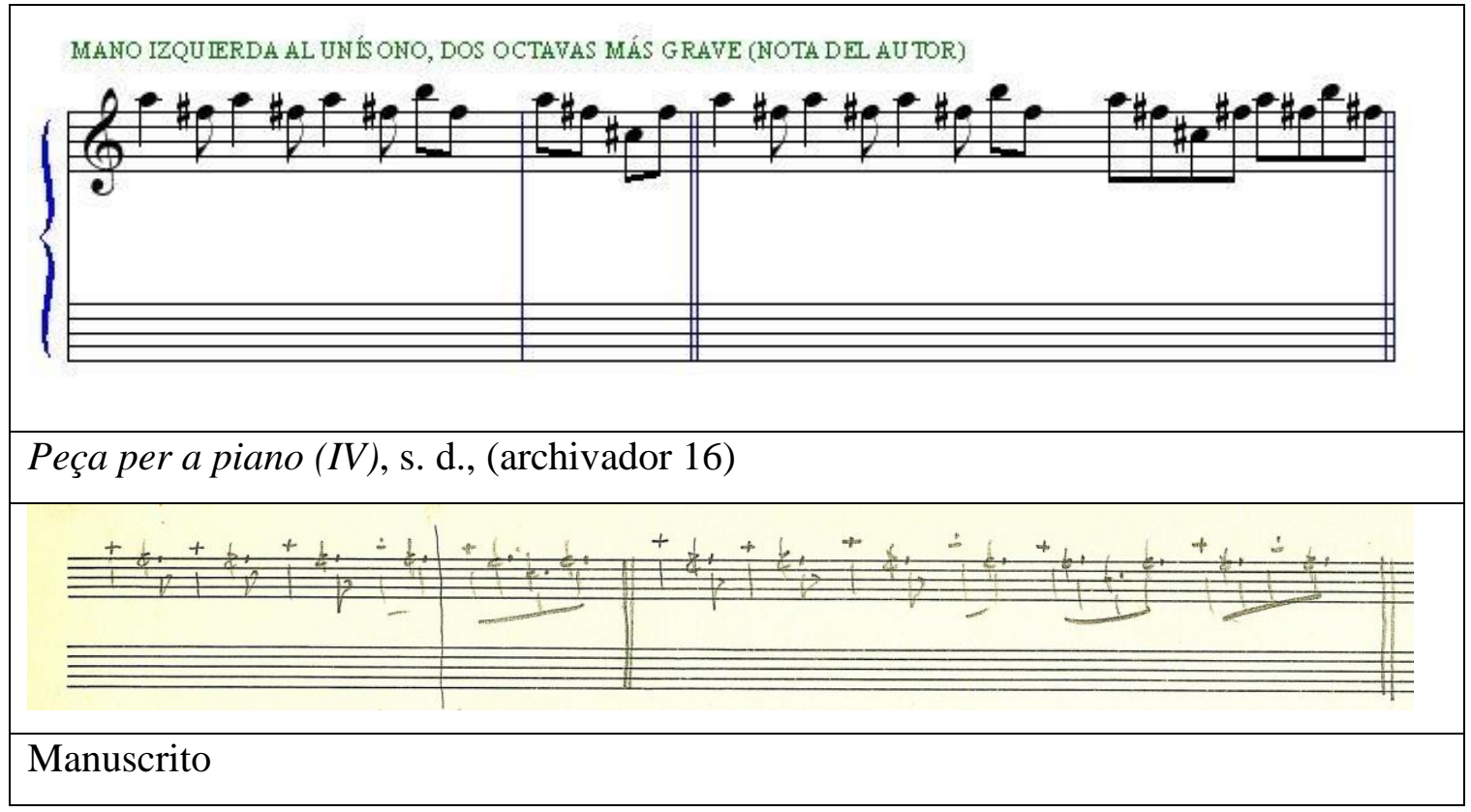

En este caso, los dos fragmentos representados son diferentes; el primero contiene dos compases ( $9 / 8+1 / 4$ el primero y 2/4 el segundo) y el segundo fragmento tendría 3 (9/8 $+1 / 4$ el primero y $2 / 4$ el segundo y tercer compás).

\section{d.- Dinámica:}

En contadas ocasiones encontramos dinámicas en los manuscritos de Santos. Las variantes dinámicas, en las secuencias repetidas, son al gusto del intérprete. Y en los fragmentos no repetidos, no suele existir tampoco ninguna indicación al respecto. Dentro de esta idea general, si encontramos detalles que fijan esta dinámica en obras como Peça piano Pelicula Cadena, en la que en las dos páginas de que consta el manuscrito, encontramos 4 indicaciones precisas aunque escritas a distintos niveles: o bien en su lugar correspondiente, por debajo del pentagrama, o bien al final de una secuencia, que ocupa todo un pentagrama. 


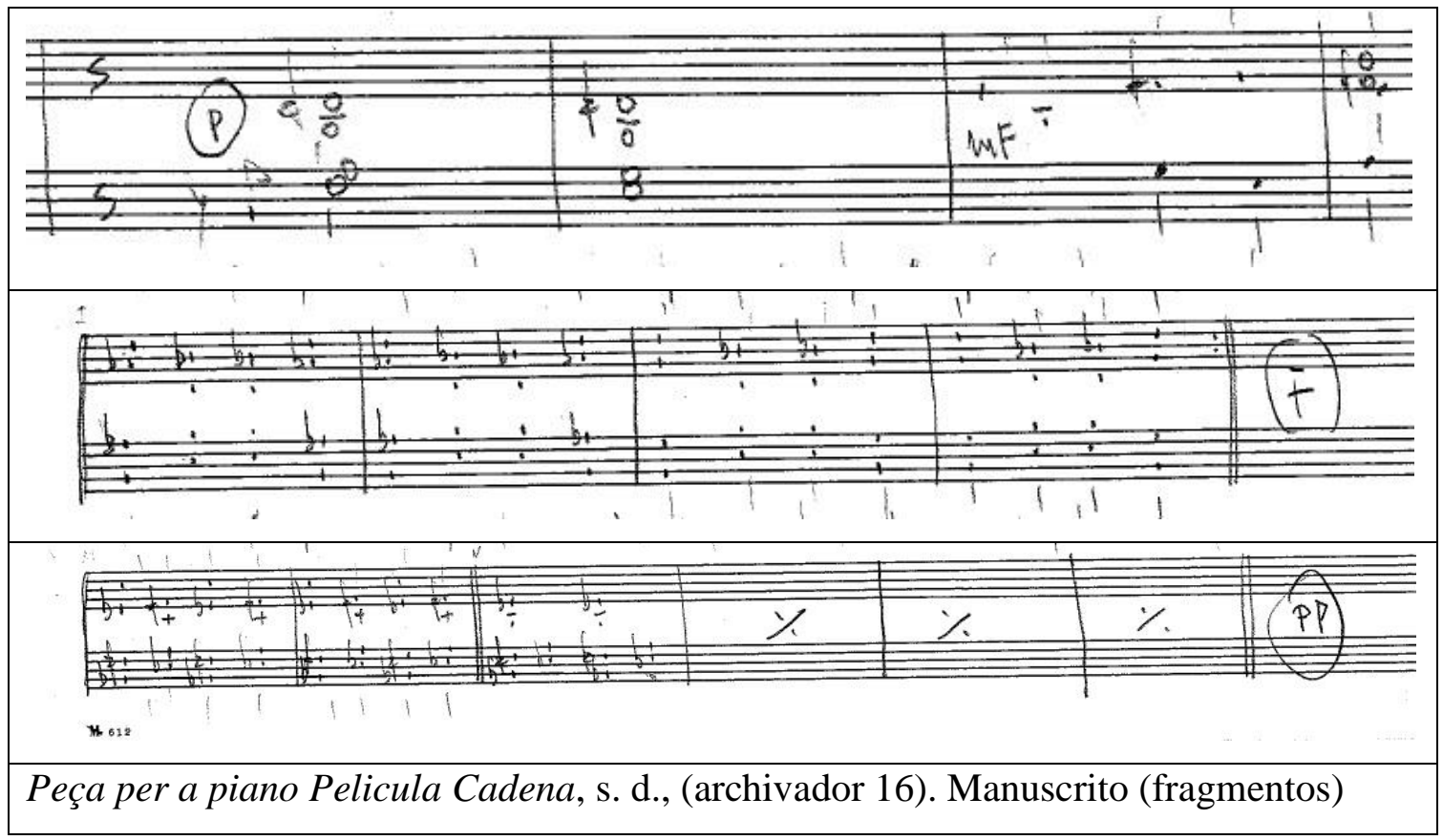

\section{e.- Agógica:}

Pocas veces el autor utiliza los recursos musicales escritos de la agógica en sus obras. Además cuando lo hace, no suele utilizar los términos italianos habituales, sino que indica la velocidad de la misma con términos en catalán (“més rapid”, "lent”, etc). En caso de no existir terminología, se debe partir de una velocidad moderada, como en el ejemplo siguiente.

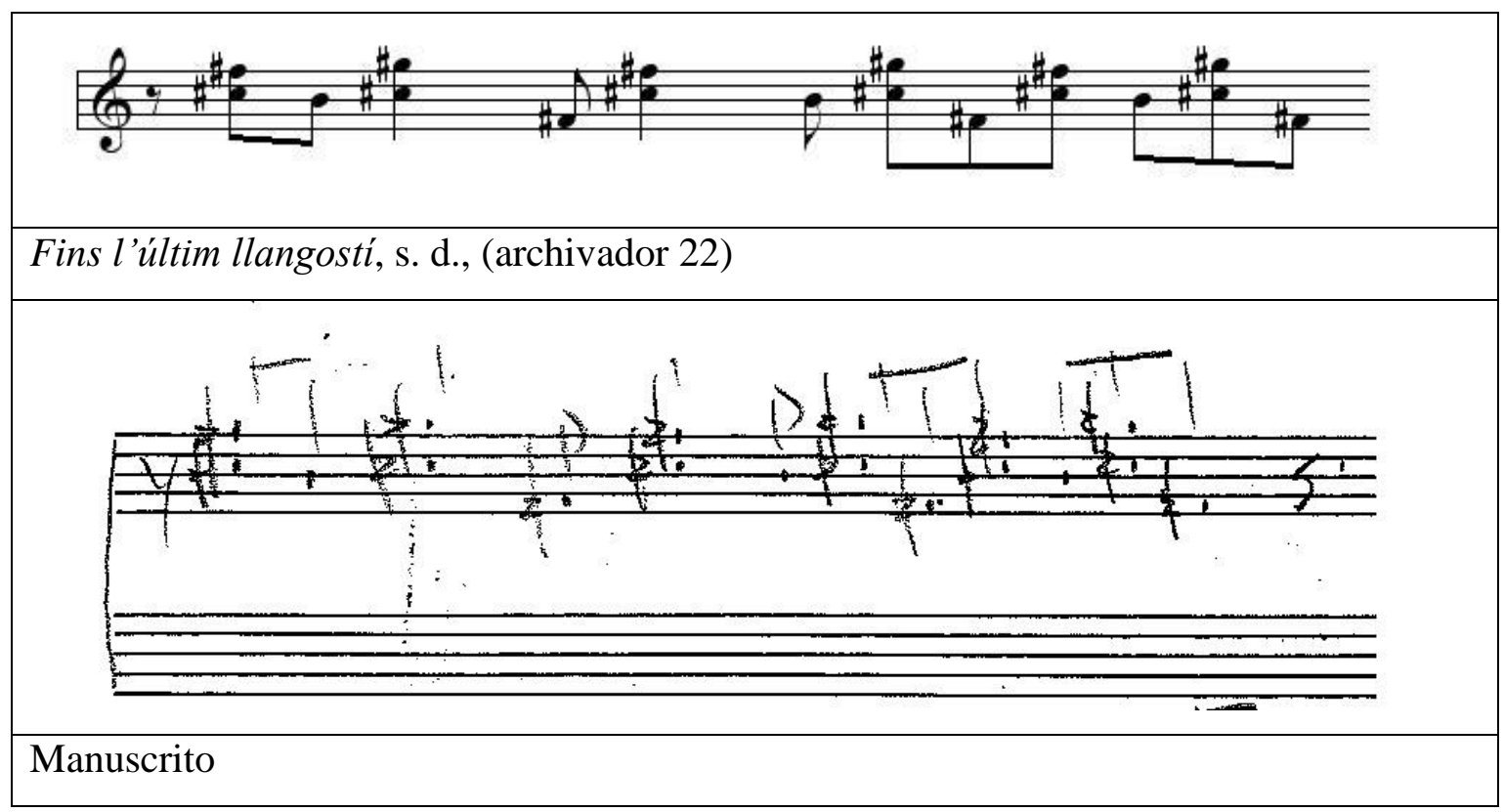


En este caso y confrontando con la grabación existente en el disco Carles Santos: Piano, la velocidad de pulsación es de 105 aproximadamente.

A continuación se muestra un ejemplo de la utilización de signos de agógica, según el autor.

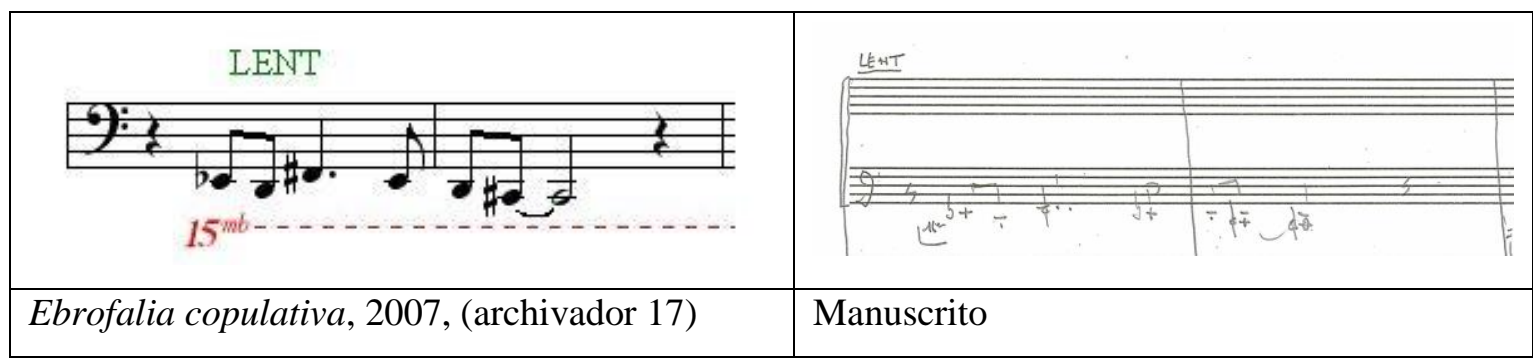

De este recurso musical existen variantes, dependiendo de la escritura musical:
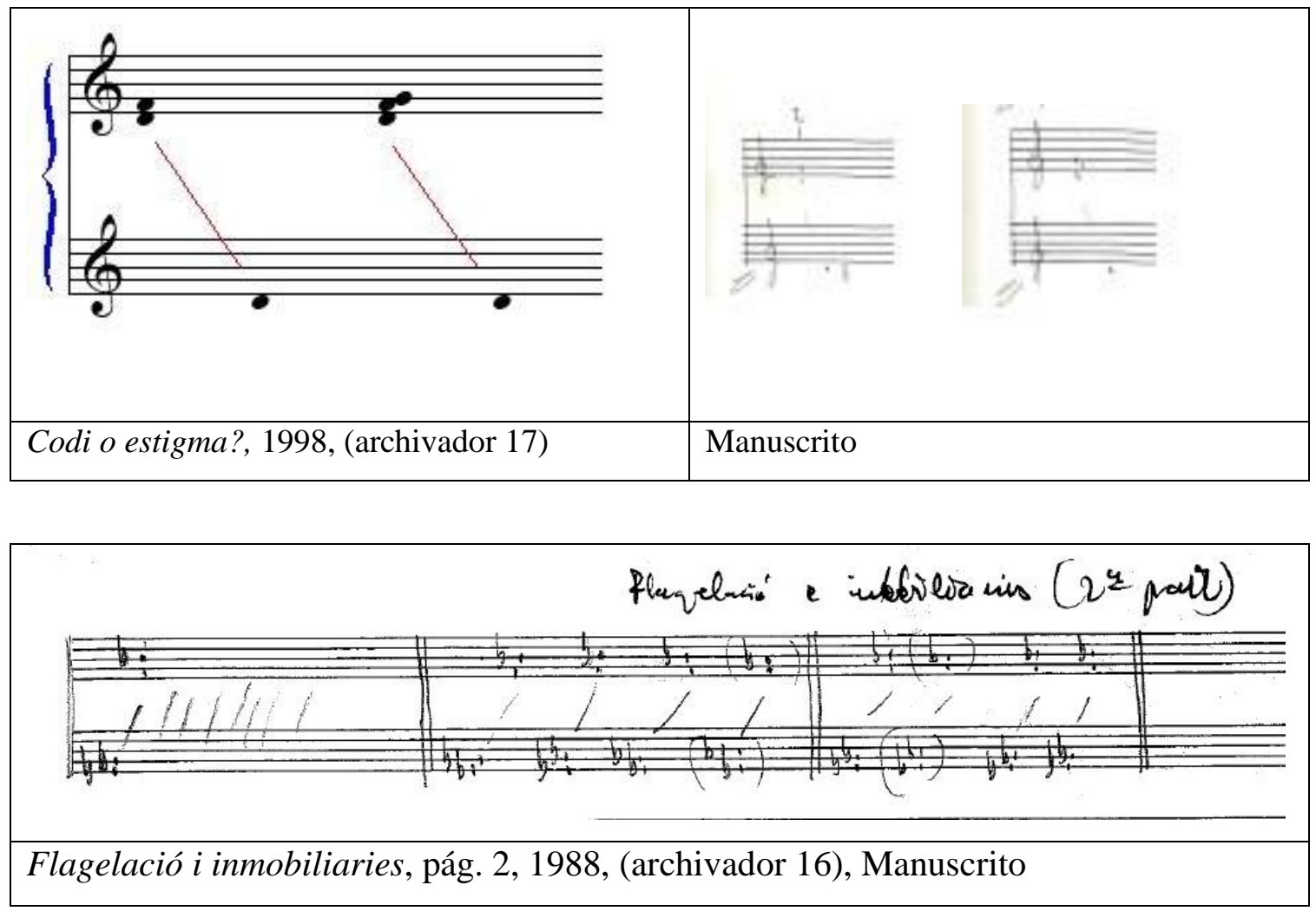

La línea que marca el compositor entre los dos grupos de notas escritos, en ambos pentagramas, indica que la velocidad de su ejecución debe ser los más elevada posible. Asimismo, las veces a interpretar ambos grupos es variable y a criterio del ejecutante. Los diseños escritos entre paréntesis son variantes a ejecutar, a gusto del intérprete. 


\section{f.- Signos de repetición:}

Los signos de repetición al uso no son utilizados por Santos. El signo habitual de la doble barra de repetición es cambiado por una doble barra al uso.

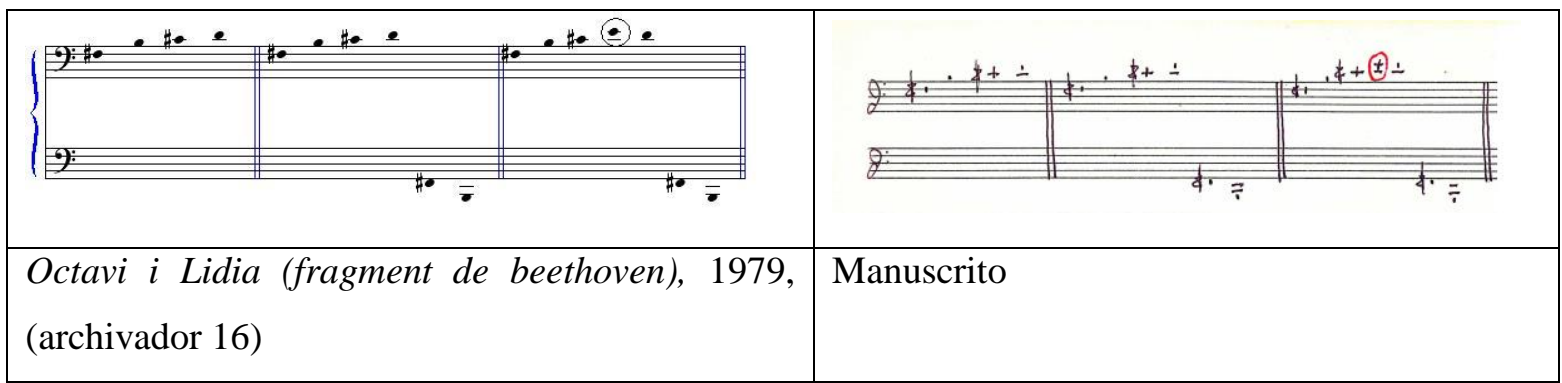

Por otra parte, las repeticiones de los fragmentos suelen realizarse 4 veces y no dos como es habitual. En algunas ocasiones, el autor lo marca, añadiendo un número entre paréntesis, o bien al final o bien a mitad del fragmento a repetir. Habitualmente, este número suele ser 4 , aunque encontramos en sus manuscritos el 6 con asiduidad.

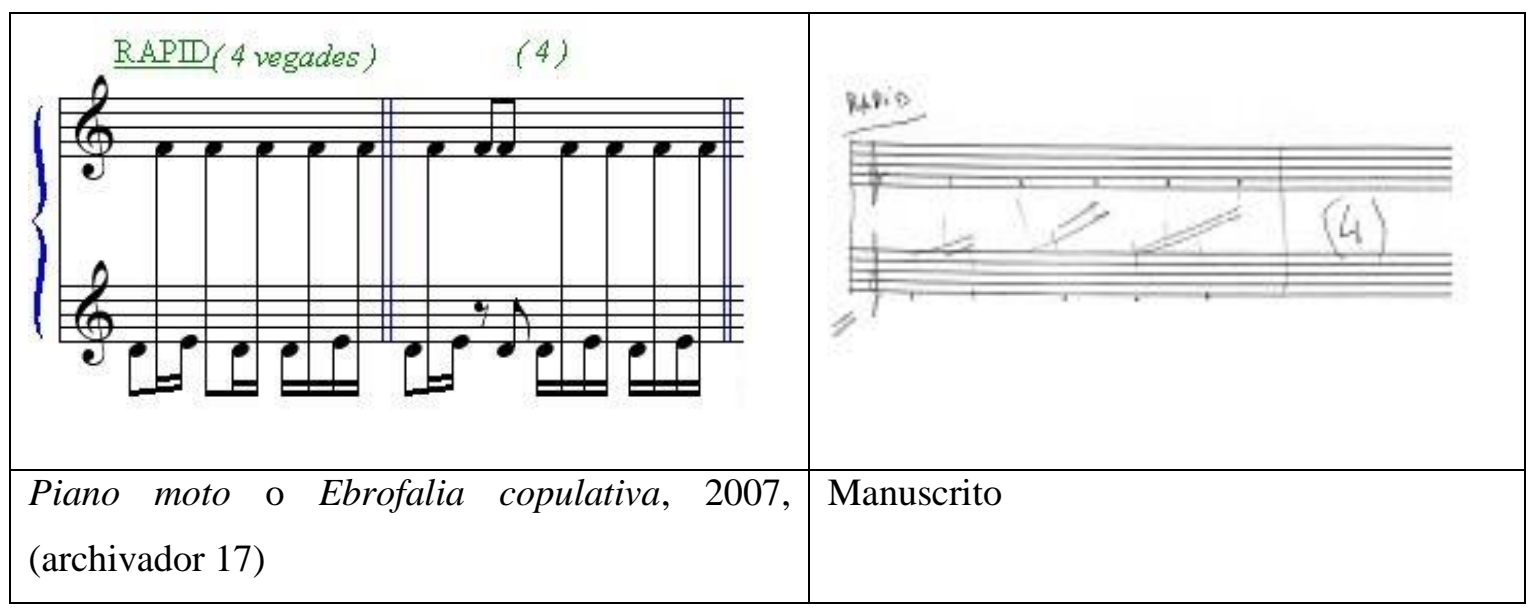




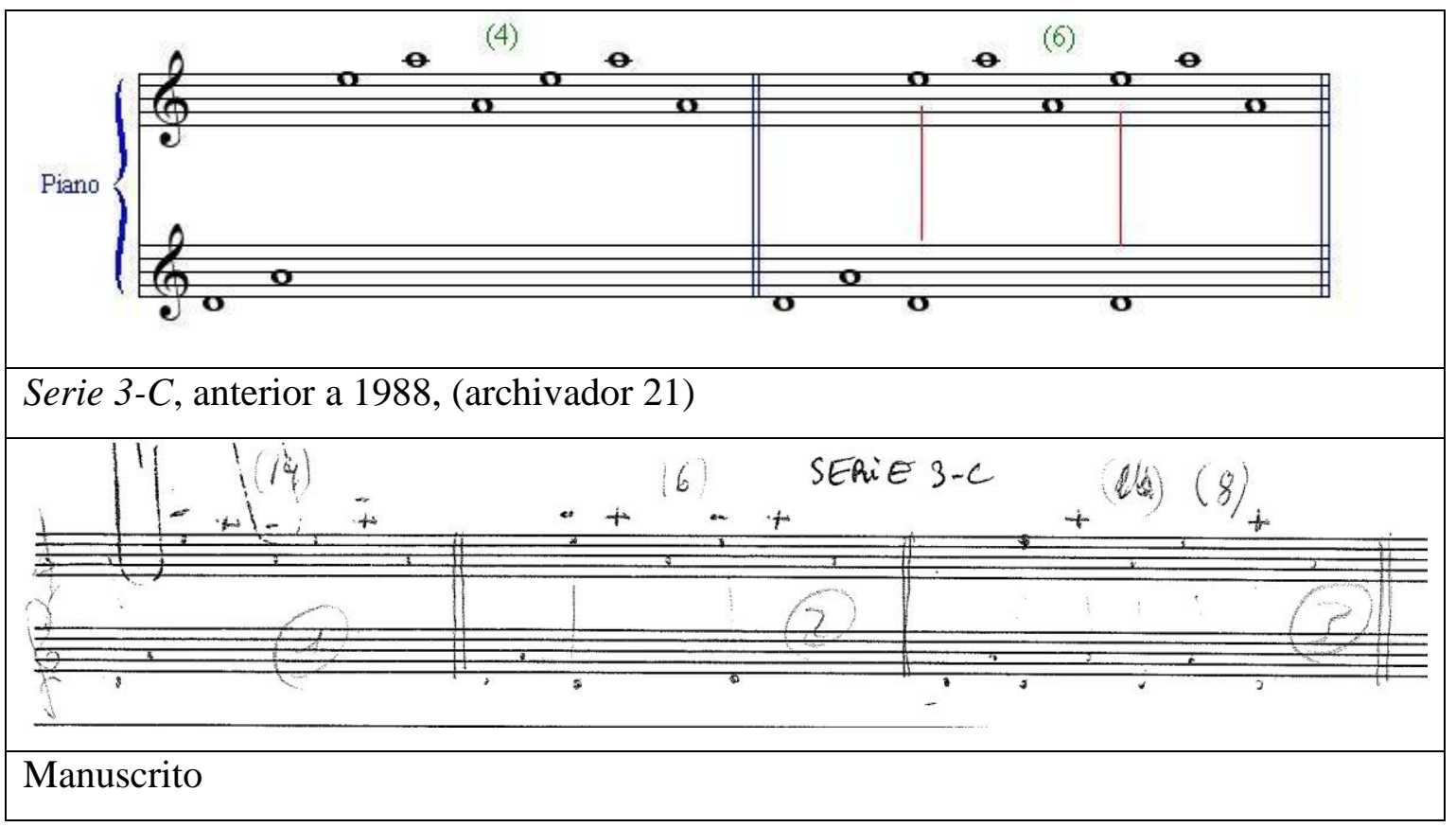

La repetición literal de un mismo compás está señalado al uso ( \% ) o bien coloca una s que abarca varios sistemas a la vez que indica el último compás escrito de forma habitual o bien que número de compás se ha de repetir, tal y como sigue en el ejemplo siguiente.

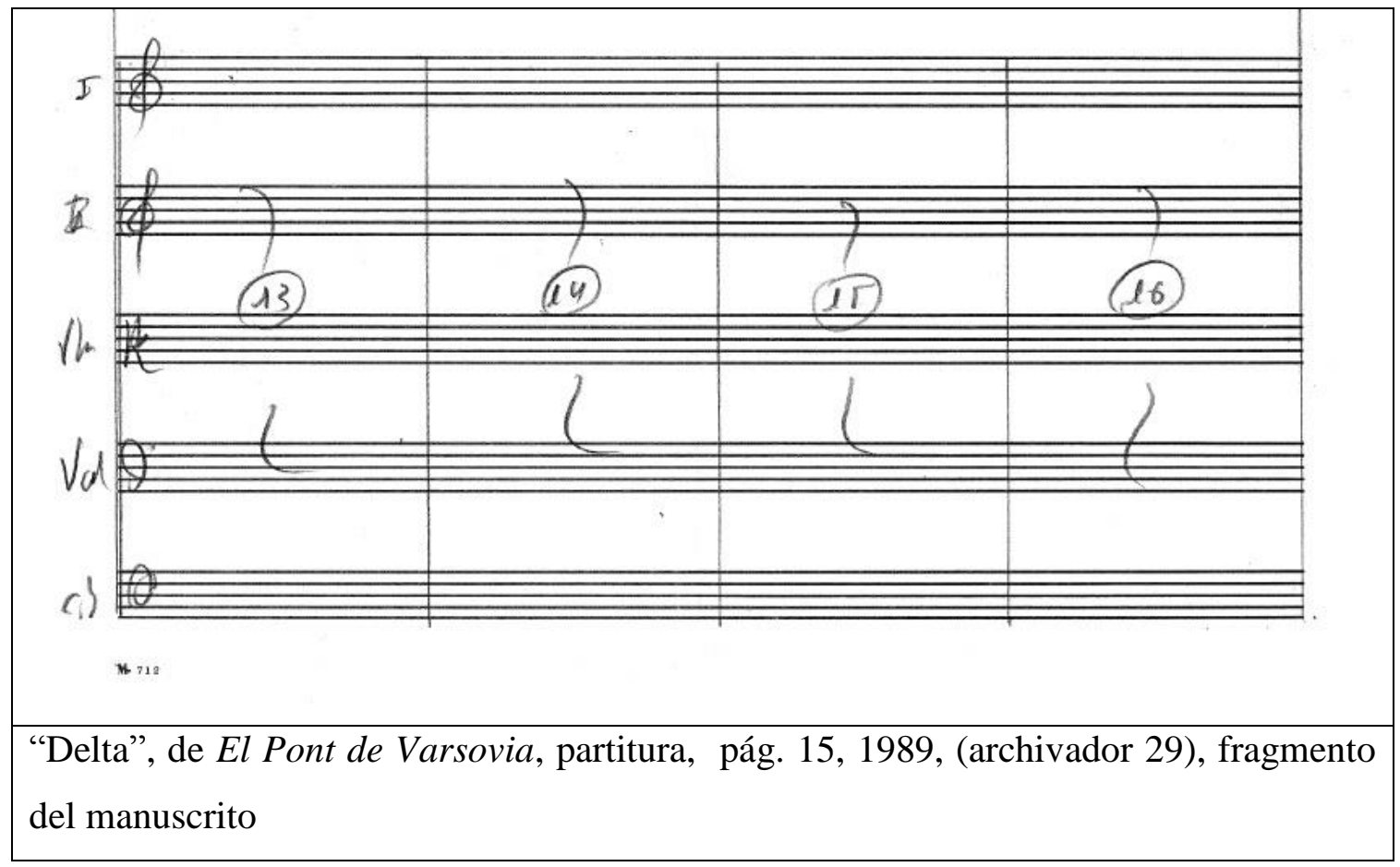


Asimismo en algunas partituras encontramos indicaciones manuscritas del autor que hacen referencia a la libertad interpretativa del ejecutante en lo referente a las secuencias escritas. Así, en la partitura manuscrita de la obra para piano Barbylet o "El silenci de la nit americana, existe la anotación "repetir cada seqüencia segons l'instint musical"59, de puño y letra del autor.

Los saltos en sus partituras, aunque suelen utilizar las palabras o signos italianos al uso, es posible en el autor que indique el lugar del salto por el número de compás al que se ha de dirigir la interpretación o bien por el número de página al que se ha de desplazar la misma.

\section{g.- Alteraciones:}

Las alteraciones accidentales utilizadas por el compositor son colocadas en cada una de las notas. Por tanto, la no utilización de la alteración, en una nota que anteriormente ha sido alterada, dentro del mismo compás, motivo o secuencia, implica que esta nota es natural, aunque no se utilice el signo del becuadro.

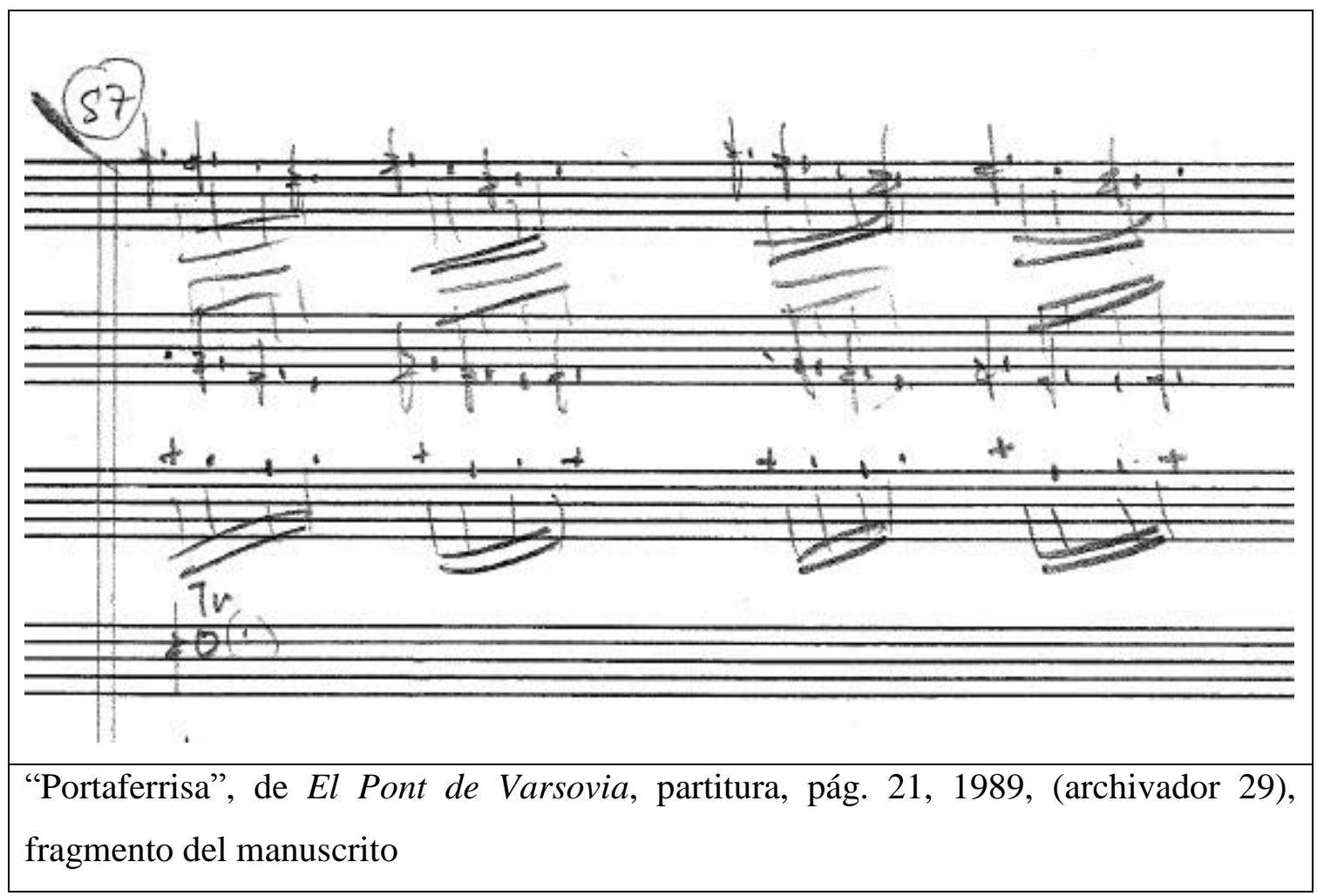

\footnotetext{
${ }^{59}$ repetir cada secuencia según el instinto musical.
} 


\section{h.- Improvisaciones:}

Los fragmentos libres o improvisados, dentro de una obra, son señalados de forma clara. Se trata de una línea continua y curva que se va desarrollando sobre sí misma. Al principio de esta línea, el autor da las calves o la base, para realizar la improvisación (sobre una nota, sobre un ritmo o sobre una letra o sonido vocal). El copista de Santos, Xavier Piquer, utiliza el mismo símbolo que el autor en sus manuscritos.

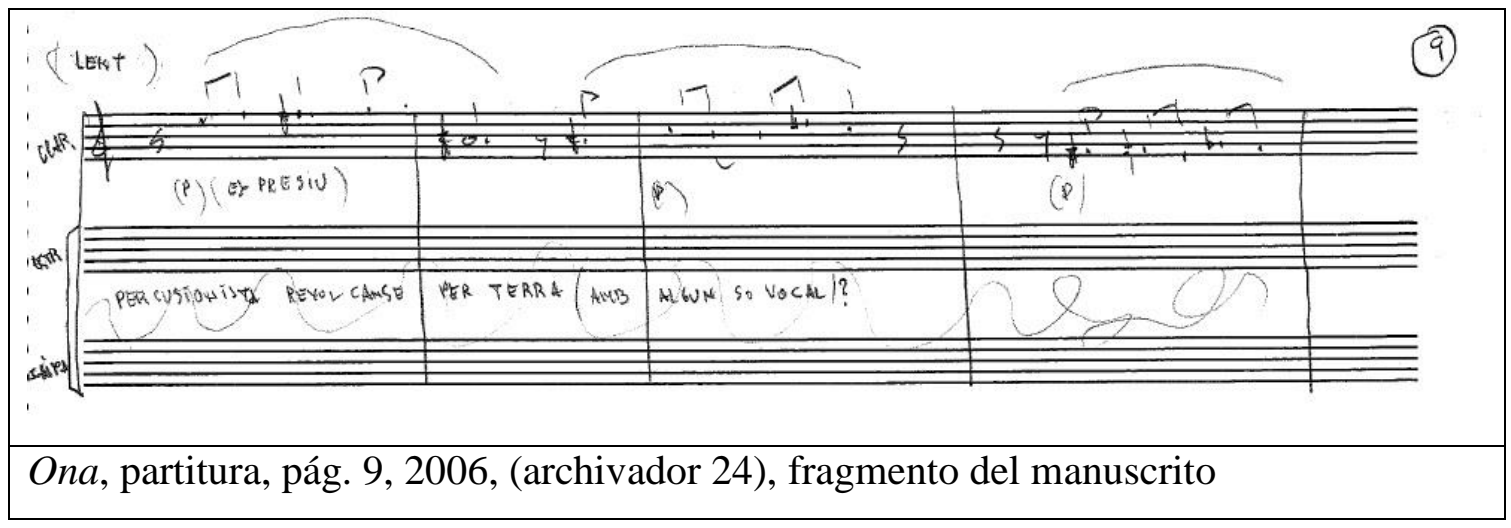

\section{i.- Pedal:}

No existe en ningún manuscrito de Santos, referencia alguna a la utilización del pedal en las interpretaciones. De sus interpretaciones grabadas se deduce que este se utiliza y va ligado, generalmente, a la armonía intrínseca de la obra.

Es más habitual su utilización en aquellas piezas o fragmentos ejecutados a una velocidad moderada, por ejemplo en las obra Xavier Riba o Pianolerolerolero Larero, en las secuencias cortas repetidas y en algunas ocasiones, aunque su interpretación sea a velocidad elevada, en los diseños rítmico-armónicos cortos y repetidos (Pianolerolerolero Larero, 3:13-3:30).

\subsubsection{INSTRUMENTACIONES:}

Santos es pianista y como tal, su herramienta de trabajo es el piano. Con él confecciona sus obras, les da forma, las modifica, las adapta y las domina. A partir de aquí, y de su época en New York, aprende, desde la experimentación, a utilizar la voz como un recurso expresivo de sus composiciones. Atendiendo a estos dos elementos, gran parte de la obra de Santos está dedicada para estos dos instrumentos. Aunque no son los únicos. Cuatro son los instrumentos o agrupaciones básicas en las obras de Santos: 
$>$ El piano.

$>$ La voz solista.

$>$ La Fanfarria.

El Coro.

En pocas ocasiones utiliza una agrupación al uso (generalmente la bandística y en contadas ocasiones la orquesta). Es habitual en sus obras reforzar la fanfarria con instrumentos de cuerda frotada, sin que estos tengan una formación al uso. Puede utilizar 4 violines y 2 violoncelos o bien 1 violín, 1 viola y 1 violonchelo. También es muy habitual la percusión en sus formaciones.

Por otra parte merece la pena resaltar la utilización de elementos o instrumentos no musicales en sus obras: 4 motocicletas, 1 motocicleta, 1 perro.

También es importante la utilización de la percusión corporal o de grupos o instrumentos vinculados a la Cobla catalana, como grullas, tenoras, dulzainas, etc.

Contando con todas estas agrupaciones, Santos escribe, sobre todo, para piano, voz solista, voz solista y piano, coro y Fanfarria con instrumentos de cuerda y percusión.

Dado que su dominio instrumental radica en el piano y la voz, y que su obra se prolonga más allá de estos instrumentos, su profesionalidad hace que delegue en otras personas ante aquello que no domina. Tal y como afirma en el libro de Josep Ruvira, el que trabaja para piano tiene que conocer un piano y el que lo hace para una orquesta también debe saberlo. De sus trabajos conjuntos con el violinista Josep Puértolas en el Grup Instrumental Català (GIC), surge una colaboración que perdurará a lo largo de gran parte de las obras de Santos. Por tanto, ante una instrumentación de su obra, Santos confía en Puértolas para la realización de la misma, habida cuenta de las dudas que el autor pueda tener ante grupos de cuerda o viento. Tal como atestigua el propio Santos, Yo, cuando escribo para orquesta, tengo una persona que está a mi lado. Se trata de Puértolas que ha trabajado siempre conmigo. Conoce muy bien la orquesta y cuando tengo una duda, sobre todo de cuerda, le consulto y él me dice "adelante" o lo contrario. Es por ello que en gran parte de la obra del autor, las instrumentaciones de las mismas sean de Josep Puértolas, conste así en la partitura o no.

\subsubsection{TEXTOS:}

El texto, en sus obras, es otro elemento más del lenguaje. Dado que este análisis trata sobre su música, no me extenderé en este apartado; pero he de hacer constar que Santos 
otorga una importancia vital a la musicalidad de sus textos. Para conseguir esta musicalidad utiliza sílabas o palabras inventadas por él. Este lenguaje propio busca la fuerza de la palabra y su impacto en el escuchante. Basta con repasar los títulos de sus espectáculos o los nombres de sus personajes para comprenderlo. Por su parte, la música subraya la fuerza del texto.

Los textos se reflejan en sus manuscritos, unas veces sin referencia musical alguna (métrica o de altura) y en otras ocasiones, existen las referencias musicales, pero no las literarias. En este caso, los cantantes deben pronunciar la vocal de la nota expuesta antecedida, generalmente de la consonante 1 (lo, le, li, la lo, la ,li) ${ }^{60}$. Este elemento es una de las señas de identidad de las composiciones de Santos.

\subsubsection{MELODÍA:}

Dos son las constantes en los fragmentos melódicos de la obra de Santos: por una parte el uso de intervalos disjuntos en aquellas melodías con carácter lírico y por otro lado el uso de interválica mayoritariamente conjunta para las composiciones con mayor fluidez de velocidad.

\subsubsection{INFLUENCIAS Y TESTIMONIOS:}

Dado el carácter multidisciplinar de la obra de Santos, debo reflejar que las personas que han influido en él en otros apartados artísticos son:

$\checkmark$ John Cage en el aspecto formal de sus obras, como elementos abiertos, que evolucionan y se adaptan al momento y a las circunstancias (indeterminación) ${ }^{61}$

$\checkmark$ Joan Brossa en su concepción teatral.

$\checkmark$ De Pere Portabella bebió su experiencia en el lenguaje del cine y lo incluyó posteriormente en sus espectáculos

$\checkmark$ De Clovis Prévost, aprendió la importancia de la fotografía como arte.

\footnotetext{
${ }^{60}$ Se puede apreciar este hecho en la grabación realzada en directo, el día de su estreno, de la obra "Promenade Concert". El texto pronunciado por la soprano no consta en su manuscrito.

${ }^{61}$ Jay Grout, D. (1984): Historia de la Música Occidental, 2. Alianza Editorial, Madrid, p.790
} 


\section{TESTIMONIOS:}

De Santos han opinado aquellos que lo conocen y los que no. Pero para todos ellos, su obra no pasa inadvertida para nadie. Para conocer mejor su creación artística (podemos encontrar una referencia al arte total de Wagner), expongo algunas consideraciones que de él y de su obra, se han publicado.

"Per a Santos, la música, el teatre, l'art, el cinema són formes de combat cultural, d'alliberament, de disidencia $i$ de ressistència contra la violencia del poder establert i de la indùstria cultural homogeneïtzadora i empobridora". ${ }^{62}$

"En Santos no hi ha fronteras entre música, teatre $i$ art. El piano no solament és l'instrument esencial de Santos, com a interpret i compositor musical, sinó que també és l'element simbòlic més emblemàtic del seu univers imaginari... ". 63

“...alló que ordena i dota de significació el discurs a qualsevol dels seus films [...] és el so, la banda sonora, aixó és, la música... ". 64

"En publicacions internacionals de màxim reconeixement com 'The New Grove Dictionary of Music and Musicians' disposa d'un espai molt superior al d'altres noms que la crítica espanyola dóna per consagrats. ${ }^{65}$

${ }^{62}$ Guerrero, M. (2006): Carles Santos. Visca el Piano!. Fundació Joan Miró. Barcelona, pag. 38.

${ }^{63}$ Ibidem, p.4.

${ }^{64}$ Ibidem, p.132 (texto de José Luís Téllez).

${ }^{65}$ Ibidem, p.132 (texto de Marta Cureses). 


\subsection{CATALOGACIÓN}

La catalogación de la obra de Carles Santos se ha realizado en base a los archivos encontrados en la sede de la Fundació Caixa Vinaròs, en Vinaròs (Castellón) y en los encontrados en la casa del autor y en su residencia de verano. A ellos se suman los recogidos de diversas fuentes, a las que se ha podido tener acceso. Dado que la obra del autor castellonense está cedida a esta Fundación, todo el material que existía en ella, en el momento que se comenzó este trabajo, así como el que se ha ido recuperando, se ha ido añadiendo a los archivos ya existentes. La metodología utilizada es la explicada en la página 18 de este trabajo.

\section{La catalogación sistemática.}

Los criterios seguidos para la catalogación son, fundamentalmente, los establecidos por el RISM (Repertoire Internacional des sources Musicales), con algunas variaciones, debido a la singularidad de la obra a catalogar:

Número de orden: El título de la obra va precedido por el número de orden correlativo de esta.

Título de la obra: El título de cada obra en negrita y mayúsculas, corresponde al utilizado por el compositor en sus manuscritos, esencialmente el que consta en la tapa de sus blocs.

Forma musical: Se especifica normalmente y si no costa se considera libre.

Tonalidad: Se indica siempre, incluso en aquellas que no siguen una tonalidad establecida. Los modos mayores se indican con mayúsculas y los menores con minúsculas. En caso de considerarse modal y no tonal, se indica la tónica del modo.

Plantilla: Se indica la plantilla que consta al principio del manuscrito o en el transcurso del mismo, por familias: Orquesta, Banda, Fanfarria, Grupo instrumental, Piano, Voces, Voz solista, Coro, Cuerda -frotada-, Viento madera, Viento metal, Percusión e instrumentos específicos. En el siguiente párrafo se detallarán todos los instrumentos 
utilizados si existiesen partes de los mismos o constasen de manera explícita. Recordamos que en los manuscritos, el autor no suele dar detalles de los mismos.

Partitura: Cuando se conserva la partitura, se indica. Asimismo si consta un guión de la música y partes. En caso de no constar alguno de ellos, no se indica.

Fecha: Se indica el año de composición de la obra si esta se ha conseguido datar, si nó se omite.

Archivo: Para finalizar se indica el archivo en el que se encuentra la obra en la Fundació Caixa Vinaròs. Estos constan de cajas grandes (G.) o Archivadores tamaño folio ampliado (arc.) numerados; los primeros del 1 al 8 y los segundos del 1 al 34. Dado que ya existían estos en el momento de comenzar este trabajo, se ha respetado la clasificación que ya había, modificándose por instrumentaciones y ampliándose. En las cajas o archivadores, consta en el exterior de los mismos, la relación de obras (por títulos) que se encuentran en su interior, así como el número de archivo dado.

Explicación plantilla: En párrafo aparte y en caso de existir partes o partituras bien desarrolladas, se realiza una exhaustiva explicación de la plantilla a utilizar.

Ver: En este párrafo se hace referencia a otros títulos que puede tener la obra, así como la sección en la que se puede encontrar, dentro de esta catalogación.

Íncipit Musical: Después de la descripción se incluye el íncipit musical según las normas del RISM, para la identificación de la misma. En caso de encontrar dos íncipits iguales de dos obras con títulos distintos, se incluyes ambas obras.

$1^{a}$ Página: Después se incluye la imagen de la primera página de la obra, que coincidirá con el íncipit anterior (parcial o totalmente).

Aclaraciones: En párrafo aparte se indican especificaciones de la obra clasificada: Motivo para el que fue compuesta, espectáculos o acciones musicales en las que se ha 
interpretado, lugar y fecha de su estreno, notas aclaratorias para su interpretación ${ }^{66}$, estructura, u otros datos de interés.

Material total: Dado que aparte de los manuscritos del autor, existen partituras, partes y copias de ambas, bien sean manuscritas o en formato informático, así como material informático en formato pdf realizado por Xavier Piquer ${ }^{67}$, se indica la totalidad del material que se encuentra en la Fundación.

El catálogo está dividido en Obra pianística, vocal, vocal-pianística, Banda, Fanfarria, Orquesta, Grupos de cuerda, obra escénica, integrales, otras agrupaciones y obra extraviada.

\footnotetext{
${ }^{66}$ Según testimonio oral del autor.

${ }^{67}$ Xavier Piquer, músico nacido en Vila-real, Profesor Superior de Clarinete y Dirección de Orquesta, es colaborador de Carles Santos en sus montajes artísticos, dedicándose a la dirección musical de los mismos, así como en la edición musical de sus obras en soporte informático.
} 
3.2.1. PIANO 
1.- 2 PIANOS (1), Libre, politonal, 2 pianos, con partitura, s. d., archivo particular de Carles Santos.

La plantilla a la que está dedicada es la de un dúo de Pianos.
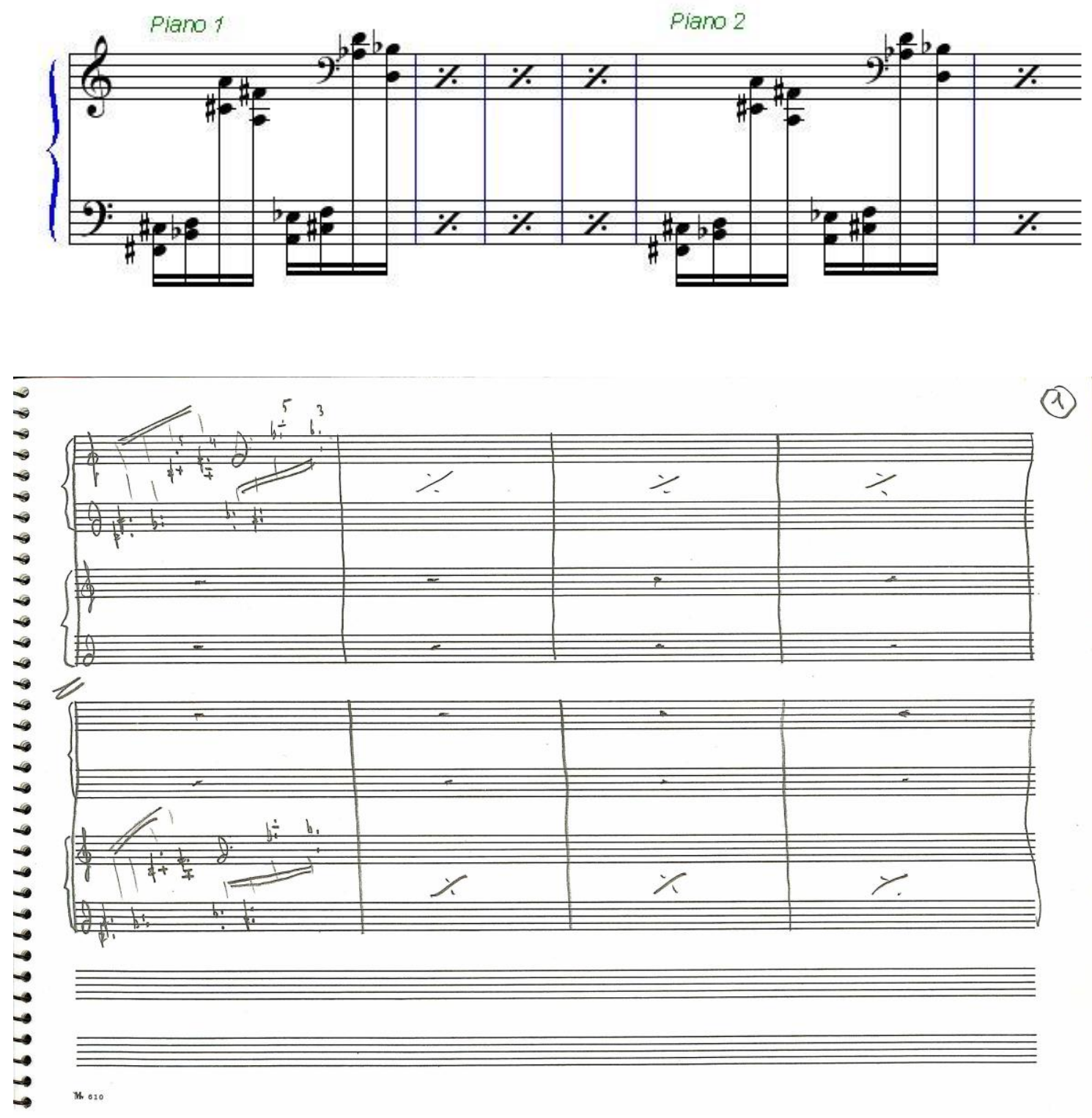

Publicada por la Diputación Provincial de Castellón 


\section{MATERIAL TOTAL:}

- Partitura de la obra: Material manuscrito del autor, original, en 2 blocs de escritura musical, numerados en el exterior. Páginas numeradas de la 1 a la 27, en el $1^{\circ}$, y de la 28 a 30 , más 8 páginas sin numerar, en el $2^{\circ}$.

- Partes: No existen partes.

- No consta relación de originales y copias. 
2.- 3 NOTES, Libre, atonal, piano, con partitura, s. d., arc. 21.

La plantilla a la que está dedicada es la de un piano.
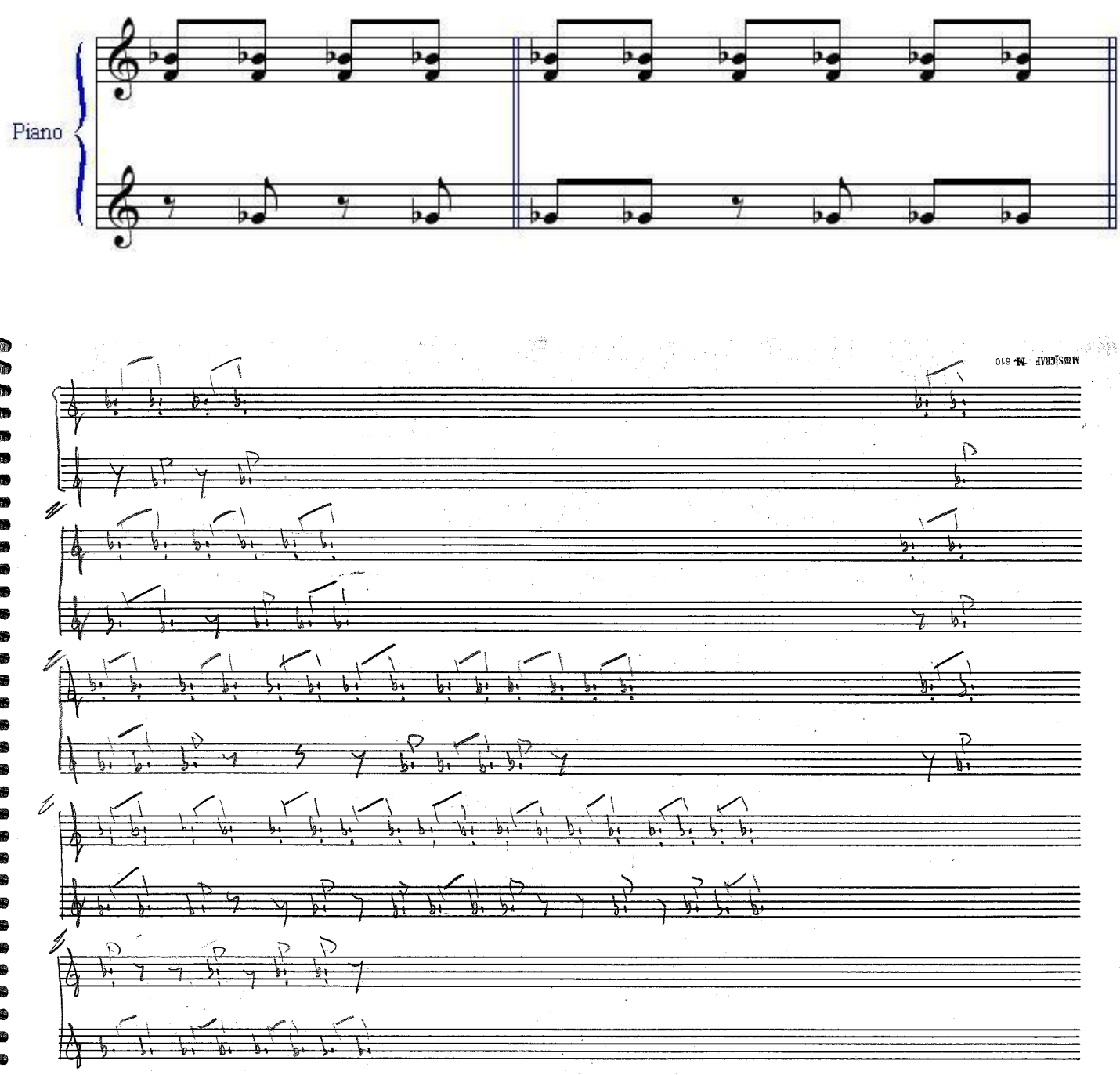

MATERIAL TOTAL:

- Partitura manuscrita y original del autor. Consta de un bloc de escritura musical con el título 3 notes en la tapa y con páginas sin numerar. Escrita en el reverso del bloc que lleva como título $88-3=85$.

- Partes: No existen partes.

- No consta relación de originales y copias. 
3.- $\mathbf{8 8}$ - $\mathbf{3}=\mathbf{8 5}$, Libre, en Re, piano, con partitura, s. d., arc. 21 .

La plantilla a la que está dedicada es la de un piano.

Ver: TRES NOTES (Sección Otras agrupaciones).
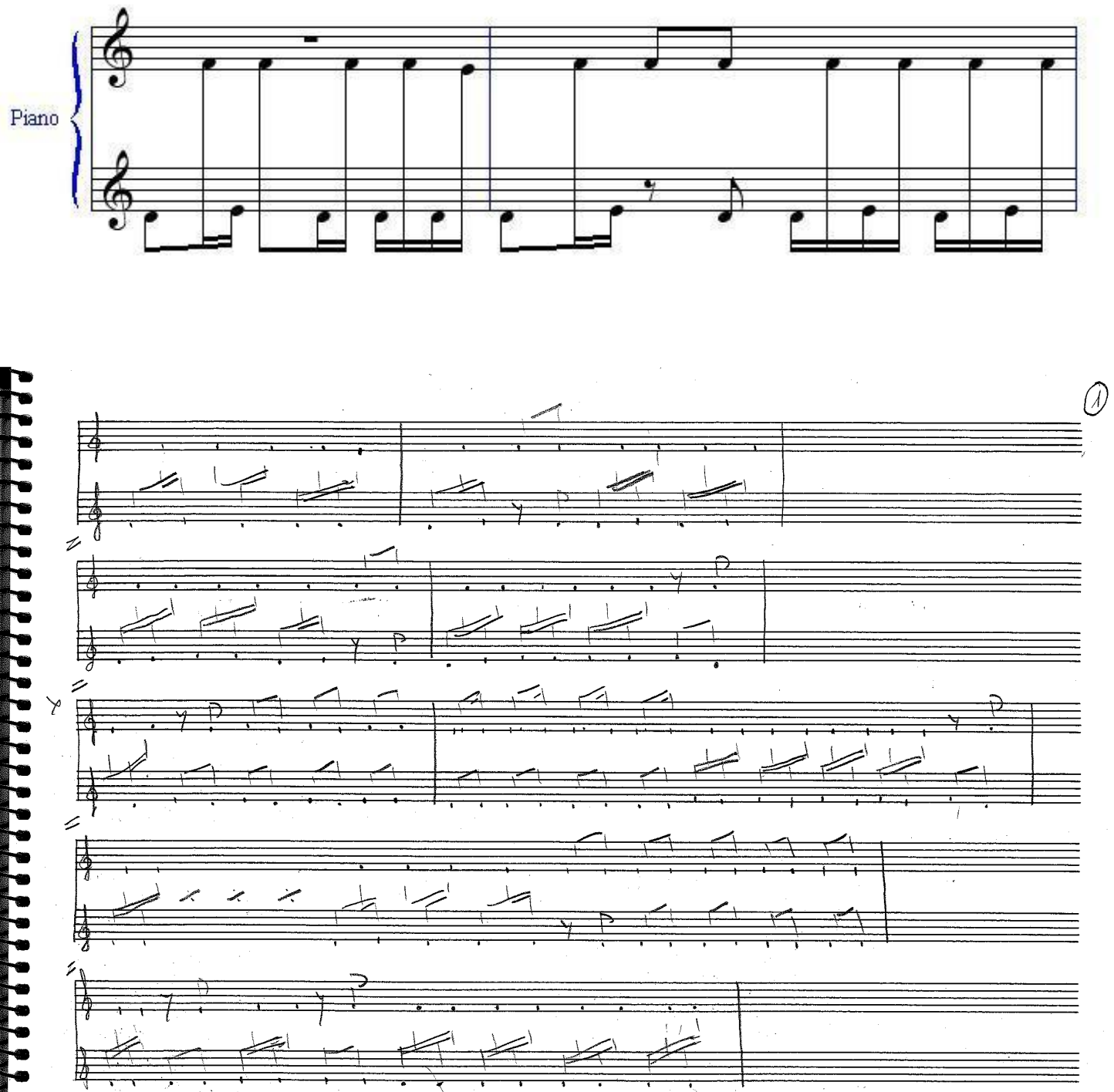

La música es la misma que la obra Tres notes o como es nombrada por el compositor,

Música en tres notes, aunque esta última, instrumentada.

La idea musical es semejante a la de la obra Ebrofagia copulativa. 


\section{MATERIAL TOTAL:}

- Partitura manuscrita y original del autor. Consta de un bloc de escritura musical con el título 88 - 3 = 85 en la tapa y con varios grupos de páginas numeradas:

- El primero de 6 páginas algunas sin numerar.

- El segundo de 2 páginas numeradas.

- El tercero de 2 páginas numeradas.

- En el reverso existen 10 páginas escritas con el título en la portada anterior de 3 notes.

- Partes: No existen partes.

- No consta relación de originales y copias. 
4.- A LA PISCINA MISERICORDIA, Libre, politonal, piano, con partitura, 1988, arc. 21

La plantilla a la que está dedicada es la de un piano.

Ver: Y (sección Grupos de cuerda)
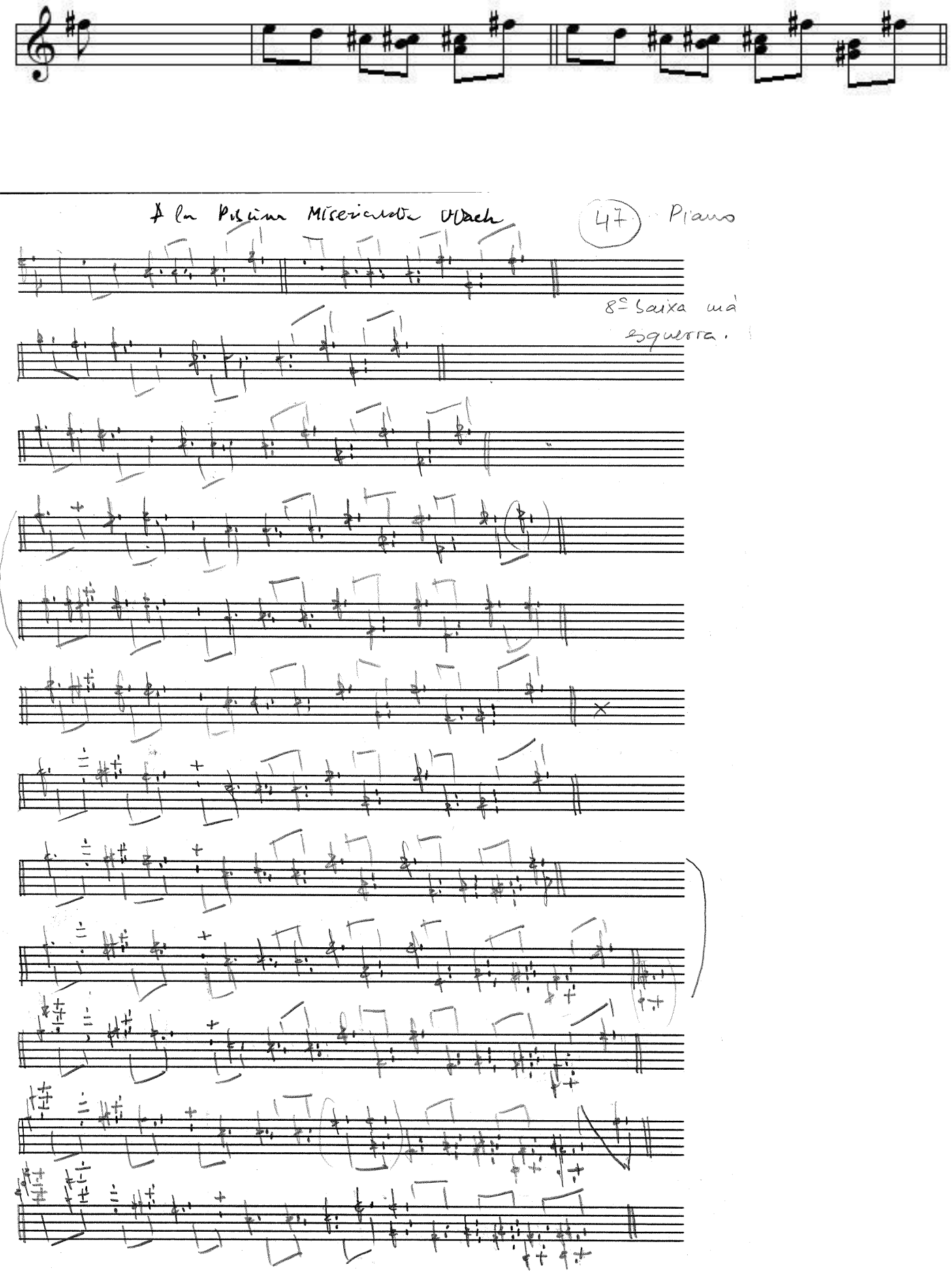
Se corresponde a la pista 2 del disco Carles Santos: Piano grabado en 1988 por Grabaciones Accidentales.

\section{MATERIAL TOTAL:}

- Partitura manuscrita y original del autor. Consta de un libreto de escritura musical con 4 páginas escritas y sin numerar y el número 47 encercado, en la $1^{\text {a }}$ página.

- Existen arreglos de esta pieza en archivador 26, bajo el nombre de $Y$, para trio y dúo de cuerda.

- Partes: No existen partes.

- No consta relación de originales y copias. 
5.- ARMANDINO '77, Libre, en La, piano, con partitura, 1977, libro. LLIBRE PER A PIANO (p.325 y 326). Arc. 10

La plantilla a la que está dedicada es la de un piano.

Ver: L'APERITIU.

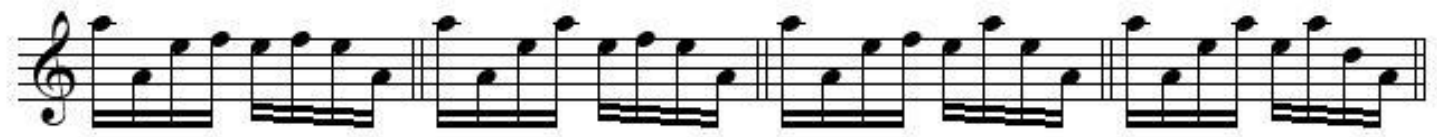

$32 \mathrm{~b}$

\section{Carles Santos · Armandino 77}
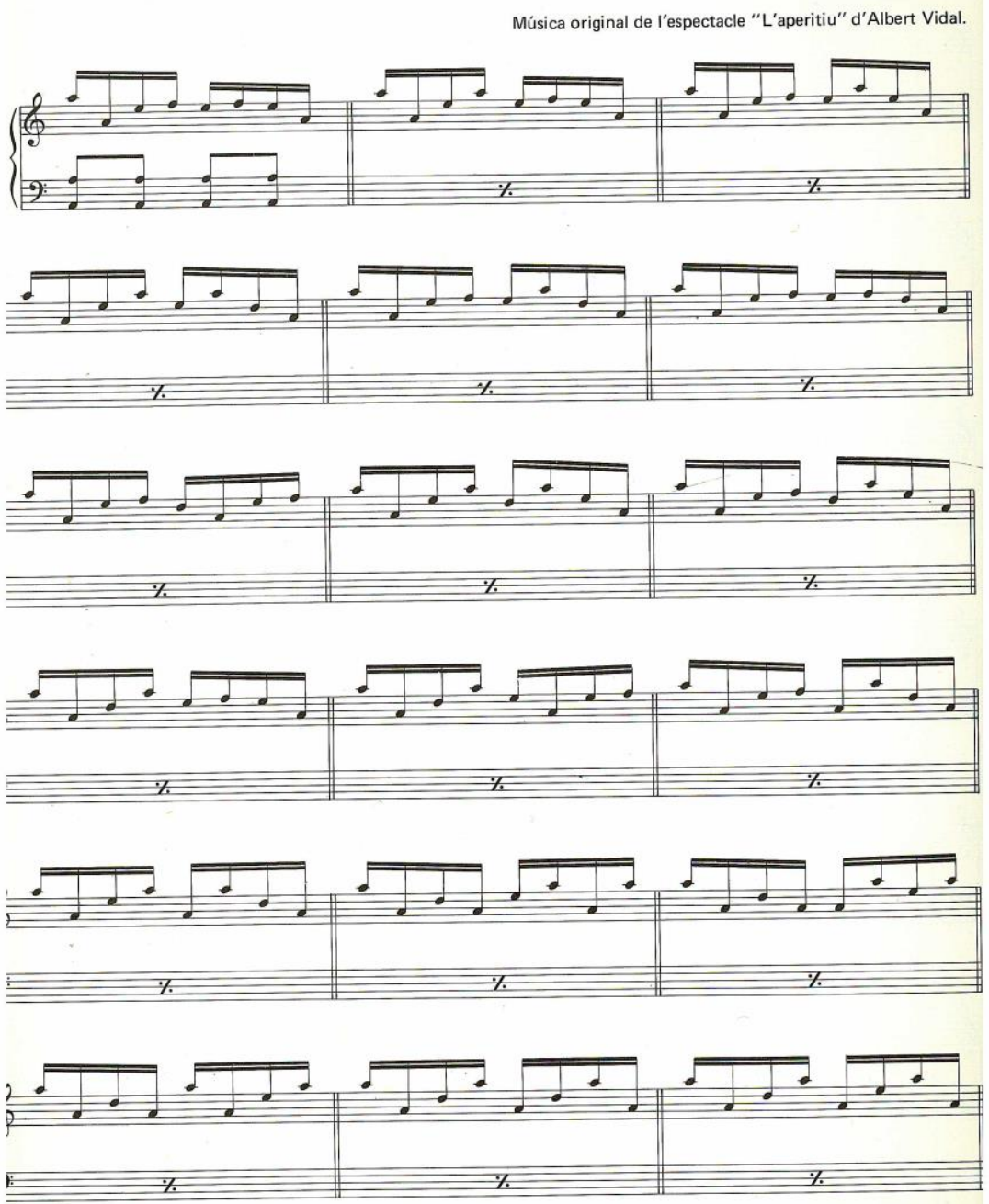

Cal repetir cada sequeència entre 15 i 20 vegades. Respecteu l'ordre de les sequències. La dinàmica pot variar dins del (f). Repetir cada secuencia entre 15 y 20 veces. Respetar el orden de las secuencias. La dinámica puede variar dentro del (f).

aquest és el final de l'obra.

暳 es el finalde la obra. 
Se corresponde a la pista 3 de la cara A, del disco Pianotrack grabado en 1984 por Linterna Música.

Material impreso incluido en el libro LLIBRE PER A PIANO de la ASOCIACIÓ CATALANA DE COMPOSITORS con Depósito legal B - 25.616 - 1980, impreso en Barcelona en 1980 (páginas 325 y 326). Esta es la música original del espectáculo L'aperitiu d'Albert Vidal.

\section{MATERIAL TOTAL:}

- Partitura de la obra: Dos hojas numeradas como 325 y 326 en el libro LLIBRE PER A PIANO.

- Existe material manuscrito y original del autor, que consta de un libreto de escritura musical con 2 páginas escritas, sin numerar, con el título Armandino 77, la anotación " Original" y el número 11 encercado, en la tapa (que también contiene apuntes de esta y otras obras).

- Asimismo existe material manuscrito y fotocopiado que no tiene la escritura del autor, que consta de 2 páginas sueltas escritas, sin numerar, con el título Armandino 77, la anotación "Repetir cada seqüencia pensant que l'obra pot durar 12" y el número 11bis en la tapa. 
6.- BARBYLET O LA NIT AMERICANA, Libre, en Re, piano, con partitura, 1981, $\operatorname{arc} .21$.

La plantilla a la que está dedicada es la de un Piano.

Ver: CANT ENERGÈTIC (sección Obra vocal) y LA NIT AMERICANA (sección Obra piano)
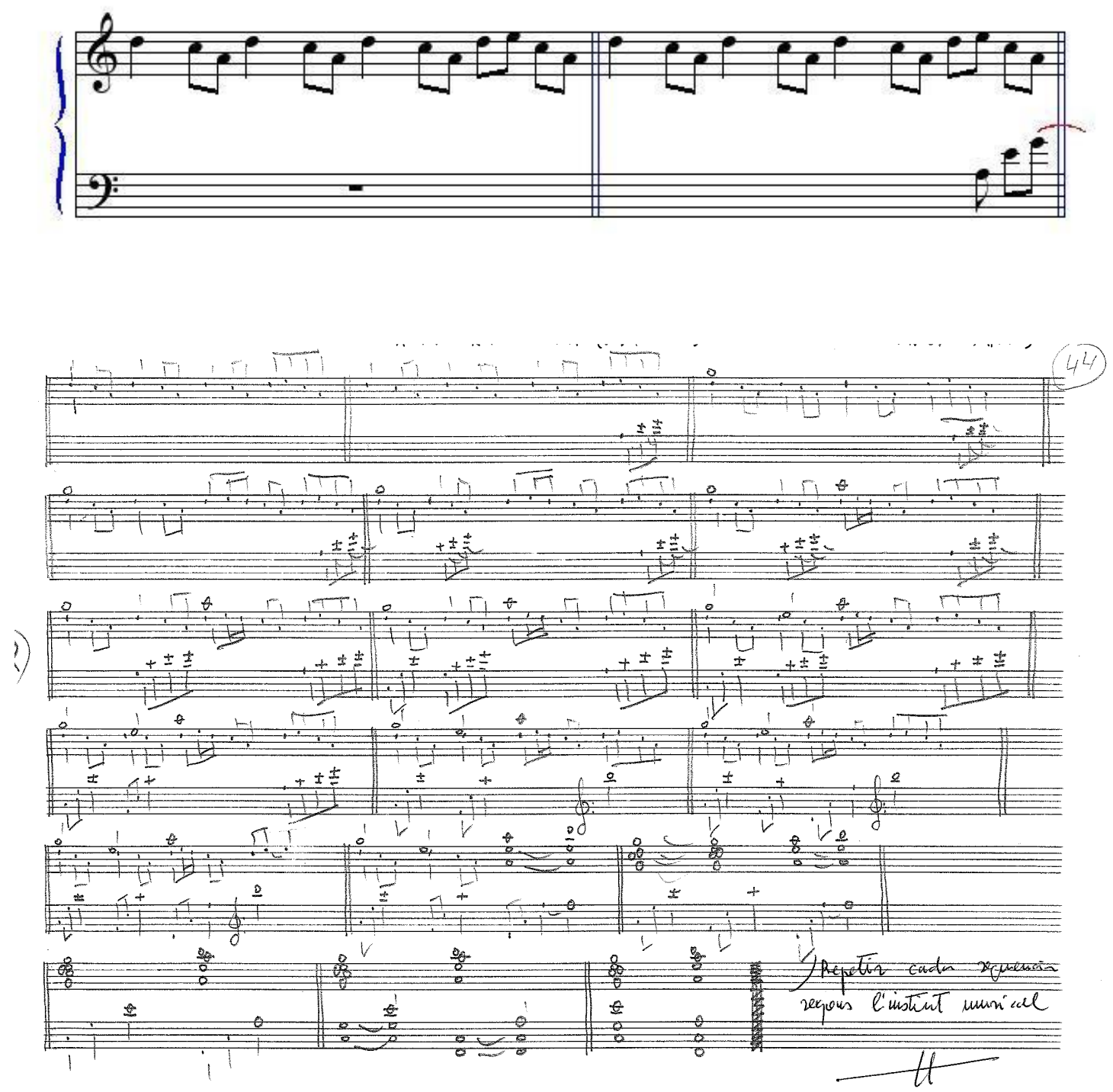

Al final del manuscrito consta la inscripción del autor "Repetir cada seqüència segons l'instint musical"'

Se corresponde a la pista 2 de la cara B, del disco Pianotrack grabado en 1984 por Linterna Música. 
El tema melódico se corresponde con el de "Cant energètic", obra para voz, incluida en el disco Voicetracks, pista 2 de la cara A.

\section{MATERIAL TOTAL:}

- Partitura manuscrita y original del autor. Consta de un libreto de escritura musical con 1 página escrita y sin numerar y el número 44 encercado, en la $1^{\text {a }}$ página. En la portada existe el título Barbylet o el silenci de la nit americana.

- Partes: No existen.

- No consta relación de originales y copias. 
7.- BUJARALOZ BY NIGHT, Libre, en Re, piano, con partitura, 1984, arc.16.

La plantilla a la que está dedicada es la de un Piano.
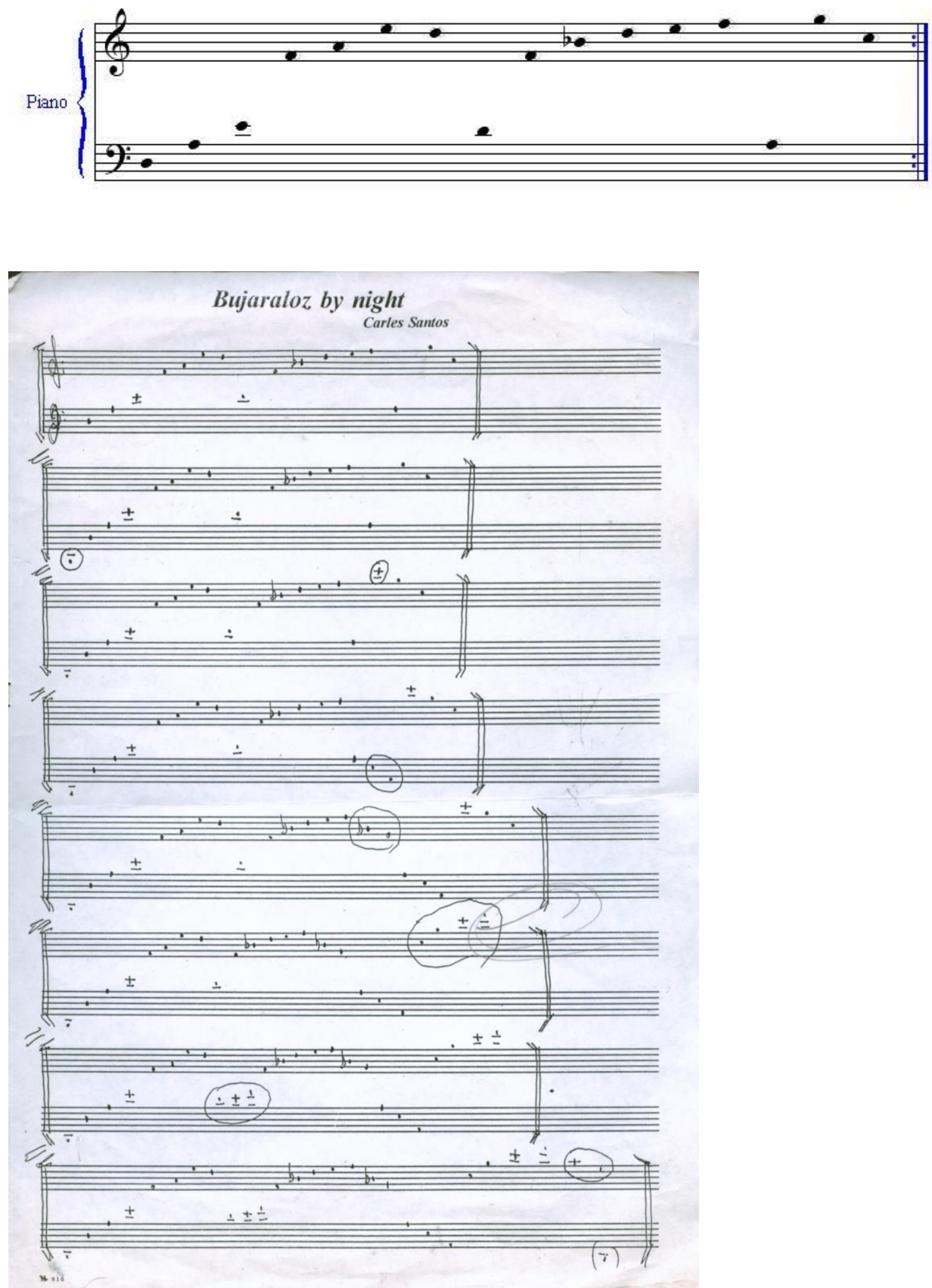
Se corresponde a la pista 1 de la cara A, del disco Pianotrack grabado en 1984 por Linterna Música.

Material cedido por la pianista Inés Borrás.

\section{MATERIAL TOTAL:}

- Partitura manuscrita y fotocopiada del autor. Consta de 2 hojas sueltas.

- Partes: No existen.

- No consta relación de originales y copias. 
8.- CAPITOL 2 (SALUT), Libre, modal, piano, con partitura, anterior a 1990, arc.22.

La plantilla a la que está dedicada es la de un Piano.
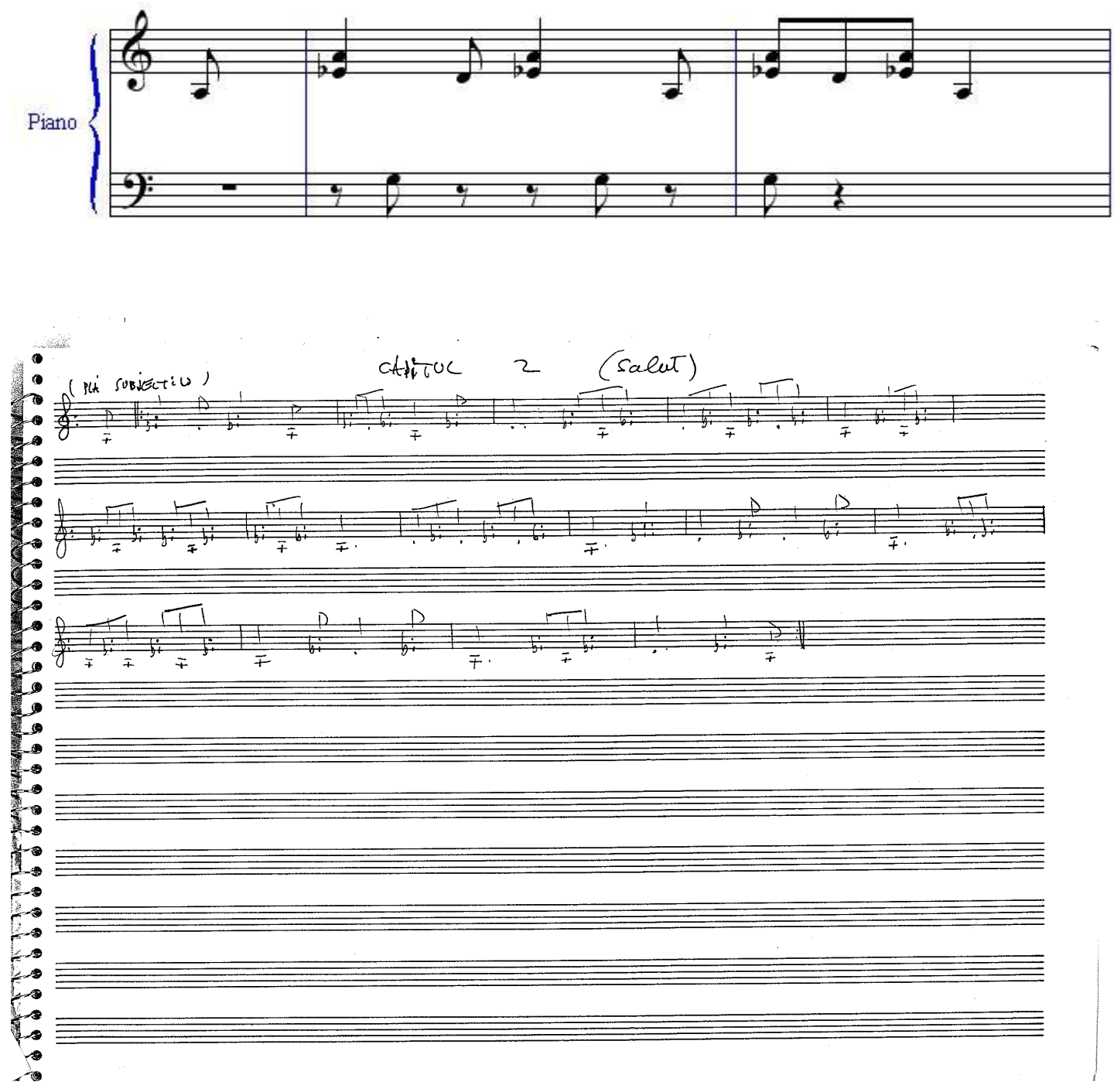

En carpeta RETROSPECCIÓ I PERTENENCIA.

"Puede formar parte de la musicalización de algunas imágenes o film" *

Puede estar relacionada con la obra vocal Capitol 6 (Comunió).

${ }^{*}$ Testimonio oral del autor. 


\section{MATERIAL TOTAL:}

- Partitura manuscrita y original del autor. Incluida en un bloc de escritura musical, sin título en el exterior, numerado con el número 30 y 4 páginas manuscritas y originales, numeradas del 5 al 9 (no existe la $\mathrm{n}^{\circ} 7$ ). Consta título en la página 5 como Capitol 2 (Salut) (Pla subjetiu). En la página 6 consta la anotación "mare i fill". En la contratapa consta el título Retrospecció $i$ pertenencia. Existen otras obras en este bloc.

- Partes: No existen partes.

- No consta relación de originales y copias. 
9.- CODI O ESTIGMA?, Libre, politonal, piano, con partitura, 1998, arc.17.

La plantilla a la que está dedicada es la de un Piano.
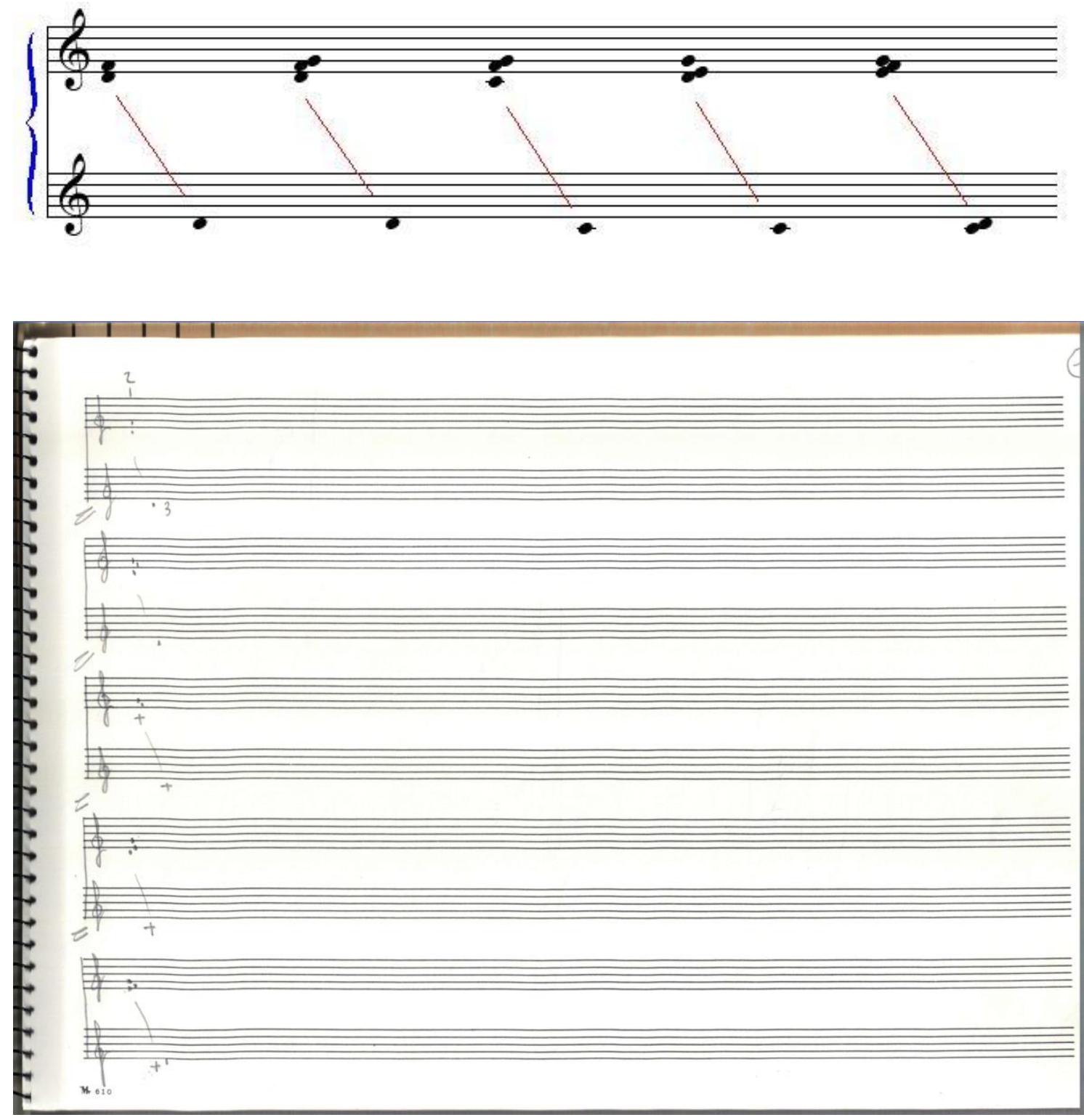

Bajo este nombre también se interpreta música de la obra No al no.

MATERIAL TOTAL:

- Partitura manuscrita y original del autor. Consta de 4 blocs de escritura musical, con los siguientes títulos: 
- Codi o estigma? (1) en el exterior (inicio de la obra) con 14 páginas numeradas y manuscritas (de la 1 a la 13 y con 10bis).

- Codi o estigma? (2) en el exterior con 14 páginas numeradas y manuscritas (de la 1 a la 13 y con 2bis).

- Codi o estigma? (3) en el exterior con 7 páginas numeradas y manuscritas. Existen 2 hojas sueltas y numeradas (6 y 7).

- Codi o estigma? (3 bis) en el exterior con 7 hojas numeradas y manuscritas. Existe 1 hoja suelta y numerada (4) y la 5 bis.

- Partes: No existen.

- No consta relación de originales y copias. 
10.- COSIMANS, Libre, en La, piano, con partitura, s. d., arc. 21.

La plantilla a la que está dedicada es la de un Piano.
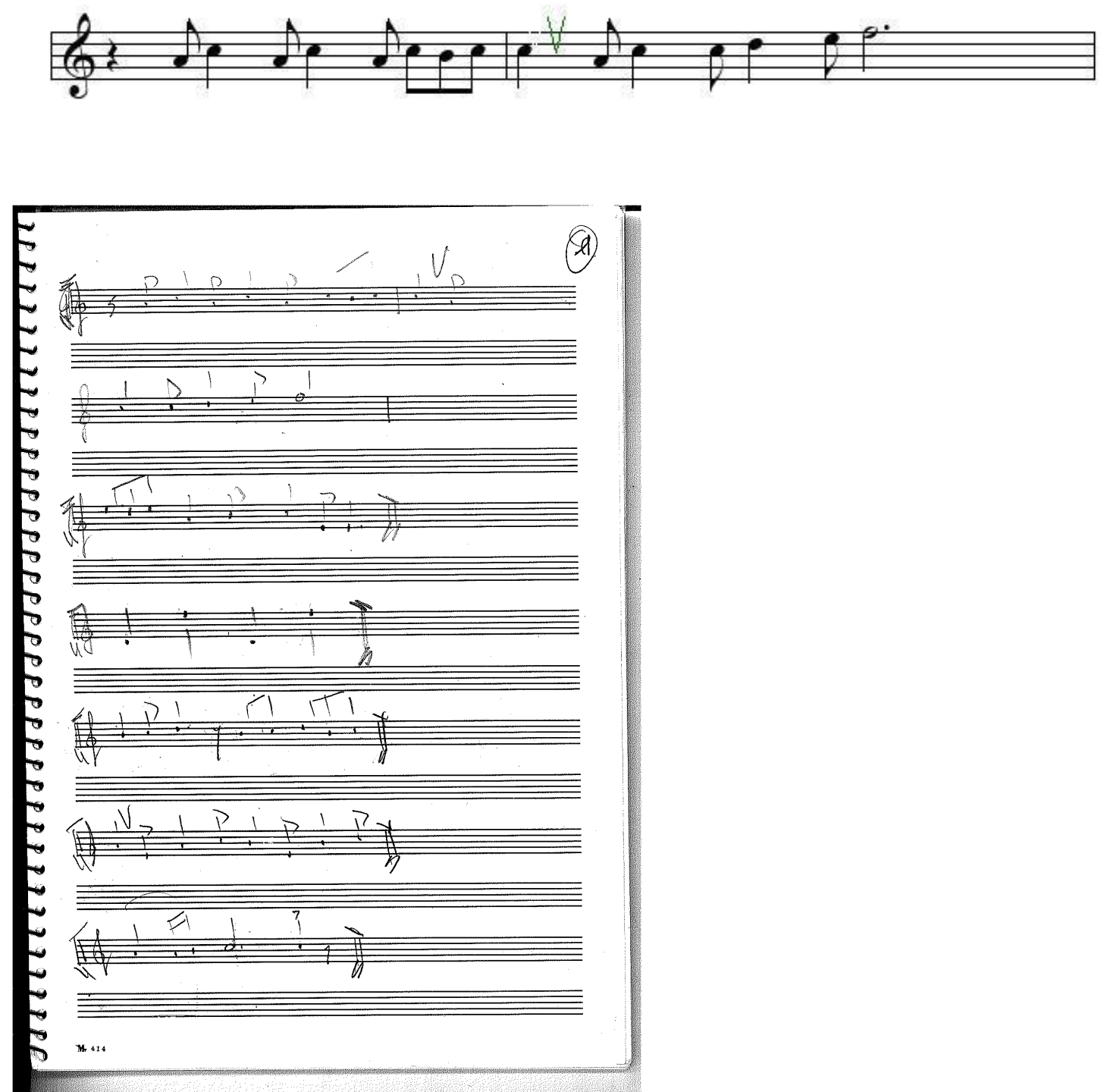

\section{MATERIAL TOTAL:}

- Partitura manuscrita y original del autor. Consta de un bloc de escritura musical con el título Cosimans en la tapa y con 3 páginas escritas y numeradas.

- Partes: No existen partes.

- No consta relación de originales y copias. 
11.- EBROFALIA COPULATIVA, Libre, politonal, piano y motocicleta, con partitura, 2007, arc.17.

La plantilla a la que está dedicada es la de un Piano con la colaboración de una moto de trial (estrenada por Adam Raga).

Ver: PIANO MOTO.
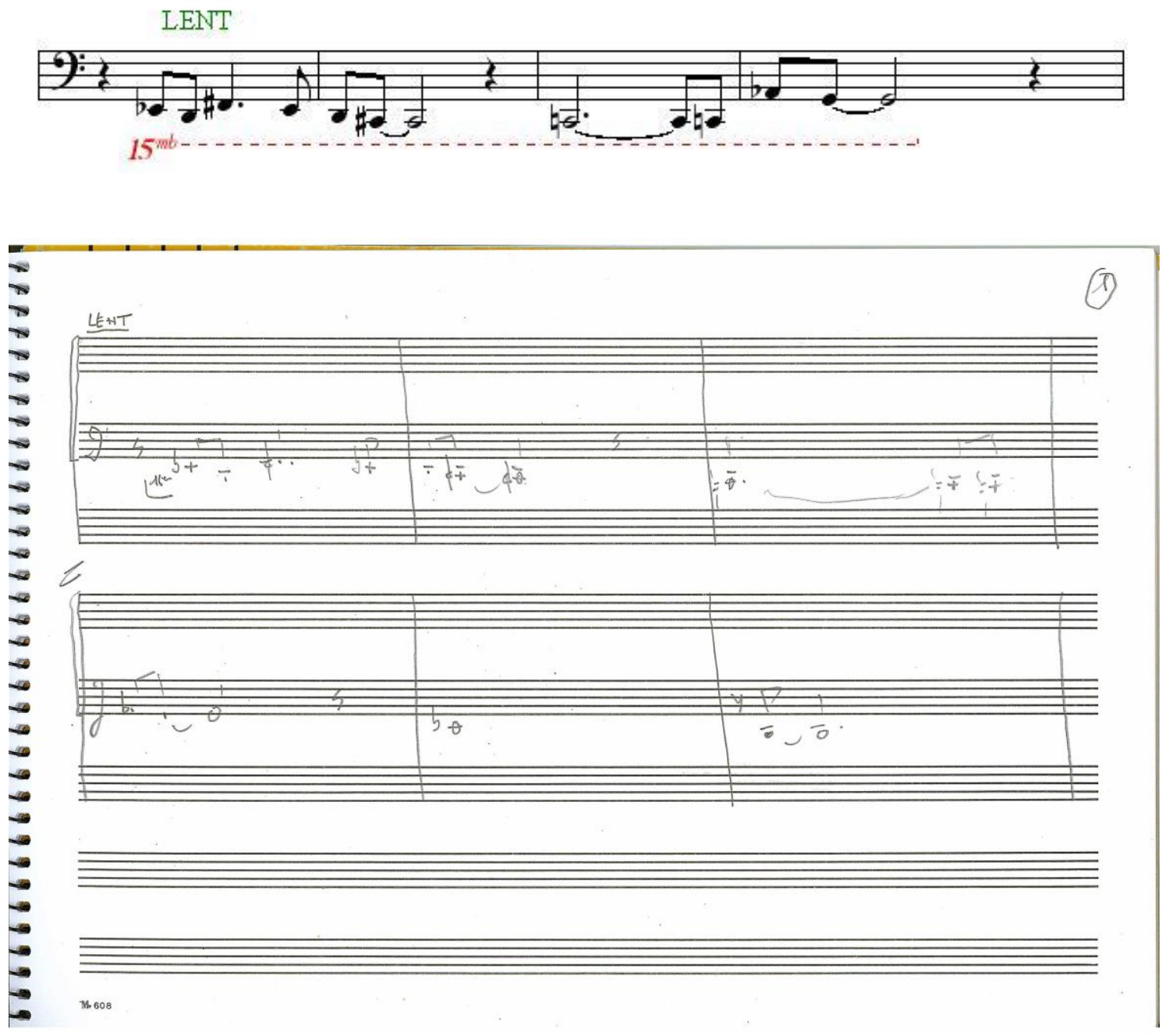

La obra en sí comienza en el segundo bloque numerado del primer cuaderno. Estrenada en el Sónar Frankfurt el 10 de octubre de 2007.

\section{MATERIAL TOTAL:}

- Partitura manuscrita y original del autor. Consta de 2 blocs de escritura musical, con el título Tinc que ser..., Amb dos dits, Piano moto (1) en el exterior y 24 
páginas manuscritas y originales, divididas en dos fragmentos: 1 a 9 y 1 a 15 . El segundo bloc lleva como título Piano moto (2) y consta de 8 páginas manuscritas y originales, numeradas de la 16 a la 18 y 5 páginas sin numerar.

- Partes: No existen.

- No consta relación de originales y copias. 
12.- EL TEU LLIT, Libre, politonal, piano, con partitura, anterior a 1988, arc.22.

La plantilla a la que está dedicada es la de un Piano.
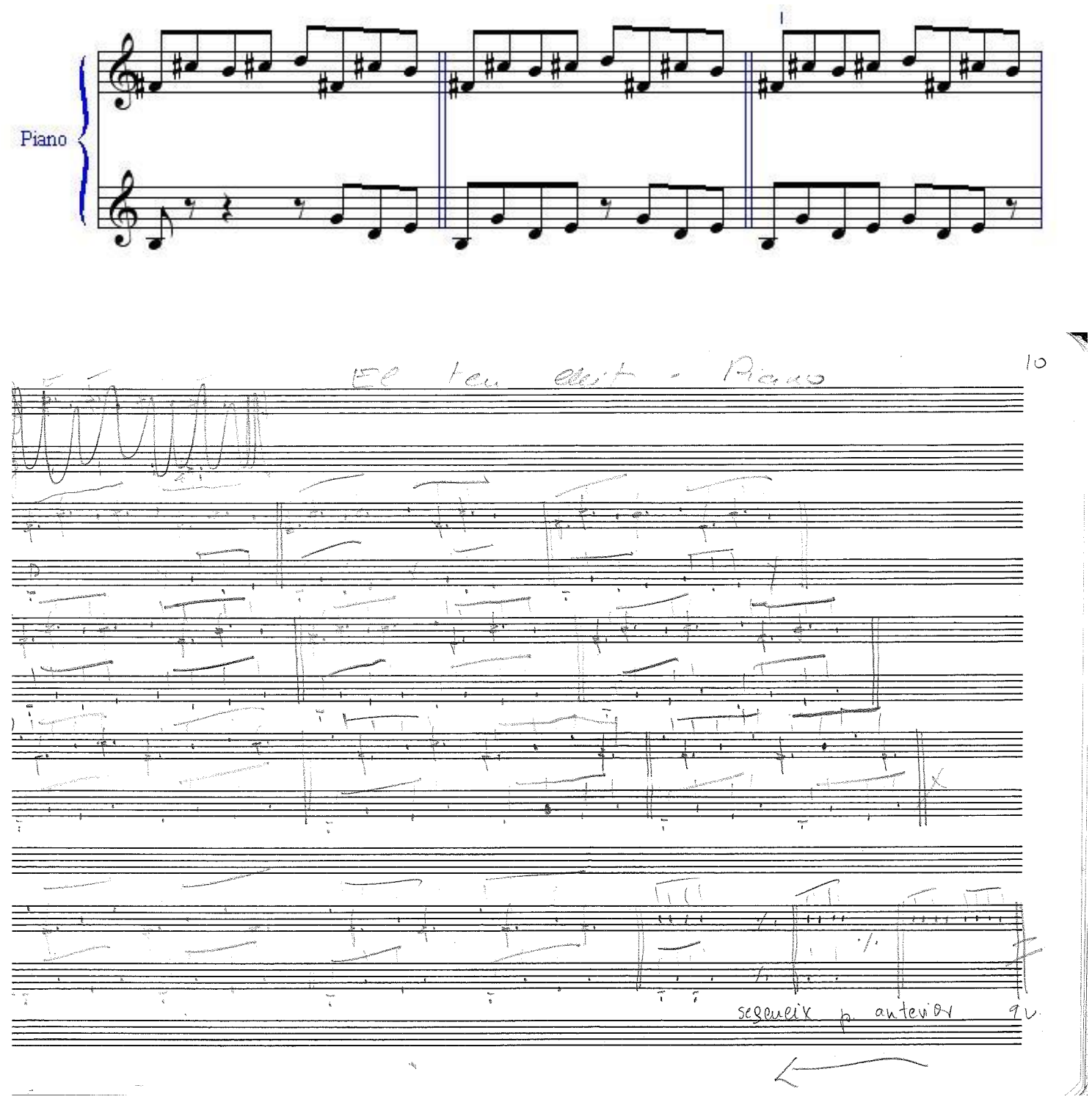

En carpeta RETROSPECCIÓ I PERTENENCIA.

Se corresponde a la pista 5 del disco Carles Santos: Piano grabado en 1988 por Grabaciones Accidentales.

"Puede formar parte de la musicalización de algunas imágenes o film" *

* Testimonio oral del autor. 


\section{MATERIAL TOTAL:}

- Partitura manuscrita y original del autor. Incluida en un bloc de escritura musical, sin título en el exterior, numerado con el número 30 y 5 páginas manuscritas y originales, numeradas del 10 al 12 (música también en el reverso). Consta título en la página 10 como El teu llit (piano). Consta título en la página 5 como Capitol 2 (Salut) (Pla subjetiu). En la contratapa consta el título Retrospecció i pertenencia. Existen otras obras en este bloc.

- Partes: No existen partes.

- No consta relación de originales y copias. 
13.- ENTREACTE, Libre, Sib menor, piano, con partitura, 2007, arc. 18.

La plantilla a la que está dedicada es la de un Piano.

Ver: TINC QUE SER CASTIGAT.
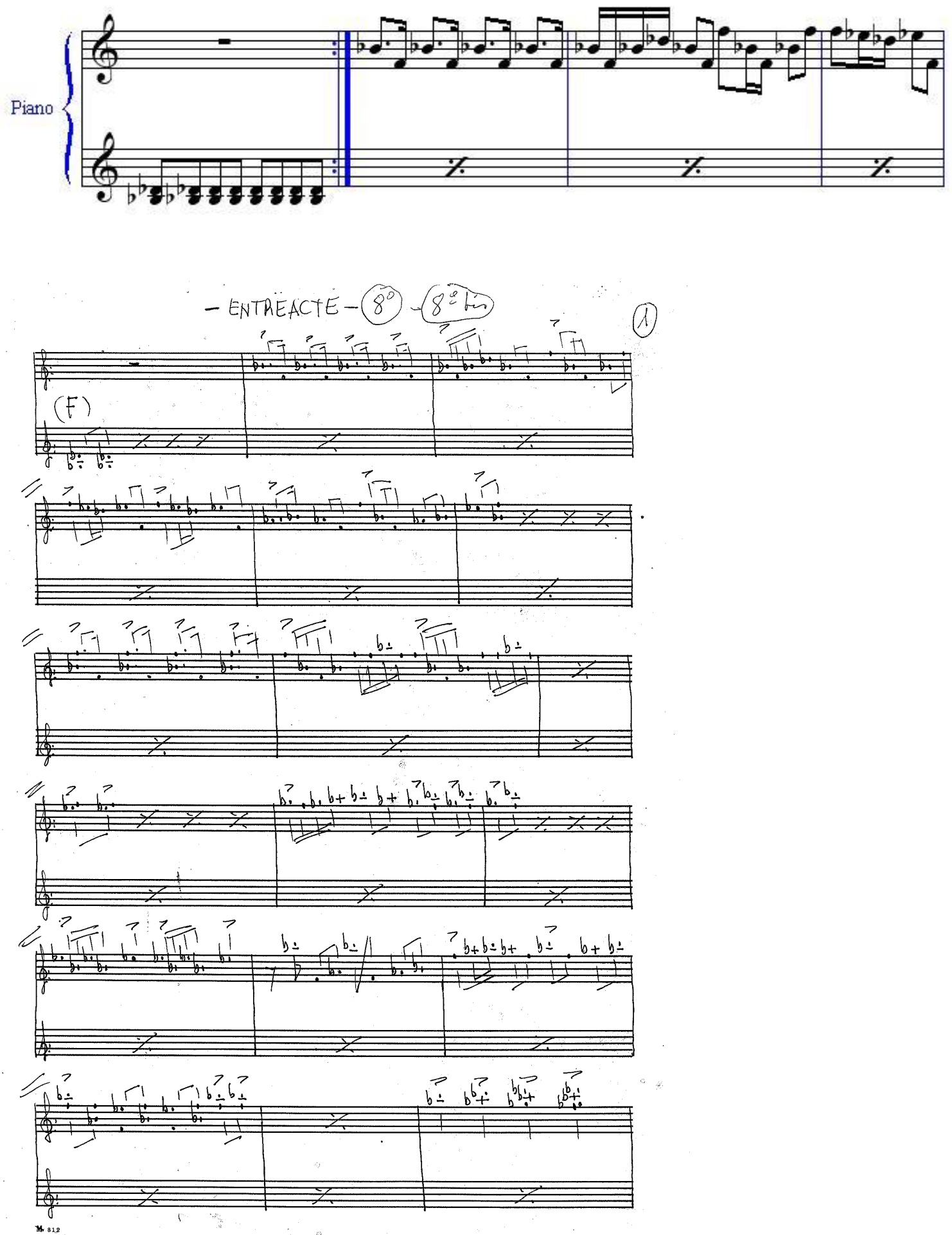


\section{MATERIAL TOTAL:}

- Material manuscrito y original del autor. Consta de 7 páginas manuscritas y originales del autor, numeradas de la 1 a la 7 , con el título Entreacte en la $1^{\text {a }}$ página. Es la parte de Piano de la obra Tinc que ser castigat, (bloc 1), aunque ligeramente modificada.

- Partes: No existen partes.

- No consta relación de originales y copias. 
14.- FINS L'ÚLTIM LLANGOSTÍ, Libre, politonal, piano, con guion, s. d., arc. 22

La plantilla a la que está dedicada es la de un piano.
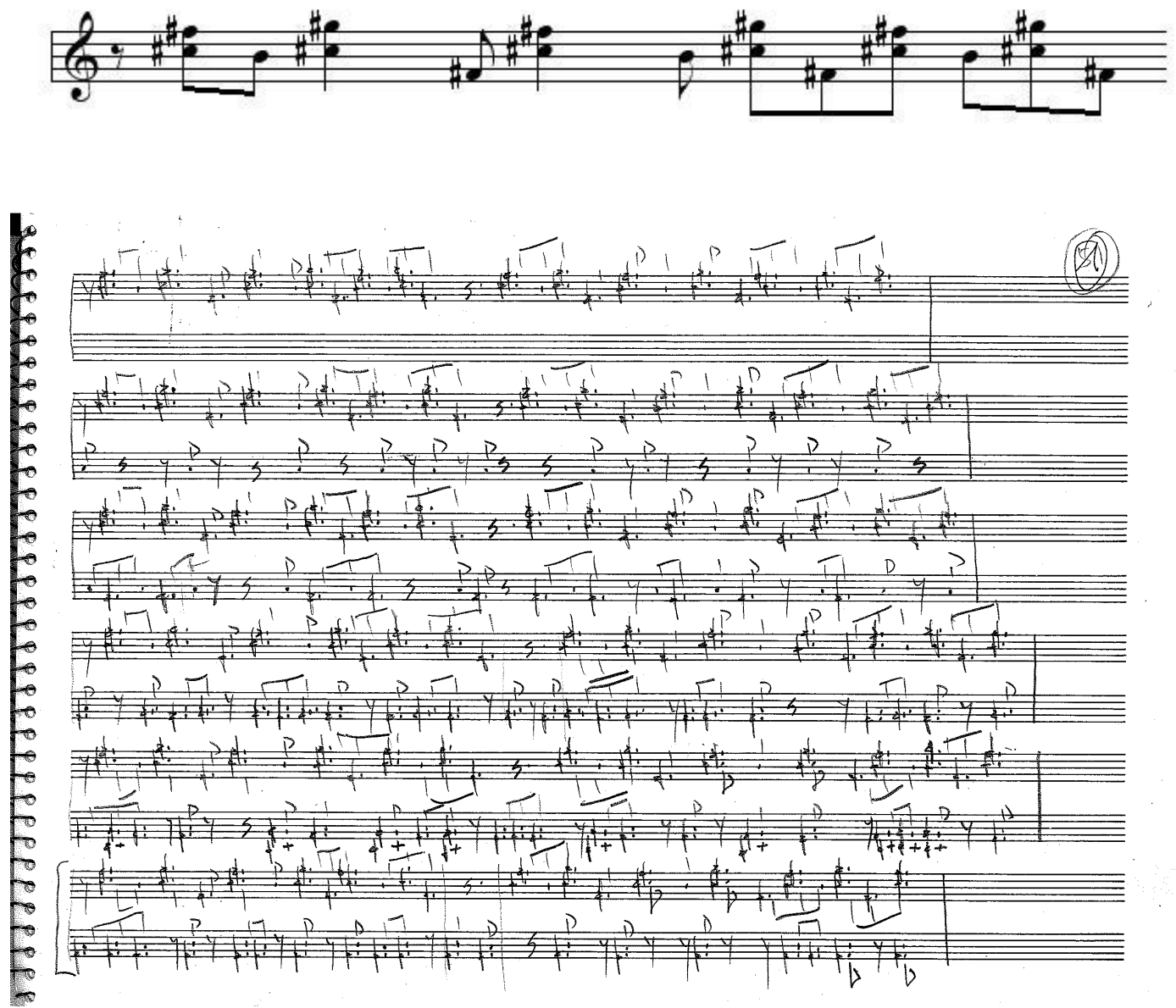

Se corresponde a la pista 1 de la cara B del disco Carles Santos: Piano grabado en 1988 por Grabaciones Accidentales.

En el bloc con el número 31, y comenzando por el reverso, se encuentra el principio de la obra No al no o Vull ser castigat.... "Este fragmento se ha utilizado en otras obras o representaciones del autor". "Es el primer tercio de la obra, aproximadamente" (Carles Santos). Este fragmento se encuentra escrito en 3 páginas consecutivas. 


\section{MATERIAL TOTAL:}

- Partitura manuscrita y original del autor. Se encuentra en el bloc de escritura musical titulado Fins l'ultim llangostí. Consta de 14 páginas escritas y numeradas las 6 primeras, de la 1 a la 6 y el número 51 encercado, en la tapa. Da la sensación de estar inconclusa. Es la misma obra que Fins l'ultim llangostí fragment- -peça 31-, que se cataloga a continuación, aunque más desarrollada.

- Partitura manuscrita y original del autor. Incluida en un bloc de escritura musical, sin título en el exterior, numerado con el número 31 y 3 páginas manuscritas y originales, sin numerar. Consta como borrador de la obra o apuntes, por el autor. Esta primera versión está escrita para voz y piano.

- Partes: No existen.

- No consta relación de originales y copias. 
15.- FLAGELACIÓ E INMOBILIARIES, Libre, politonal, piano, con partitura, 1988, Arc.16.

La plantilla a la que está dedicada es la de un Piano.
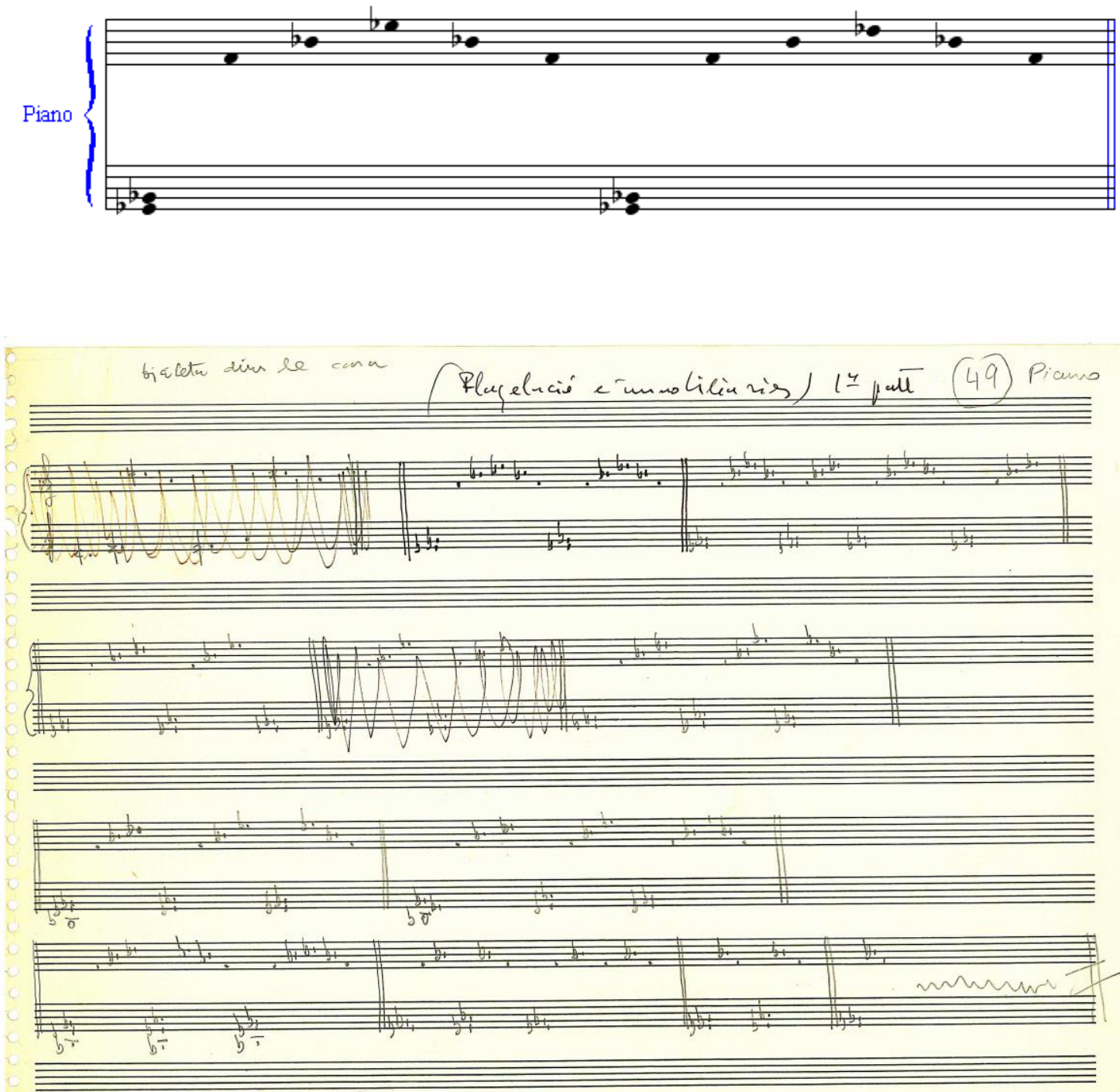

La partitura está numerada como 49 por el autor. La copia que incluye las voces está numerada como 54.

Se corresponde a la pista 1 de la cara A del disco Carles Santos: Piano grabado en 1988 por Grabaciones Accidentales. 


\section{MATERIAL TOTAL:}

- Partitura de la obra: Manuscrito original del autor. Consta de 4 hojas sueltas. Páginas sin numerar. El original del autor comprende la parte de piano.

- Partitura de la obra: Manuscrito original que no es del autor, en dos facsímiles con páginas numeradas de 1 a 5 . Sólo comprende la música de las 2 primeras páginas del manuscrito de piano. Existen 2 copias de este original.

- Existe una versión para 4 voces blancas y piano en otra copia diferente. Esta copia, con la música del piano y de las voces, con medida exacta, que es del autor, comprende las iniciales O.C.S.A. El texto de las voces debe ser la vocal de la nota escrita. Comprende sólo las 2 primeras páginas del manuscrito de piano. Las dos últimas páginas manuscritas están sin desarrollar en sus voces y medida exacta. Posiblemente de 1989.

- Existe otro material con la inscripción "Versió per a piano i 3 veus femenines" y numerado con el 54 encercado, aunque no está completo (sólo constan los 13 primeros sistemas) que coincide con el anterior. Junto a este constan 5 páginas más numeradas, que no parece que sean de la misma obra. Además consta un material fotocopiado de este material desconocido, que incluye la página 1. Existe otro material formado por 2 páginas sueltas y un libreto de escritura musical apaisado (en total 3 páginas escritas y numeradas), manuscrito y original del autor, con el título Fragment Flagelació $i$ inmobiliaries y la inscripción "(no es va enregistrar)" y numerado con el 54 encercado.

- Partes: No existen partes.

- No consta relación de originales y copias.

Dobles barras de cada fragmento indican repeticiones, el número de las cuales será a libertad del intérprete. En la partitura en la que constan las voces se indica el número de veces a repetir. 
16.- FUGA EN LA MENOR, Libre, La menor, piano, con guion, s. d., arc. 16

La plantilla a la que está dedicada es la de un piano.
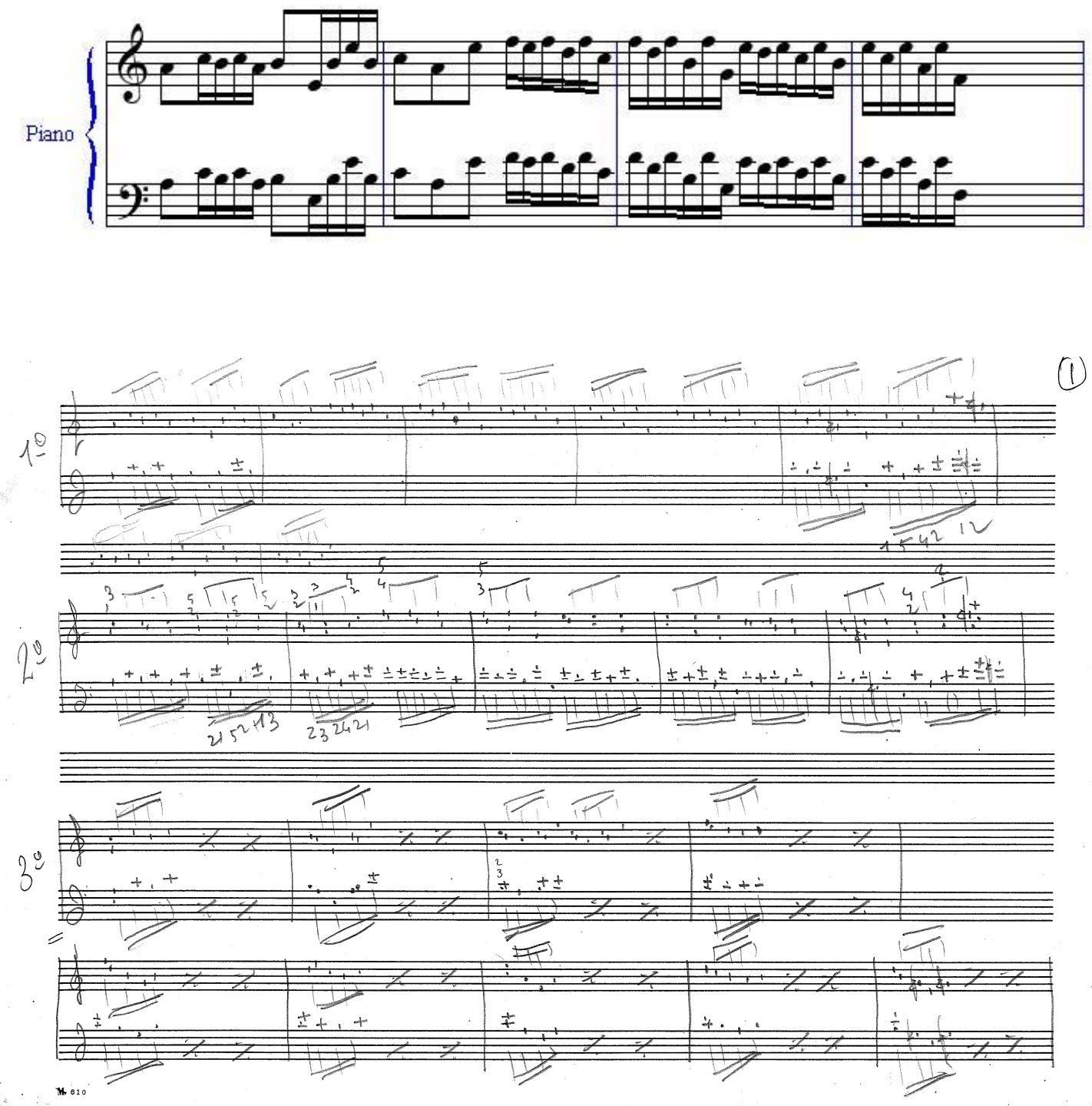

Se trata de una construcción musical a partir del Preludio y Fuga en La menor, BWV 543 de J. S. Bach.

Es una de las obras recurrentes del autor, que ha sido interpretada en numerosas ocasiones y de diferentes maneras (a solo, a dúo, de pie, sentado, etc.) 


\section{MATERIAL TOTAL:}

- Material manuscrito y original del autor. Consta de 1 facsímil de escritura musical, sin título en el exterior. Consta de 8 páginas numeradas con la música para piano, del autor.

- Existe una versión para dos voces, en 1 facsímil de escritura musical, con el título Tony-Mari y Variacions Fonètiques en el exterior que consta de 5 páginas manuscritas y numeradas.

- Existe otra versión para coro, en 1 facsímil de escritura musical, sin título en el exterior que consta de 10 páginas manuscritas y numeradas.

- Partes: No existen partes.

- No consta relación de originales y copias. 
17.- L’APERITIU, Libre, en La, piano, con partitura, 1980, arc.10.

La plantilla a la que está dedicada es la de un piano.

Ver: ARMANDINO '77.
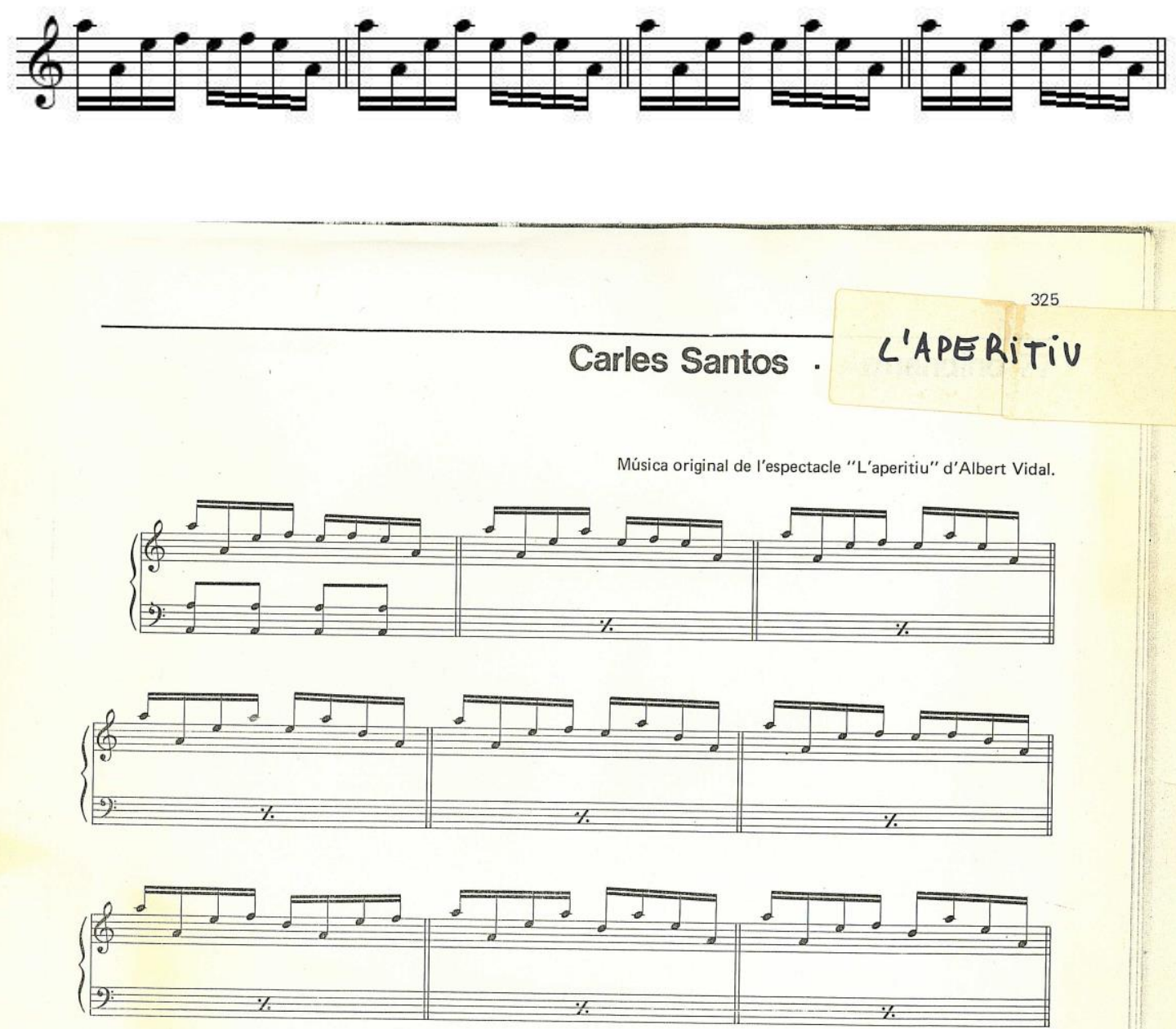

En el material impreso, el título original de la pieza es Armandino 77.

\section{MATERIAL TOTAL:}

- Partitura de la obra: Partitura manuscrita y original del autor. Consta de una hoja de escritura musical. Existe material impreso de la obra en dos hojas numeradas como 325 y 326 y con la indicación "Música original de l'espectacle L'aperitiu, d'Albert Vidal." ${ }^{68}$.

\footnotetext{
${ }^{68}$ Albert Vidal es un mimo que representa su acción al ritmo de la música de Santos
} 
En el material impreso, el título original de la pieza es Armandino 77.

- Partes: Existe parte de piano impresa.

- No consta relación de originales y copias. 
18.- LA CONVALIDACIÓ O LA CANÇÓ DEL TREMALL, Libre, Mib menor, piano, con partitura, 1983, arc.21.

La plantilla a la que está dedicada es la de un Piano.
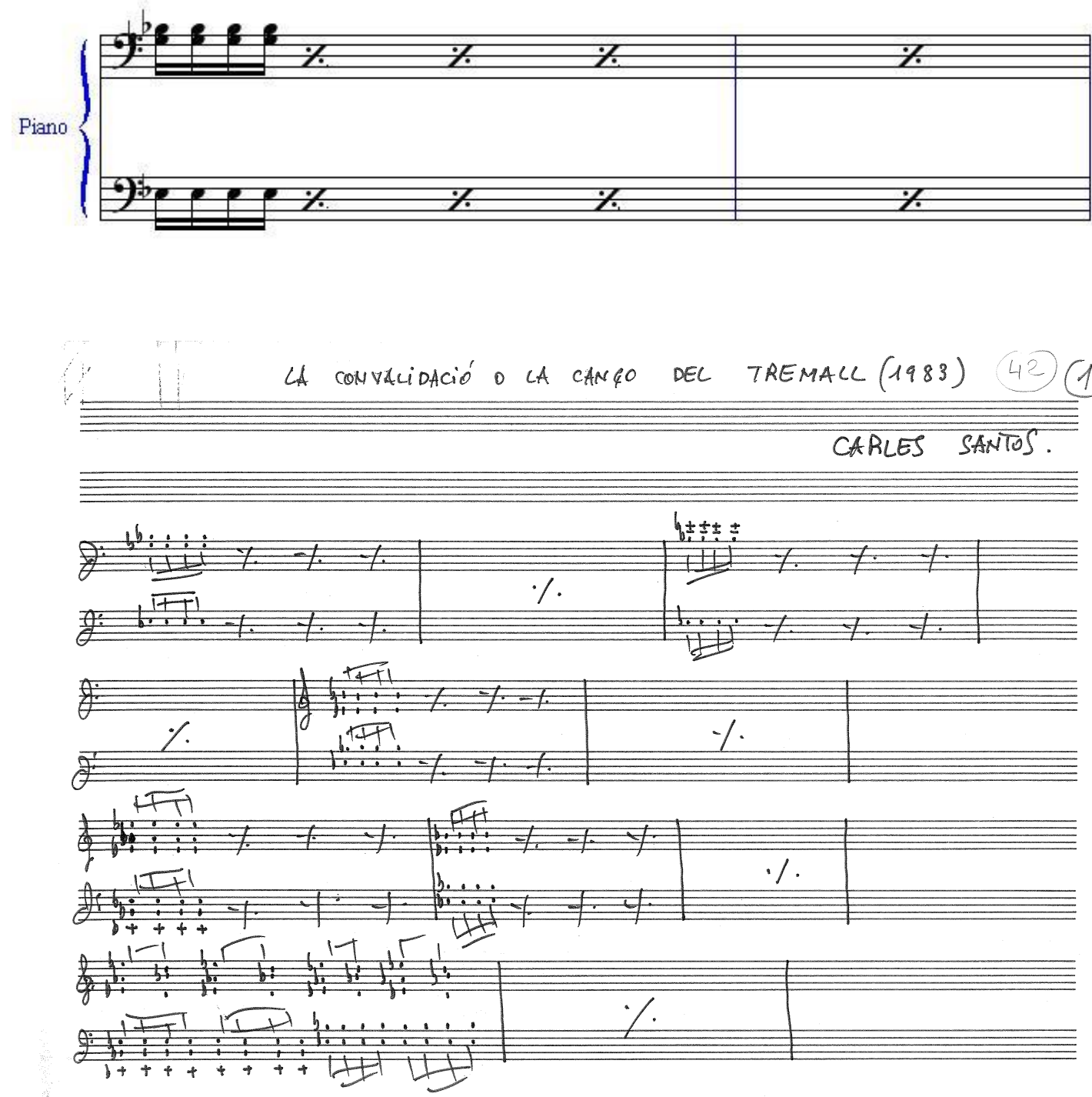

La partitura está numerada como 42 por el autor.

Se corresponde a la pista 3 de la cara B, del disco Pianotrack grabado en 1984 por Linterna Música. 


\section{MATERIAL TOTAL:}

- Partitura manuscrita y original del autor. Consta de dos libretos de escritura musical con 6 páginas escritas y numeradas, con el título La convalidació o La cançó del tremall (1983) y el número 42 encercado, en la $1^{a}$ página.

- Partes: No existen partes.

- No consta relación de originales y copias. 
19.- LA NIT AMERICANA, Libre, en Re, piano, con partitura, 1981, arc.21.

La plantilla a la que está dedicada es la de un Piano.

Ver: BARBYLET O LA NIT AMERICANA (sección Obra piano) y CANT ENERGÈTIC (sección Obra vocal).

Se corresponde a la pista 2 de la cara B, del disco Pianotrack grabado en 1984 por Linterna Música. 
20.- LA PORCA I VIBRÀTICA TECLURIA, Libre, politonal, piano, con partitura, 1994, arc.17.

La plantilla a la que está dedicada es la de un Piano.
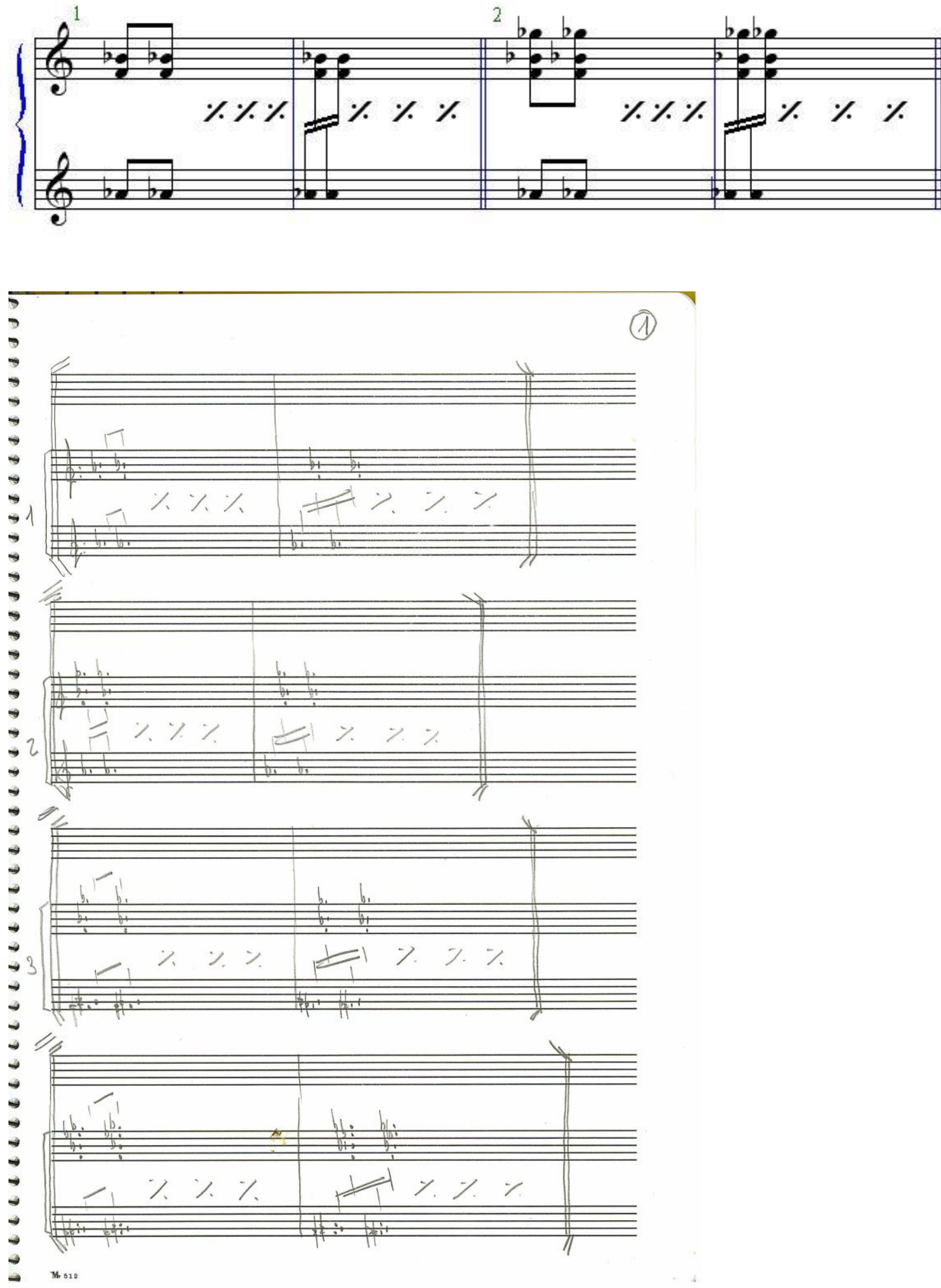
Estrenada al Palau de la Música Catalana el 14 de noviembre de 1994.

Disco Publicado en 1994 por Plusmusic, con el mismo título, con una sola pista, instrumentado para piano.

El 11 de julio de 2011 es relanzado y editado por Satélite K (ASIN: B009CZOBQI)

\section{MATERIAL TOTAL:}

- Partitura manuscrita y original del autor. Consta de un bloc de escritura musical, con el título La porca i vibràtica tecluria en el exterior y 5 páginas manuscritas y originales. Comenzando por el reverso existen apuntes musicales en 5 páginas. Da la sensación de no estar terminado.

- Partes: No existen.

- No consta relación de originales y copias. 
21.- MINIMALET SÛR MER, Libre, politonal, piano, con partitura, 1988, arc. 34.

La plantilla a la que está dedicada es la de un Piano.

Ver: PEÇA A LA MAR (sección Obra piano)

Música para acción musical realizada en Vinaròs en 1988 en la que el compositor realiza la interpretación sobre una plataforma flotante, al mismo tiempo que una soprano canta desde una superficie elevada en el puerto. 
22.- MÚSICA PER A CESC GELABERT, Libre, politonal, piano, con partitura, s. d., $\operatorname{arc} .14$

La plantilla a la que está dedicada es Piano.

Ver: MÚSICA PER A LA DANSA y NO AL NO
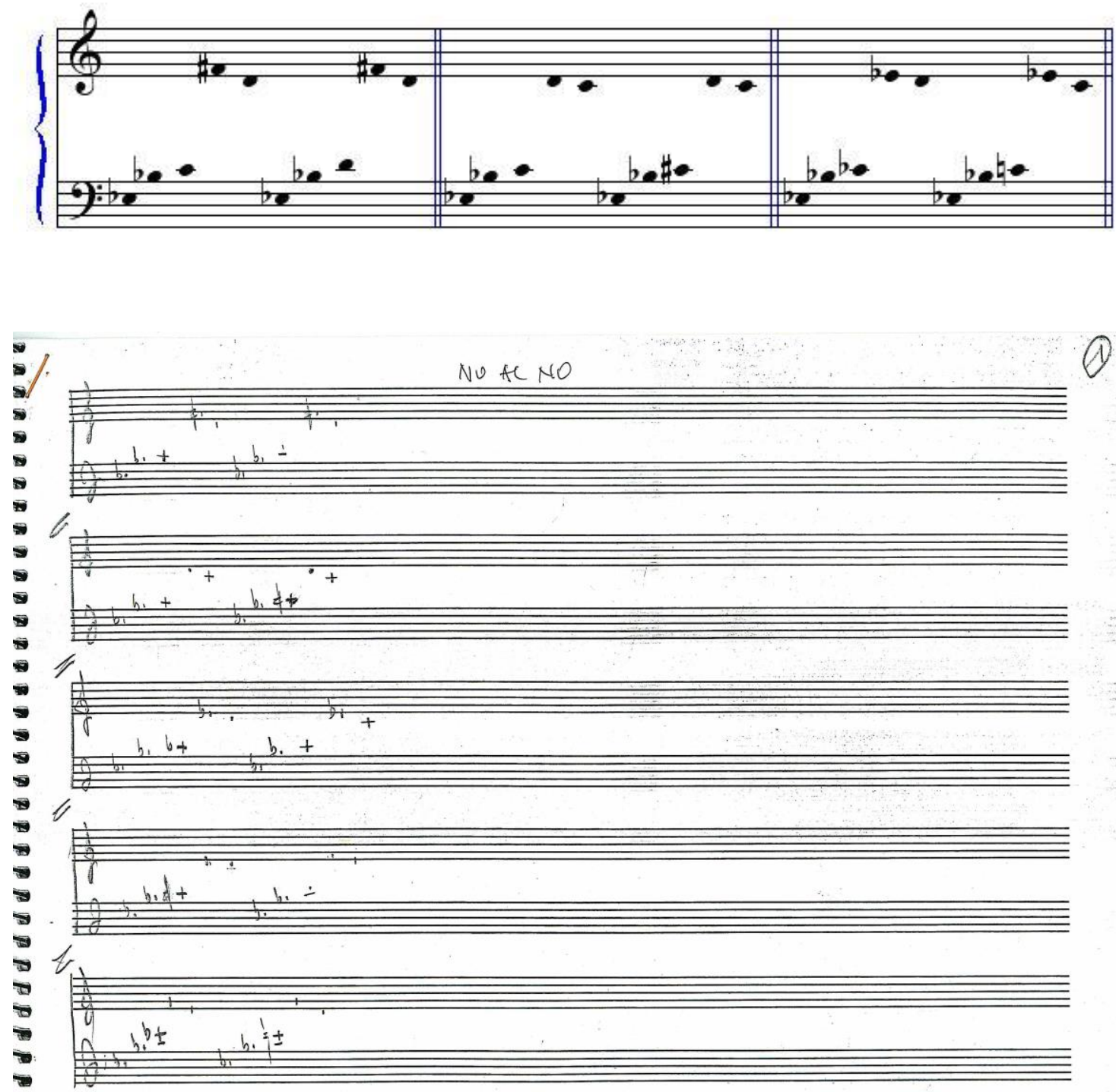

La música es la misma que Música per a dansa. 


\section{MATERIAL TOTAL:}

- Partitura de la obra: Existen partes manuscritas del autor, fotocopiadas y partes impresas, fotocopiadas, sueltas. El material es idéntica al de la obra Música per a dansa. Se interpretan las partes que no son de la obra No al no.

- Partes: No existen partes.

- No consta relación de originales y copias. 
23.- MÚSICA PER A LA DANSA, Libre, politonal, piano, con partitura, s. d., arc.14

La plantilla a la que está dedicada es Piano.
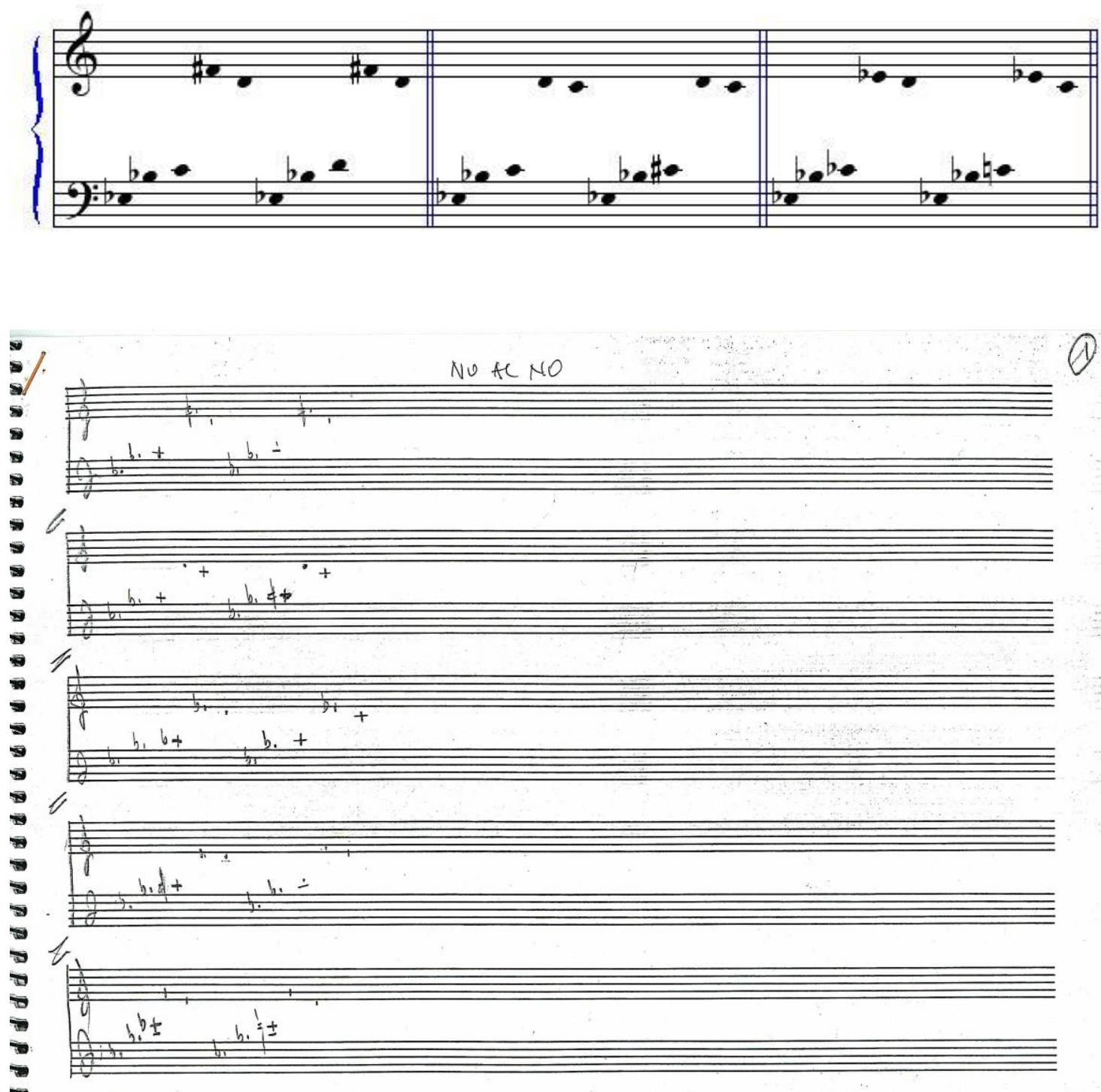

Análisis de la música encuadernada: El primer y segundo tema impreso corresponde a la obra No al no. Estos fragmentos los utiliza el autor en sus interpretaciones, como bis y se trata de los fragmentos interpretados con la cabeza y con los puños cerrados.

El tercer tema impreso se utiliza en esta pieza y también es el tema, interpretado en segundo lugar, de la obra No al no. El cuarto tema impreso si corresponde a la obra y también, posiblemente, el quinto, a falta de confirmarlo por el autor. El sexto tema 
corresponde a la obra No al no, según una adaptación posterior que realizó el autor. Los fragmentos manuscritos de los mismos se encuentran en la misma encuadernación y se observa, confirmado por el autor, que no todos los fragmentos manuscritos se encuentran en la parte impresa. El motivo es que el autor ha ido desechando algunos en el transcurso de su vida. El primer material manuscrito (numerado como 1 y 2), corresponde al $4^{\circ}$ tema impreso. El segundo material manuscrito (numerado del 1 al 6), pertenece a No al no y es el que hemos comentado con anterioridad. Se interpreta a continuación del último material manuscrito de esta encuadernación. Faltan algunos fragmentos que el autor interpreta al final, después del fragmento numerado como $20 \mathrm{y}$ que no constan en este material estudiado.

Siguen los apuntes del tema impreso $\mathrm{n}^{\circ} 5$ (numerado del 1 al 4), que difieren de este ya que, al igual que antes, el manuscrito posee más material que el impreso.

\section{MATERIAL TOTAL:}

- Partitura de la obra: Existen partes manuscritas del autor, fotocopiadas y partes impresas, fotocopiadas, encuadernadas. El principio (material impreso) es el mismo de la pieza No al no. Las 4 últimas páginas manuscritas del material encuadernado (que forman un grupo), son apuntes de las 2 primeras páginas impresas $(9 / 8,6 / 8,12 / 8)$. Asimismo, existe un grupo de 6 páginas manuscritas (que forman un grupo), que son apuntes de las 3 páginas impresas con estructuras que han sido numeradas en el momento de la catalogación, del 1 al 20, en el material encuadernado.

- Partes: No existen partes.

- No consta relación de originales y copias. 
24.- MÚSICA PIANO 2005, Libre, politonal, piano, con partitura, 2005, arc. 21

La plantilla a la que está dedicada es Piano.

Ver: PREMIS OCTUBRE '05 (sección Obra piano)
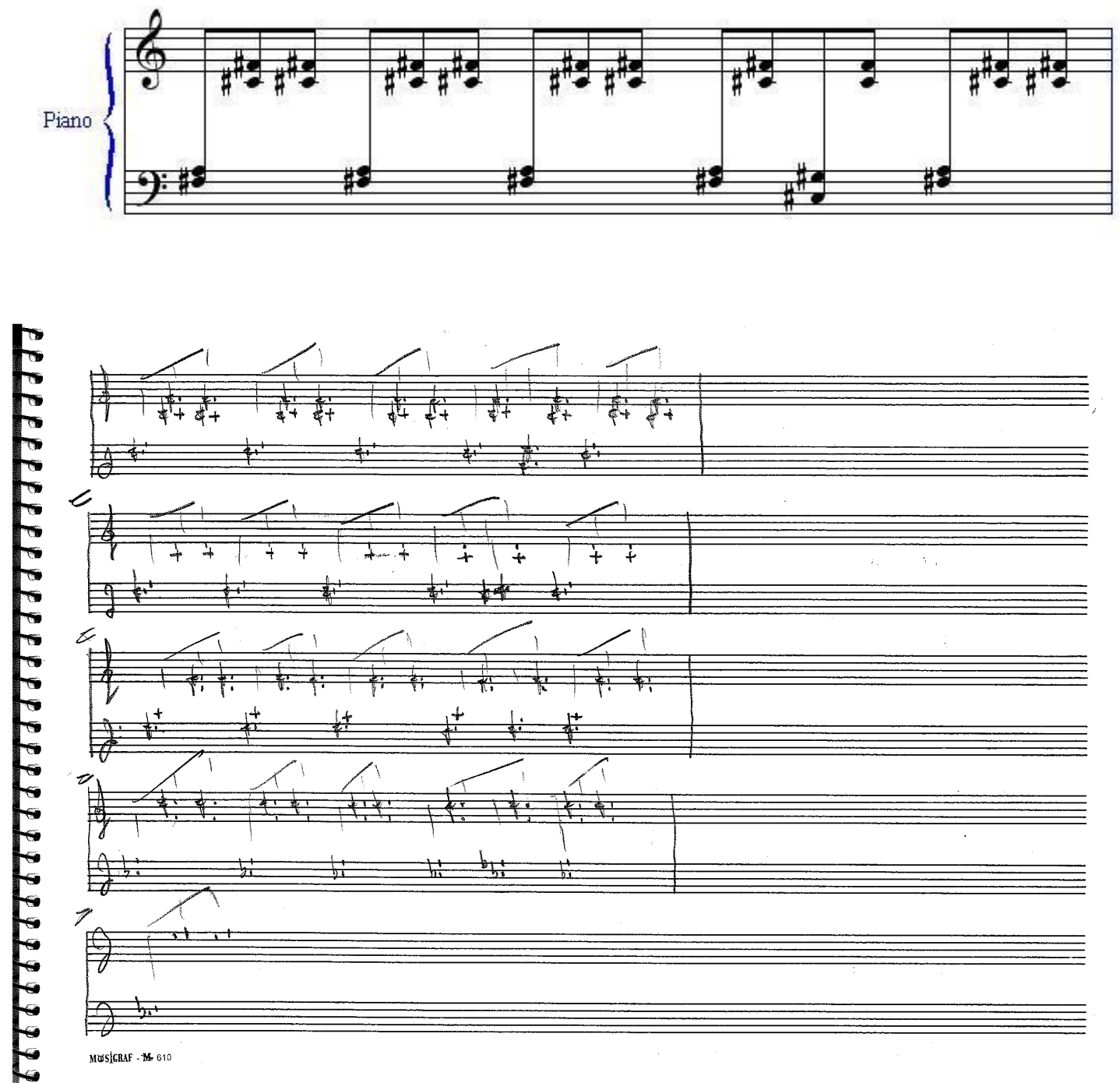

MATERIAL TOTAL:

- Partitura manuscrita y original del autor. Consta de un bloc de escritura musical con el título Música piano 2005 en la tapa y con 3 páginas escritas y sin numerar. En el reverso existen 2 páginas con apuntes de una obra para piano.

- Partes: No existen partes.

- No consta relación de originales y copias. 
25.- NO AL NO, Libre, politonal, piano, con partitura, 2002, Arc. 14

La plantilla a la que está dedicada es la de un Piano.
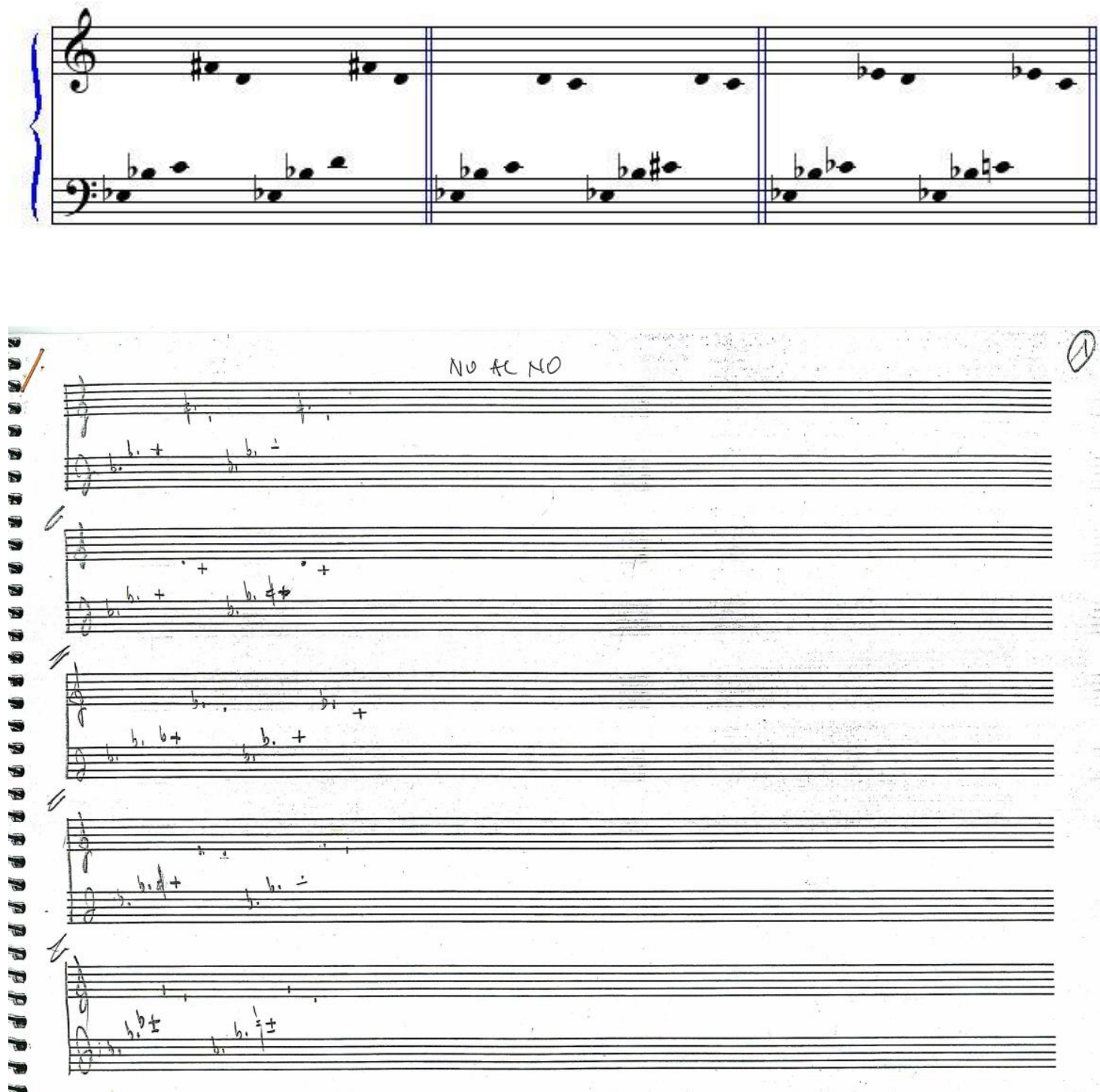

Fotocopia del original manuscrito. Dos copias, una encuadernada.

Estrenada a la Sala Fabià Puigserver (en el Festival de Edimburgo, el 24 de agosto de 2002, según Guerrero (2006: 44)). Bajo el nombre de Codi o estigma?, también se interpreta música contenida en estos manuscritos. 
Análisis de la música encuadernada: El primer material, manuscrito, (numerado del 1 al 3), no se interpreta. El segundo y tercer material, impreso, (4 páginas), los utiliza el autor en sus interpretaciones, como bis y se trata de los fragmentos interpretados con la cabeza y con los puños cerrados. El cuarto material, impreso, (numerado del 1 al 3), se interpreta en segundo lugar. El quinto material, manuscrito, (numerado del 1 al 2), no se ha interpretado nunca y son apuntes del autor. El sexto material, manuscrito, (numerado del 1 al 3), corresponde al principio de la obra y debe interpretarse, Prestísimo. El séptimo material, manuscrito, (numerado del 1 al 3), y que posee indicación de "veu", no se ha interpretado nunca y son apuntes del autor. El octavo material, manuscrito, (numerado del 1 al 6), corresponde al final de la obra, y debe interpretarse como última variación. El noveno material, manuscrito, (numerado del 1 al 6), y con el título "El vals de la bola Bengie", se interpreta por parte del instrumentista con una pelota (la bola Bengie, en homenaje al autor de este elemento) cogida en la mano izquierda, con la cual realiza glisandos sobre el teclado a modo de clusters. Existe otra variación similar pero interpretándose con la bola en la mano derecha, que no aparece en los manuscritos encontrados. El décimo material, manuscrito, (numerado del 1 al 6 bis), y que posee indicación de "veu i piano", no se ha interpretado nunca y son apuntes del autor. . El undécimo material, manuscrito, (numerado del 1 al 6), si se interpreta, aunque el autor no ha facilitado en que lugar del orden establecido.

\section{MATERIAL TOTAL:}

- Partitura de la obra: Existen partes manuscritas del autor, fotocopiadas y partes impresas, fotocopiadas, encuadernadas (las comentadas en el párrafo anterior). Existe otro material igual, pero separado y grapado por secciones. Las secciones existentes llevan por títulos: "El vals de la Bola "Bengie".

- Existe un fragmento de esta obra (primer tercio, según el autor) en el bloc $\mathrm{n}^{\circ} 31$, catalogado con el $\mathrm{n}^{\mathrm{o}}$ de orden $123^{*}$.

- Partes: No existen partes.

- No consta relación de originales y copias.

\footnotetext{
${ }^{*}$ En $n^{\circ}$ de orden al que se hace referencia corresponde a una tabla EXCEL utilizada en el inventario del material encontrado.
} 
26.- OBRA CONJUNTA, Libre, politonal, piano, con partitura, s. d. (de 2000, aproximadamente), arc.17.

La plantilla a la que está dedicada es la de un Piano.
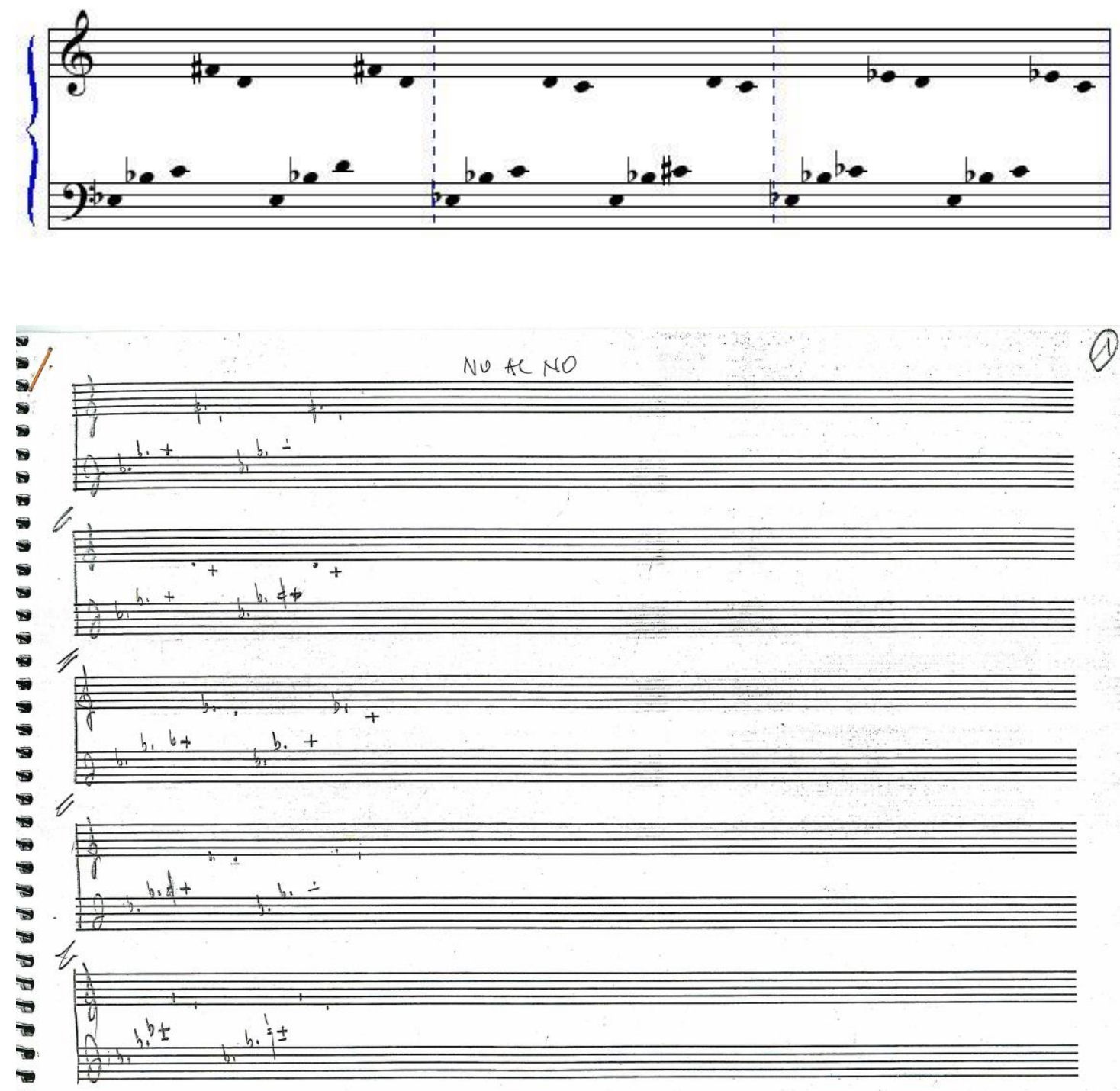

La plantilla a la que está dedicada es la de un Piano, interpretándose con la participación de bolas y algún fragmento con la cabeza.

Es la primera versión de la obra No al no, que el autor ha ido modificando y desarrollando con el tiempo. Compuesta con anterioridad al año 2000. "Su interpretación, dado que está formada por fragmentos libres, puede adaptarse al 
momento y lugar, en cuanto a los fragmentos interpretados como al orden de interpretación de los mismos"**.

\section{MATERIAL TOTAL:}

- Partitura manuscrita y original del autor. Consta de 5 blocs de escritura musical, con los siguientes títulos:

○ "Obra Conjunta" "Amb un dit" "Punys" "Rapida" en el exterior (inicio de la obra) con 14 páginas numeradas y manuscritas en 4 grupos: de la 1 a la 3 con el título "Punys", de la 1 a la 3, de la 1 a la 6 y de la 1 a la 2.

○ "Ma esquerra" "Ma esquerra +" en el exterior con 6 páginas numeradas y manuscritas en 2 grupos: de la 1 a la 3 y de la 1 a la 3 ("este bloc no se corresponde con esta obra" Carles Santos).

○ "Amb el cap" en el exterior con 4 páginas numeradas y manuscritas. Existen 4 hojas sueltas y numeradas que no se corresponden con este fragmento (pueden ser de una obra pianística catalogada al principio).

○ "Bola ma dreta" en el exterior con 6 hojas numeradas y manuscritas en 3 grupos: las 4 primeras páginas sin numerar, de la 1 a la 3 y una página sin numerar con el título "Bola (2)".

○ "Final?" "Bola?" "+ Calmada" en el exterior con 12 páginas numeradas y manuscritas en 2 grupos: de la 1 a la 6 y de la 1 a la 6 con anotación final del autor "agafar la pilota".

- Partes: No existen.

- No consta relación de originales y copias.

${ }^{*}$ Testimonio oral del autor. 
27.- OCTAVI I LIDIA (FRAGMENT DE BEETHOVEN), Libre, politonal, piano, con partitura, 1979, arc.16.

La plantilla a la que está dedicada es la de un Piano.
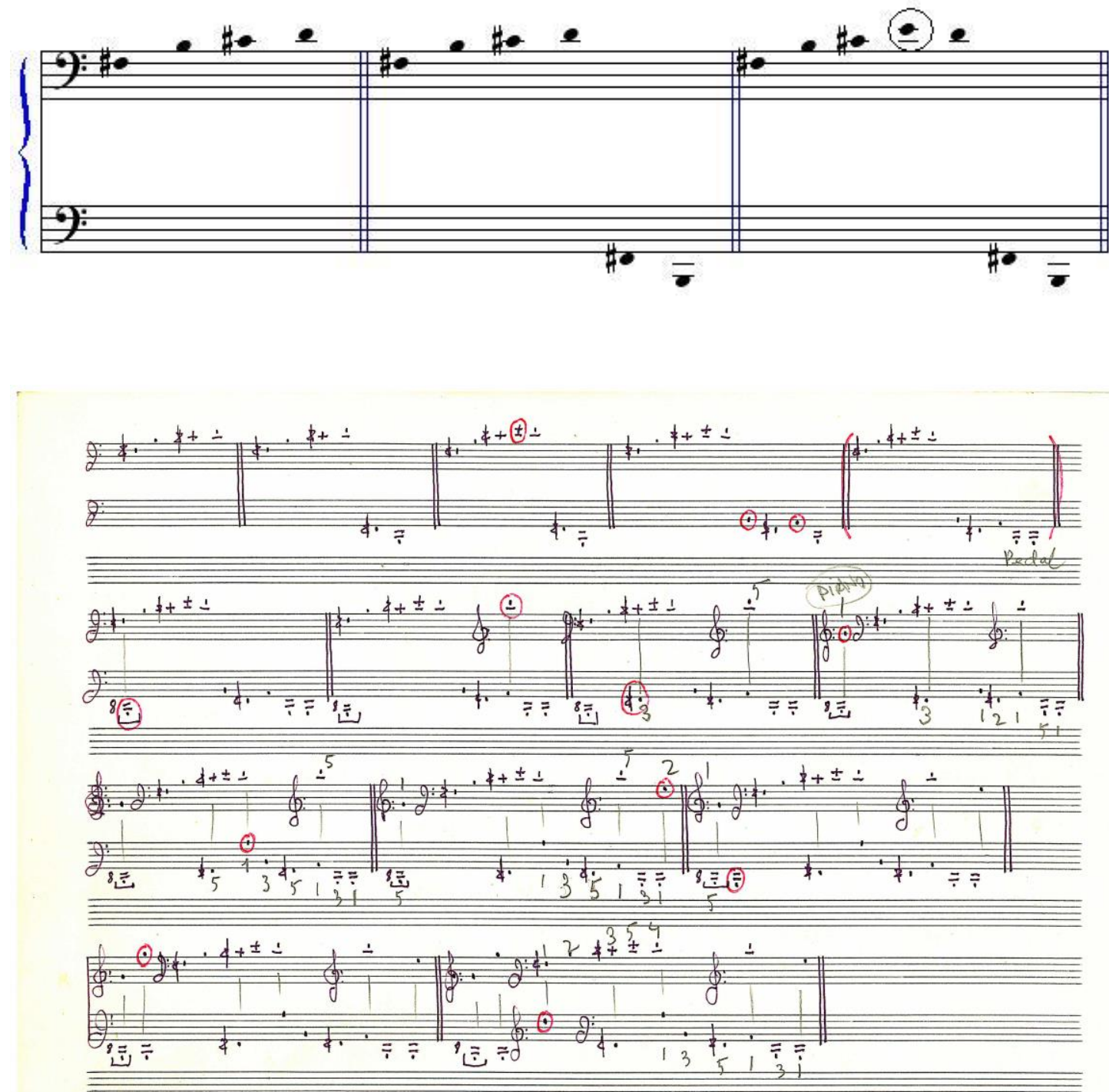

Podría tratarse de un fragmento de la obra escénica Beethoven, si tanco la tapa....que passa?. Las notas rodeadas en rojo son las nuevas. 


\section{MATERIAL TOTAL:}

- Partitura de la obra: Manuscrito original del autor. Consta de 2 hojas escritas de un facsímile. Fechada en 1979. Numerada como 3.

- Partes: No existen partes.

- No consta relación de originales y copias.

Dobles barras de cada fragmento indican repeticiones, el número de las cuales será a libertad del intérprete. 
28.- PEÇA A LA MAR, Libre, politonal, piano, con partitura, 1988, arc. 34.

La plantilla a la que está dedicada es la de un Piano.

Ver: MINIMALET SÛR MER (sección Obra piano)
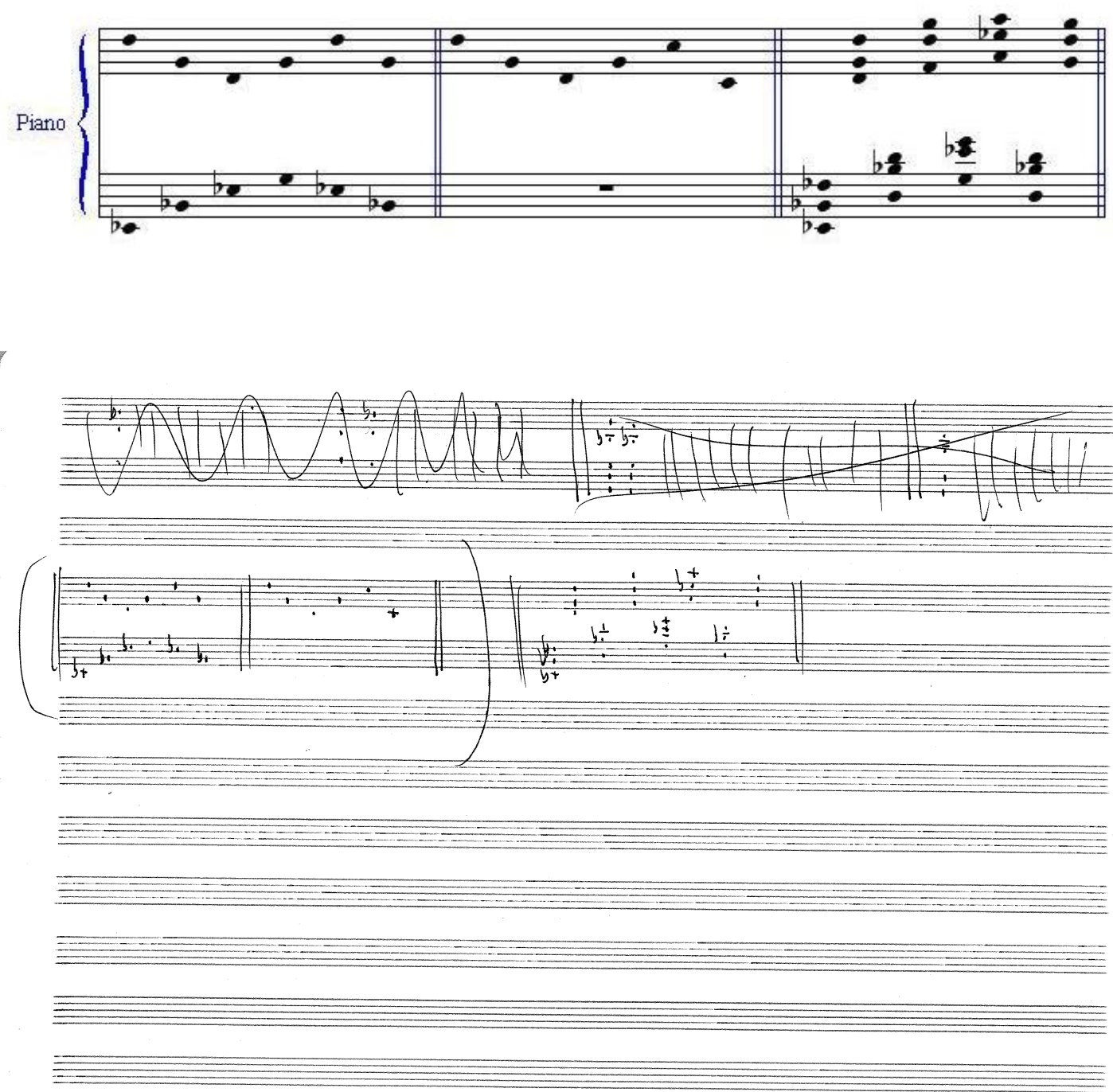

Música para acción musical realizada en Vinaròs en 1988 en la que el compositor realiza la interpretación sobre una plataforma flotante, al mismo tiempo que una soprano canta desde una superficie elevada en el puerto.

No se ha encontrado la música interpretada por la cantante.

Existe video. 


\section{MATERIAL TOTAL:}

- Material manuscrito y original del autor. Consta de 1 bloc de escritura musical, sin título en el exterior. En el reverso se encuentran las páginas sin numerar que contienen los apuntes de la obra.

- Se encuentra integrado en el mismo bloc que la obra Minimalet $\left(2^{\circ} \mathrm{bloc}\right)$.

- Partes: No existen partes.

- No consta relación de originales y copias. 
29.- PEÇA PER A PIANO (I), Libre, politonal, piano, con partitura, s. d., arc.16.

La plantilla a la que está dedicada es la de un Piano.
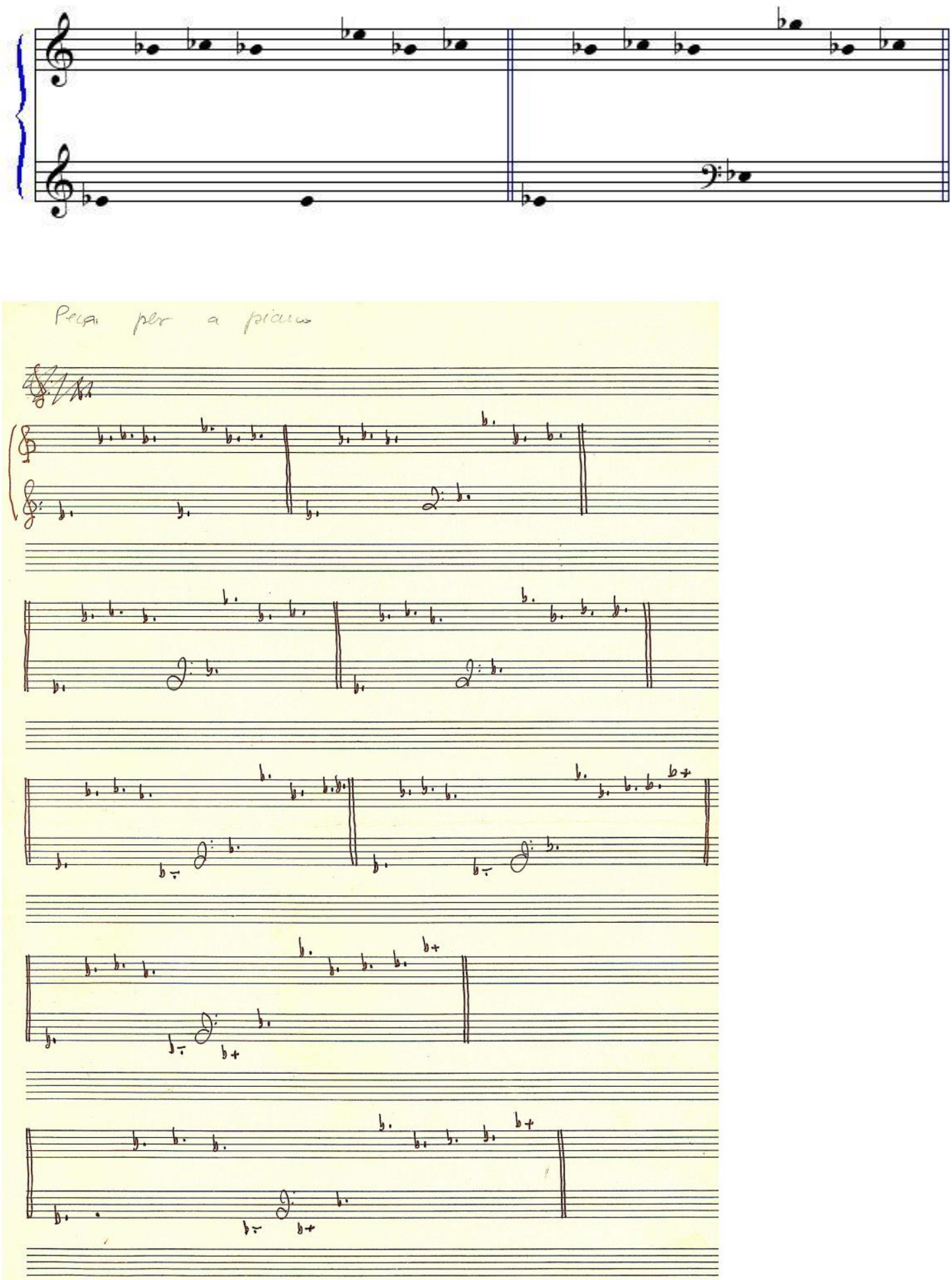
Palabras del autor: "La interpretación ha de ser libre, dando el intérprete, el carácter bucólico que quiere el compositor. En caso de publicarse, la publicación se hará tal y como consta en esta partitura manuscrita"*.

Dobles barras de cada fragmento indican repeticiones, el número de las cuales será a libertad del intérprete.

Obra interpretada en directo aunque no grabada. La última página son apuntes del compositor.

\section{MATERIAL TOTAL:}

- Partitura de la obra: Manuscrito fotocopiado del autor en un díptico de cartón sobre el que se hallan pegadas algunas hojas de la obra. La obra está incompleta.

- Partes: No existen partes.

- No consta relación de originales y copias.

* Testimonio oral del autor. 
30.- PEÇA PER A PIANO (II), Libre, politonal, piano, con partitura, s. d., arc.16.

La plantilla a la que está dedicada es la de un Piano.
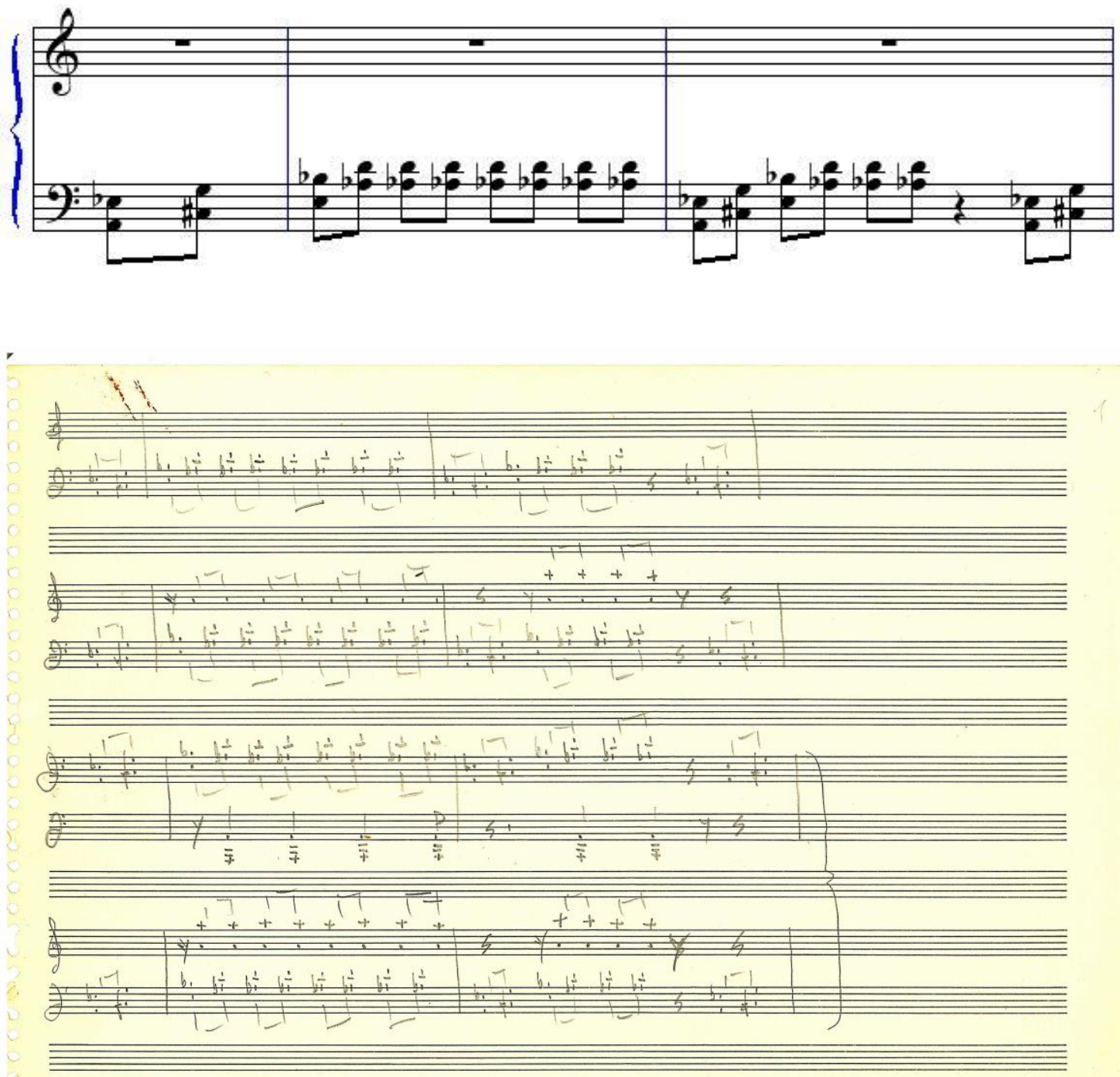

\section{MATERIAL TOTAL:}

- Partitura de la obra: Manuscrito original del autor en 4 hojas sueltas, numeradas del 1 al 5. La numeración de las mismas se ha realizado en el momento de la catalogación, supervisada por el autor. Existen algunas páginas que son apuntes (reverso de 1) o partes de otra obra (reverso de 3)

- Partes: No existen partes.

- No consta relación de originales y copias. 
31.- PEÇA PER A PIANO (III), Libre, politonal, piano, con partitura, s. d., arc.16.

La plantilla a la que está dedicada es la de un Piano.
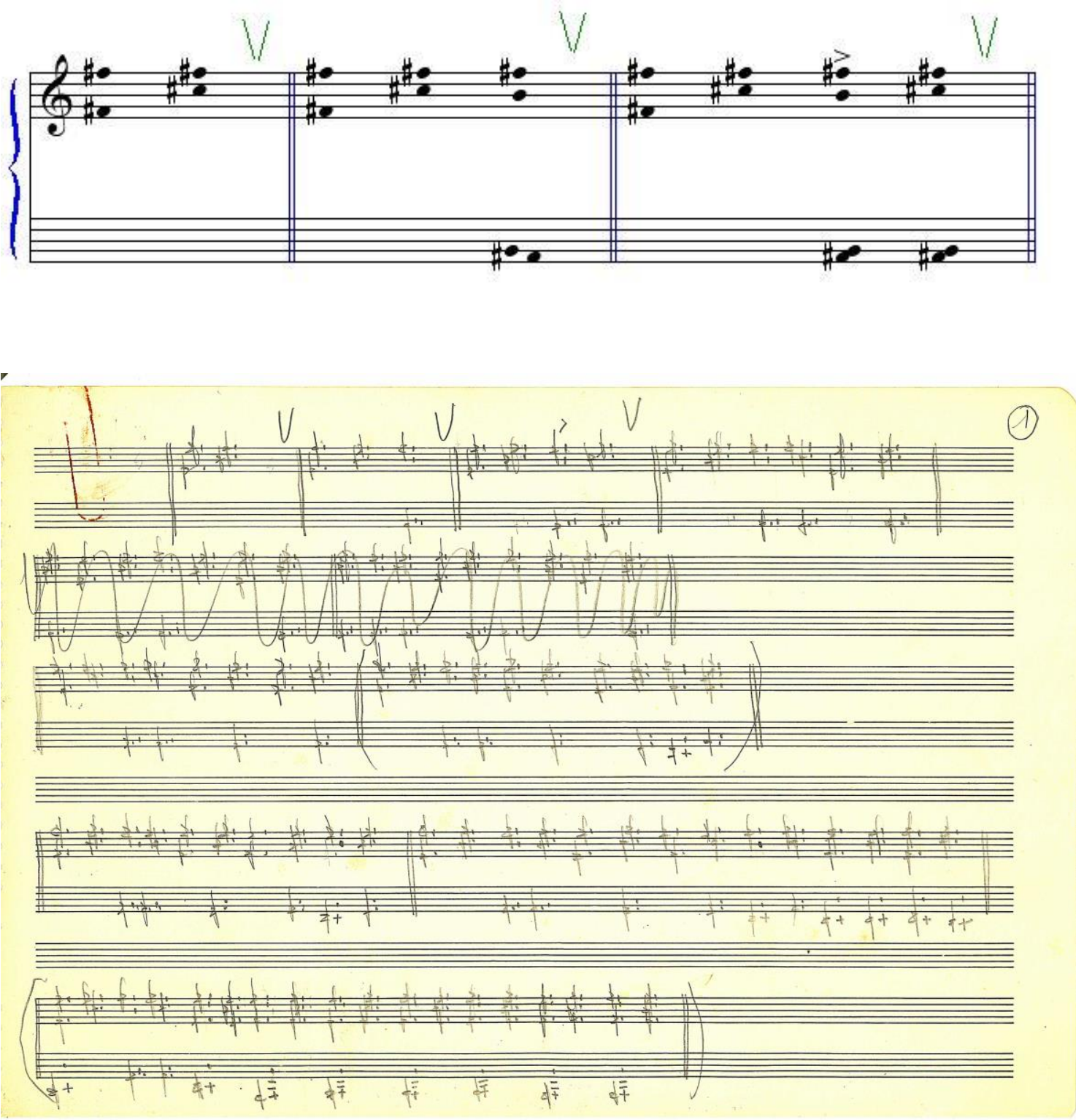

“Interpretación y publicación como la Peça per a piano (I)."

\section{MATERIAL TOTAL:}

- Partitura de la obra: Manuscrito original del autor en 2 hojas sueltas, numeradas del 1 al 2. Existen algunas páginas que son apuntes (reverso de 2).

- Partes: No existen partes.

- No consta relación de originales y copias.

${ }^{*}$ Testimonio oral del autor. 
32.- PEÇA PER A PIANO (IV), Libre, politonal, piano, con partitura, s. d., arc.16.

La plantilla a la que está dedicada es la de un Piano.
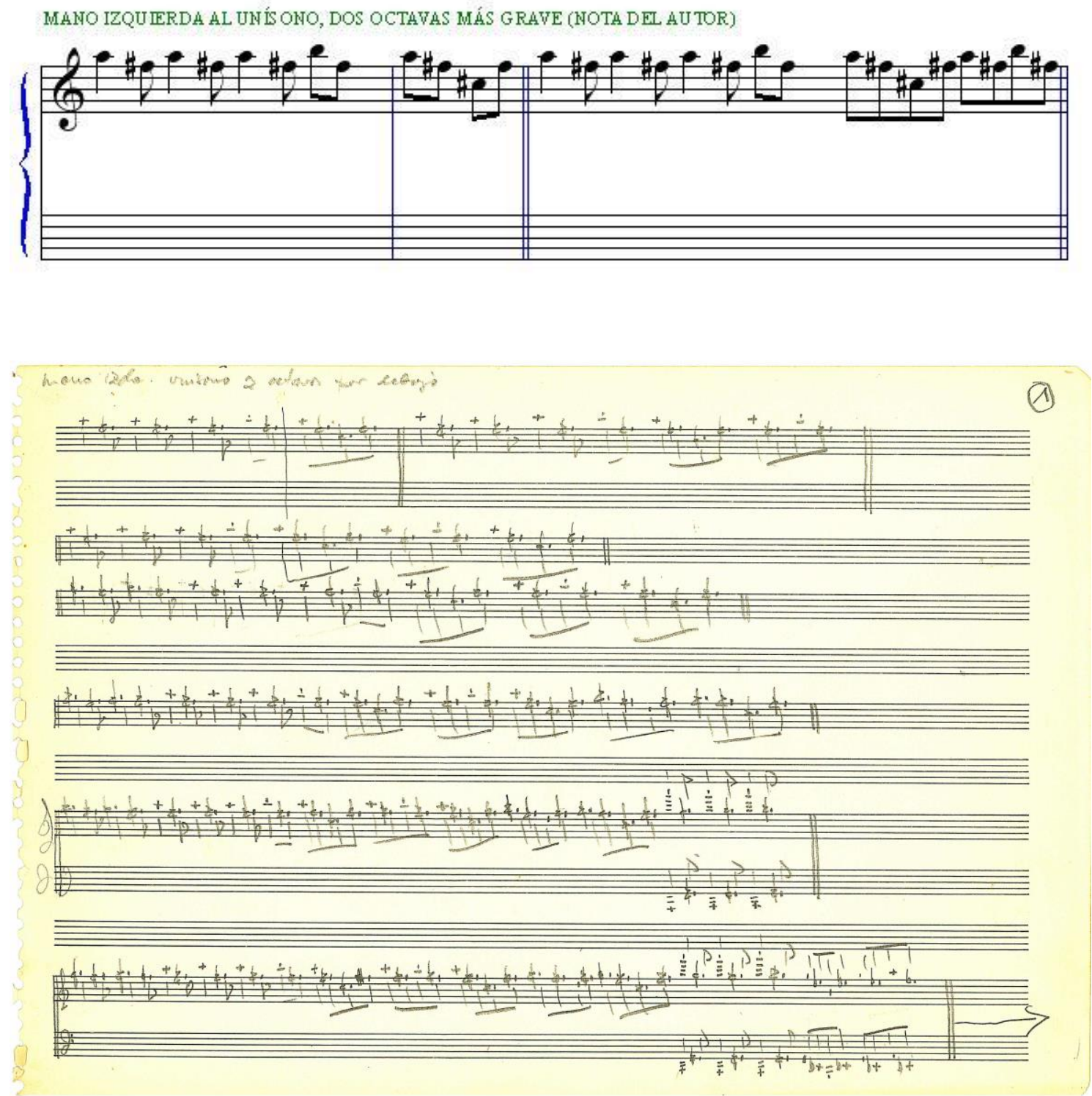

"La interpretación ha de realizarse con la mano izquierda, al unísono de la derecha, dos octavas por debajo, excepto cuando ambas manos estén separadas".*

${ }^{*}$ Testimonio oral del autor. 


\section{MATERIAL TOTAL:}

- Partitura de la obra: Manuscrito original del autor en 2 hojas sueltas, numeradas del 1 al 2 bis. Existen algunas páginas que son apuntes (reverso de 2).

- Partes: No existen partes.

- No consta relación de originales y copias. 
33.- PEÇA PER A PIANO (V), Libre, politonal, piano, con partitura, s. d., arc.16.

La plantilla a la que está dedicada es la de un Piano.
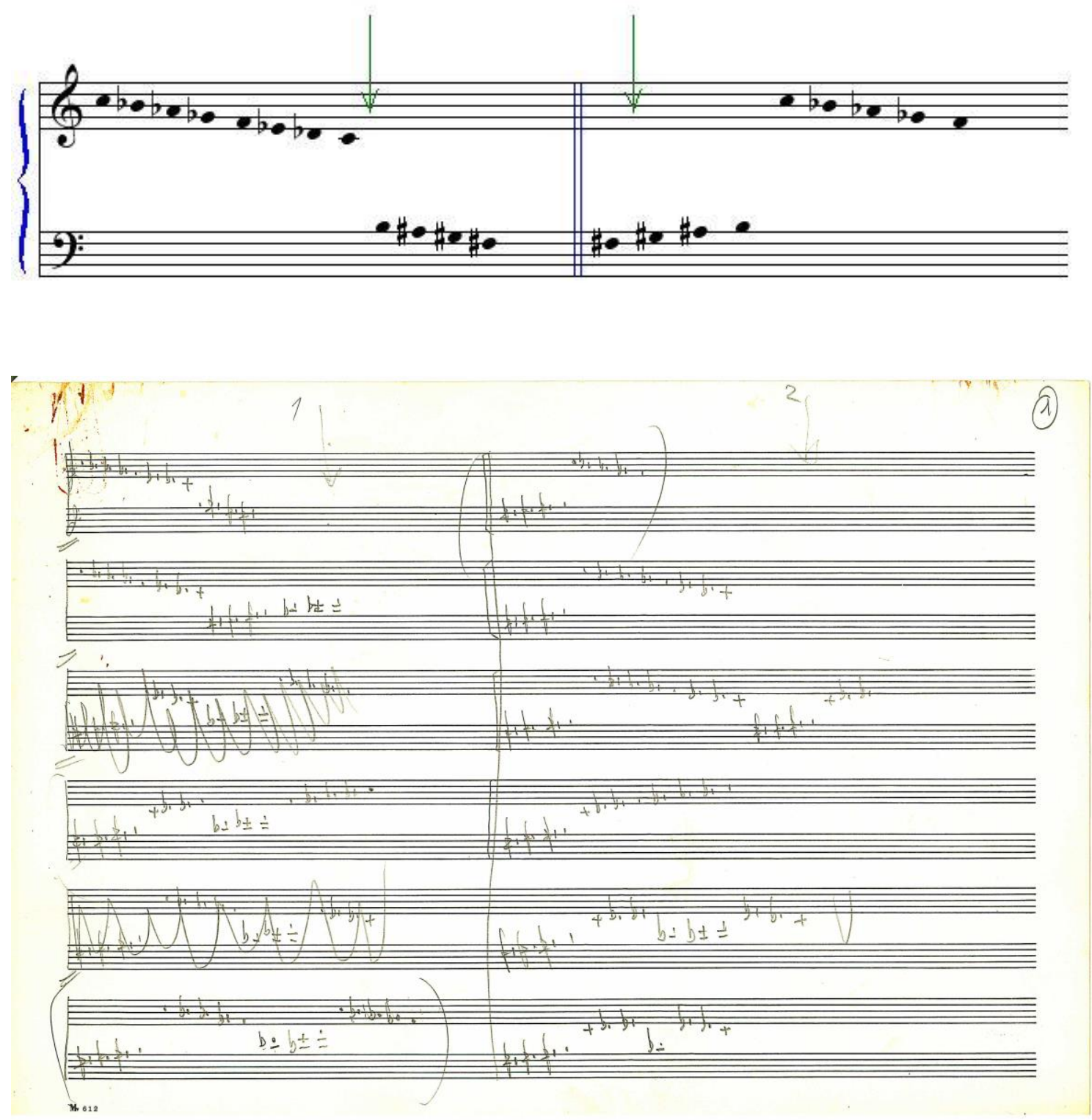

"La mitad inferior de la página 3 son apuntes". "La interpretación ha de realizarse como las que constan en Peça per a Piano (I). "No se ha estrenado".*

${ }^{*}$ Testimonio oral del autor. 


\section{MATERIAL TOTAL:}

- Partitura de la obra: Manuscrito original del autor en 3 hojas sueltas, numeradas del 1 al 2 (la 3 no está numerada). La primera página contiene dos columnas de música. Existen algunas páginas que son apuntes (reverso de 2).

- Partes: No existen partes.

- No consta relación de originales y copias. 
34.- PEÇA PER A PIANO (VI), Libre, en sol modal, piano, con partitura, 1975 aprox., arc. 19 .

La plantilla a la que está dedicada es la de un Piano.
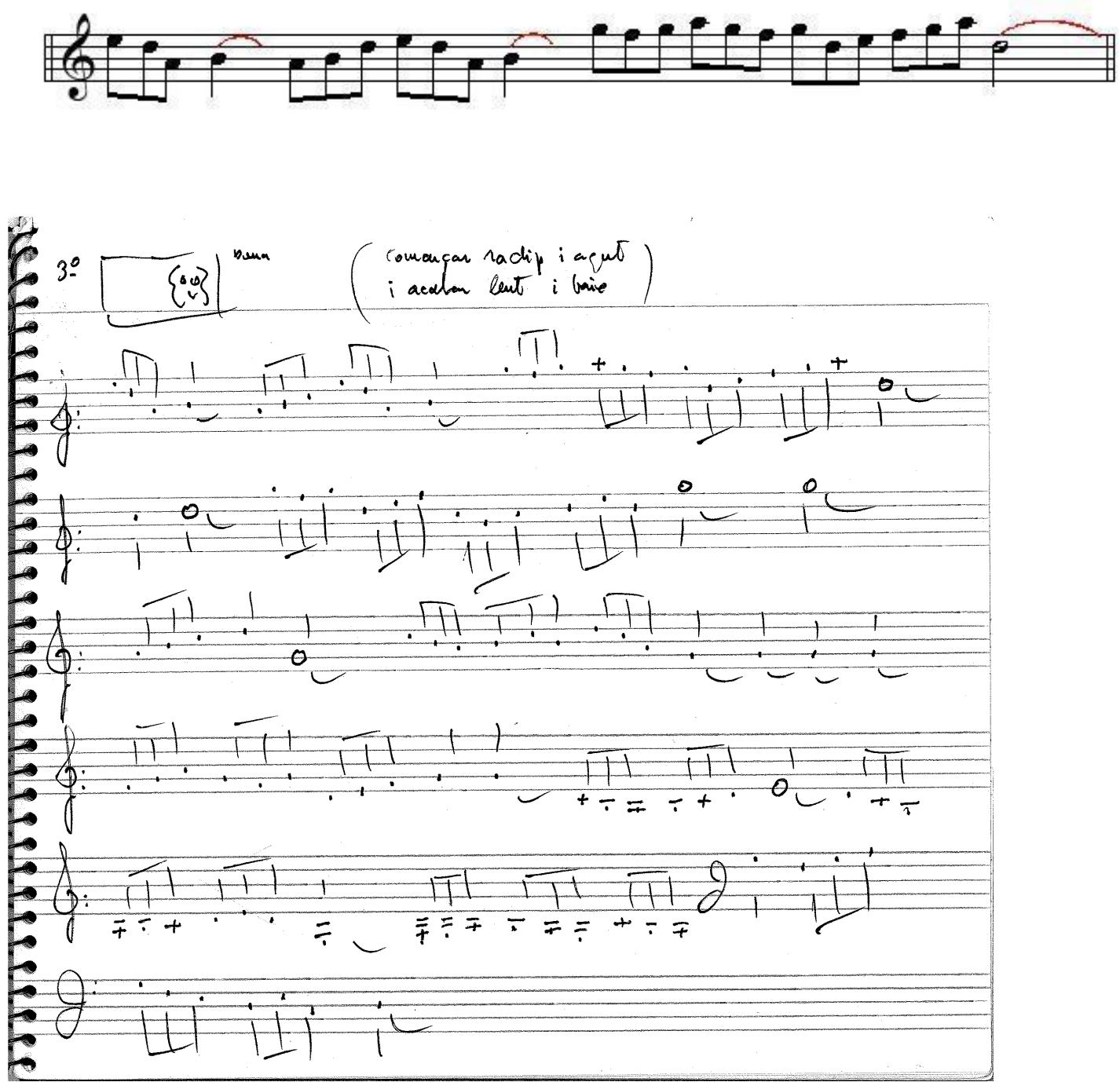

\section{MATERIAL TOTAL:}

- Material manuscrito y original del autor. Consta de 1 bloc de escritura musical, sin título en el exterior, de color marrón que contiene la estructura de un espectáculo ofrecido por el autor en New York. La obra se encuentra en la $3^{\text {a }}$ página escrita. Entre las obras desarrolladas en su interior se encuentra Un gat es un gat, así como Calixa.

- Partes: No existen partes.

- No consta relación de originales y copias. 
35.- PEÇA PER A PIANO (VII), Libre, politonal, piano, con partitura, s. d., arc.16.

La plantilla a la que está dedicada es la de un Piano.
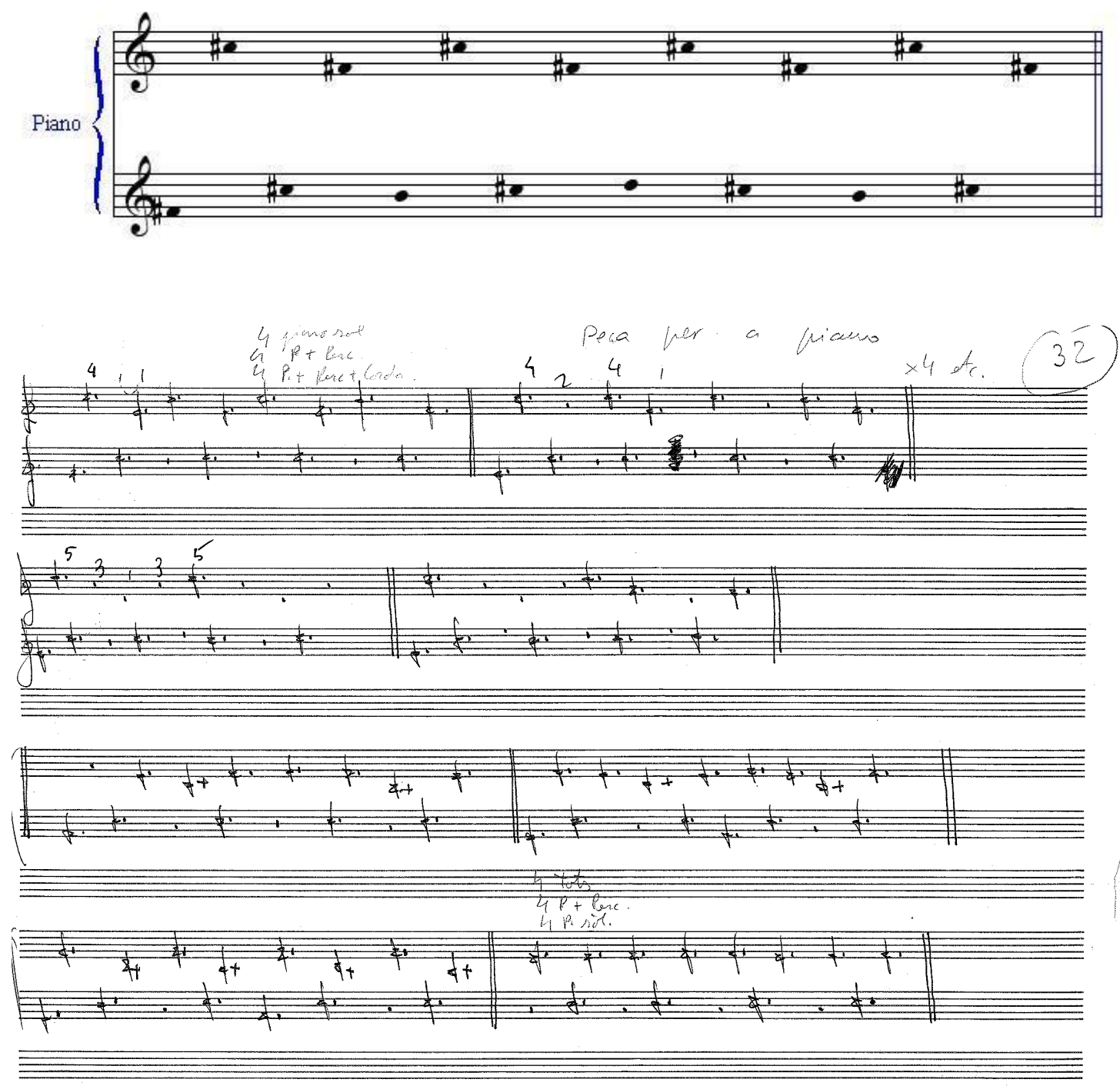

\section{MATERIAL TOTAL:}

- Partitura manuscrita y original del autor. Consta de 1 hoja suelta. Consta título como Peça per a piano y las anotaciones "4 piano sol, 4 P. + Perc, 4 P. + Perc. + Corda" y el número 32 encercado.

- Partes: No existen partes.

- No consta relación de originales y copias. 
36.- PEÇA PER A PIANO (VIII), Libre, politonal, piano, con partitura, s. d., arc.16.

La plantilla a la que está dedicada es la de un Piano.
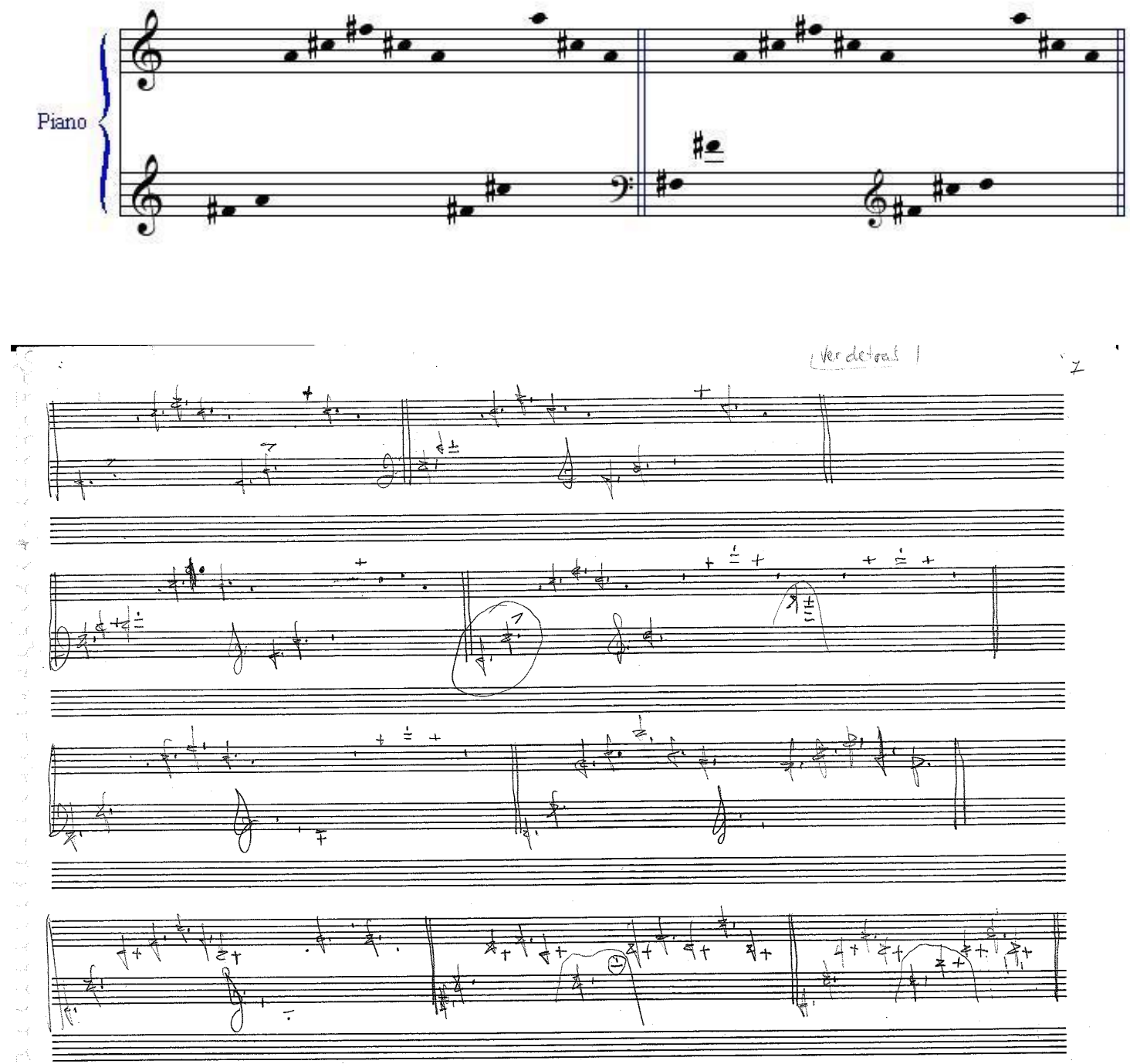

\section{MATERIAL TOTAL:}

- Partitura manuscrita y original del autor. Consta de 1 hoja suelta, numerada con el 7. La indicación "ver detrás" es mía. En el reverso de la obra existen apuntes de otra obra.

- Partes: No existen partes.

- No consta relación de originales y copias. 
37.- PEÇA PER A PIANO (IX), Libre, politonal, piano, con partitura, s. d., arc.16.

La plantilla a la que está dedicada es la de un Piano.
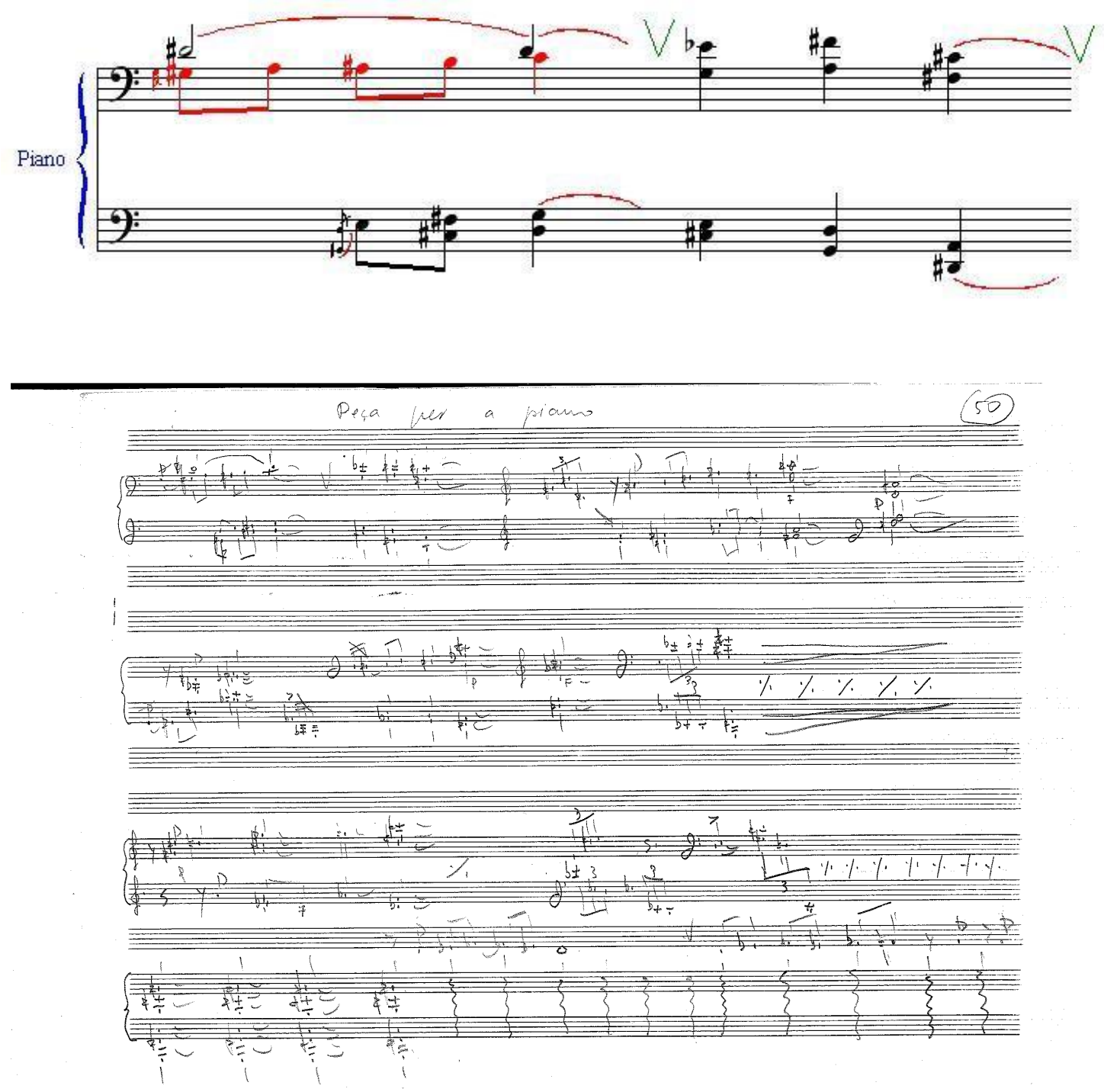

\section{MATERIAL TOTAL:}

- Partitura manuscrita y original del autor. Consta de un libreto de escritura musical, con 2 páginas sin numerar y el número 50 encercado. A partir del cuarto sistema aparece música en el pentagrama superior, posiblemente para voz. Existen partes de piano sin desarrollar.

- Partes: No existen partes.

- No consta relación de originales y copias. 
38.- PEÇA PER A PIANO (X), Libre, politonal, piano, con partitura, 1986?, arc.16.

La plantilla a la que está dedicada es la de un Piano.

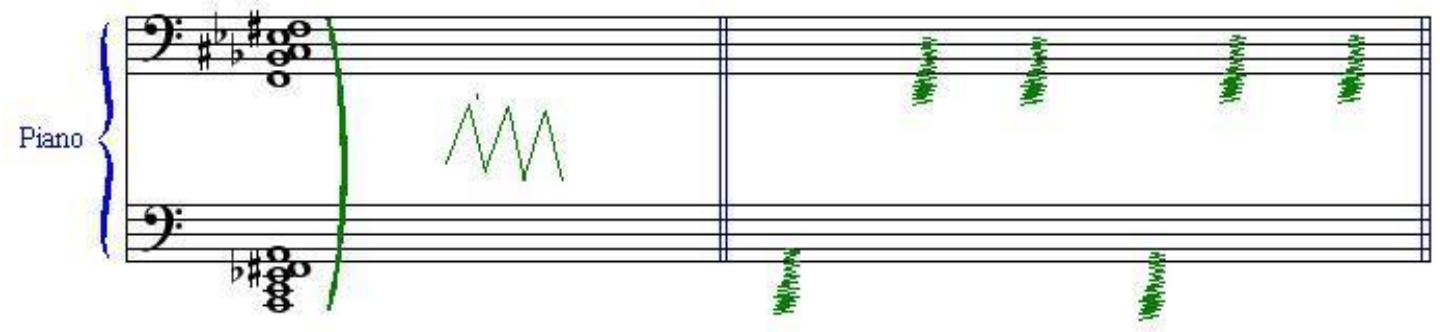

Pera fer a frians 1986?
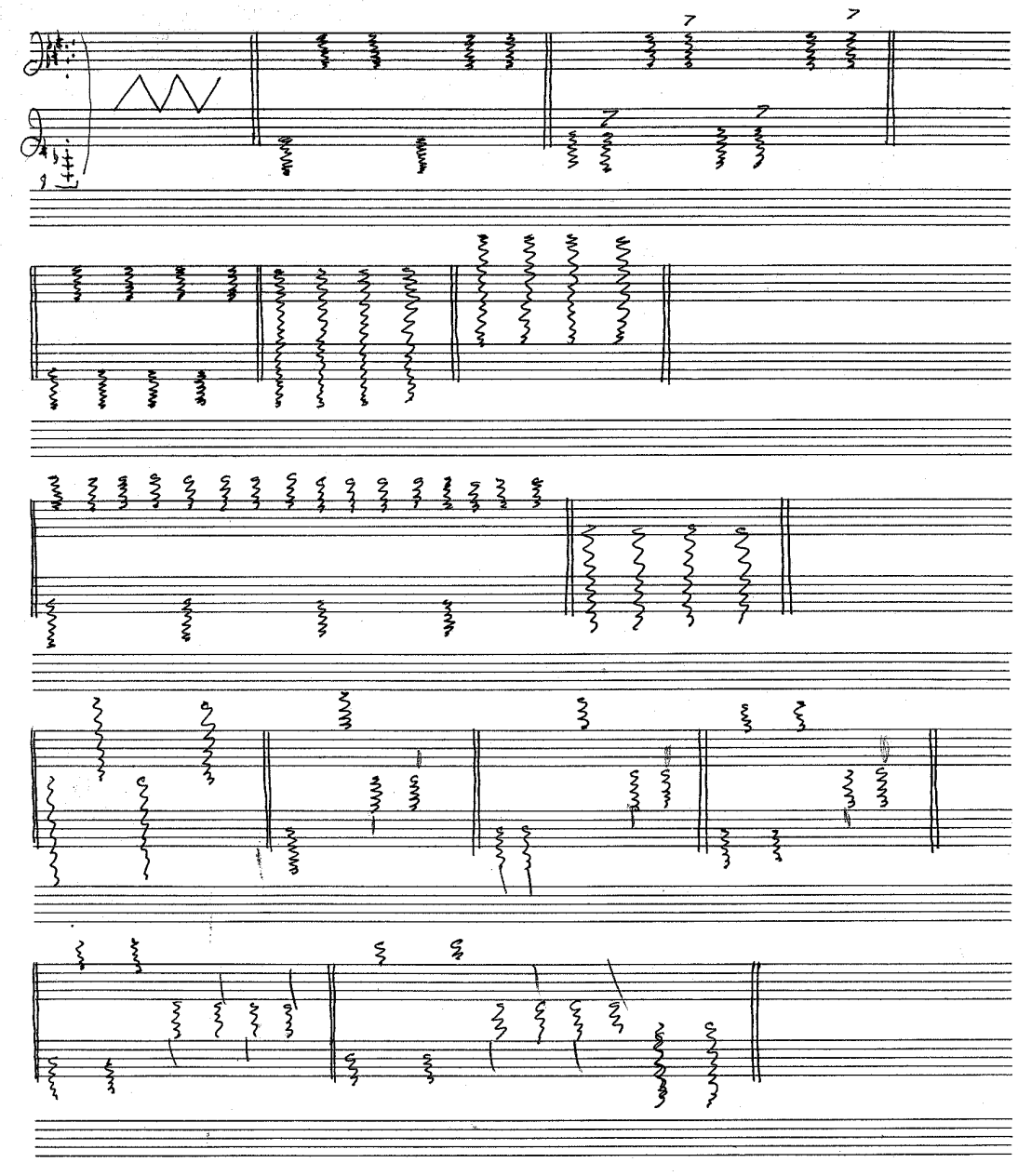

El libreto sobre el que está escrita la obra ha sido adquirido en New York. 


\section{MATERIAL TOTAL:}

- Partitura manuscrita y original del autor. Consta de un libreto de escritura musical, con 2 páginas sin numerar. En la parte superior consta la fecha de 1986 con un interrogante.

- Partes: No existen partes.

- No consta relación de originales y copias. 
39.- PEÇA PER A PIANO (XI), Libre, en Re, piano, con partitura, 1985?, arc.16.

La plantilla a la que está dedicada es la de un Piano.
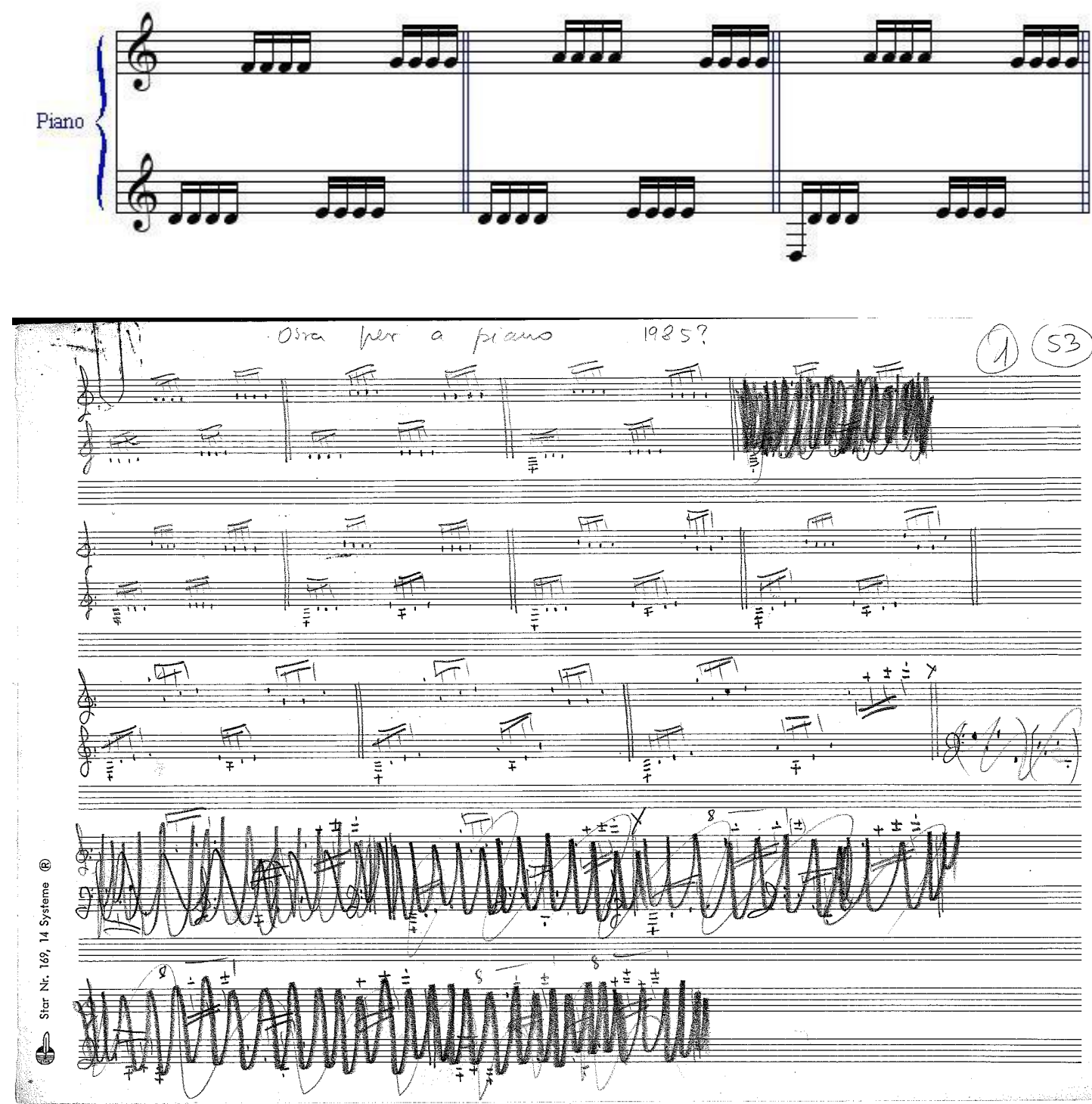

Las hojas sobre las que está escrita la obra han sido adquiridas en New York.

"Son los primeros apuntes de lo que posteriormente será el concierto Piturrino fa de músic" *

${ }^{*}$ Testimonio oral del autor. 


\section{MATERIAL TOTAL:}

- Partitura manuscrita y original del autor. Consta de 4 hojas de escritura musical, numeradas, y con el número 53 encercado. En la parte superior consta la fecha de 1985 con un interrogante.

- Partes: No existen partes.

- No consta relación de originales y copias. 
40.- PEÇA PER A PIANO (XII), Libre, Re m, piano, 1985 aprox., arc.16.

La plantilla a la que está dedicada es la de un Piano.
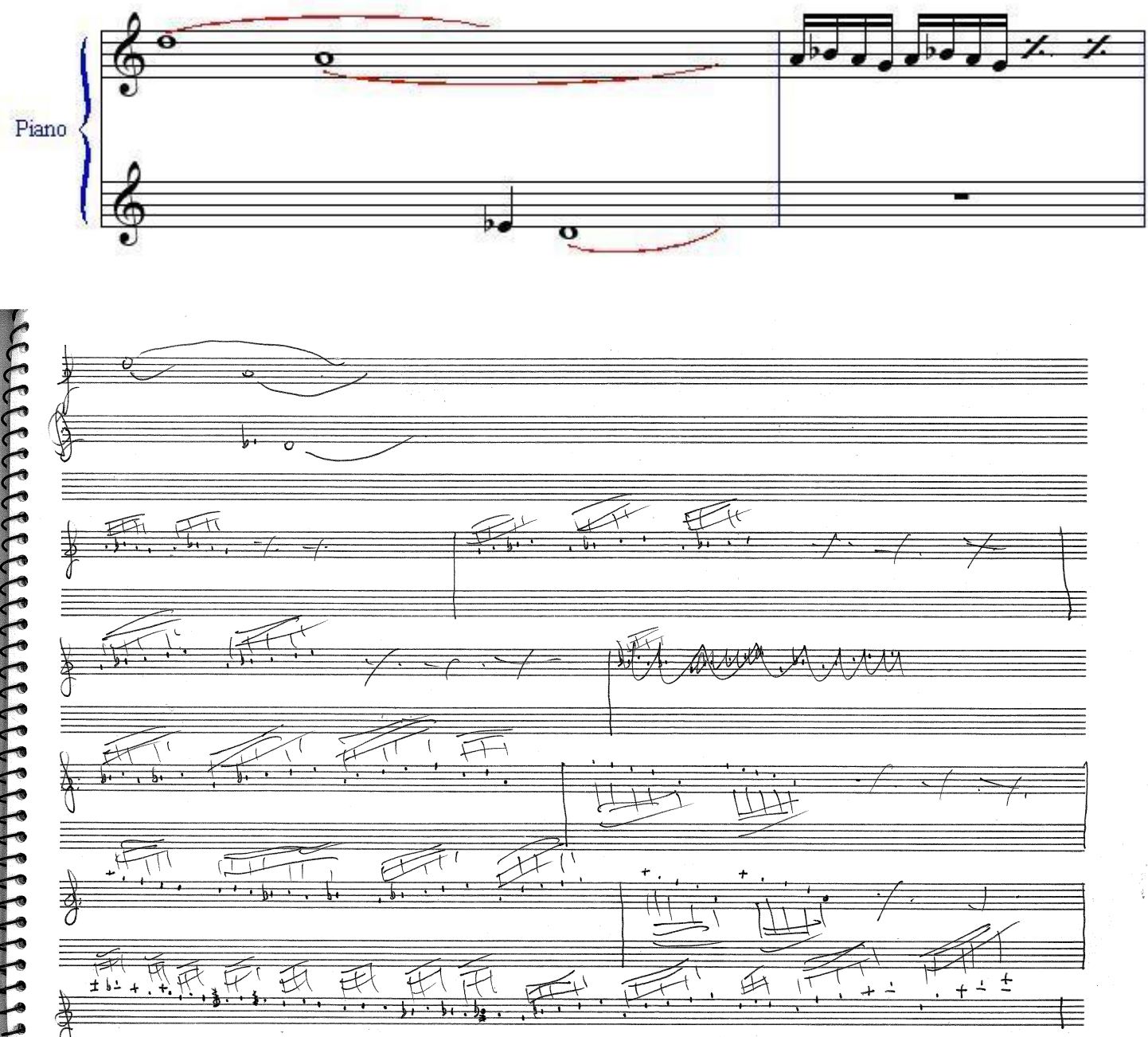

MATERIAL TOTAL:

- Material manuscrito y original del autor. Consta de 1 bloc de escritura musical, perteneciente a la década de los 80 , sin título en el exterior aunque con las letras "AA" en la tapa. La obra se encuentra en las páginas 4 y 5. Páginas sin numerar. Contiene otras obras para piano.

- Partes: No existen partes.

- No consta relación de originales y copias. 
41.- PEÇA PER A PIANO (XIII), Libre, politonal, piano, con partitura, 1985 aprox., arc.16.

La plantilla a la que está dedicada es la de un Piano.
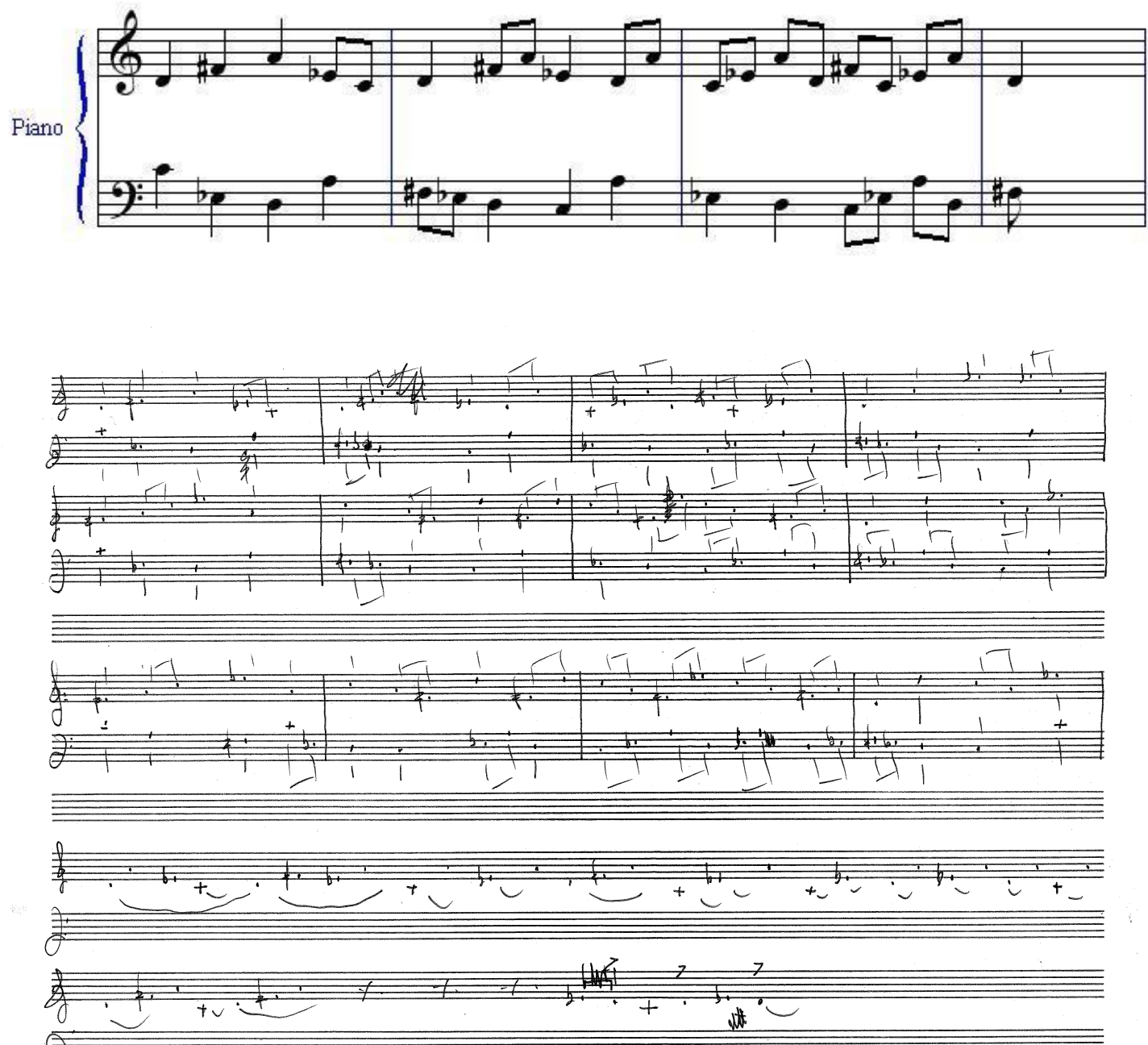

MATERIAL TOTAL:

- Material manuscrito y original del autor. Consta de 1 bloc de escritura musical, perteneciente a la década de los 80 , sin título en el exterior aunque con las letras "AA" en la tapa. La obra se encuentra en las páginas 6 y 7. Parecen ser apuntes o desarrollo de la obra Aquesta Es La Història Que Mai Podré Oblidar; Una Trista Història D'Amor, D'Un Amor Que Mai, Mai, Mai Podrà Acabar. Páginas sin numerar. Contiene otras obras para piano.

- Partes: No existen partes.

- No consta relación de originales y copias. 
42.- PEÇA PER A PIANO (XIV), Libre, politonal, piano, con partitura, 1985 aprox., arc. 16 .

La plantilla a la que está dedicada es la de un Piano.
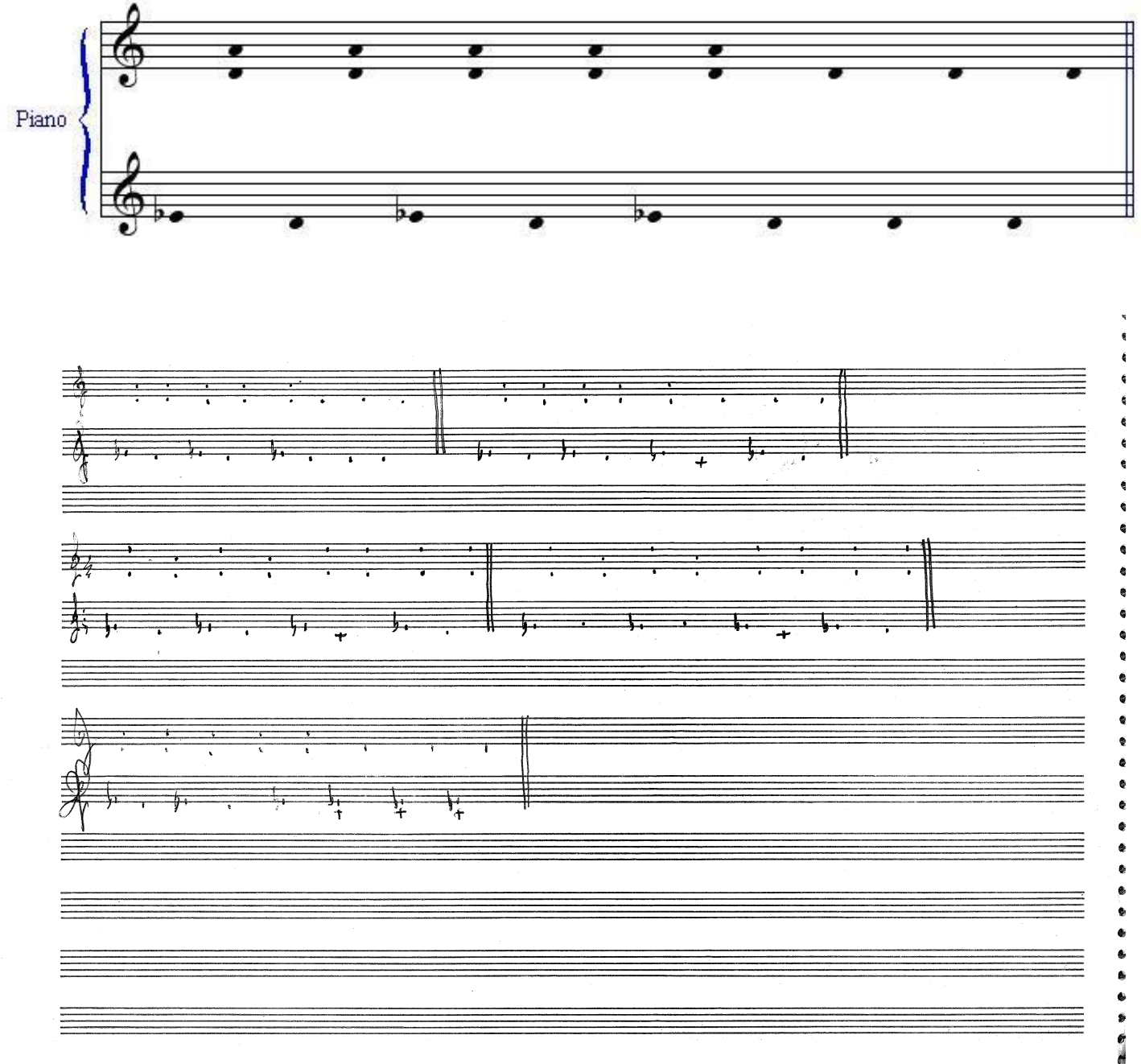

\section{MATERIAL TOTAL:}

- Material manuscrito y original del autor. Consta de 1 bloc de escritura musical, perteneciente a la década de los 80 , sin título en el exterior aunque con las letras "AA" en la tapa. La obra se encuentra en las páginas 12 y 13. Parecen ser apuntes o desarrollo de la obra Aquesta Es La Història Que Mai Podré Oblidar; Una Trista Història D'Amor, D'Un Amor Que Mai, Mai, Mai Podrà Acabar. Páginas sin numerar. Contiene otras obras para piano. 
- Partes: No existen partes.

- No consta relación de originales y copias. 
43.- PEÇA PER A PIANO (XV), Libre, politonal, piano, con partitura, 1985 aprox., arc.16.

La plantilla a la que está dedicada es la de un Piano.
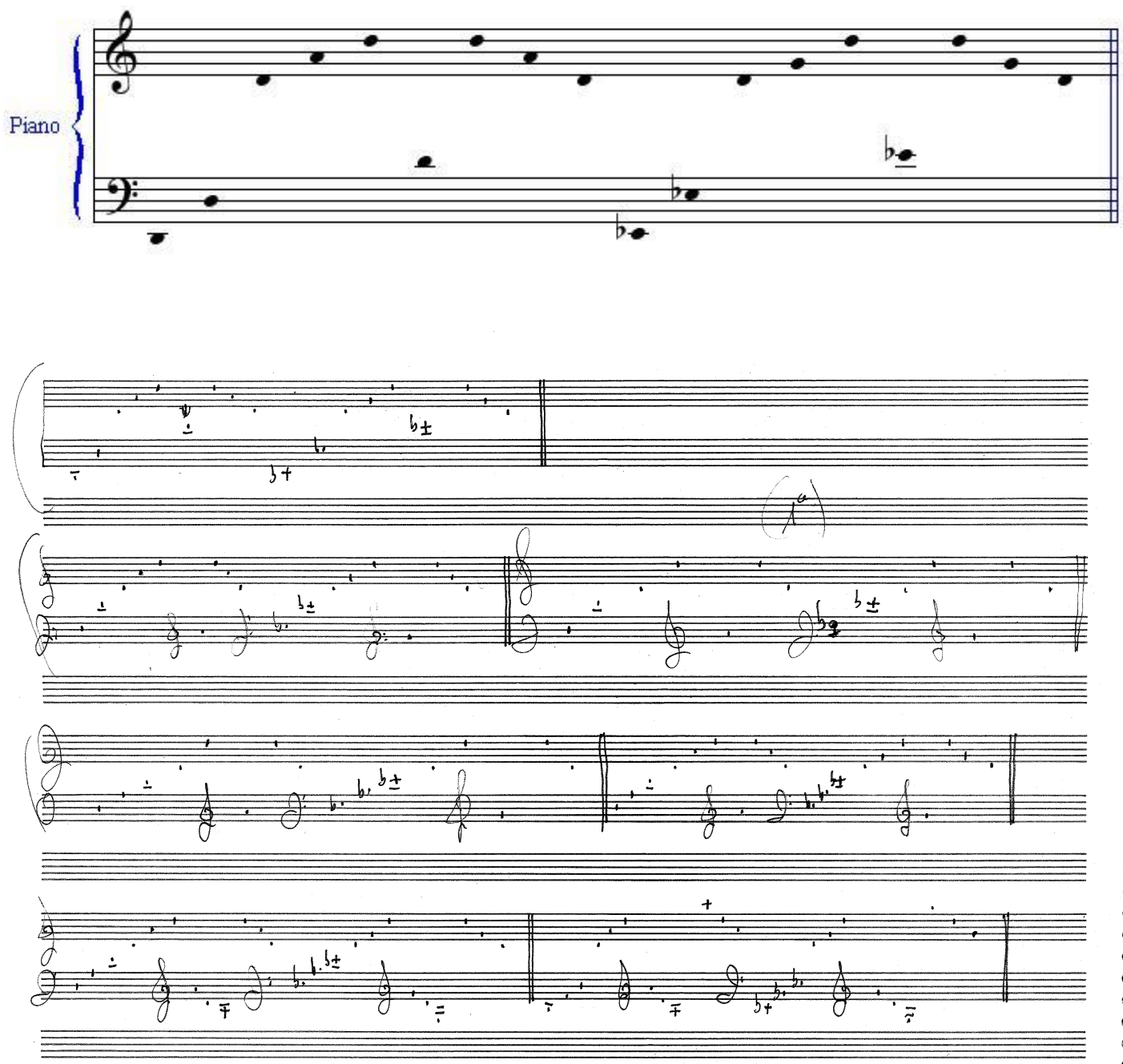

\section{MATERIAL TOTAL:}

- Material manuscrito y original del autor. Consta de 1 bloc de escritura musical, perteneciente a la década de los 80 , sin título en el exterior aunque con las letras "AA" en la tapa. La obra se encuentra en las páginas 32 y 33. Parecen ser apuntes o desarrollo de la obra Aquesta Es La Història Que Mai Podré Oblidar; Una Trista Història D'Amor, D'Un Amor Que Mai, Mai, Mai Podrà Acabar. Páginas sin numerar. Contiene otras obras para piano. 
- Partes: No existen partes.

- No consta relación de originales y copias. 
44.- PEÇA PER A PIANO (XVI), Libre, politonal, piano, con partitura, 1985 aprox., arc.16.

La plantilla a la que está dedicada es la de un Piano.
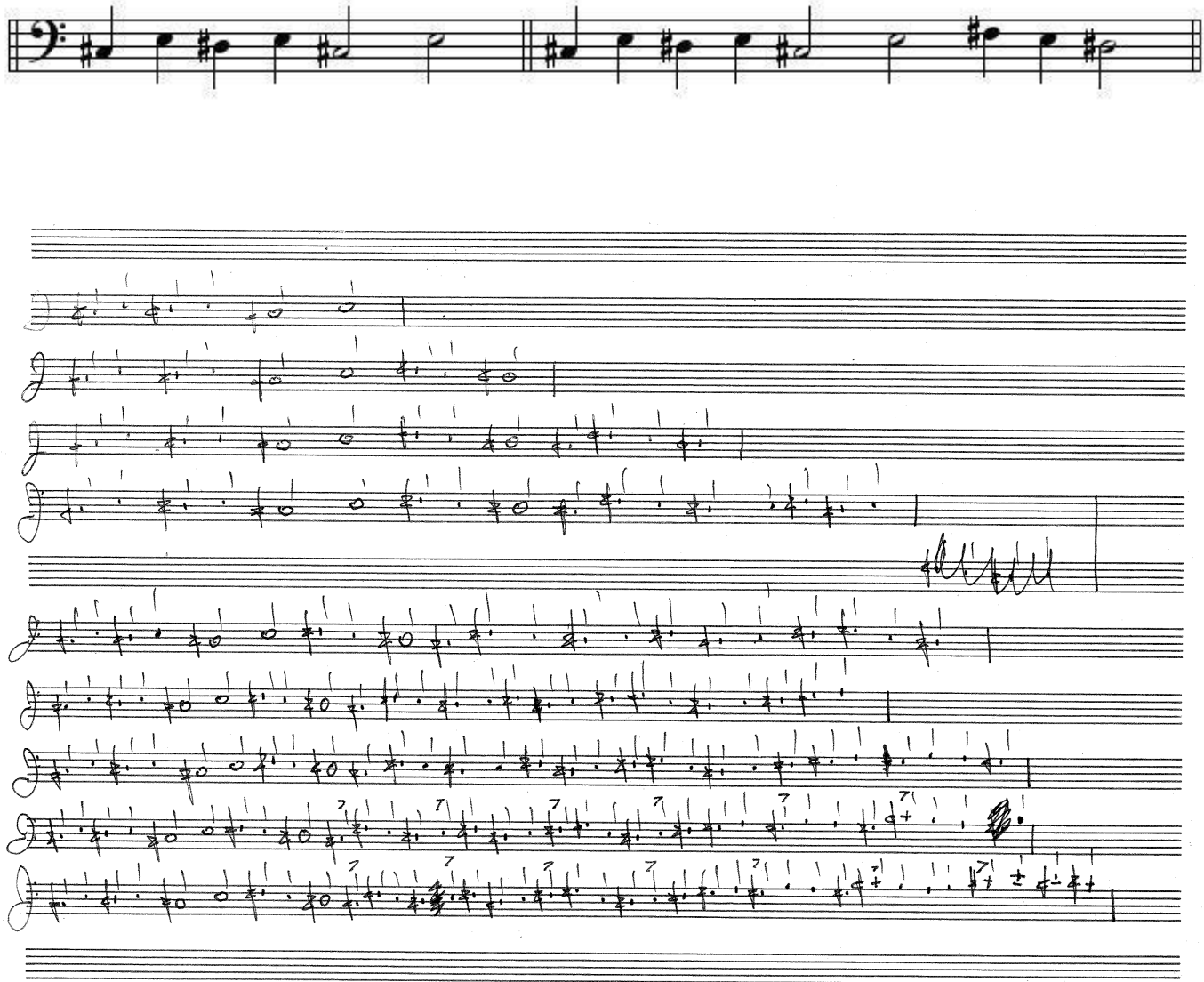

\section{MATERIAL TOTAL:}

- Material manuscrito y original del autor. Consta de 1 bloc de escritura musical, perteneciente a la década de los 80 , sin título en el exterior aunque con las letras "AA" en la tapa. La obra se encuentra en las páginas 43 a 45 . Parecen ser apuntes o desarrollo de la obra Aquesta Es La Història Que Mai Podré Oblidar; Una Trista Història D'Amor, D'Un Amor Que Mai, Mai, Mai Podrà Acabar. Páginas sin numerar. Contiene otras obras para piano.

- Partes: No existen partes.

- No consta relación de originales y copias. 
45.- PELICULA DE JORDI CADENA, Libre, politonal, piano, con partitura, s. d., arc.16.

La plantilla a la que está dedicada es la de un piano.

Ver: "X" (obra grupos de cuerda)
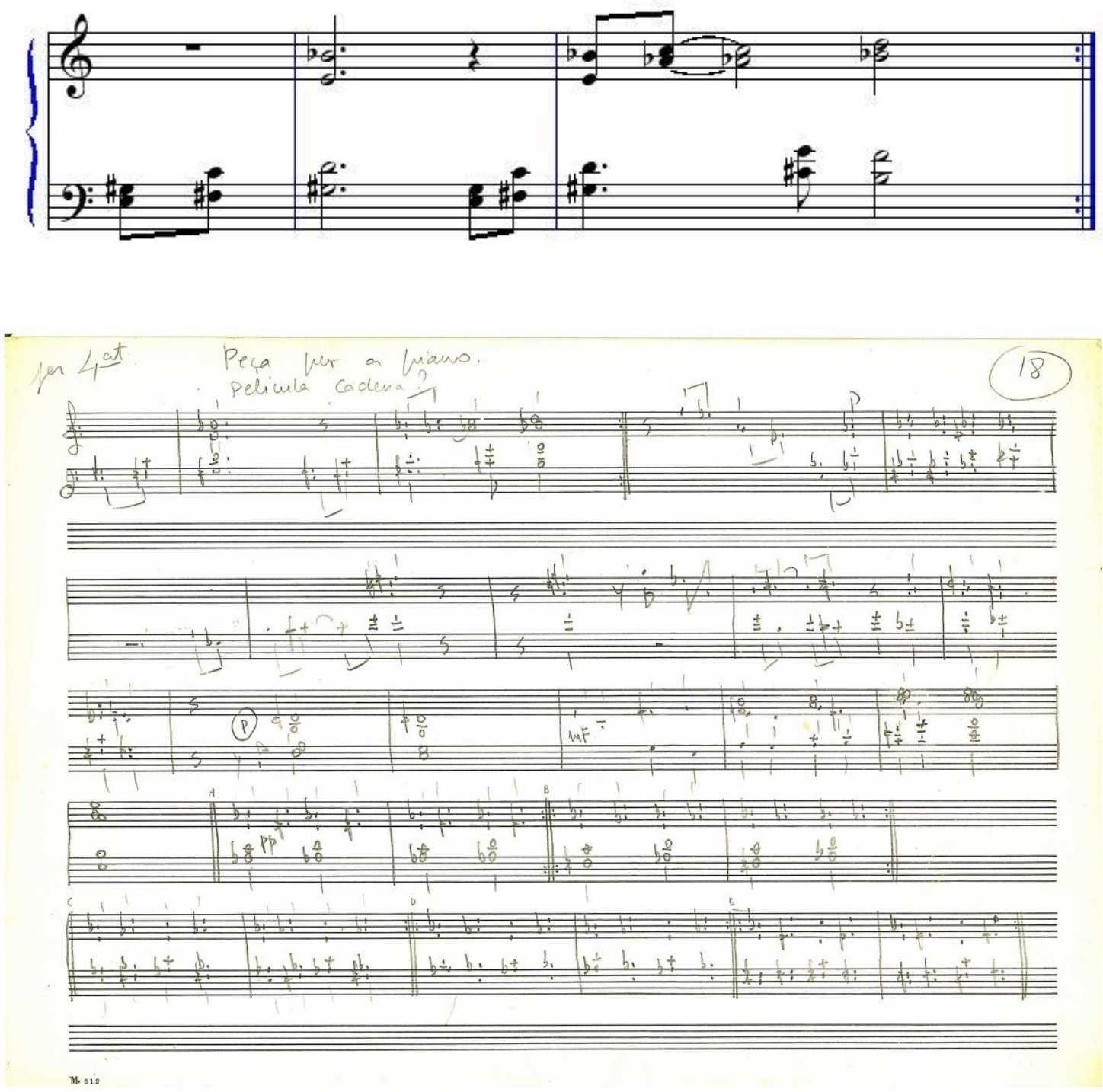

La pieza está concebida para la ambientación musical de una película de Jordi Cadena.

"La medida siempre es a pulsación de negra".

${ }^{*}$ Testimonio oral del autor. 


\section{MATERIAL TOTAL:}

- Partitura de la obra: Partitura manuscrita y original del autor. Consta de un facsímile con 2 hojas escritas, sin numerar. Numerada como 18 por el autor.

- Partes: No existen partes.

- No consta relación de originales y copias. 
46.- PIANO A 4 MANS, Libre, politonal, piano, con partitura, 1982, aprox., arc.16.

La plantilla a la que está dedicada es la de dos pianistas en un solo Piano.
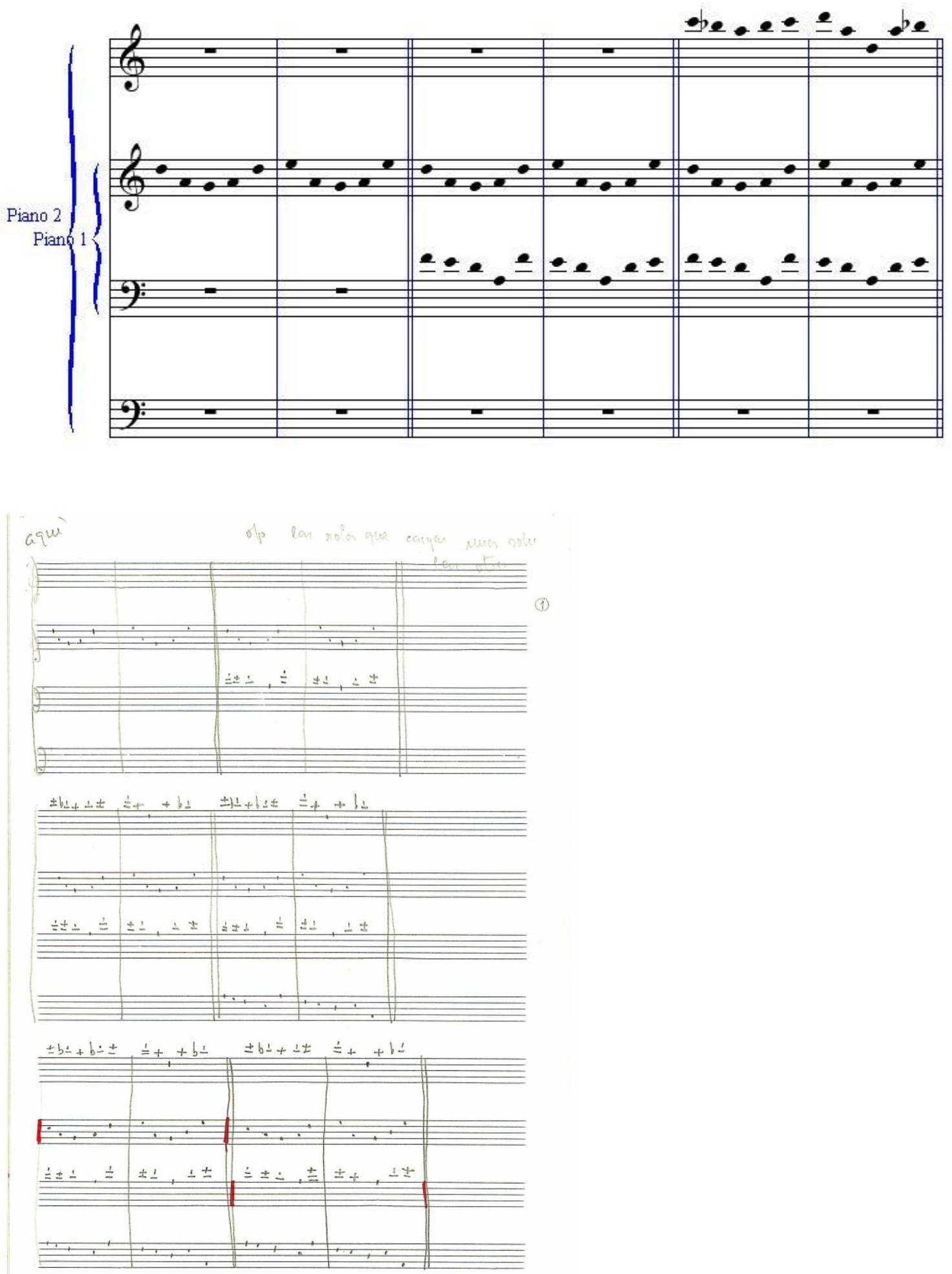
"Se ha interpretado en numerosas ocasiones. La interpretación es distinta a la habitual de un piano a 4 manos; los 2 pentagramas centrales son interpretados por un pianista y los extremos por el otro, que debe sentarse detrás y no al lado, del primero, con los brazos abiertos para alcanzar las notas. El tempo es prestissimo, realizando grupos de 5 sonidos tal y como están escritos, repitiendo las veces que se considere oportuno. Al llegar al final del manuscrito, se debe interpretar en sentido opuesto (siempre cada pentagrama de izquierda a derecha) hasta llegar al principio de la obra".*

La última interpretación en directo tuvo lugar en el Auditorio de Castellón, en compañía de la pianista Inés Borrás, en diciembre de 2011 (existen programas y grabaciones en video -2- realizadas por el auditorio y por mí mismo).

Formó parte del espectáculo Beethoven, si tanco la tapa que passa...? interpretándose junto a Agustí Fernández. *

\section{MATERIAL TOTAL:}

- Partitura de la obra: Manuscrito original del autor. Consta de 4 facsímiles numerados en rojo, con 2 hojas escritas en cada uno numeradas de 1 a 7 , que indican el orden de interpretación (se interpretan de izquierda a derecha). Existe un segundo material en el archivo particular de Carles Santos.

- Partes: No existen partes.

- No consta relación de originales y copias.

La interpretación de esta pieza, por la forma de sentarse los dos intérpretes, es muy particular.

\footnotetext{
* Testimonio oral del autor.

* Testimonio oral del autor.
} 
47.- PIANO MOTO, Libre, politonal, piano y motocicleta, con partitura, s. d., arc.17.

La plantilla a la que está dedicada es la de un Piano con la colaboración de una moto de trial.

Ver: EBROFALIA COPULATIVA
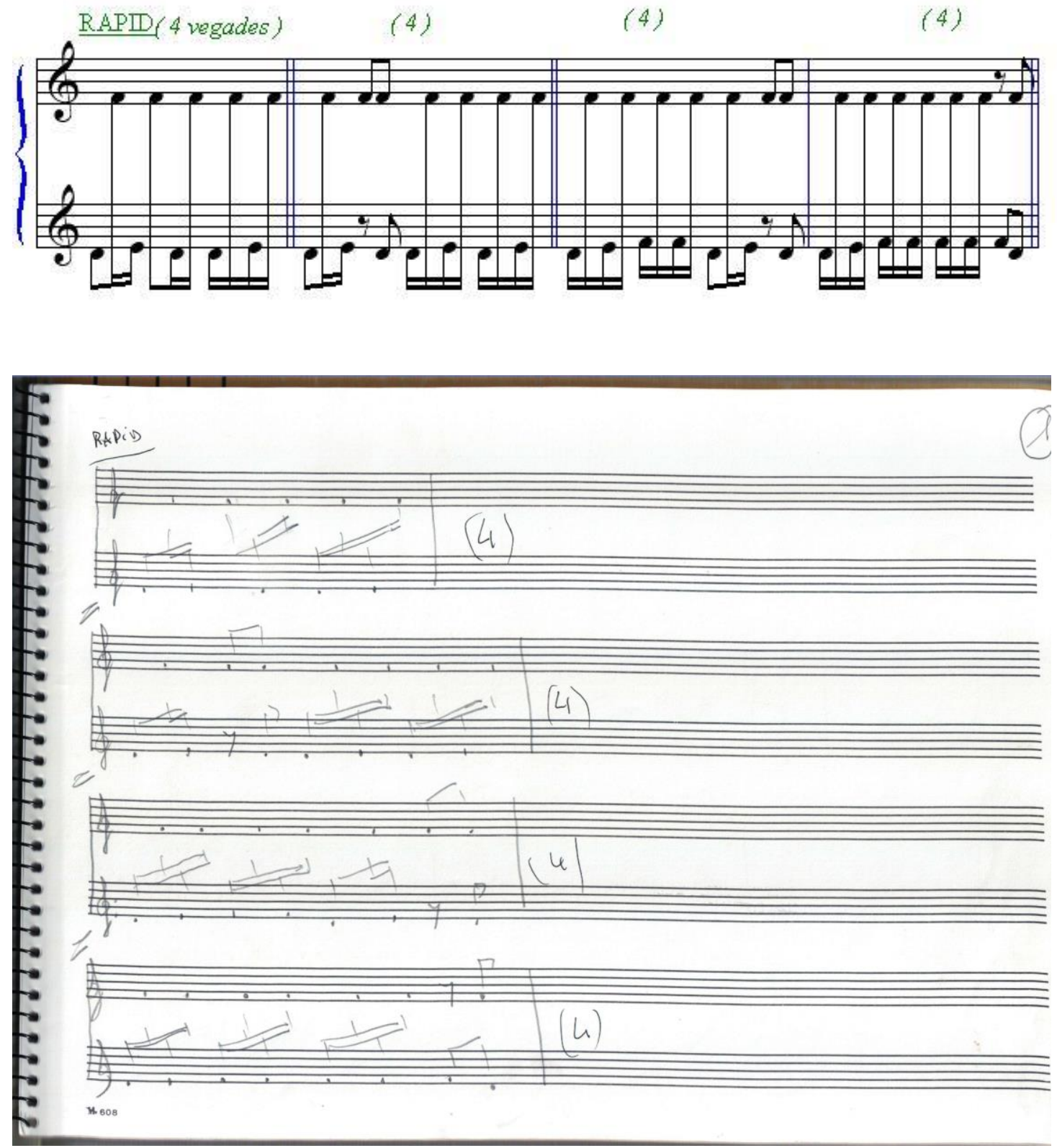

Las páginas numeradas del 1 al 9 del primer cuaderno forman parte de la obra que el autor titula Música en 3 notes y que se ha utilizado, entre otros espectáculos, en Piturrino fa de músic. 


\section{MATERIAL TOTAL:}

- Partitura manuscrita y original del autor. Consta de 2 blocs de escritura musical, con el título Tinc que ser..., Amb dos dits, Piano moto (1) en el exterior y 24 páginas manuscritas y originales, divididas en dos fragmentos: 1 a 9 y 1 a 15 . El segundo bloc lleva como título Piano moto (2) y consta de 8 páginas manuscritas y originales, numeradas de la 16 a la 18 y 5 páginas sin numerar.

- Partes: No existen.

- No consta relación de originales y copias. 
48.- PIANO SOL, Libre, en La, piano, con partitura, 1970, aprox., arc.16.

La plantilla a la que está dedicada es la de un Piano.
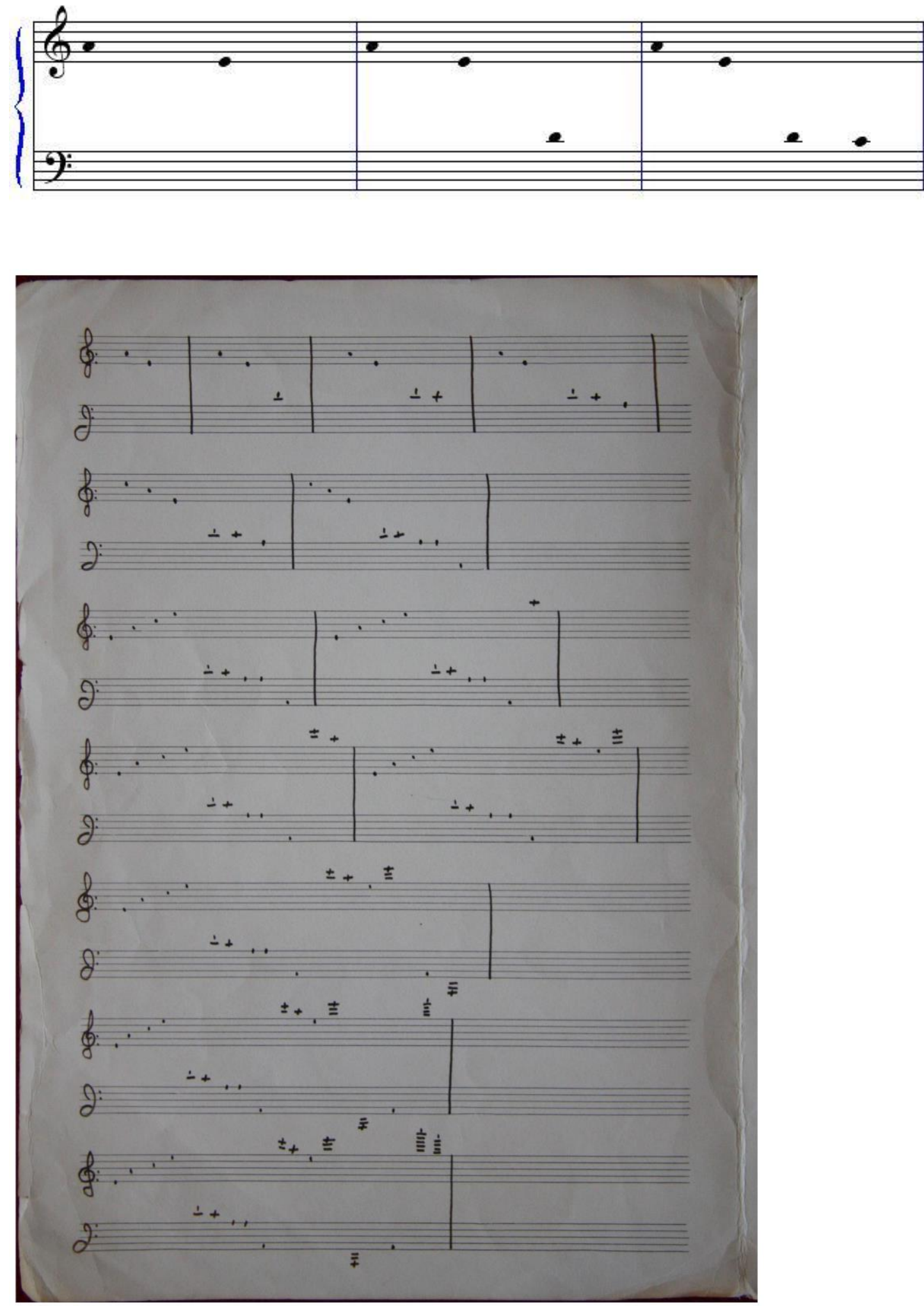
"Se ha interpretado". "La interpretación, como en gran parte de mis obras, se deja al instinto musical del intérprete y a las características del momento y lugar de la interpretación".*

\section{MATERIAL TOTAL:}

- Partitura de la obra: Manuscrito original del autor. Consta de 2 hojas escritas de un facsímile. Fechada en 1970?. Numerada como 35 por el autor. Existe un segundo facsímile que son apuntes del autor.

- Partes: No existen partes.

- No consta relación de originales y copias.

* Testimonio oral del autor. 
49.- PIANOLEROLEROLERO-LARERO, Libre, Mib menor, piano, con partitura, 1982, arc.21.

La plantilla a la que está dedicada es la de un Piano.
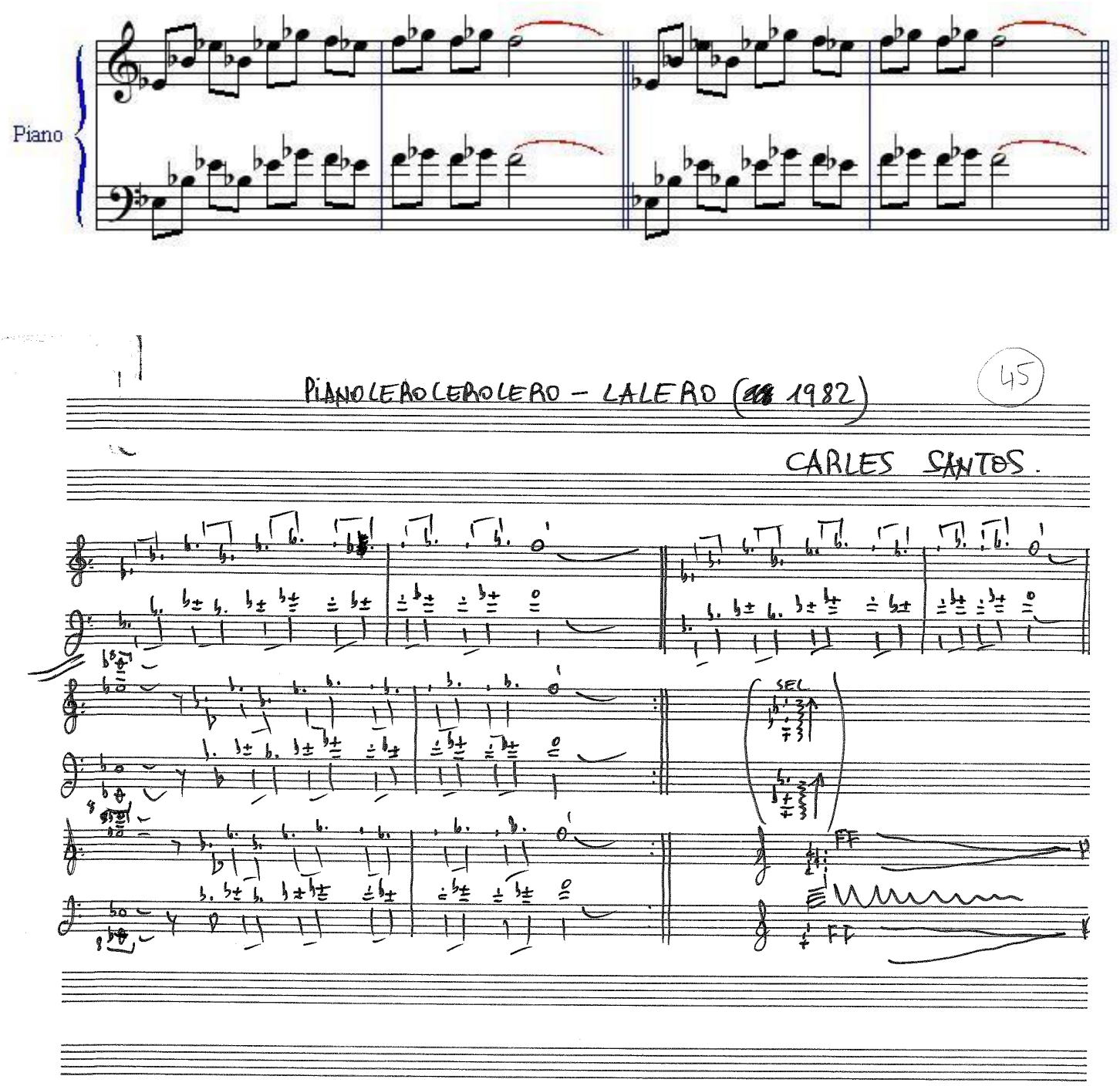

La partitura está numerada como 45 por el autor.

Se corresponde a la pista 2 de la cara A, del disco Pianotrack grabado en 1984 por Linterna Música. 


\section{MATERIAL TOTAL:}

- Partitura manuscrita y original del autor. Consta de dos libretos de escritura musical con 7 páginas escritas y numeradas, con el título Pianolerolerolerolalero (1982) y el número 45 encercado, en la $1^{\text {a }}$ página.

- Partes: No existen partes.

- No consta relación de originales y copias. 
50.- POSIBLE AL LLIURE, Libre, politonal, con partitura, 1997 aprox., arc.17.

La plantilla a la que está dedicada es la de un Piano.
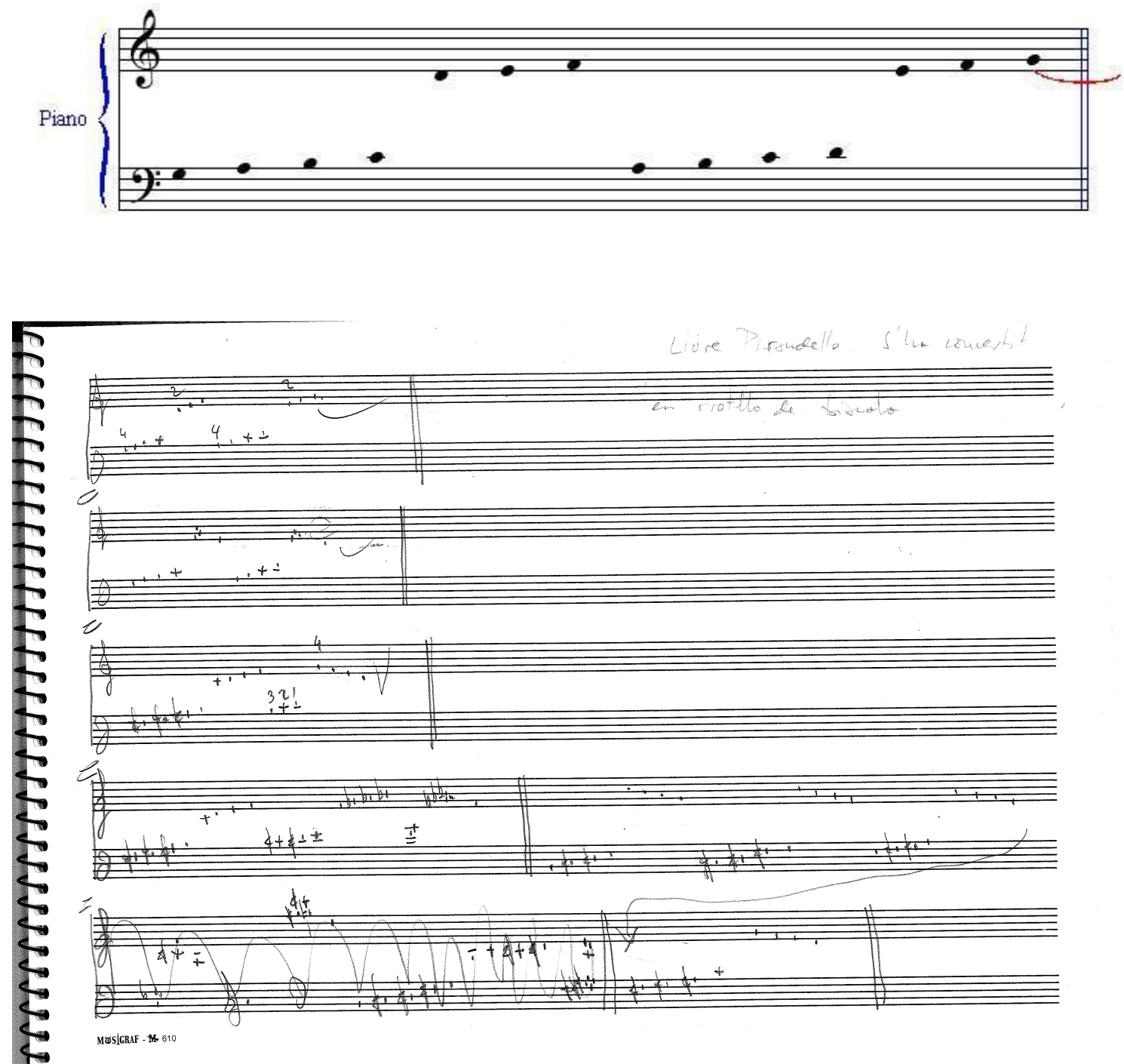

"Se ha convertido en rollo de pianola"*. Esta música es la que suena en la pianola móvil que el autor utiliza en sus espectáculos, entre ellos, La Pantera Imperial.

${ }^{*}$ Testimonio oral del autor. 


\section{MATERIAL TOTAL:}

- Partitura manuscrita y original del autor. Consta de un bloc de escritura musical, con el título Posible al Lliure en el exterior y 2 páginas manuscritas y originales, sin numerar.

- Partes: No existen partes.

- No consta relación de originales y copias. 
51.- PREMIS OCTUBRE '05, Libre, politonal, piano, con partitura, 2005, arc. 21

La plantilla a la que está dedicada es Piano.

Ver: MÚSICA PIANO 2005 (sección Obra piano)
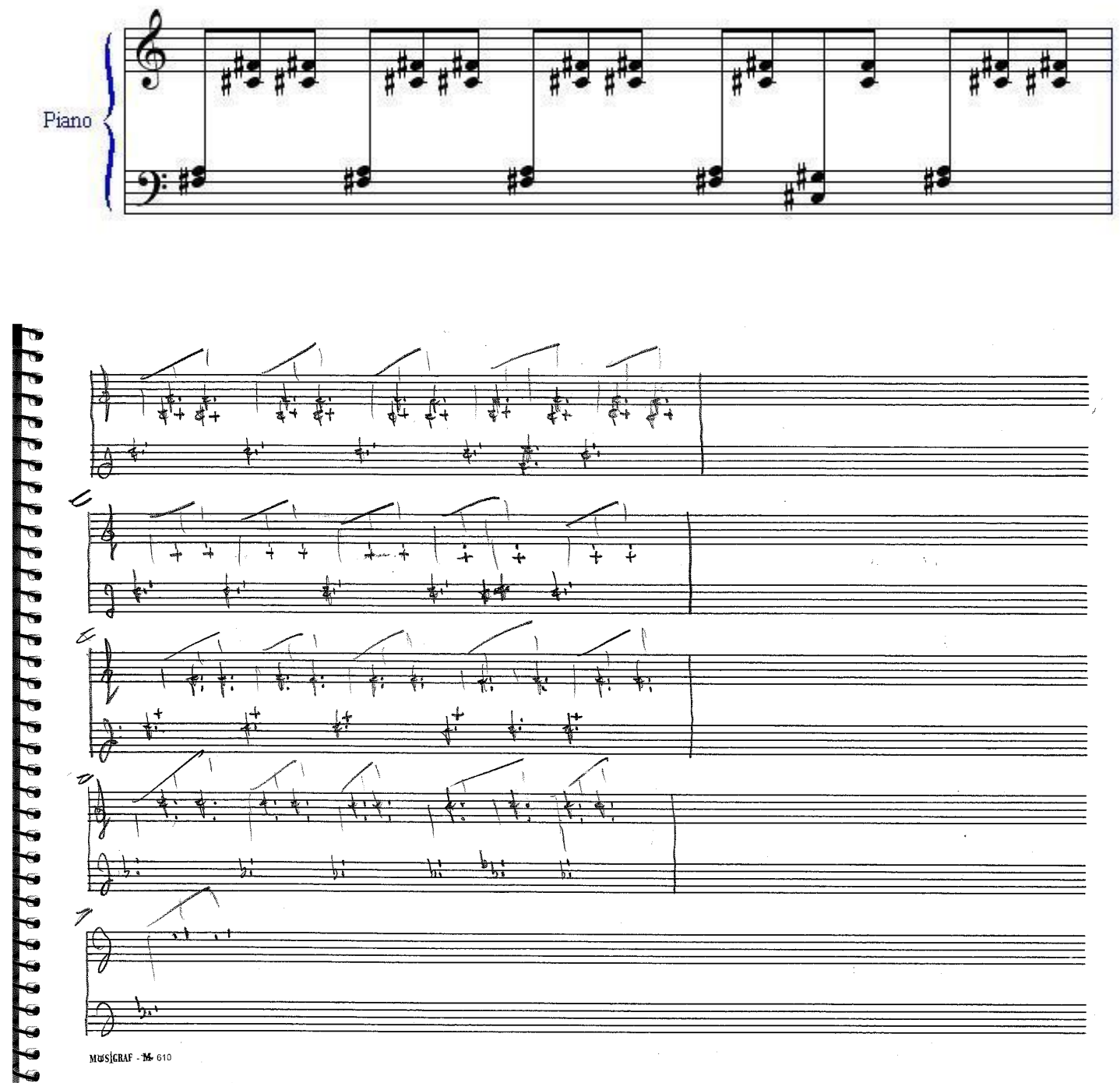

MATERIAL TOTAL:

- Partitura manuscrita y original del autor. Consta de un bloc de escritura musical con el título Música Piano 2005 en la tapa y con 3 páginas escritas y sin numerar. En el reverso existen 2 páginas con apuntes de una obra para piano.

- Partes: No existen partes.

- No consta relación de originales y copias. 
52.- REFLEX, Libre, en La, piano, con partitura, s. d., arc.12

La plantilla a la que está dedicada es Piano.
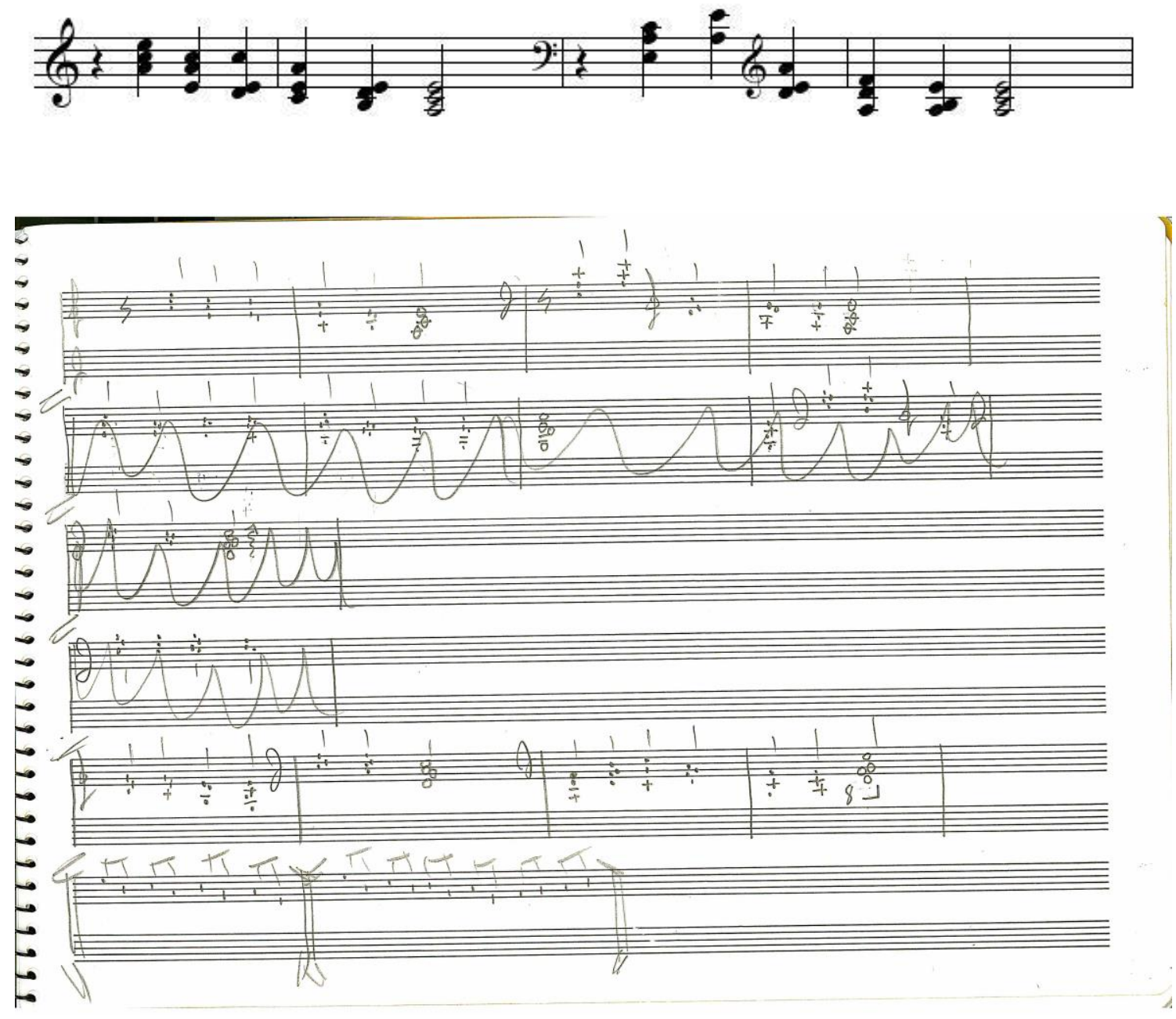

\section{MATERIAL TOTAL:}

- Partitura de la obra: Manuscrito original del autor en un bloc de escritura musical. En el mismo bloc, por la parte posterior se encuentra la obra Cuina que comprende la parte coral de la obra Congrés de cuina catalana. Da la impresión de ser apuntes de la obra, bien estructurados.

- Partes: No existen partes.

- No consta relación de originales y copias. 
53.- SEGADORS (VERSIÓ FRANKFURT), Libre, en Mi, piano y danza, con partitura, 2007/2008, arc.20.

La plantilla a la que está dedicada es la de un piano.

(4)

(4)
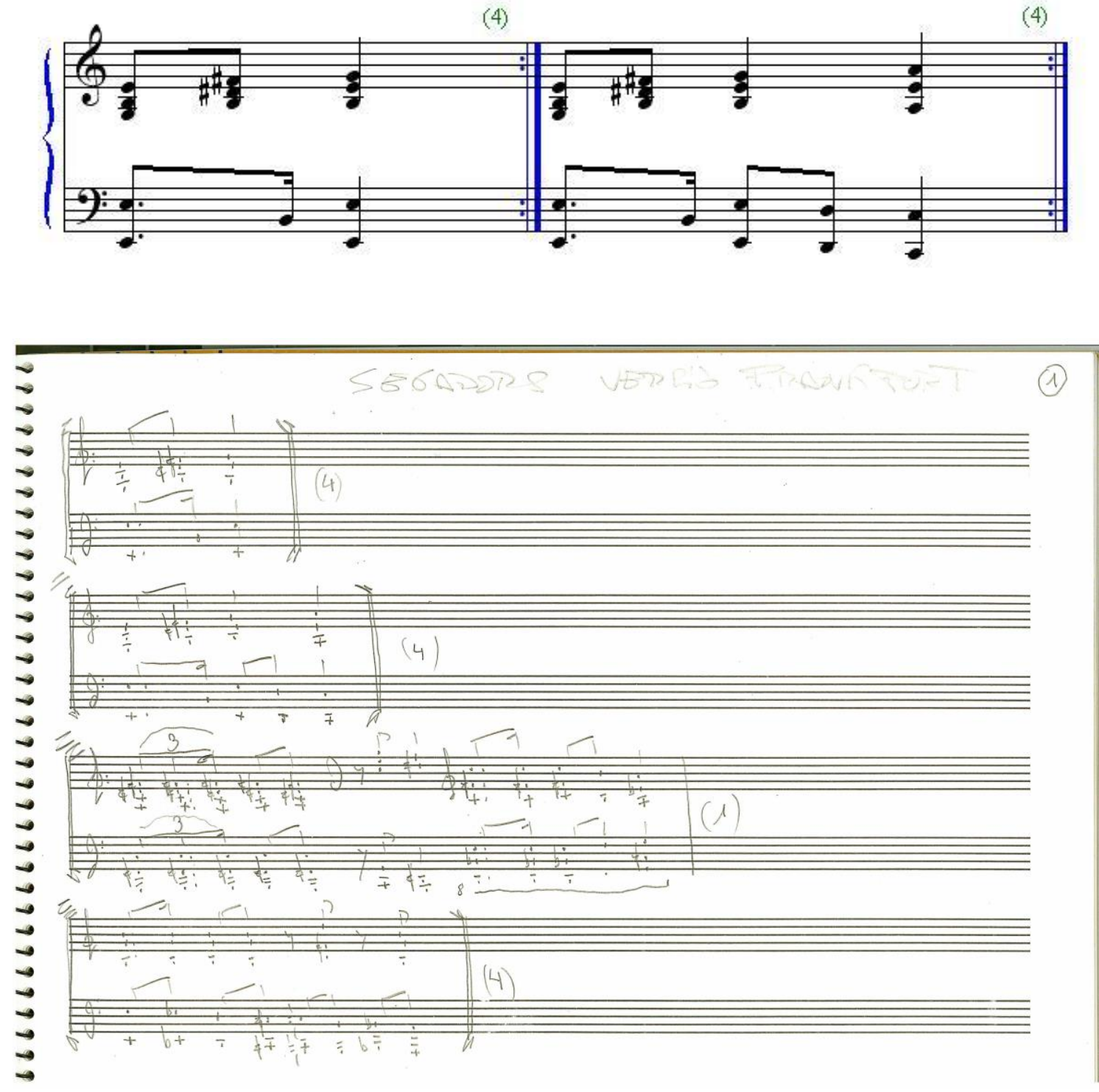

Acción para piano y la bailarina Sol Picó con versión del himno de Els Segadors en el marco de la Cultura Catalana en la Feria del Libro de Frankfurt. Estrenada en la temporada 2007-2008. 


\section{MATERIAL TOTAL:}

- Partitura manuscrita y original del autor. Consta de un bloc de escritura musical, con el título "Segadors" en el exterior y 10 páginas manuscritas y originales. De este material, existe partitura impresa, de 13 páginas, con el título Segadors versió Frankfurt en la primera página. Existe otro bloc de escritura musical, con el título "Segadors" en el exterior y 7 páginas manuscritas y originales, que es anterior, pues consta como apuntes de la obra, ya que existen rectificaciones del propio autor.

- Partes: No existen.

- No consta relación de originales y copias. 
54.- SERIE 3-C, Libre, en La, piano, con partitura, anterior a 1988, arc. 21.

La plantilla a la que está dedicada es la de un Piano.
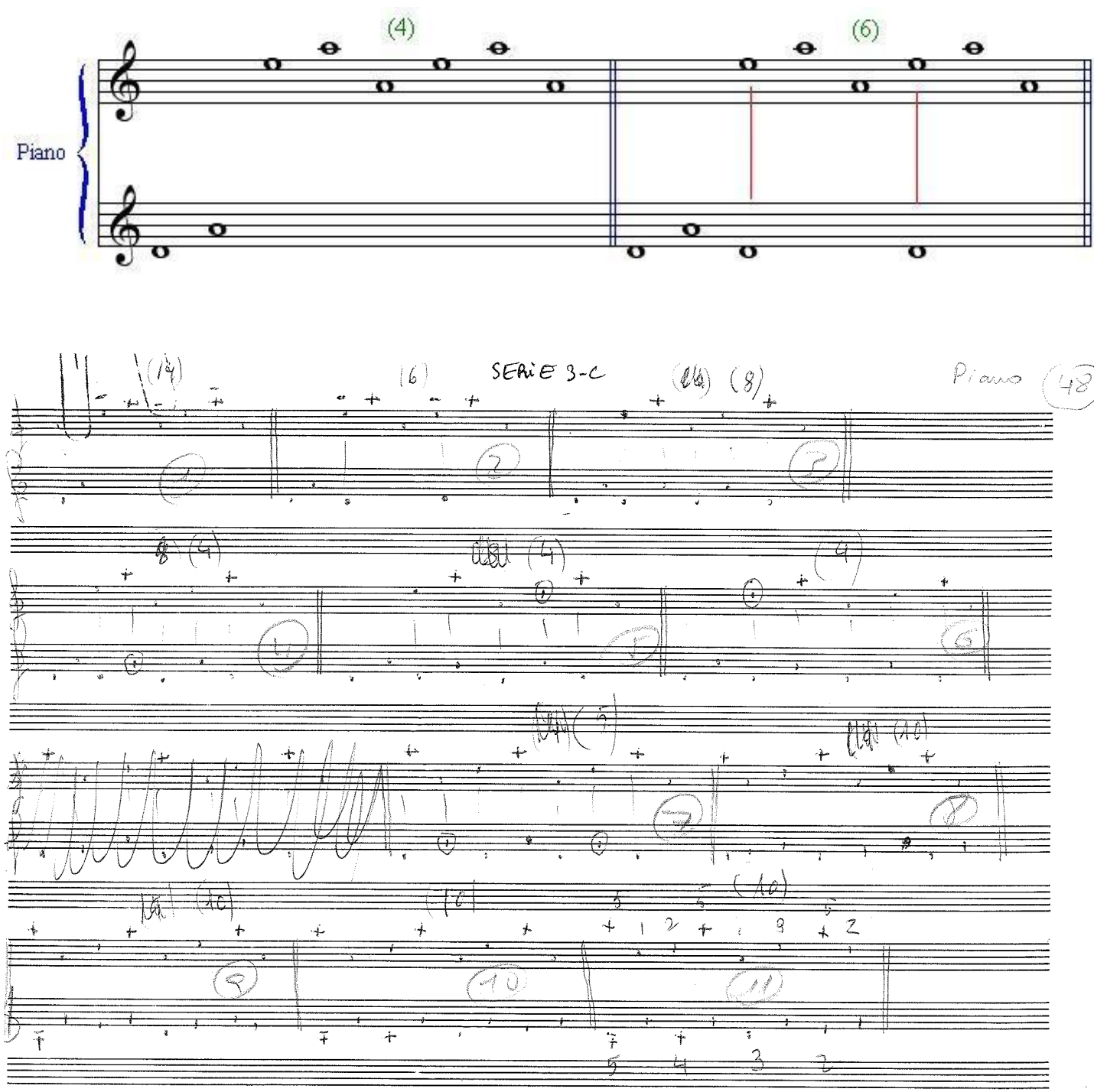

La partitura está numerada como 48 por el autor.

Se corresponde a la pista 3 de la cara A, del disco Piano: Carles Santos grabado en 1988 por Grabaciones Accidentales.

\section{MATERIAL TOTAL:}

- Partitura manuscrita y original del autor. Consta de 3 hojas sueltas sin numerar. Consta título en la página 1 como Serie 3-C, la anotación "piano" y el número 48 
encercado. Consta de 21 fragmentos + el final, numerados del 1 al 18 con lápiz y encercados, (hay 3 fragmentos sin numerar) y encima de cada fragmento, el número de veces que ha de interpretarse. En la segunda página consta indicación metronómica y en la tercera página la anotación "doble temps".

- Partes: No existen partes.

- No consta relación de originales y copias. 


\section{5.- TINC QUE SER CASTIGAT PER NO HAVER ESTIMAT MAI NINGÚ,}

Concierto, Politonal, piano, con partitura y guion, 2007. Arc.18

La plantilla a la que está dedicada es la de un Piano.

Ver: ENTREACTE
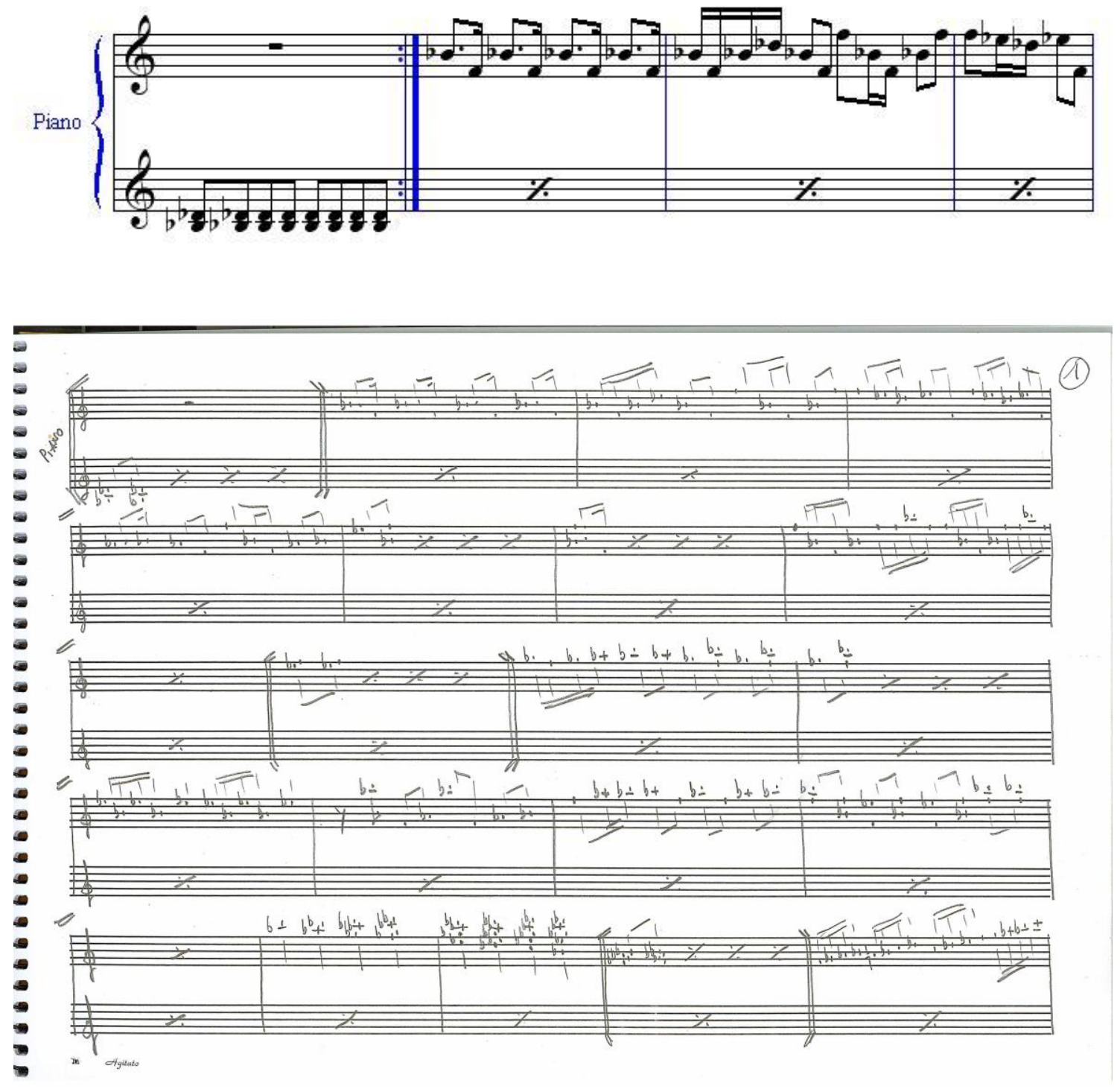

Presentado en el Teatre Lliure la temporada 2006-2007 


\section{MATERIAL TOTAL:}

- Partitura manuscrita y original del autor. Consta de 4 blocs de escritura musical, con los siguientes títulos:

- Tinc que ser castigat... (1) en el exterior con 28 páginas numeradas y manuscritas.

○ Tinc que ser castigat... (2) en el exterior con 29 páginas numeradas y manuscritas (de la 29 a la 57).

○ Tinc que ser castigat... (3) en el exterior con 30 páginas numeradas y manuscritas (de la 58 a la 87 ).

- Tinc que ser castigat... (4) en el exterior con 12 páginas numeradas y manuscritas (de la 88 a la 100). La obra está inconclusa.

- Partes: No existen.

- No consta relación de originales y copias. 
56.- UNA NIT ABANS DE LA NIT AMERICANA, Libre, politonal, piano, con partitura, 1982, arc.16.

La plantilla a la que está dedicada es la de un Piano.

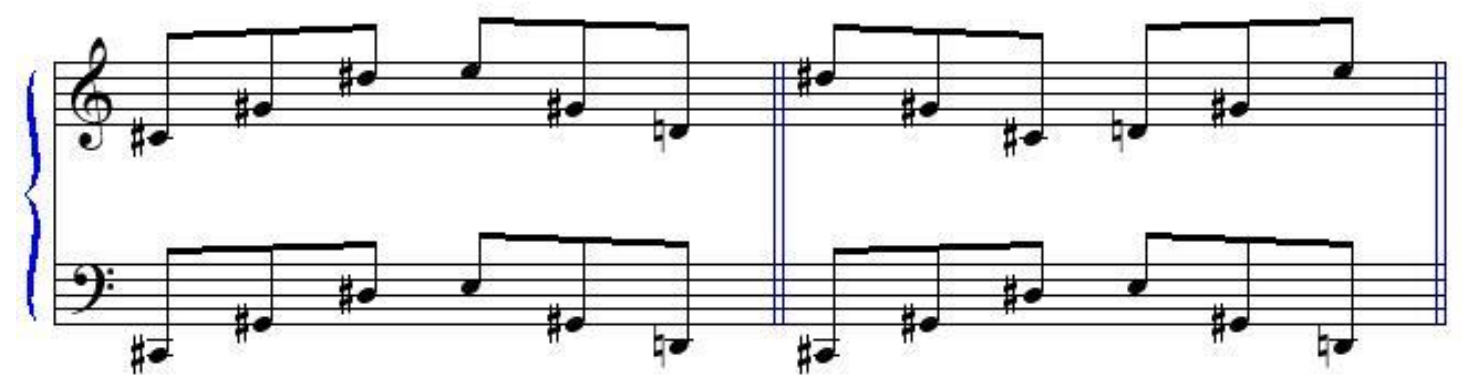

UNA WiT aBas de la nit americana (1982) carles santos.

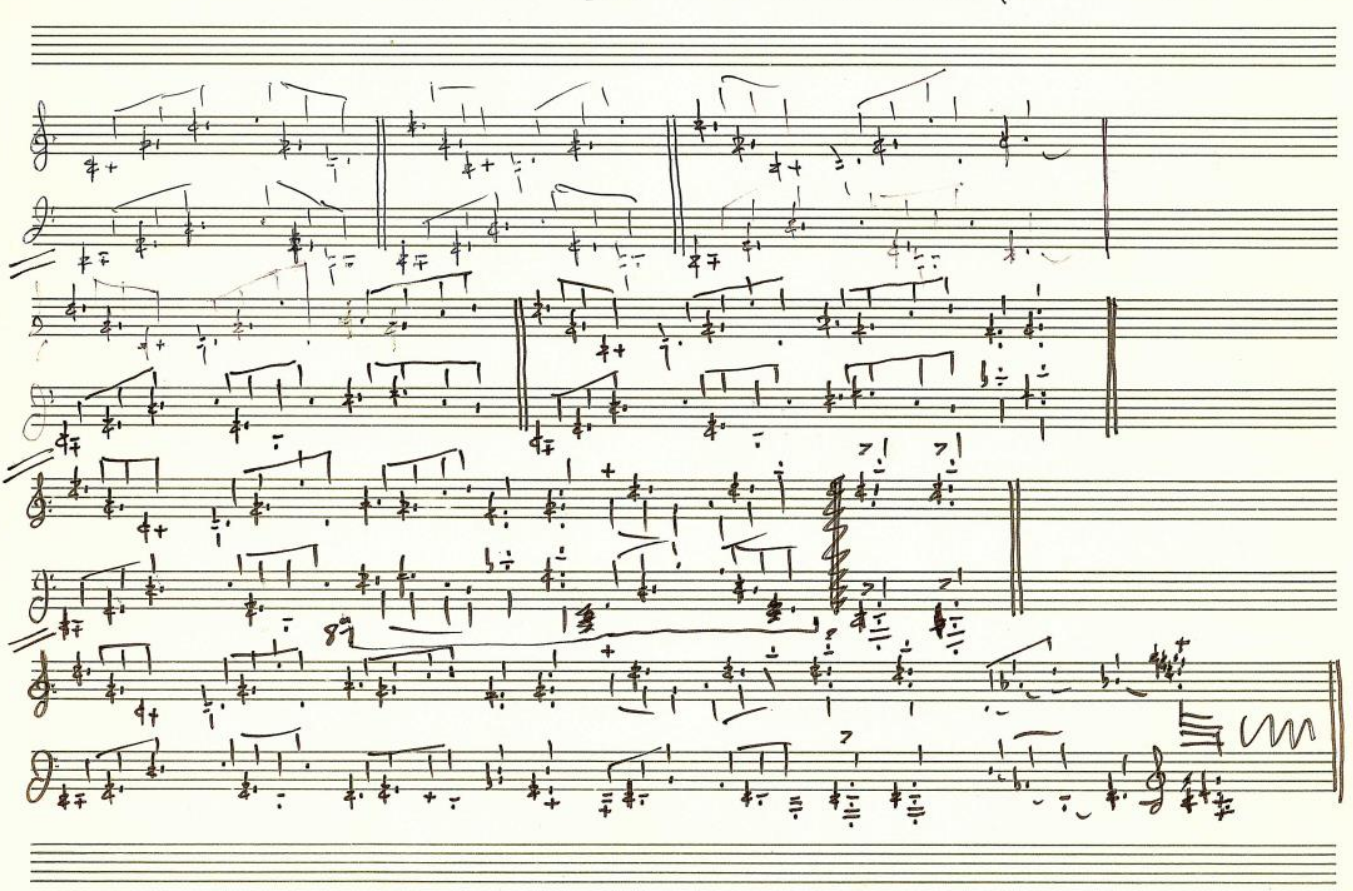

"Se ha interpretado y existe una grabación de dicha interpretación"*

Se corresponde a la pista 1 de la cara B, del disco Pianotrack grabado en 1984 por Linterna Música.

${ }^{*}$ Testimonio oral del autor. 


\section{MATERIAL TOTAL:}

- Partitura de la obra: Manuscrito original del autor. Consta de 2 hojas escritas de un facsímile. Fechada en 1982. Numerada como 22 por el autor.

- Partes: No existen partes.

- No consta relación de originales y copias.

Dobles barras de cada fragmento indican repeticiones, el número de las cuales será a libertad del intérprete. 
3.2.2. VOZ 
1.- AVIGNO 79, Libre, recitada, voz solista, con partitura, 1979, Arc. 23.

La plantilla a la que está dedicada es 1 voz solista.
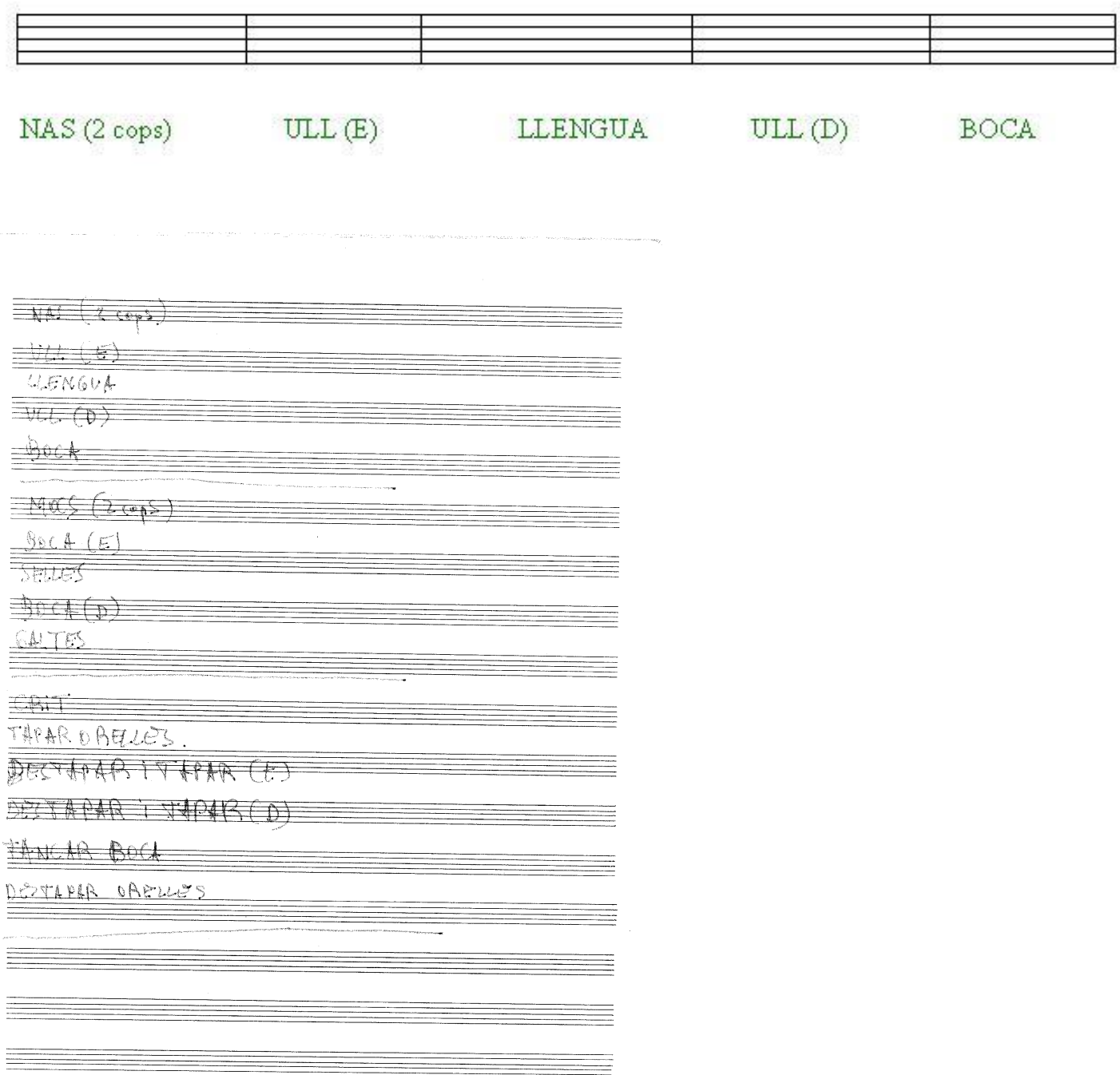

\section{MATERIAL TOTAL:}

- Partitura manuscrita y original del autor. Consta de un libreto de escritura musical con 2 páginas escritas con el título Avigno 79 y el número 40 encercado, en la $1^{\mathrm{a}}$ página.

- Partes: No existen partes.

- No consta relación de originales y copias. 
2.- BEETHOVEN...SI TANCO LA TAPA, QUE PASSA?, Libre, recitada y politonal, 2 voces solistas, coro y piano, con partitura, 1982, Arc. 23.

La plantilla a la que está dedicada son 2 voces solistas, coro y piano.

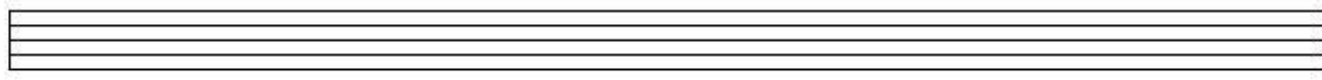
IAMB TOT (3 vegades)
vull acabar
SI TANCO LA TAPA QUE PASSA?

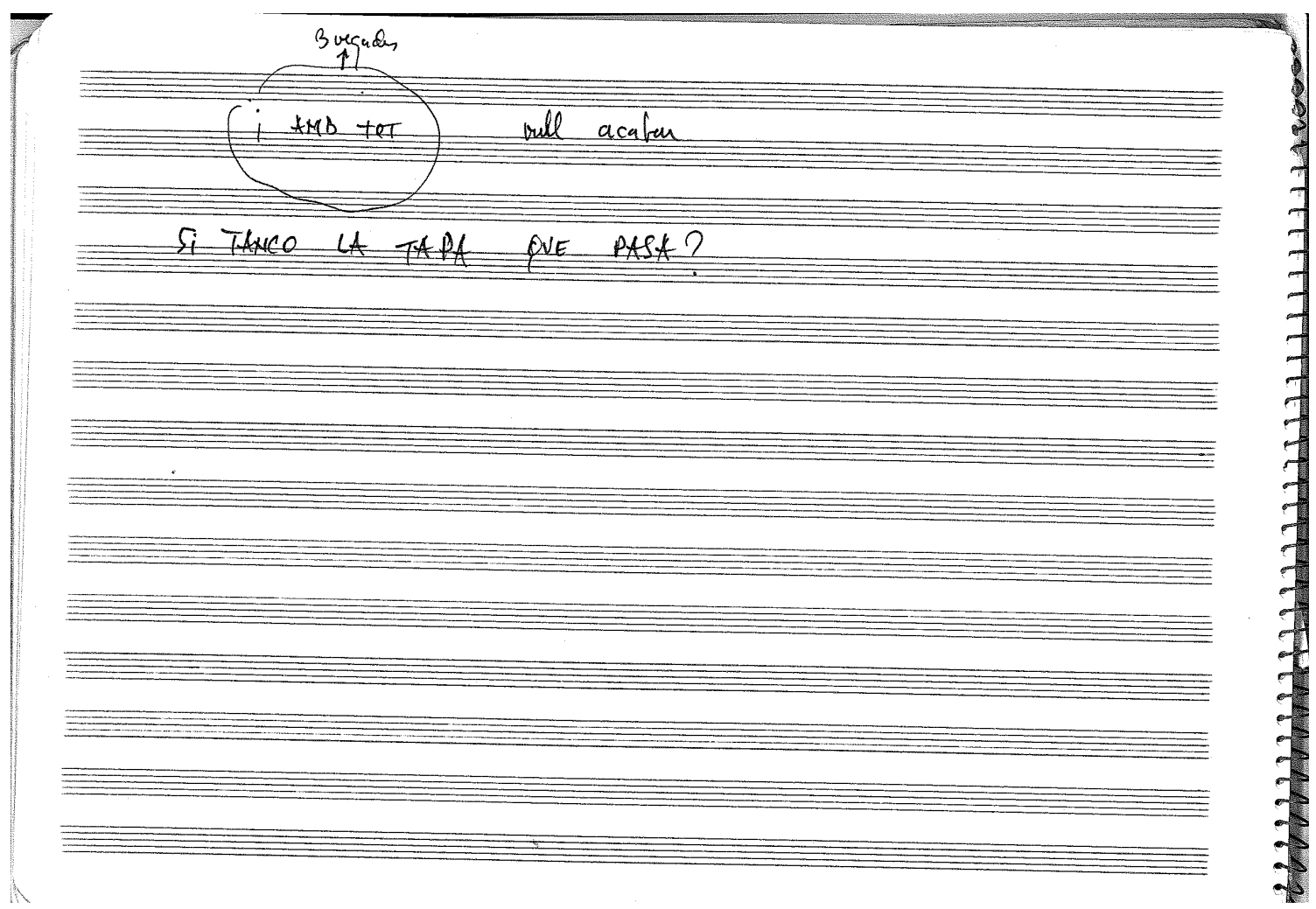

Beethoven...si tanco la tapa, que passa? es un espectáculo escénico compuesto por diversas obras del autor. En la página 8 (numerada como 9) existe un guion del espectáculo. En el mismo se observa las piezas interpretadas en el mismo. Entre las piezas vocales incluidas en este material destaca La banqueta chopera, pieza recitada, que se puede apreciar en otros espectáculos del autor y que, al igual que Un gat es un gat, Dorema domare o Calixa, entre otras, son de uso habitual en los espectáculos de Santos. 


\section{MATERIAL TOTAL:}

- Partitura manuscrita y original del autor. Incluida en un bloc de escritura musical, con el título "Veu" en el exterior, numerado con el número 3 y 26 páginas manuscritas y numeradas del 6 al 21 (música también en el reverso) y originales (la página 16 pertenece a otra obra). Constan como apuntes. En la página 30 existen otros apuntes de la obra. El bloc incluye apuntes de otras obras (Que no donaria jo per una mica de sol).

- Partes: No existen partes.

- No consta relación de originales y copias. 
3.- BUSCA LA PERDIU, Libre, politonal, coro a capella, con partitura, s. d., 1986?, Arc.16.

La plantilla a la que está dedicada es la de un Coro a capella.
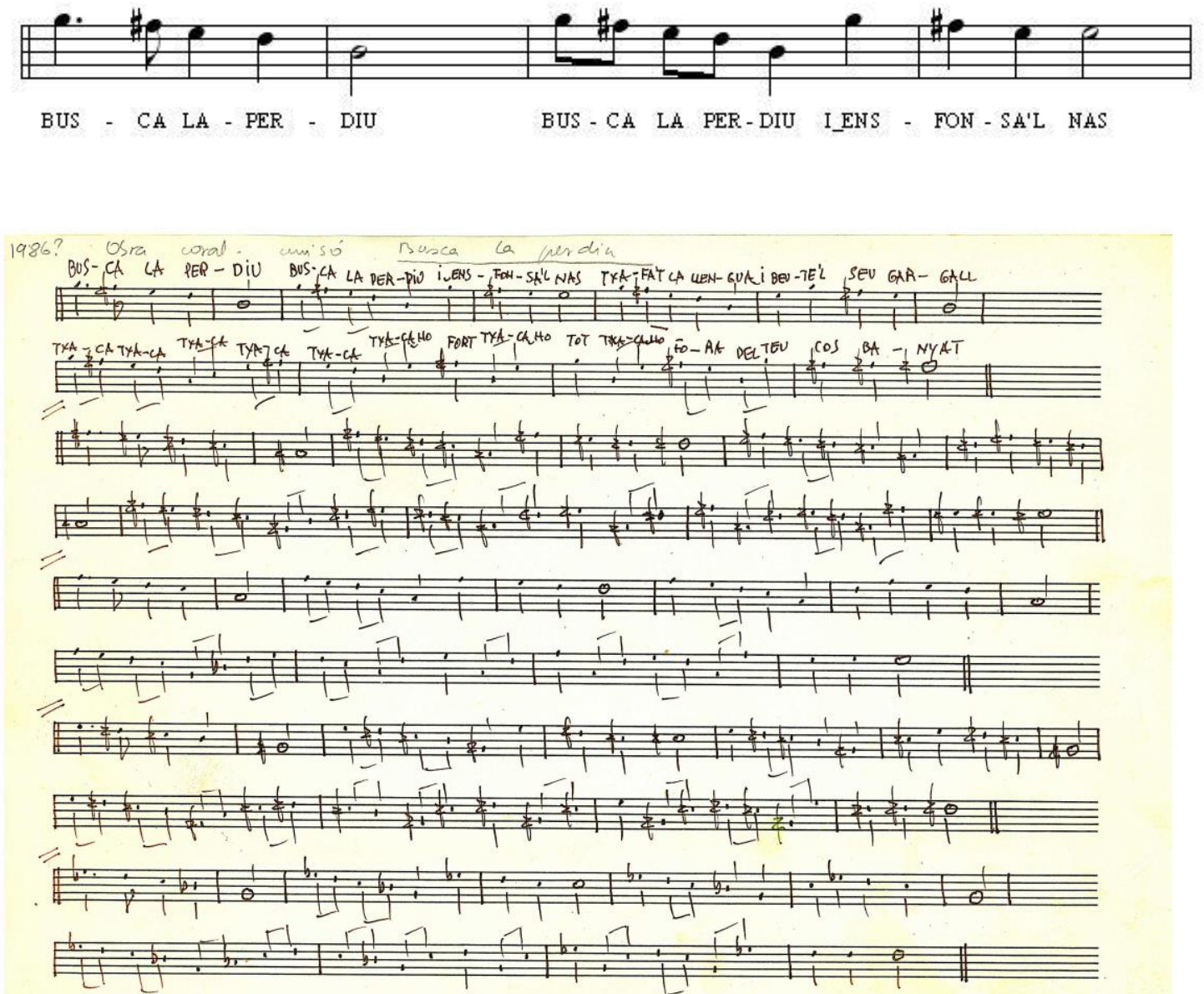

Estrenada en la I Bienal d'Art d'Hospitalet, en la Sala Tecla.

"La interpretación se realiza con los cantantes de pie, sobre los que cae agua de lluvia".*

\section{MATERIAL TOTAL:}

- Partitura de la obra: Manuscrito original del autor, escrito en un bloc de escritura musical, que contiene la música (numerado como 7 bis) y un facsímile con 3 hojas escritas, que contiene el texto en la primera estrofa (numerado como 7).

- Partes: No existen partes.

- No consta relación de originales y copias.

\footnotetext{
${ }^{*}$ Testimonio oral del autor.
} 
4.- CALIXA, Libre, recitado, 1 voz solista, con partitura, 1975 aproximadamente, Arc. 19.

La plantilla a la que está dedicada es la de una voz solista (sin determinar).
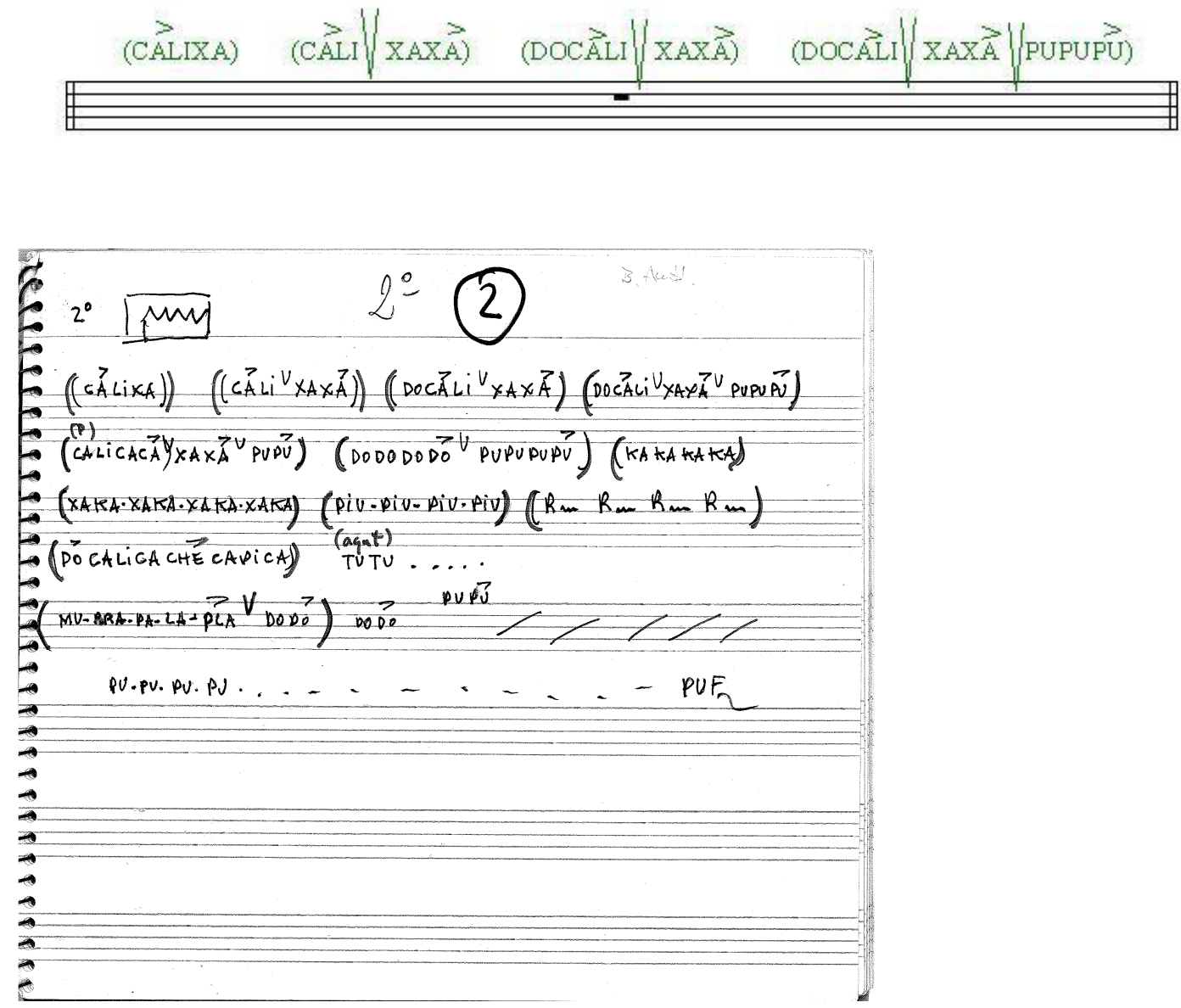

Pieza recitada, que, al igual que Un gat es un gat o Dorema domare, entre otras, son de uso habitual en los espectáculos de Santos.

\section{MATERIAL TOTAL:}

- Material manuscrito y original del autor. Consta de 1 bloc de escritura musical, sin título en el exterior, de color marrón que contiene la estructura de un espectáculo ofrecido por el autor en New York. Entre las obras desarrolladas en su interior se encuentra Calixa, así como Un gat es un gat.

- Partes: No existen partes.

- No consta relación de originales y copias. 
5.- CANT ENERGETIC, libre, atonal, voz solista, con partitura, 1978, Arc. 23

La plantilla a la que está dedicada es la de una voz solista (sin determinar su tipo).
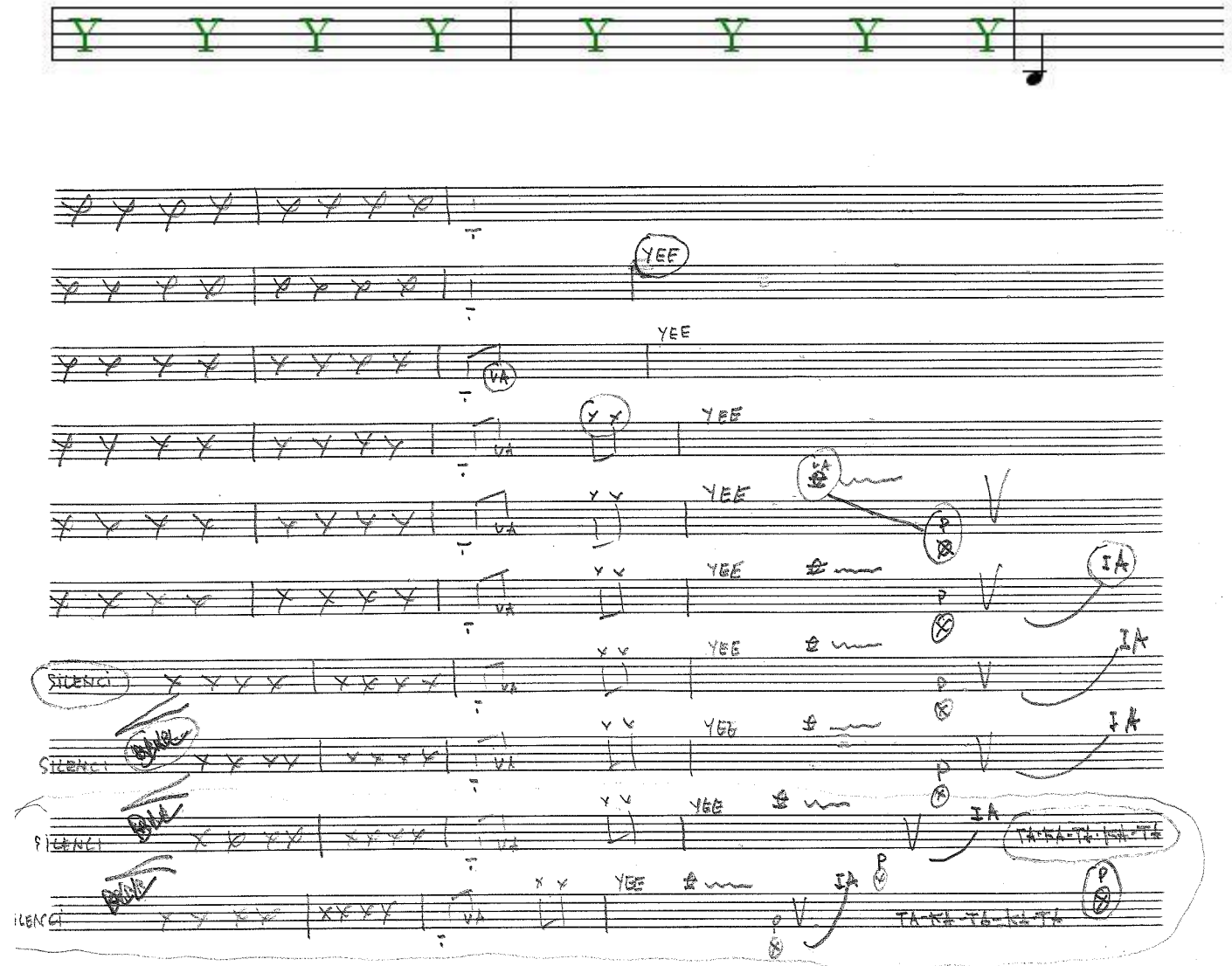

La partitura está numerada como 10 por el autor.

Se corresponde a la pista 2 del disco Voicetracks grabado en 1981 por R.A. Taylor.

El principio de la obra no se corresponde con la grabación ya que el autor comienza con una melodía vocal entonada.

\section{MATERIAL TOTAL:}

- Partitura manuscrita y original del autor. Consta de un libreto de escritura musical con 2 páginas escritas con el título Cant energetic (1978), y las anotaciones "Enregistrat a: Voicetracks (1980)" y el número 10 encercado, en la $1^{a}$ página.

- Partes: No existen partes.

- No consta relación de originales y copias. 
6.- CANT I DANÇA, libre, recitado, voz solista, con partitura, s. d., Arc. 23

La plantilla a la que está dedicada es la de una voz solista (sin determinar su tipo).
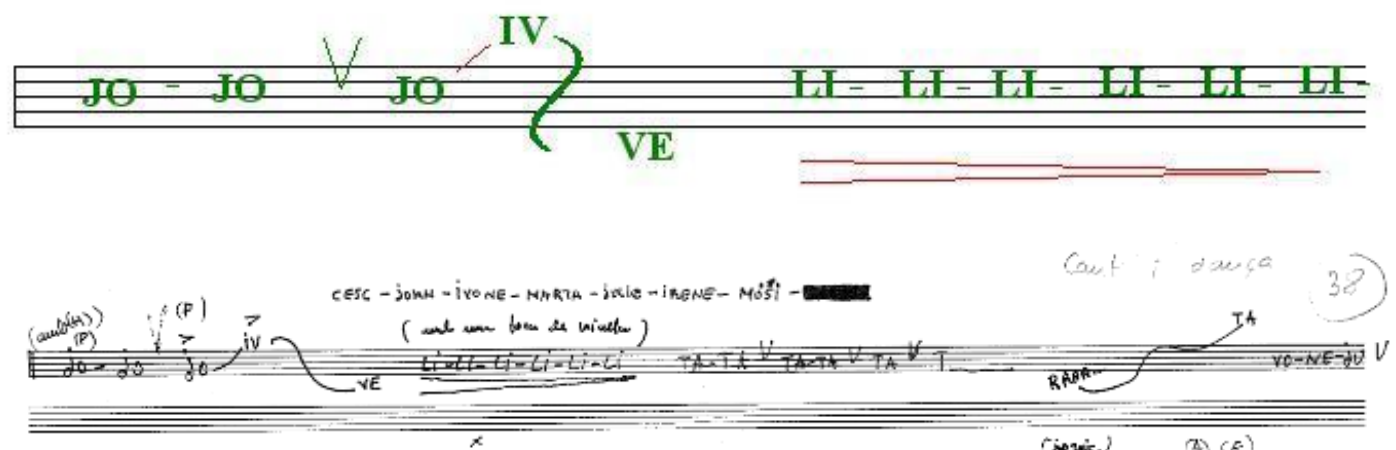

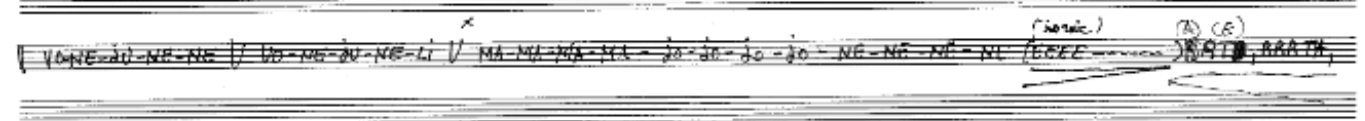
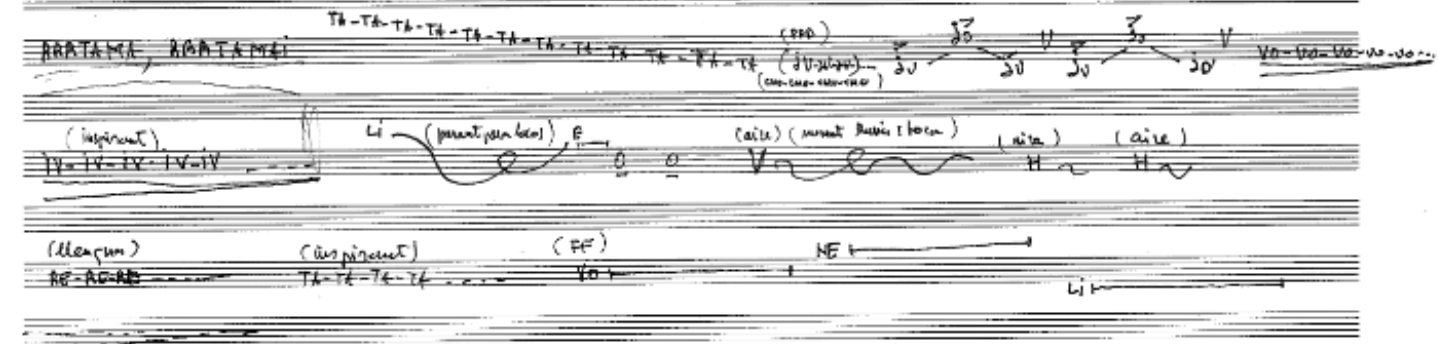

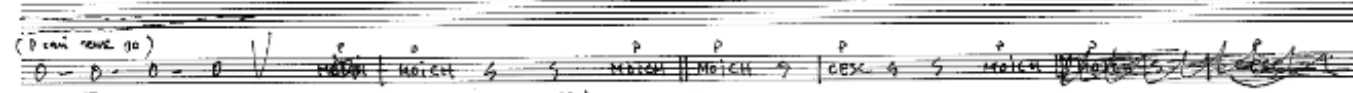

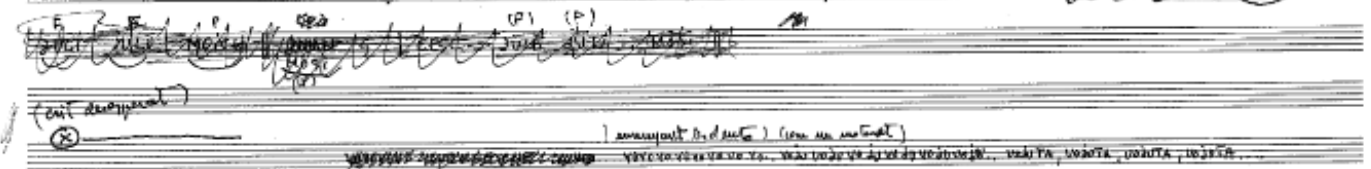

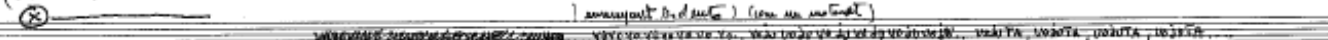

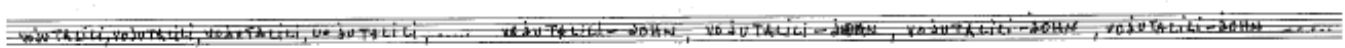

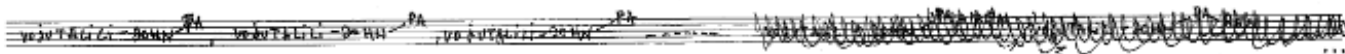

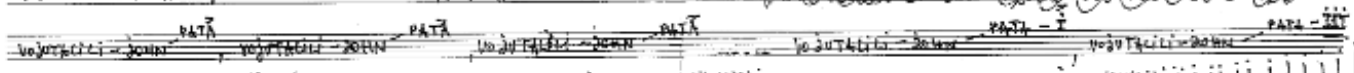

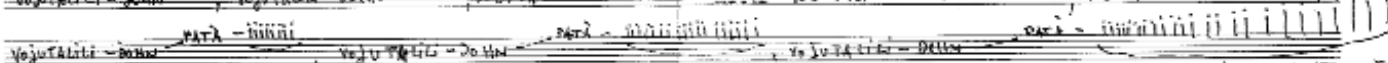

La partitura está numerada como 38 por el autor.

Pieza vocal, sin entonación y con indicaciones de expresiones corporales. En el texto aparecen personajes (Cesc, John, Ivone, Marta, Julie, Irene y Mosi)

\section{MATERIAL TOTAL:}

- Partitura manuscrita y original del autor. Consta de 1 hoja suelta, escrita por ambas caras. Consta título como Cant i dança y el número 38 encercado.

- Partes: No existen partes.

- No consta relación de originales y copias. 
7.- CANTATA (MANRESA), Cantata, politonal, voces solistas y coro, con partitura, 2009, Arc. 19

La plantilla a la que está dedicada es la de 5 voces solistas (sin determinar su tipo) y Coro.

Ver: ELS MONTS o LA VEU ASSUMPTE/A
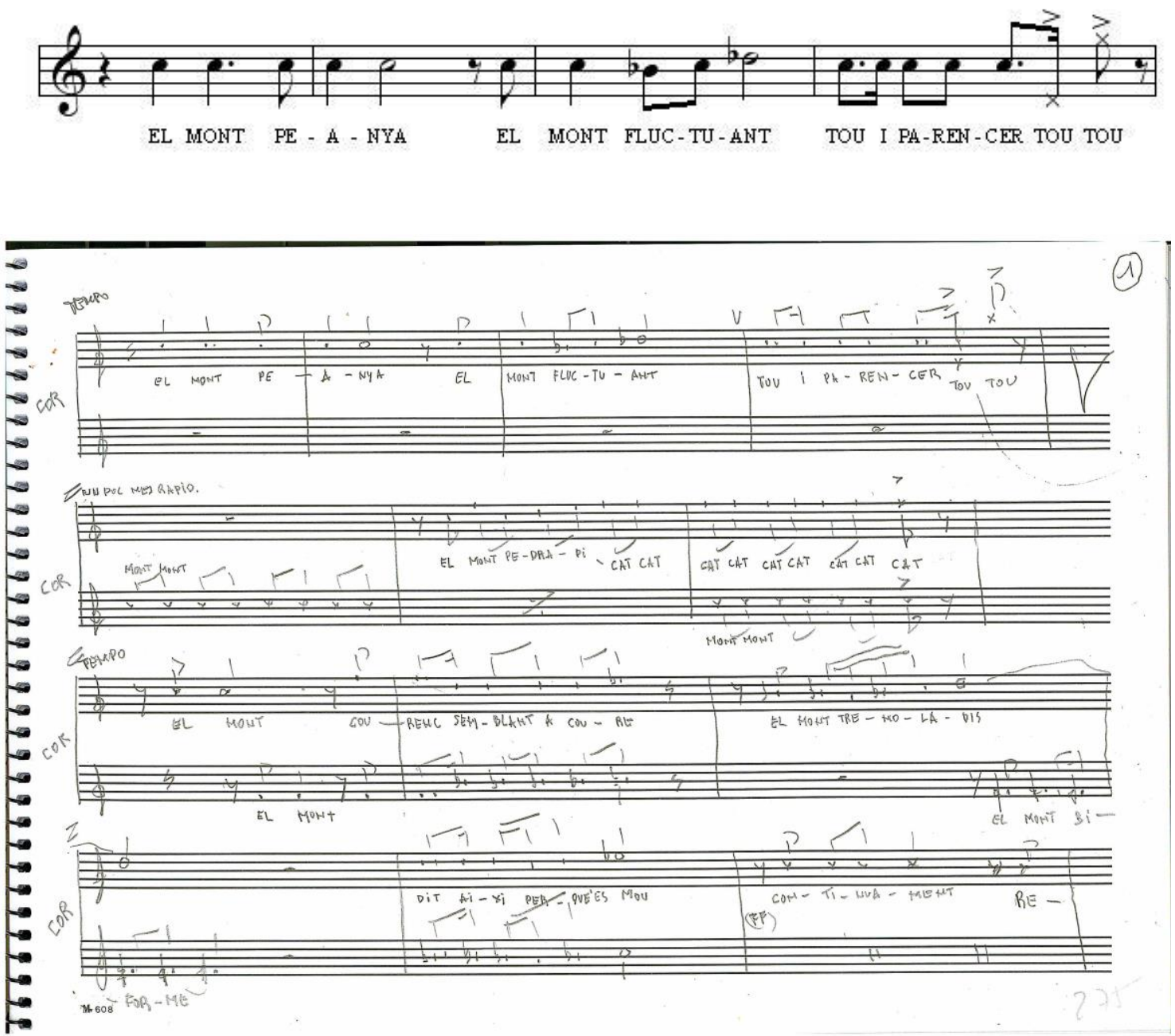

Se puede encontrar con los títulos Els monts o La veu assumpte/a

Obra escrita para el evento "Mediterranea '09" celebrado en Manresa en 2009 dentro de la $12^{\mathrm{a}}$ Feria Mediterránea de Manresa. Texto de Pere Jaume.

Para este evento, el autor escribió otras obras: Tenora i Piano, 6 Tenoras i Piano y Soprano i tenora. 


\section{MATERIAL TOTAL:}

- Partitura manuscrita y original del autor. Consta de 1 bloc de escritura musical, con el título Cantata (Manresa) en el exterior con 13 páginas numeradas y manuscritas. Contiene 3 grupos de 4 hojas, con el título Els monts o La veu assumpte/a, con el texto completo de la obra. En el manuscrito musical no está toda la obra.

- Partes: No existen.

- No consta relación de originales y copias. 
8.- CAPITOL 6 (COMUNIÓ), Libre, politonal, 3 voces solistas, con partitura, anterior a 1990, Arc. 23

La plantilla a la que está dedicada es la de 3 voces solistas (sin determinar su tipo).
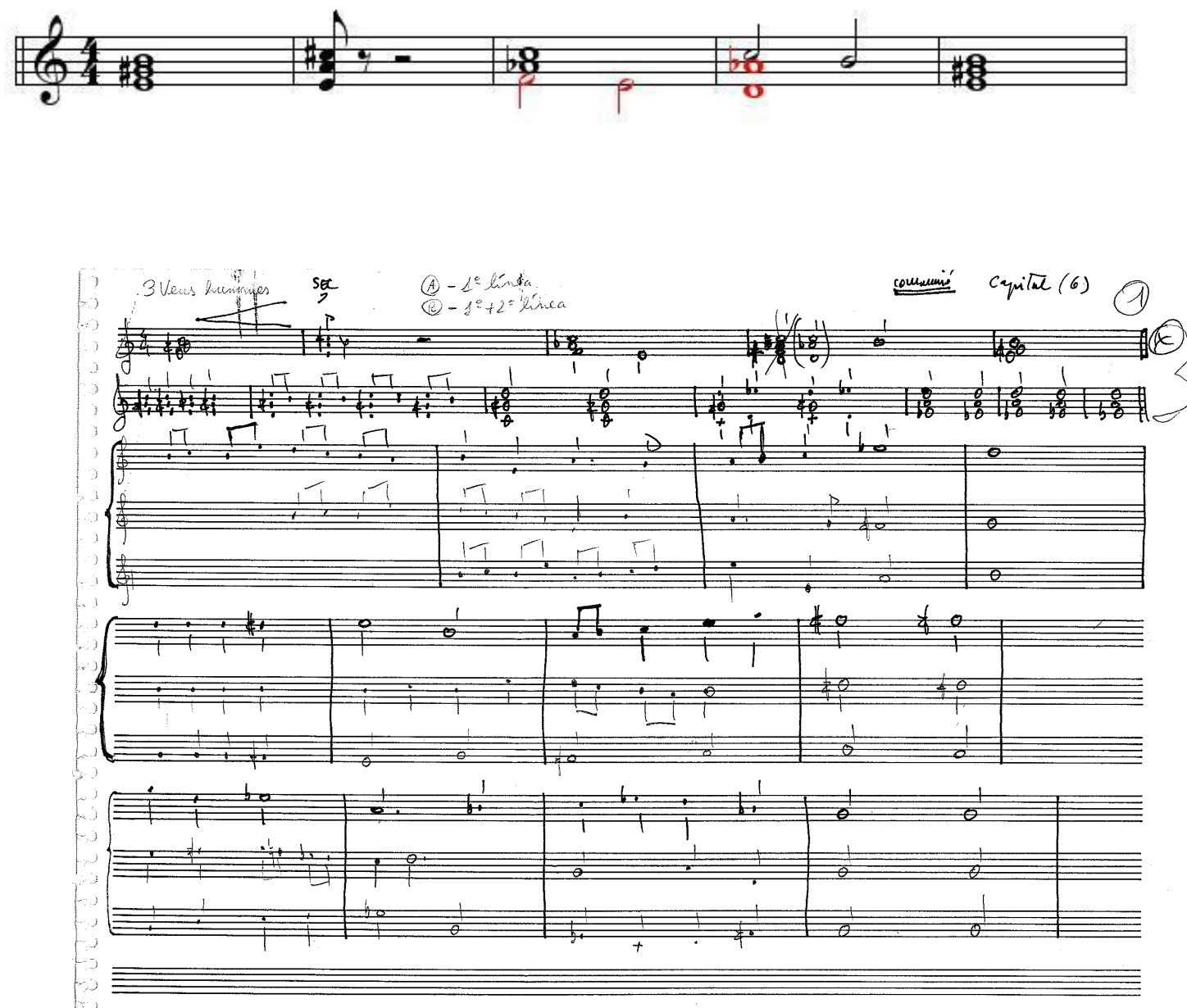

Puede formar parte de la musicalización de algunas imágenes o film. Puede estar relacionada con la obra para piano Capitol 2 (Salut).

\section{MATERIAL TOTAL:}

- Partitura manuscrita y original del autor. Consta de 3 páginas sueltas y numeradas. Consta título en la página 1 como Capitol 6 (Comunió).

- Partes: No existen partes.

- No consta relación de originales y copias. 
9.- CONILL AMB CARAGOLS, libre, politonal, coro, con partitura, 2011, Arc. 23

La plantilla a la que está dedicada es la de un Coro.

Ver: VI SONOR
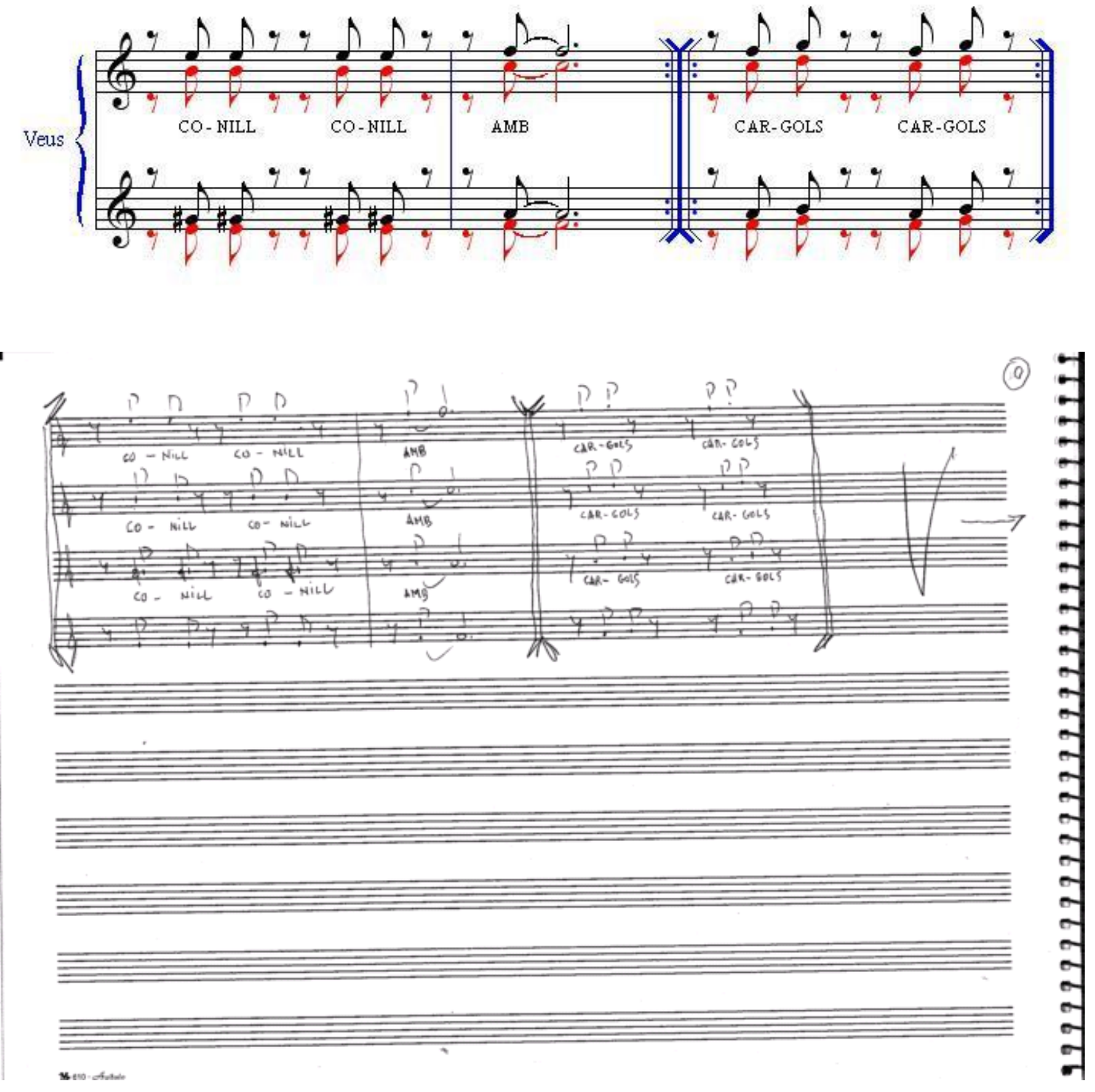

Compuesta para la Acción musical realizada en Pobla de Gervoles (cerca de Agramunt) el 2 de julio de 2011, como homenaje a los vinos de la bodega Celler Mas Blanch i Jové, que creó la denominada La Vinya dels Artistes. La acción transcurría en los viñedos. Mediante un paseo, los invitados degustaban comida típica de los periodos clásico, romántico, impresionismo, siglo XX y la actualidad, al mismo tiempo que un pianista interpretaba música propia del periodo al que se hace referencia. Los camareros 
vestían de acuerdo con la época. En total participan 5 pianistas (Oscar Campos, Inés Borrás, Albert Giménez, Miquel Villalva y Carles Santos) con 5 pianos colocados en puntos estratégicos del recorrido, un coro (que interpreta la música al tiempo que los invitados recorren el espacio que separa una época de la siguiente) y una violinista, Katy Reus, encima de una grúa. Encima de los pianos se depositaros productos típicos de cada periodo. La acción comenzó con la interpretación de la obra a cargo de El Cor Eurídice de les Borges Blanques dirigido por la compositora Dolors Ricart. El mismo coro fue el encargado de interpretar las 3 obras corales de Santos ("Saó Blanc", "Saó Expressiu" i "Saó Rosat") en los paseos de transición de un lugar a otro de las viñas de la bodega.

\section{MATERIAL TOTAL:}

- Partitura manuscrita y original del autor. Consta de un bloc de escritura musical con el título $V i$ sonor en el exterior y 19 páginas manuscritas y originales, divididas en 4 grupos numerados, que representan a las 4 obras:

○ “Saó Rosat”, con 3 páginas numeradas,

○ “Saó Expressiu”, con 2 páginas numeradas,

- Conill amb caragols, con 9 páginas numeradas, y

○ “Saó Blanc”, con 5 páginas numeradas,

- Partes: No existen partes impresas.

- No consta relación de originales y copias. 
10.- CONVERSA, libre, politonal, voz solista, con partitura, 1980, Arc. 23

La plantilla a la que está dedicada es la de una voz solista.
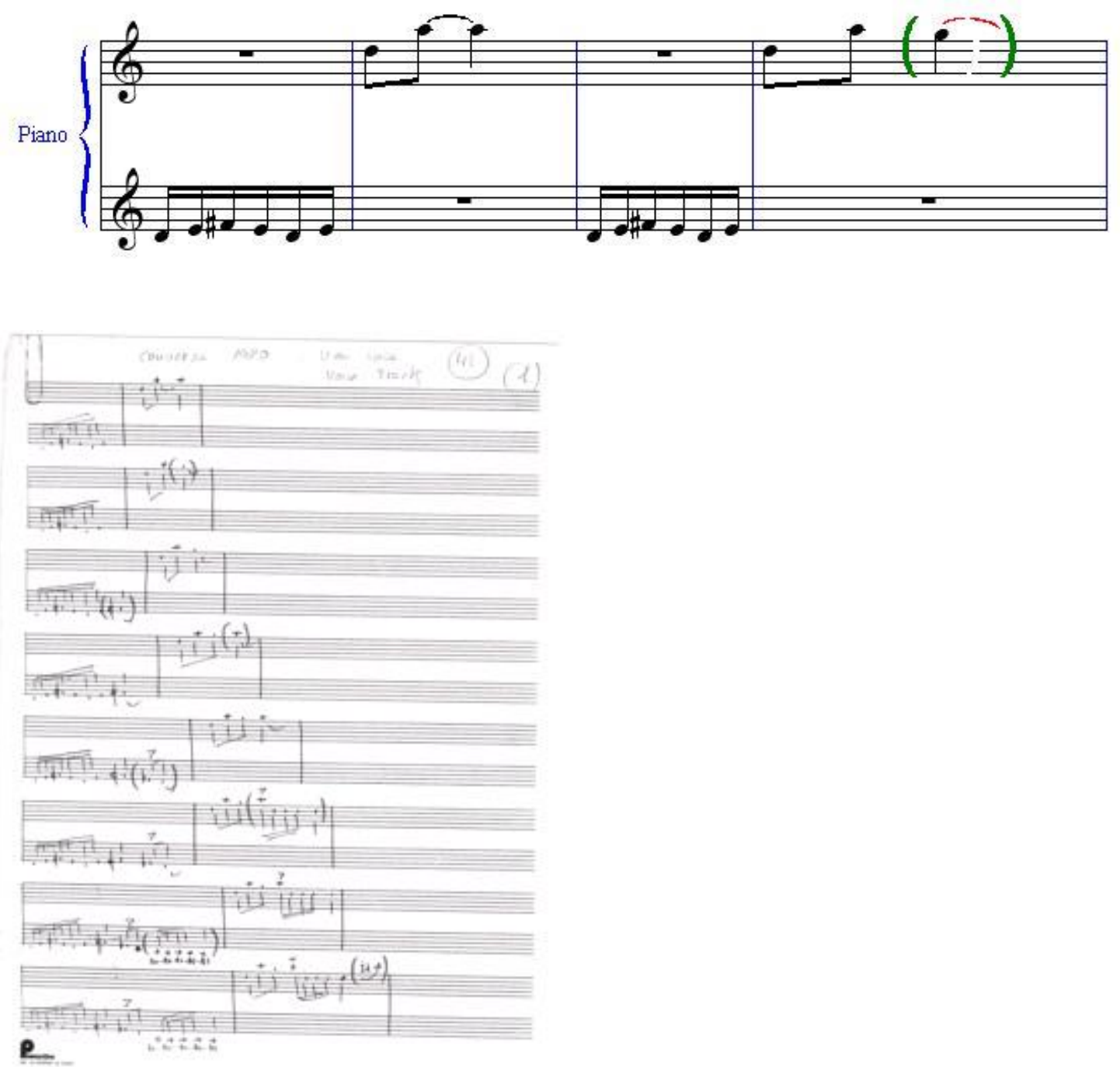

Se corresponde a la pista 5 ( $1^{\text {a }}$ de la cara B) del disco Voicetracks grabado en 1981 por R.A. Taylor.

La partitura está numerada con el 41 por el autor.

MATERIAL TOTAL:

- Partitura manuscrita y original del autor. Consta de 2 hojas sueltas y numeradas del 1 al 3. Consta título en la página 1 como Conversa 1980 y las anotaciones "veu sola, Voice track" y el número 41 encercado.

- Partes: No existen partes impresas.

- No consta relación de originales y copias. 
11.- DEMANA-HO, libre, recitado, voz y piano, con partitura, 1985 aproximadamente, Arc. 34

La plantilla a la que está dedicada es la de una voz (sin especificar) y piano.

\section{Ver: DEMANAU}
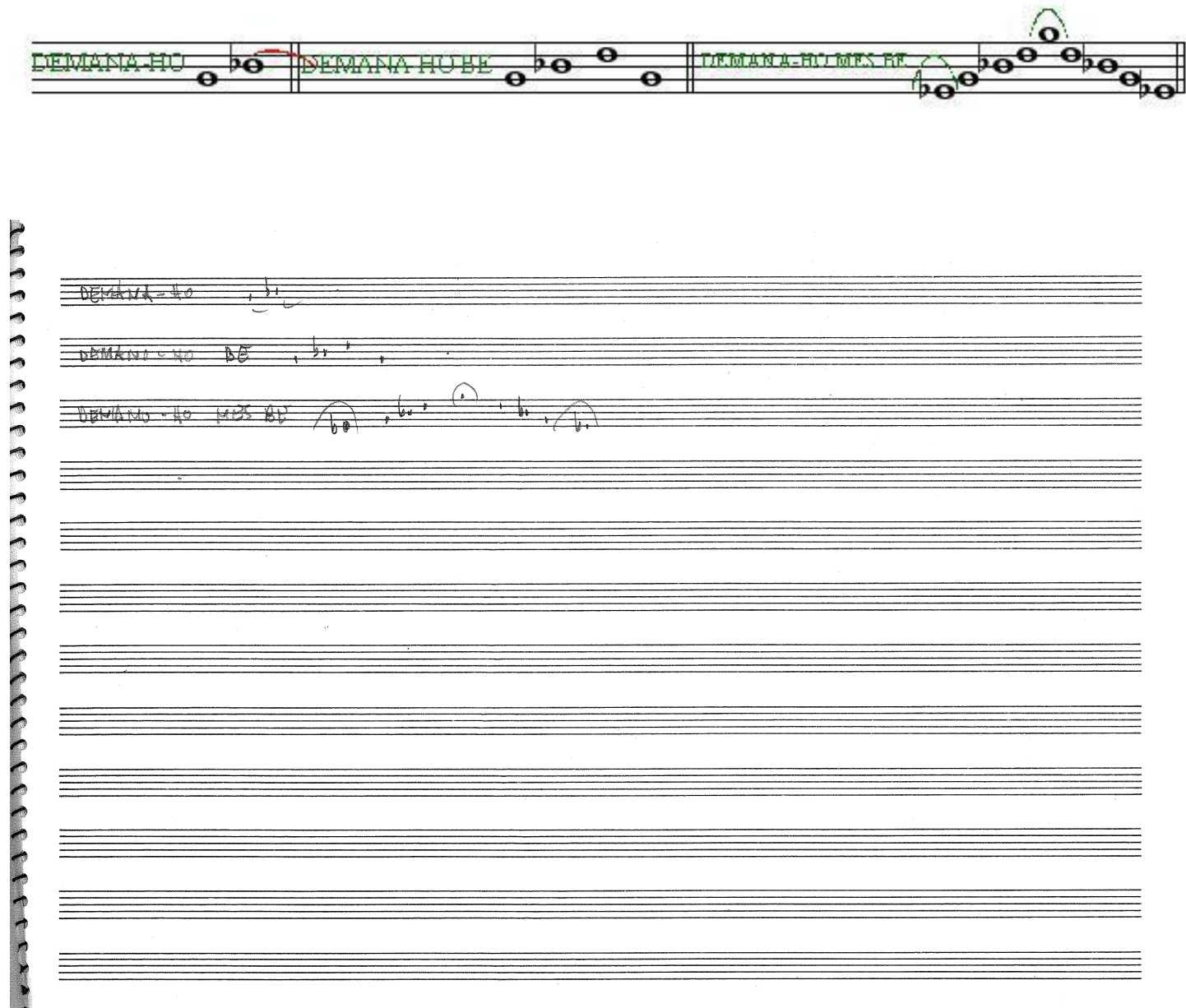

Música que forma parte del espectáculo Credi tonal, junto a Peça veu amb Cesc Gelabert y Credit tonal.

Parece ser el desarrollo de la obra Demanau, aunque los textos no coinciden exactamente, por lo que puede ser una versión de la obra. Esta pieza puede formar parte de la obra escénica Arganchulla Arganchulla Gallac. 


\section{MATERIAL TOTAL:}

- Material manuscrito y original del autor. Consta de 1 bloc de escritura musical, sin título en el exterior. Las hojas 9, 10 y 11 contienen los apuntes de la obra. En el mismo bloc se encuentran las obras Credi tonal y Peça veu amb Cesc Gelabert. Existe otro texto de la obra en el bloc de la obra con $n^{\circ}$ de orden 90.

- Partes: No existen partes impresas.

- No consta relación de originales y copias. 
12.- DEMANAU, libre, recitado, dúo vocal, con partitura, 1985 aproximadamente, Arc. 17

La plantilla a la que está dedicada es la de un dúo vocal (sin especificar).

\section{Ver: DEMANA-HO}
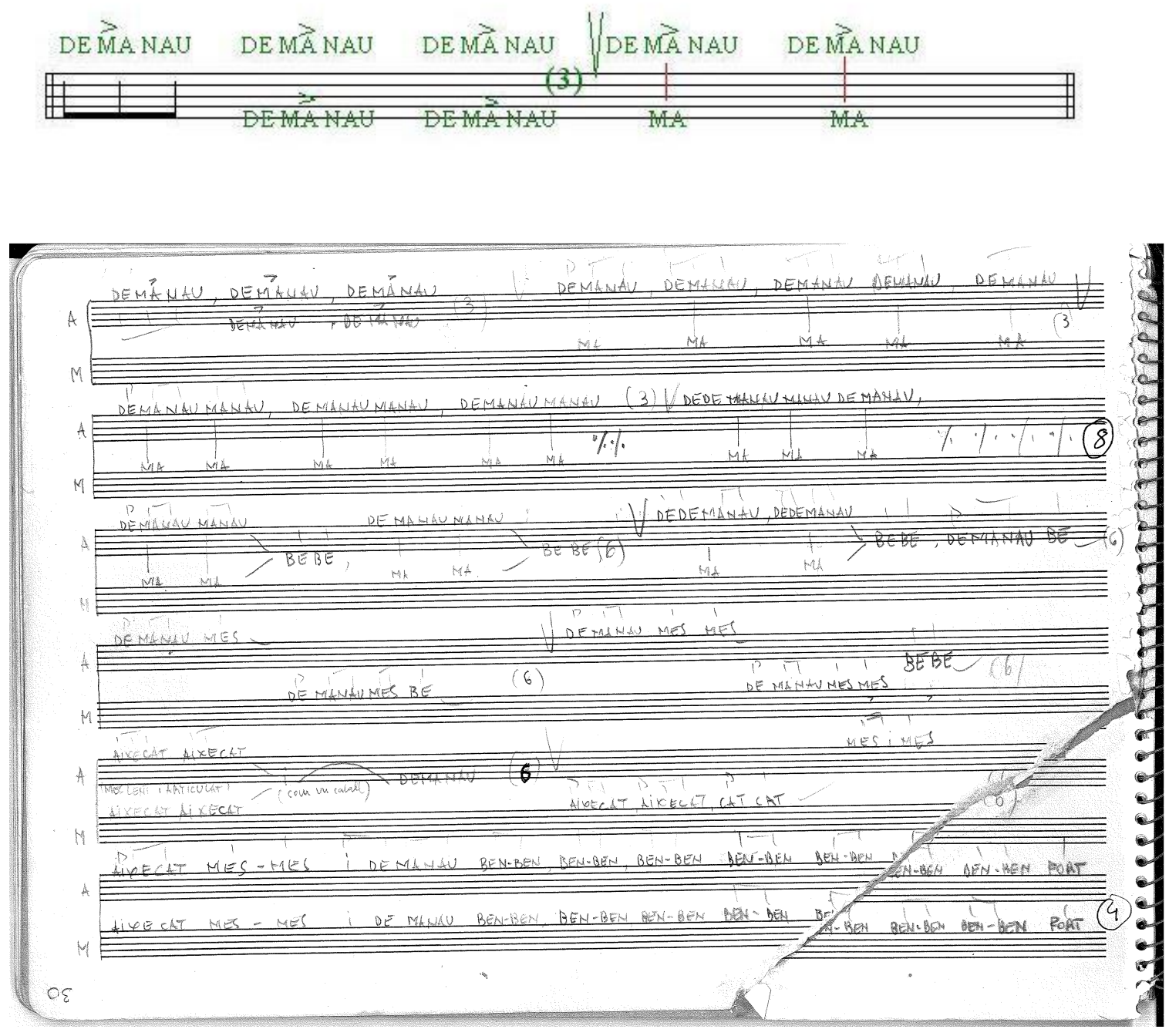

Parece ser el inicio de la obra Demana-ho o al menos, los textos de la misma. Aunque los textos no coinciden exactamente, puede ser una versión de la obra. Esta pieza puede formar parte de la obra escénica Arganchulla Arganchulla Gallac.

\section{MATERIAL TOTAL:}

- Material manuscrito y original del autor. Consta de 1 bloc de escritura musical, con el título Arganchulla en el exterior y el número 4 encercado. En el reverso 
de este bloc y en 4 páginas sin numerar, manuscritas y originales, se encuentra la música y el texto de la obra Demanau.

- Partes: No existen partes impresas.

- No consta relación de originales y copias. 
13.- DOREMA-DOMARE, libre, recitado, voz, con partitura, 1978 aproximadamente, Arc. 19

La plantilla a la que está dedicada es la de una voz solista (sin especificar).

DOREMA DOM̈ARE

DORE DORE AO DOAN

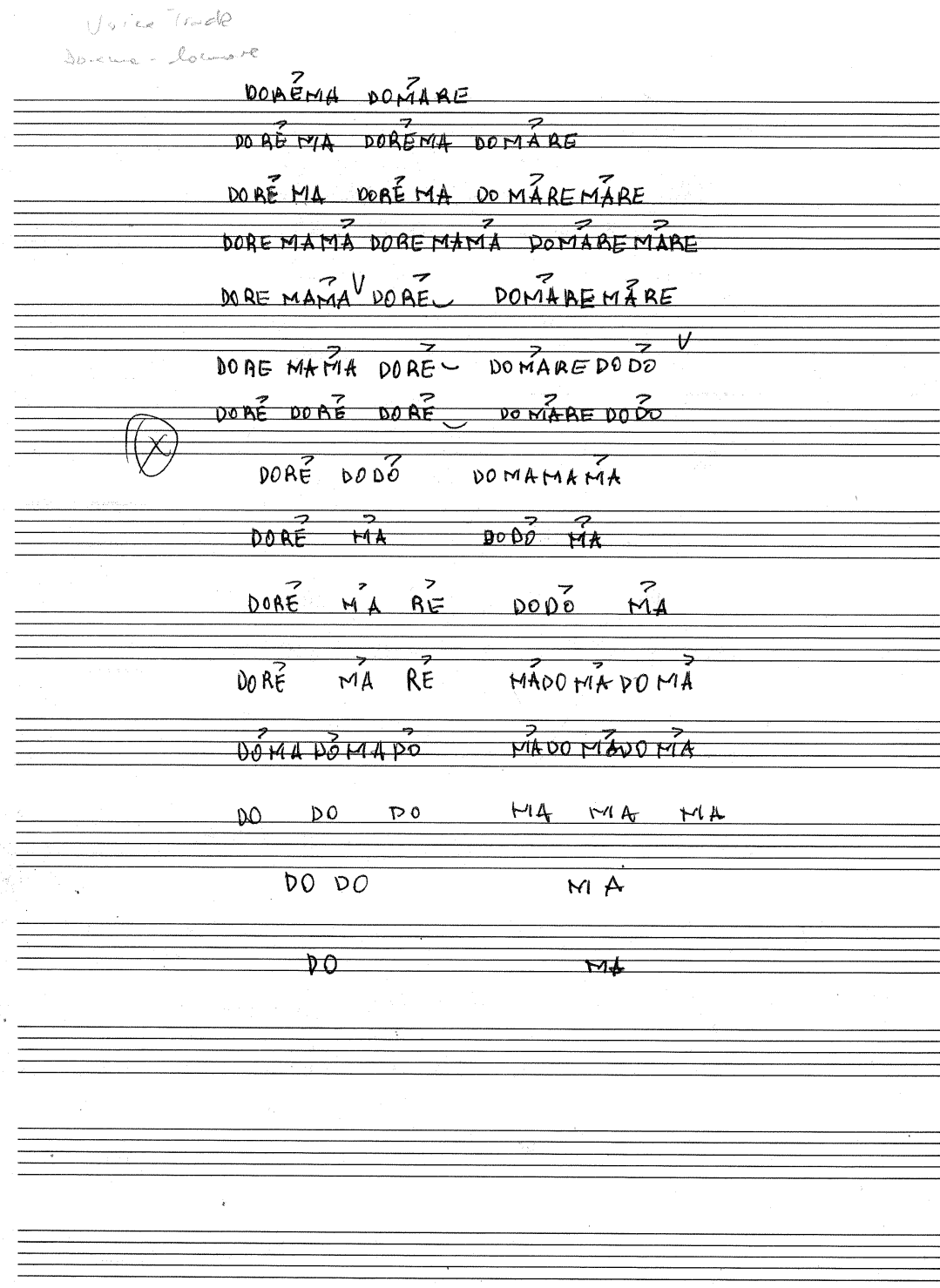

Pieza recitada, que, al igual que Un gat es un gat o Calixa, entre otras, son de uso habitual en los espectáculos de Santos. 


\section{MATERIAL TOTAL:}

- Material manuscrito y original del autor. Consta de 1 bloc de escritura musical, perteneciente a la década de los 70 y adquirido en New York, sin título en el exterior. La obra está escrita en las 16 primeras hojas. Los textos expuestos constan en 3 hojas $(6,7$ y 8$)$ de dicho bloc. Se desconoce el origen y título del resto del material del bloc.

- Partes: No existen partes impresas.

- No consta relación de originales y copias. 
14.- ELS MONTS, cantata, politonal, 3 solistas vocales, Coro y Coro de Cámara, con partitura, 2009, Arc.verde.

La plantilla a la que está dedicada es la de 3 solistas vocales, Coro y Coro de Cámara.

\section{Ver: CANTATA (MANRESA) o LA VEU ASSUMPTE/A}
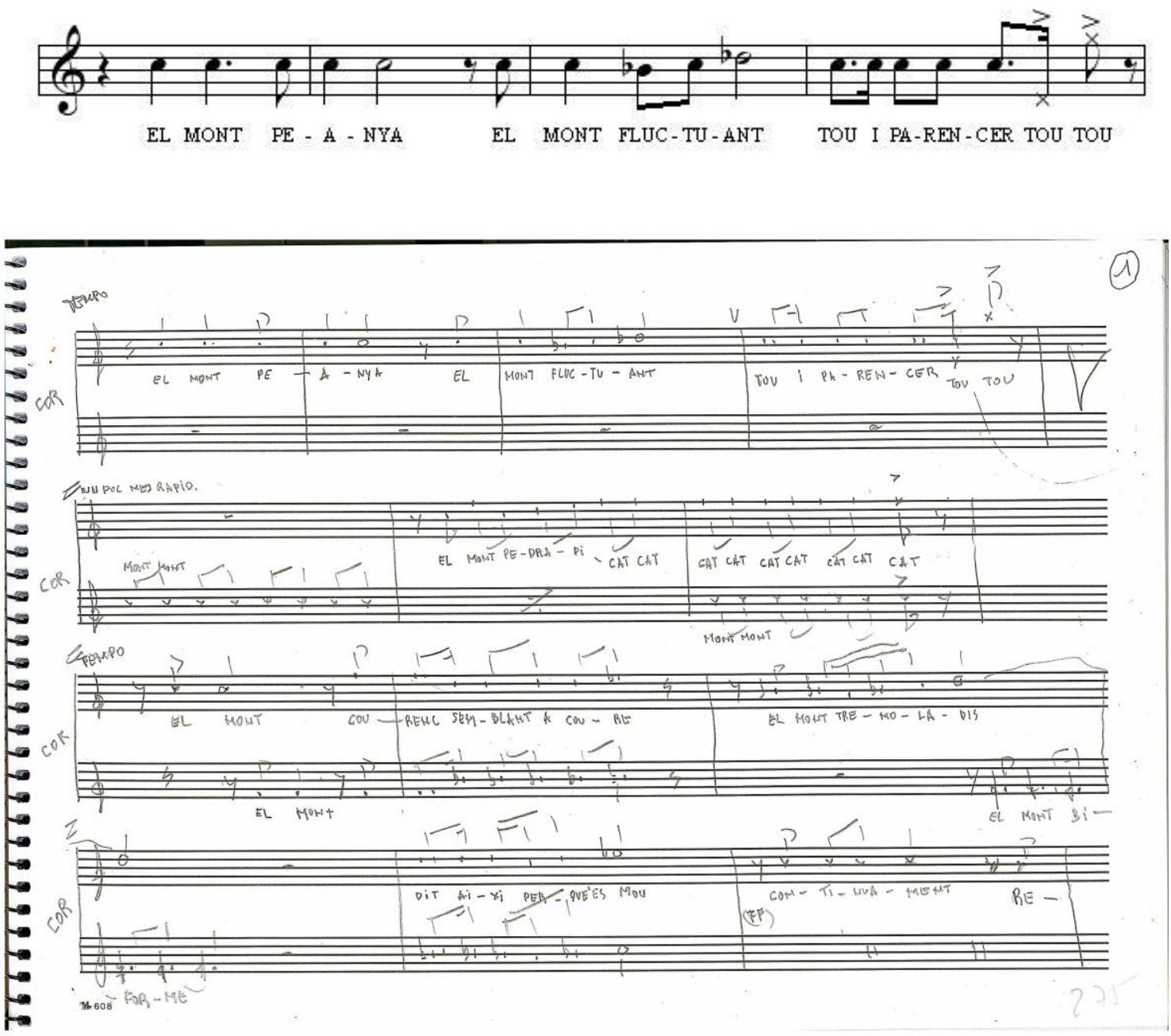

Obra escrita para el evento "Mediterranea '09" celebrado en Manresa en 2009. Texto de Pere Jaume.

Es el material impreso de la obra Cantata (Manresa). 


\section{MATERIAL TOTAL:}

- Partitura impresa de 32 páginas, sin encuadernar. PDF realizado por Xavier Piquer con software Sibelius (Mac). No existen manuscritos.

- Partes: Existen partes de software y originales. Existe texto de la Cantata.

- No consta relación de originales y copias. 
15.- LA MOTO, libre, en Si, cuarteto vocal, con partitura, s. d., Arc. 28

La plantilla a la que está dedicada es la de un cuarteto vocal.
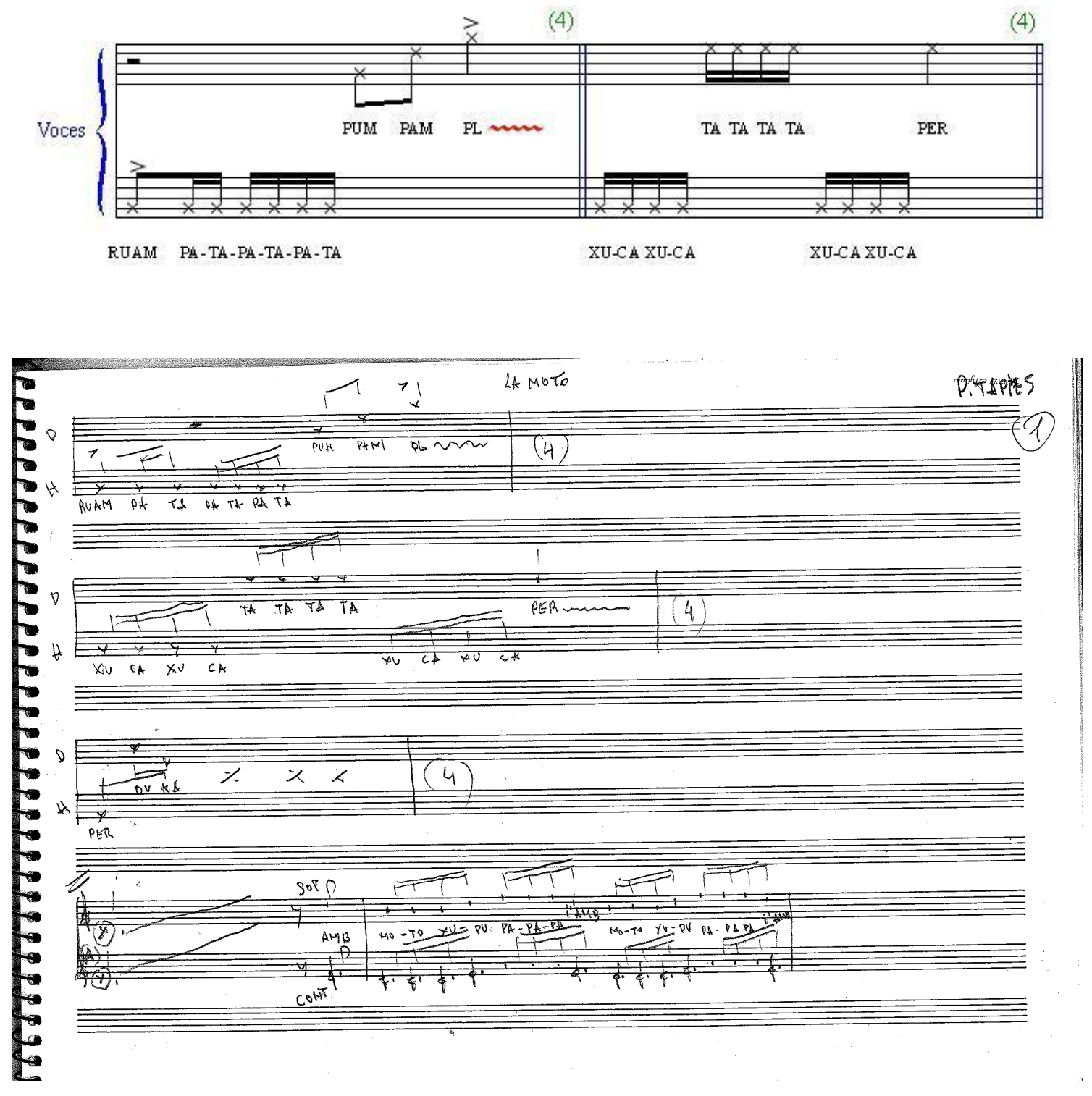

Escrita para Pere Tapies. No ha llegado a estrenarse.

MATERIAL TOTAL:

- Partitura manuscrita y original del autor. Consta de un bloc de escritura musical con 5 páginas escritas y numeradas. Escrito en el reverso del bloc, no contiene la totalidad de la obra. Existen 2 páginas impresas que contienen la totalidad de la obra aunque solamente de una de las voces del coro, sin especificar cuál de ellas 
(la clave hace pensar en el tenor). Esta música no se corresponde con ninguna de las voces manuscritas. Da la sensación de ser una adaptación para una voz solista.

- Partes: No existen partes.

- No consta relación de originales y copias. 
16.- LA SI LA LA, libre, en La, voz solista, con partitura, s. d., Arc. 23

La plantilla a la que está dedicada es la de una voz solista (sin determinar).
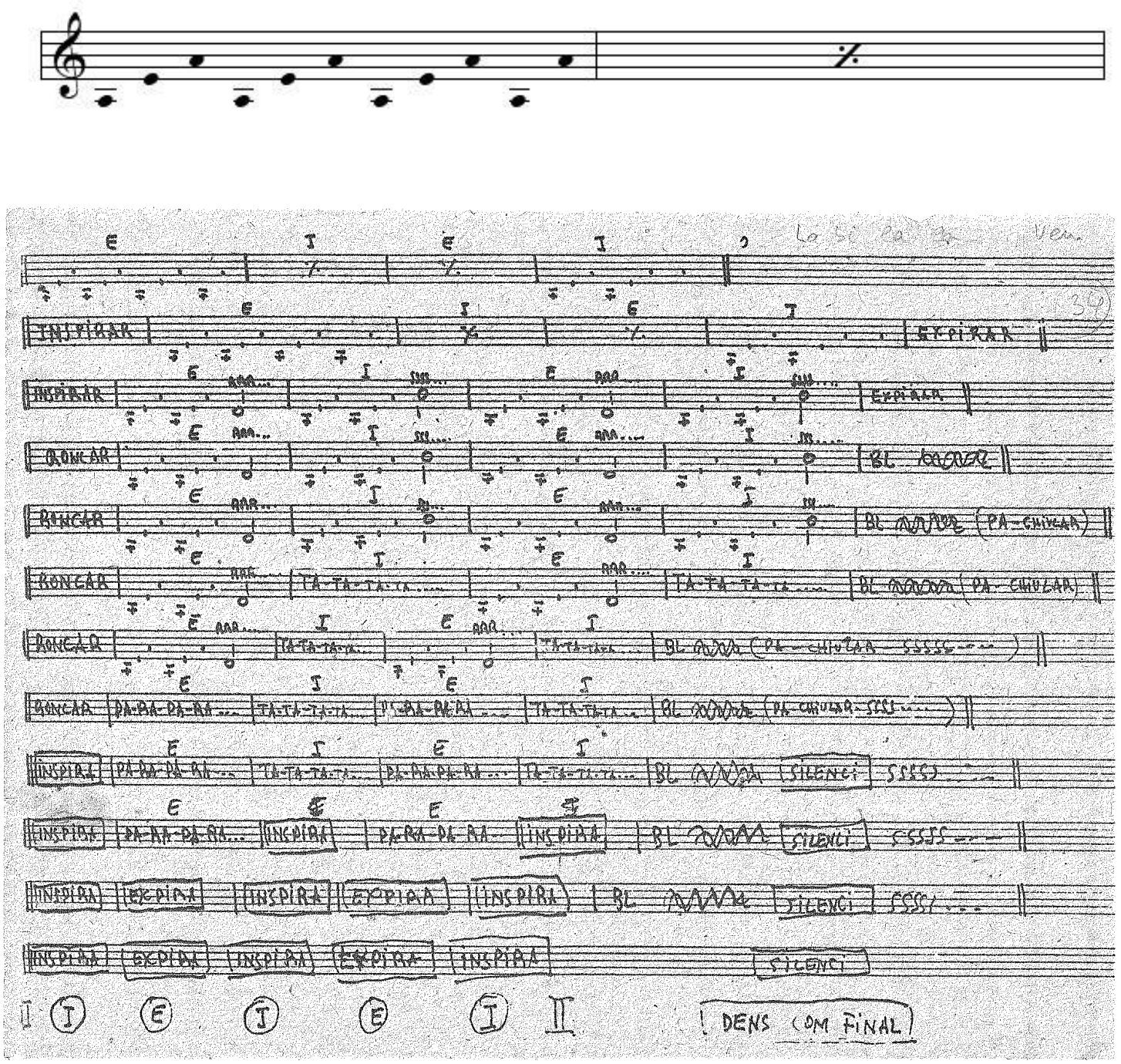

MATERIAL TOTAL:

- Partitura manuscrita y original del autor. Consta de 1 hoja suelta. Consta título como La si la la veu y el número 34 encercado. Existen 2 copias de la misma.

- Partes: No existen partes.

- No consta relación de originales y copias. 
17.- MISA, Misa, politonal, coro y órgano, con partitura, s. d., Arc.18

La plantilla a la que está dedicada es la de 6 voces solistas (Be, Anonim, Nau, Pep, Canut, Mingo), un Órgano, actores y 2 sopranos.
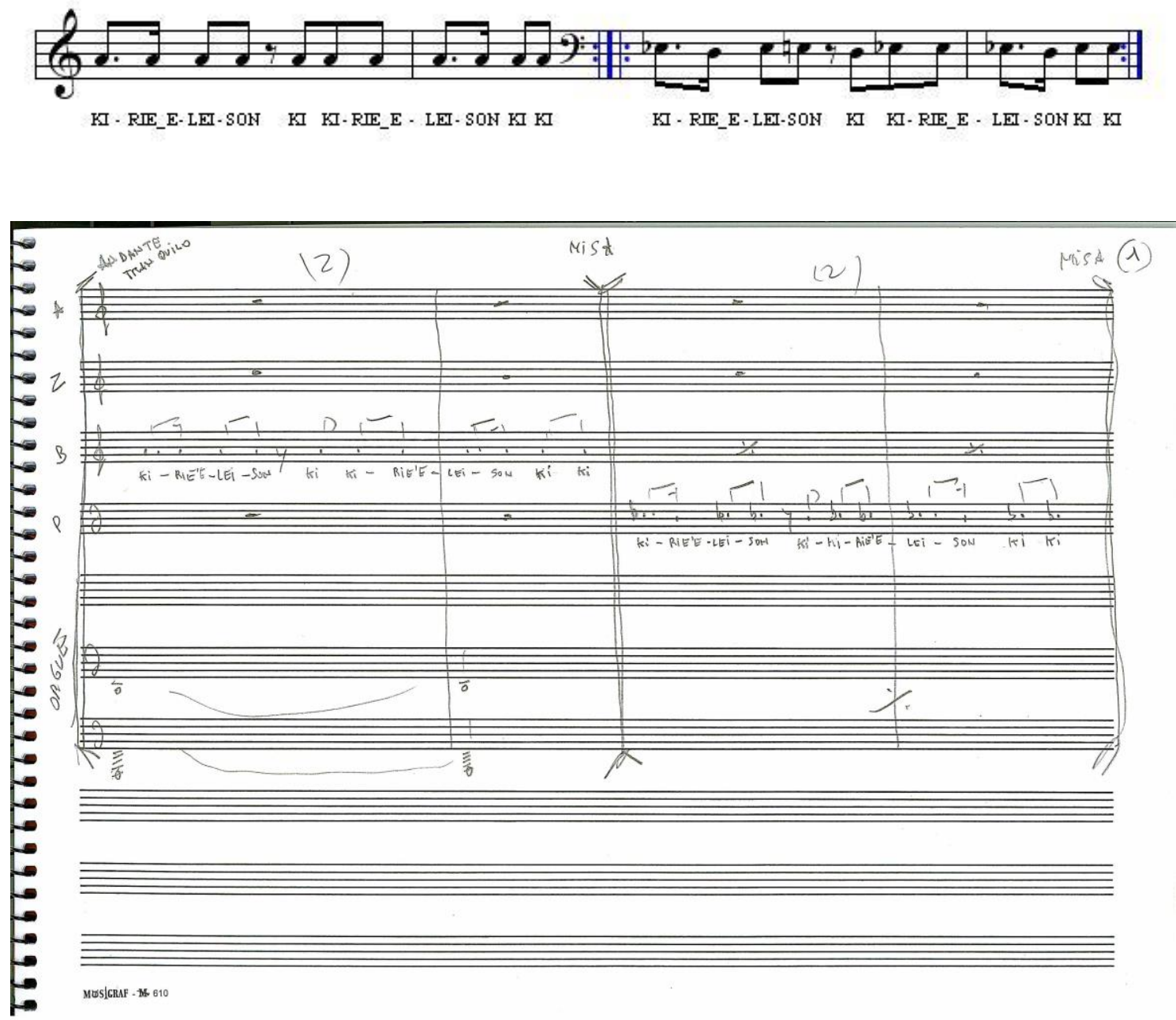

\section{MATERIAL TOTAL:}

- Partitura manuscrita y original del autor. Consta de 1 bloc de escritura musical, con el título (3) Misa. Salve Regina en el exterior con 23 páginas numeradas y manuscritas en 2 grupos: de la 1 a la 11 que corresponde a la Misa, y de la 1 a la 12 que corresponde a la parte Salve Regina.

- Partes: No existen.

- No consta relación de originales y copias. 
18.- MORELLAR MORELLA (desfile), Libre, en La, coro mixto a 2 voces, con partitura, 2011, Arc. 20.

La plantilla a la que está dedicada es un coro mixto a 2 voces.

Ver: MORELLAR MORELLA (Sección Obra Banda)
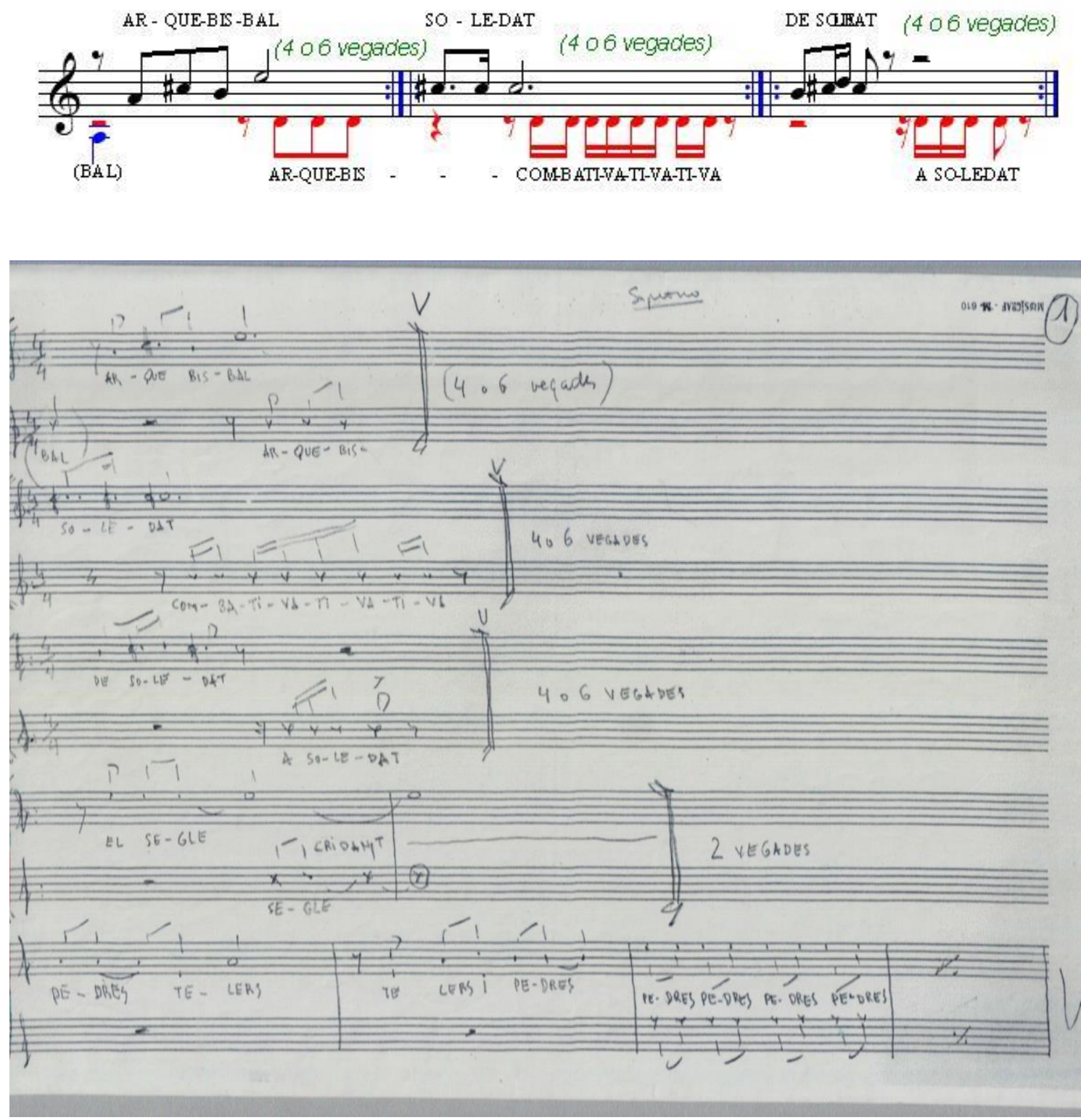

Compuesta para el evento “Com sona l'ESO” de 2011, celebrado en Morella (11 a 14 de mayo) En concreto para el desfile del día 12.

Es una parte de la obra Morellar Morella, que se complementa con otra obra para Solista vocal, Órgano y Banda 


\section{MATERIAL TOTAL:}

- Consta de 3 páginas manuscritas y fotocopiadas del autor.

- Partitura de la obra: PDF realizado por una profesora en soporte informático (Finale para PC) sobre apuntes del autor, el original manuscrito del cual, está en poder de la profesora $\mathrm{M}^{\mathrm{a}}$ Elena Llopis Bueno, del IES "Violant de Casalduch" de Benicàssim.

- Partes: PDF originales sacados de la partitura anterior y que se encuentran en la página web de Com sona l'ESO.

- Existe otro material original y manuscrito del autor, incluido en el reverso del bloc Cabo (1) (n orden 113$)^{*}$, que consta de 3 páginas.

- No consta relación de originales y copias.

\footnotetext{
${ }^{*}$ En $n^{\circ}$ de orden al que se hace referencia corresponde a una tabla EXCEL utilizada en el inventario del material encontrado.
} 


\section{9.- MÚSICA PER AL IV CENTENARI DE L'ARRIBADA DE LA RELÍQUIA}

DE ST. SEBASTIÀ A VINARÒS, Libre, politonal, contratenor y coro de hombres, con partitura, 2010, Arc.20.

La plantilla a la que está dedicada es la de un solista vocal (Contratenor) y un coro de voces masculinas.
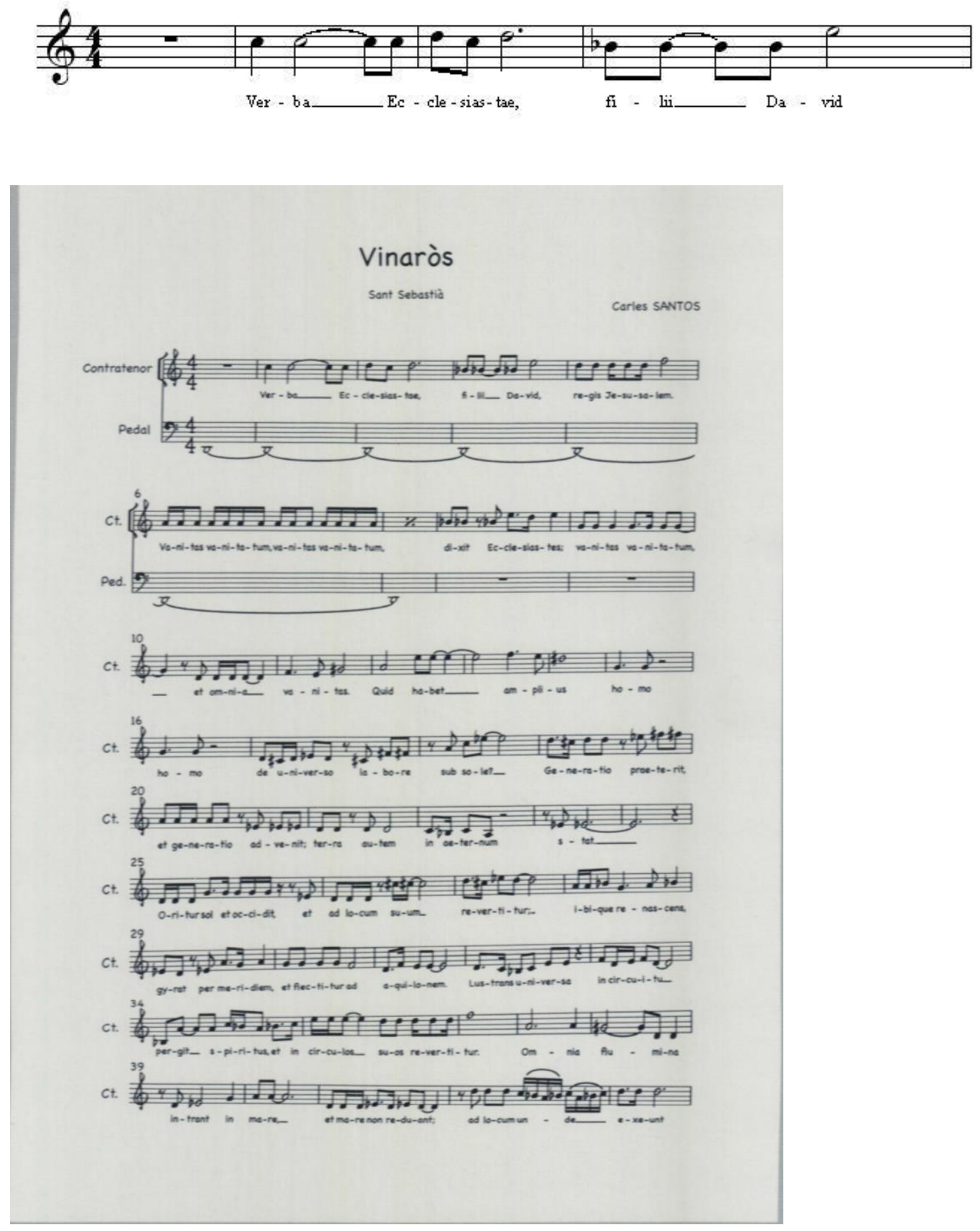
Estrenada el 24/01/2010 en Vinaròs.

\section{MATERIAL TOTAL:}

- Partitura manuscrita y fotocopiada del autor. Consta de 5 páginas.

- Asimismo existe otro material manuscrito y original del autor. Consta de un bloc de escritura musical, tamaño A4 apaisado, de 29 hojas, con el título $I V$ Centenari (Cor) en el exterior y 24 páginas numeradas, manuscritas y originales. Contienen la música del coro.

- También existe material manuscrito y original del autor. Consta de un bloc de escritura musical, tamaño A4 apaisado, de 30 hojas, con el título IV Centenari (C. Tenor) en el exterior y 6 páginas numeradas, manuscritas y originales. Contienen la música del Contratenor solista.

- Partitura impresa. PDF realizado por Xavier Piquer con software Sibelius (Mac)

- Partes: No existen.

- No consta relación de originales y copias. 
20.- PENTAGRAMA O ESPERMA?, Libre, La menor, 2 voces solistas, con partitura, 2003, Arc. 28.

La plantilla a la que está dedicada es la de 2 voces solistas.
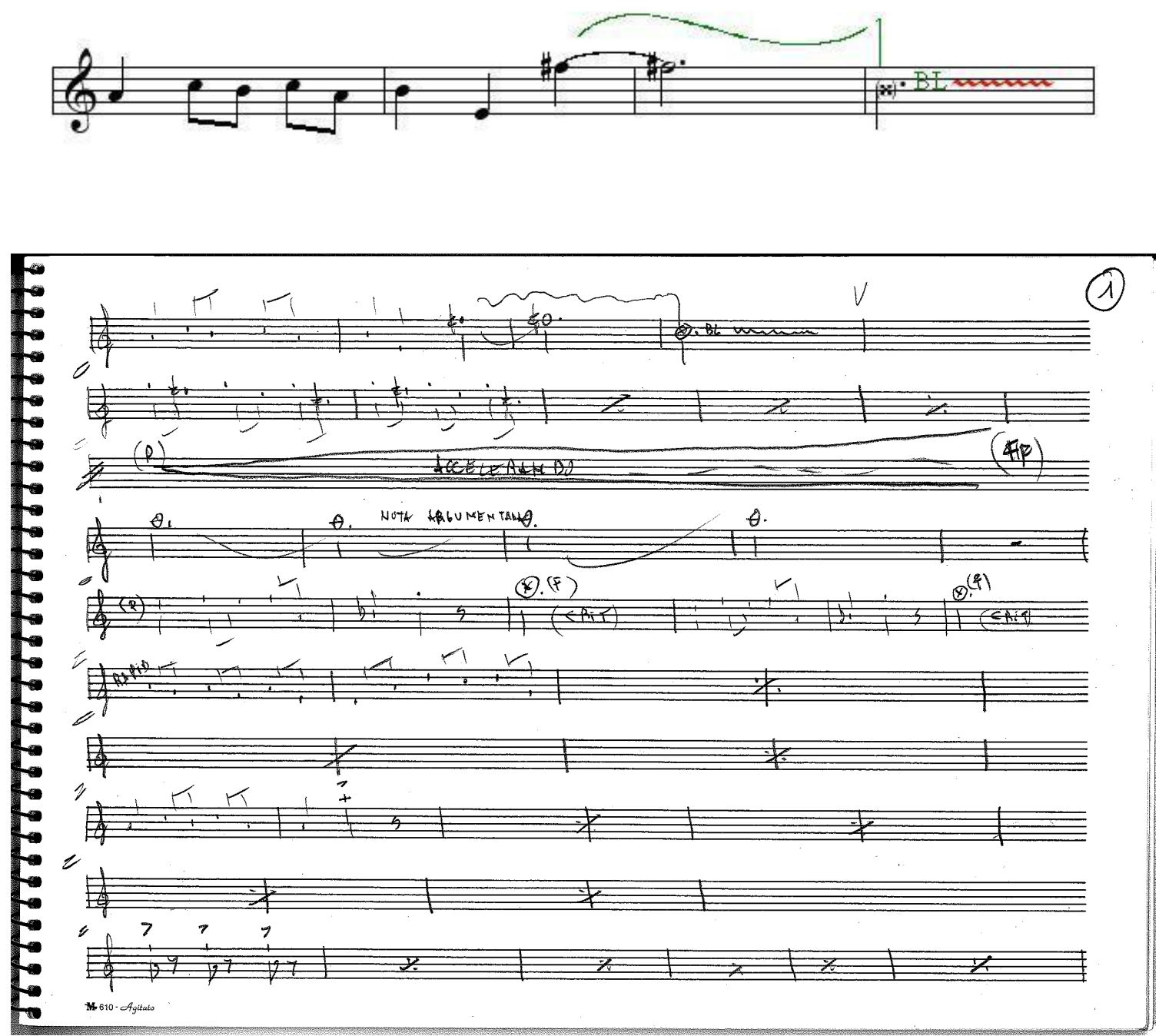

Material utilizado por el compositor para las clases que tuvieron lugar en Toulousse, entre enero y marzo de 2004.

El tema musical utilizado está extraído de la fuga en La menor, BWV 543 de J. S. Bach.

\section{MATERIAL TOTAL:}

- Partitura manuscrita y original del autor. Consta de un bloc de escritura musical con 13 páginas escritas y numeradas, en 3 bloques. 
○ El primer bloque consta de 3 páginas y está escrito para 2 voces solistas.

○ El segundo bloque, de 6 páginas escritas y numeradas, contiene la música de Katralla.

- El tercer bloque, de 4 páginas escritas y numeradas, contiene la música de Lluis-Anaïs.

- Existe otro material compuesto por un bloc de 9 páginas manuscritas y fotocopiadas, que contiene música para 3 voces. Este material pertenece a la obra escénica del autor, Ricardo y Elena, de su $7^{\text {a }}$ Seqüencia.

- Asimismo existen diversos textos del autor ("Es posible formular una primera pregunta?" -de El fervor de la perseverancia-), La meua filla soc jo, Els urinaris públics, etc) y un esquema con las sesiones realizadas en dicho encuentro.

- Partes: No existen partes.

- No consta relación de originales y copias. 
21.- PEPA, Libre, atonal, voz solista, con partitura, 1980, Arc.16.

La plantilla a la que está dedicada es la de una voz.
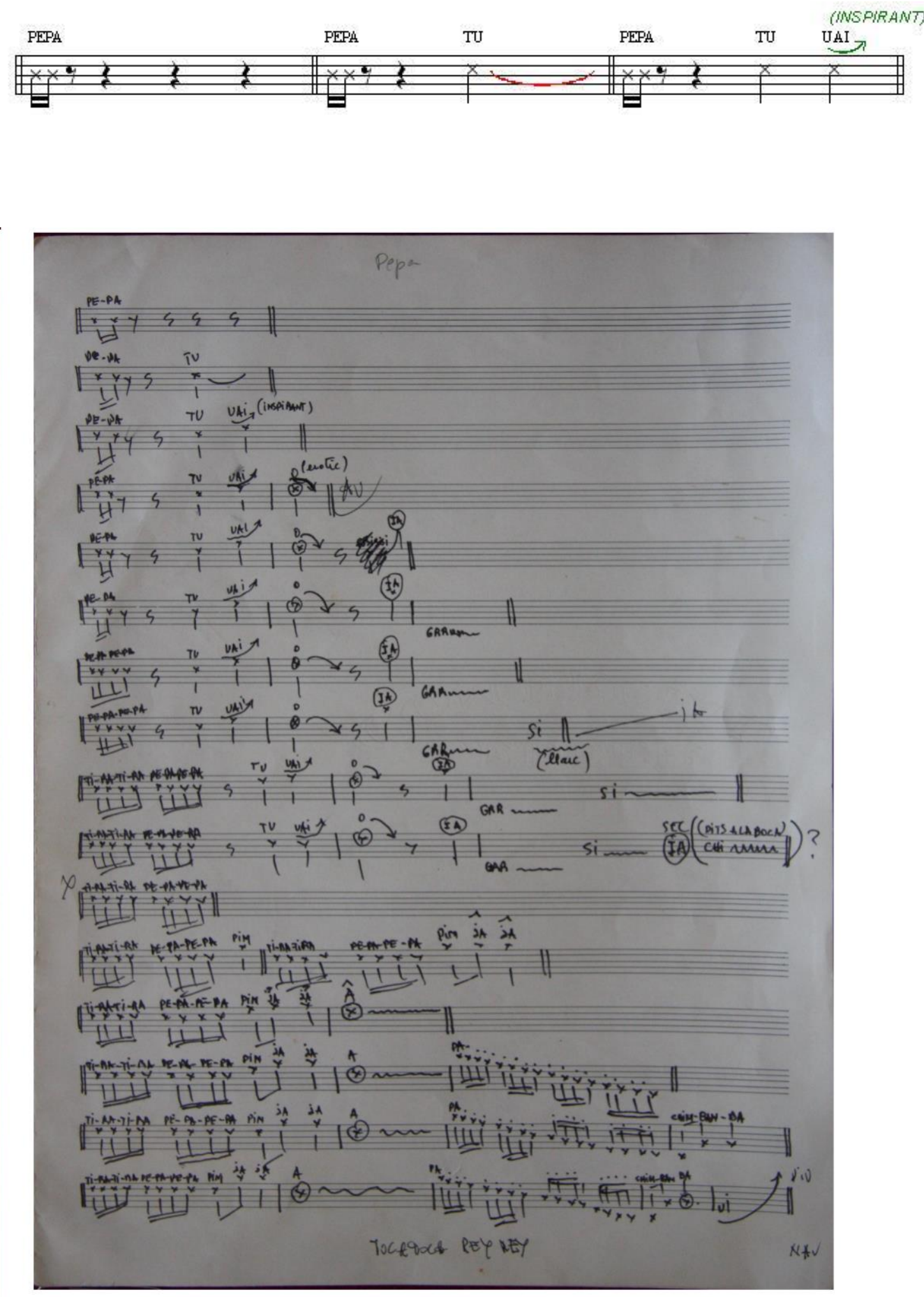
Se corresponde a la pista 3 del disco Voicetracks grabado en 1981 por R.A. Taylor.

La pieza recibe el título de una antigua novia del autor.

\section{MATERIAL TOTAL:}

- Partitura de la obra: Partitura manuscrita y original del autor. Consta de un facsímile con 1 hojas escritas, sin numerar. No existen partes. En la parte interior de este facsímile, consta el original manuscrito de la obra Arrosegant el Piano.

- Existe otra partitura de la misma obra, manuscrita y original del autor, que consta de 1 hoja escrita por ambos lados, con el título Pepa y el número 12 encercado y una anotación al final de la partitura que reza "Barcelona-New York, 22 febrer 1980. avió TWA".

- Partes: No existen partes.

- No consta relación de originales y copias. 
22.- $\boldsymbol{\pi}$ (PI), Libre, politonal, voces solistas y coro, con partitura, 1991, Arc. 19

La plantilla a la que está dedicada es la de voces solistas (sin determinar su tipo) y Coro.
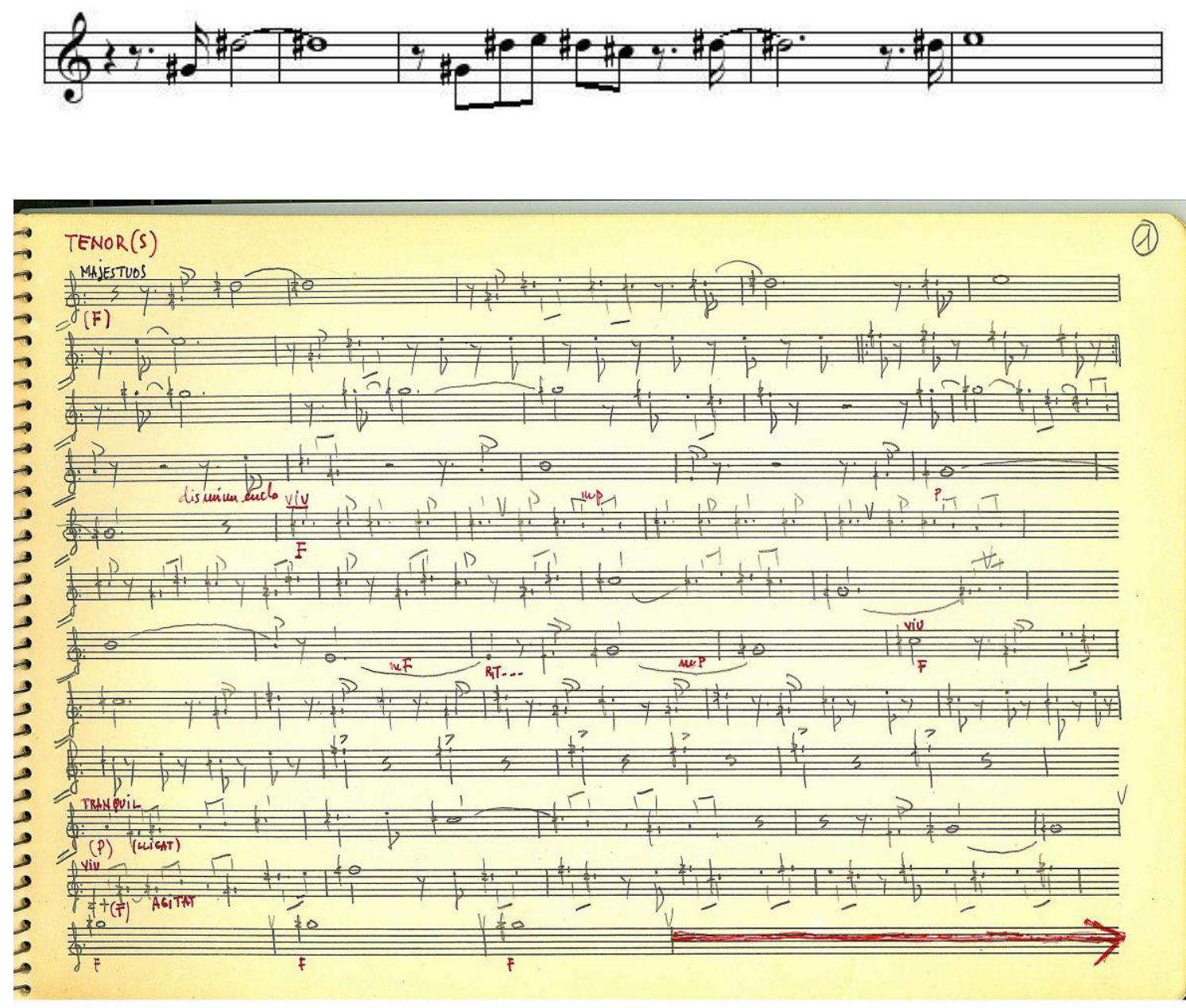

Estrenada el 28 de noviembre de 1991. Cia. Vianants Dansa. Música para un espectáculo de danza.

\section{MATERIAL TOTAL:}

- Partitura manuscrita y original del autor. Consta de 3 blocs de escritura musical, con los siguientes títulos:

- $P i$ en el exterior con 16 páginas manuscritas sin numerar. Contiene anotaciones de cómo debe interpretarse la obra. 
$\circ \pi(A)$ en el exterior (inicio de la obra) con 23 páginas numeradas y manuscritas;

○ $\pi(B)$ en el exterior con 13 páginas numeradas y manuscritas (de la 24 a la 36); Las páginas 17 y 29 están en blanco y consta la indicación "Secció reservada".

- Partes: No existen.

- No consta relación de originales y copias. 
23.- PIEDRA DE OXIDIANA, Libre, en Re, voz solista, con partitura, 1978, Arc. 23

La plantilla a la que está dedicada es la de 1 voz solista (sin determinar su tipo).
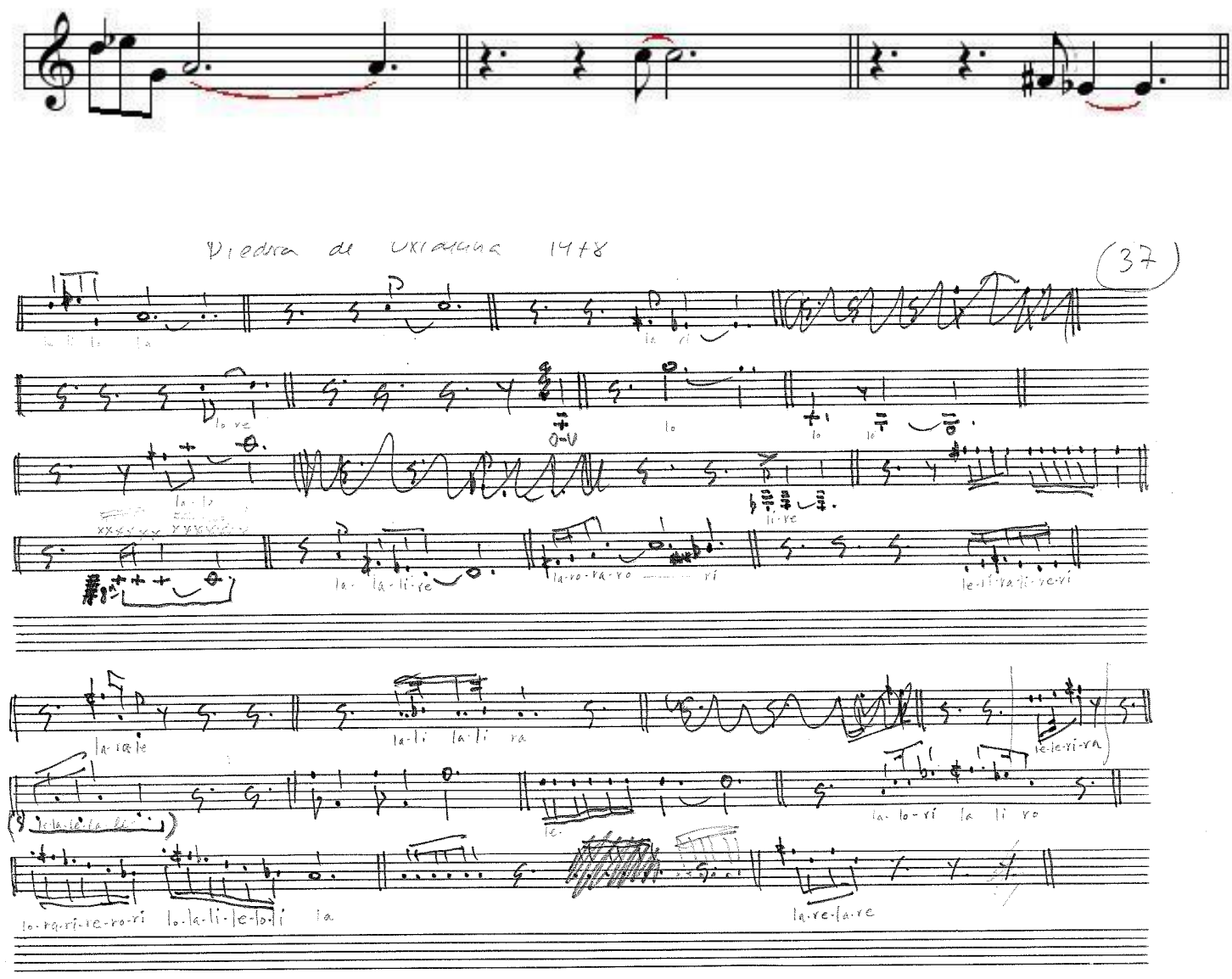

La partitura está numerada como 37 por el autor.

\section{MATERIAL TOTAL:}

- Partitura manuscrita y original del autor. Consta de un libreto de escritura musical con 1 página escrita con el título Piedra de Oxidiana 1978 y el número 37 encercado.

- Partes: No existen.

- No consta relación de originales y copias. 
24.- QUE NO DONARIA JO PER UNA MICA DE SOL, Libre, en Re, 2 voces solistas, con partitura, 1982, Arc. 23

La plantilla a la que está dedicada es la de 2 voces solistas (sin determinar su tipo).
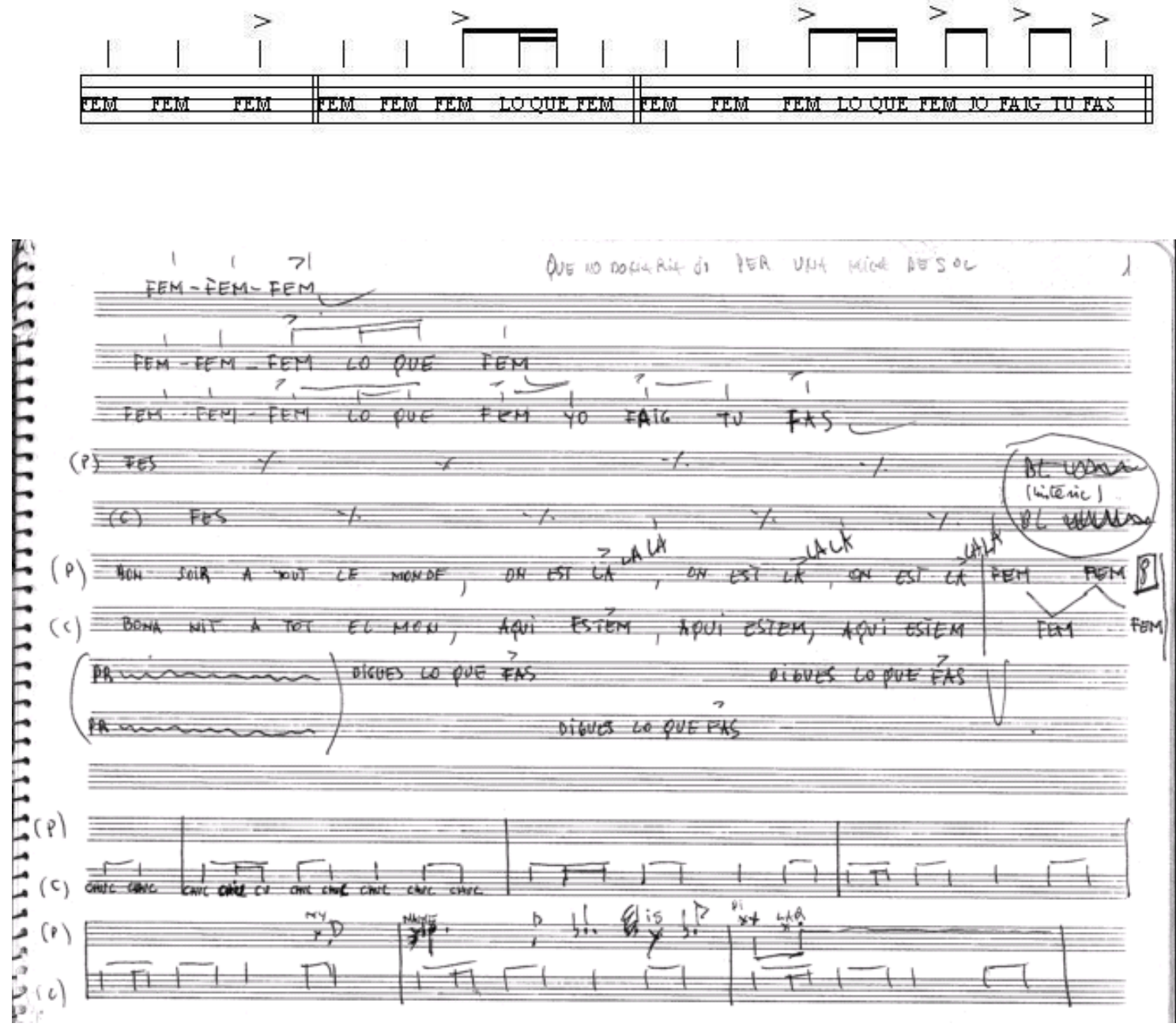

Pueden ser apuntes de la obra. El texto, mayoritariamente, está en francés.

\section{MATERIAL TOTAL:}

- Partitura manuscrita y original del autor. Incluida en un bloc de escritura musical, con el título "Veu" en el exterior, numerado con el número 3 y 5 páginas manuscritas y numeradas del 1 al 3 (música también en el reverso) y originales. En las páginas 16 y 30 existen otros apuntes de la obra. El bloc incluye apuntes de otras obras (Beethoven...si tanco la tapa, que passa?).

- Partes: No existen partes.

- No consta relación de originales y copias. 
25.- SAUNA DE LA BOQUETA, libre, en Sol menor, 3 voces femeninas, con partitura, 1985, Archivador 22.

La plantilla a la que está dedicada es la de 3 voces femeninas.
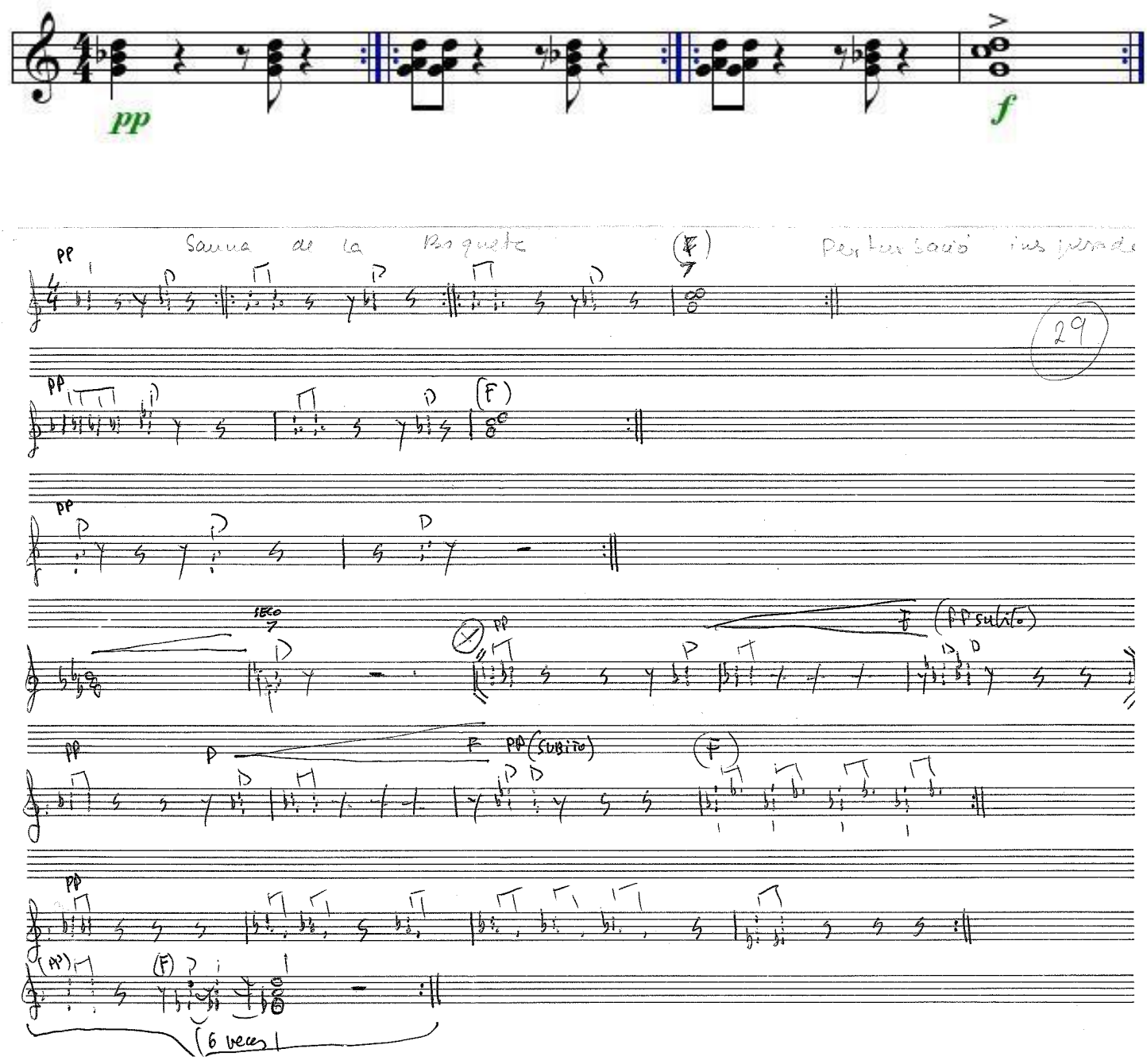

Se corresponde a la pista 1 del disco Perturbació inesperada grabado en 1986 por Linterna Música.

La partitura está numerada como 29 por el autor. 


\section{MATERIAL TOTAL:}

- Partitura manuscrita y original del autor. Consta de un libreto de escritura musical con 1 página escrita con el título Sauna de la boqueta, la anotación Perturbació inesperada y el número 29 encercado.

- Partes: No existen partes.

- No consta relación de originales y copias. 
26.- SOPRANO I TENORA, libre, politonal, soprano y tenora, con partitura, 2009, Archivador 12.

La plantilla a la que está dedicada es la de 1 soprano y tenora.

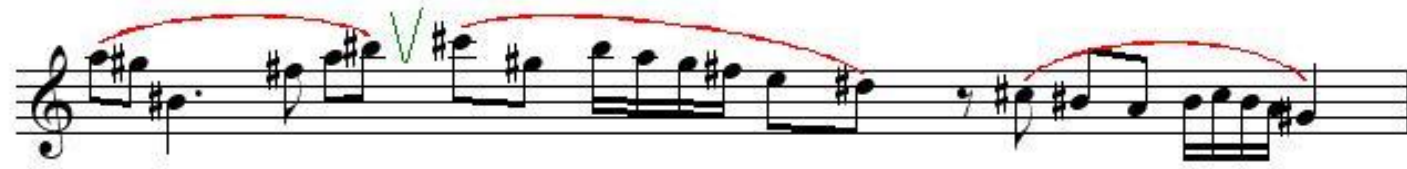

\section{Soprano i Tenora}

Mediterrània '09 - Manresa

Carles SANTOS

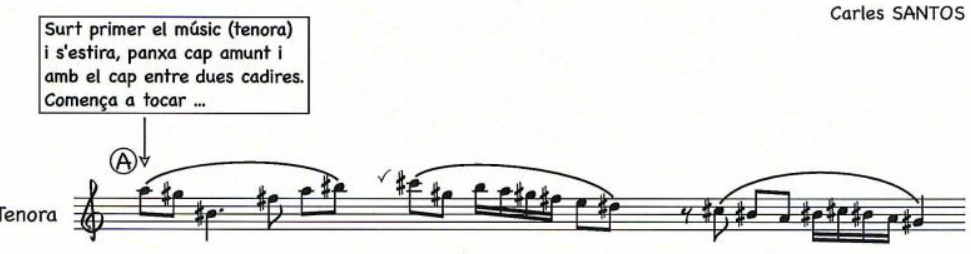

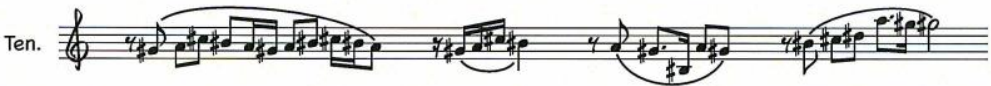
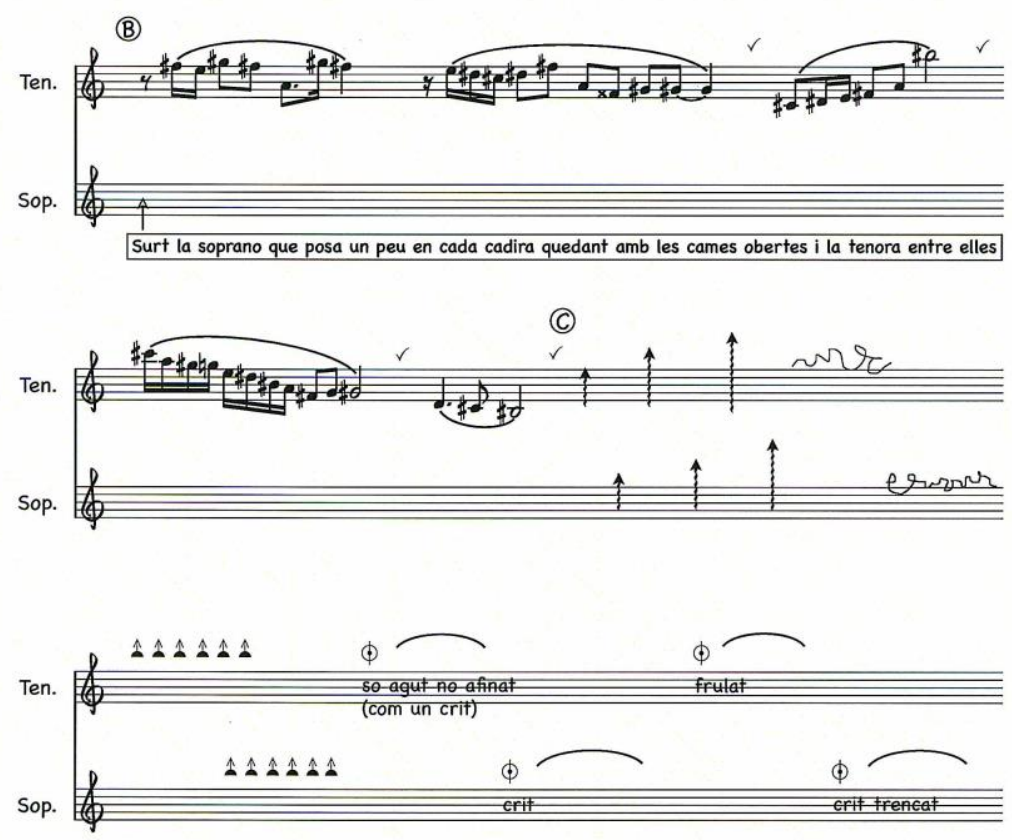
Obra escrita para el evento "Mediterranea '09" celebrado en Manresa en 2009. Texto de Pere Jaume. Para este evento, el autor escribió otras obras: Tenora i Piano, 6 Tenoras $i$ Piano y la cantata Els Monts.

\section{MATERIAL TOTAL:}

- Partitura impresa de software, de 4 páginas, sin encuadernar. PDF realizado por Xavier Piquer con software Sibelius (Mac). No existen manuscritos.

- Partes: Existen partes de software y originales.

- No consta relación de originales y copias. 
27.- TOCATICOTOCATÁ, Libre, recitada, voz solista, con partitura, 1978, Arc. 15

La plantilla a la que está dedicada es la de una voz solista y percusión corporal.
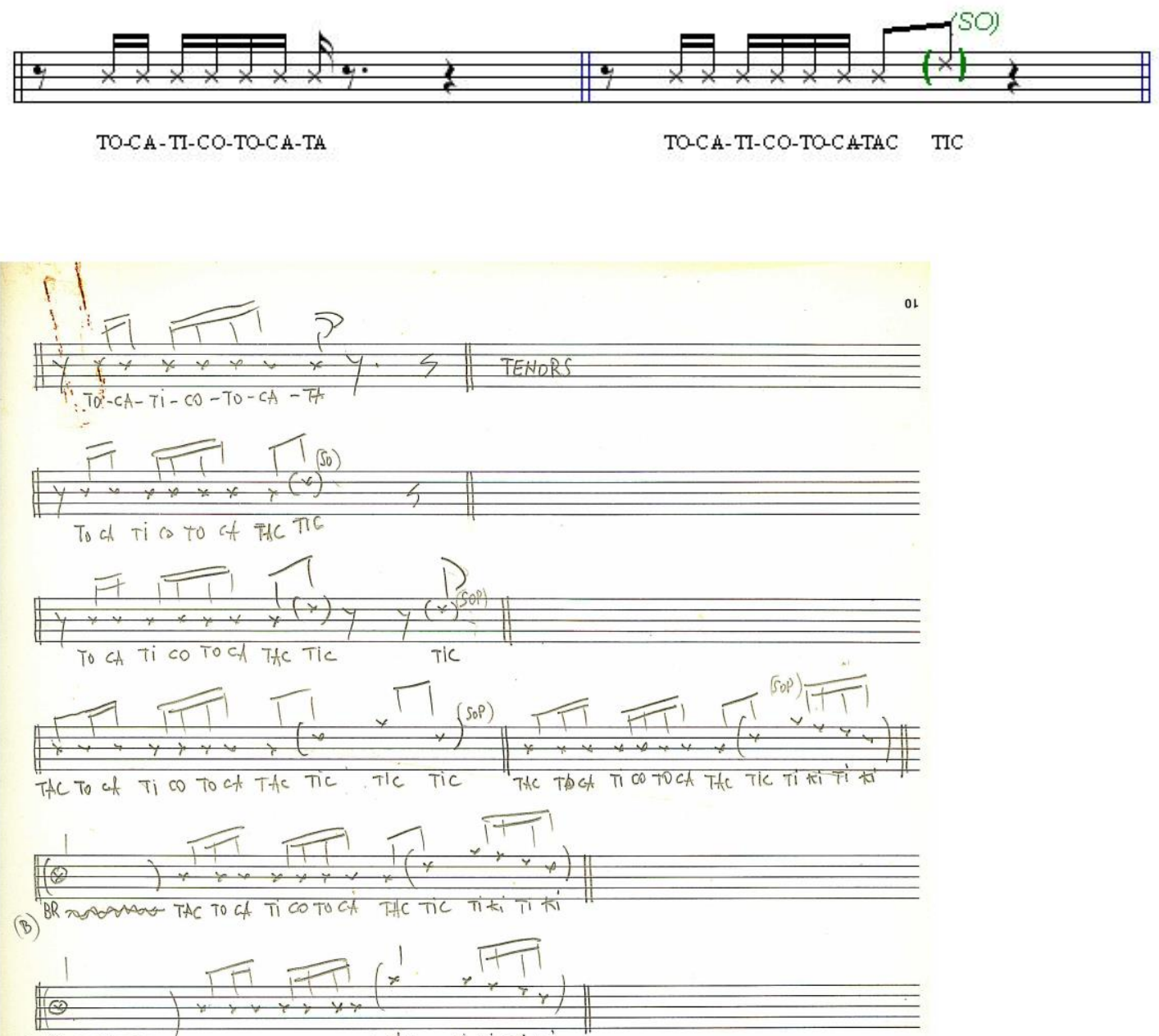

(B) BR $2000000 x$ PiM Tiki Tiki
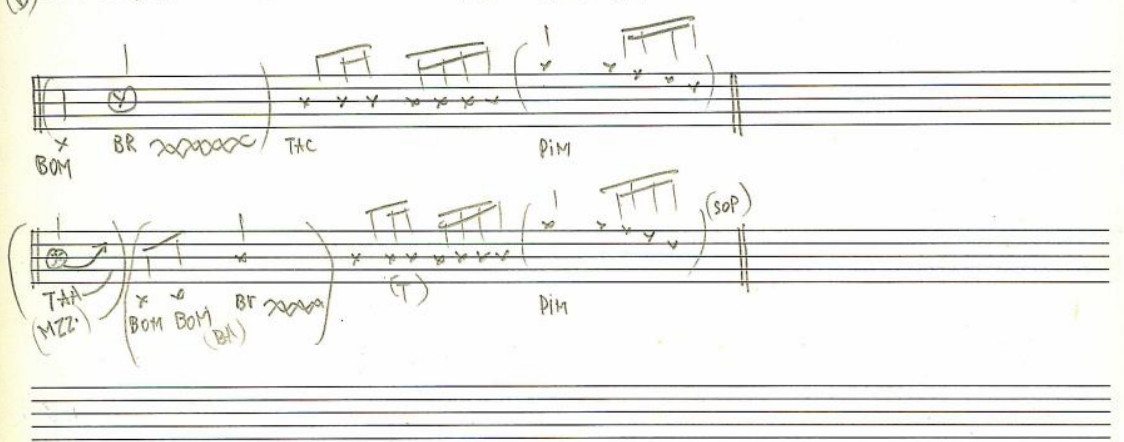

(so)

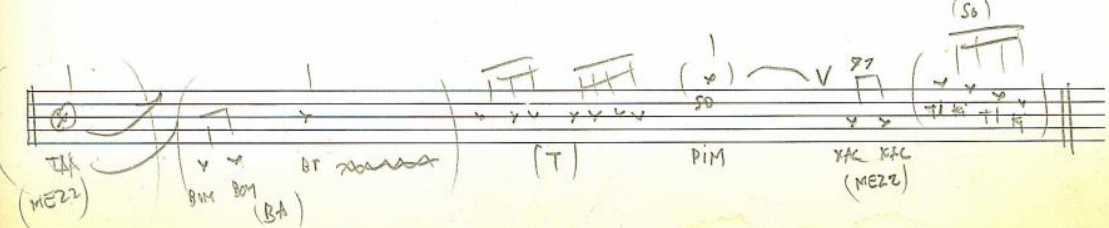


Se corresponde a la pista 1 del disco Voicetracks grabado en 1981 por R.A. Taylor.

Existe video en internet, de una versión bastante antigua.

\section{MATERIAL TOTAL:}

- Partitura de la obra: Manuscrito original del autor en dos facsímiles con un total de 2 páginas numeradas.

- Existe otra versión semejante, manuscrita y original del autor, dividida en 4 facsímiles numerados, con el número 13 encercado, en la tapa. En la primera página consta la inscripción "Original".

- Existe otra versión para coro mixto que consta de partitura manuscrita y original del autor de 8 hojas sueltas y numeradas, escritas en la primera página.

- Existe asimismo otra versión para voz solista y coro mixto que consta de partitura manuscrita y original del autor, en un bloc de escritura musical con el título "Ull de cona (2)" en el exterior y tachado, y 4 páginas escritas. Se trata de una versión "para realizarla con el Coro de Cámara del Palau de la Música de Barcelona. La primera página era interpretada por mí y a partir de la segunda página, se añadían el resto de las voces" *.

- Partes: No existen partes.

- No consta relación de originales y copias.

\footnotetext{
${ }^{*}$ Testimonio oral del autor.
} 
28.- TOT QUEDA EN FAMILIA, Libre, en La, tríos vocales, con partitura, s. d., Arc. 26.

La plantilla a la que está dedicada es la de dos tríos vocales:

- 3 sopranos y

- 2 sopranos y 1 tenor.

Ver: TOT QUEDA EN FAMILIA (sección Obra vocal).
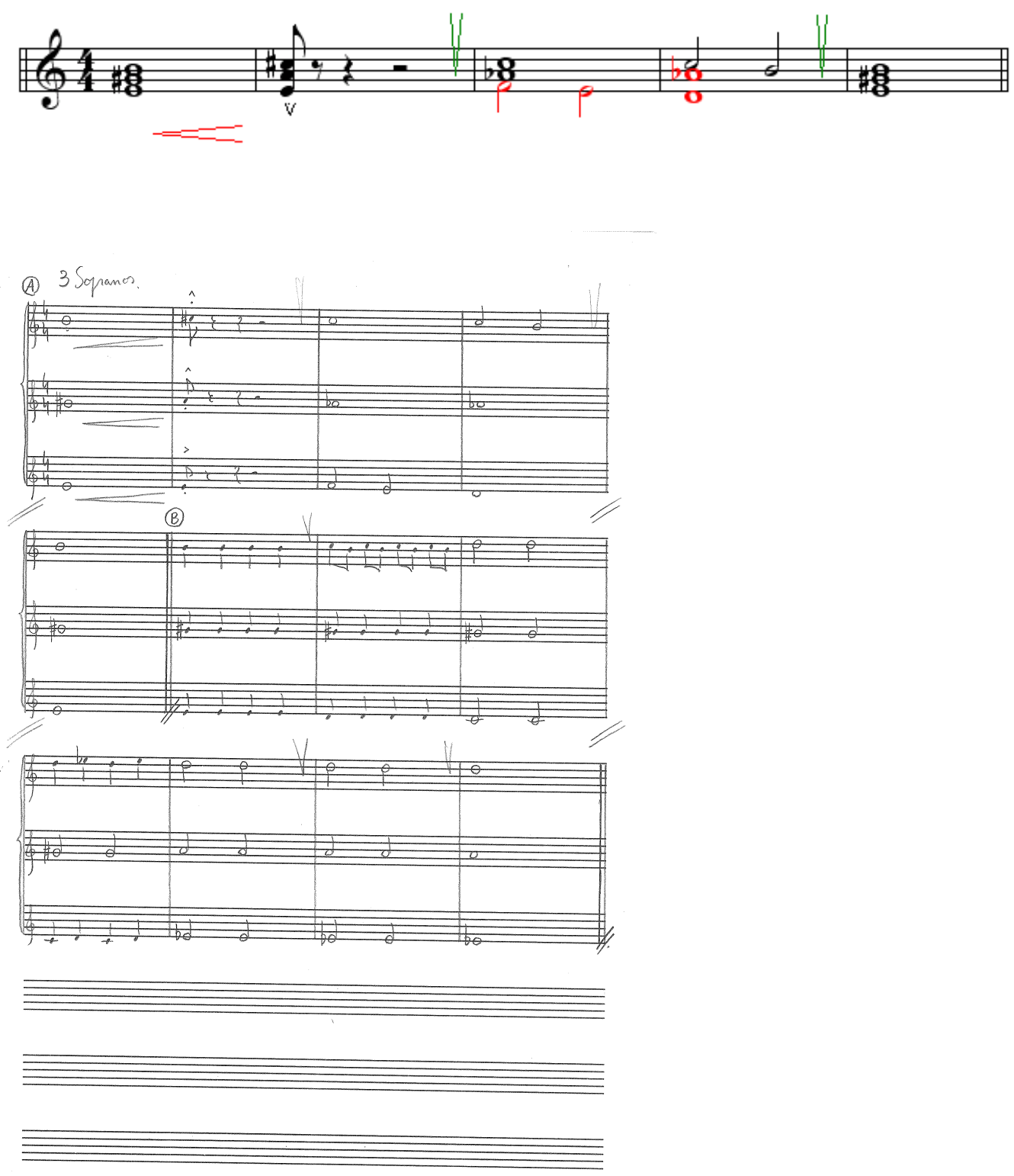

Puede formar parte de la musicalización de algunas imágenes o film. 

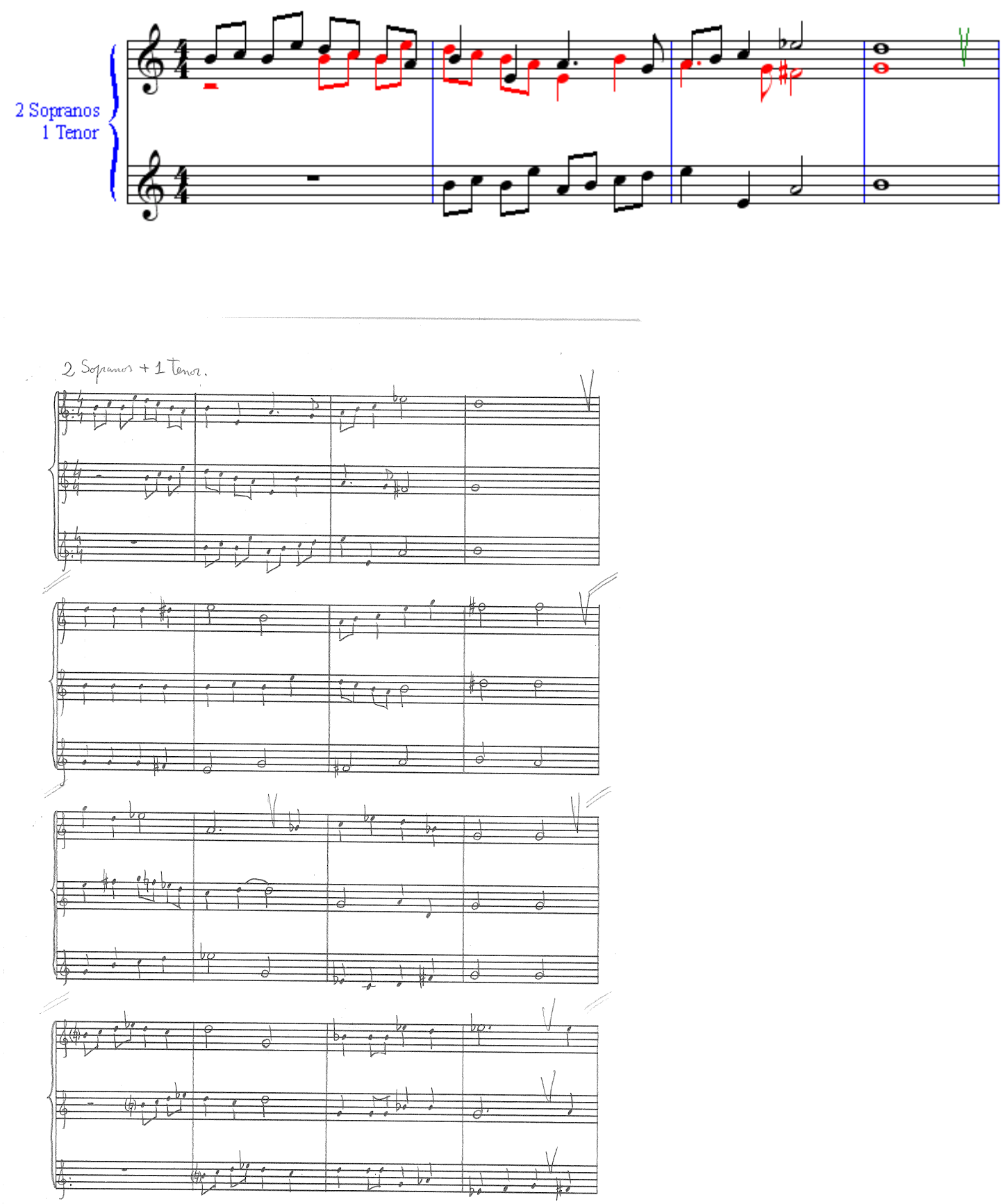

Puede formar parte de la musicalización de algunas imágenes o film.

\section{MATERIAL TOTAL:}

- Partitura manuscrita y original del autor que consta de un libreto de escritura musical con 2 páginas escritas con el título "3 Sopranos" en la $1^{a}$ página. 
- Asimismo existe otra partitura distinta, manuscrita y original del autor que consta de un libreto de escritura musical con 2 páginas escritas con el título "2 Sopranos +1 Tenor" en la $1^{\mathrm{a}}$ página.

- También existe otra partitura manuscrita y original del autor. Consta de un libreto de escritura musical con 2 páginas escritas con el título "Quartet de Corda (Capìtol 'gelosies')" en la $1^{\text {a }}$ página. Existe, asimismo, otra partitura de la misma obra, escrita en 2 páginas sueltas, con el mismo título.

- Partes: No existen partes.

- No consta relación de originales y copias. 
29.- UN GAT ES UN GAT, Libre, recitada, voz solista, con partitura, 1975 aproximadamente, Arc. 19

La plantilla a la que está dedicada es la de una voz solista.
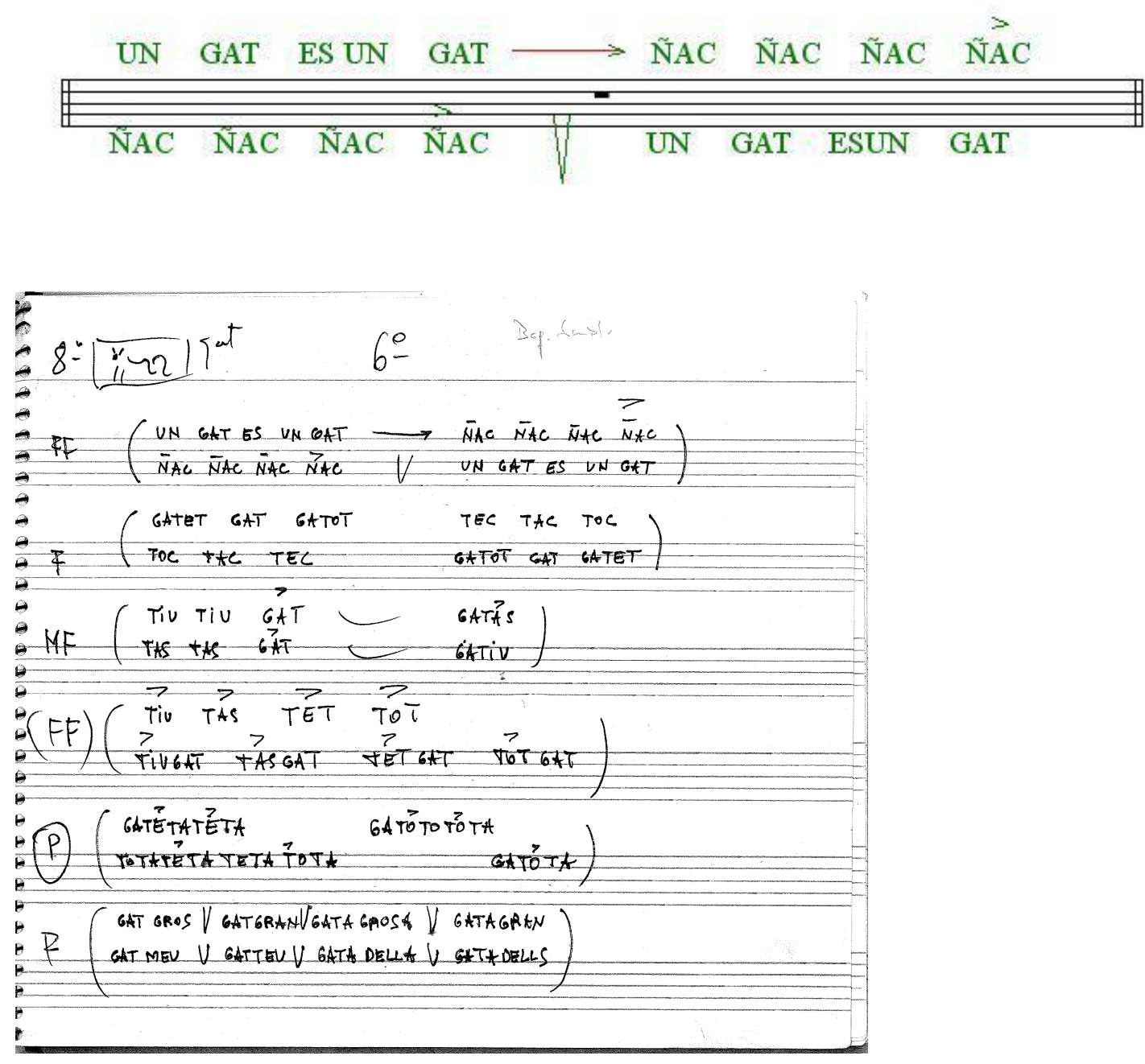

Pieza recitada, que, al igual que Calixa o Dorema domare, entre otras, son de uso habitual en los espectáculos de Santos.

\section{MATERIAL TOTAL:}

- Material manuscrito y original del autor. Consta de 1 bloc de escritura musical, sin título en el exterior, de color marrón que contiene la estructura de un espectáculo ofrecido por el autor en New York. Entre las obras desarrolladas en su interior se encuentra Un gat es un gat, así como Calixa.

- Partes: No existen partes.

- No consta relación de originales y copias. 
30.- VI SONOR, libre, politonal, coro, con partitura, 2011, Arc. 23

La plantilla a la que está dedicada es la de un Coro.

Ver: CONILL AMB CARAGOLS
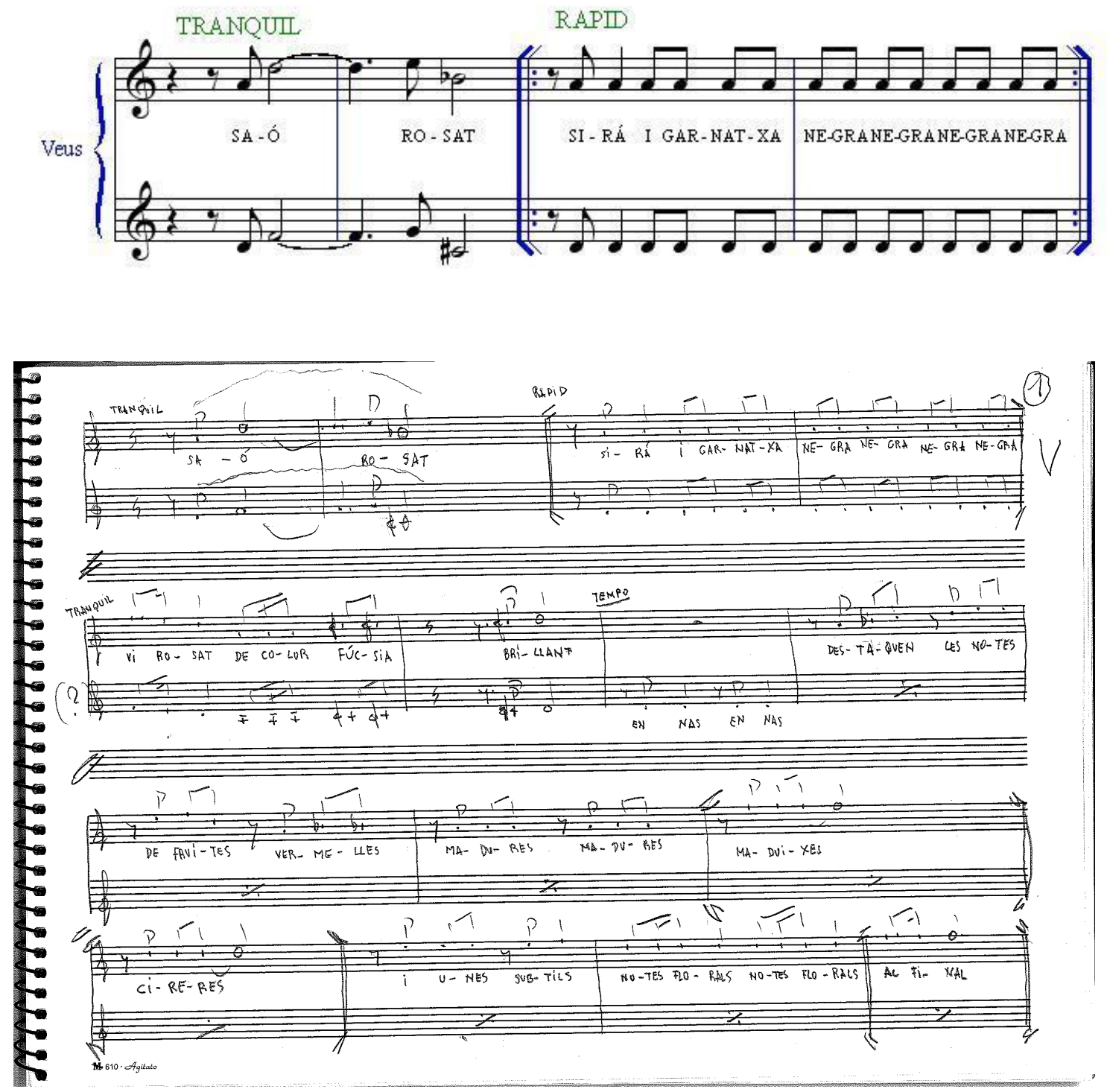

Compuesta para la Acción musical realizada en Pobla de Gervoles (cerca de Agramunt) el 2 de julio de 2011, como homenaje a los vinos de la bodega Celler Mas Blanch i Jové, que creó la denominada La Vinya dels Artistes. La acción transcurría en los viñedos. Mediante un paseo, los invitados degustaban comida típica de los periodos clásico, romántico, impresionismo, siglo XX y la actualidad, al mismo tiempo que un pianista interpretaba música propia del periodo al que se hace referencia. Los camareros 
vestían de acuerdo con la época. En total participan 5 pianistas (Oscar Campos, Inés Borrás, Albert Giménez, Miquel Villalva y Carles Santos) con 5 pianos colocados en puntos estratégicos del recorrido, un coro (que interpreta la música al tiempo que los invitados recorren el espacio que separa una época de la siguiente) y una violinista, Katy Reus, encima de una grúa. Encima de los pianos se depositaros productos típicos de cada periodo. La acción comenzó con la interpretación de la obra a cargo de El Cor Eurídice de les Borges Blanques dirigido por la compositora Dolors Ricart. El mismo coro fue el encargado de interpretar las 3 obras corales de Santos ("Saó Blanc", "Saó Expressiu" i "Saó Rosat") en los paseos de transición de un lugar a otro de las viñas de la bodega.

\section{MATERIAL TOTAL:}

- Partitura manuscrita y original del autor. Consta de un bloc de escritura musical con el título $V i$ sonor en el exterior y 19 páginas manuscritas y originales, divididas en 4 grupos numerados, que representan a las 4 obras:

○ “Saó Rosat”, con 3 páginas numeradas,

○ “Saó Expressiu”, con 2 páginas numeradas,

- Conill amb caragols, con 9 páginas numeradas, y

○ “Saó Blanc”, con 5 páginas numeradas,

- Partes: No existen partes impresas.

- No consta relación de originales y copias. 
31.- VIDEO BANYERA, Libre, en Sol, voz solista, con partitura, 1980 aproximadamente, Arc. 23

La plantilla a la que está dedicada es la de una voz solista.
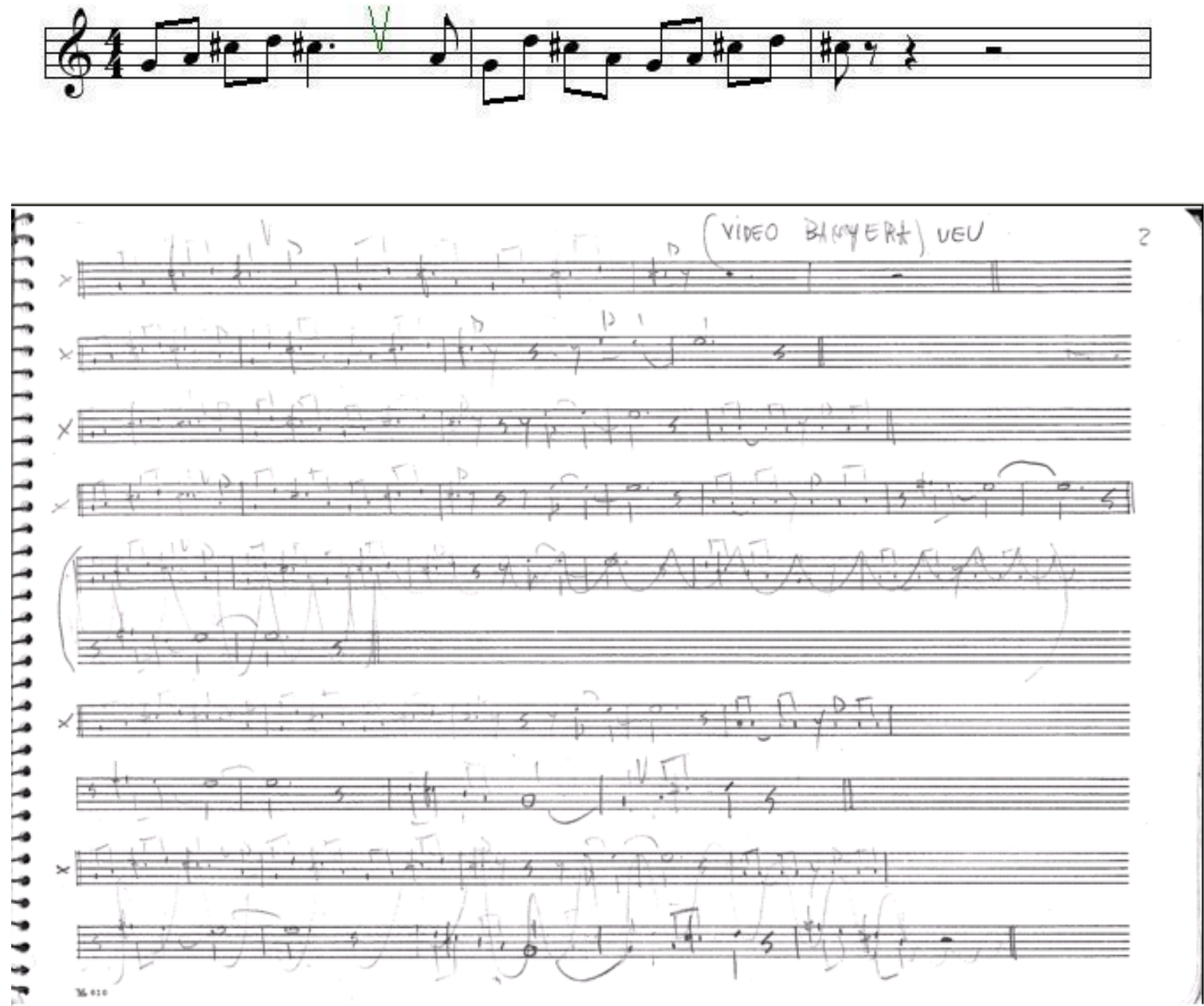

Puede formar parte de la musicalización de algunas imágenes o film. "Imágenes rodadas en Madrid, para un documental de TVE, en las cuales se paseó, por las calles de Madrid, una plataforma, encima de la cual se encontraba una bañera llena de agua con una modelo dentro. El autor, también encima de la plataforma, iba cantando, al tiempo que sumergía a la actriz en la bañera" (Carles Santos Ventura). Se desconoce si alguien tocaba el piano al mismo tiempo.

Existe video en internet (fragmento) 


\section{MATERIAL TOTAL:}

- Partitura manuscrita y original del autor. Incluida en un bloc de escritura musical, con el título "Veu" en el exterior, numerado con el número 5 y 6 páginas manuscritas y originales, numeradas.

- Partes: No existen partes.

- No consta relación de originales y copias. 
3.2.3. VOZ Y PIANO 
1.- 58-57 (PEÇA), Libre, atonal y recitado, voz solista (sin determinar) y piano, con partitura, septiembre 1981, Arc. 22.

La plantilla a la que está dedicada es la de una voz solista (sin determinar) y piano.
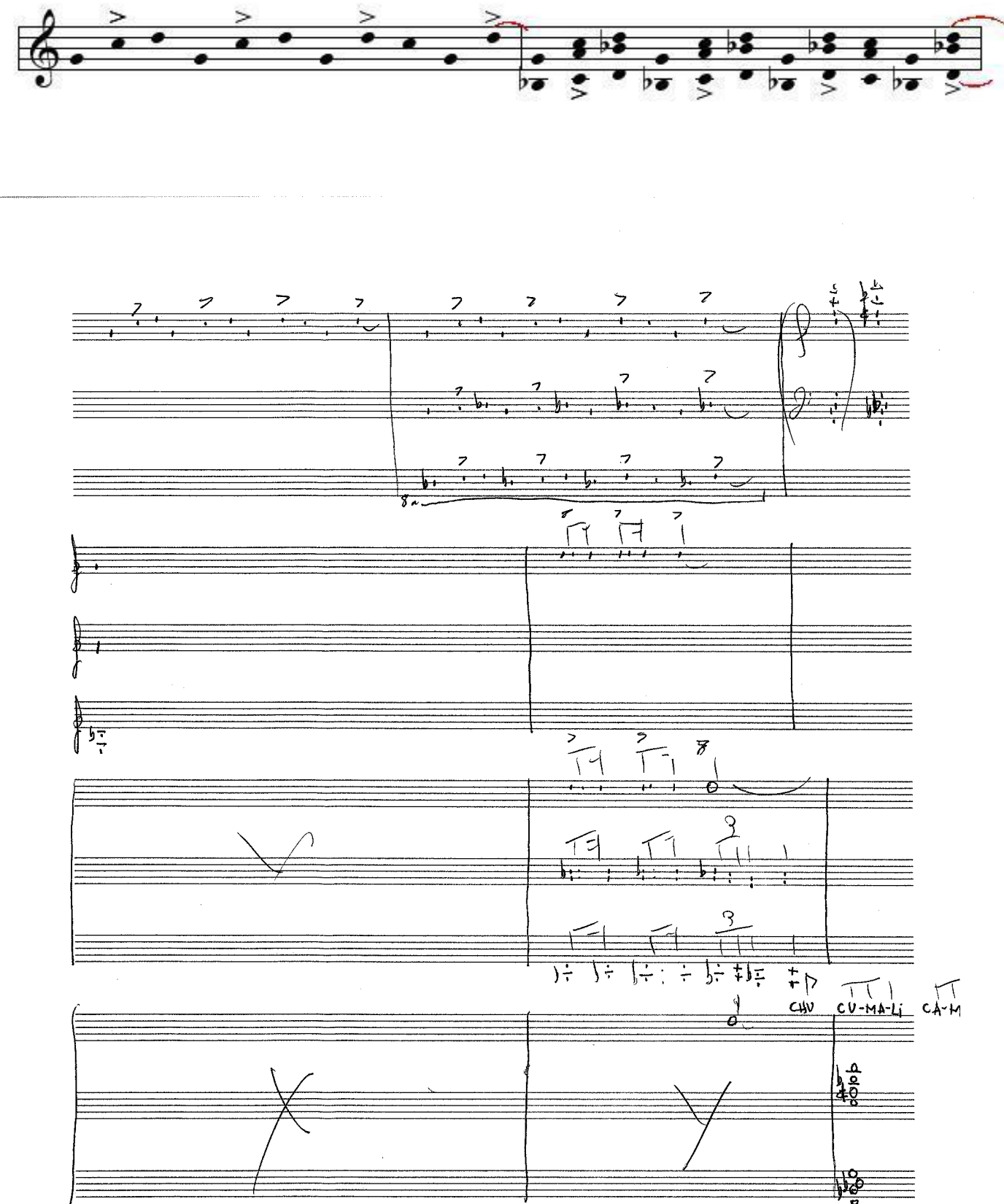


\section{MATERIAL TOTAL:}

- Partitura manuscrita y original del autor. Consta de seis libretos de escritura musical, numerados del 1 al 6, con 12 páginas escritas, sin título y los números 58 y 57 encercados, por este orden, en la tapa. Al final de la pieza consta la inscripción "NY SEP 1981".

- Partes: No existen partes.

- No consta relación de originales y copias. 
2.- ANEM, ANEM, ANEM, ANEM A VOLAR, Libre, politonal, 2 voces mixtas y piano, con partitura, 1982, Arc. 16.

La plantilla a la que está dedicada es la de un Piano y 2 voces mixtas (sin identificar).
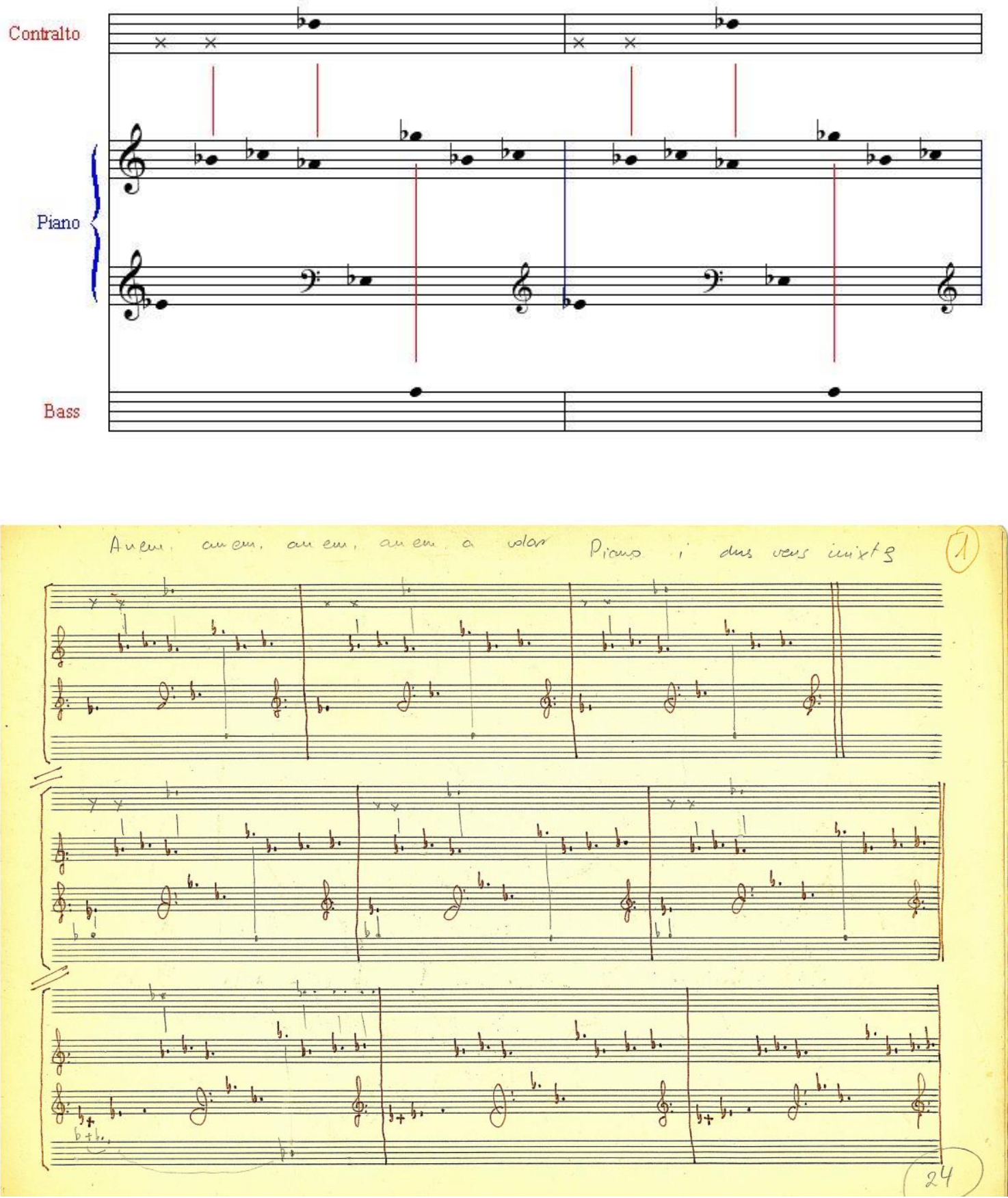
"El reverso, escrito en lápiz, no es original mía". Al parecer, la interpretación debe hacerse abriendo los 2 facsímiles e interpretando de izquierda a derecha, dada la evolución de la música.

"Se ha interpretado y existe un video de dicha interpretación".. Música escrita para la acción musical desarrollada por Las Ramblas de Barcelona en 1982, empujando el autor un piano por la calle al tiempo que una cantante, se mantenía encima del instrumento. Al llegar al punto de destino, se interpretó la música escrita.

El vídeo está incluido en el listado "Vídeos Archivo Artea", que están disponibles para su consulta y visualización en Matadero Madrid. Centro de Creación Contemporánea (Paseo de la chopera, 14. 28045 Madrid. www.mataderomadrid.com)

\section{MATERIAL TOTAL:}

- Partitura de la obra: Manuscrito original del autor. Consta de 4 hojas escritas en dos facsímiles numerados. Numerada como 24 por el autor.

- Partes: No existen partes.

- No consta relación de originales y copias.

* Testimonio oral del autor.

* Idem.. 


\section{3.- AQUESTA ES LA HISTÒRIA QUE MAI PODRÉ OBLIDAR; UNA TRISTA HISTÒRIA D'AMOR, D'UN AMOR QUE MAI, MAI, MAI PODRÀ ACABAR,}

Libre, politonal, voz solista (sin determinar) y piano, con partitura, 1984, Arc. 34.

La plantilla a la que está dedicada es la de una voz solista (sin determinar) y piano.
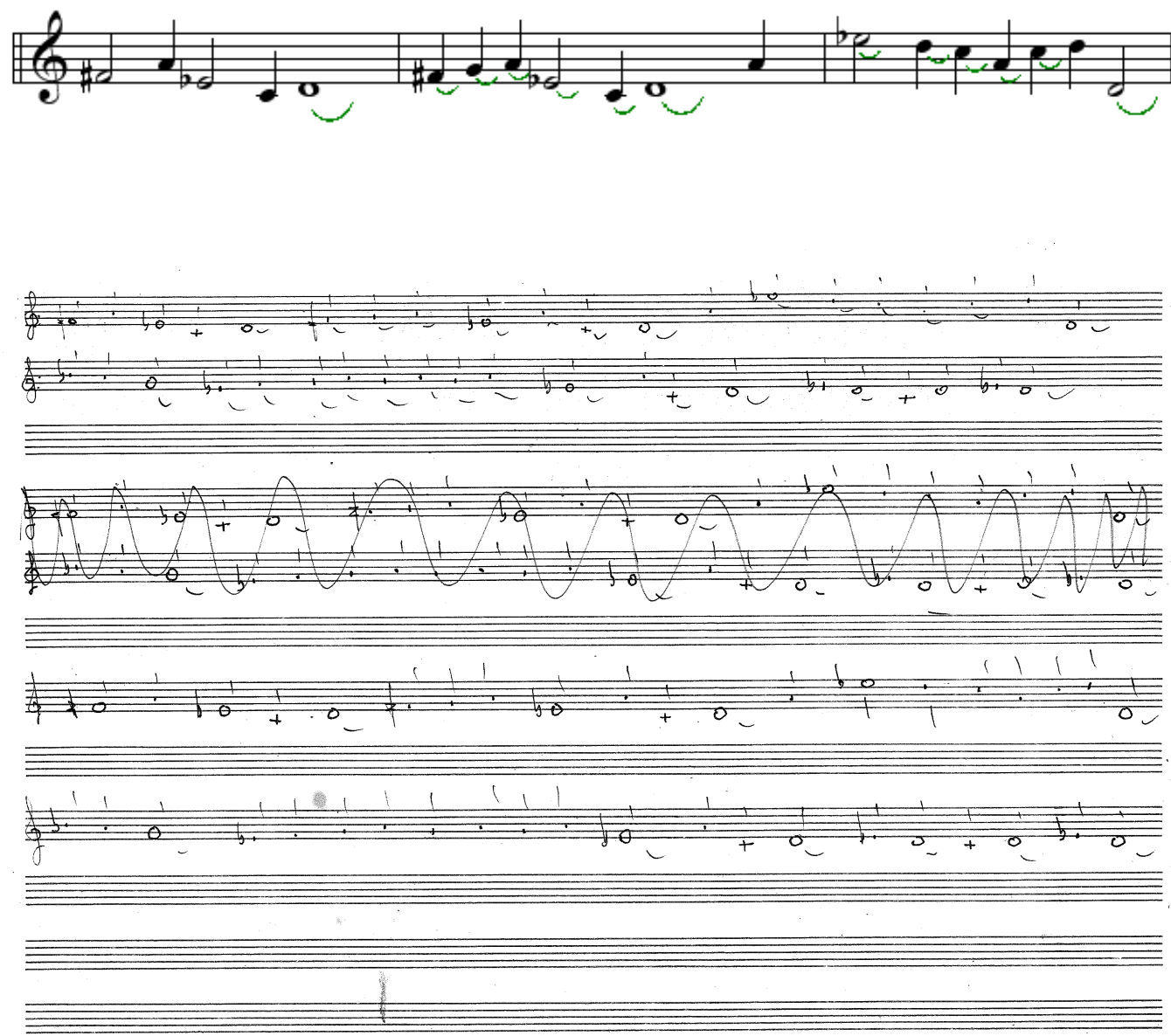

Se corresponde a la pista 1 de la cara A del disco Perturbació Inesperada grabado en 1986 por Linterna Música.

\section{MATERIAL TOTAL:}

- Material manuscrito y original del autor. Consta de 1 bloc de escritura musical, perteneciente a la década de los 80 , sin título en el exterior aunque con la letra "P" en la tapa. La obra va siguiendo la estructura de la grabación del disco, aunque no consta entera ni tampoco está desarrollada en su totalidad. También se encuentra material de esta obra, manuscrito y original del autor, en 1 bloc de 
escritura musical, con el título Boqueta amplificada en el exterior. Páginas sin numerar. En las 9 primeras hojas se encuentran los apuntes del material de la obra Aquesta es la historia.....

- Partes: No existen partes.

- No consta relación de originales y copias. 
4.- ARROSEGANT EL PIANO, Libre, en La, voz solista (sin determinar) y piano, con partitura, 1980, Arc. 16.

La plantilla a la que está dedicada es la de un piano y una voz.
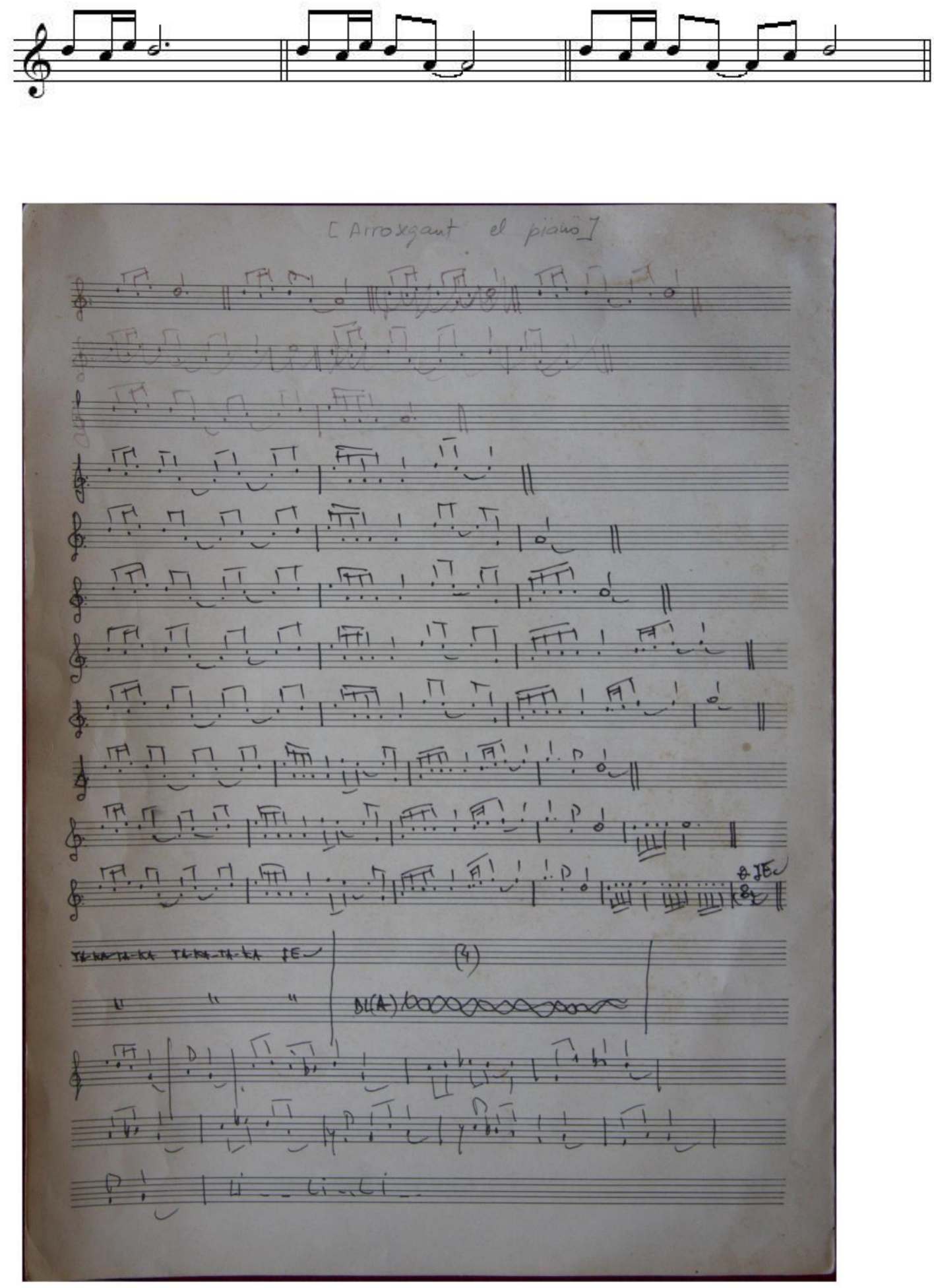
La pieza está concebida para la salida al escenario del autor, que canta libremente mientras empuja el piano al centro del escenario.

\section{MATERIAL TOTAL:}

- Partitura de la obra: Partitura manuscrita y original del autor. Consta de un facsímile con 1 hoja escrita, sin numerar. En la parte exterior de este facsímile, consta el original manuscrito de la obra Pepa, incluida en el disco Voicetracks.

- Existe otra partitura de la misma obra, manuscrita y original del autor, que consta de un libreto de escritura musical con 3 páginas escritas, con el título Arrosegant el piano ,una anotación al final de la partitura que reza "Milan-New York, TWA, 15 juliol 1980", y el número 36 encercado. En la parte interior del libreto vuelve a comenzar la obra desde el principio.

- Partes: No existen partes.

- No consta relación de originales y copias. 
5.- CARLES MOR, Libre, politonal, voz solista (sin determinar) y piano, con partitura, s. d., Arc. 22.

La plantilla a la que está dedicada es la de un piano y una voz (sin determinar).
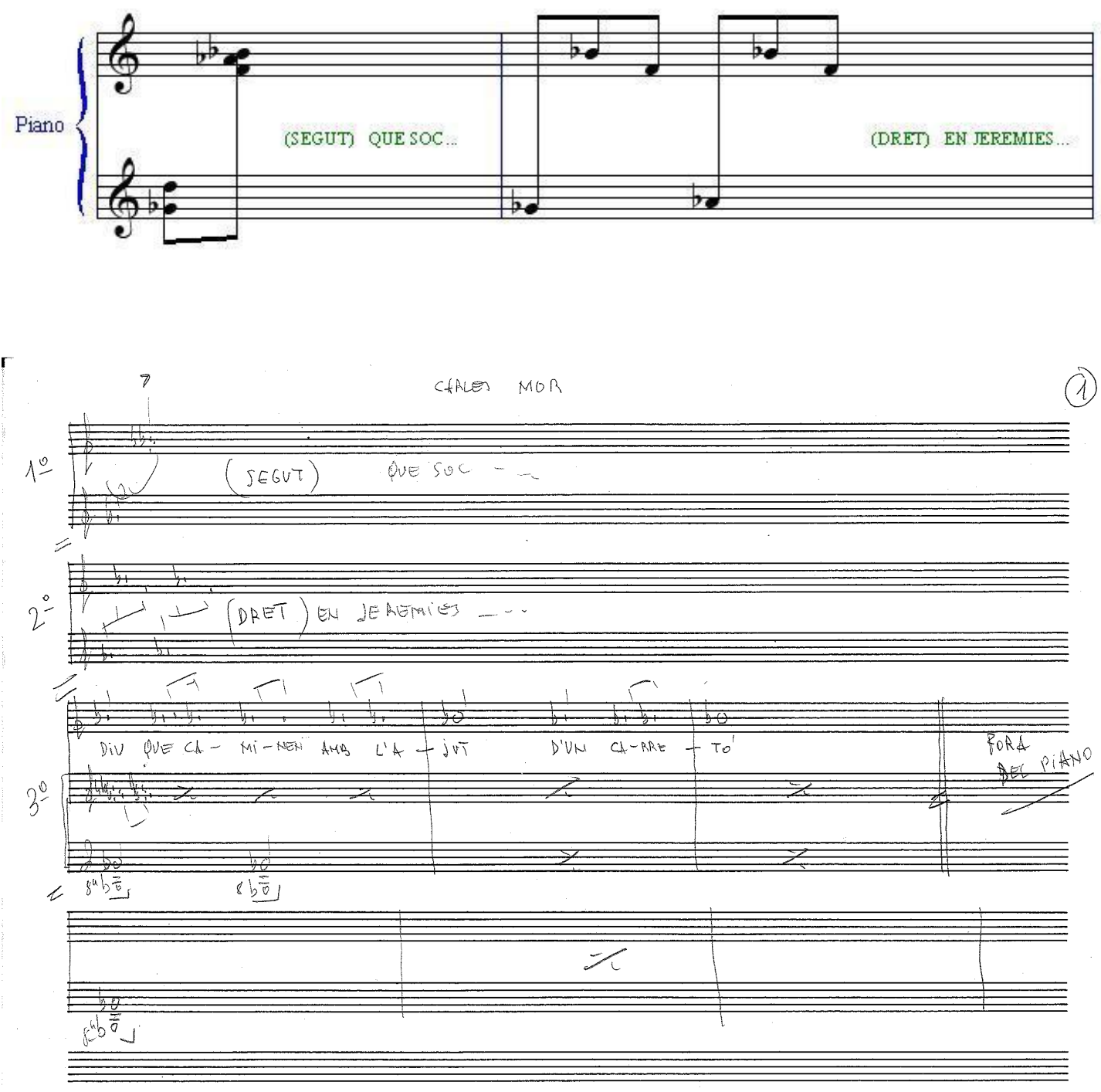

พ.610

\section{MATERIAL TOTAL:}

- Partitura manuscrita y original del autor. Consta de un libreto de escritura musical con 5 páginas escritas y numeradas.

- Partes: No existen partes.

- No consta relación de originales y copias. 
6.- CONCERT IRREGULAR, Libre, politonal, voz solista (sin determinar) y piano, con partitura, 1967, Arc. 19.

La plantilla a la que está dedicada es la de un piano y una voz (sin determinar).
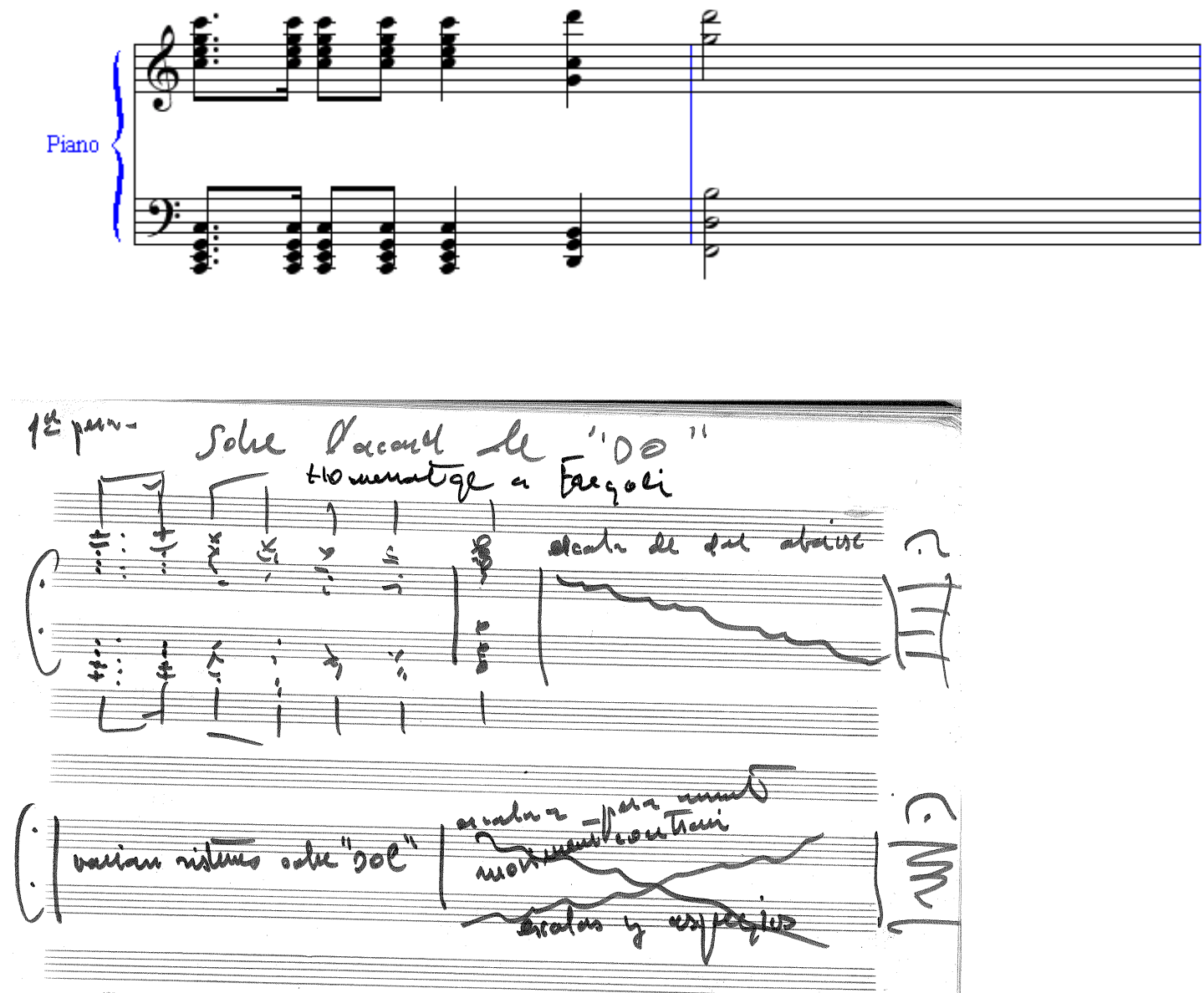

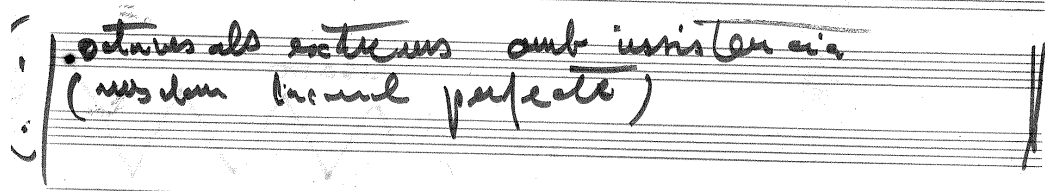

- Ioctaves al stran y al wity alternades

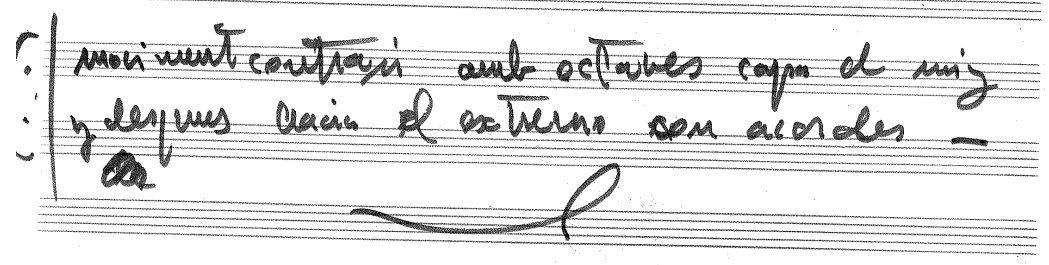


Para festejar el 75 aniversario de Joan Miró. Estrenada a la Fundación Maeght de Sant Pau de Vença. Carles Santos y Anna Ricci.

\section{MATERIAL TOTAL:}

- Material manuscrito y original del autor. Consta de 1 bloc de escritura musical, perteneciente a la década de los 60, con tapa azul oscura, sin título en el exterior. La obra está escrita en 19 páginas. En ella consta la estructura del espectáculo y lo que debe realizar el pianista, aunque en la mayoría de la estructura, no está desarrollado el que ha de tocar aunque si como ha de interpretarlo. Asimismo existe un facsímil de 3 hojas, con música desarrollada. Se desconoce si pertenece al espectáculo. También existe un facsímil de 4 hojas con música desarrollada, aunque se desconoce para que momento del espectáculo está escrito. En una de las hojas, al igual que en el bloc, consta la inscripción "dilluns". Existe también una carta con la biografía de Joan Brossa y un texto de "Le moulin de Jupiter", espectáculo musical, de Joan Brossa.

- Partes: No existen partes.

- No consta relación de originales y copias. 
7.- CUINA, Libre, politonal, cuarteto vocal/coro (S. A. T. y B.) y piano, con partitura, s. d., Arc. 12

La plantilla a la que está dedicada es la de un cuarteto vocal o coro (S. A. T. y B.) y Piano.
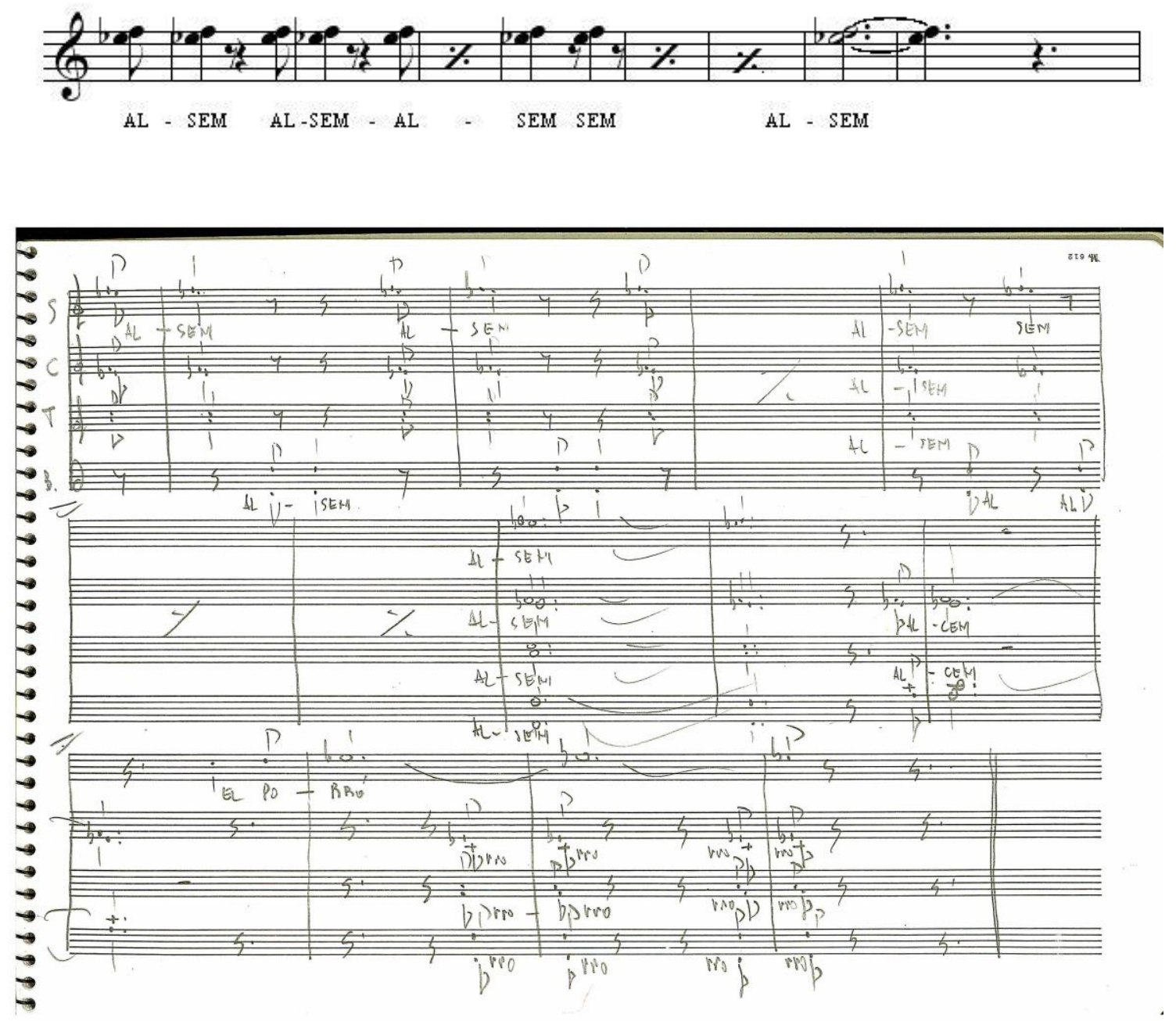

\section{MATERIAL TOTAL:}

- Partitura de la obra: Manuscrito original del autor en un bloc de escritura musical. Después de la página 8A, da la impresión de ser apuntes de esta obra, o bien de otra, bien estructurados. En el mismo bloc, por la parte posterior se encuentra la obra Reflex.

- Partes: No existen partes.

- No consta relación de originales y copias. 
8.- DEMANA-HO, libre, recitado, voz y piano, con partitura, 1985 aproximadamente, Arc. 34

La plantilla a la que está dedicada es la de una voz (sin especificar) y piano.

Ver: DEMANAU (en sección obra vocal)
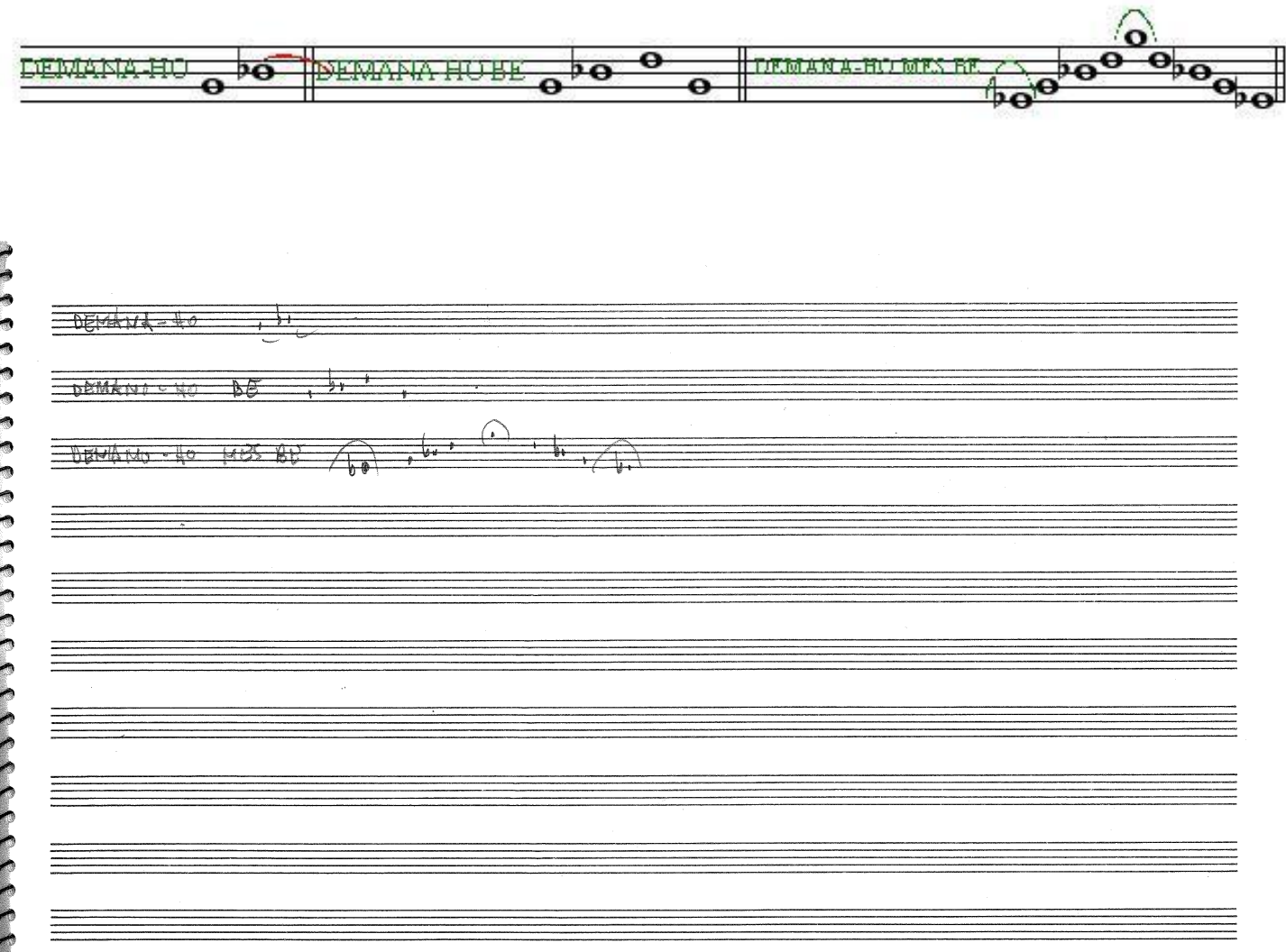

Parece ser el desarrollo de la obra Demanau, aunque los textos no coinciden exactamente, por lo que puede ser una versión de la obra. Esta pieza puede formar parte de la obra escénica Arganchulla Arganchulla Gallac.

\section{MATERIAL TOTAL:}

- Material manuscrito y original del autor. Consta de 1 bloc de escritura musical, sin título en el exterior. Las hojas 9, 10 y 11 contienen los apuntes de la obra. En el mismo bloc se encuentran las obras Credi tonal y Peça veu amb Cesc Gelabert. Existe otro texto de la obra en un bloc de la obra Argamchulla con el número 4 encercado en el exterior.

- Partes: No existen partes impresas.

- No consta relación de originales y copias. 
9.- ESPECTACLE PER A DANÇA, VEU I PIANO, Libre, en Re, voz solista y piano, con partitura, 1982?, Arc. 22

La plantilla a la que está dedicada es la de una voz solista (sin determinar) y Piano.
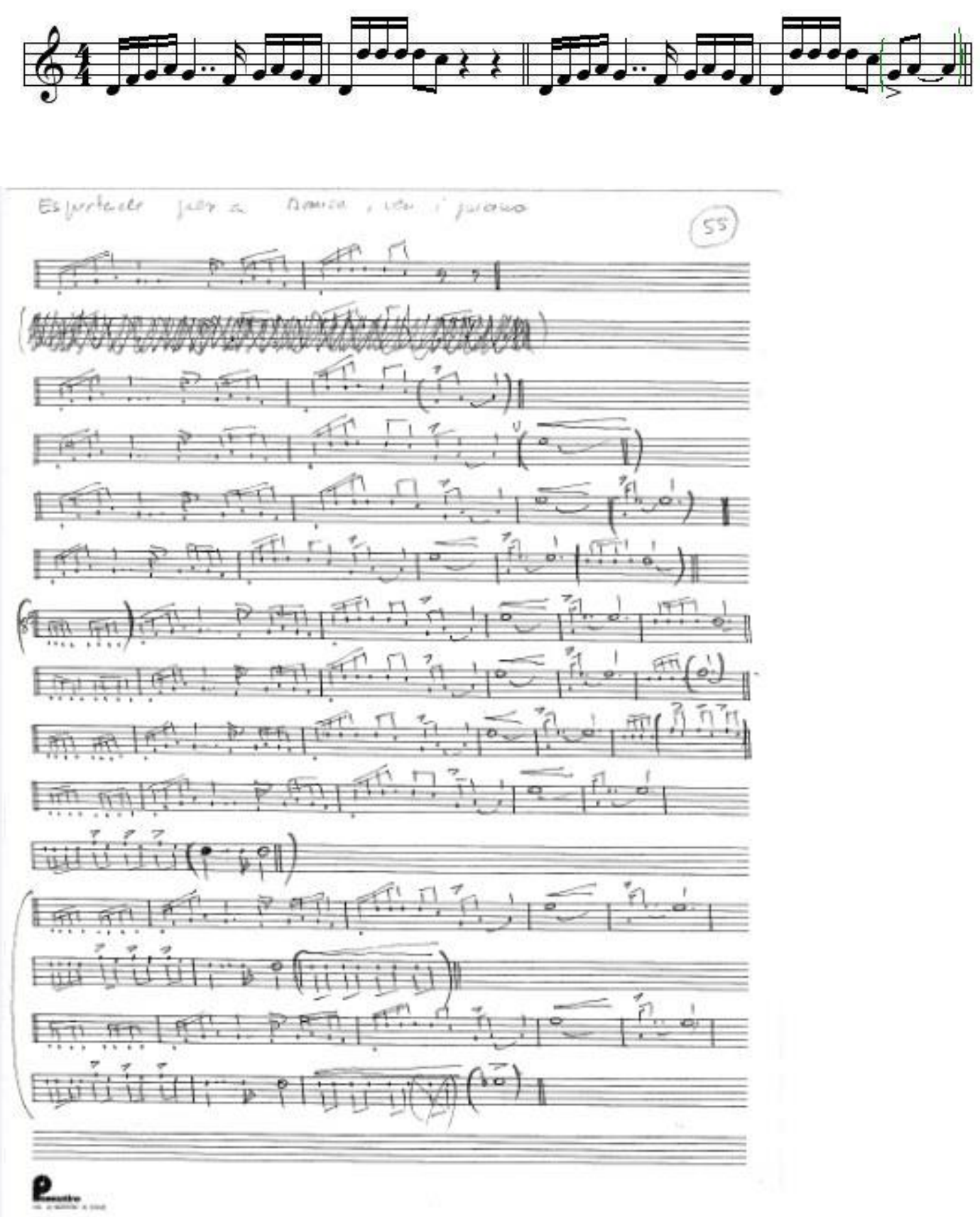

La partitura está numerada como 55 por el autor.

Pieza vocal, con entonación y sin indicaciones de intervenciones del piano. 


\section{MATERIAL TOTAL:}

- Partitura manuscrita y original del autor. Consta de 1 hoja suelta, escrita por ambas caras. Consta título como Espectacle per a dança, veu $i$ piano y el número 55 encercado.

- Partes: No existen partes.

- No consta relación de originales y copias. 
10.- FLOR D'ESCARABAT, Cantata, en La, Voz, Coro de niños, Piano y Percusión, con partitura, 2007, Arc. 18

La plantilla a la que está dedicada es la de una voz solista (sin determinar), Coro de niños, Piano y Percusión.

Ver: CANTATA
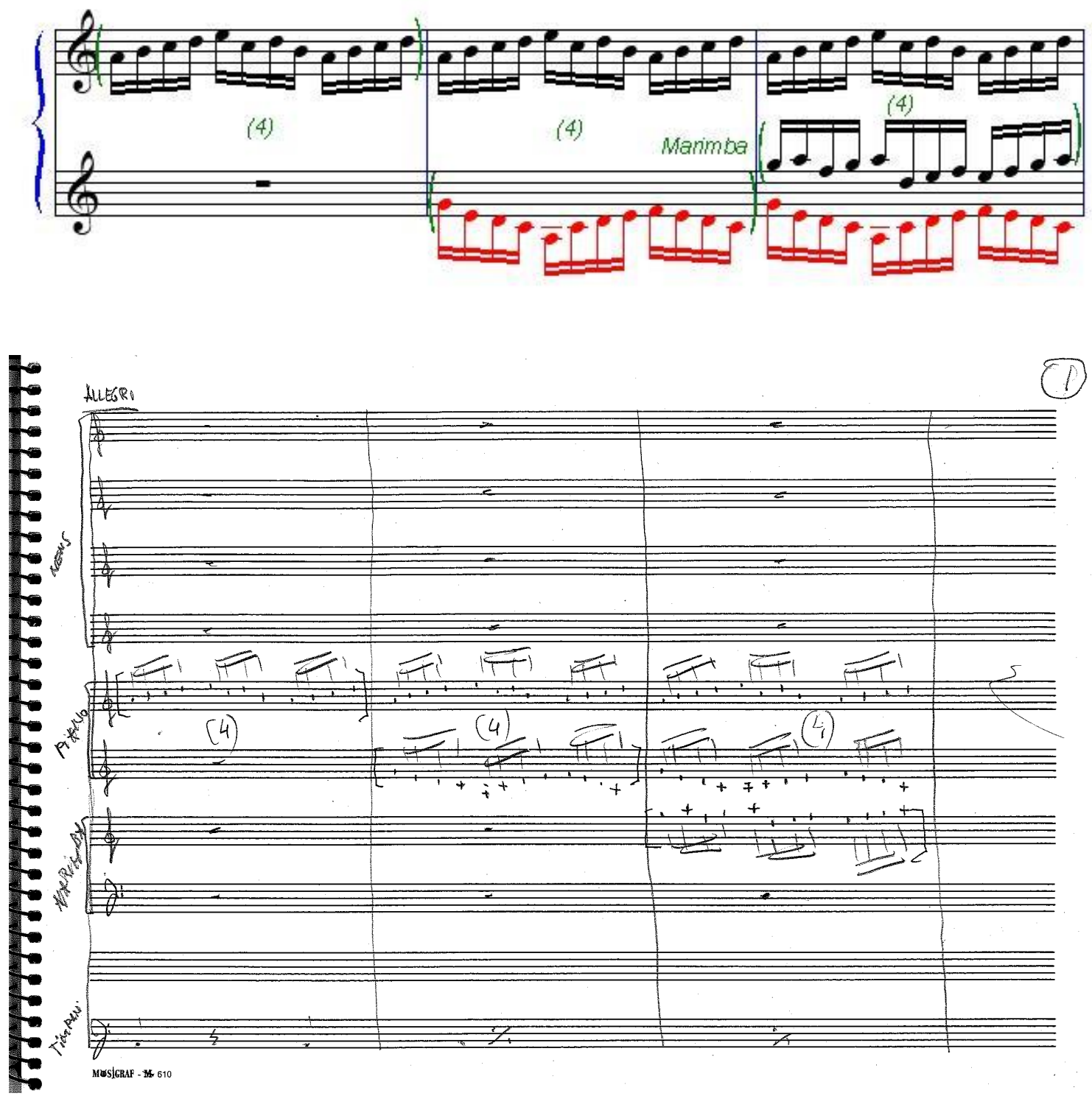

Misma obra que Cantata, incluida en el grupo de Otras agrupaciones.

Estrenada en el Palau San Jordi en 2007.

Coro de 3000 niños.

Encargo del Secretariat de Corals Infantils de Catalunya 


\section{MATERIAL TOTAL:}

- Partitura manuscrita y original del autor. Consta de 4 blocs de escritura musical, correlativos y con los siguientes títulos en el exterior: Cantata (1) a Cantata (4) con 116 páginas numeradas y manuscritas (de la 1 a la 29, 30 a 59, 60 a 89, 90a 116).

- Existe otra versión de esta obra con el título Flor d'escarabat, impresa por DINSIC PUBLICACIONS MUSICALS, S.L. Consta de una partitura de 80 páginas que contiene los poemas de Manuel de Barros y Albert Roig. La obra es la misma pero con otro título.

- Partes: No existen partes.

- No consta relación de originales y copias. 
11.- LA PRIMAVERA DEL DISSENY, Libre, politonal, dúo vocal (S y T) y piano, con partitura, 1999, Arc. 14

La plantilla a la que está dedicada es la de un dúo de voces (soprano y Tenor) y Piano.
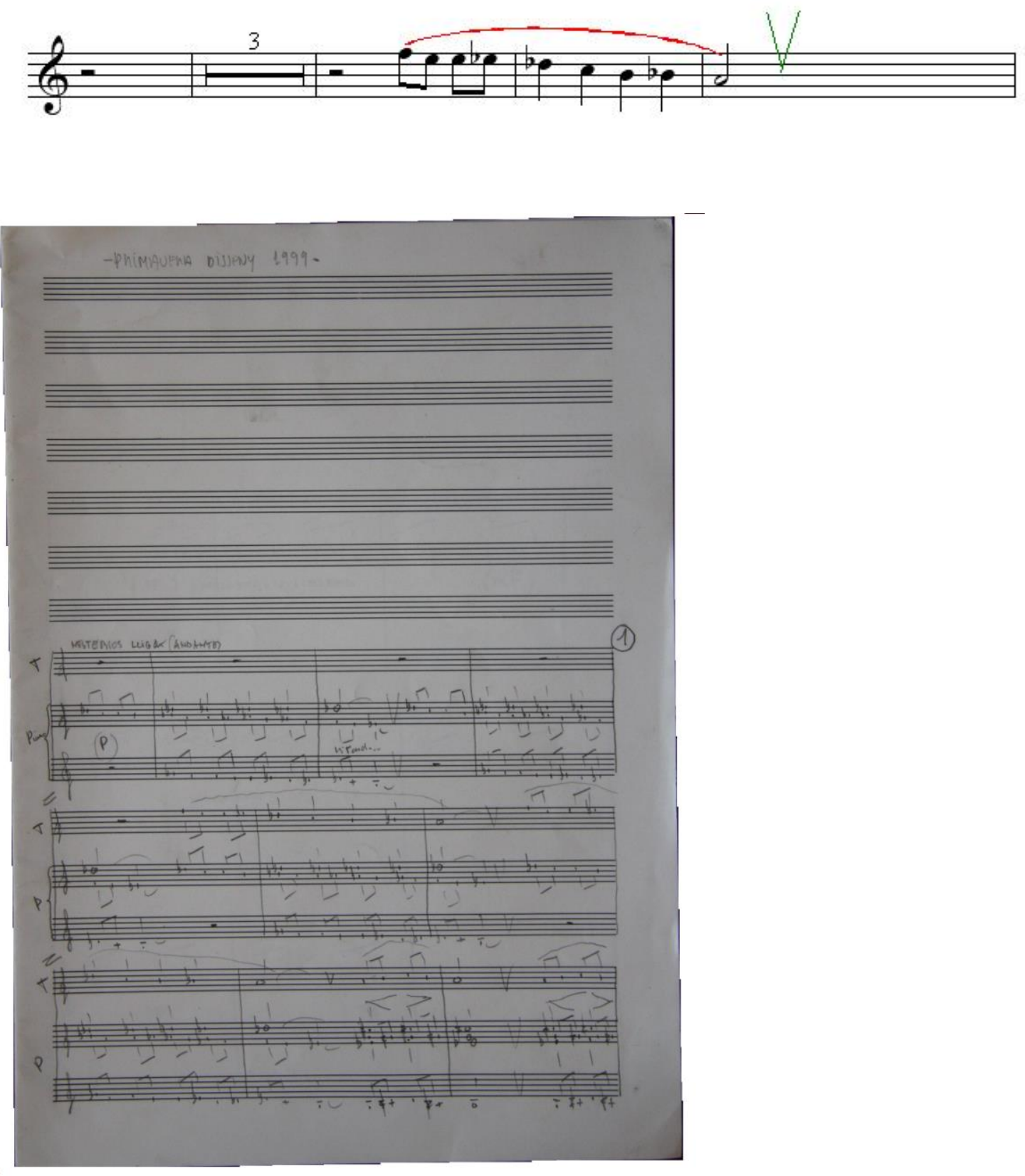

Estrenada el 8 de abril de 1999 en la Fundación Miró de Barcelona. No existe material impreso. 


\section{MATERIAL TOTAL:}

- Partitura de la obra: Manuscrito original del autor y material igual, fotocopiado y encuadernado.

- Partes: No existen partes.

- No consta relación de originales y copias. 
12.- LAURA, Libre, politonal, voz y piano, con partitura, s. d., Arc. 22

La plantilla a la que está dedicada es la de un Piano y voz (sin identificar).
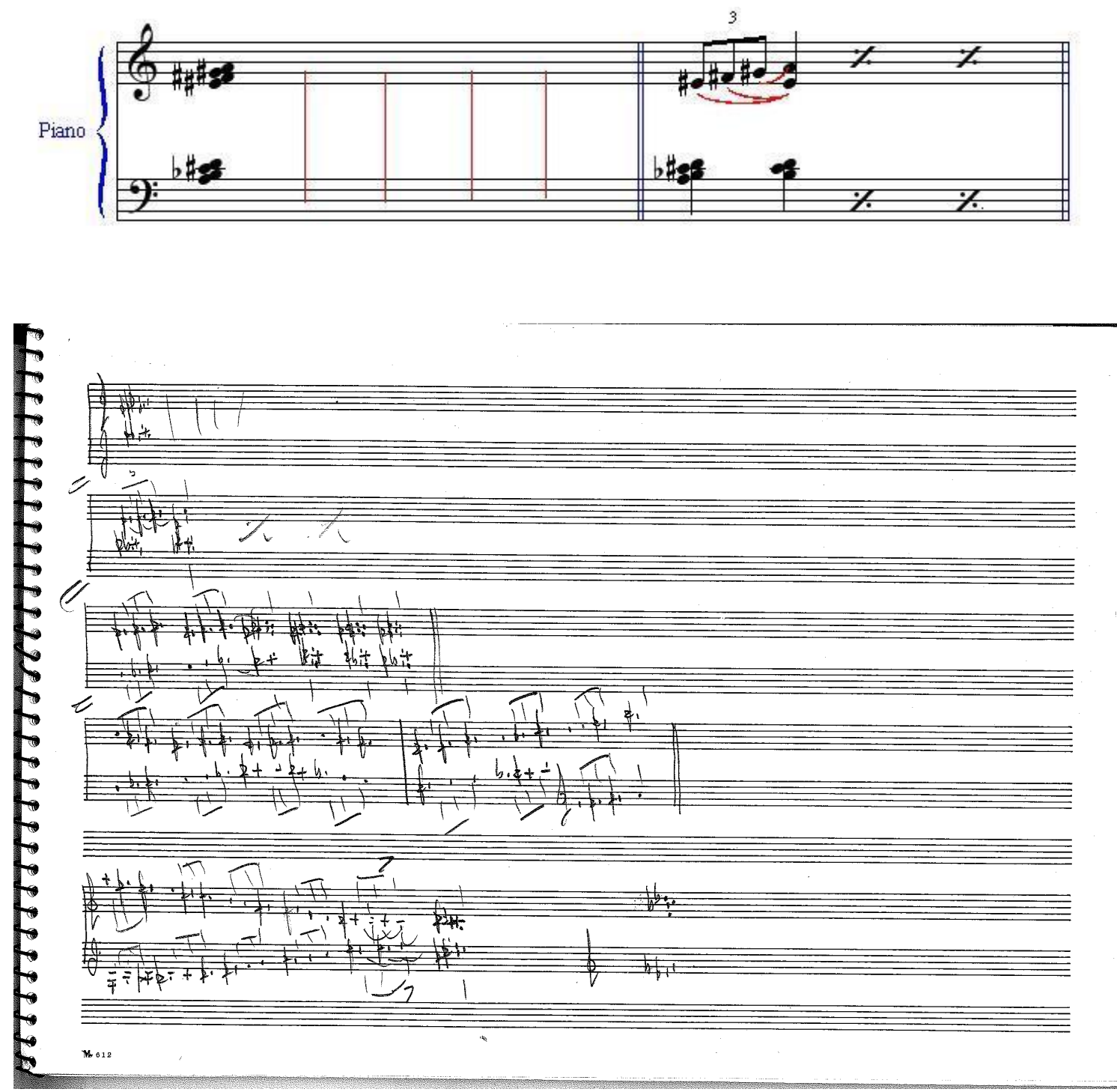

Pueden ser apuntes de otras obras.

\section{MATERIAL TOTAL:}

- Partitura manuscrita y original del autor. Consta de dos blocs de escritura musical,

- el primero con 25 páginas escritas y no todas numeradas. Las 11 primeras sin numerar. A continuación, 2 numeradas (1 y 2). Sigue 1 sin numerar y 2 numeradas (3 y 4). 4 sin numerar (las 2 primeras da la 
sensación de ser una obra independiente, al estilo de Bujaraloz) y 5 numeradas (5 a 9).

- El segundo bloc, titulado Laura-2, contiene la música del primer bloc, comprendida entre las páginas numeradas del 5 a 9. Asimismo el primer bloc contiene música escrita en el reverso ( 2 páginas) que parecen apuntes de otra obra vocal, puesto que tiene texto.

- Partes: No existen partes.

- No consta relación de originales y copias. 
13.- MÚSICA PER A VEU SOLA, Libre, politonal, voz y piano, con partitura, s. d., Arc. 16.

La plantilla a la que está dedicada es la de un Piano y voz (sin identificar).
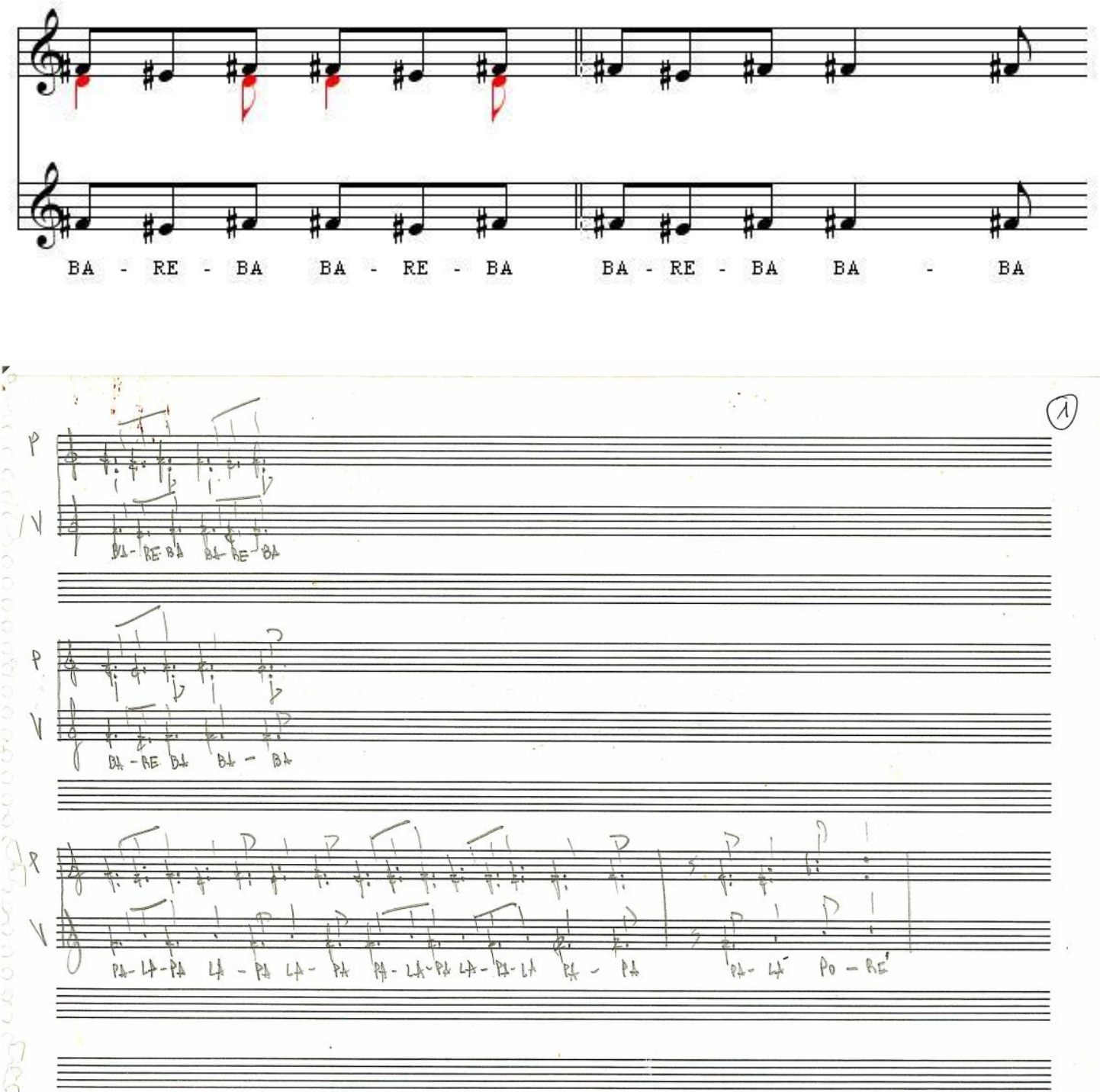

"No se ha estrenado".

${ }^{*}$ Testimonio oral del autor. 


\section{MATERIAL TOTAL:}

- Partitura de la obra: Manuscrito original del autor. Consta de 6 hojas sueltas. Páginas numeradas de la 1 a la 6 por el autor.

- Partes: No existen partes.

- No consta relación de originales y copias. 
14.- PEÇA MEXIC 1979 -PEÇA 56-, Libre, politonal, voz y piano, con partitura, 1979, Arc. 22.

La plantilla a la que está dedicada es la de un Piano y voz (sin identificar).
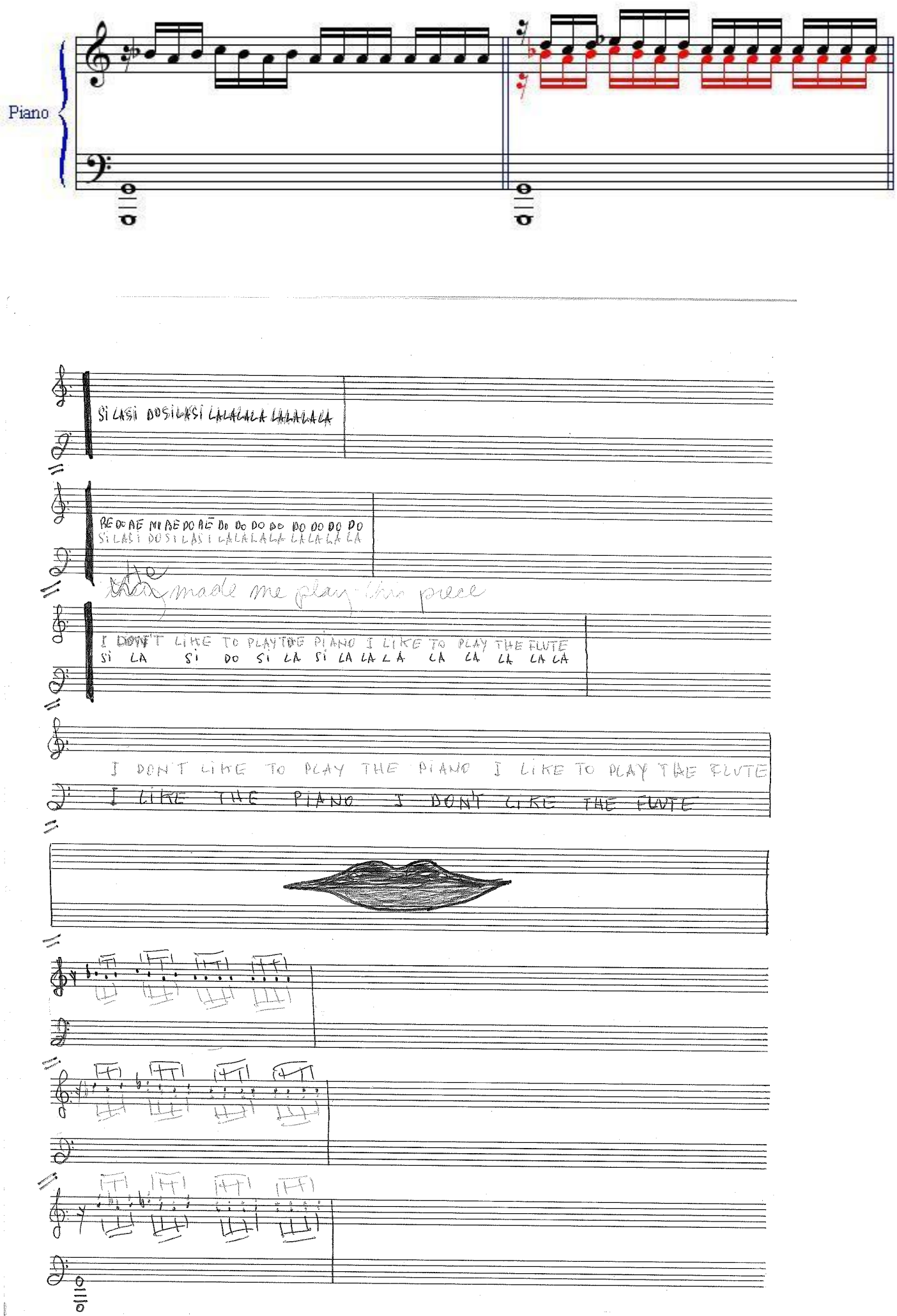


\section{MATERIAL TOTAL:}

- Partitura manuscrita y original del autor. Consta de dos libretos de escritura musical, numerados, con 4 páginas escritas, sin título y el número 56 encercado, en la tapa. Al final de la pieza consta la inscripción "MEXIC 29-XII-79".

- Partes: No existen partes.

- No consta relación de originales y copias.

Los dibujos y colores utilizados en la partitura tienen paralelismo con los utilizados en la pieza Barby flute. 
15.- PEÇA VEU AMB CESC GELABERT, Libre, politonal y recitado, voz y piano, con partitura, 1986, Arc. 34.

La plantilla a la que está dedicada es la de un Piano y voz (sin identificar).
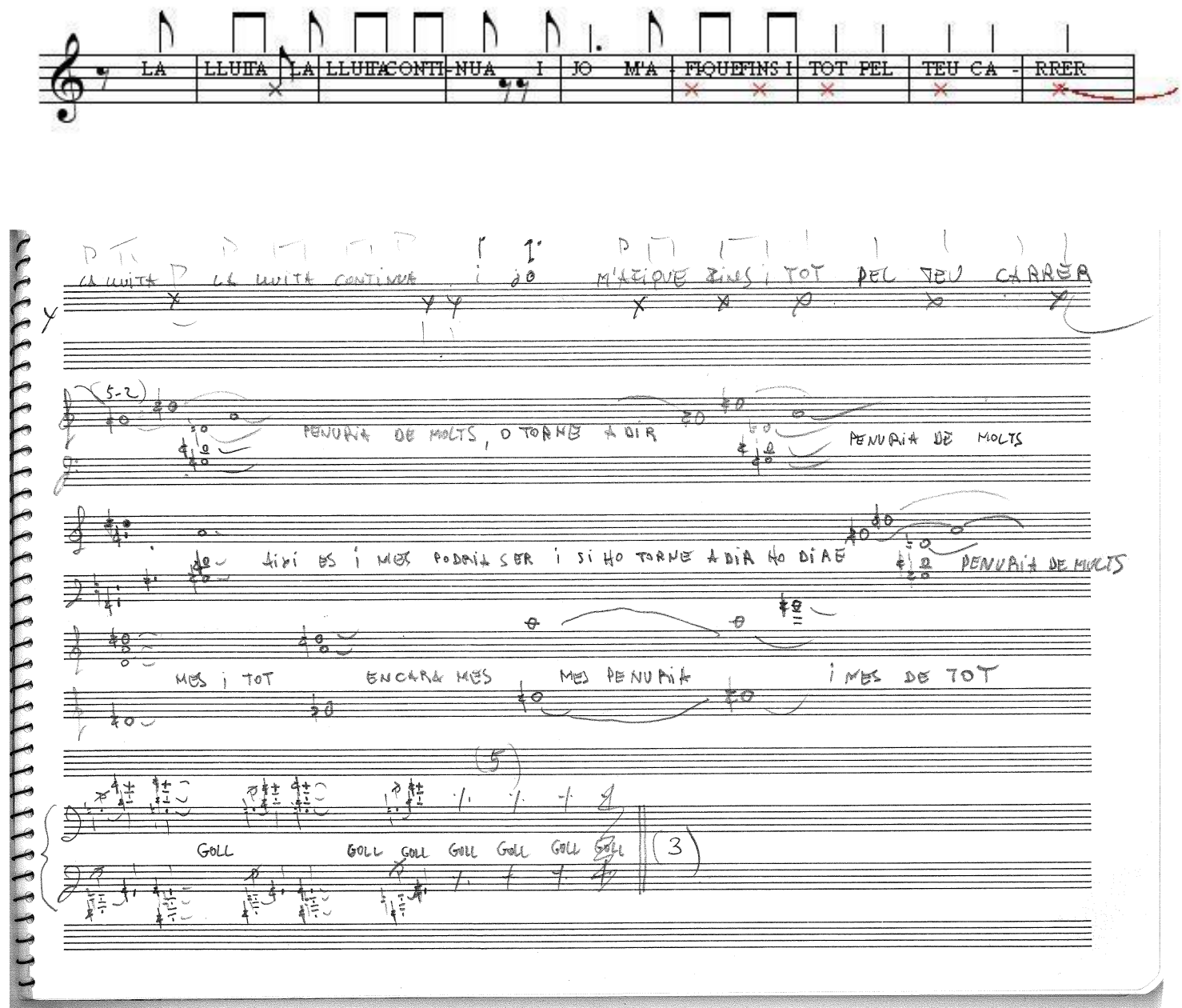

Música que forma parte del espectáculo escénico Credit tonal, conjuntamente con las otras dos obras contenidas en este bloc. En el mismo bloc se encuentran los apuntes de las obras Credit tonal, Peça veu amb Cesc Gelabert y Demana-ho.

\section{MATERIAL TOTAL:}

- Material manuscrito y original del autor. Consta de 1 bloc de escritura musical, sin título en el exterior. Las hojas 5 y 6 contienen los apuntes de la obra. En el mismo bloc se encuentran las obras Credit tonal y Demana-ho.

- Partes: No existen partes.

- No consta relación de originales y copias. 
16.- PIROMUSICAL, Libre, politonal, sexteto vocal (sin especificar) y piano, con partitura, 1992, Grande 8

La plantilla a la que está dedicada es la de un coro a 6 partes y Piano.
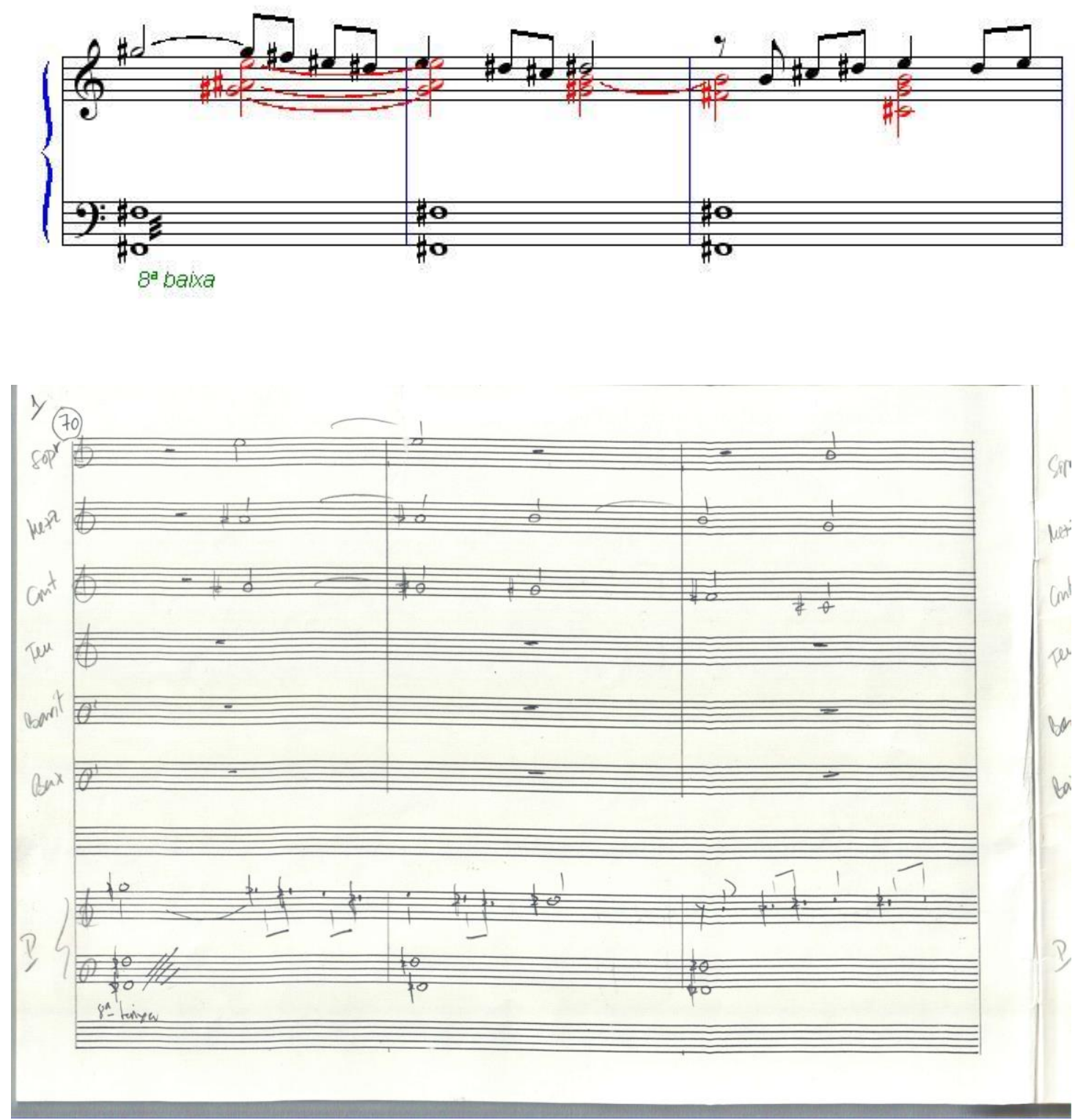

Es la `parte del coro de la música de la ceremonia de clausura de los JJ. OO. Barcelona 92.

Se corresponde a la pista 15, "Piromusical" del disco Música para las Ceremonias Olímpicas Barcelona '92 grabado en 1993 por On The Rocks. 
MATERIAL TOTAL:

- Partitura de la obra: Manuscrito original del autor en dos facsímiles con un total de 37 páginas numeradas. Existe una copia del material.

- Partes: No existen partes.

- No consta relación de originales y copias. 
17.- SI QUE TÉ LO QUE TÉ, Libre, politonal y recitado, Piano y voces, con partitura, 1983, Arc. 34.

La plantilla a la que está dedicada es la de un Piano y voz (sin identificar).

Ver: TE XINA LA FINA PETXINA DE XINA (sección Obra escénica)
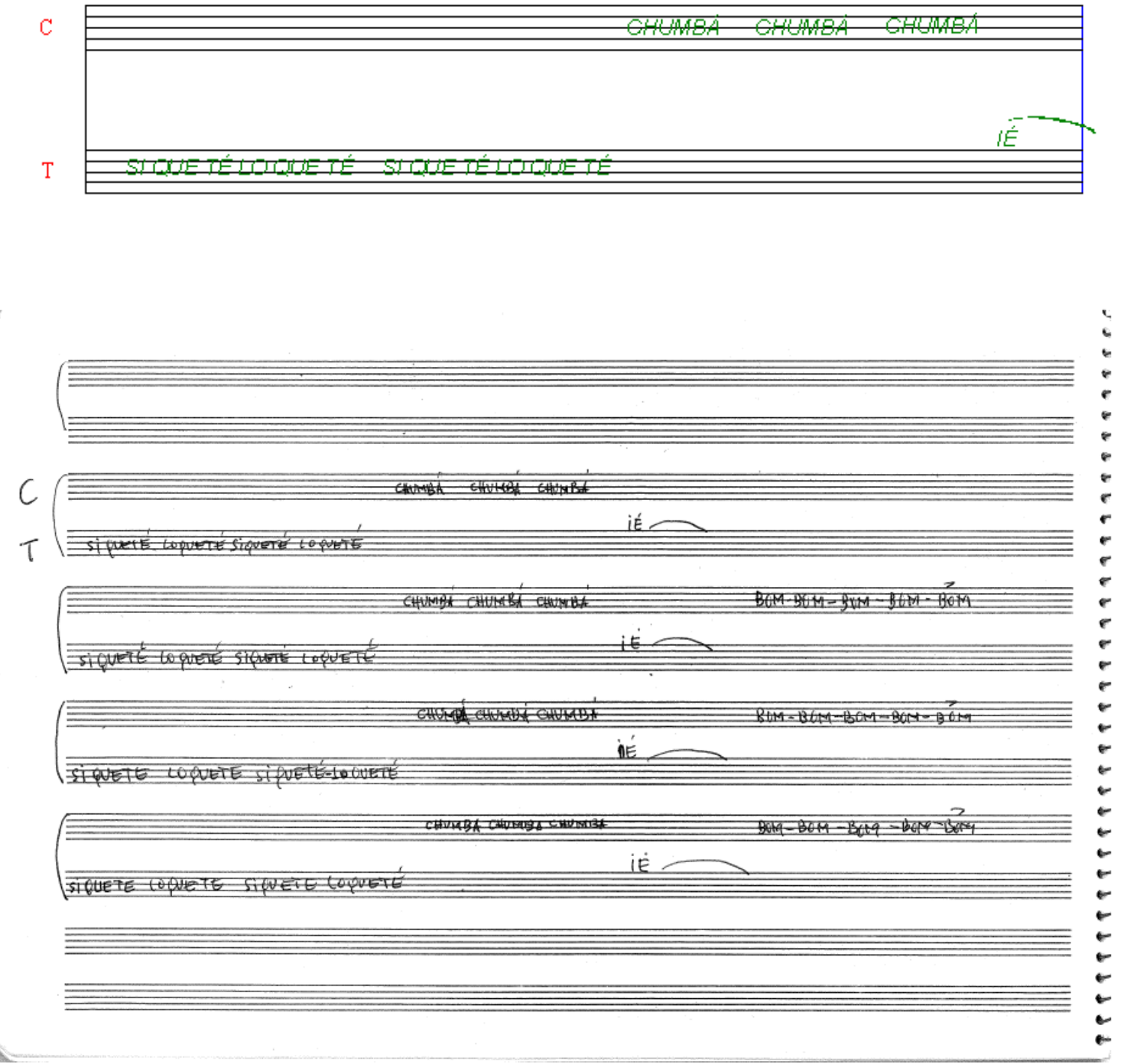

\section{MATERIAL TOTAL:}

- Material manuscrito y original del autor. Consta de 1 bloc de escritura musical, con el título Te xina la fina petxina de Xina en el exterior. Páginas sin numerar. En la hoja octava, se encuentra el texto de esta obra. Da la sensación de formar parte de la obra más extensa Te xina la fina petxina de Xina. Dado que la obra 
registrada en la SGAE es Te xina la fina petxina de Xina, damos a esta la titularidad formal de la misma.

- Partes: No existen partes.

- No consta relación de originales y copias. 
18.- SOUND FIGHT, Libre, politonal, voz y piano, con partitura, 1980 aprox., Arc. 19

La plantilla a la que está dedicada es la de una voz (sin determinar) y piano.
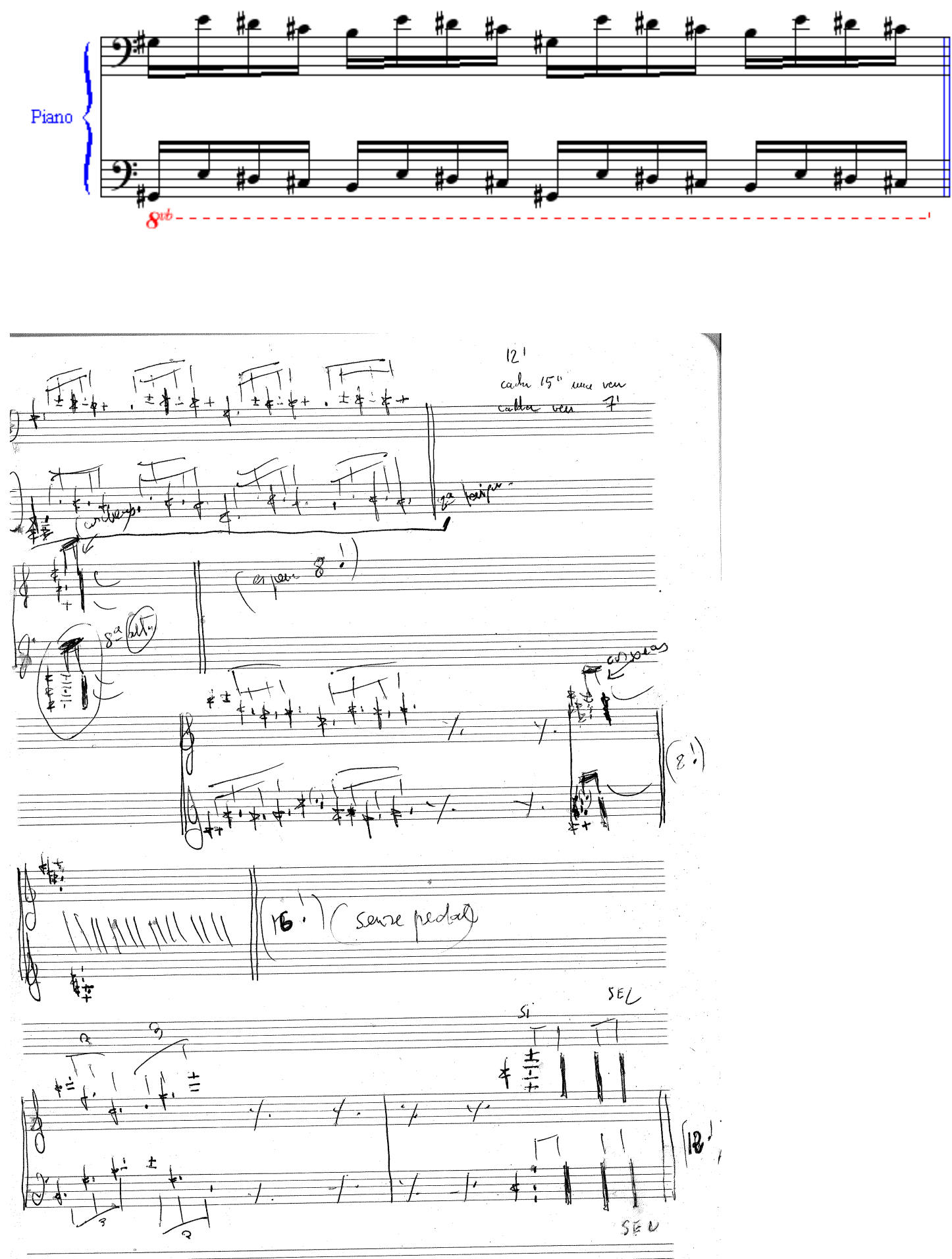
Estrenada el 14 de marzo de 1981 en el Bobby Gleason Gym de New York.

"Performance 'The Heavyweight Sound Fight' entre Charlie Morrow y Carles Santos"69

\section{MATERIAL TOTAL:}

- Material manuscrito y original del autor. Consta de 1 bloc de escritura musical, sin título en el exterior, de color amarillo, que contiene la estructura de un espectáculo ofrecido por el autor, al parecer, en New York. Las 12 primeras páginas hacen referencia al espectáculo ofrecido por Carles Santos y Charlie Morrow el 14 de marzo de 1981 en New York, ya que en los textos hace referencia a Charly en algunas ocasiones, presentando un diálogo o combate con este personaje. En la última página del bloc se encuentra la plantilla instrumental que se necesita para el espectáculo, que coincide con la que se muestra en fotografías visionadas de dicho espectáculo. A continuación se encuentran apuntes de piezas pianísticas y vocales. Entre las obras desarrolladas en su interior se encuentra Calixa, así como Un gat es un gat o fragmentos melódicos que coinciden con los desarrollados en el bloc de color marrón oscuro y catalogado en el número de orden 227, bajo el título de Un gat es un gat.

- Partes: No existen partes.

- No consta relación de originales y copias.

${ }^{69}$ Guerrero, Manuel ((2006): “Carles Santos. Visca el Piano!”. Ed. Actard. Barcelona. Pág.1819. 
19.- TINC QUE TINC..., Concierto, Politonal, voz solista y piano, con partitura, 2007. Arc. 18

La plantilla a la que está dedicada es la de Voz (sin determinar su tipo) y Piano.
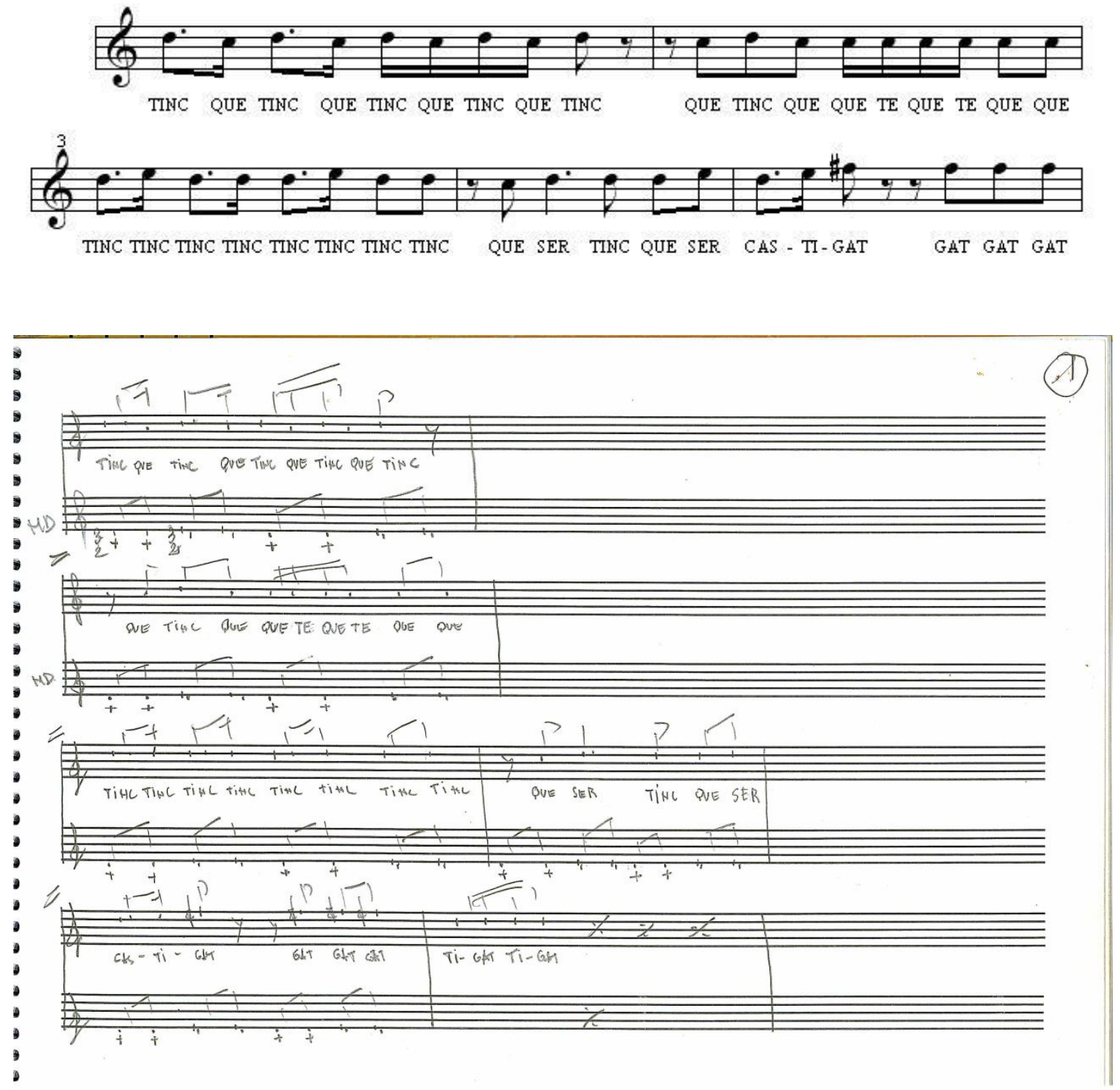

Da la sensación de no estar completa y que forma parte de la obra Tinc que ser castigat (confirmado por el autor el 27/07/2011).

\section{MATERIAL TOTAL:}

- Partitura manuscrita y original del autor. Consta de 1 bloc de escritura musical, con el título Tinc que tinc... en el exterior con 7 páginas numeradas y 
manuscritas. Contiene planning de actuación en Berlín, fechas 16 y 17 de marzo de 2008, para interpretar El fervor.

- Partes: No existen.

- No consta relación de originales y copias. 
3.2.4. FANFARRIA 
1.- 11.509 NOTES PER A 2.001 MÚSICS, Libre, politonal, fanfarria, con partitura y partes, 2001, G. 9

La plantilla a la que está dedicada es la de una Fanfarria (4 Trompetas, 4 Trompas, 3 Trombones, Bombardino, Tuba y Percusión). La orquestación consta de P. J. Puértolas.
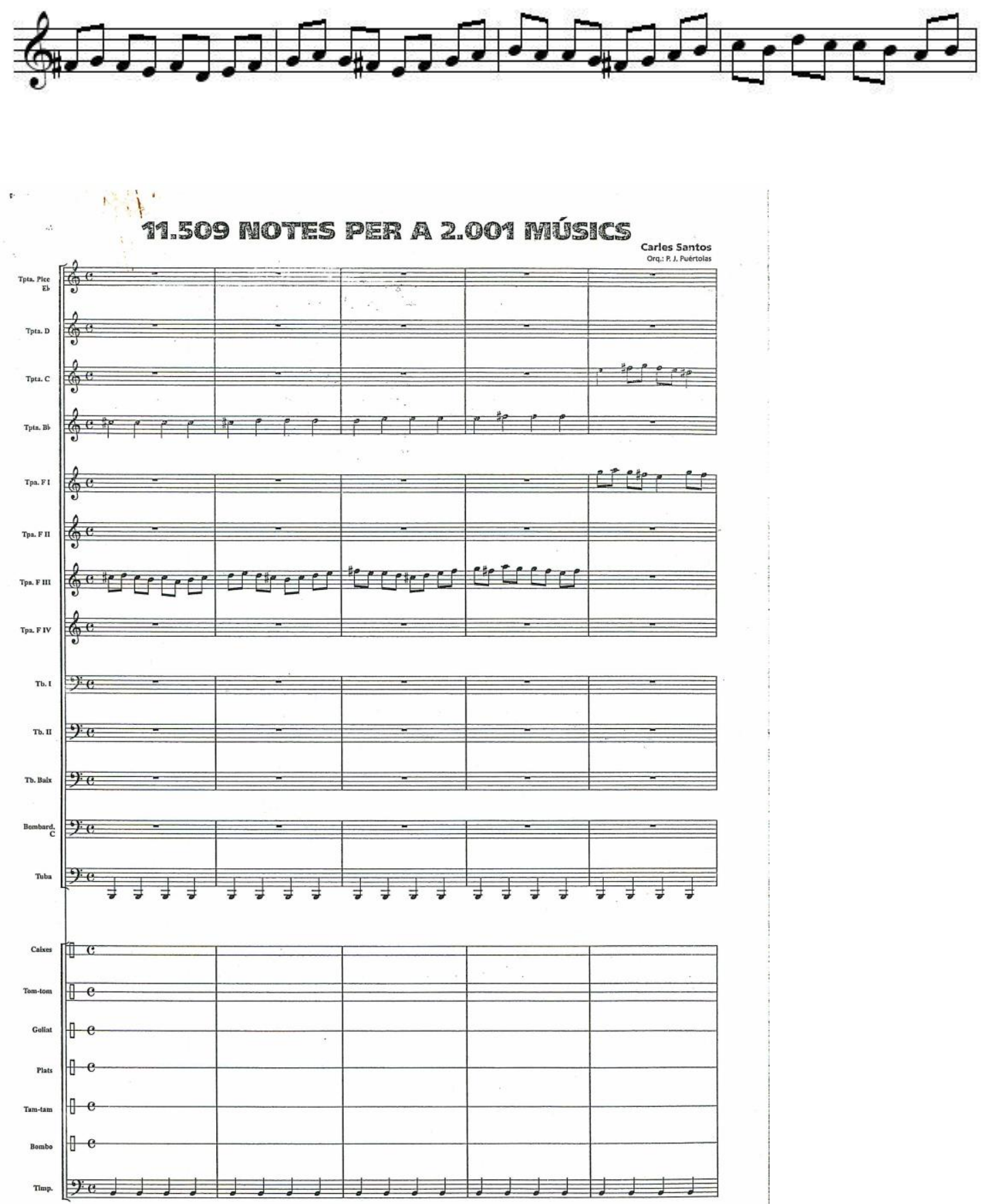
Estrenada para la Bienal de Valencia en la Ciutat de les Arts i de les Ciències, junto a un espectáculo ofrecido por la Fura dels Baus el 10 de junio de 2001. Instrumentación de P. J. Puértolas.

Material en poder de la Banda "La Alianza" de Vinaròs y cedido por José Ramón Renovell, director de la misma.

\section{MATERIAL TOTAL:}

- Material manuscrito del autor, original, en 2 blocs de escritura musical, con el título Valencia (1) 2001 y Valencia (2) 2001 en el exterior. Páginas numeradas de la 1 a la 31 , en el $1^{\circ}$, y de la 32 a 46 , en el $2^{\circ}$.

- Partitura de la obra: Impresa y fotocopiada de copista, con 6 copias de la misma.

- Partes: Partes impresas y fotocopiadas de copista y tres copias de las partes instrumentales, todas ellas encuadernadas. Existen sobrantes.

- Existe pdf de la partitura y las partes instrumentales. 
2.- FANFÀRRIA BIENNAL, Libre, politonal, fanfarria, con partitura y partes, 2001, G. 9

La plantilla a la que está dedicada es la de una Fanfarria (4 Trompetas, 4 Trompas, 3 Trombones, Bombardino, Tuba y Percusión). La orquestación consta de P. J. Puértolas.
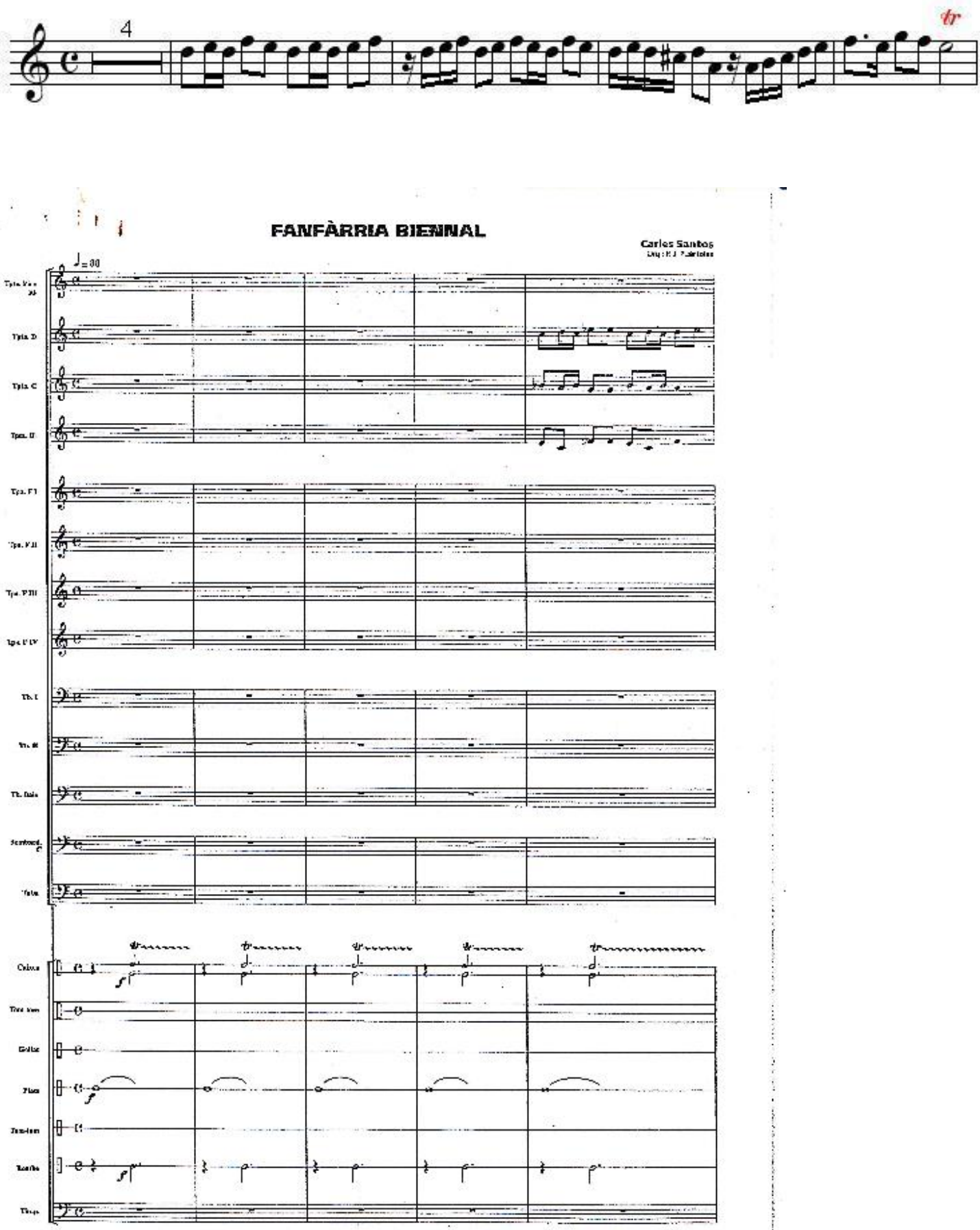
No consta ningún material original del autor. Estrenada en Valencia en 2001. Instrumentación de P. J. Puértolas.

Material en el archivo de la Banda "La Alianza" de Vinaròs y cedido por José Ramón Renovell, director de la misma.

\section{MATERIAL TOTAL:}

- Material manuscrito del autor, original, en 1 bloc de escritura musical, con el título Bienal Valencia (Fanfarria) en el exterior y 22 páginas numeradas de la 1 a la 22. Existe material fotocopiado y grapado de este material.

- Partitura de la obra: Impresa y fotocopiada de copista, con el título Fanfàrria bienal y con 5 copias de la misma.

- Partes: Partes impresas y fotocopiadas de copista.

- Existe pdf de la partitura y las partes instrumentales. 
3.- MEDALLES (FANFÀRRIA), Libre, en Mi, fanfarria, con partitura y partes, 1992, G. 8 .

La plantilla a la que está dedicada es la de una Fanfarria (4 Trompetas en Re, 4 Trompetas en Sib, 4 Trompas, 3 Trombones, y Timbales).
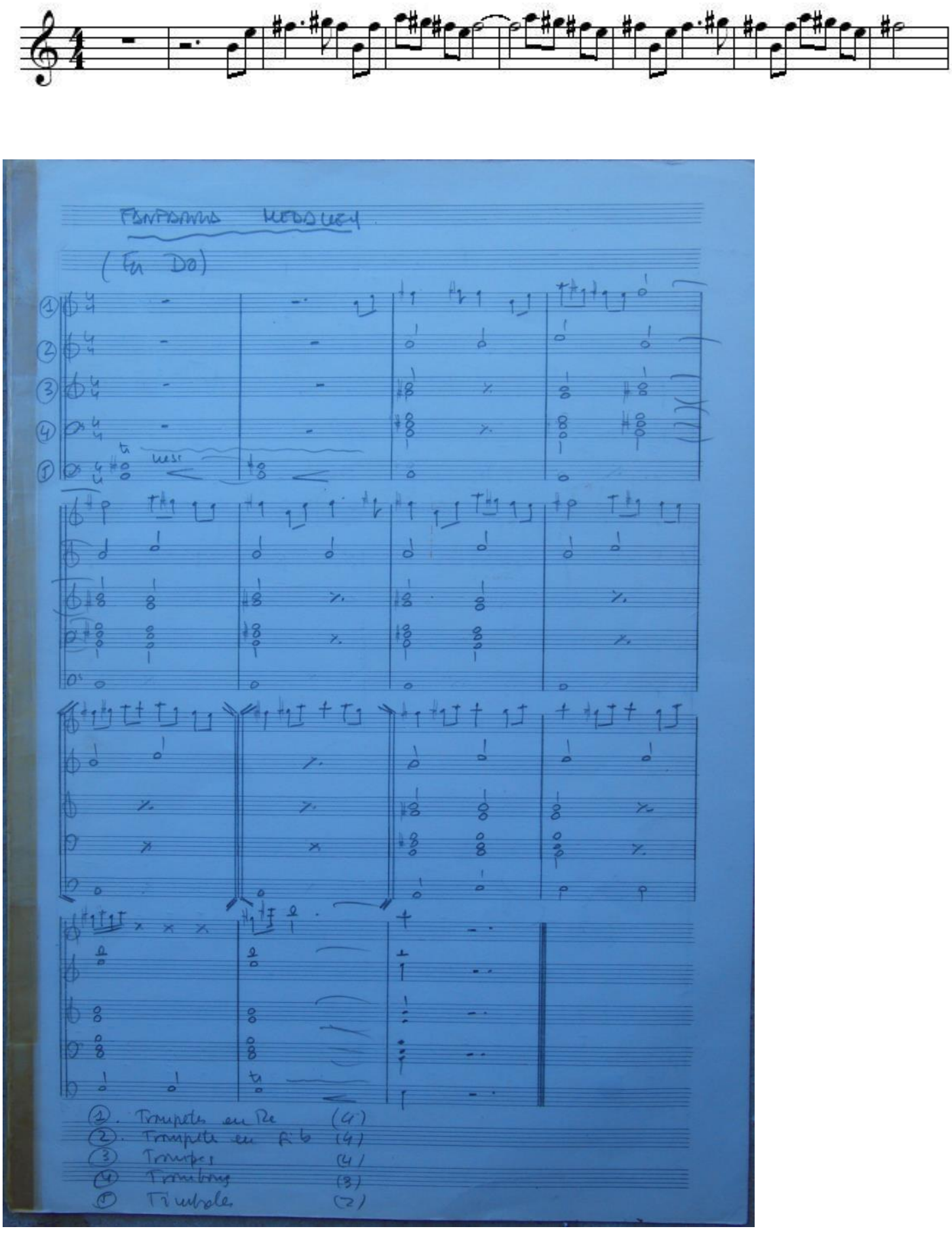
Música compuesta para la imposición de medallas en los JJ. OO. de Barcelona de 1992.

\section{MATERIAL TOTAL:}

- Partitura de la obra: manuscrita y fotocopiada de copista, en tamaño A3.

- Partitura de la obra: manuscrita y fotocopiada de copista, reducción de la anterior en tamaño A4 (3 unidades).

- Partitura de la obra: manuscrita y original, en un facsímile de 4 páginas, del que ocupa la primera página. Las otras dos son guiones de la entrega de medallas y de la Pasacaglia.

- Partes: Partes manuscritas y originales de copista.

- Existe una versión orquestal (solamente la partitura manuscrita y original) junto a la versión orquestal de la Pasacaglia (Promenade) en un facsímile de 12 páginas con el título Medallas: Fanfarra, Pasacaglia (ORQ)

- No consta relación de originales y copias. 
3.2.5. BANDA 
1.- ALÉ VINAROÇENC, Libre, en Mi, banda, con guion, 2007, Arc. 27

La plantilla a la que está dedicada es la de una banda.

Ver: FANFARRIA.
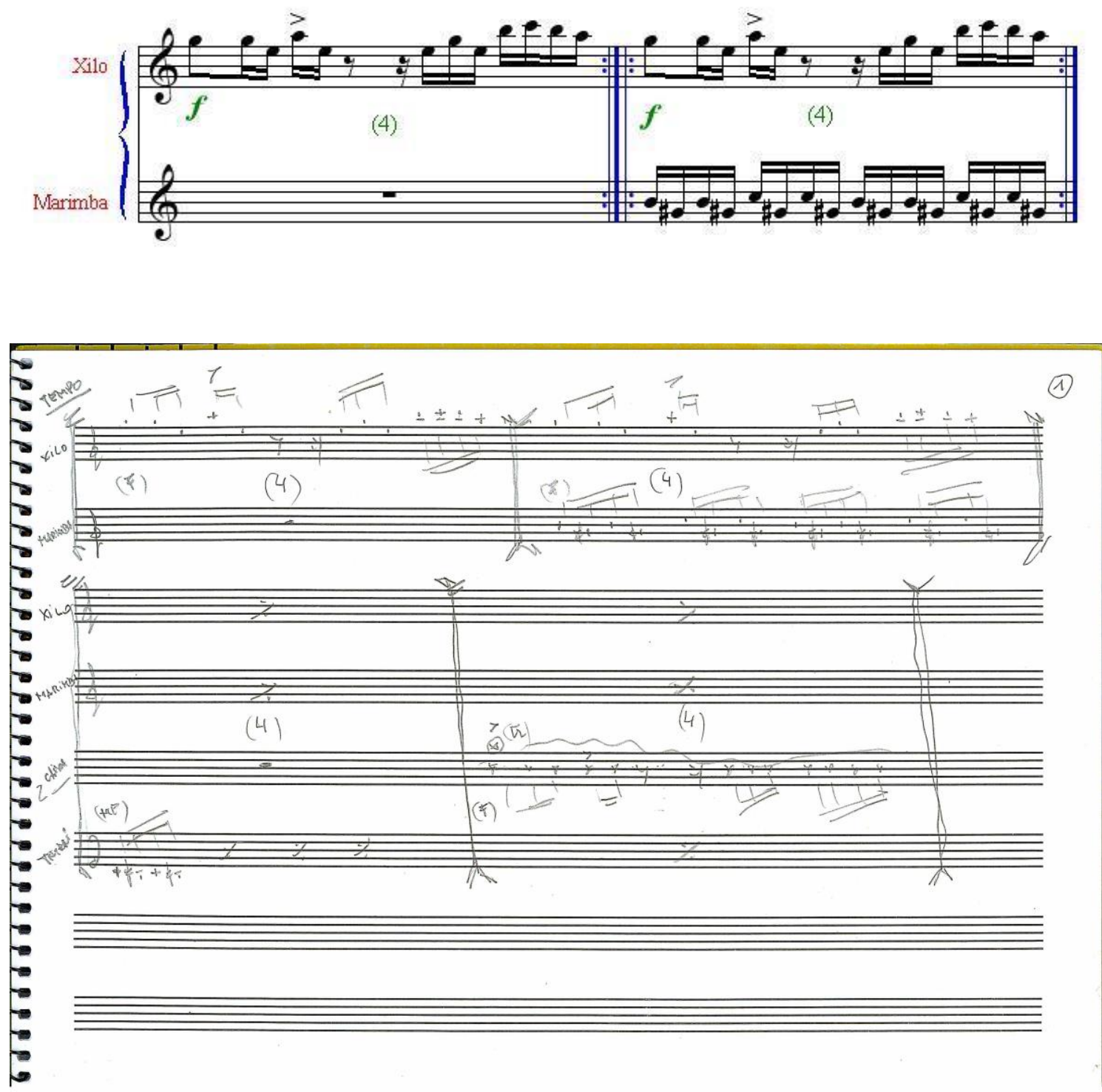

Compuesta para la Acción musical realizada en Vinaròs, el 30 de junio de 2007 con motivo de la entrega del Premio "Alé Vinaroçenc" a la Banda de Vinaròs, por parte de la Caixa Rural de Vinaròs (Mecenas de la Fundación). La interpretación se realiza subiendo los intérpretes de uno en uno (o por grupos instrumentales) al escenario y una vez en el mismo, comienzan la ejecución escrita. Poco a poco el escenario va llenándose de músicos hasta que el director ocupa su lugar en última posición. En su estreno no se 
interpretó la totalidad de la obra. Por el momento no existe el estreno en su versión actual, acabada.

Es la misma obra que Fanfarria.

\section{MATERIAL TOTAL:}

- Partitura manuscrita y original del autor. Consta de un bloc de escritura musical, tamaño A4 apaisado de 26 hojas, con el título Alé en el exterior y 33 páginas manuscritas y originales. Puede existir copia impresa.

- Partes: No existen partes.

- No consta relación de originales y copias. 
2.- BELMONTE, Pasodoble, Sol m, banda sinfónica, con partitura y partes, 1988, G. 4

La plantilla a la que está dedicada es la de una banda sinfónica (incluye cuerda).

Obra dividida en 18 partes. Las 8 primeras (A a $\mathrm{F}(\mathrm{c})$ ) se suelen interpretar independientemente.
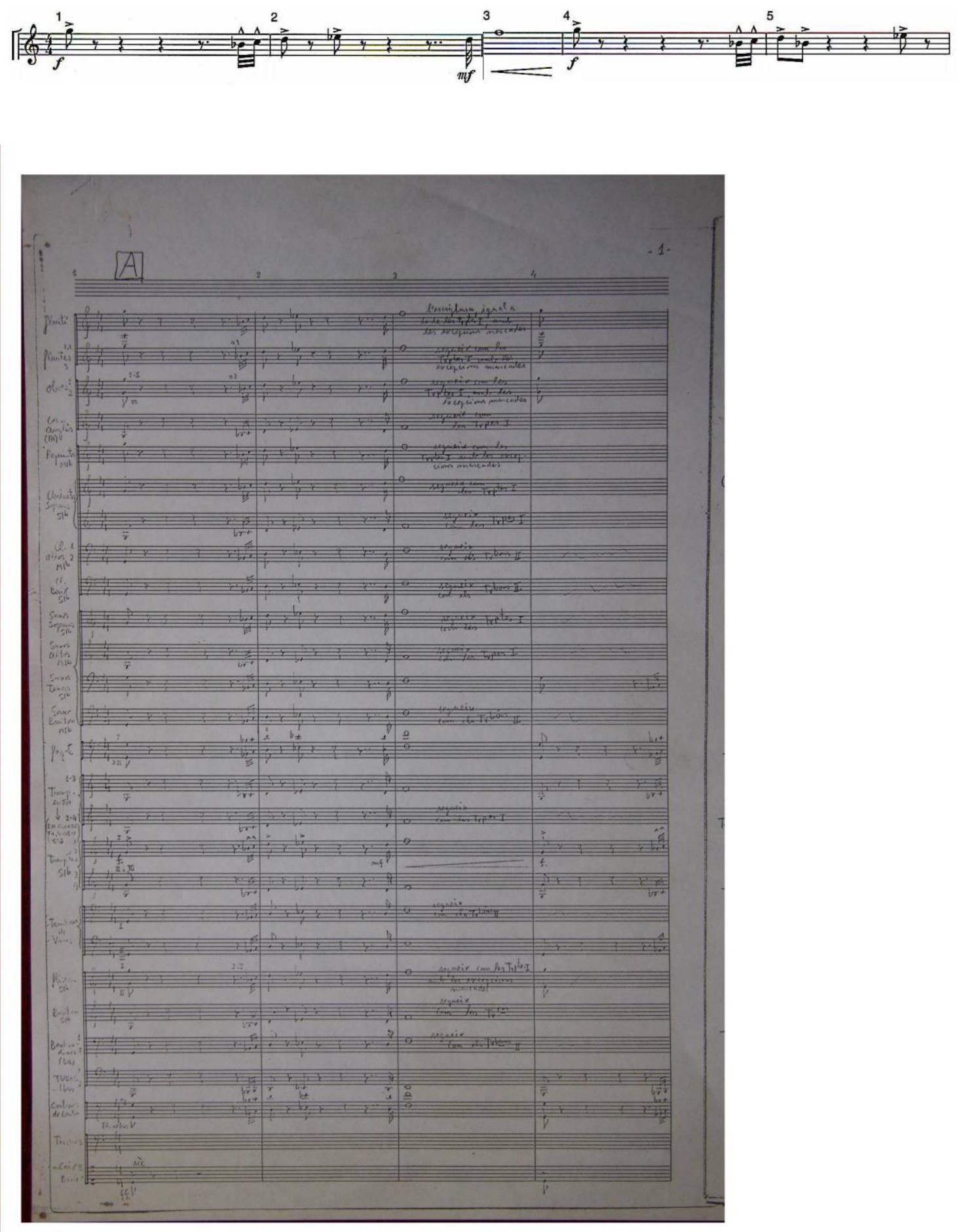
Encargada a la Banda Municipal de Barcelona. Estrenada el 4 de noviembre de 1988 con la Banda Sinfónica Unió Musical de Lliria.

Existe una grabación en CD editado por Virgin, en 1990.

\section{MATERIAL TOTAL:}

- Partitura de la obra: manuscrito del autor, fotocopia, 195 páginas, Todos los papeles en Do. Título Belmonte.

- Partitura de la obra: manuscrito del autor, fotocopia, 234 páginas, Todos los papeles en Do. Sin título.

- Partitura de la obra: manuscrito del autor, fotocopia, como la anterior, dividida por partes.

- Partitura de la obra: impresa ${ }^{70}$, original, en formato A4, sin encuadernar, 188 páginas. Todos los papeles en Do. El número de compases de cada parte es el siguiente:

\begin{tabular}{|c|c|c|c|c|c|}
\hline PARTE & COMPASES & PARTE & COMPASES & PARTE & COMPASES \\
\hline $\mathrm{A}$ & 54 & B & 88 & C & 60 \\
\hline $\mathrm{D}$ & 62 & $\mathrm{E}$ & 56 & F (a) & 137 \\
\hline $\mathrm{F}(\mathrm{b})$ & 137 & $\mathrm{~F}(\mathrm{c})$ & 137 & $\begin{array}{l}\text { Sortida del } \\
\text { bou }\end{array}$ & 18 \\
\hline $\mathrm{G}$ & 81 & $\begin{array}{l}\text { Primera llamada } \\
\text { de Trompa }\end{array}$ & 7 & Progressió & 149 \\
\hline $\begin{array}{l}\text { Segona llamada } \\
\text { de Trompa }\end{array}$ & 11 & Banderilles & 95 & Brindis & 47 \\
\hline Pasodoble & 414 & $\begin{array}{l}\text { Tercera llamada } \\
\text { de Trompa }\end{array}$ & 9 & $\mathbf{J}$ & 96 \\
\hline
\end{tabular}

- Partitura de la obra: impresa, copia ampliada de la anterior que contiene las partes $\mathrm{A}$ a $\mathrm{F}(\mathrm{c})$.

- Partes de la obra individuales, manuscritas y originales del autor, con estas referencias:

\footnotetext{
${ }^{70}$ Material realizado por Xavi Piquer con programa Sibelius
} 
- B: Guion manuscrito y original del autor. Consta de un libreto de 8 hojas y 4 páginas numeradas además del reverso de la página 3 , de escritura musical con el título "B (1, 2, 3 i4)". Existen referencias a instrumentos a utilizar.

- C: Partitura manuscrita y original del autor. Consta de un libreto de escritura musical con 3 páginas escritas y numeradas con el título "C (1, $2,3) "$.

○ D: Partitura manuscrita y original del autor. Consta de un libreto de escritura musical con 2 páginas escritas y numeradas con el título "D (1 i 2)". Existen anotaciones para posterior instrumentación.

○ E: Partitura manuscrita y original del autor. Consta de un libreto de escritura musical con 2 páginas escritas y numeradas con el título "E (1 i 2). 3 Trombons".

- F: Partitura manuscrita y original del autor. Consta de 3 hojas sueltas apaisadas de escritura musical con 3 páginas escritas y numeradas, con 133 compases numerados y con el título "F (1, 2 i 3 )". Existen anotaciones para posterior instrumentación.

○ G: Partitura manuscrita y original del autor. Consta de un libreto de escritura musical con 4 páginas escritas, sin numerar y con el título "G (3 Trompetes)". Existen anotaciones para posterior instrumentación. Existe también una partitura manuscrita y fotocopiada de este material, formada por 14 páginas en $\mathrm{A} 3$, más extensa que la anterior, que contiene la instrumentación para toda la banda.

○ J: Partitura manuscrita y original del autor. Consta de 6 hojas sueltas, escritas y numeradas con el título "J, Cantada + solo de tuba" en la primera página. Existen anotaciones del autor para una posterior instrumentación.

- Partes Existen partes manuscritas (copias). En los archivadores 1 y 2 (archivadores verdes) se encuentran las partes de los instrumentos, aunque son fotocopias en su gran mayoría.

- No existen del material impreso.

- No consta relación de originales y copias. 
3.- BLOC DE PROGRÈS 6 DE MAIG, Libre, banda, con partitura y sin partes, s. d., G. 6

La plantilla a la que está dedicada es una plantilla bandística al uso.
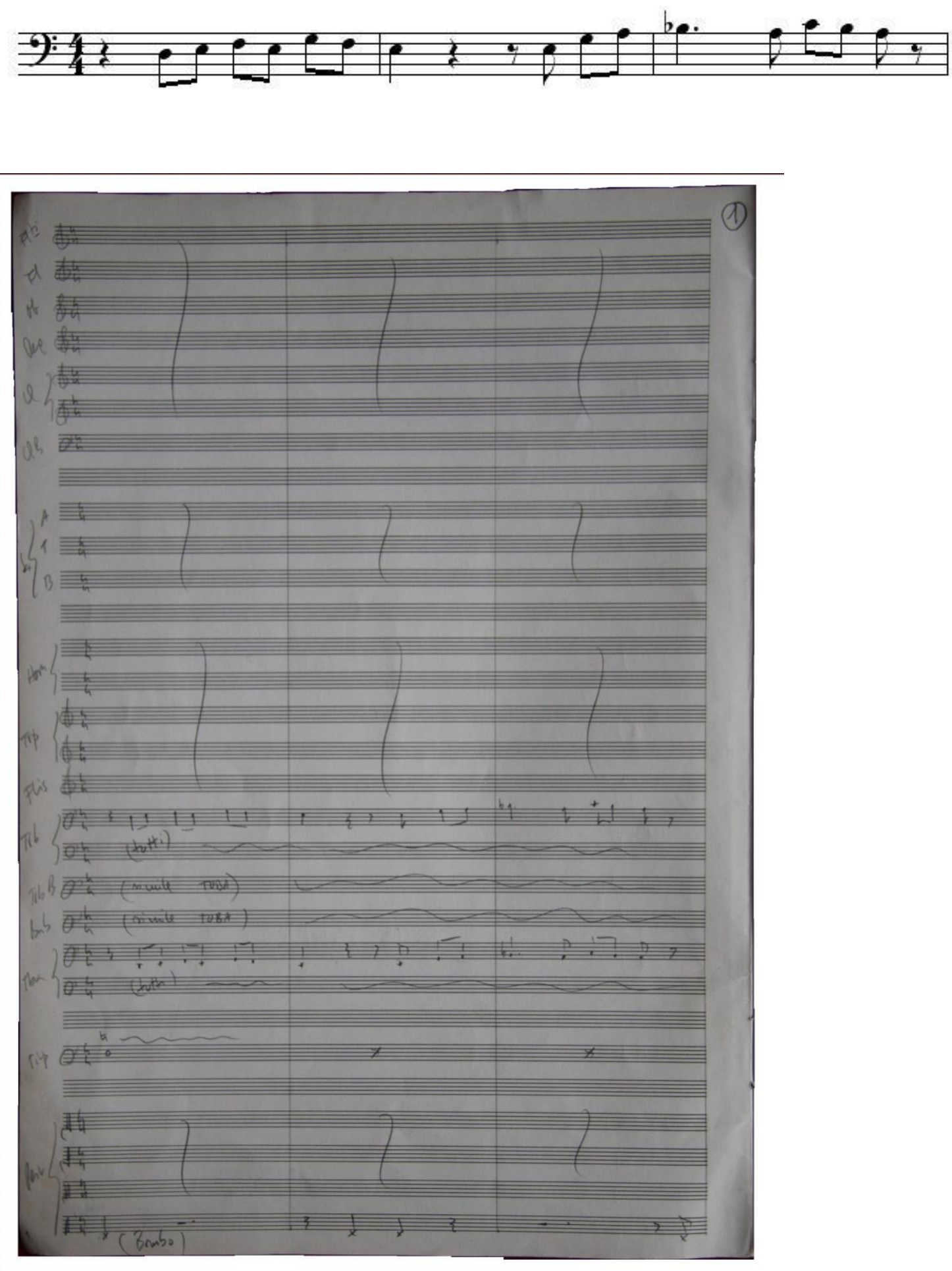
Existe material impreso (fotocopia) y material manuscrito del autor (fotocopia). El material manuscrito da la impresión de ser apuntes del impreso, ya que existe material que, posteriormente no se ha impreso.

\section{MATERIAL TOTAL:}

- Material manuscrito del autor, original, en un bloc de escritura musical con el título inicial de 6 de maig. Bloc de progrés en la tapa y 14 páginas numeradas. Parece ser borrador del material, ya que constan referencias a instrumentos concretos.

- Partitura de la obra: manuscrito del autor, original, 26 páginas, 79 compases. Todos los papeles en Do. Título: Bloc de Progrès 6 de maig. Existe una anotación del autor referente al transporte de algunos instrumentos al hacer las partes.

- Partitura original y manuscrita del autor, en 4 facsímiles numerados (1 a 20, 21 a 40,41 a 60 y 61 a 71) 
4.- COMEDIANS, Libre, politonal, banda y coro (S. A. T. y B.), con partitura y partes, 1992, G. 8

La plantilla a la que está dedicada es la de una banda con la participación de un coro. Ver: PIROMUSICAL
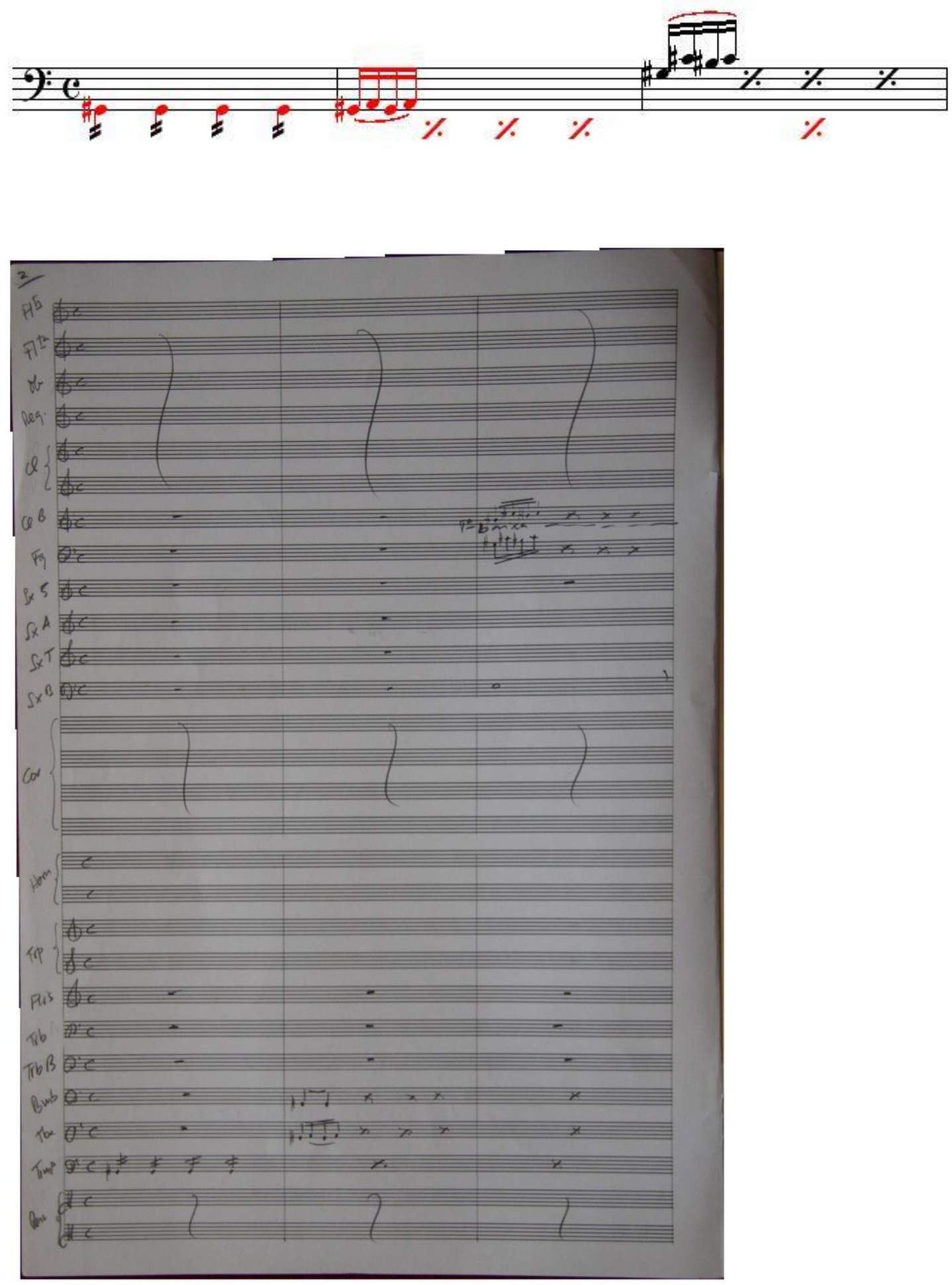
Música escrita e interpretada en el acto de Clausura de los JJ. OO. De Barcelona 92’.

Se corresponde a la pista 15, "Piromusical" del disco Música para las Ceremonias Olímpicas Barcelona '92 grabado en 1993 por On The Rocks.

\section{MATERIAL TOTAL:}

- Partitura de la obra: Partitura manuscrita y original del autor, dividida en 4 facsímiles. Fotocopia encuadernada de toda la partitura con indicaciones del autor (2 unidades).

- Partes: Partes manuscritas y originales de copista (desconocido). Sobrantes fotocopiados. Existen solamente las de la parte instrumental. No existen las de la parte del coro.

- Consta relación de originales y copias. 
4.- CONGRÉS DE CUINA CATALANA, Libre, en Sol, Soprano, Banda y Coro, con partitura, 1995, Arc. 12.

La plantilla a la que está dedicada es la de una banda al uso, soprano solista y coro mixto.

Ver: CUINA CATALANA.
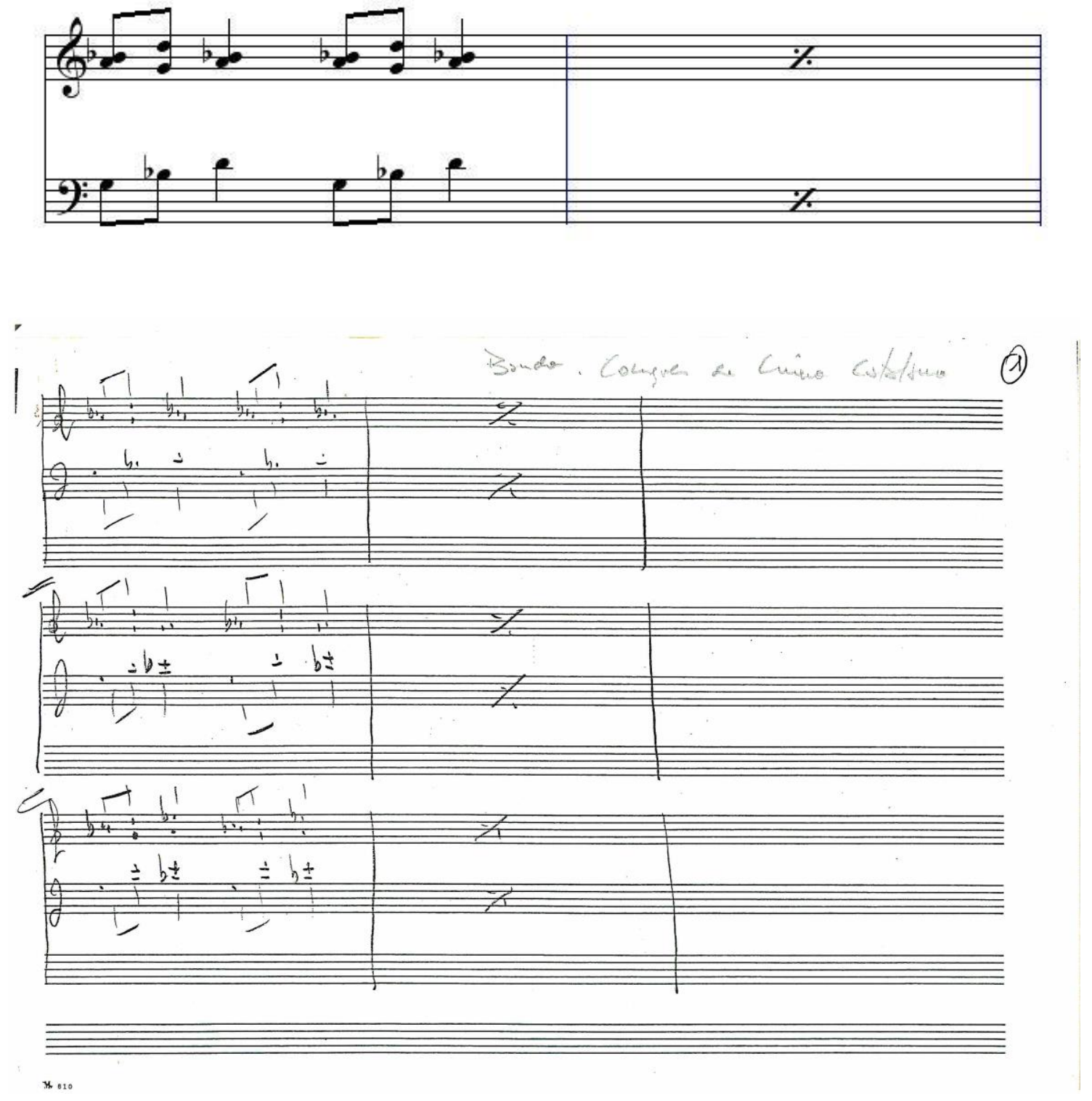

"Forma parte de los apuntes de la música compuesta para el Congrés de Cuina Catalana que posteriormente se instrumentará para Banda". *

Música incluida en el CD Himne, grabado por K-Industria Cultural, en 1995.

${ }^{*}$ Testimonio oral del autor. 


\section{MATERIAL TOTAL:}

- Partitura de la obra: Partitura manuscrita y fotocopiada del autor. Consta de 2 hojas escritas, sueltas y numeradas.

- Partes: No existen partes.

- No consta relación de originales y copias. 
5.- CUINA CATALANA, Libre, en Sol, Soprano, Banda y Coro, con partitura, 1995, Arc. 12.

La plantilla a la que está dedicada es la de una banda al uso, soprano solista y un coro mixto.

\section{Ver: CONGRÉS DE CUINA CATALANA.}
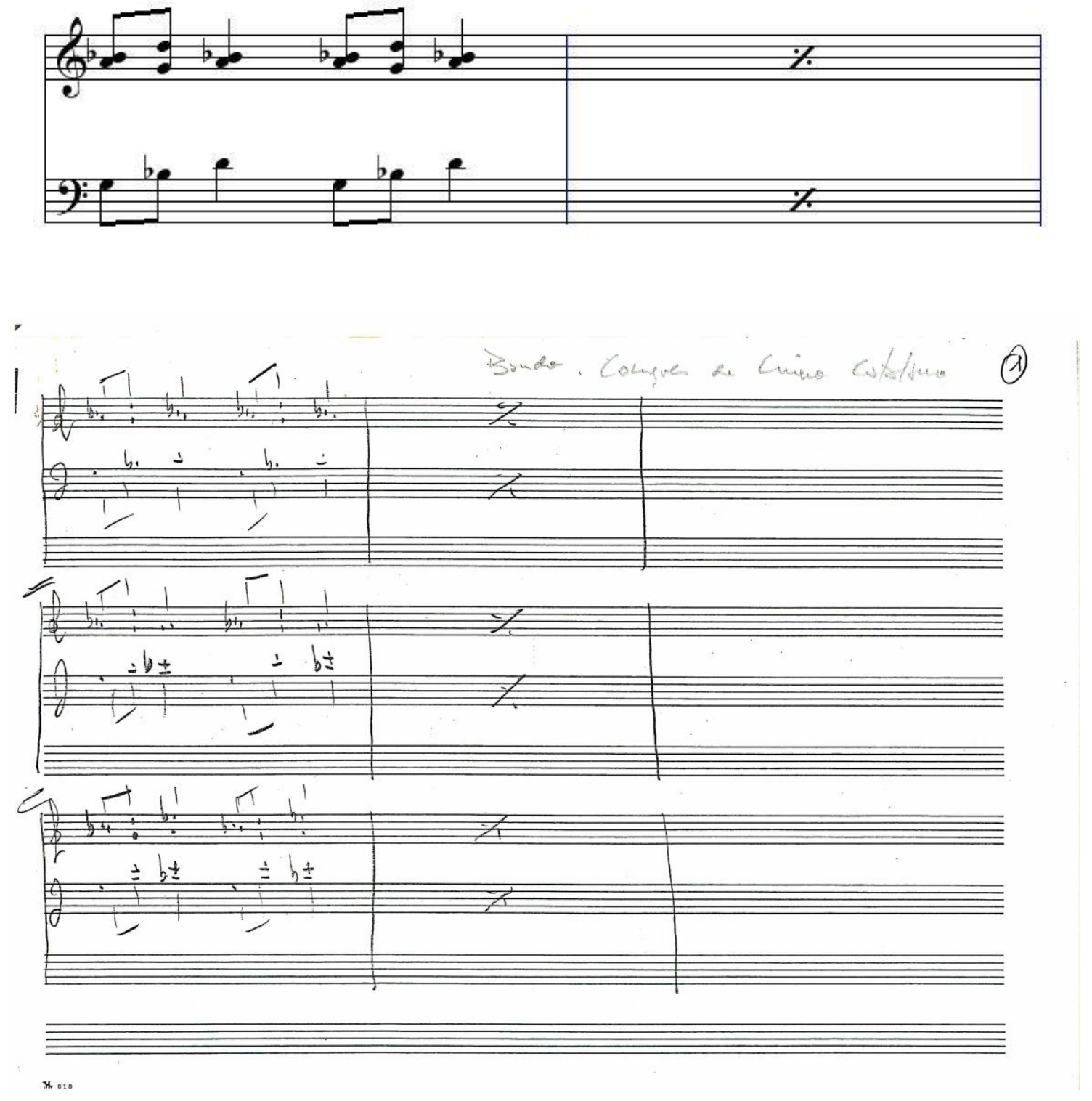

Partitura de la obra incluida en el CD Himne, aunque no sigue la pauta de la grabación. Música incluida en el CD Himne, grabado por K-Industria Cultural, en 1995. 


\section{MATERIAL TOTAL:}

- El material es diverso y pasamos a enumerarlo:

- Material expuesto en la obra Congrés de Cuina Catalana, sección banda.

- Partitura manuscrita y original del autor. Consta de 5 facsímiles numerados (el último como apendix). Existen partes manuscritas y originales, aunque de copista desconocido. Existe guion manuscrito y fotocopiado.

- Material manuscrito del autor, original, en un bloc de escritura musical con los títulos Cuina y Reflex en la tapa. La obra Cuina ocupa 23 páginas y en ella se encuentran los apuntes de la obra, a modo de guion, y la parte del coro, sin desarrollar. En el mismo bloc, por la parte posterior se encuentra la obra Reflex.

- La organización de la obra, grabada en el CD Himne, es la siguiente:

- PRINCIPIO: Congrés de Cuina Catalana, $\mathrm{n}^{\mathrm{o}}$ orden 59* (instrumental), $\operatorname{arx} 12$

○ CORO de Cuina, $\mathrm{n}^{\circ}$ orden 17 (coro), página 2.

- PARTITURA de Cuina Catalana, $\mathrm{n}^{\mathrm{o}}$ orden 70 (instrumental), página 1 a 37, (grabación hasta 9'03')

- VOZ SOLISTA de Cuina, $\mathrm{n}^{\circ}$ orden 17 (voz solista + banda), página 3 a 17, (grabación hasta 12'10'’)

- PARTITURA de Cuina Catalana, $\mathrm{n}^{\circ}$ orden 70 (instrumental), páginas 37 a 52, (grabación hasta 14'23'’)

- CORO de Cuina, $\mathrm{n}^{\circ}$ orden 17 (coro), página 20 a 23, (grabación hasta 16 '02'’)

- PARTITURA de Cuina Catalana, $\mathrm{n}^{\circ}$ orden 70 (instrumental), página 52 a 64, (grabación hasta final)

- De la pág. 65 a la 69 de la partitura, hay un apéndice, que se corresponde con la instrumentación del inicio de la obra (Congrés de Cuina Catalana, $\mathrm{n}^{\circ}$ orden 59 instrumental-)

- Partes: Existen partes.

- Existe relación de partes y copias.

\footnotetext{
${ }^{*}$ En $n^{\circ}$ de orden al que se hace referencia corresponde a una tabla EXCEL utilizada en el inventario del material encontrado.
} 
6.- FANFARRIA, Libre, en Mi, banda, con guion y partes, 2007, Arc. 27

La plantilla a la que está dedicada es la de una Banda Sinfónica.

Ver: ALÉ VINAROÇENC.
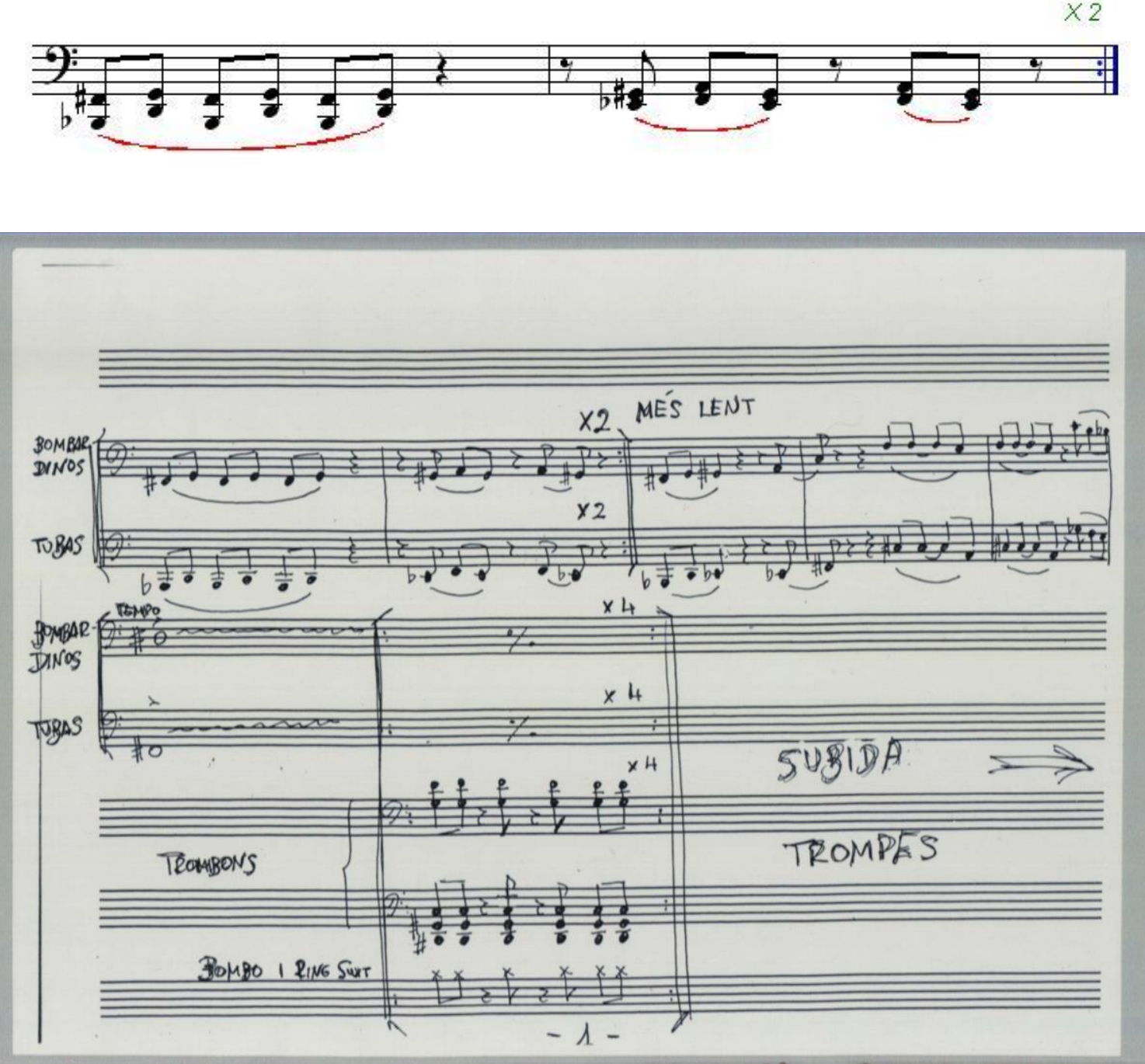

Música escrita para conmemorar el centenario de la fundación de la Banda de Música "La Alianza" de Vinaròs en 2007.

Es la misma obra que Alé vinaroçenc.

\section{MATERIAL TOTAL:}

- Partitura de la obra: Guión manuscrito y original del autor en un bloc de escritura musical con páginas numeradas en el interior de la 1 a la 12. Archivo 
particular de Carles Santos. Partitura manuscrita y fotocopiada del autor (2 materiales grapados).

- Partitura adjunta de la obra: Manuscritas y fotocopiadas de copista (José Ramón Renovell), que consta como una partitura adjunta (2 unidades).

- Partes: Partes manuscritas y fotocopiadas de copista (José Ramón Renovell). Sacadas de la misma partitura adjunta. Existen partes de percusión que no están reflejadas en el guión del autor ni en la partitura adjunta. Existen sobrantes. Material en el archivo de la Banda "La Alianza" de Vinaròs y cedido por José Ramón Renovell, director de la misma. 
7.- F.N.A.C., Pasodoble, Do M, banda, con partitura y partes, 1997, G. 2

La plantilla a la que está dedicada es una plantilla bandística al uso. La armonía empleada tiene como base acordes de 4 sonidos, de $7^{\text {a }}$, sustituyendo la $3^{\mathrm{a}}$ del acorde por la $4^{\mathrm{a}}$. Tonalmente comienza en Do M y finaliza en un acorde sobre el Mib.
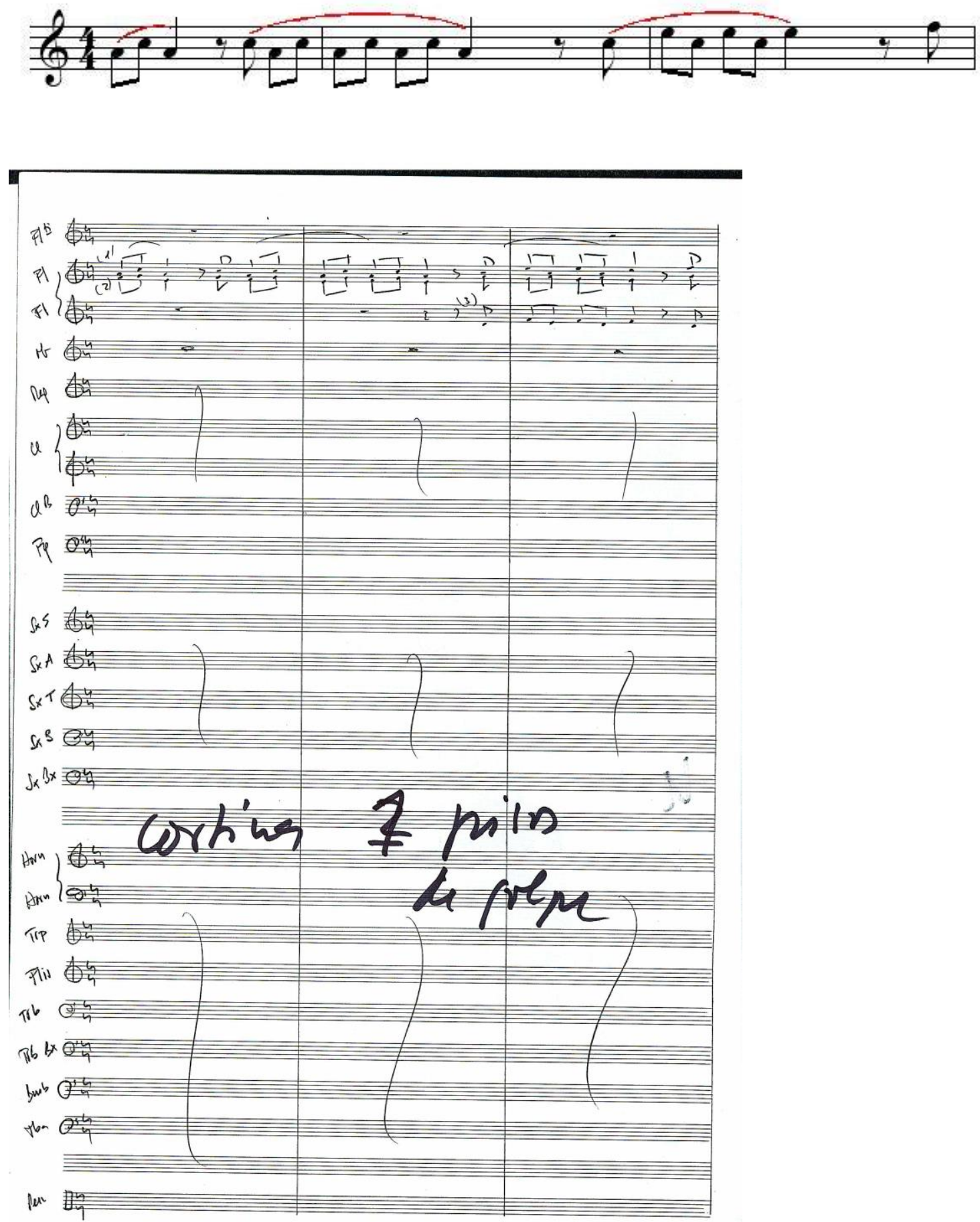
Partitura original y manuscrita del autor. Contiene una fotocopia de la partitura con anotaciones del autor sobre elementos escénicos (cortinas) en diversos momentos de la interpretación. Sólo existen partes, no originales, de Trompeta y Trombón.

Compuesta para la inauguración del espacio FNAC de Valencia, sito en la calle Guillem de Castro, el 3 de noviembre de 1997. La Banda participante fue la Unió Musical de Lliria.

\section{MATERIAL TOTAL:}

- Partitura de la obra: manuscrito del autor, original, 17 páginas, 55 compases. Todos los instrumentos en Do. Título F.N.A.C.. Contiene una fotocopia de la partitura con anotaciones del autor sobre elementos escénicos (cortinas) en diversos momentos de la interpretación. No existen anotaciones del autor en los referente al transporte de algunos instrumentos al hacer las partes, lo cual hace pensar que estas no se realizaron.

- Partes: No existen partes.

- No consta relación de partes y copias. 
8.- GANDÍA, libre, politonal, Soprano y Bajo solista, Coro de niños, Coro mixto y Banda, con partitura, 2010, Arc 27.

La plantilla a la que está dedicada es Soprano y Bajo solista, Coro de niños, Coro mixto y Banda.

Ver: GANDÍA (sección Otras agrupaciones).

También conocida como El cant del Duc.
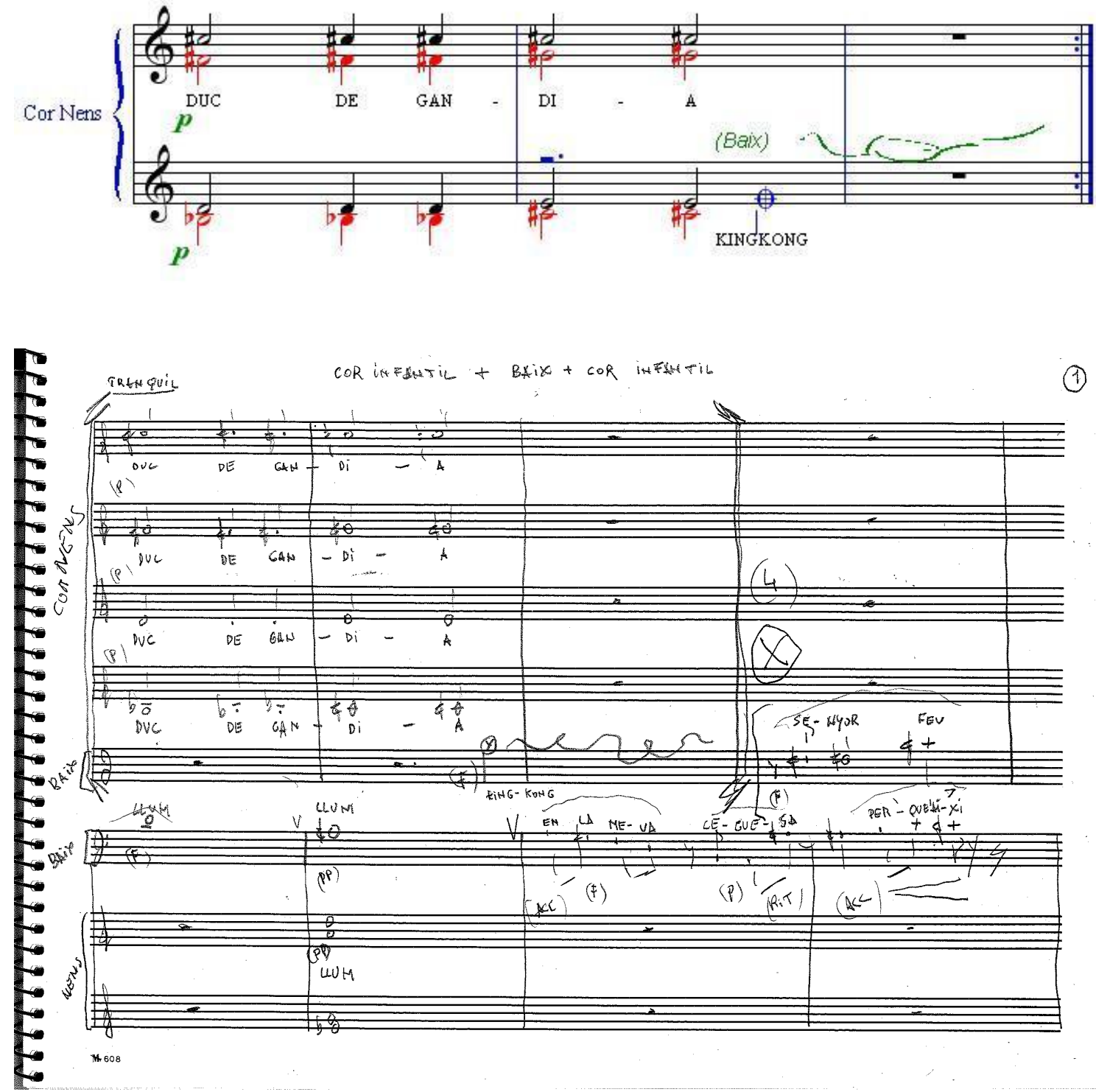
9.- LA VEU DE LA TERRA, Cantata, en Re M., banda, coro y dulzainas, con partitura y partes, 1997, archivador 12.

La plantilla a la que está dedicada es la de una banda de Música, coro y grupo de dulzainas.
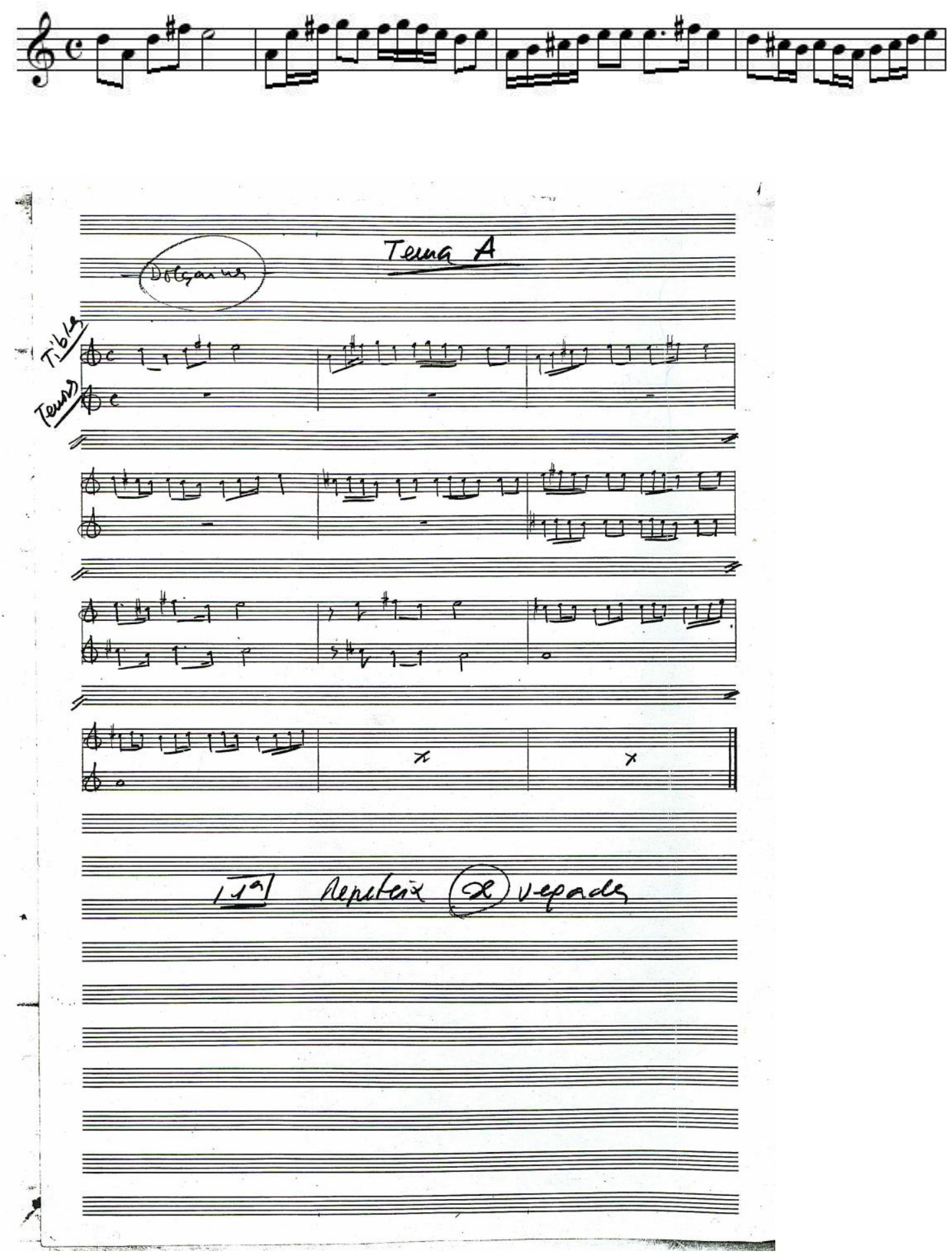
Obra dividida en 4 partes: Temas "A", "B", "C" y "Moixeranga".

Compuesta para el homenaje a Joan Fuster. Estrenada en la Plaza de toros de Valencia el 26/04/1997.

\section{MATERIAL TOTAL:}

- Partitura de la obra: Partitura manuscrita y fotocopiada del autor. Consta de un facsímile con 29 hojas escritas y sin numerar. Existe una copia de la partitura.

- Partes: Existen partes originales y manuscritas de cada instrumento.

- No consta relación de originales y copias. 
10.- LLIRIA-VINARÒS, Pasodoble, Do m, banda, con partitura y partes, s. d., G. 6

La plantilla a la que está dedicada es una plantilla bandística al uso, teniendo como particularidad papeles de Saxo Soprano y Saxo bajo.
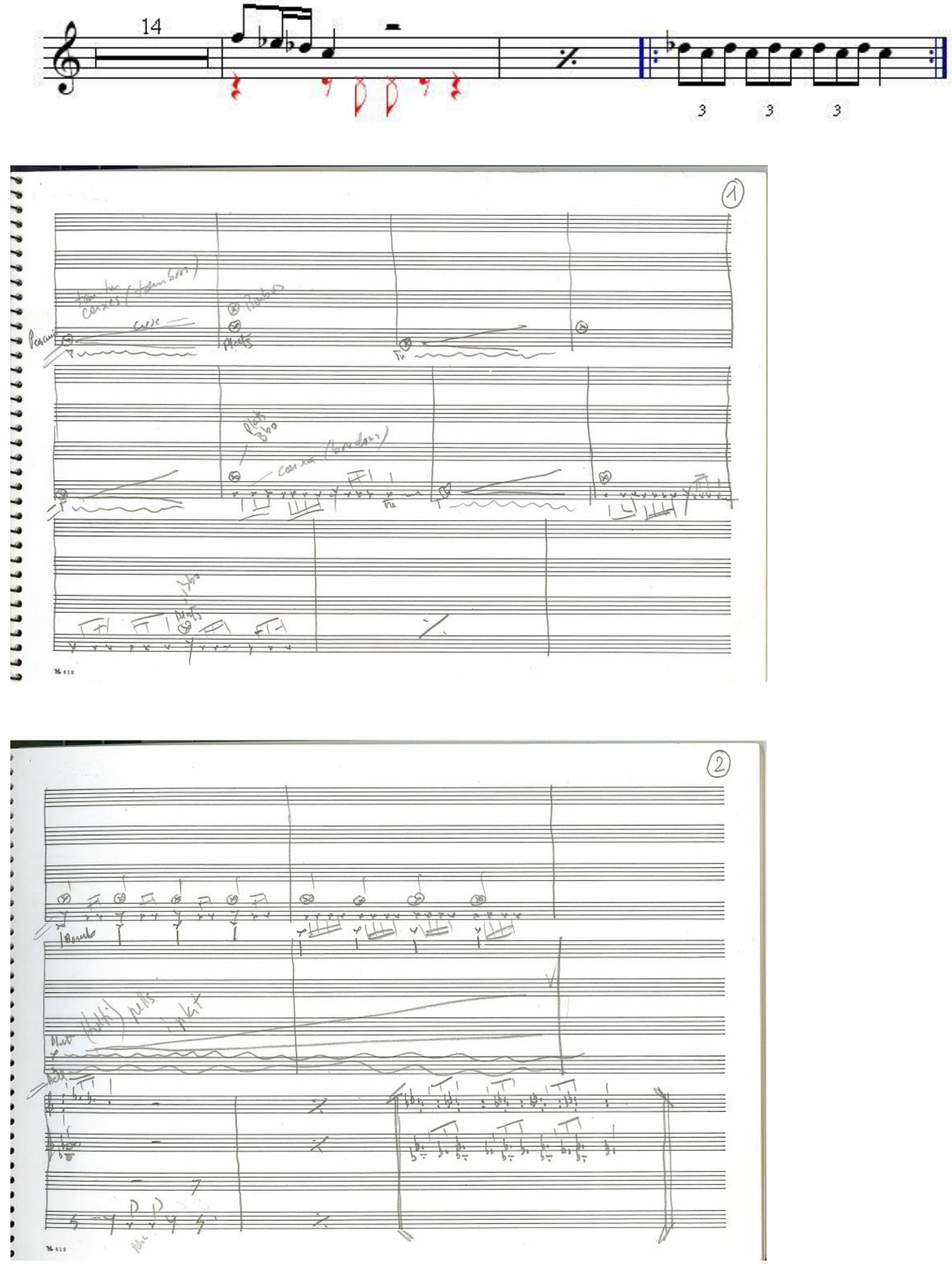
Material en el archivo de la U. M. de Lliria. Faltan partes de Fagot, Trombón Bajo, Bombardino, Tuba i 1 ó 2 papeles de Percusión (Toms, Platos i Bombo).

\section{MATERIAL TOTAL:}

- Guión de la obra: manuscrito del autor, original, 23 páginas, 223 compases. Contiene una dirección particular en la última página. Título: Lliria-Vinaròs. Escrita en un bloc de escritura musical escolar.

- Partitura manuscrita del autor, original, en 2 facsímiles grandes.

- Partes: manuscritas y originales, en formato grande. Existen copias. y sobrantes fotocopiados.

- Consta relación de originales y copias. 
11.- MISTERI D'ELX, Libre, Re m, banda, solamente partes, 1995?, Arc. 14

La plantilla a la que está dedicada es la de una banda.
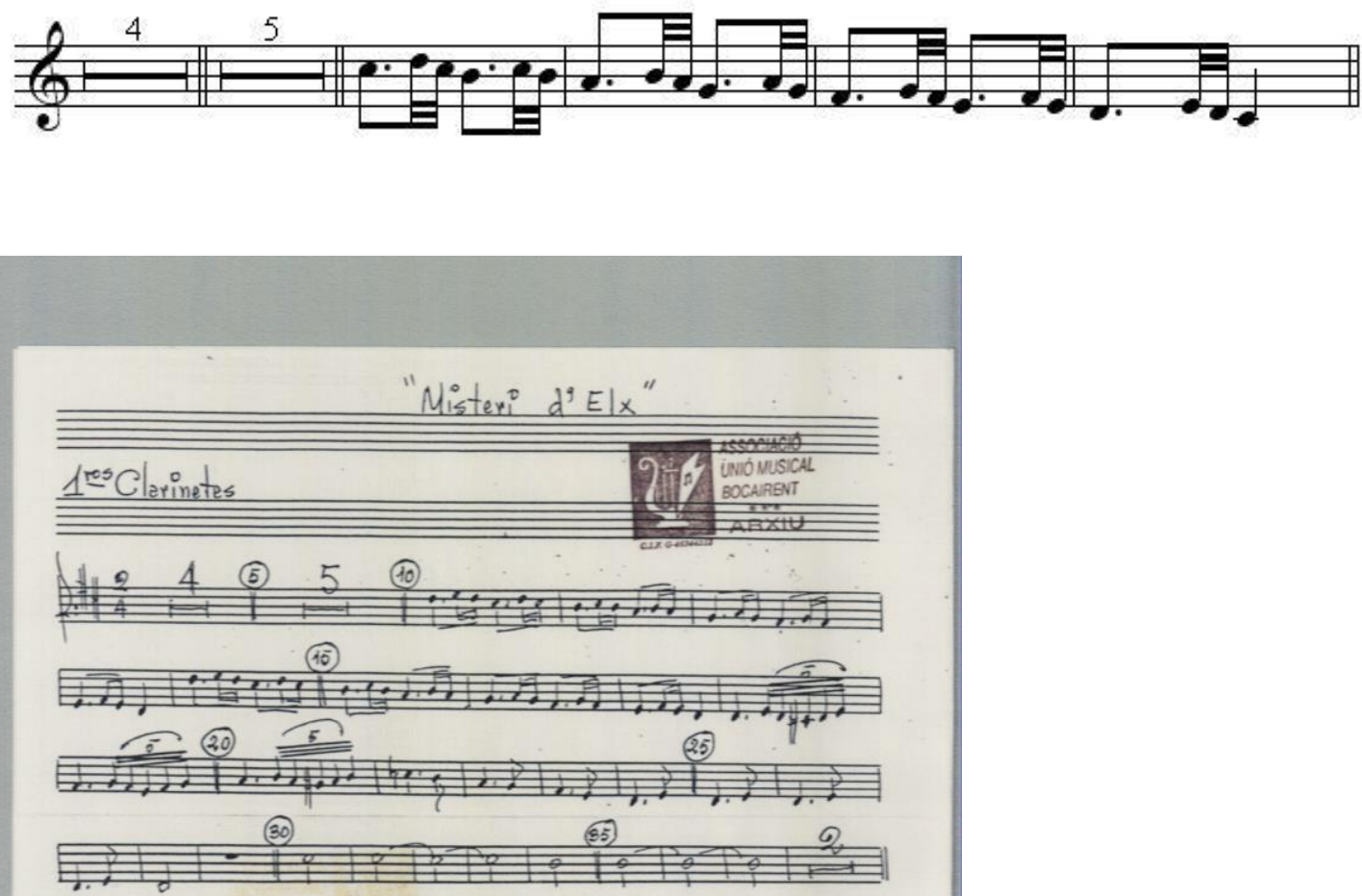
(40)

(45)
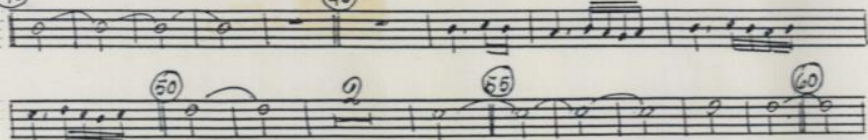

(101)

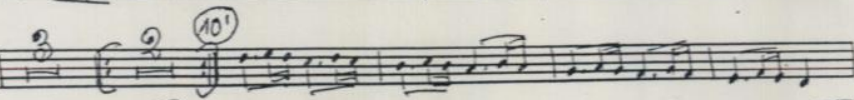

(15i)
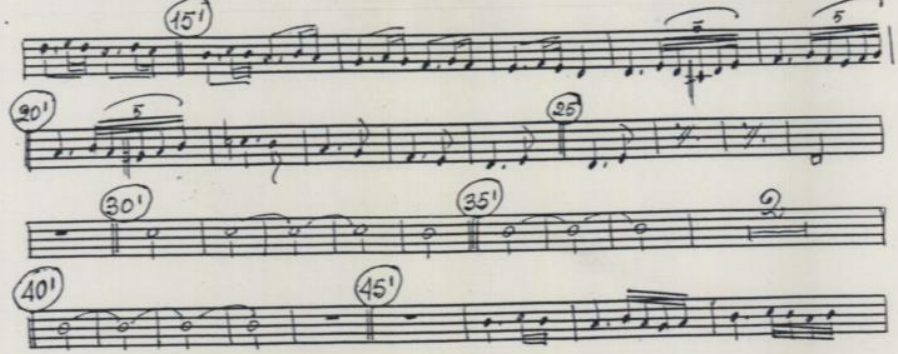


\section{MATERIAL TOTAL:}

- Partitura de la obra: No consta. Tampoco Guión.

- Partes Existen partes manuscritas, copias (de Clarinetes a Percusión, faltan flautas, oboes y fagot, si los hubiese). Las copias llevan el cuño del archivo de la Associació Unió Musical de Bocairent.

- No consta relación de originales y copias. Tampoco el nombre del autor por lo que queda en entredicho la autoría de la misma. Santos, debido a la falta de material, tampoco puede, hoy por hoy, asegurar esta autoría. 
12.- MORELLAR MORELLA, Libre, en Re menor, banda, órgano, coro y soprano solista, con partitura y partes, 2011., Arc. 20.

La plantilla a la que está dedicada es una plantilla bandística al uso, incluyendo Órgano, Coro y Soprano solista.
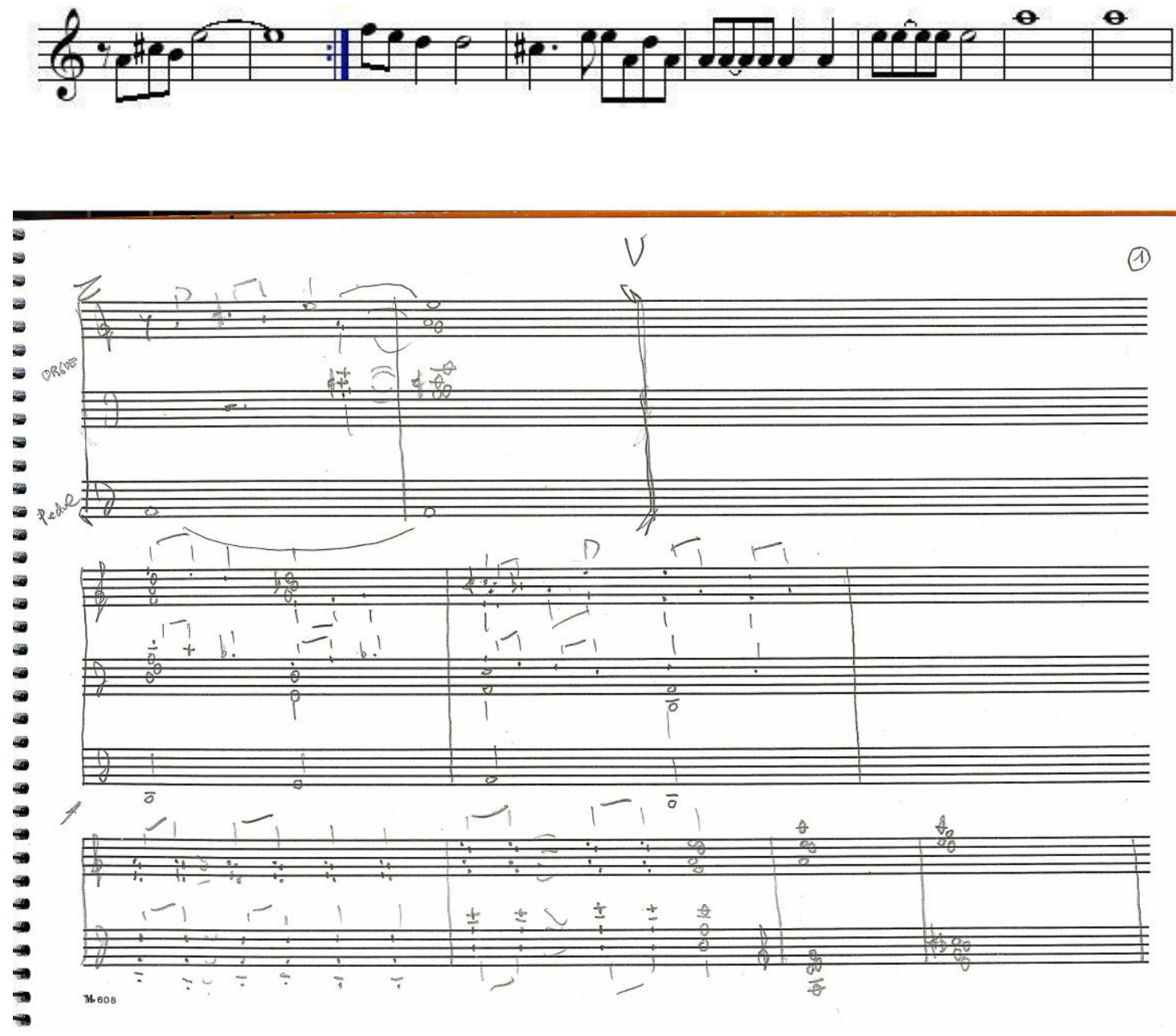

Compuesta para el evento "Com sona l'ESO” de 2011, celebrado en Morella (Castellón) (11 a 14 de mayo)

\section{MATERIAL TOTAL:}

- Partitura de la obra: Guión manuscrito y original del autor en un bloc de escritura musical, tamaño A4 apaisado de 28 hojas, con el título (Morella) en el exterior y 26 páginas manuscritas y originales. 
- Partitura de la obra: PDF realizado por Xavi Piquer en soporte informático (Sibelius para Mac) sobre el guión del autor antes mencionado.

- Partes: PDF originales sacados de la partitura anterior.

- No consta relación de originales y copias. 
13.- MUSICA PER LES VICTIMES DE LA INTOLERANCIA, Pasodoble, Re m, banda, solamente partes, 1995?, Arc. 14

La plantilla a la que está dedicada es la de una banda.
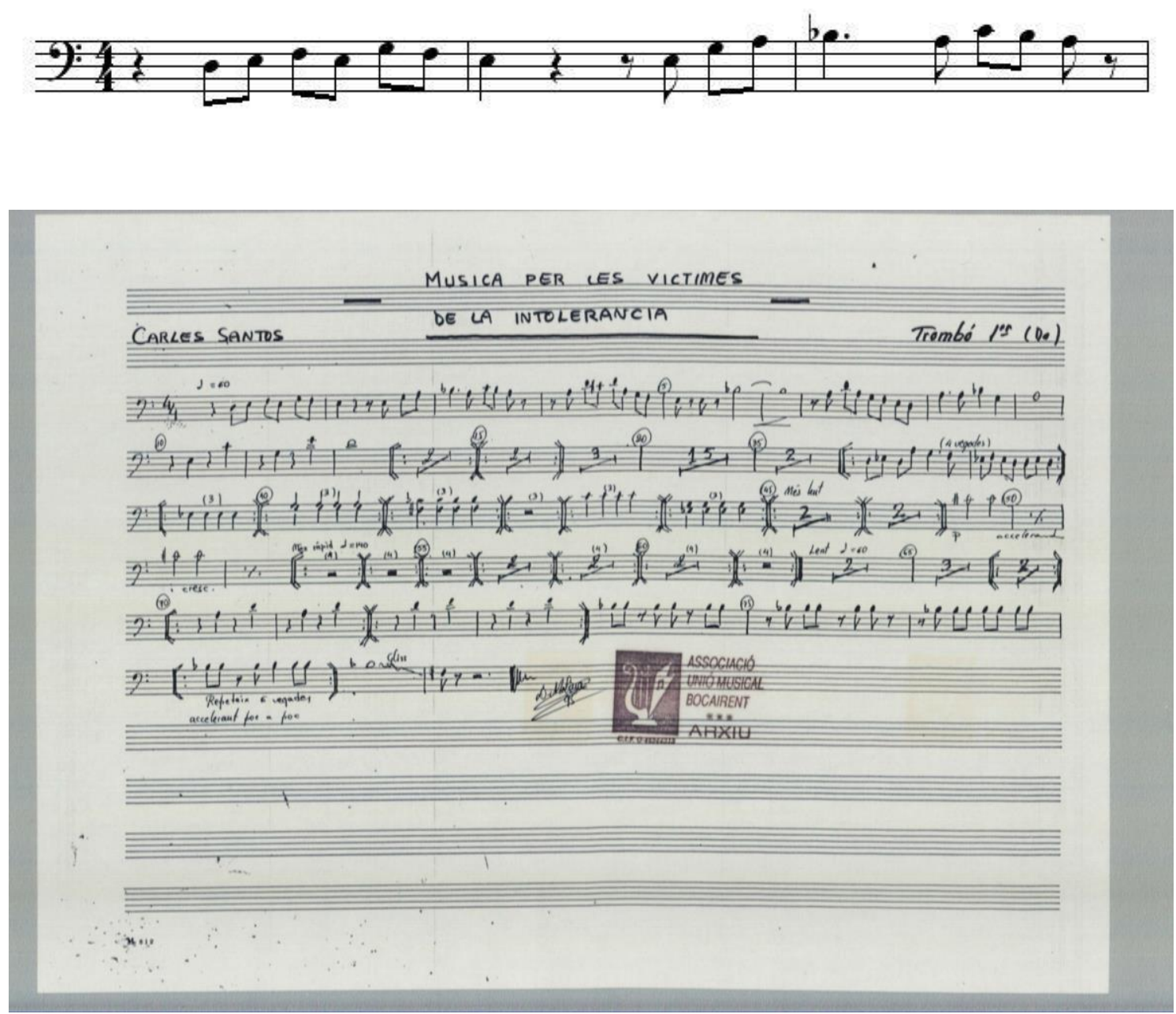

El íncipit es el mismo que el de la obra Bloc de progrés 6 de maig. Dado que no existe partitura ni guión de esta pieza que estamos catalogando, no se puede asegurar que es la misma, aun que con otro título. 


\section{MATERIAL TOTAL:}

- Partitura de la obra: No consta. Tampoco Guión.

- Partes Existen partes manuscritas, originales y copias, así como sobrantes. Las copias llevan el cuño del archivo de la Associació Unió Musical de Bocairent. Copista de las partes: D. Molina. Existen sobrantes.

- No consta relación de originales y copias. 
14.- PASODOBLE-2, Pasodoble, Si m, banda, con partitura y partes, 1992. G. 1

La plantilla a la que está dedicada es una plantilla bandística al uso.

Ver: SEVILLA
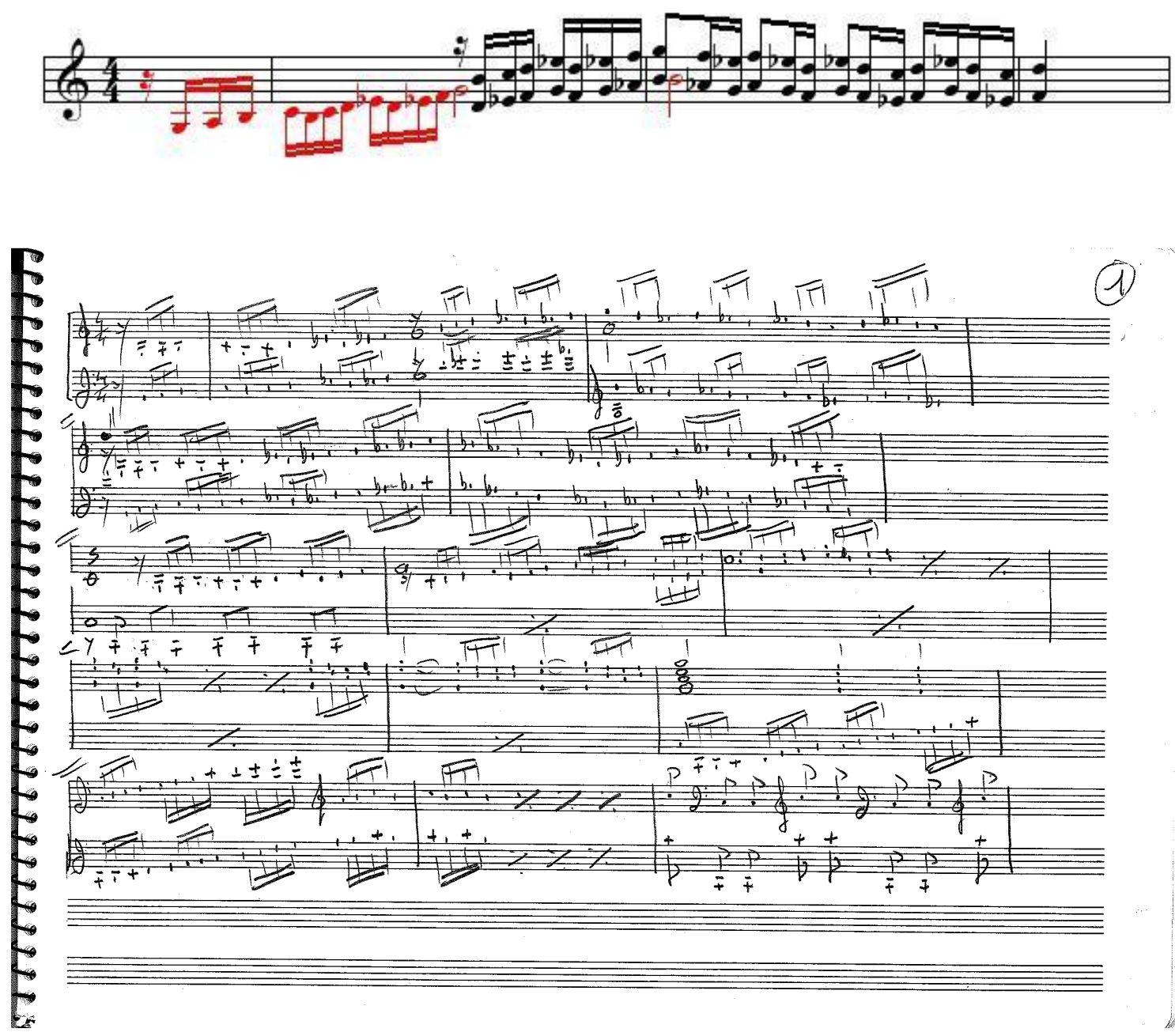

Composición para celebrar la Exposición Universal de Sevilla '92.

MATERIAL TOTAL:

- Partitura manuscrita y original del autor. Consta de un bloc de escritura musical con el título Pasodoble-2 en la tapa y con 23 páginas escritas y numeradas a las que siguen 5 páginas más. La música escrita en este material es igual a la música escrita en la obra Sevilla, aunque comienza a mitad de la misma.

- Partes: No existen partes.

- No consta relación de originales y copias. 
15.- PRINCIPI DEL GENESIS, Libre, politonal, Banda e instrumentos de lata, con partitura, s. d., s. 1.

La plantilla a la que está dedicada es una Banda e instrumentos de lata.
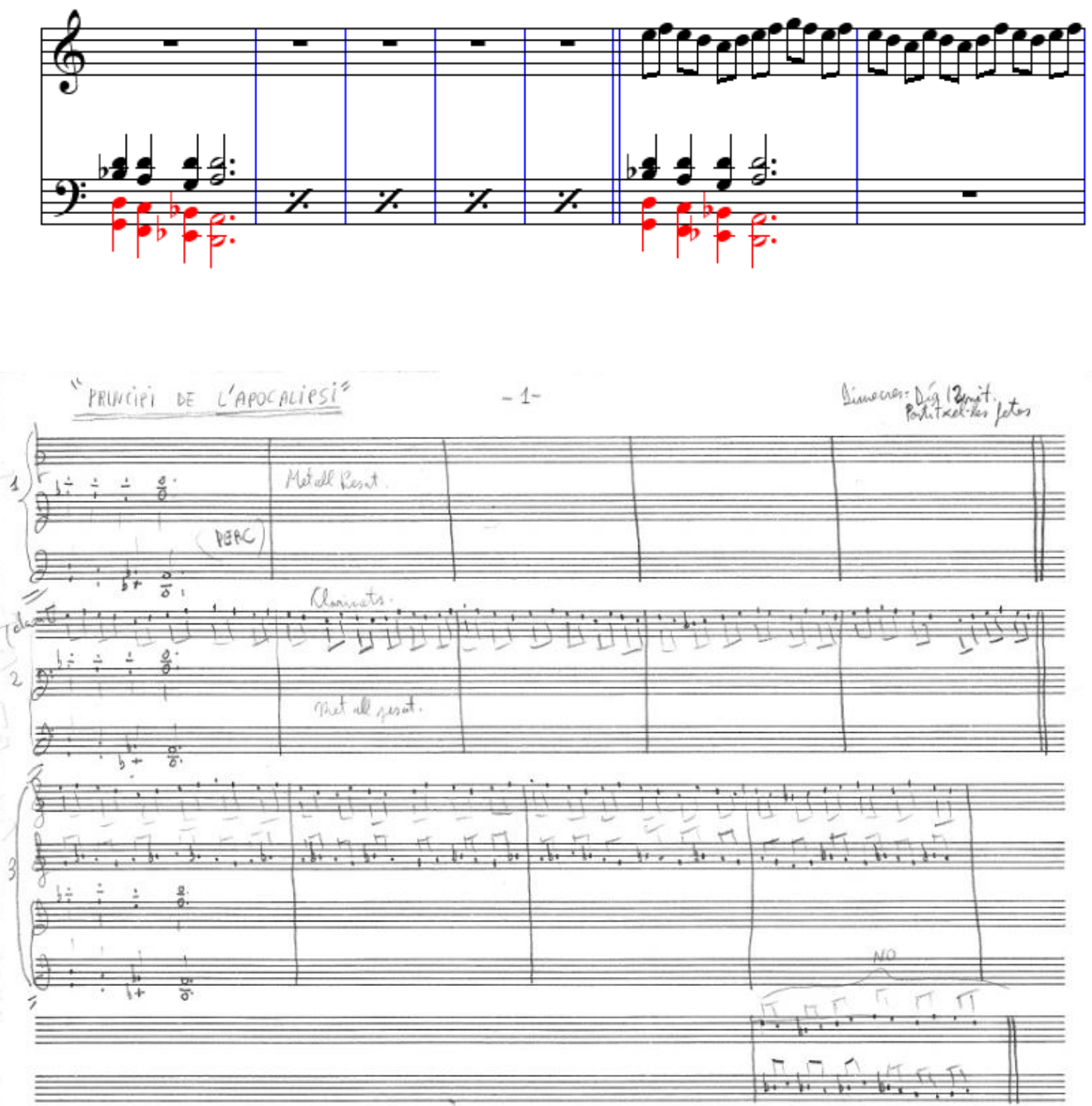

\section{MATERIAL TOTAL:}

- Material manuscrito y original del autor. Consta de 1 partitura de escritura musical, con el título Principi de Gènesis en el exterior. Páginas numeradas de la 1 a la 53. La partitura se divide en varias partes: "Principi de l'Apocalipsi", "A", "1er interludi de llaunes", "B”, “2n interludi de llaunes", “C”, “3er interludi de llaunes", "D”, “4t interludi de llaunes", "E”. 
- Asimismo existen 4 hojas sueltas con indicaciones de la estructura y la instrumentación de la obra.

- Partes: No existen partes.

- No consta relación de originales y copias. 
16.- PROMENADE, Marcha, Sol M, banda, con partitura y partes, 1992, G. 8

La plantilla a la que está dedicada es una plantilla bandística al uso, con metales muy divididos (trombones y trompetas x5).
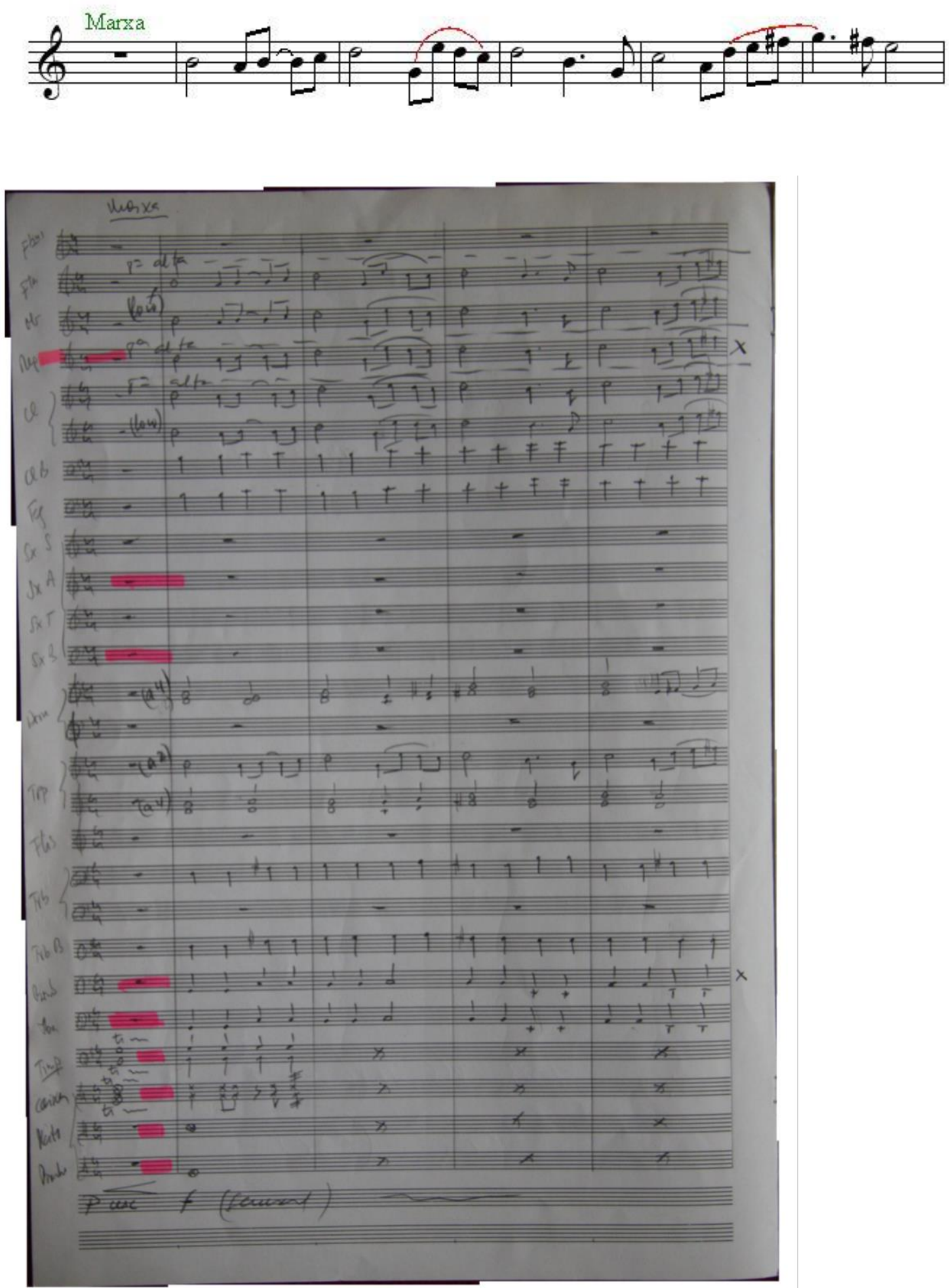
Se corresponde a la pista 2, "Fanfarra Promenade (entrega de medallas)" del disco Música para las Ceremonias Olímpicas Barcelona '92 grabado en 1993 por On The Rocks.

Obra cíclica sin final. El final lo marca el director en cualquier momento. Compuesta para el acto de imposición de medallas en las Olimpiadas de Barcelona 92'. Estructura A-A1-A2.

Existe una partitura para orquesta. (Ver: MEDALLES PROMENADE (sección Orquesta).

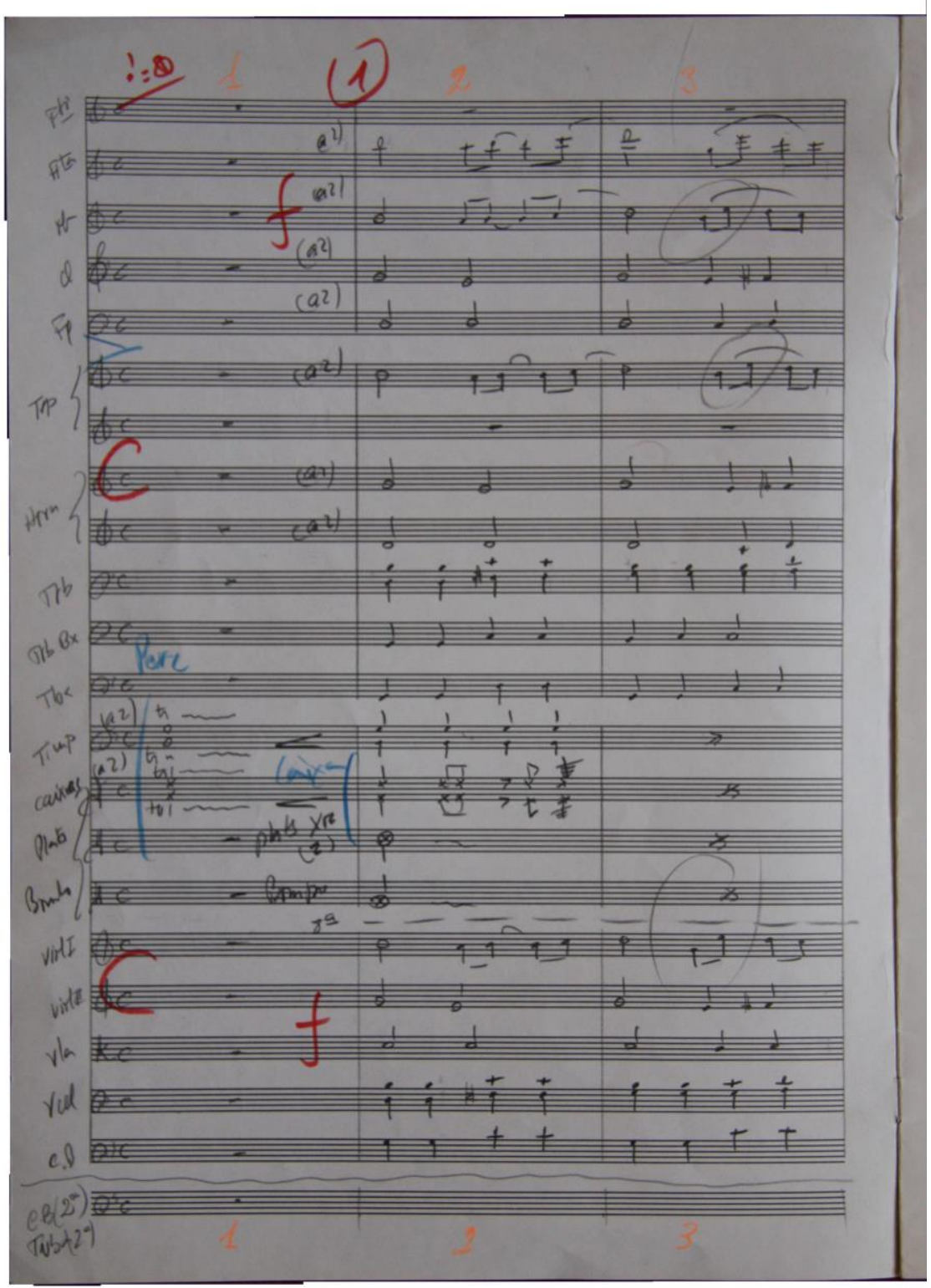




\section{MATERIAL TOTAL:}

- Partitura de la obra: manuscrito del autor, original, 8 páginas, 25 compases. Todos los papeles en Do. Título: Promenade. Existe una fotocopia.

- Partes: manuscritas y originales, en formato grande. Existen copias. y sobrantes fotocopiados.

- Consta relación de originales y copias. 
17.- RIERADA MUSICAL, Libre, politonal, banda, coro, orquesta sinfónica, tibles y gralles, con partitura y partes, 1999, Arc.11.

La plantilla a la que está dedicada es múltiple, admitiendo otras formaciones diversas. Ver: RIERADA MUSIAL (sección Otras agrupaciones).

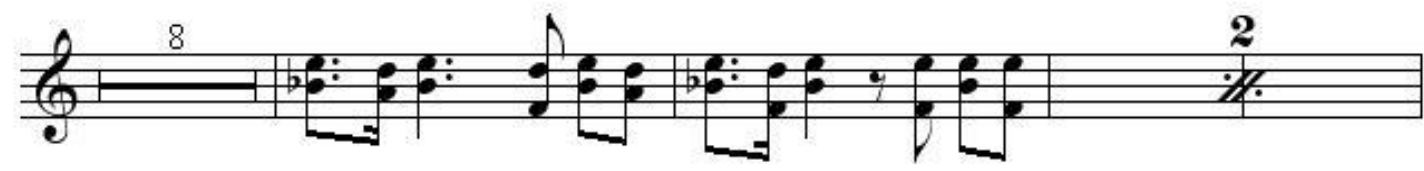

$R_{i}$
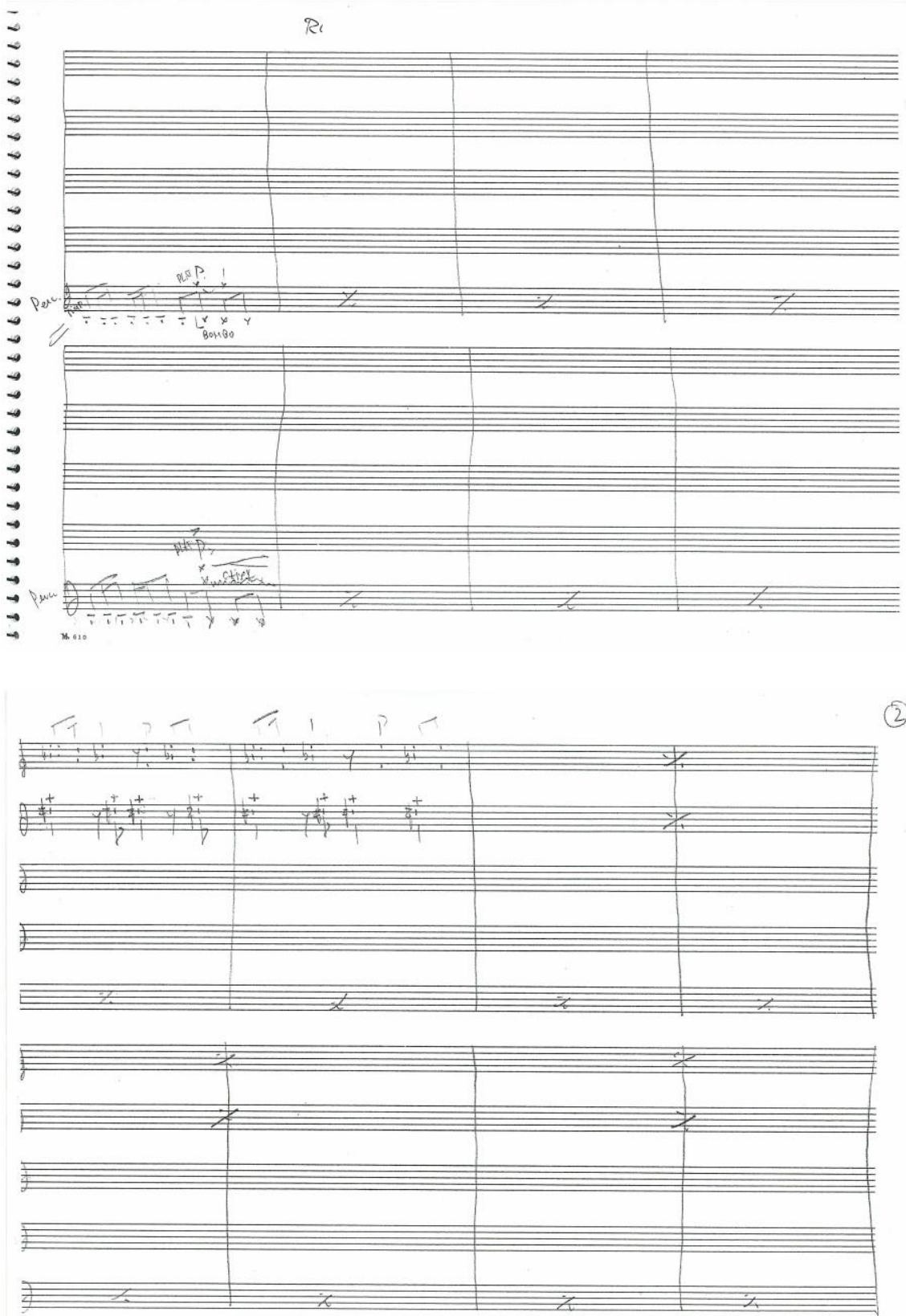
18.- SARDANA GELABERT, Sardana, politonal, banda y Cobla, con partitura y partes, 2011, Arc 28.

La plantilla a la que está dedicada es múltiple, admitiendo otras formaciones diversas. Ver: SARDANA GELABERT (sección Otras agrupaciones).
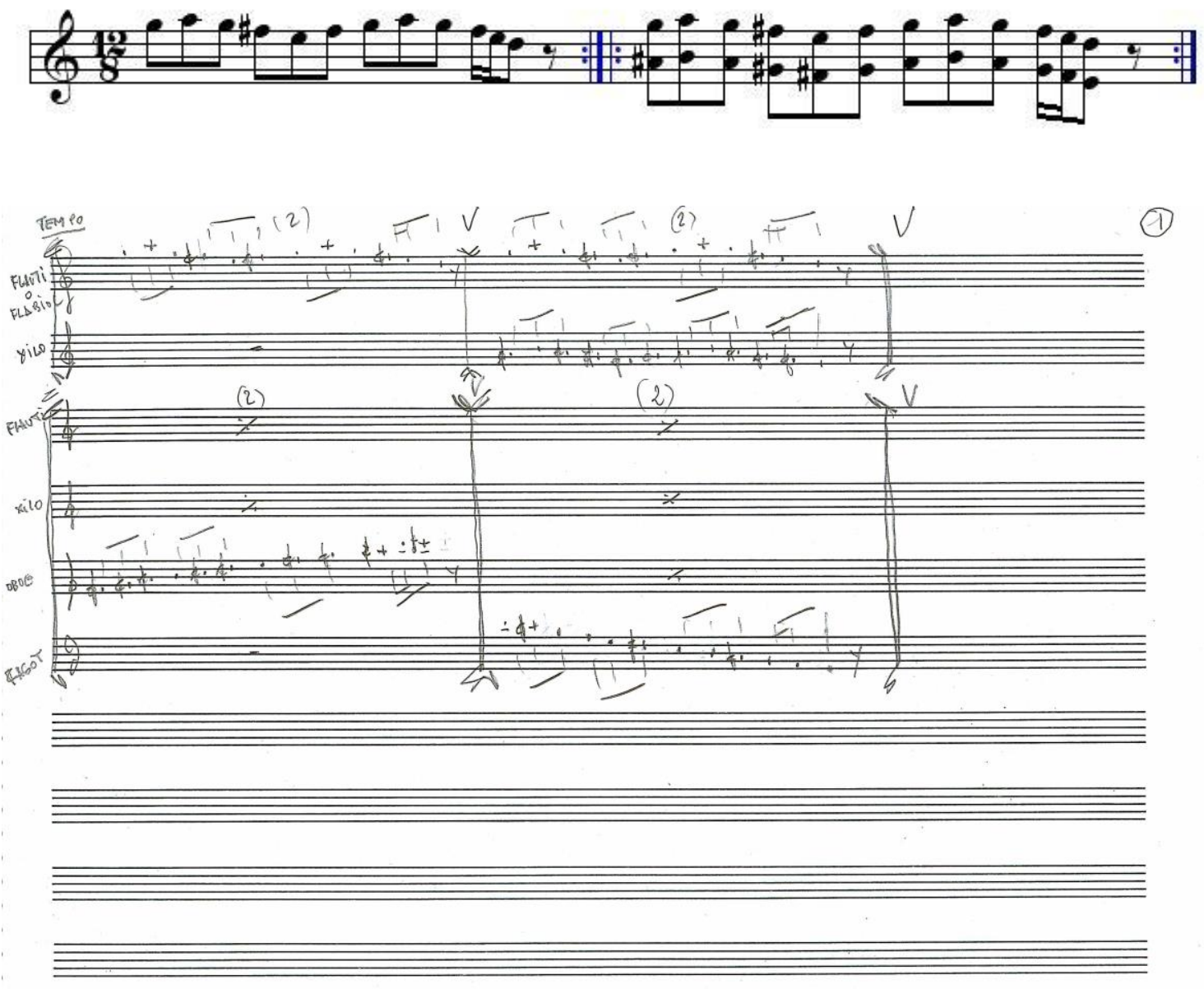

MøŚGRAF - \$t 610

Se corresponde a la pista 10, "Sardana Gelabert" del disco La muntanya al teu voltant grabado en 2011 por el Festival Grec 2011. 
19.- SEVILLA, Pasodoble, Si m, banda, con partitura y partes, 1992. G. 1

La plantilla a la que está dedicada es una plantilla bandística al uso, teniendo como particularidad que está dividida en 2 únicos papeles de Clarinete y tiene Saxo Soprano y Saxo bajo
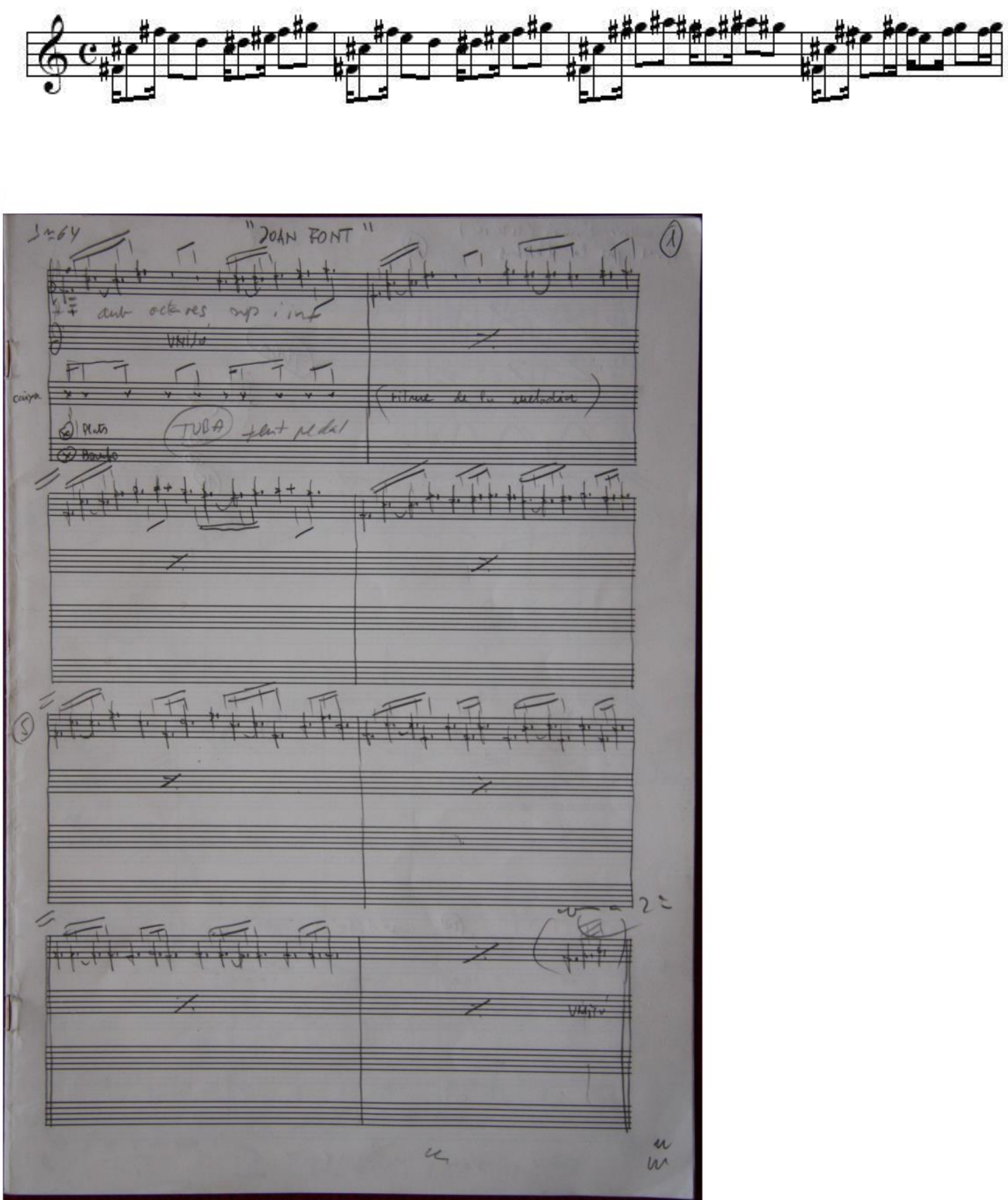
Título inicial: Joan Font, (Director de "Els Comediants"). Título compartido (consta en CD): Marrajo.

Existe un material similar bajo el nombre de Pasodoble 2.

Se corresponde a la pista 13, "Marrajo (Pasodoble)" del disco Música para las Ceremonias Olímpicas Barcelona '92 grabado en 1993 por On The Rocks.

Composición para celebrar la Exposición Universal de Sevilla '92.

Existe el manuscrito original de los apuntes y fotocopia de la primera partitura manuscrita de Santos. En ella los instrumentos están en Do, con anotación del autor de realizar el transporte pertinente.

Existen dos materiales distintos, que difieren en la tonalidad. La tonalidad original es $\mathrm{Si}$ $\mathrm{m}$ y la del segundo material Do $\mathrm{m}$

Existen diferencias formales e instrumentales entre la partitura manuscrita del autor (existen 2 copias fotocopiadas, A y B) y la primera copia de Miquel Barona aunque algunas de estas diferencias ya las marca el autor en una revisión de esta partitura (B) donde ya consta de su puño y letra el título definitivo, Sevilla, así como referencias a otros artistas (Nino Rota -c.70-, Kurtz Weil -c. 76-).

\begin{tabular}{|l|l|l|}
\hline Compás manuscrito & Compás copia & Diferencia \\
\hline 10 & 10 & Formal \\
\hline 16 y 17 & 17 y 18 & Instrumentación \\
\hline 20 a 22 & 21 a 23 & Instrumentación \\
\hline 24 a 26 & 25 a 27 & Instrumentación \\
\hline
\end{tabular}

Existe un material, fotocopiado, en el que no está la obra completa. Parece ser que pudiese interpretarse solamente este fragmento (c. 101 a final -Tpo. De Pasacaglia-) en alguna ocasión, o bien que el autor quisiese realizar alguna adaptación o revisión del mismo.

MATERIAL TOTAL:

- Esbozo de la obra: manuscrito, original, 18 páginas, 158 compases. Contiene tesitura de los instrumentos. Título: Joan Font. 
- Material manuscrito del autor, original, en un bloc de escritura musical con el título inicial de Sevilla en la tapa. 42 Páginas sin numerar. Parece ser borrador del material, ya que constan referencias a instrumentos concretos.

- Asimismo existe un principio de instrumentación del material, manuscrito y original del autor, que consta de un facsímil de papel pautado con 15 páginas numeradas y referencias a instrumentos concretos. Este material comienza en la página 19 del bloc anterior y es la $2^{\mathrm{a}}$ parte de la obra.

- Partitura manuscrita y original del autor. Consta de un bloc de escritura musical con el título Pasodoble-2 en la tapa y con 23 páginas escritas y numeradas a las que siguen 5 páginas más. Este material comienza a mitad de la música escrita en el anterior.

- Partitura (A): manuscrita, fotocopia, 53 páginas, 158 compases.

- Partitura (B): manuscrita (igual a la anterior), fotocopia, 53 páginas con anotaciones del autor. El autor modifica el título original a Sevilla.

- Partitura: a ordenador, original, 55 páginas, 160 compases, en Si m.

○ con partes originales y sobrantes fotocopiados.

- Consta relación de originales y copias.

- Partituras (2): Fotocopias de la anterior y ampliadas.

- Partitura: a ordenador, original, 54 páginas, 160 compases, en Si m.

- Partitura: a ordenador, fotocopia del original, ampliada, 53 páginas, 158 compases, en Do m. con partes originales y sobrantes fotocopiados.

- Partitura: a ordenador, fotocopia de la de 54 páginas, y partes. Sólo consta desde el compás 101. 
20.- SOMNIS MARMOLENCS, Libre, politonal, banda, con partitura y partes, 2010, Arc. 27.

La plantilla a la que está dedicada es la de una formación bandística al uso, coro y voz solista (soprano o tenor).

\section{Ver: ULLDECONA}

Tranquil
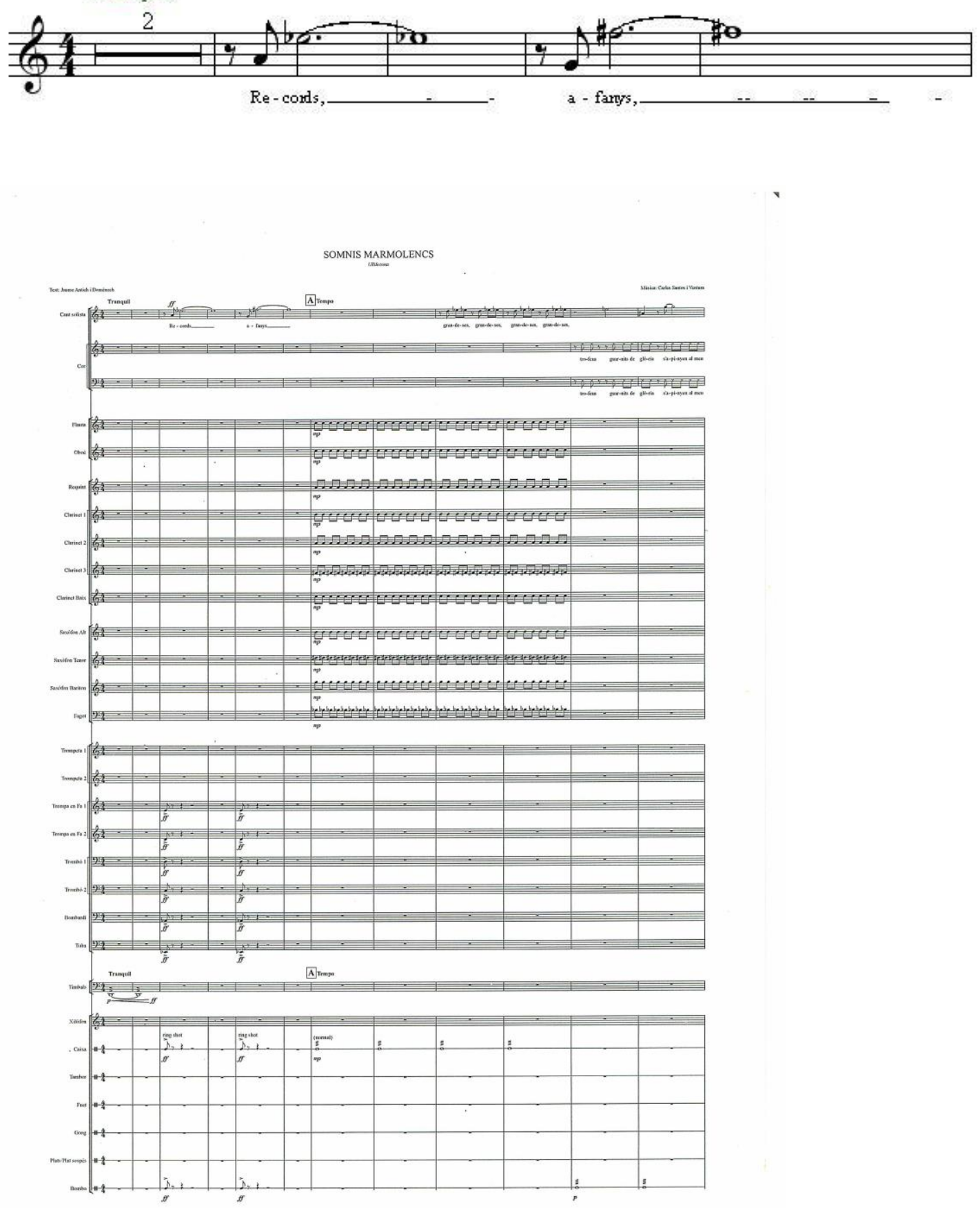
Música de Carles Santos y textos de Jaume Antich i Doménech. Compuesta para la Banda de Ulldecona, no ha llegado a ser estrenada.

\section{MATERIAL TOTAL:}

- Partitura de la obra: partitura impresa, realizada con software Sibelius para Mac, por Xavi Piquer, en formato A4 y A3, de 18 páginas y 175 compases. Existe otra con pentagramas optimizados. No existen manuscritos.

- Existe otra partitura de 22 páginas y 175 compases, grapada, en formato A3. Asimismo, la misma partitura está en formato A4.

- Asimismo existe el libro original del cual se sacaron los textos de la obra.

- Partes: Existen partes de todos los instrumentos, impresas.

- No consta relación de originales y copias. 
21.- ULLDECONA, Libre, politonal, banda, con guion, 2010, Arc. 27.

La plantilla a la que está dedicada es la de una formación bandística al uso, coro y voz solista (soprano o tenor).

\section{Ver: SOMNIS MARMOLENCS}
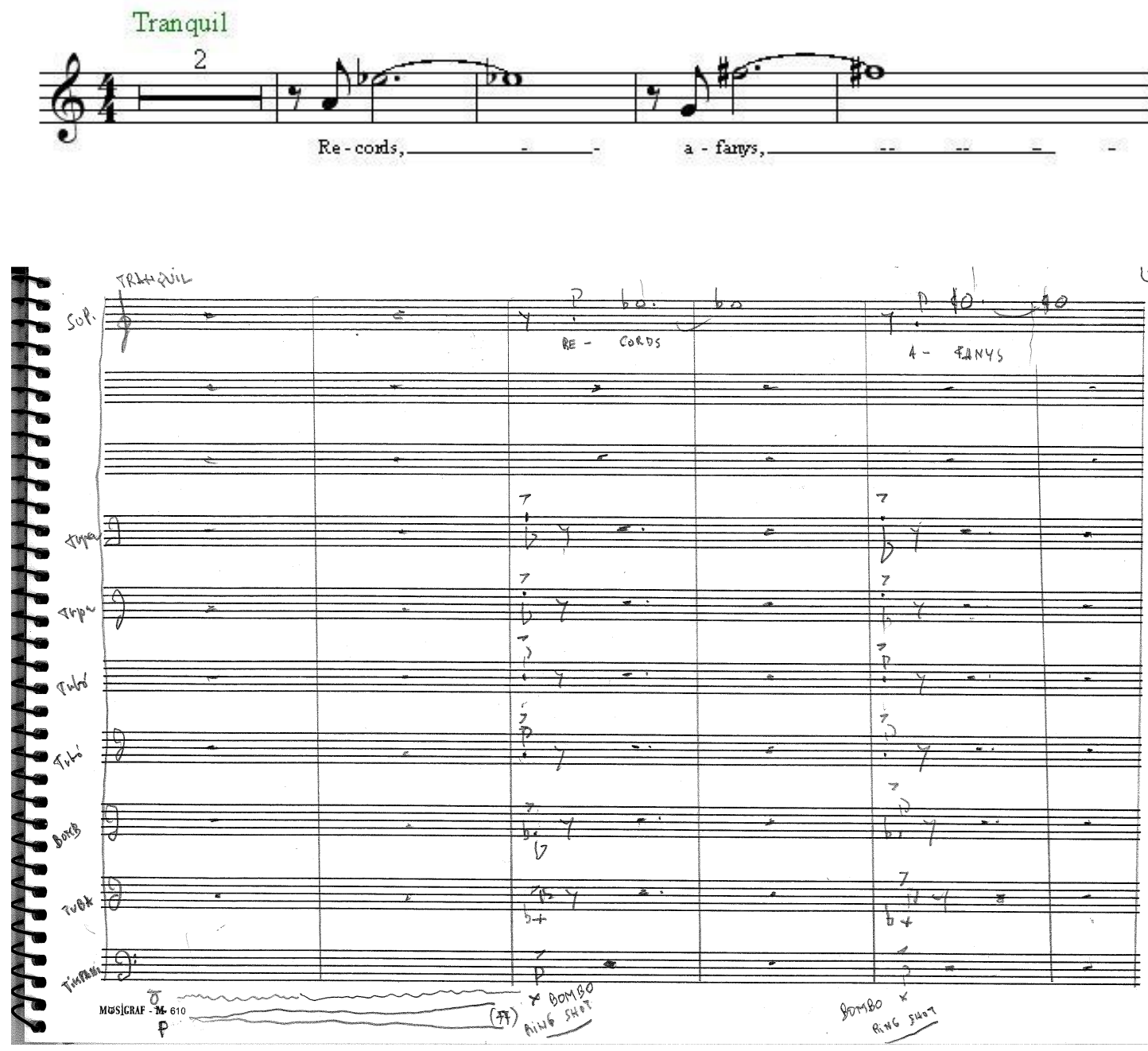

Es el manuscrito de la obra Somnis marmolencs $\left(\mathrm{n}^{\circ}\right.$ orden 82$)$.

\section{MATERIAL TOTAL:}

- Material manuscrito y original del autor. Consta de 1 bloc de escritura musical, con el título Ulldecona en el exterior. Páginas numeradas de la 1 a la 29, con página 19bis, suelta.

- Partes: No existen partes. 
22.- VALENCIA PREMIS OCTUBRE ‘95, Libre, politonal, banda, con guión, 1995, Arc.15.

No existe una plantilla determinada a la que va destinada la obra. Existen anotaciones manuscritas del autor que sí hacen referencia, en momentos determinados, a formas de interpretación (pizz.) o instrumentos determinados.
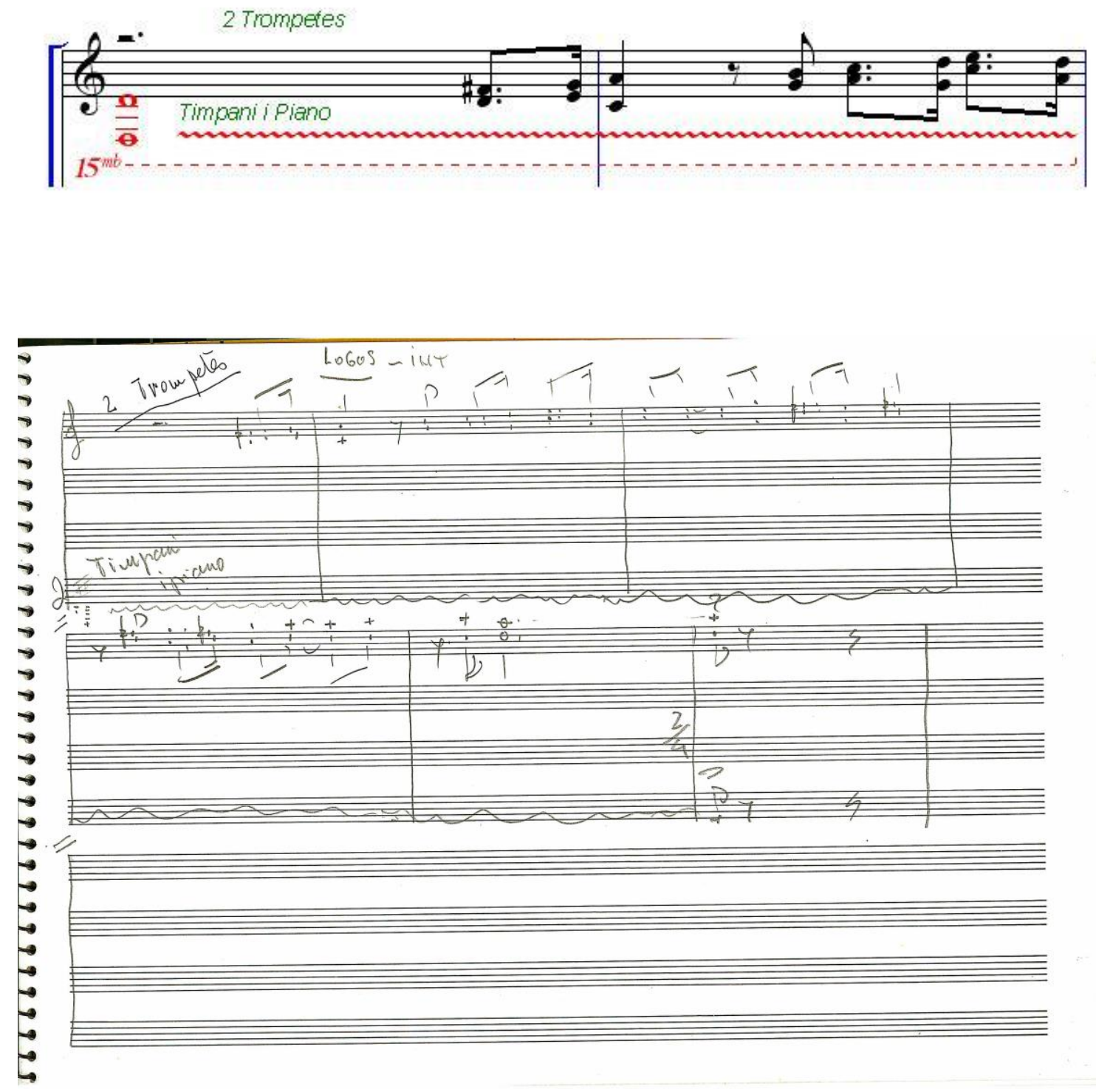

Parece ser borrador del material, ya que constan referencias a instrumentos concretos, pero no están las partes.

Al parecer, música escrita para la entrega de premios en Valencia. Constan anotaciones del autor que hacen referencia a diversos momentos de la entrega o personajes que 
intervienen $\left(\log o s\right.$, Pichi Alonso $1^{\mathrm{a}}$, Pichi Alonso $2^{\circ}$, Pichi Alonso $3^{\circ}$, Mendiluce $1^{\mathrm{a}}$, Mendiluce (2), Mendiluce (3), Mikimoto (1), Mikimoto (2), Mikimoto (3), Premi assaig (octubre), Fanfarra-logos $\left(1^{\mathrm{a}}\right)$, Fanfarra- $\log \operatorname{los}\left(2^{\mathrm{a}}\right)$, Flotats $\left(1^{\mathrm{a}}\right)$, Flotats $\left(2^{\mathrm{a}}\right)$, Flotats $\left(3^{\mathrm{a}}\right)$, Mariscal (1 $\left.1^{\mathrm{a}}\right)$, Mariscal (2), Mariscal ( $\left.3^{\mathrm{a}}\right)$, Nacho Duato $\left(1^{\mathrm{a}}\right)$, Nacho $\left(2^{\mathrm{o}}\right)$, Nacho $\left(3^{\mathrm{a}}\right)$, Poesía (octubre) el mateix-sin música-, Logo $1^{\text {a }}$-sin música-, Logo $2^{\text {a }}$-sin música-, Música $1^{\mathrm{a}}$, Improvisació, Música $2^{\mathrm{a}}$, improvisació, Música $3^{\mathrm{a}}$, improvisació -todos estos sin música-, $1^{\mathrm{a}}$ moda, Cinema $\left(1^{\mathrm{a}}\right)$, Cinema $\left(2^{\mathrm{a}}\right)$ aire, Cinema $\left(3^{\mathrm{a}}\right)$.

\section{MATERIAL TOTAL:}

- Partitura de la obra: Manuscrito original del autor en un bloc de escritura musical, sin numerar y sin numerar tampoco sus páginas.

- Partes: Existen originales de las partes instrumentales. De ellas se deduce que la agrupación a quien va dirigida es una banda.

- No consta relación de originales y copias. 
3.2.6. ORQUESTA 
1.- DELTA, Libre, politonal, orquesta, con guion, partitura y partes, 1989? Arc. 29.

La plantilla a la que está dedicada es una plantilla orquestal al uso.
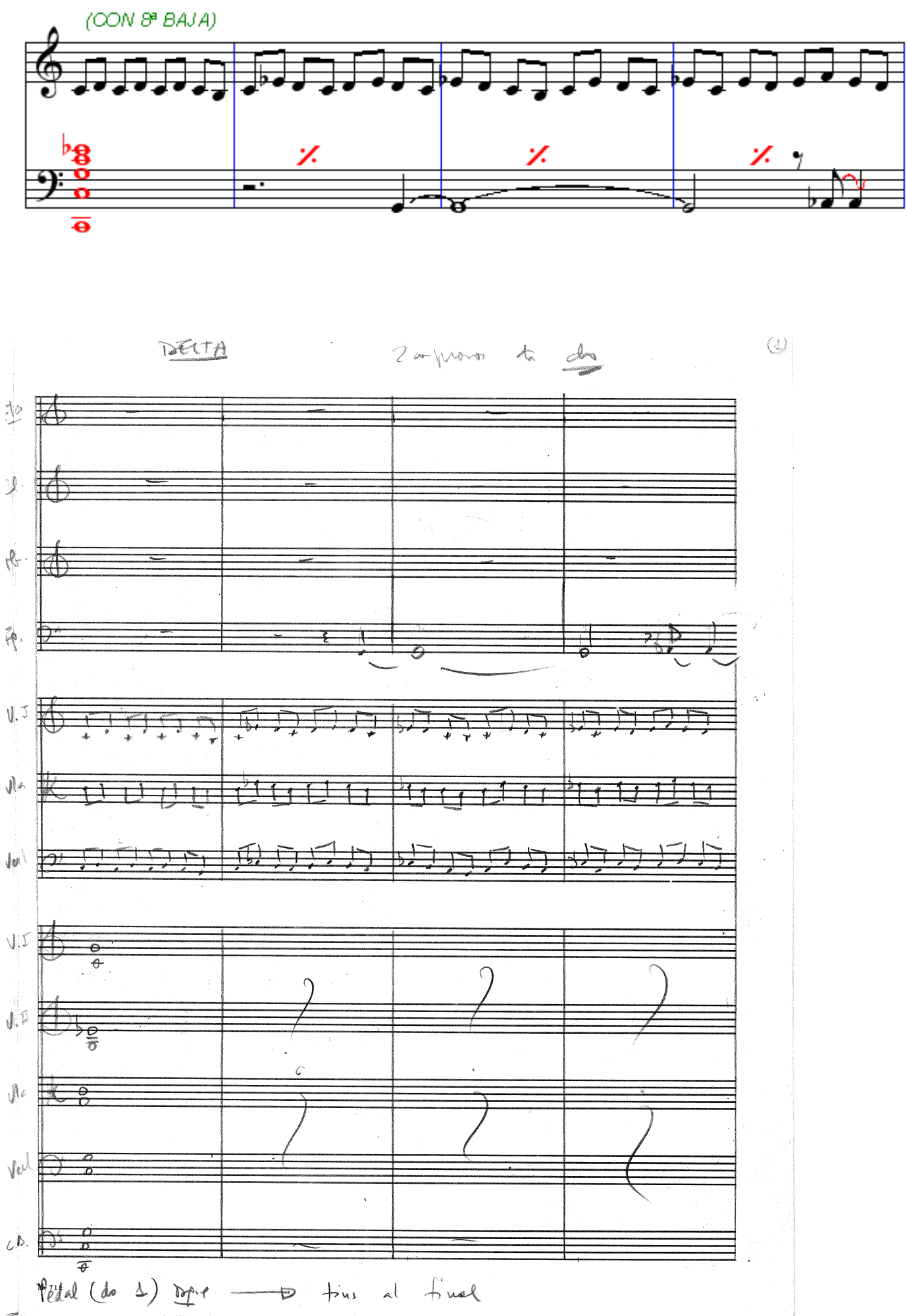
Forma parte de la BSO de la película El pont de Varsovia.

Las partituras están numeradas como 52 por el autor.

\section{MATERIAL TOTAL:}

- Material manuscrito y original del autor. Consta de 4 páginas sueltas y numeradas de escritura musical, sin título en el exterior. Asimismo existe la partitura desarrollada de esta música en un libreto de 19 páginas numeradas y partes instrumentales de la misma.

- Partes: existen partes.

- No consta relación de originales y copias. 
2.- INAUGURACIÓ, Libre, fa\# M, orquesta y fagotes (2), con guion, partitura y partes, 2007. G. 2

La plantilla a la que está dedicada es una plantilla orquestal al uso, incluyendo papel de Fagot I-II.
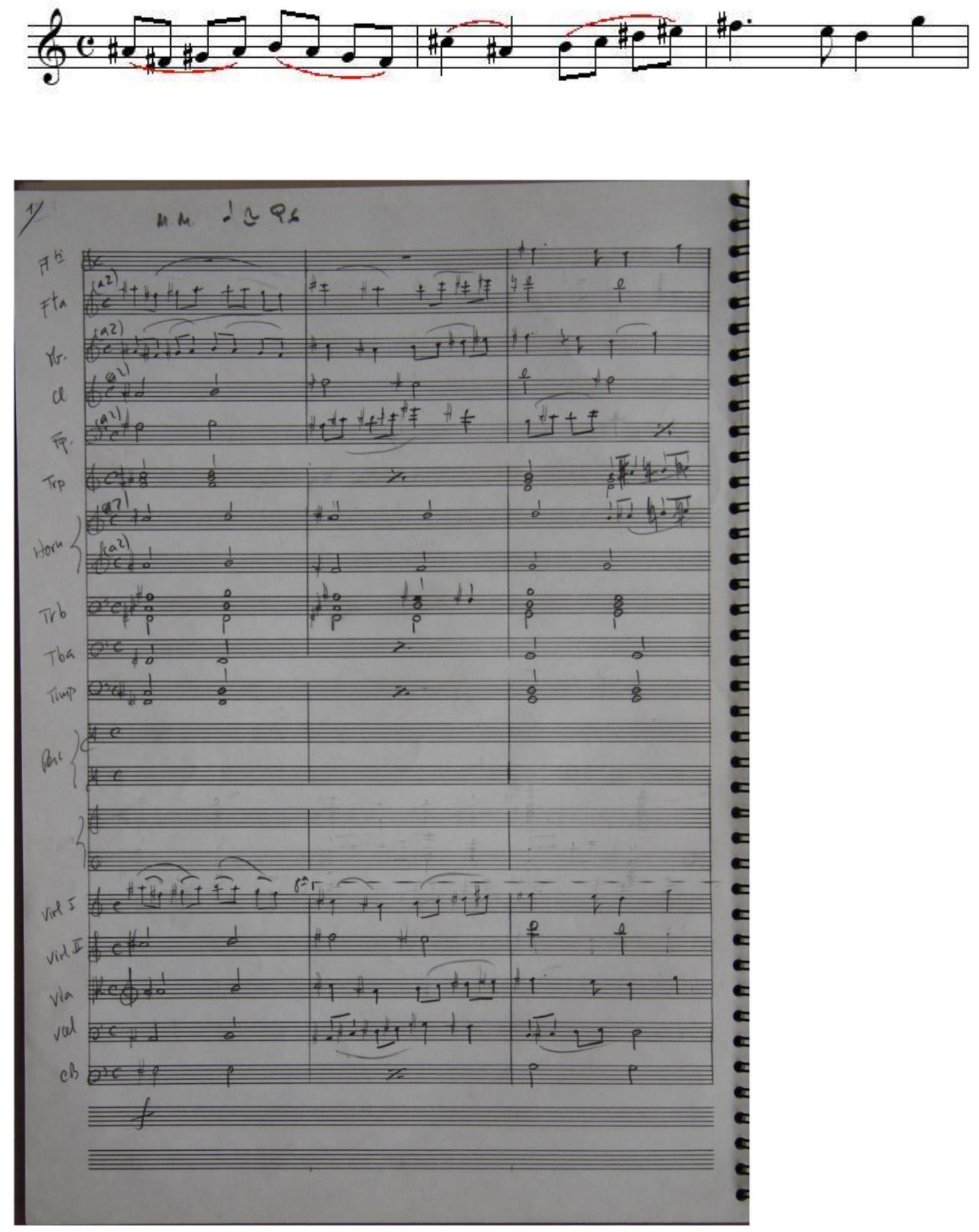


\section{MATERIAL TOTAL:}

- Partitura de la obra o guion: Partitura manuscrita del autor, original, 41 páginas, 142 compases. Todos los papeles en Do. Título: Inauguració. Existe una anotación del autor referente al transporte de algunos instrumentos al hacer las partes.

- Existe material fotocopiado que consta de 3 partituras más encuadernadas y 2 más grapadas.

- 2 guiones manuscritos y fotocopiados del autor, ambos grapados.

- Partes: manuscritas y fotocopiadas, en formato grande, 142 compases. Título Inauguració. No existe el nombre del autor en las partes. Partes numeradas. Falta un papel, el $\mathrm{n}^{\mathrm{o}} 1$, de cada instrumento. Partes: Violín I (7 copias), Violín II (6), Viola (5), Violoncello (5), Contrabajo (4) y Fagot I-II (1)

- No consta relación de originales y copias. 
3.- MEDALLES (PROMENADE), Marcha, Sol M, orquesta, con partitura y partes, 1992, G. 8

La plantilla a la que está dedicada es una plantilla orquestal al uso.

Ver: PROMENADE (sección Banda).
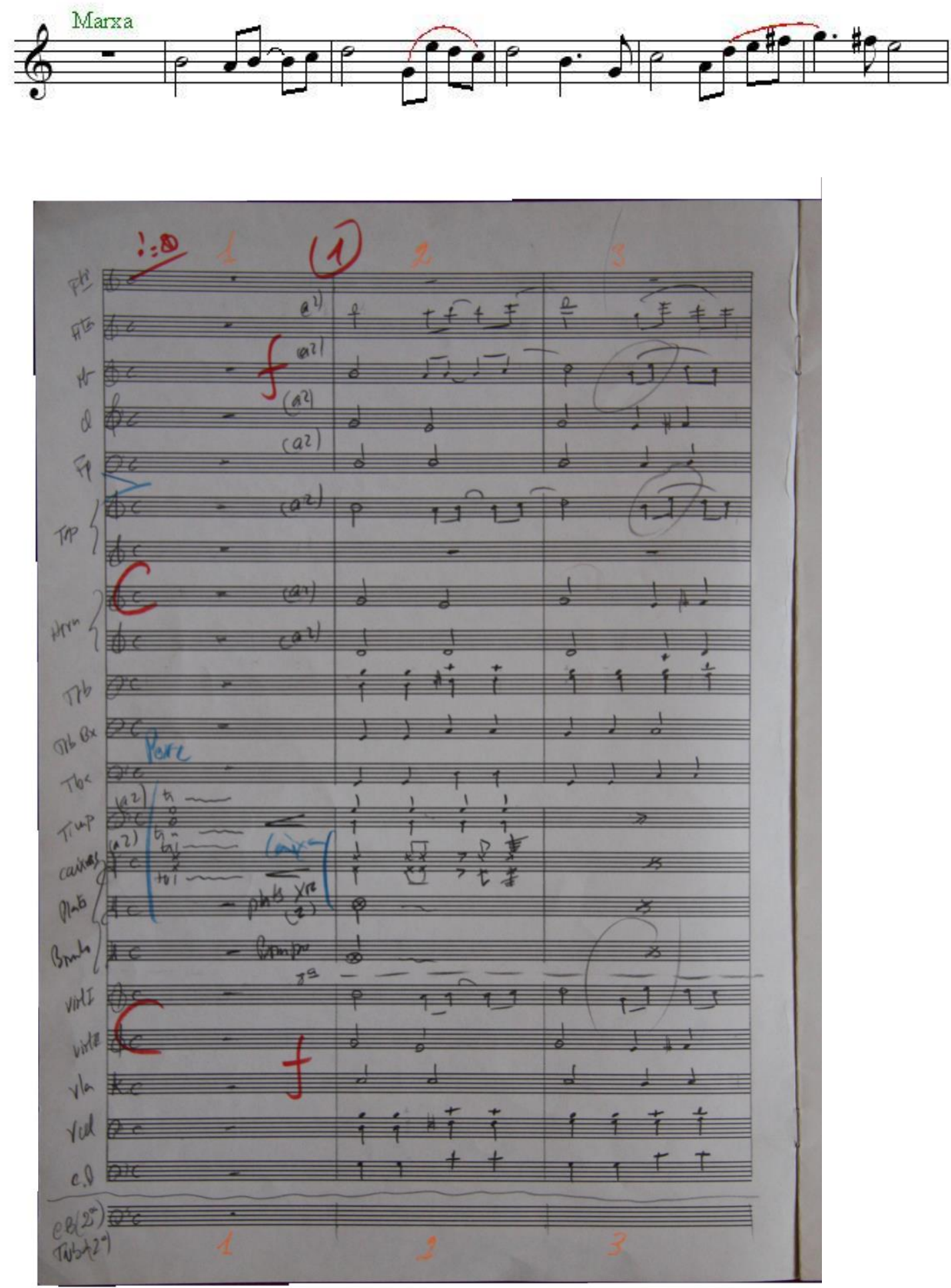
Material correspondiente a la música utilizada en los JJ. OO. de Barcelona en 1992. En concreto, música para el desfile de la imposición de medallas.

\section{MATERIAL TOTAL:}

- Partitura manuscrita y original del autor. En la partitura consta la inscripción Promenade que se corresponde a la Pasacaglia aunque más instrumentada.

- Partes: manuscritas y originales de copista (desconocido), en formato grande.

- No consta relación de originales y copias. 
3.2.7. GRUPOS DE CUERDA

3.2.7.1. PIANO Y VIOLÍN

3.2.7.2. PIANO Y CELLO

3.2.7.3. TRIO DE CUERDA

3.2.7.4. CUARTETO DE CUERDA

3.2.7.5. QUINTETO DE CUERDA 


\subsubsection{PIANO Y VIOLÍN}

1.- DESIG, Libre, politonal, violín y piano, con partitura, s. d., Arc.10.

La plantilla a la que está dedicada es la de un dúo de Violín y Piano con intervención de la voz.
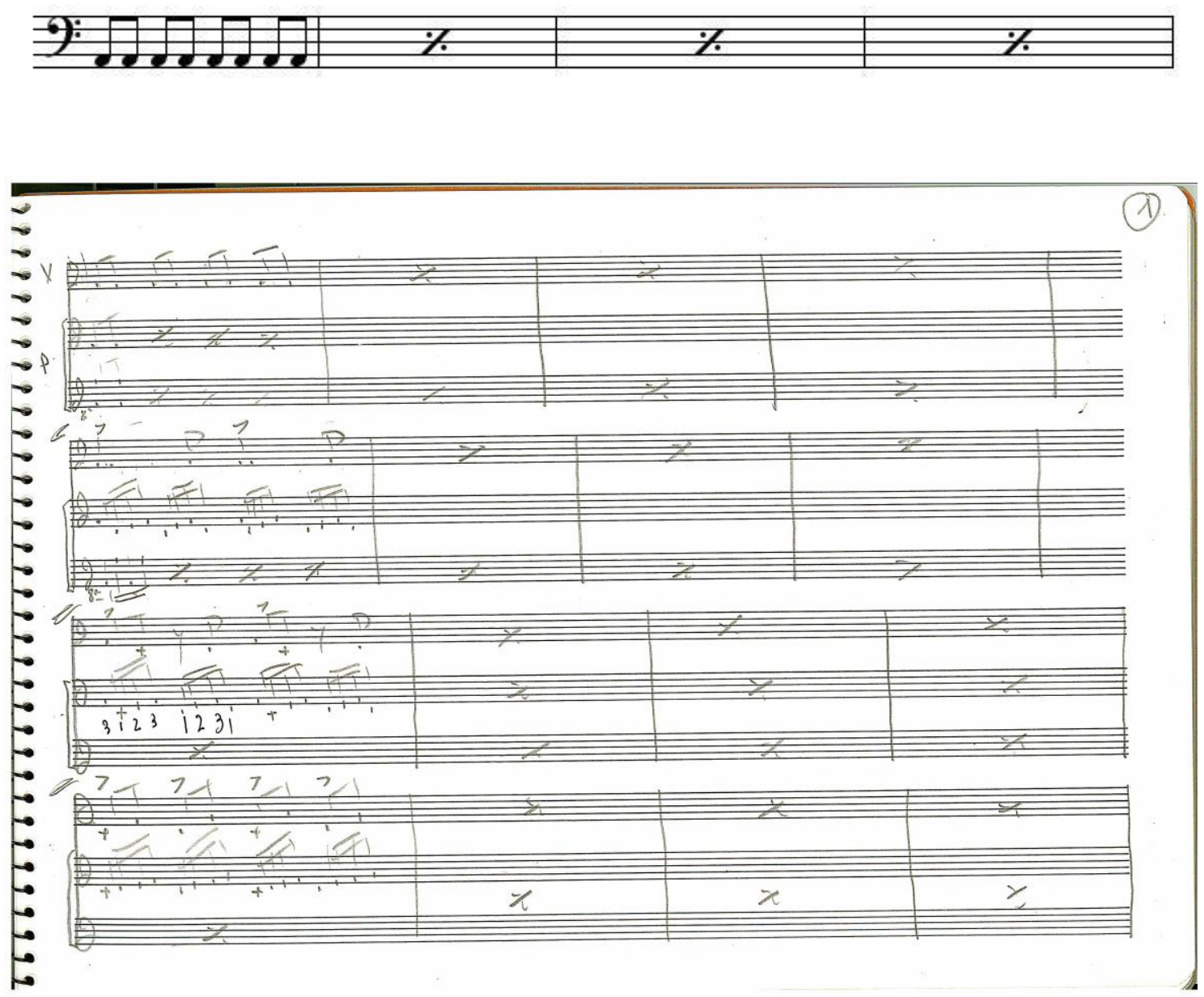

Obra, al parecer, dividida en 5 partes.

\section{MATERIAL TOTAL:}

- Partitura de la obra: Material manuscrito del autor, original, en 1 bloc de escritura musical, con título en el exterior. Páginas numeradas en 5 grupos: de 1 a 6 , de 1 a 4 , de 1 a 3 , de 1 a 2 y una página sin numerar.

- Partes: No existen partes.

- No consta relación de originales y copias. 
2.- XAVIER RIBA, Libre, en Re, violín, y piano, con partitura, 1986, Arc. 22.

La plantilla a la que está dedicada es la de un dúo de Violín y Piano.
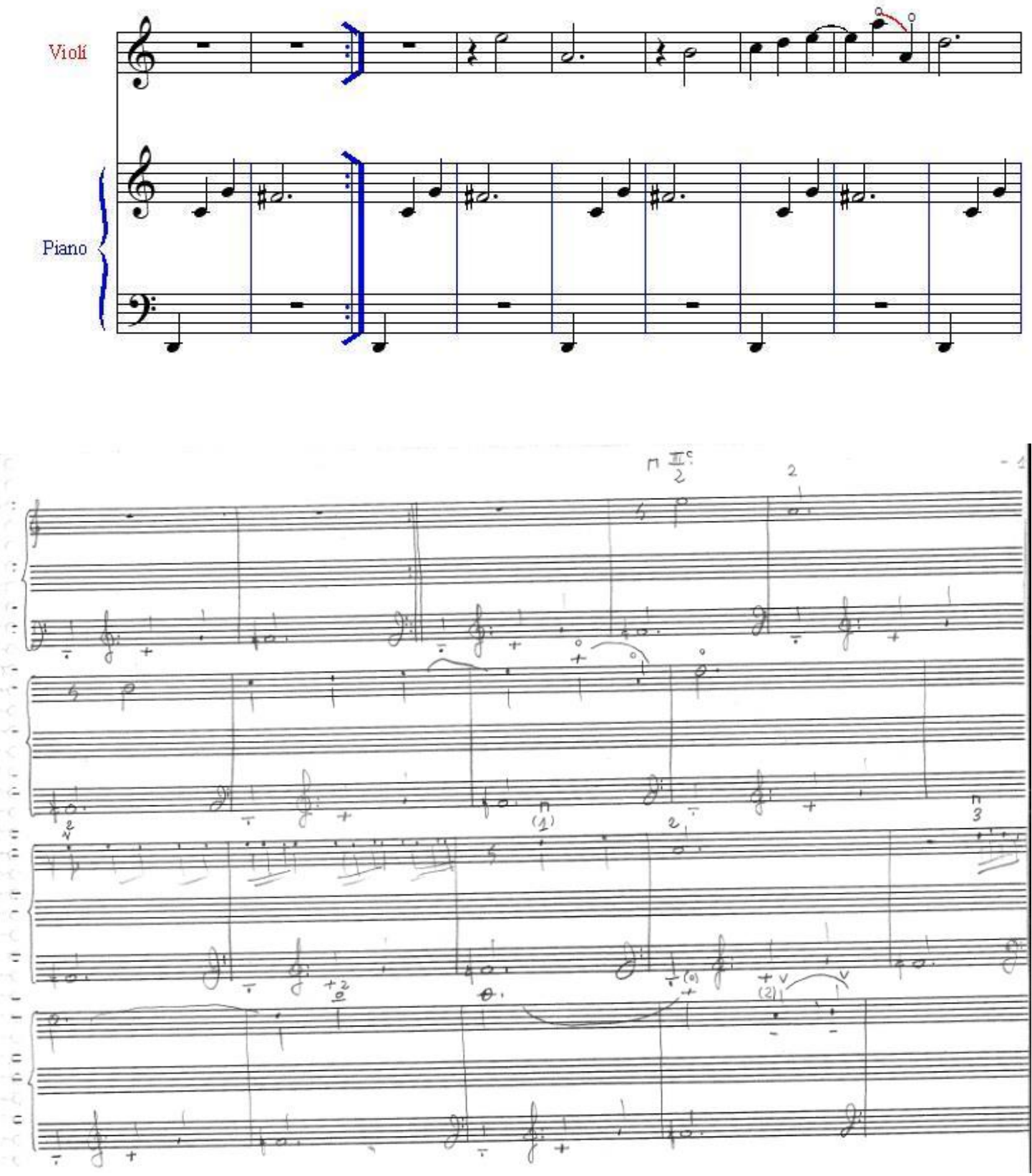

Se corresponde a la pista 3 de la cara B del disco Perturbació Inesperada grabado en 1986 por Linterna Música. 


\section{MATERIAL TOTAL:}

- Partitura manuscrita y original del autor. Consta de dos páginas pegadas y numeradas de escritura musical. En la tapa consta el título Xavier Riba "Violí i Piano" (Disc. Perturbació inesperada).

- Partes: No existen partes.

- No consta relación de originales y copias. 


\subsubsection{PIANO Y VIOLONCHELLO}

3.- OBRA PER A PIANO I CELLO, Libre, en Mib m, violoncello y piano, con partitura, s. d., Arc. 24.

La plantilla a la que está dedicada es la de un dúo de violoncello y Piano.
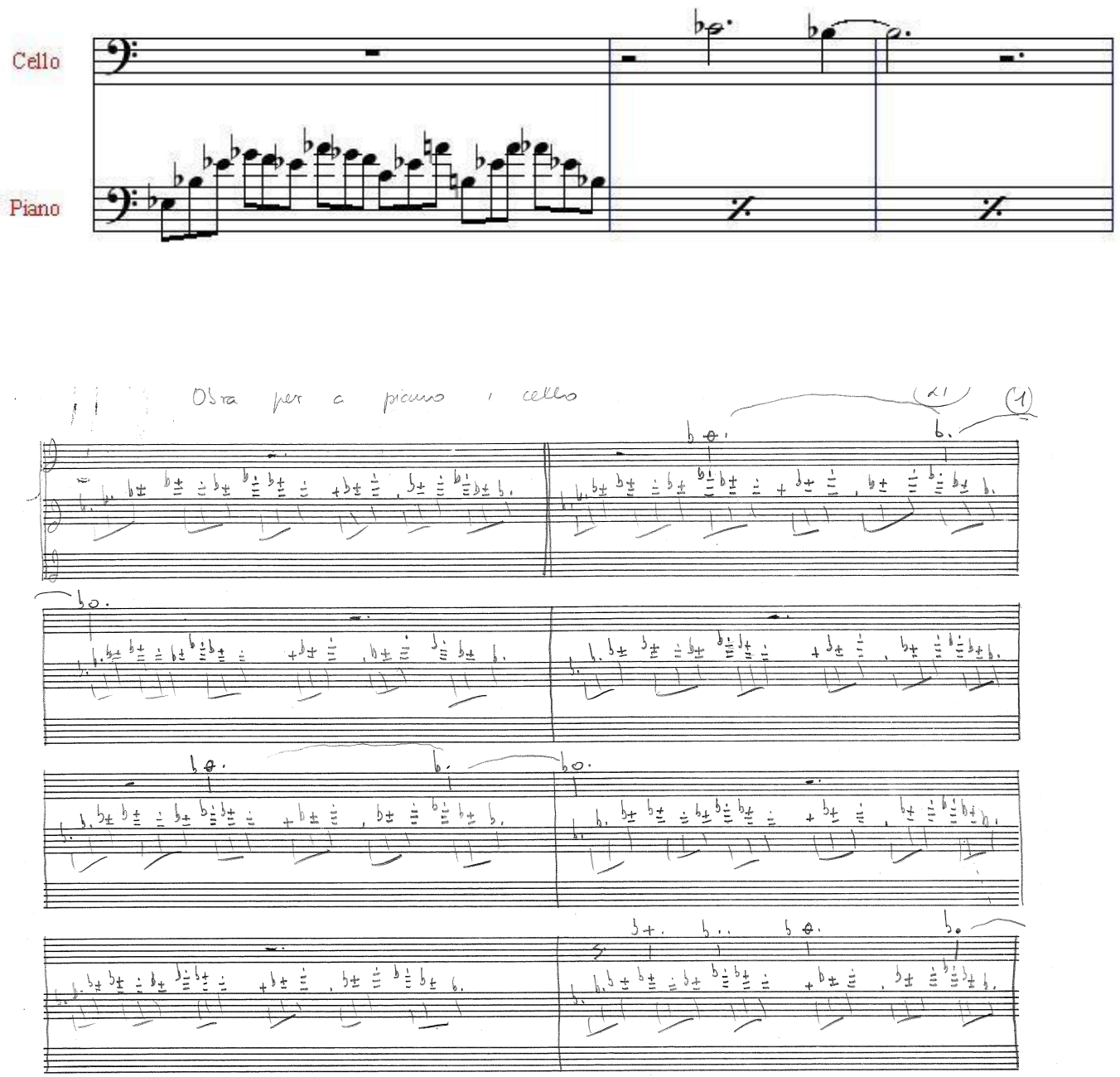

M. 012

La partitura está numerada como 21 por el autor.

MATERIAL TOTAL:

- Partitura manuscrita y original del autor, mas 2 materiales fotocopiados. Consta de siete hojas sueltas apaisadas de escritura musical con 7 páginas escritas y numeradas, del 1 al 4 con el título Obra per a piano $i$ cello y el número 21 encercado, en la $1^{\mathrm{a}}$ página.

- Partes: No existen partes.

- No consta relación de originales y copias. 


\subsubsection{TRIO DE CUERDA}

4.- TRIO DE CORDA, Libre, en Re, Trio cuerda, con partitura, s. d., Arc. 26.

La plantilla a la que está dedicada es la de un trio cuerda (violín, viola y violoncello).
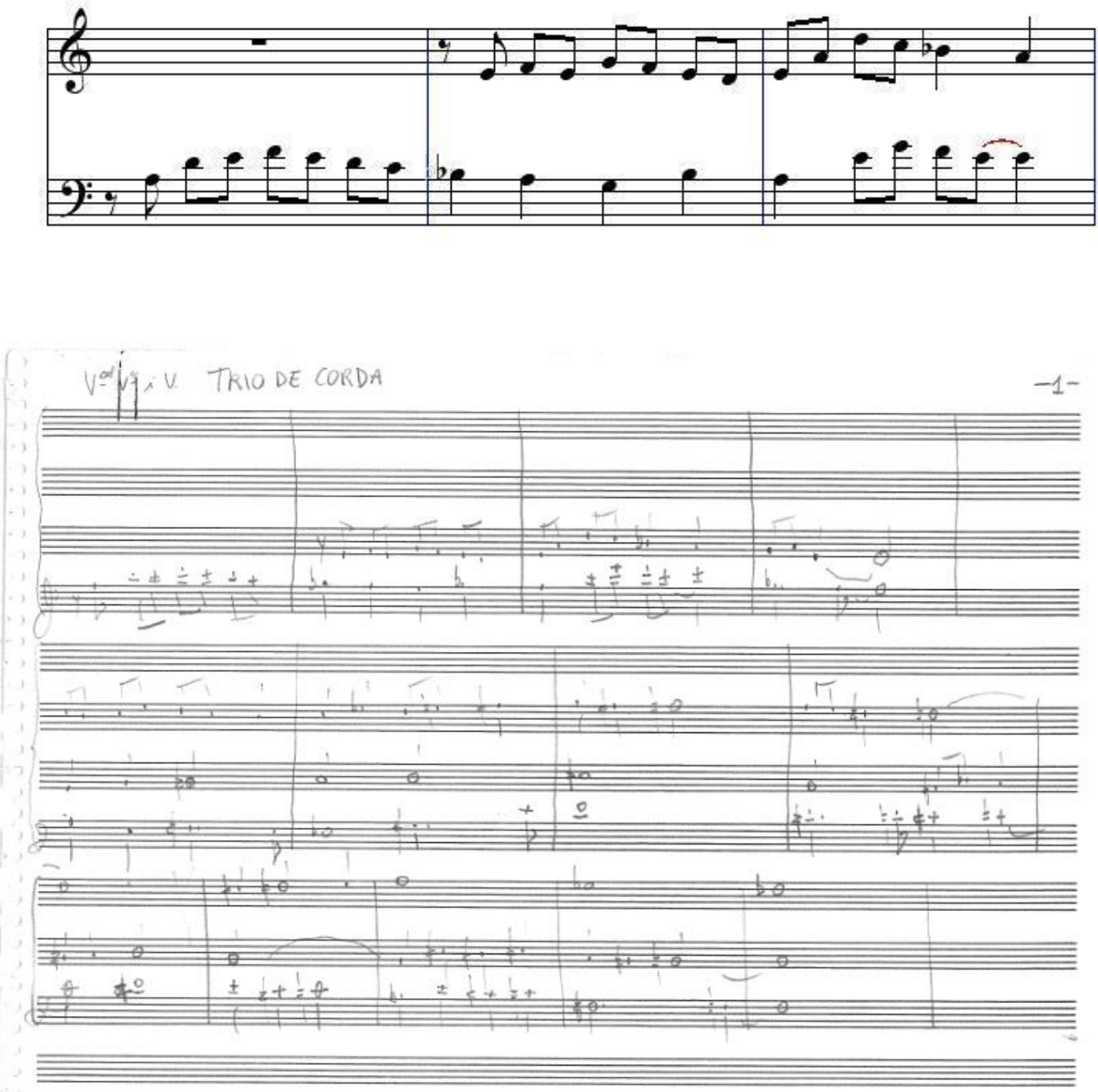

MATERIAL TOTAL:

- Partitura manuscrita y original del autor en un libreto de escritura musical con 2 páginas escritas. Consta título en la página 1 de ambos materiales como Trio de corda (Violín, Viola y Violoncello). 
- Consta otra partitura manuscrita y original del autor. Consta de 2 páginas sueltas y numeradas. En el reverso de la página 2 consta otra obra con el título Violí + acompanyament de trémolos.

- Partes: No existen partes.

- No consta relación de originales y copias. 
5.- Y, Libre, en La M, Trio cuerda, con partitura, s. d., Arc. 26.

La plantilla a la que está dedicada es la de un trio cuerda (3 violines).

Ver: A LA PISCINA DE MISERICÒRDIA UBACH (sección Obra piano)
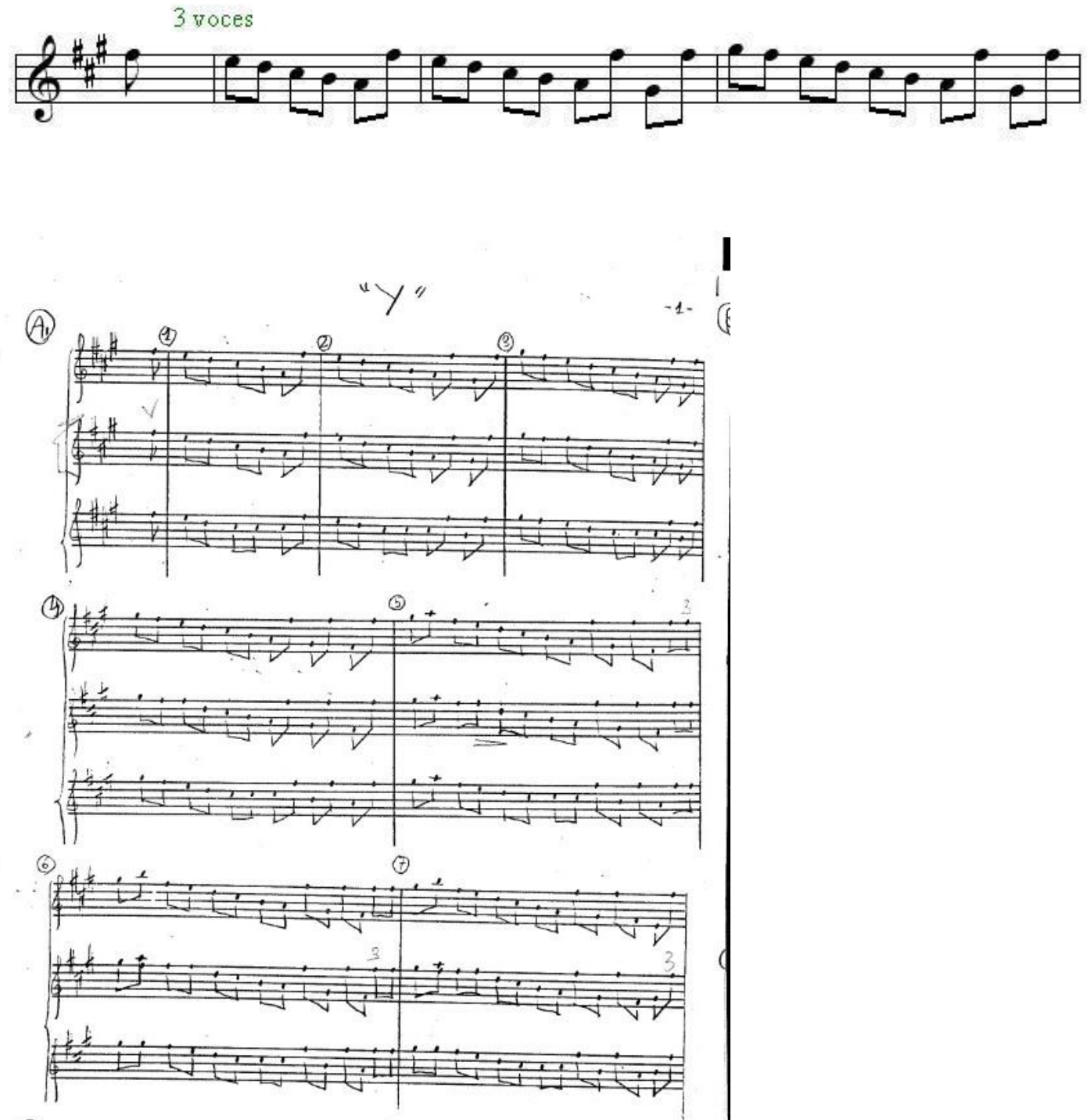

(8)

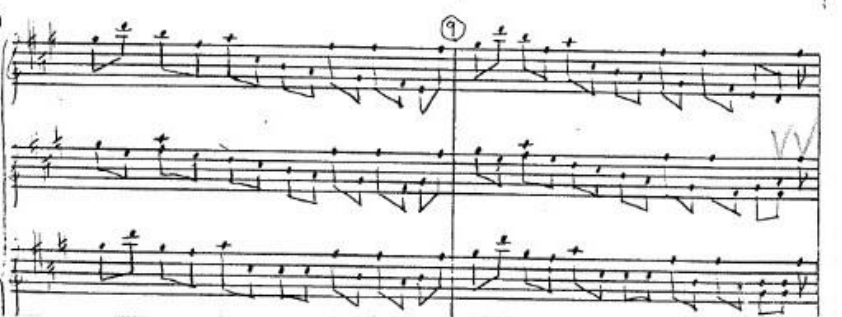

Es un arreglo de la pieza La piscina de Misericòrdia Ubach, incluida en el CD Piano:

Carles Santos y cuyo original consta en la sección Obra pianística, de este trabajo. 
Se corresponde a la pista 2 de la cara A del disco Piano: Carles Santos grabado en 1988, por Grabaciones Accidentales.

\section{MATERIAL TOTAL:}

- Partitura manuscrita y fotocopiada del autor. Consta de un libreto de 2 páginas numeradas de escritura musical con el título $Y$, y el comentario "Piscina de $\mathrm{M}$. Usac" en la portada y el $\mathrm{n}^{\circ}$ 16. Consta de 14 compases (cada uno con pulsaciones diferentes) y dos bloques (A1 y B1).

- Existen 2 versiones de la misma obra (trio de cuerda -3 violines- y dúo de cuerda -viola y cello).

- Partes: No existen partes.

- No consta relación de originales y copias. 


\subsubsection{CUARTETO DE CUERDA}

6.- EL PONT DE VARSOVIA, Libre, politonal, Cuarteto cuerda, con guion, 1989, Arc. 29.

La plantilla a la que está dedicada es la de un Cuarteto cuerda.

Ver: EL PONT DE VARSOVIA (sección B. S. O.)
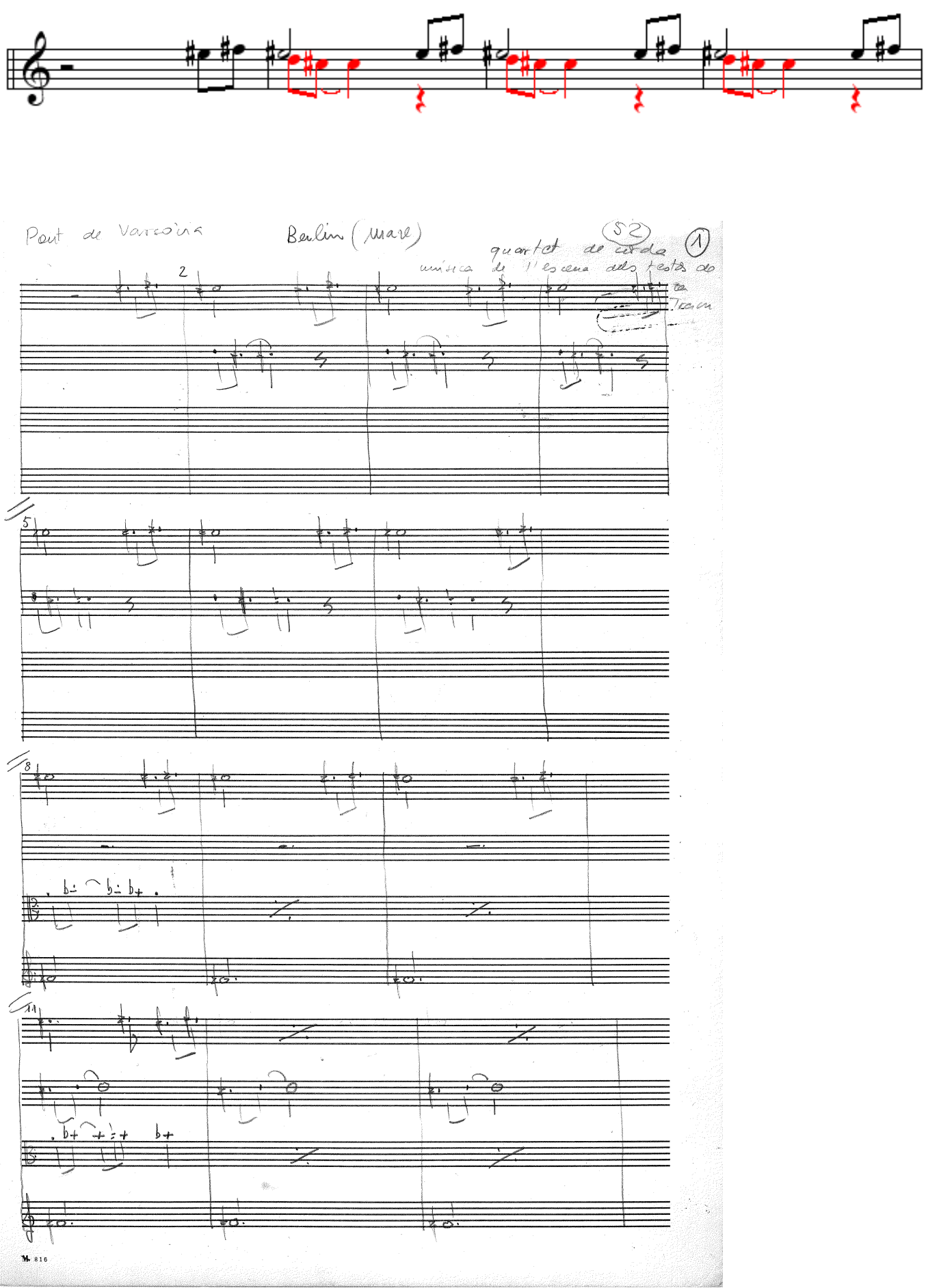
Forma parte de la B. S. O. de la película El pont de Varsovia, film dirigido por Pere Portabella en 1989.

La obra está numerada como 52 por el autor.

\section{MATERIAL TOTAL:}

- Consta de varios materiales en los cuales existe el título de El pont de Varsovia en las primeras páginas de todos ellos.

- Partitura manuscrita y original del autor. Libreto de escritura musical con 4 páginas escritas y numeradas, el título "Berlin (Mare)" y el número 52 encercado, en la $1^{a}$ página. La instrumentación del mismo es para un cuarteto de cuerda.

- Partes: No existen partes.

- No consta relación de originales y copias. 
7.- MARID RELEXIONANT AL DESPATX, Libre, en La, Cuarteto cuerda, con guion, 1986, Arc. 22.

La plantilla a la que está dedicada es la de un Cuarteto cuerda.
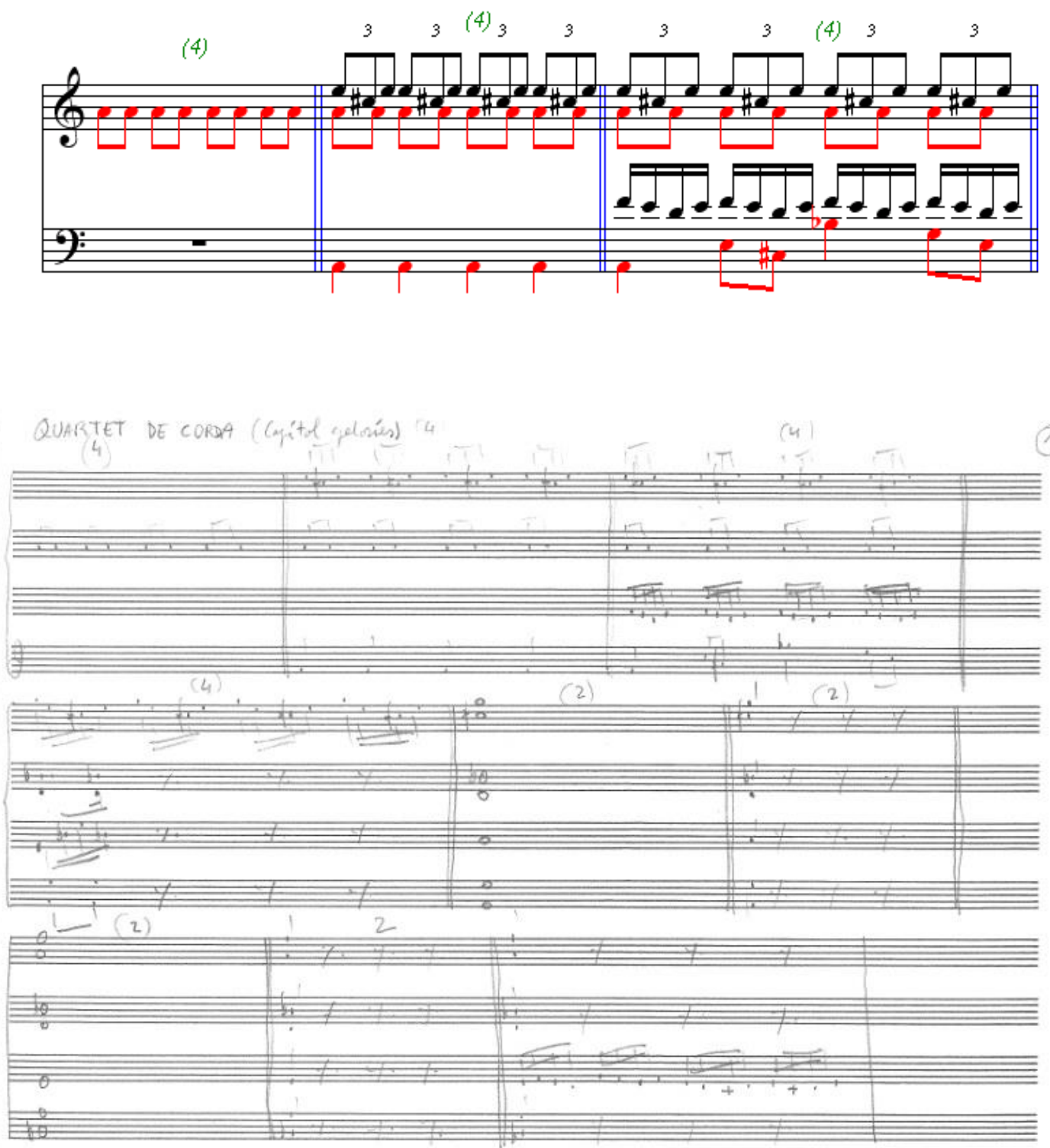

Se corresponde a la pista 4 de la cara B del disco Perturbació Inesperada grabado en 1986 por Linterna Música.

Puede formar parte de la musicalización de algunas imágenes o film 


\section{MATERIAL TOTAL:}

- Partitura manuscrita y original del autor. Incluida en un bloc de escritura musical, sin título en el exterior, numerado con el número 30 y 2 páginas manuscritas y originales, sin numerar. Constan títulos en la contratapa como Perturbació inesperada i Marid al despaix reflexionant. La música escaneada no se corresponde con la grabada en el disco Perturbació inesperada, track "Marid al despaix reflexionant".

- Existen otras obras en este bloc. No existen partes. El verdadero material lleva como título Quartet de corda "Capitol gelocies". Consta de una partitura con música para cuarteto de cuerda. No consta el original, sino fotocopias manuscritas que no son de copia del autor. Existen varios materiales. Se encuentra en la carpeta Tot queda en familia.

- Partes: No existen partes.

- No consta relación de originales y copias. 
8.- TOT QUEDA EN FAMILIA, Libre, en La, Cuarteto cuerda, con guion, 1986, Arc. 22.

La plantilla a la que está dedicada es la de un Cuarteto cuerda.

Ver: MARID RELEXIONANT AL DESPATX y TOT QUEDA EN FAMILIA (sección Obra vocal)
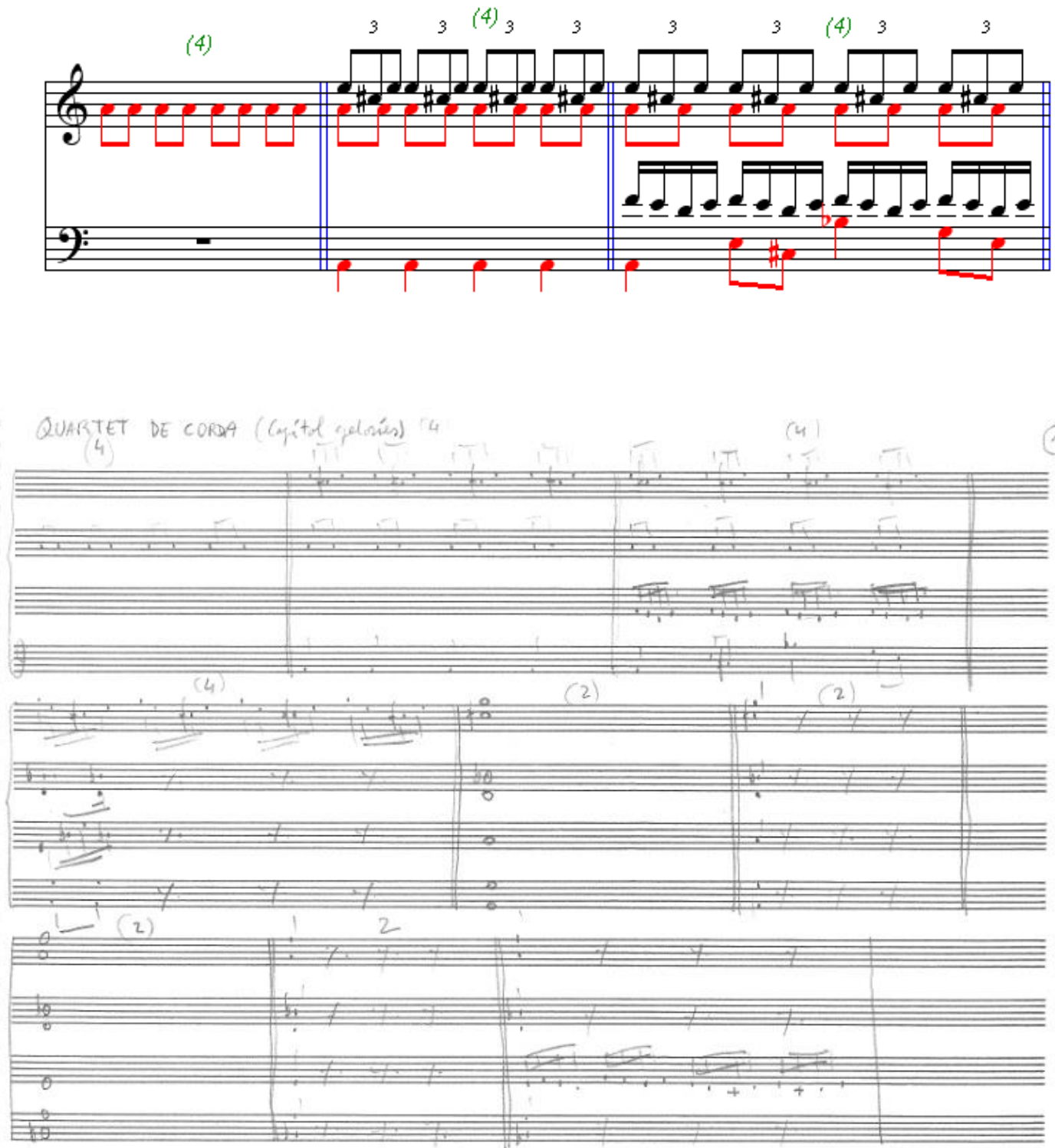

Puede formar parte de la musicalización de algunas imágenes o film. 


\section{MATERIAL TOTAL:}

- Partitura manuscrita y original del autor. Consta de un libreto de escritura musical con 2 páginas escritas con el título Quartet de corda (Capìtol "gelosies") en la $1^{\text {a }}$ página. Existe, asimismo, otra partitura de la misma obra, escrita en 2 páginas sueltas, con el mismo título.

- También existe otra partitura manuscrita y original del autor que consta de un libreto de escritura musical con 2 páginas escritas con el título "3 Sopranos" en la $1^{a}$ página.

- Asimismo existe otra partitura distinta, manuscrita y original del autor que consta de un libreto de escritura musical con 2 páginas escritas con el título "2 Sopranos +1 Tenor" en la $1^{\text {a }}$ página.

- Partes: No existen partes.

- No consta relación de originales y copias. 
9.- VIOLÍ SOBRE FONS DE TRÉMOLOS, Libre, politonal, Cuarteto cuerda, con partitura y guion, s. d., Arc. 26.

La plantilla a la que está dedicada es la de un Cuarteto cuerda.
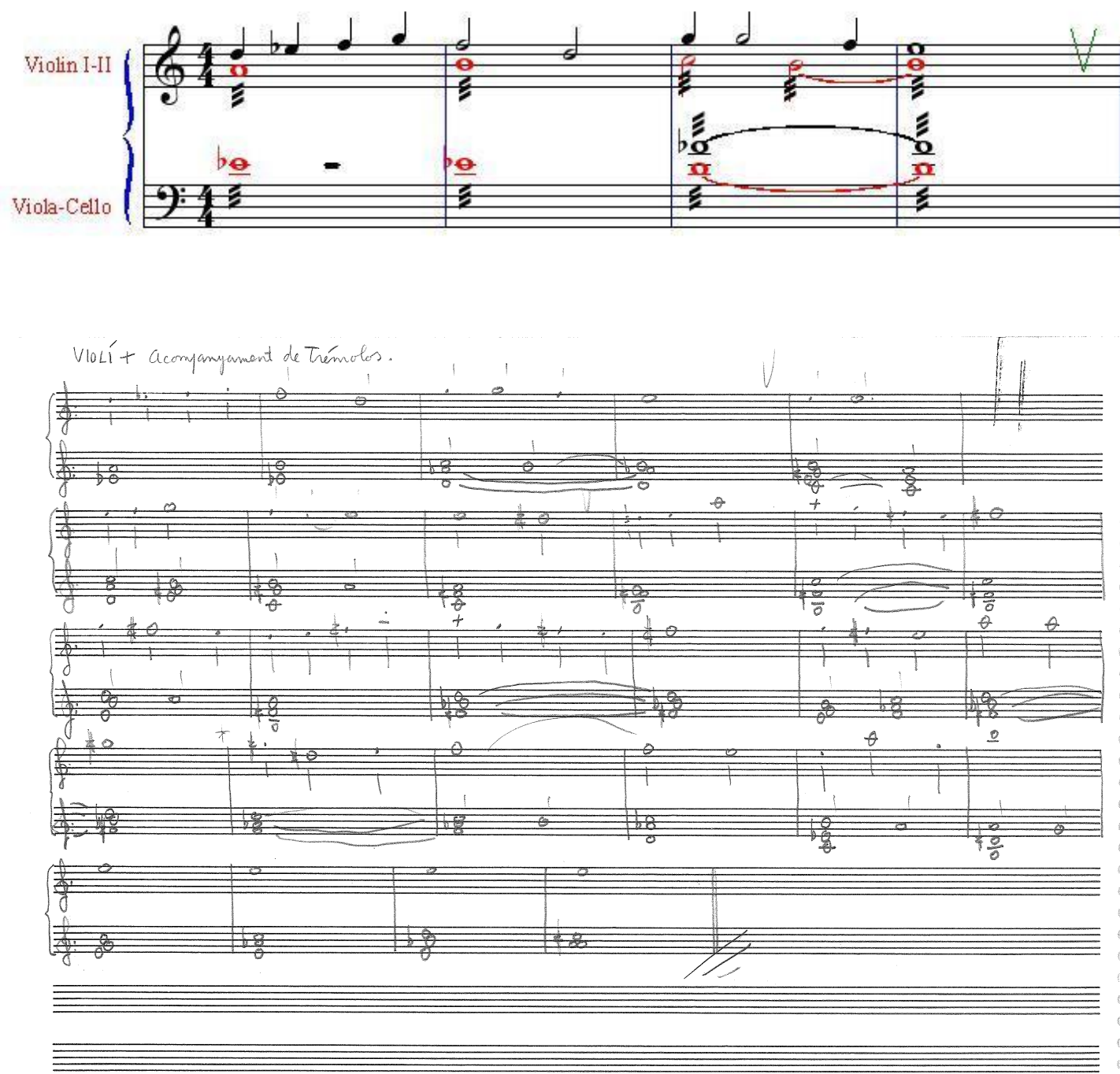

\section{MATERIAL TOTAL:}

- Partitura manuscrita y original del autor. Consta de un libreto de escritura musical con 2 páginas escritas. También hay una fotocopia de esta partitura. Existe otro guion con el título "Violí + Acompanyament de trémolos", en el reverso de la página 2 de la obra Trio de corda.

- Partes: No existen partes.

- No consta relación de originales y copias. 
10.- X, Libre, politonal, Cuarteto cuerda, con guion, s. d., Arc. 26.

La plantilla a la que está dedicada es la de un Cuarteto cuerda.

Ver: "ES QUAN DORMO..." (Obra grupos de cuerda) y PELICULA DE JORDI

CADENA (Obra piano).

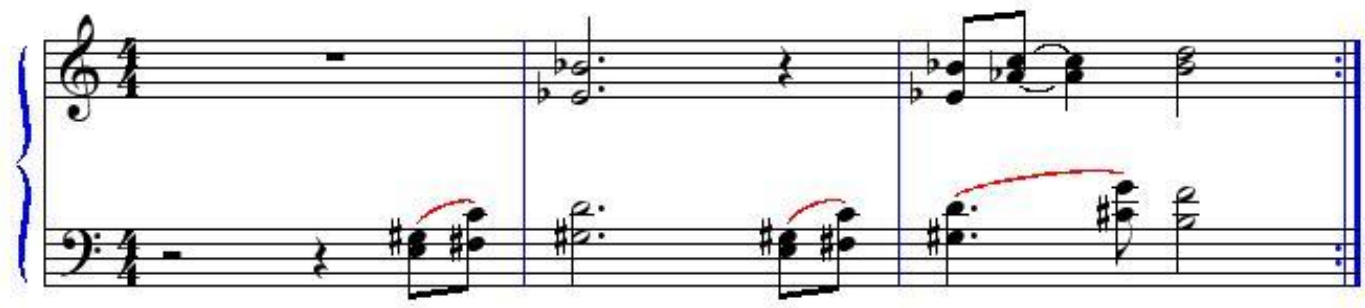

Es un arreglo de la pieza La piscina de Misericòrdia Ubach, incluida en el CD Piano: Carles Santos y cuyo original consta en la sección Obra pianística, de este trabajo.

El material es el mismo que el de la obra Pelicula de Jordi Cadena (Obra piano) aunque instrumentado para cuarteto de cuerda. Posiblemente, al igual que la obra $Y$ (Obra grupos de cuerda), se haya utilizado para la musicalización de algunas imágenes.

\section{MATERIAL TOTAL:}

- Partitura manuscrita y fotocopiada del autor. Consta de dos libretos, de 3 páginas cada uno, con el título $X$ en la portada. El primer libreto contiene la música de los 2 violines y el segundo contiene la música de la Viola y Violoncello. Consta de 14 partes (A a N) con distinta duración cada una de ellas.

- Partes: No existen partes.

- No consta relación de originales y copias. 
11.- PERTURBACIÓ INESPERADA, Libre, en Re, Cuarteto cuerda y Piano, con guion, 1986, Arc. 22.

La plantilla a la que está dedicada es la de un Cuarteto cuerda y Piano.
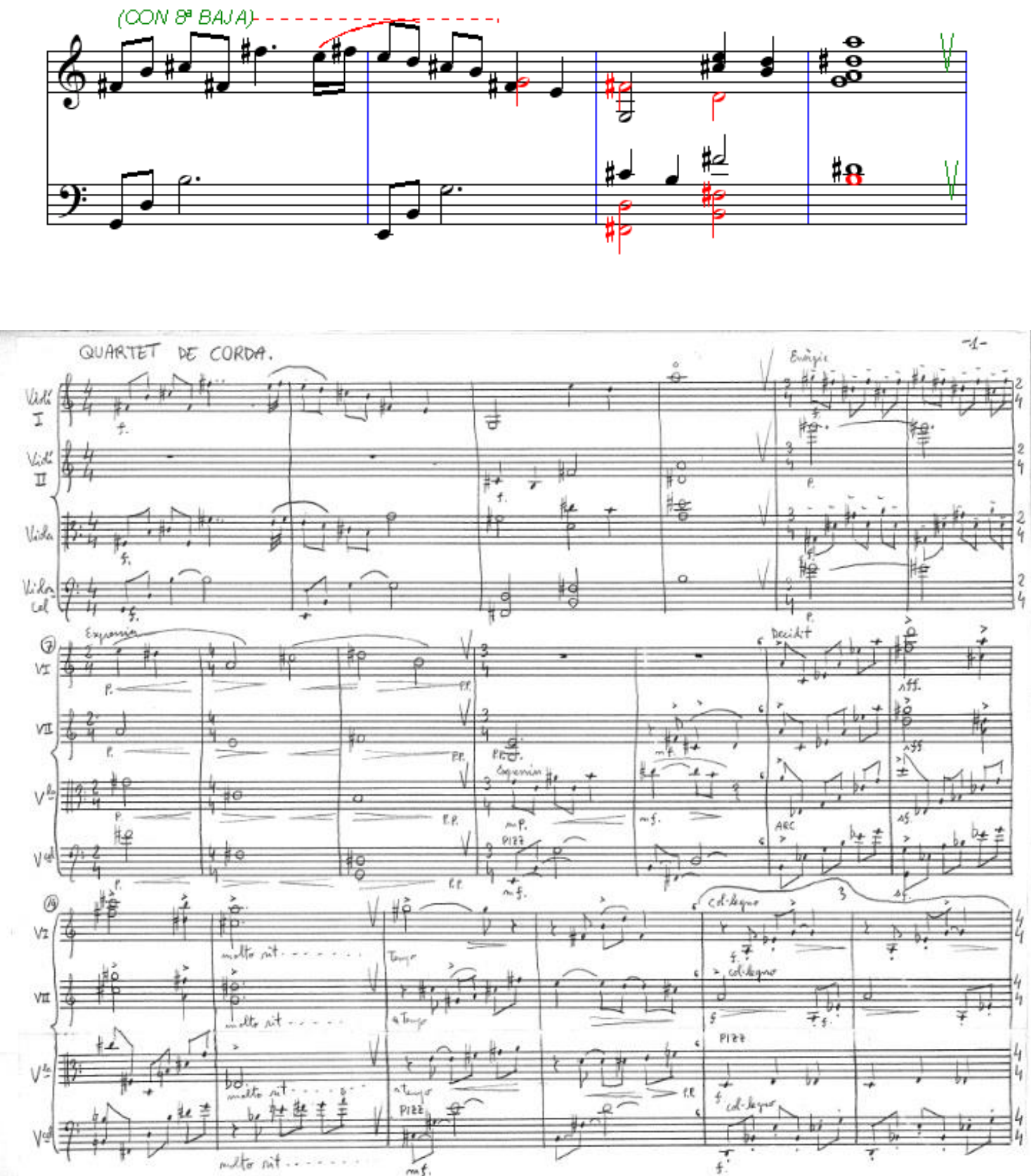

Se corresponde a la pista 5 de la cara B del disco Perturbació Inesperada grabado en 1986 por Linterna Música.

Puede formar parte de la musicalización de algunas imágenes o film 


\section{MATERIAL TOTAL:}

- Partitura manuscrita y original del autor. Incluida en un bloc de escritura musical, sin título en el exterior, numerado con el número 30 y 2 páginas manuscritas y originales, sin numerar. Constan títulos en la contratapa como Perturbació inesperada i Marid al despaix reflexionant. Existen otras obras en este bloc.

- Asimismo existe otro material compuesto por 3 hojas originales y manuscritas escritas por ambas caras, con música y texto, con título en la primera página "Fragments Perturbació inesperada" y el número 23 encercado.

- También hay otro material que consta de 6 páginas fotocopiadas y originales del autor, numeradas, en papel no apaisado. El verdadero material, que se corresponde con la pista 6 del disco Perturbació inesperada, se esconde bajo el título Quartet de corda o Quartet de corda per complementar un piano.

- Partes: No existen partes.

- No consta relación de originales y copias. 


\subsubsection{QUINTETO DE CUERDA}

12.- EL PONT DE VARSOVIA, Libre, politonal, Quinteto de cuerda, con guion, 1989, Arc. 29.

La plantilla a la que está dedicada es la de un Quinteto de cuerda.

Ver: EL PONT DE VARSOVIA (sección Integrales)
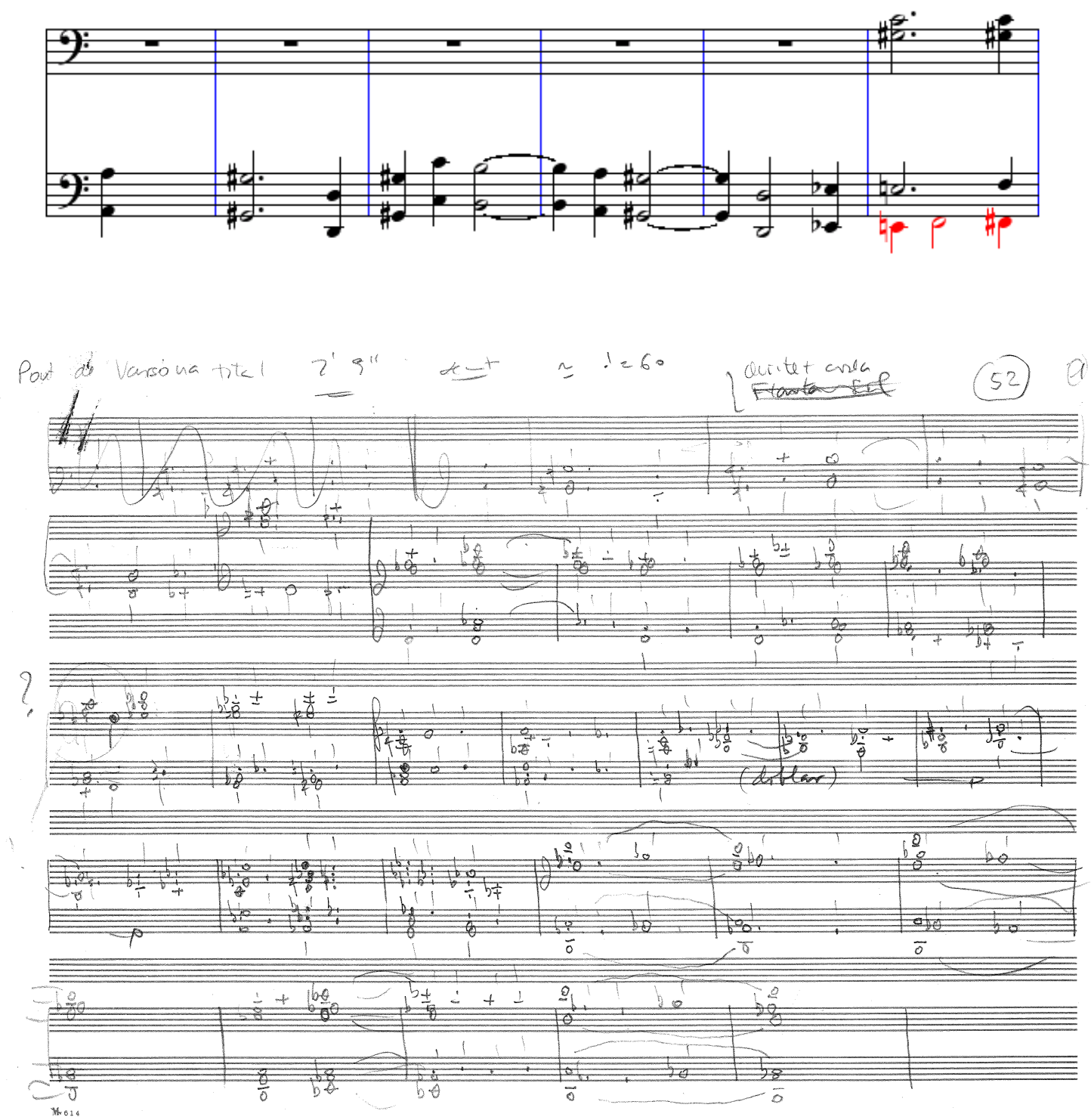

Forma parte de la B. S. O. de la película El pont de Varsovia, film dirigido por Pere Portabella en 1989.

La obra está numerada como 52 por el autor. 


\section{MATERIAL TOTAL:}

- Consta de varios materiales en los cuales existe el título de Pont de Varsovia en las primeras páginas de todos ellos. Partituras manuscritas y originales del autor.

- El material consta de 2 páginas sueltas y numeradas, el título Quintet corda y el número 52 encercado, en la $1^{\mathrm{a}}$ página. Primeros apuntes de la obra.

- Material manuscrito y original del autor. Consta de un libreto manuscrito y original, de 4 páginas, como partitura, sin título en el exterior. Asimismo existe partes instrumentales de la misma.

- Partes: Existen partes.

- No consta relación de originales y copias. 
13.- QUINTET DE CORDA. PORTABELLA, Libre, politonal, Quinteto de cuerda, con partitura, s. d., Arc. 29.

La plantilla a la que está dedicada es la de un Quinteto de cuerda.

$\mathrm{Cb}$
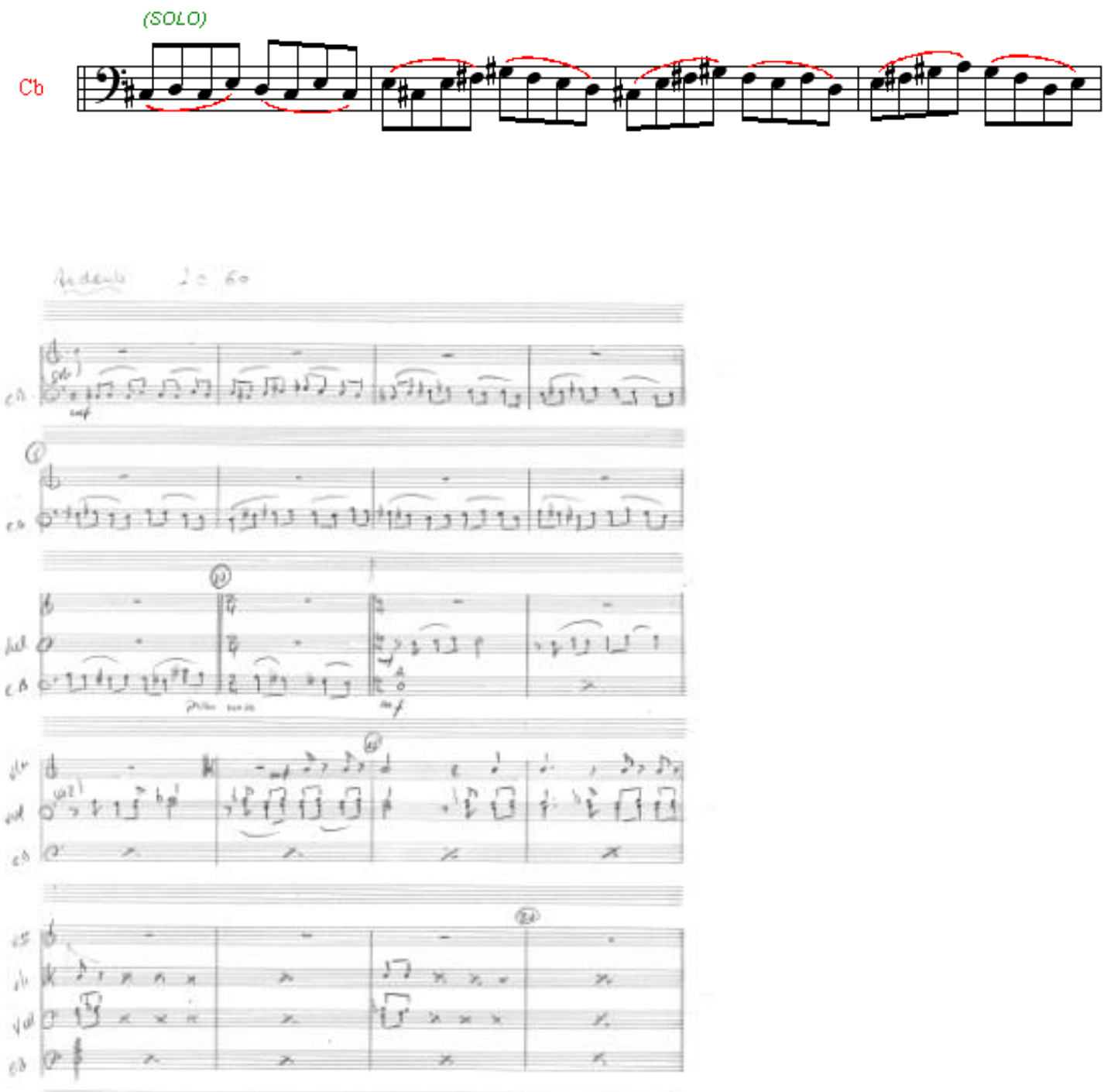

Forma parte de la B. S. O. de la película El pont de Varsovia, film dirigido por Pere Portabella en 1989.

La obra está numerada como 52 por el autor. 


\section{MATERIAL TOTAL:}

- Material manuscrito y original del autor. Consta de un libreto manuscrito y original, de 8 páginas, con el título Quintet de corda y Portabella en el exterior.

- Partes: Existen partes instrumentales de la misma.

- No consta relación de originales y copias. 
3.2.8. OBRA ESCÉNICA 
1.- ARgANChULla, ARGANCHULla-GALlAC, Ópera, politonal, Solistas vocales (4 voces femeninas y 1 voz masculina), Piano y Percusión, con guion, 1985, Arc.17.

Obra escénica. Dividida en diversas secuencias.
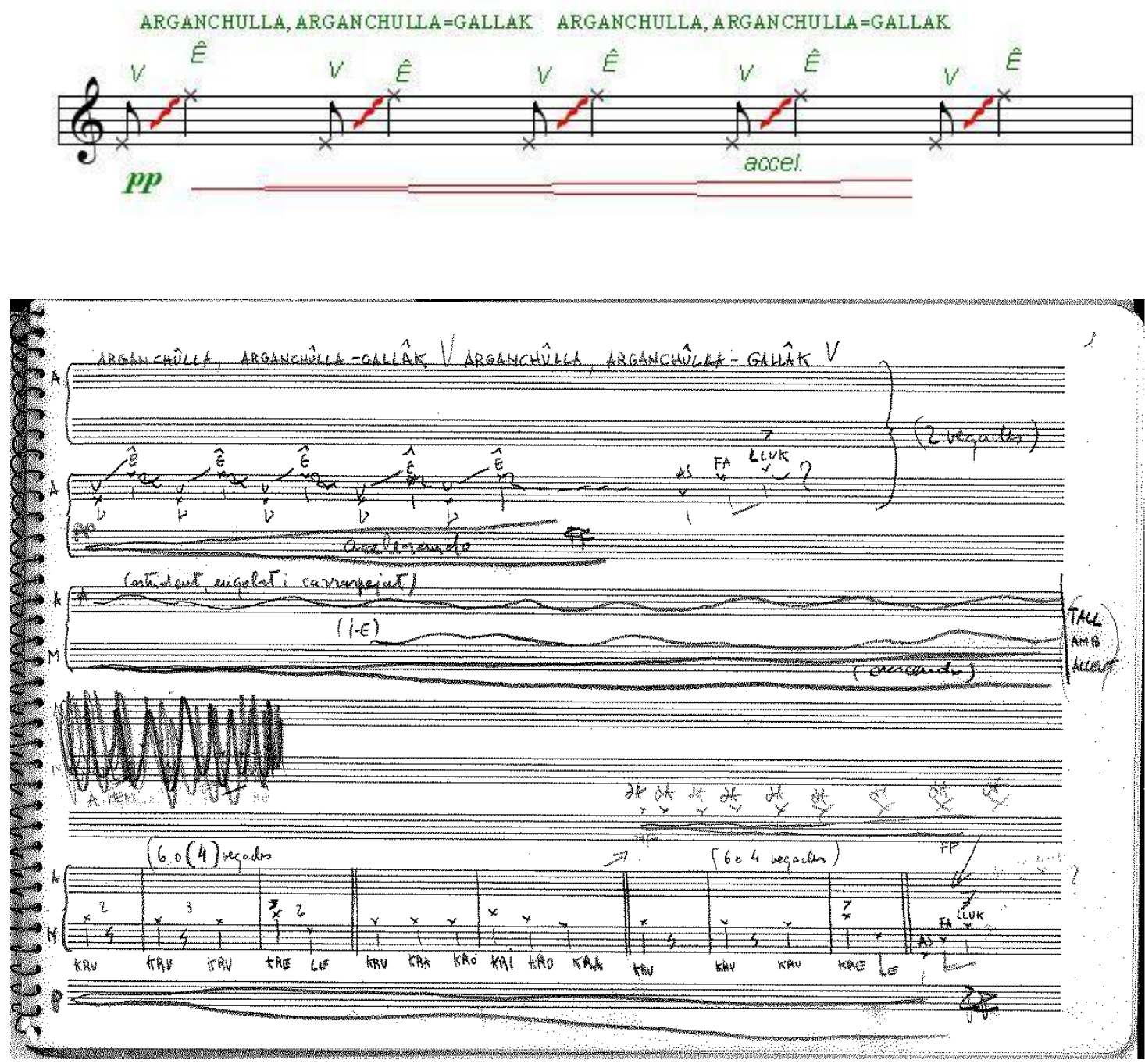

Encargo de la Akademie der Kunste Berlín en 1987. Estrenada en el Festival Inventionen el 12 de febrero de 1987. 
"En la obra no se explica ninguna historia ni tampoco hay ningún hilo conductor: Son secuencias distintas en las que algunos personajes se repiten, pero sin que sea posible encontrar algo, ni formal ni temáticamente, que las una" Carles Santos, ${ }^{71}$

Las partes vocales no tienen texto " los actores cantan, pero sin utilizar ningún idioma, solamente emiten sonidos" (C. S. $)^{72}$

Existe anotación de fecha 1980? En pag. 8.

MATERIAL TOTAL:

- Partitura manuscrita y original del autor. Consta de dos blocs de escritura musical, con el título "Piano" "Argamchulla" y el número 2 encerclado en el exterior y 24 páginas numeradas manuscritas y originales. Puede haber música de otras obras (entre ellas la de una receta culinaria, y por tanto obra con voz pág. 14bis- y la de una obra para piano sin determinar -pág. 8-. No existe la pág. 10. En la pág. 12 existe la anotación "part d'Argamxulla. Argamxulla ballac. Per a veu"). Incluye los fragmentos musicales de la obra escénica.

- Asimismo existe otro bloc de escritura musical con el título Argamchulla y el número 4 encercado en el exterior y 13 páginas numeradas manuscritas y originales. En el reverso de este bloc existen 4 páginas sin numerar, manuscritas y originales, que contienen la música y el texto de la obra Demanau.

- Otro material de la obra: Partitura manuscrita y original del autor. Consta de un bloc de escritura musical, con el título "Percussió argamchulla" y el número 4 bis encercado en el exterior y 12 páginas numeradas manuscritas y originales. Existe otra versión de la obra con el título "Versió percussió Pipi", que consta de 6 páginas sueltas, numeradas, con la partitura de esta versión y el $\mathrm{n}^{\mathrm{o}} 33$ encercado en el exterior y 68 compases.

Existen 4 páginas con dibujos de la representación escénica.

- Partes: Existen partes, de percusión, cada una en un facsímil, originales y manuscritos, del autor. Son partes de la obra catalogada en el $n^{\circ}$ de orden 90 . Del resto no existen partes.

- No consta relación de originales y copias.

\footnotetext{
${ }^{71}$ [Arganchulla, Argan chulla, GaIlac, abre el Grec '87]. (4 de agosto de 1987). El periódico de Cataluña. Recuperado de: (http://archivo.elperiodico.com/ed/19870804/pag_029.html). (20 de julio de 2015)

${ }^{72}$ Idem.
} 
2.- ASDRÚBILA, Ópera, politonal, Solistas vocales, Coro, Órgano, Teclado, Piano, Cuerda, Metales y Percusión, con partitura, 1992, Grande 3.

Obra escénica. Ópera dividida en 10 secuéncias con títulos inversos a lo habitual (Final ópera, Notaría, Restaurant, Germinativa, Sesió informativa, Sentiment de venjança, Tórrida, Subasta, Tranplantament, Obertura). La plantilla a la que está dedicada consta en el libreto de la obra aunque existen discrepancias entre el número de instrumentistas y las particellas encontradas.

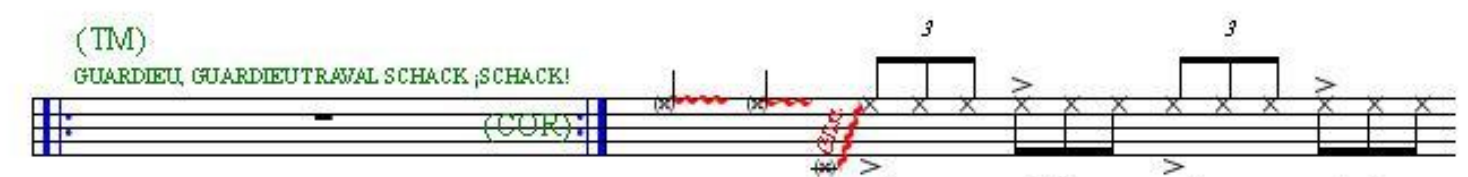

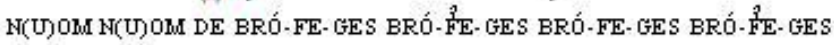

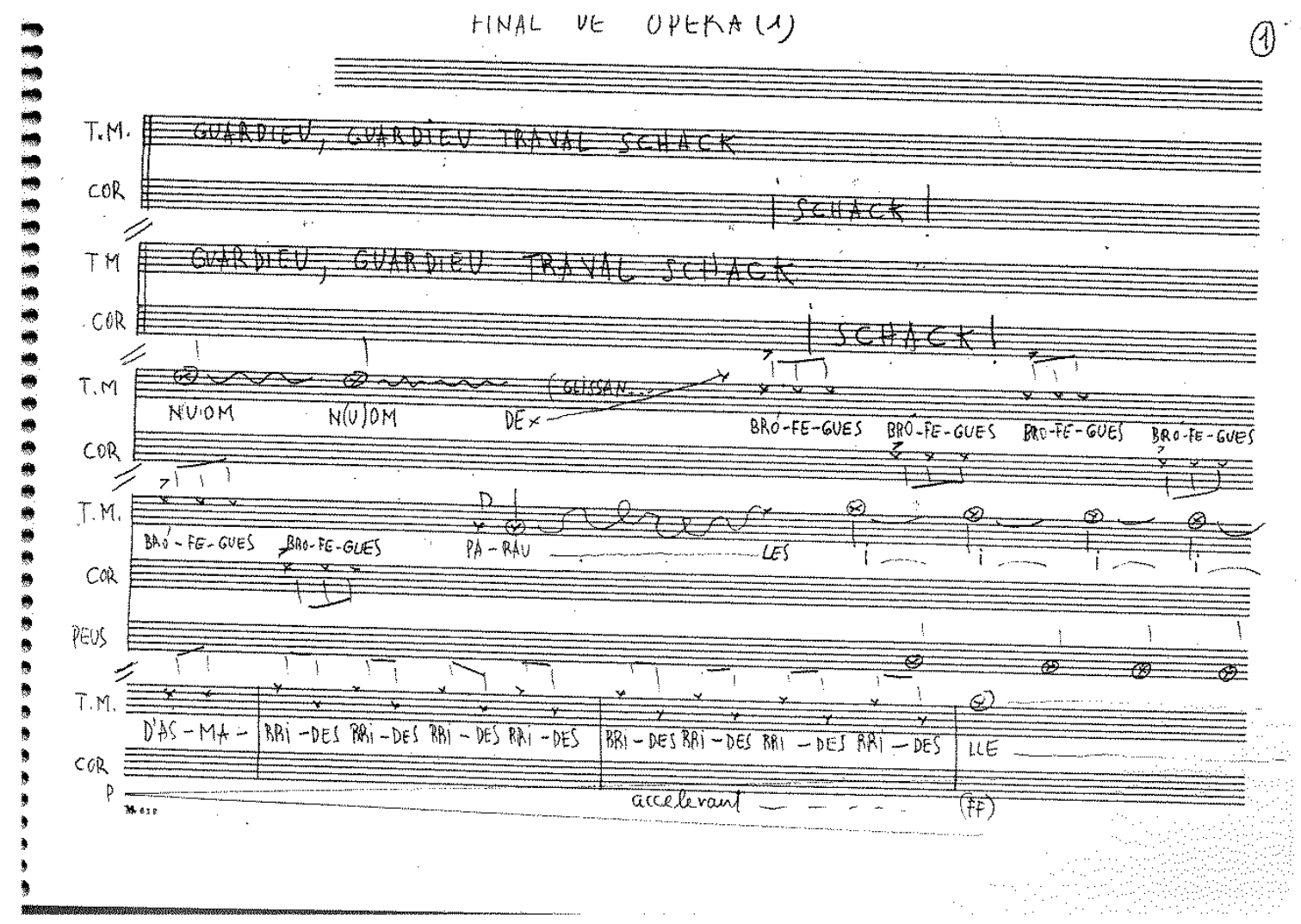

Los instrumentos de percusión son elementos o utensilios de cocina, indicados en la partitura.

Estrenada en el Teatro Tívoli de Barcelona el 20 de julio de 1992, dentro del Festival Olímpic de les Arts. 


\section{MATERIAL TOTAL:}

El material es diverso. Nos centramos en el siguiente:

- Un libro fotocopiado y encuadernado, guion, que contiene toda la obra, con originales fotocopiados y manuscritos del autor y dividido en las siguientes partes:

○ 56 páginas manuscritas y originales del autor, divididas en 2 grupos, que contienen el guion de la parte "Final Ópera" (40 pág.) y "Notaría" (16 pág.);

○ 62 páginas manuscritas y originales del autor, que contienen el guion de la parte "Restaurant ";

○ 34 páginas manuscritas y originales del autor, que contienen el guion de la parte "Germinativa";

○ 70 páginas manuscritas y originales del autor, divididas en 2 grupos, que contienen el guion de la parte "Informativa" (39 pág.) y "Torrida" (31 pág.);

○ 26 páginas manuscritas y originales del autor, que contienen el guion de la parte "Obertura".

- Otro material consta de guion manuscrito y fotocopiado del autor, dividido en 15 grupos:

○ $1^{\circ}$ con el título "Final Ópera (1)" en el exterior y 20 páginas manuscritas y numeradas;

○ $\quad 2^{\circ}$ con el título "Final Ópera (2)" en el exterior y 18 páginas manuscritas y numeradas. Comienza con el tema de la "Trompeta asesina". Contiene el título "Aria R. R. Chovera" en la página 3;

- $3^{\circ}$ con el título "Notaría" en el exterior y 16 páginas manuscritas y numeradas. En la última consta la nota "empalma amb 'Restaurant'" de puño y letra del autor;

- $4^{\circ}$ con el título "Restaurant" en el exterior y 20 páginas manuscritas y numeradas;

○ $\quad 5^{\circ}$ con el título "Restaurant (2)" en el exterior y 19 páginas manuscritas y numeradas, de la 21 a la 39, como continuación de la parte anterior;

○ $6^{\circ}$ con el título "Restaurant (3) R. R. Chóvera" en el exterior y 12 páginas manuscritas y numeradas. En la última consta la nota "empalma amb "Final Restaurant (a capella)" de puño y letra del autor; 
○ $7^{\circ}$ con el título "Final Restaurant 3 " en el exterior y 10 páginas manuscritas y numeradas, con música para el coro;

- $8^{\circ}$ con el título "Final Restaurant" en el exterior y 10 páginas manuscritas y numeradas;

○ $9^{\circ}$ con el título "Germinativa (Música) (Banda)" en el exterior y 18 páginas manuscritas y numeradas, escritas por ambas caras;

- $10^{\circ}$ con el título "Canto de Asdrubila acompañado por el Coro" escrito por mí, en el exterior y 16 páginas manuscritas y numeradas;

- $11^{\circ}$ con el título "Informativa" en el exterior y 15 páginas manuscritas y sin numerar, con el texto en alemán. A esta serie le siguen 11 páginas manuscritas y numeradas, escritas en latín. En la última página consta la nota "Cor a capella" de puño y letra del autor;

○ $12^{\circ}$ con el título "Informativa (2)" en el exterior y 11 páginas manuscritas y sin numerar, con el texto en alemán;

○ $13^{\circ}$ con el título "Torrida" en el exterior y 7 páginas manuscritas y numeradas, con música instrumental, a las que siguen 10 páginas manuscritas y sin numerar;

○ $14^{\circ}$ con el título "Torrida (2)" escrito por mí, en el exterior y 15 páginas manuscritas y sin numerar;

- $15^{\circ}$ con el título "Obertura" escrito por mí, en el exterior y 26 páginas manuscritas y numeradas.

La parte "Sentiment de venjança" es instrumental, y no consta la música manuscrita del autor. La parte "Subasta" contiene música basada en "La trompeta asesina", según el autor. No existe el material de las partes "Subasta" y "Tranplantament".

Asimismo existen fotocopias de los siguientes materiales: "Final de Ópera", 2; "Restaurant", 2; "Final Restaurant", 1; "Germinativa", 1; "Informativa", 1; "Torrida", 2; "Torrida (2)", 1; "Obertura", 1.

- Otros materiales existentes son los siguientes:

- 7 páginas pautadas con la estructura general de la obra, manuscrita y original del autor;

- 16 páginas (facsímil) manuscritas y originales, aunque no del autor, en tamaño A3, que contienen la partitura general de los cantantes solistas, coro, piano, órgano e instrumentos de cuerda, de las partes "Final Ópera" y "Final Ópera (2)"; 
○ 35 páginas (facsímil) manuscritas y originales, aunque no del autor, en tamaño A3, que contienen la partitura general de los cantantes solistas, coro, piano, órgano, instrumentos de viento e instrumentos de cuerda, de la parte "Restaurant". El primer facsímil presenta 19 páginas y el segundo, las 16 restantes;

- 18 páginas manuscritas y fotocopiadas, aunque no del autor, que contienen la partitura general, de la parte " Germinativa ";

○ 9 páginas manuscritas y originales del autor, divididas en 2 grupos, que contienen la partitura del coro y de la solista, de la parte "Torrida" (2 pág.), y "Cant d'Asdrùbila" (7 pág.);

○ 36 páginas manuscritas, divididas en 2 grupos, que contienen la partitura del coro, del piano y de los instrumentos de metal, de 17 páginas, fotocopiadas y manuscritas del autor, a las que siguen las 19 restantes, manuscritas y originales, aunque no del autor, que contienen la partitura de los instrumentos de metal, de la parte "Germinativa";

- 17 páginas manuscritas y originales, aunque no del autor, divididas en 2 grupos, que contienen la partitura de los instrumentos de metal y de percusión, de 5 páginas, de la parte "Informativa (2)", a las que siguen las 11 restantes, de la parte "Obertura";

○ 8 páginas manuscritas y originales del autor, que contienen la partitura de los instrumentos de percusión, de toda la obra;

- 18 páginas manuscritas y originales, aunque no del autor, divididas en 2 grupos, que contienen la partitura de los instrumentos y del piano, de la parte "Torrida" (14 pág.), y "Germinativa (Final)" (4 pág.);

○ 10 páginas manuscritas y originales, aunque no del autor, que contienen la partitura de los instrumentos de cuerda, de las partes "Final de Ópera" y "Restaurant (3)";

○ 7 páginas manuscritas y originales, aunque no del autor, que contienen la partitura de los instrumentos de cuerda, de las partes "Germinativa (2)" y "Informativa";

○ 7 páginas manuscritas y originales, aunque no del autor, que contienen la partitura de los instrumentos de cuerda, de la parte "Torrida".

- Partes: Existen particellas manuscritas de los instrumentos de las partes: "Final Ópera", "Restaurant (3)", "Informativa (2)", "Germinativa", "Tórrida", 
"Obertura" y del coro de las partes: "Germinativa", "Tórrida". En cuanto a estas particellas, no existen las de metal de "Final Ópera". Tampoco las de Órgano, Teclado y Piano, de toda la obra.

- Existen, asimismo, 2 copias de Libreto de la Ópera y 4 copias del libreto con los contenidos visuales y conceptuales, aunque en desarrollo.

- Los personajes principales son los siguientes:
○ Llevera (Uf): Soprano.
- Reblata Reblata Chovera: Mezzosoprano.
○ Teodau Millat: Bajo profundo.
○ Asdrúbila: Contratenor.
- Guardieu Traval Schack: Tenor.

- No consta relación de originales y copias. 
3.- BROSSALOBROSSOTDEBROSSAT, Obra escénica, politonal, Voz y Piano, con partitura, 2008, Arc. 20.

Las voces utilizadas son: 1 voz femenina y 2 voces masculinas (una de ellas tenor), que actúan en el espectáculo, al mismo tiempo que la pianista, que también interactúa.

Ópera original del autor, que se complementa con fragmentos de filmografía, generalmente de Brossa, y fragmentos musicales ya existentes, de Pierre Henry, Brahms, John Cage y Richard Wagner y el propio Carles Santos.
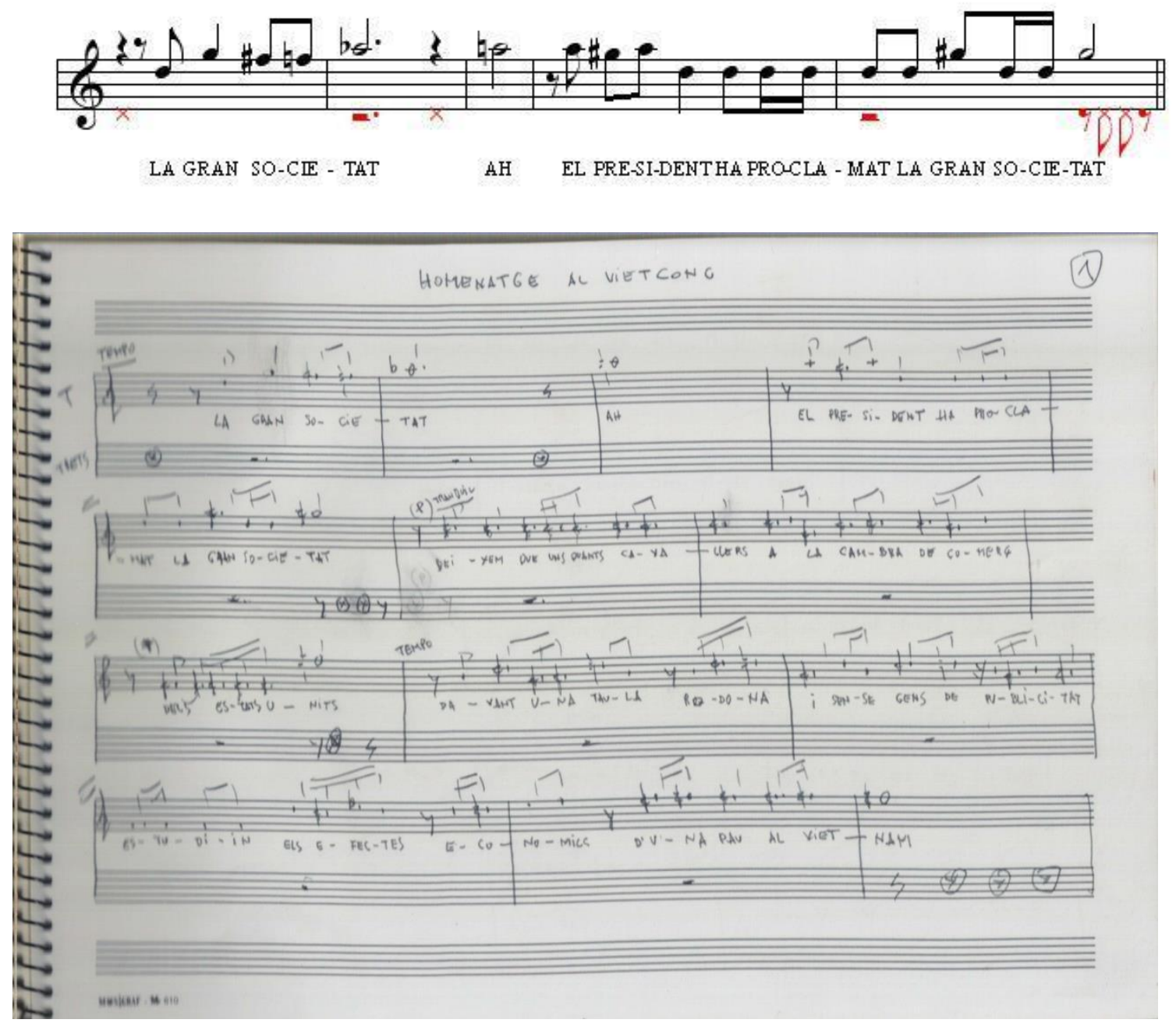

Estrenada el 8 de mayo de 2008 en el Teatre Lliure de Barcelona

\section{MATERIAL TOTAL:}

- Partitura manuscrita y original del autor. Consta de un bloc de escritura musical, con el título Brossa en el exterior y 4 páginas manuscritas y originales. Las tres 
primeras llevan el título de "Homenatge al Vietcong" (pertenecen a una obra anterior de Carles Santos, registrada en disco -ver libro ;Visca el Piano!-) y la última lleva el título de "El Mariner” (se interpreta en la escena 19, por un tenor). Además contiene 3 páginas manuscritas y fotocopiadas, con el título "Sextina Brossa", que corresponden a la música de la escena 6 del espectáculo.

- Partes: No existen partes.

- No consta relación de originales y copias. 
4.- CAL DE RÓN, Obra escénica, politonal, 3 Solistas vocales, Niño, coro, 2 Armonios, Órgano y Percusión, guion y partitura, 2012, Arc. 28.

VER: EL GRAN TEATRO DEL MUNDO
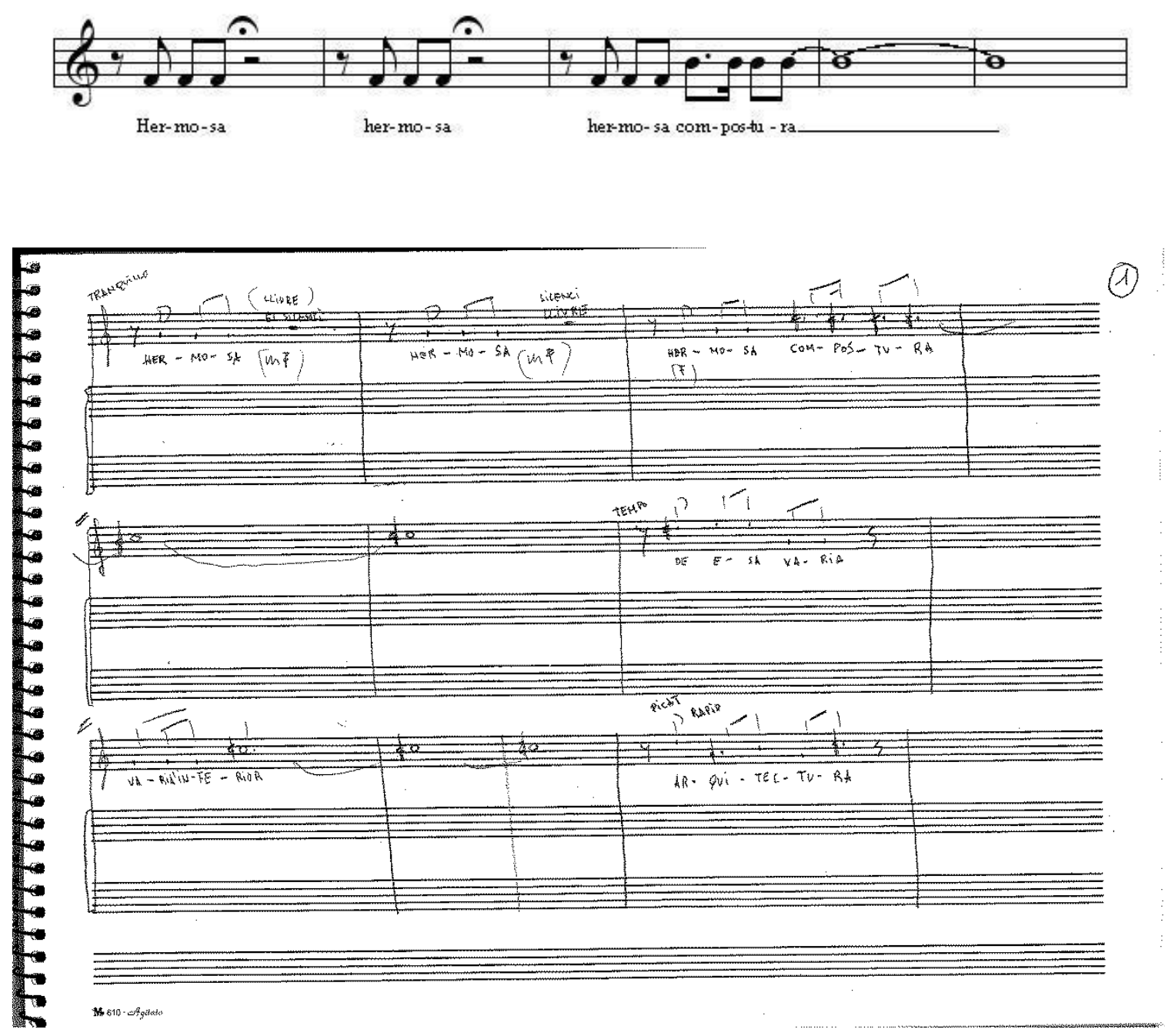
5.- CHICHA MONTENEGRO GALLERY, Obra escénica, politonal, 4 voces solistas y coro femenino, con guion, 2010, Arc. 28.

Las 4 voces solistas se encuentran suspendidas con arneses, del techo.
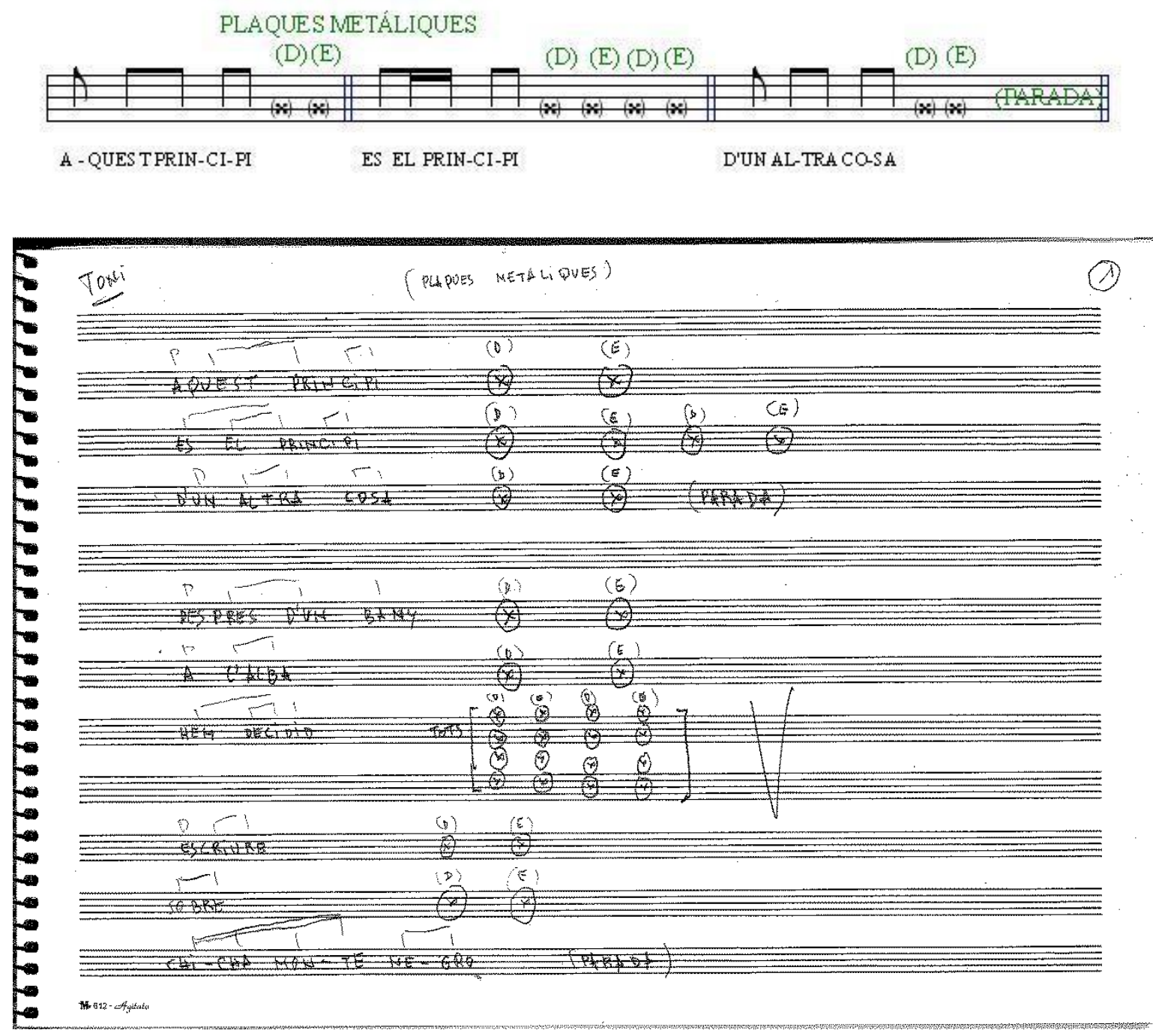

Original de la obra escénica. Incluye la adaptación posterior de Chicha Montenegro Gallery que contiene la música de la obra anterior, en diferente orden, comenzando esta con la obra Iv Centenari de la Reliquia de St. Sebastià. En esta obra, los actores se encuentran suspendidos en el techo durante toda la obra, pasando de una parte del escenario a otra y golpeando con los pies placas metálicas.

Chicha Montenegro Gallery se estrena el viernes 1 de octubre de 2010 en el Teatre Municipal de Girona, en el marco del Temporada Alta - Festival de Tardor de Catalunya - Girona/Salt. 


\section{MATERIAL TOTAL:}

- Partitura manuscrita y original del autor. Consta de dos blocs de escritura musical con 18 páginas escritas y numeradas,

- el primero, en el que el título del mismo consta como La moto. Material dividido en 3 partes, cada una con un título y numeración diferente:

- A.-"Plaques metáliques” y 6 páginas numeradas.

- B.- "Cinturó” y 8 páginas numeradas.

- C.- "Sang" y 4 páginas numeradas (existe hoja aparte con el texto utilizado en este fragmento). Existen 6 páginas que contienen dibujos de la escenografía de la obra.

- El segundo bloc lleva como título exterior "Chicha Montenegro" y consta de 17 páginas numeradas, divididas en 2 bloques o partes cada una con un título y numeración diferente:

- A.- "Llagrimes" y 8 páginas numeradas.

- B.- "Llet humana" y 9 páginas numeradas (existe hoja aparte con el texto utilizado en este fragmento). Este segundo material contiene coro femenino.

- Asimismo existe material impreso de la obra -partitura- realizado por Xavier Piquer con programa Sibelius.

- Partes: No existen partes.

- No consta relación de originales y copias. 
6.- CONCERT IRREGULAR, Obra escénica, politonal, Piano y voz, con guion, 1967, Arc. 19.

La plantilla a la que está dedicada es la de un piano y una voz, sin determinar.
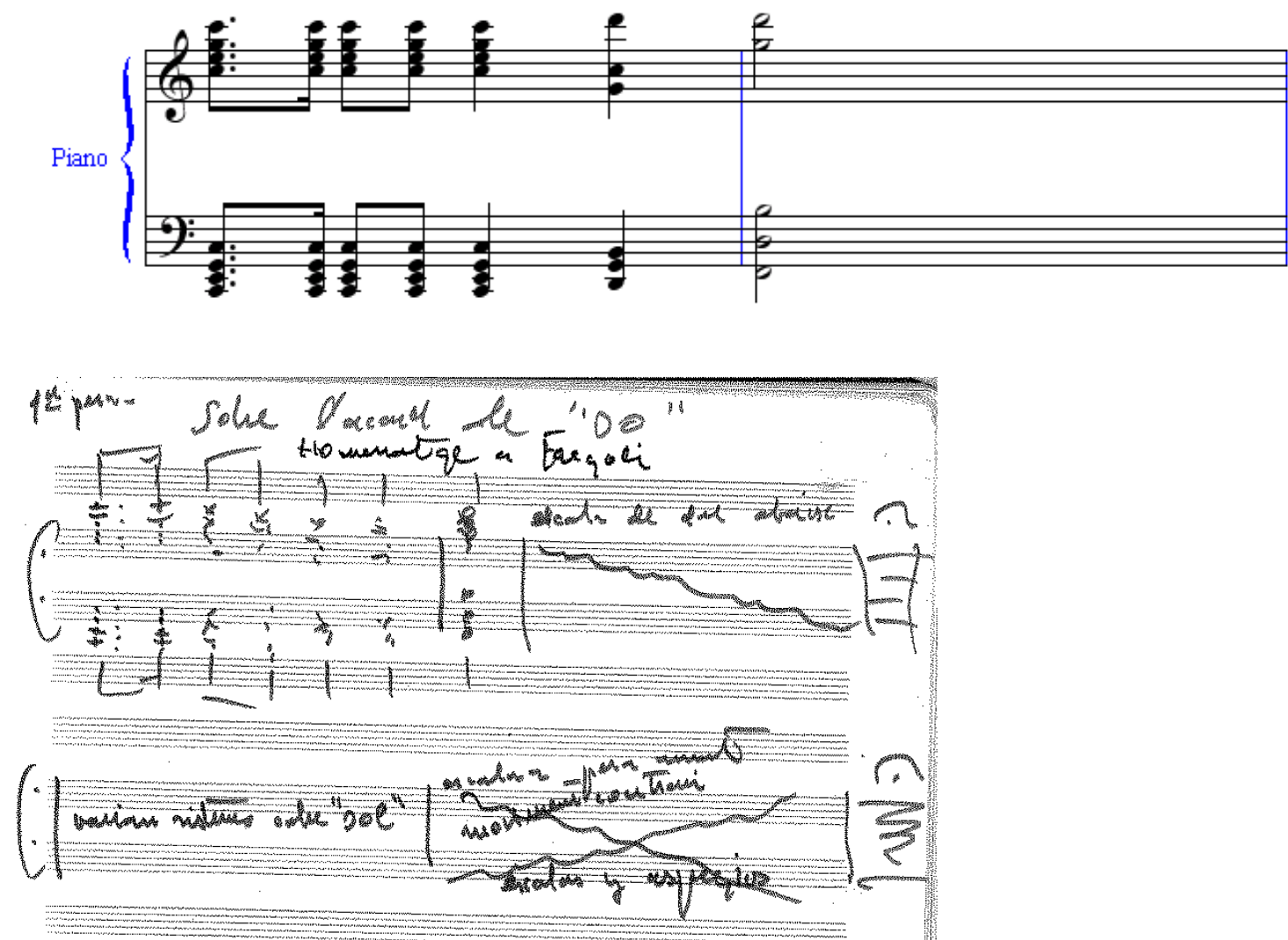

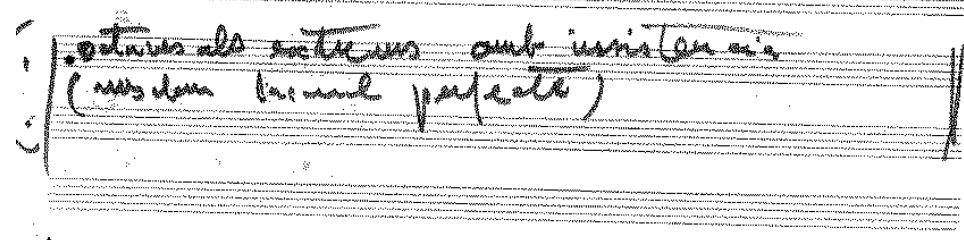

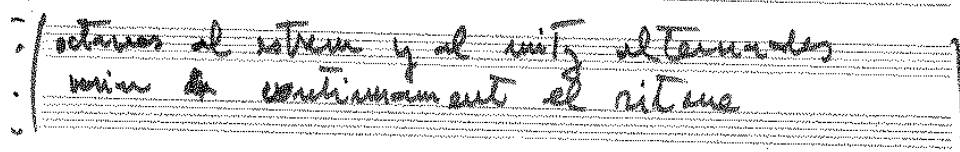

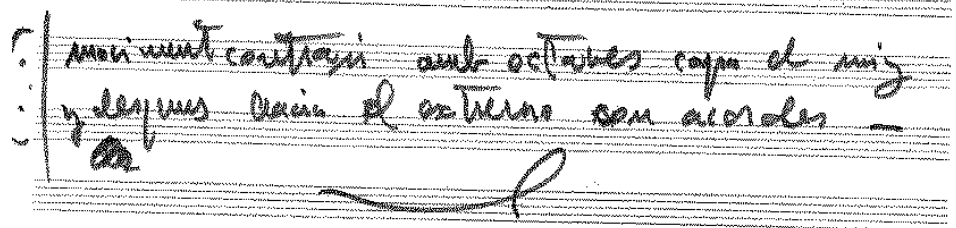

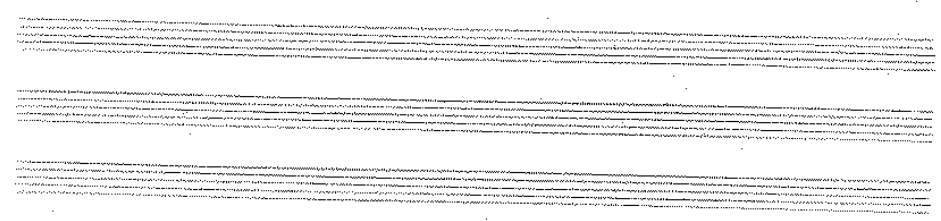


Para festejar el 75 aniversario de Joan Miró. Estrenada a la Fundación Maeght de Sant Pau de Vença. Carles Santos y Anna Ricci.

\section{MATERIAL TOTAL:}

- Material manuscrito y original del autor. Consta de 1 bloc de escritura musical, perteneciente a la década de los 60, con tapa azul oscura, sin título en el exterior. La obra está escrita en 19 páginas. En ella consta la estructura del espectáculo y lo que debe realizar el pianista, aunque en la mayoría de la estructura, no está desarrollado el que ha de tocar aunque si como ha de interpretarlo. Asimismo existe un facsímil de 3 hojas, con música desarrollada. Se desconoce si pertenece al espectáculo. También existe un facsímil de 4 hojas con música desarrollada, aunque se desconoce para que momento del espectáculo está escrito. En una de las hojas, al igual que en el bloc, consta la inscripción "dilluns". Existe también una carta con la biografía de Joan Brossa y un texto de Le Moulin de Jupiter, espectaculo musical, de Joan Brossa.

- Partes: No existen partes.

- No consta relación de originales y copias. 
7.- CREDIT TONAL, Obra escénica, politonal, Piano y voz, con guion, 1986, Arc. 34.

La plantilla a la que está dedicada es la de un piano y una voz, sin determinar.

Ver: PEÇA VEU AMB CESC GELABERT y DEMANA-HO (sección Obra piano y voz)
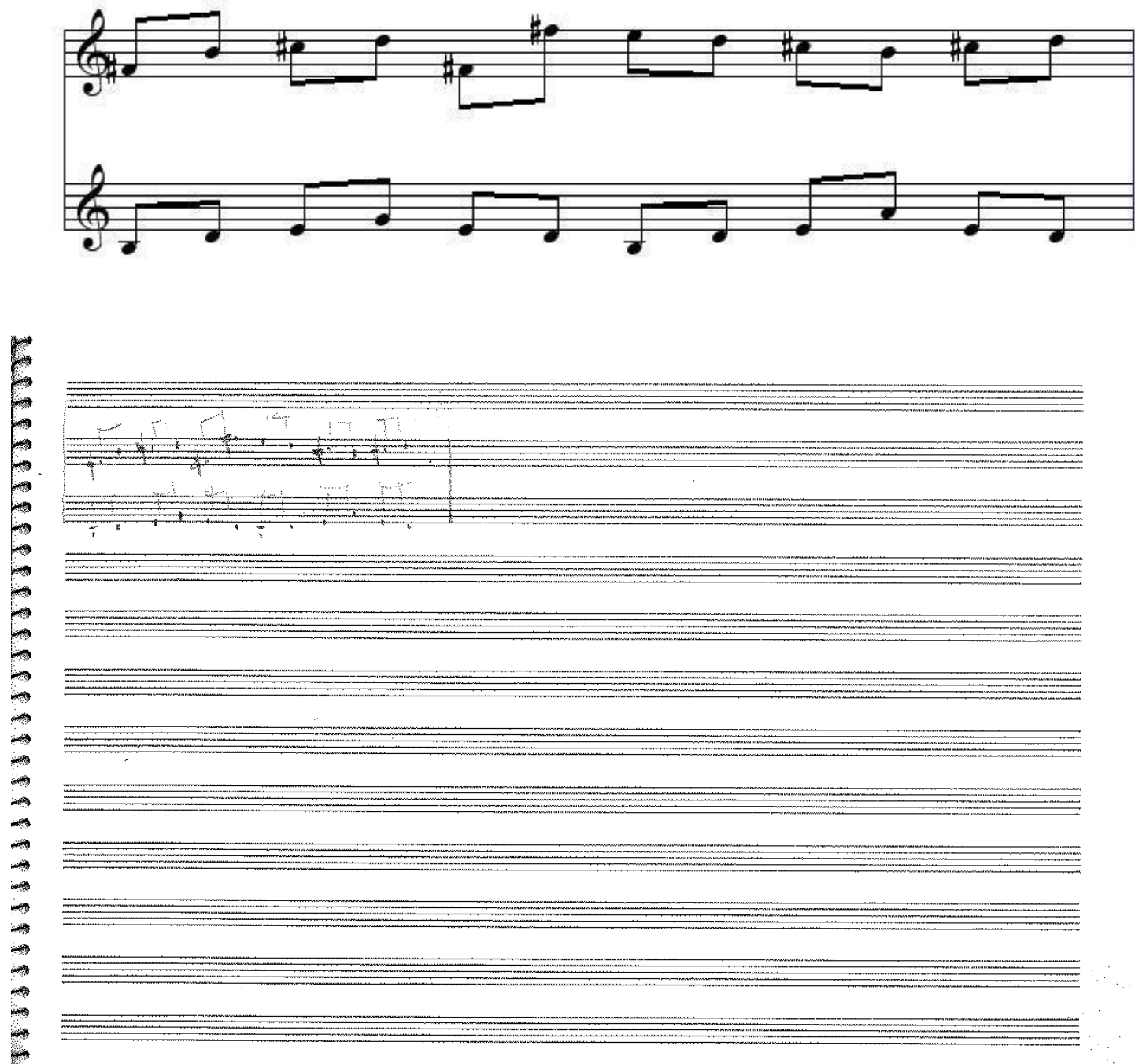

En el mismo bloc se encuentran los apuntes de las obras Credit tonal, Peça veu amb Cesc Gelabert y Demana-ho.

Las tres obras forman parte del espectáculo o Concierto, que "Santos, junto a Cesc Gelabert (bailarín), Carina Mora (voz), Montse Colomé (bailarina) y Serena Vergano 
(actriz) ofrecieron en el Palau de la Música Catalana el 14 de mayo de 1986. Es la primera actuación de Santos en la que interpreta repertorio propio en su totalidad". ${ }^{73}$

\section{MATERIAL TOTAL:}

- Material manuscrito y original del autor. Consta de 1 bloc de escritura musical, sin título en el exterior. Las 4 primeras páginas contienen los apuntes de la obra. En el mismo bloc se encuentran las obras Demana-ho y Peça veu amb Cesc Gelabert.

- Partes: No existen partes.

- No consta relación de originales y copias.

\footnotetext{
${ }^{73}$ Guerrero, M. (2006): Carles Santos. Visca el Piano!. Fundació Joan Miró. Barcelona. Página 470.
} 
8.- EL BARBERO DE SEVILLA, Ópera, politonal, voces solistas, coro, Piano y Orquesta, con guion, 2000, Arc. 31.
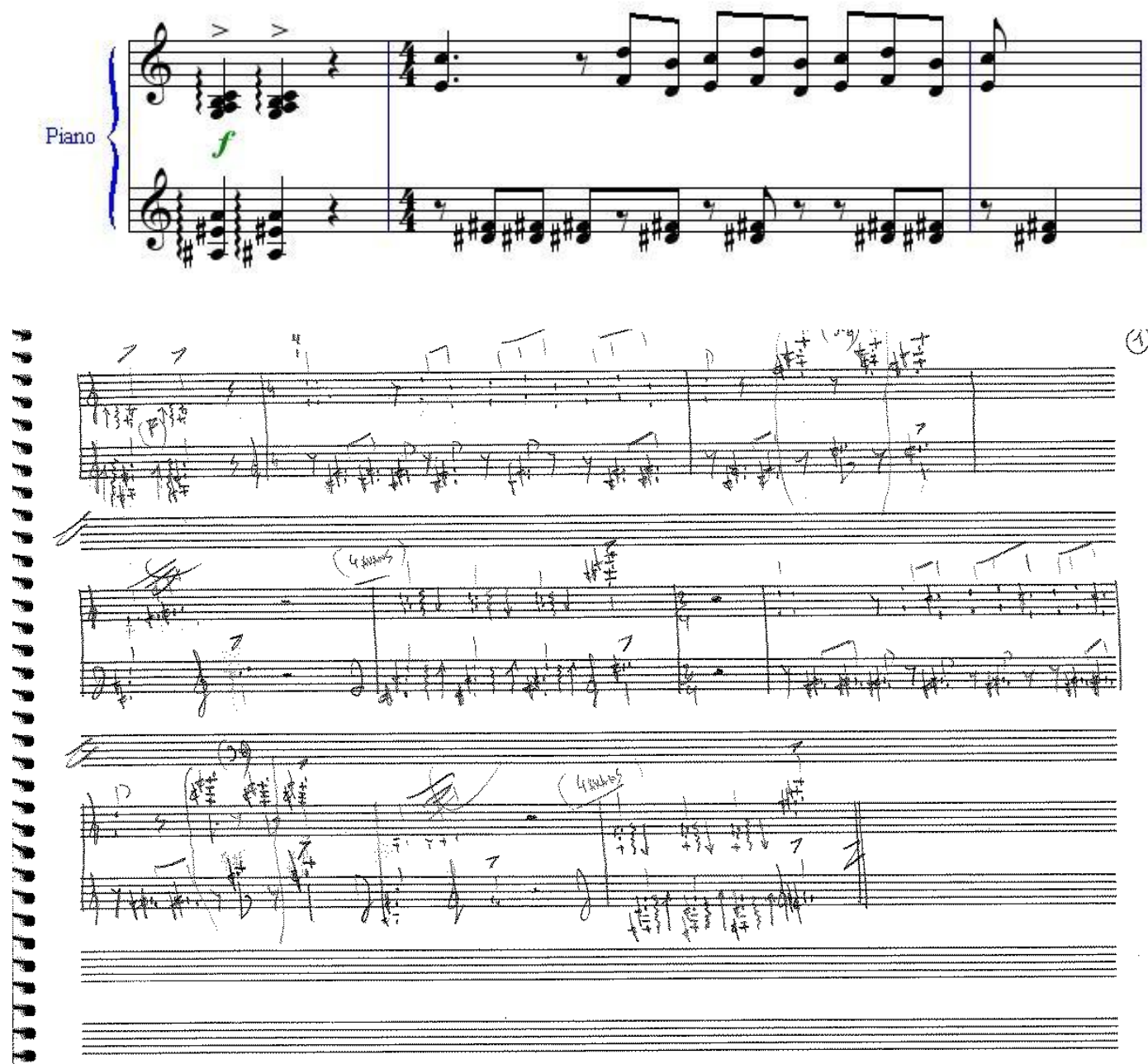

Estrenada el 4/08/2000 al XIV Festival Castell de Peralada.

Debut de Carles Santos como director de escena.

\section{MATERIAL TOTAL:}

- Material manuscrito y original del autor. Consta de 1 bloc de escritura musical, con el título "Barbero (1)" en el exterior y los títulos "Piano" "Cantant" "Cuiner" y "Pecadora". Consta de 19 páginas numeradas con la música para piano, del autor. En el mismo bloc se encuentran la "Gota a la ma" (3 páginas numeradas), "Gota a la boca" (3 páginas numeradas) y "Gota de la pecadora" (3 páginas numeradas). 
- Partes: No existen partes.

- No consta relación de originales y copias. 
9.- EL COMPOSITOR, LA CANTANT, EL CUINER I LA PECADORA, Ópera, politonal, Solistas vocales (Mezzo-soprano, Tenor, Soprano) y Piano, partitura, 2003, Arc. 6.

Ópera original del autor, que se complementa con fragmentos musicales ya existentes, de Rossini.
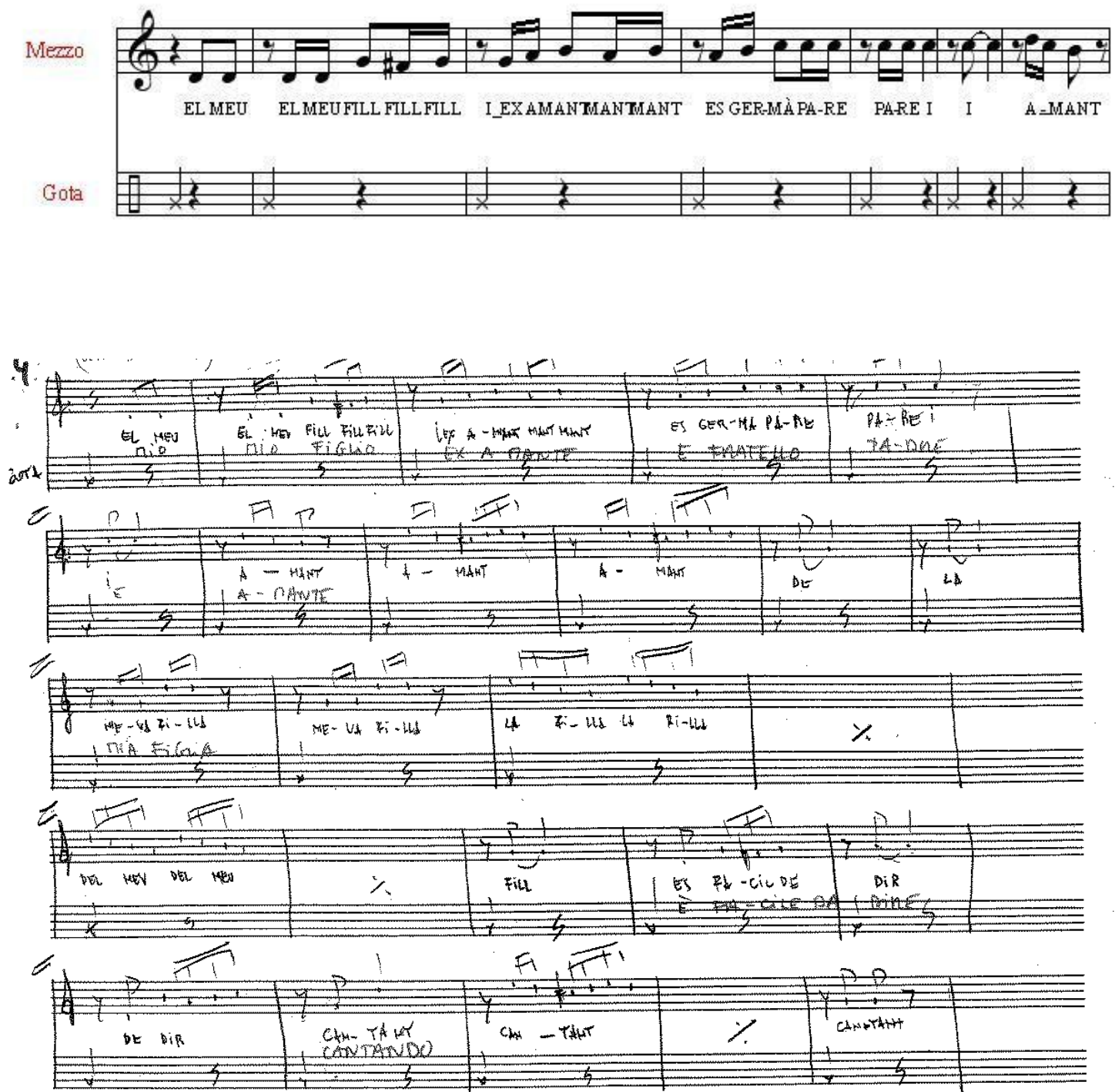

Estrenada en el TNC de Barcelona el 4 de noviembre de 2003.

Ganadora de 3 premios MAX, en la edición de 2005, a Mejor espectáculo musical, Mejor dirección musical y Mejor composición musical

El orden de los fragmentos musicales empleados en la obra, es el siguiente: 
- Rossini (1816 - 24 años) Il Barniere di Siviglia, commedia. Fragmento del ária del Conde "Ah. Il più lieto, il più felice".

- Rossini (1813 - 21 años) L'Italiana in Algieri, dramma giocoso. Fragmento del ária d'Isabella "Per liu che adoro".

- Rossini (1829-37 años) Guillaume Tell, Opera. Fragmento de "Pas de six".

- Rossini (1825-33 años) Il vaggio a Reims, dramma giocoso. Fragmento del duo de "Libenskof i Melibea".

- Santos. Primera Gota, pera mezzosoprano.

- Santos. Segunda Gota, para soprano.

- Santos. Tercera Gota, para tenor.

- Santos. Variaciones sobre la cavatina de Fígaro de Il Barbiere di Siviglia, para piano solo.

- Rossini (1813-21 años) Collage de diversos recitativos de la Italiana in Algieri.

- Rossini (1970-18 años) La Cambiale di Matrimonio, farsa cómica. Fragmento del duo "Tornami a dir che m'ami".

- Rossini (1842-50 años) Stabat Mater. Coro y recitativo "Eja, mater, fons amoris".

- Santos. Gotas, trio.

- Rossini (1816-24 años) Il Barbieri di Siviglia. Temporale

- Rossini (1817-25 años) La Cenerentola, Temporale.

- Santos. Trio con piano.

- Rossini (1804-11 años) Sonata a quattro número 5 en Mi bemol mayor Andante.

- Rossini (1823-31 años) Semiramide, melodramma trágico. Fragmento del duo "Alle più care immagini".

- Rossini (1822-30 años) Zelmira, dramma. Fragmento de la cabaletta de tenor "Cara, deh, attendimi".

- Rossini (1864-72 años) Quelques mesures de chant funèbre: à mon pauvre ami Meyerbeer. Colección Péchés de Vielliese. Volum III: Morceaux résevés.

\section{MATERIAL TOTAL:}

- Partitura manuscrita y fotocopiada del autor, de los fragmentos en los que la música es suya (el resto es de Rossini). Consta de 5 fragmentos, grapados, que se corresponden a las escenas: 
○ 4, "Gota de la cantant" (3 pág. mezzo + ritmo),

○ 5, "Gota de la pecadora" (3 pág. soprano + ritmo),

○ 6, "Gota del cuiner" (3 pág. tenor + ritmo),

○ 11, "Trio abans de la tempesta" (9 pág. trio vocal) y

○ 13, "Trio al llit" (8 pág. trio vocal + piano).

Todas las hojas están numeradas. No existen partes.

El material se complementa con fragmentos fotocopiados de las obras de otros autores interpretados en el espectáculo. Existen también 1 fragmento pasado a ordenador, que comprende el material musical de la escena 3 ( $2^{\mathrm{a}}$ parte) con instrumentación de orquesta sinfónica y coro.

Falta el material musical de las escenas

○ 3.1 ("Pas de six", instrumental),

○ 7 ("Variaciones sobre la cavatina de Fígaro", piano),

○ 8 (collage de diversos recitativos de "L'italiana in Algeri" amb música de clave),

○ 9 (fragmento del Duo "Tornami a dir che m'ami" de "La cambiale de matrimonio"),

○ 10 (fragmento del "Stabat Mater" y el Coro y recitativo "Eja, mater, fons amoris"),

○ 12 ("il barbieri di Siviglia" y "La cenerentolla")

○ 14 (Andante de la "Sonata a quattro $\mathrm{n}^{\circ} 5$ en $\mathrm{Eb}$ ) y

○ 17 (Canto fúnebre "Mon pauvre ami Meyerbeer").

Las partes instrumentales y del coro no existen, así como las partes de piano.

- Existe guion literario, con los elementos escénicos a utilizar y la escenografía (fechado a 10/11/ 2003) y guion de las músicas a utilizar, de 7 páginas.

- Los personajes principales son los siguientes:
○ Cuiner: Tenor.
○ Pecadora: Soprano.
○ Cantant: Mezzosoprano.
- Compositor: Carles Santos (piano).
- 2 bailarines

- Partes: No existen partes.

- No consta relación de originales y copias. 
10.- EL FERVOR DE LA PERSEVERÈNCIA, Ópera de pequeño formato, politonal, Solistas vocales (Soprano y mezzosoprano) y Piano, con guion, 2006, Arc. 6.

Ópera de pequeño formato, original del autor, que se complementa con fragmentos musicales ya existentes, de Frederic Chopin, Tomás Luis de Victoria, Carles Santos, Richard Wagner y Hugo Wolf.
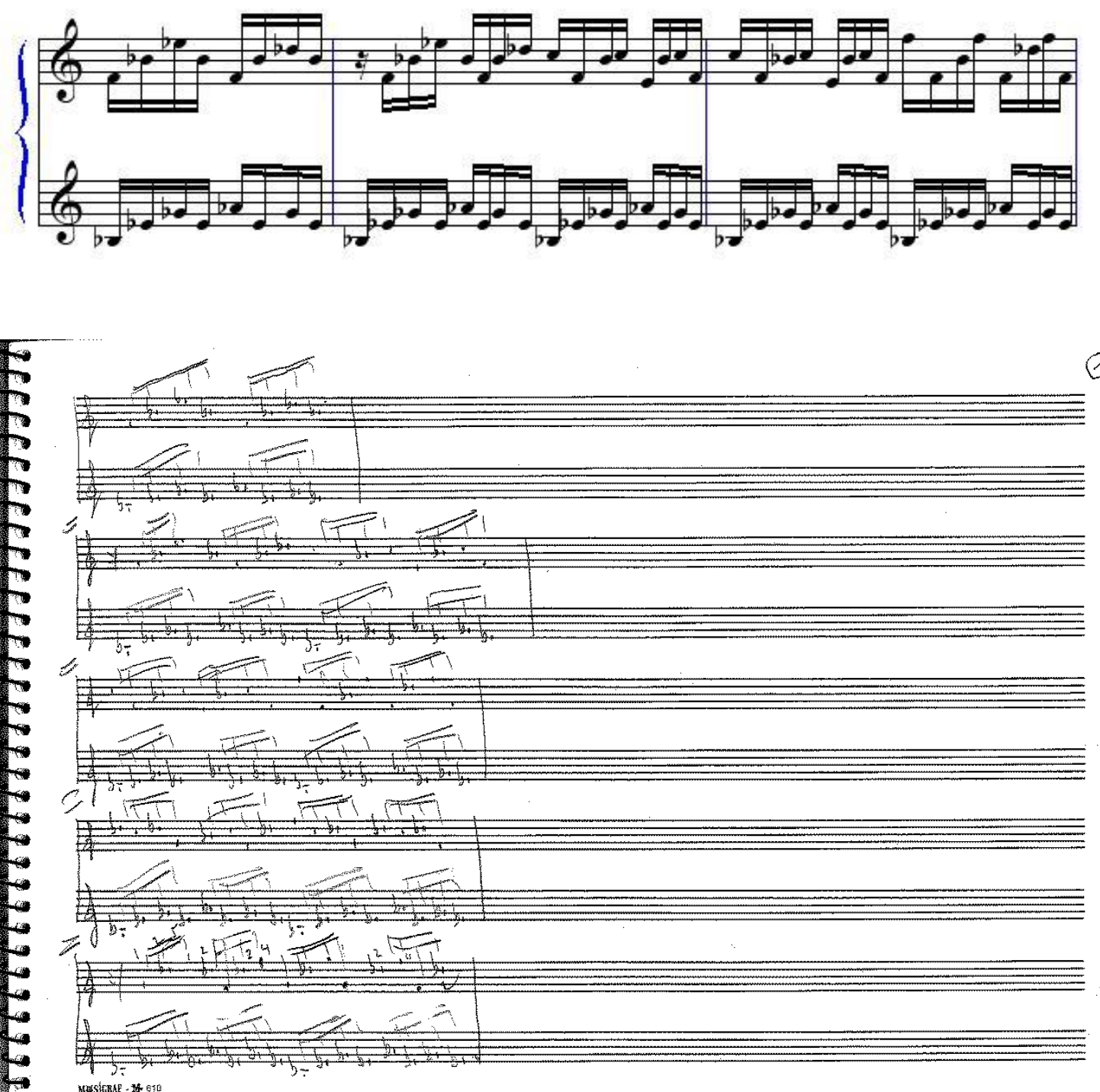

Estrenada en la Temporada Alta - Girona, Salt Festival de Tardor de Catalunya, el 18 de noviembre 2006. 


\section{MATERIAL TOTAL:}

- Partitura manuscrita y original del autor. Consta de 2 blocs de escritura musical, con los siguientes títulos:

- Fervor en el exterior con 8 páginas seminumeradas y manuscritas. Contiene la parte pianística que se interpreta al comienzo del espectáculo.

○ "Fervor (Claudia)" en el exterior con 4 páginas numeradas y manuscritas. Contiene la parte vocal. En el reverso de este cuaderno existen 28 páginas numeradas y manuscritas con partes conjuntas de voz y piano.

- Existen los textos de la obra.

- Partes: No existen partes.

- No consta relación de originales y copias. 
11.- EL GRAN TEATRO DEL MUNDO, Obra escénica, politonal, 3 Solistas vocales, Niño, coro, 2 Armonios, Órgano y Percusión, guion y partitura, 2012, Arc. 28.

El material original manuscrito de la obra consta como Cal-de-rón.

Música de Santos para la representación de Barcelona Internacional Teatre (BIT) bajo la dirección de Calixto Bieito. Los versos son extraídos de la obra de Calderón de la Barca.
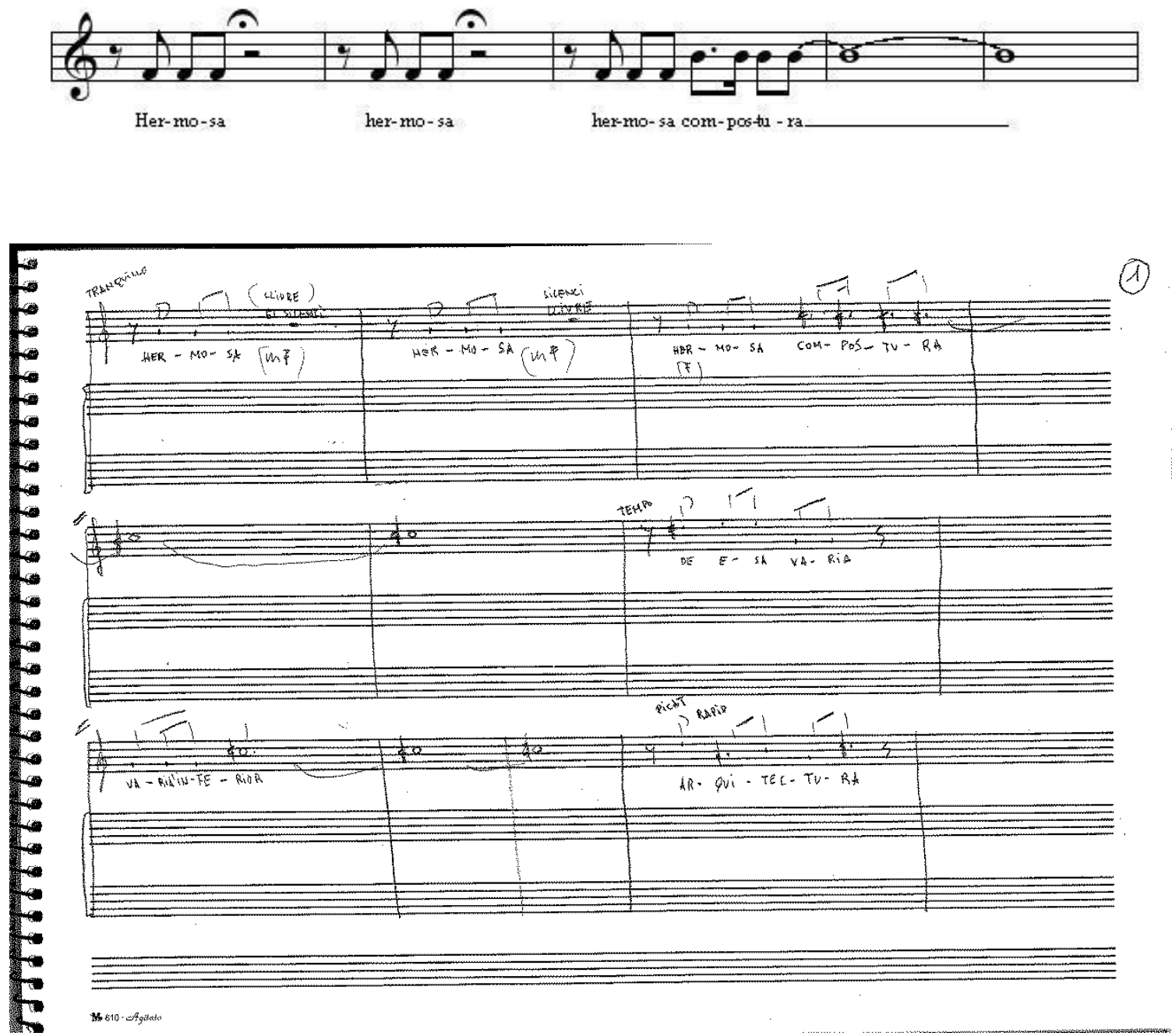

Estrenada el 10 de noviembre de 2011 en Friburgo.

\section{MATERIAL TOTAL:}

- Partitura manuscrita y original del autor. Consta de dos blocs de escritura musical, tamaño A4 apaisados, de 30 hojas ambos, el primero, con el título Cal- 
de-rón (1) en el exterior y 27 páginas manuscritas y originales, y el segundo con el título Cal-de-rón (2) en el exterior y 31 páginas manuscritas y originales. No existen partes.

- Partitura impresa en formato pdf (de Sibelius) por Xavier Piquer. Consta de una partitura de 29 páginas (está incompleta).

- Los personajes principales son los siguientes:
○ Autor.
○ Mundo.
○ Niño.
○ Ley de Gracia.
○ Coro Mortales.

- Partes: No existen partes.

- No consta relación de originales y copias. 
12.- FIGASANTOS FAGOTROP: missatge al contestador: soparem a les nou, Ópera/Obra escénica, politonal, Voces solistas (4 sopranos), Violín, Piano, Fanfarria y Percusión, guion/partitura, 1996, Arc. 9.
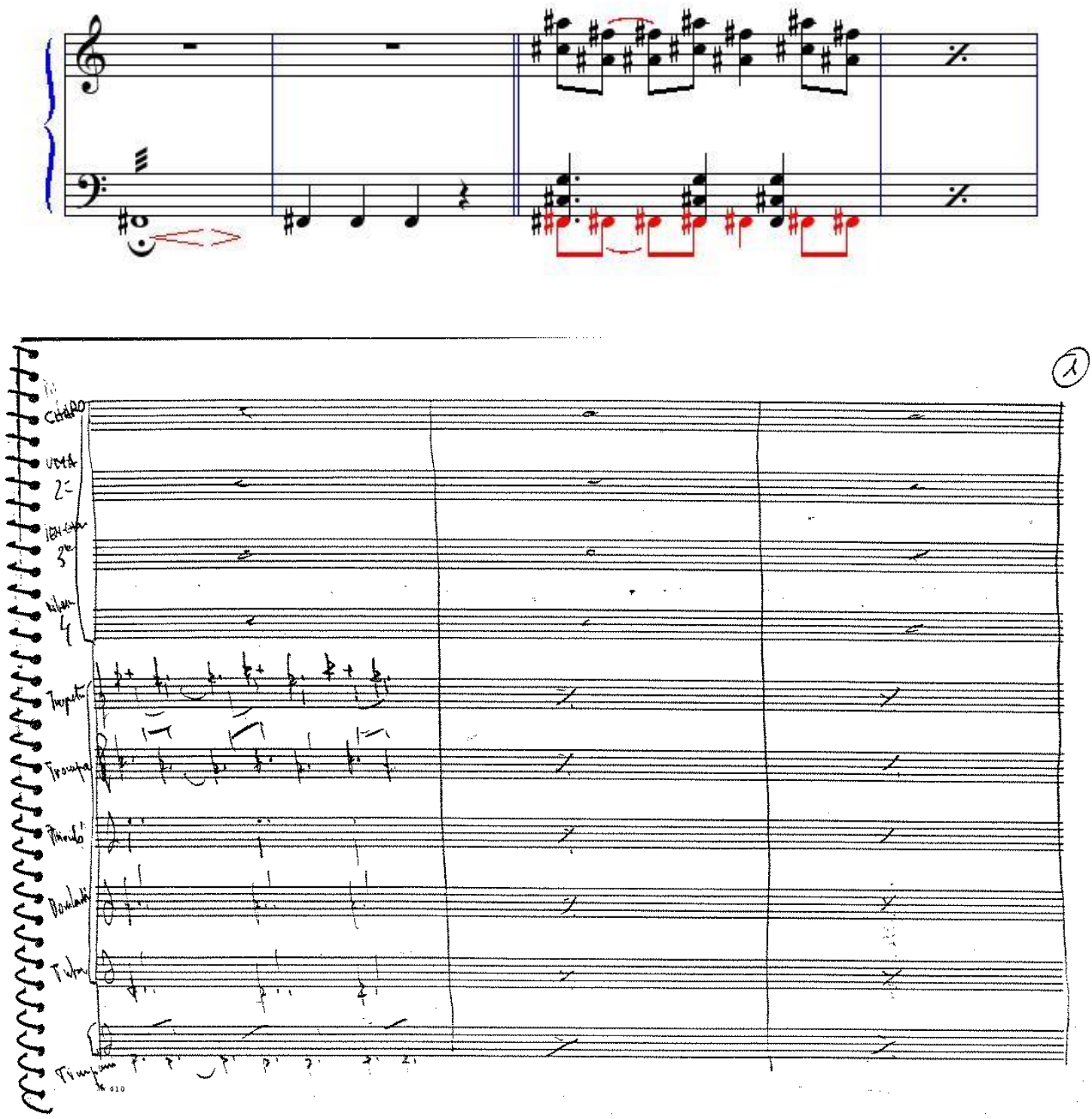

Estrenada el 18 de abril de 1996 en el Teatre Poliorama, Barcelona.

El montaje reúne en escena a 16 personas, entre sopranos, músicos y actores polivalentes. "Los músicos son actores que en lugar de expresarse con la palabra lo hacen con sus instrumentos" (Carles Santos). 


\section{MATERIAL TOTAL:}

- Material manuscrito y fotocopiado del autor. Consta de 1 partitura de escritura musical, con el título Missatge... en el exterior. La obra se divide en varias secciones subtituladas:

○ A.- "Desfilada i sopar", 113 páginas numeradas; en la pág. 30 aparece el título "Preludi i desfilada"; en la pág. 49 aparece el título "Sopar";

○ B.- "Sordera", 12 páginas numeradas; en la pág. 1 aparece el título "Sordera $1^{\mathrm{a} "}$;

○ C.- "Zapping", 14 páginas numeradas; aparecen los subtítulos Zapping-1 a Zapping-9;

○ D.- "Caragran", 20 páginas numeradas; aparece el subtítulo "Caragran (Serrada)" en la pág. 9, que consta de 3 páginas con numeración aparte. Sigue en la página 9;

○ E.- "Improvització", sin material;

○ F.- "Reflexió", 4 páginas numeradas;

○ G.- "Baixell de paper", 2 páginas numeradas;

○ H.- "Galería", 21 páginas numeradas; aparece el subtítulo "Galeria - Gran nota - María..." en la pág. 1;

○ I.- "Bosc Trompetes", 2 páginas numeradas y tachadas; coinciden con las páginas 1 y 2 de " Baixell de paper ";

○ J.- "Bar", 46 páginas numeradas; al principio se dividen en BAR $1^{\mathrm{a}}$ a $5^{\mathrm{a}}$; en la pág. 40 aparece el título "Solo Trompa. Final bar"; en la pág. 42 aparece el título "Platea $1^{\mathrm{a}}$ ", que se divide en Platea 1 a 5;

○ K.- "Pernil i vida", 22 páginas numeradas;

○ L.- "Zapping bis", 3 páginas numeradas; M.- "Sopar i final", 47 páginas numeradas; en la pág. 29 aparece el título "Final";

- Los personajes principales son los siguientes:

- María.

○ Jen-Chen.

○ Alejandra.

○ Charo.

○ Mary.

○ Marc. 

○ Uma.
○ Olvido.
○ Judit.
○ Pere.
○ Vicent.
○ $\mathrm{M}^{\mathrm{a}}$ José.
○ Bernardo.

- Partes: Existen partes instrumentales, manuscritas y originales. Asimismo existen copias de este material: 1 copia grapada y por partes; "Zaping", encuadernada; "Bar", encuadernada; "Caragran", encuadernada; "Desfilada i sopar", encuadernada (2 copias).

- No consta relación de originales y copias. 
13.- LA BOQUETA AMPLIFICADA, Espectáculo escénico, Sol m, Voz solista (soprano), trio de cuerda y Piano, con guion y partitura, 1985, Arc. 26.
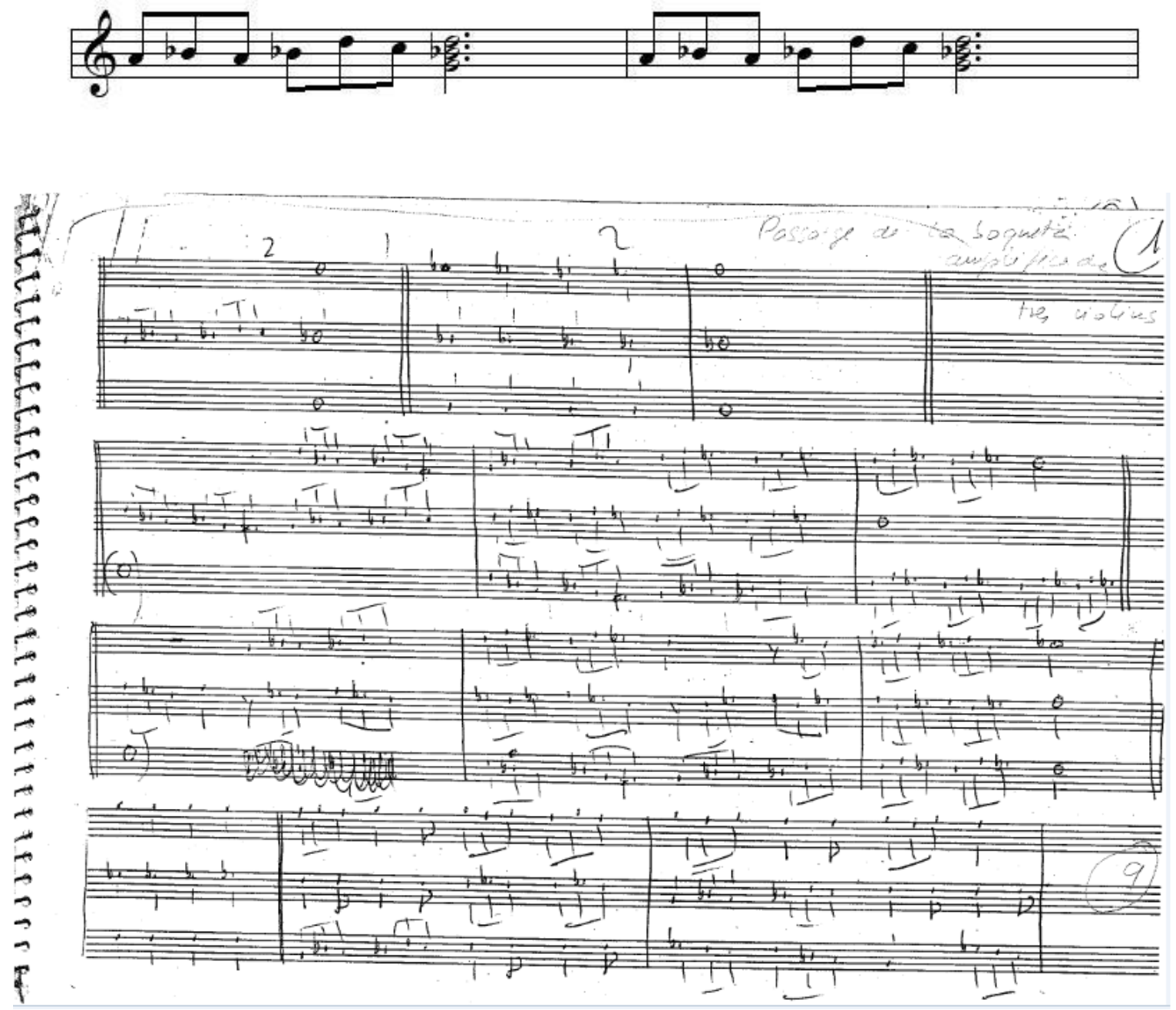

Puede tratarse de la música del espectáculo "estrenado el 21 de mayo de 1985 dentro del Cicle de Teatre Obert del teatre de L'Aliança del Poble Nou, Barcelona"74. En el bloc constan apuntes de la obra Aquesta Es La Història Que Mai Podré Oblidar; Una Trista Història D'Amor, D'Un Amor Que Mai, Mai, Mai Podrà Acabar, incluída en el disco CD Perturbació inesperada. Esta obra también se encuentra en otro archivador, catalogada con otro número.

\footnotetext{
${ }^{74}$ Guerrero, M. (2006): Carles Santos. Visca el Piano!. Fundació Joan Miró. Barcelona. Pág. 470
} 


\section{MATERIAL TOTAL:}

- Partitura manuscrita y original del autor. Consta de un bloc de escritura musical con el título Boqueta amplificada en el exterior y 28 páginas escritas, aunque no numeradas en su totalidad. Este material forma parte del espectáculo La boqueta amplificada. En las 9 primeras hojas se encuentran los apuntes del material de la obra Aquesta es la historia..... En el mismo bloc se encuentran los apuntes de las obras Boqueta amplificada, Te xina la fina petxina de Xina (fragmento) y Trio instrumental (La obra comienza en hoja $\mathrm{n}^{\circ}$ 15. Páginas numeradas de la 1 a la 7 y la última sin numerar. Posiblemente sea un fragmento de otra obra. No existen partes. Además de este material, existe material diverso, que es el siguiente:

○ un libreto de 4 hojas y 4 páginas numeradas de escritura musical con el título Boqueta amplificada y el comentario "Trio de corda. Material" en la portada y el $\mathrm{n}^{\mathrm{o}} 20$. Consta de 49 compases. El contenido de este material se corresponde con el que se encuentra en el bloc anteriormente citado y que se interpretaba en el espectáculo anteriormente citado, por 3 voces (C. S.). Existen 2 juegos fotocopiados del mismo material. No existen las partes.

- Existe otro material diferente con el mismo título y el comentario "tres violins" y el número 9 encercado, formado por 8 hojas manuscritas y fotocopiadas del autor (posiblemente las 4 últimas formen parte de otra obra).

- Asimismo existe un bloc de escritura, sin título, que contiene los textos de la obra; en las páginas interiores, numeradas de la 1 a la 5, y 3 páginas más sin numerar. Al principio de este bloc se encuentra la estructura de un espectáculo, con las piezas a interpretar en un orden concreto. Asimismo, se encuentra el texto de la grabación del disco, en catalán. No existen partes.

- En otro bloc perteneciente a la década de los 70 y adquirido en New York, se encuentra música y textos, pertenecientes a esta obra y otras grabadas en el disco Voicetracks. Estos fragmentos se dividen en 18 apartados a piezas. Entre estos fragmentos destacan Un gat es un gat, Dorema-domare, Conversa.

- Partes: No existen partes

- No consta relación de originales y copias. 
14.- LA GRENYA DE PASQUAL PICANYA, (assessor jurídic-administratiu), Espectáculo escénico, politonal, Voz solista (soprano), Percusión y Piano, con partitura aunque no entera, 1991, G. 5.

Voz
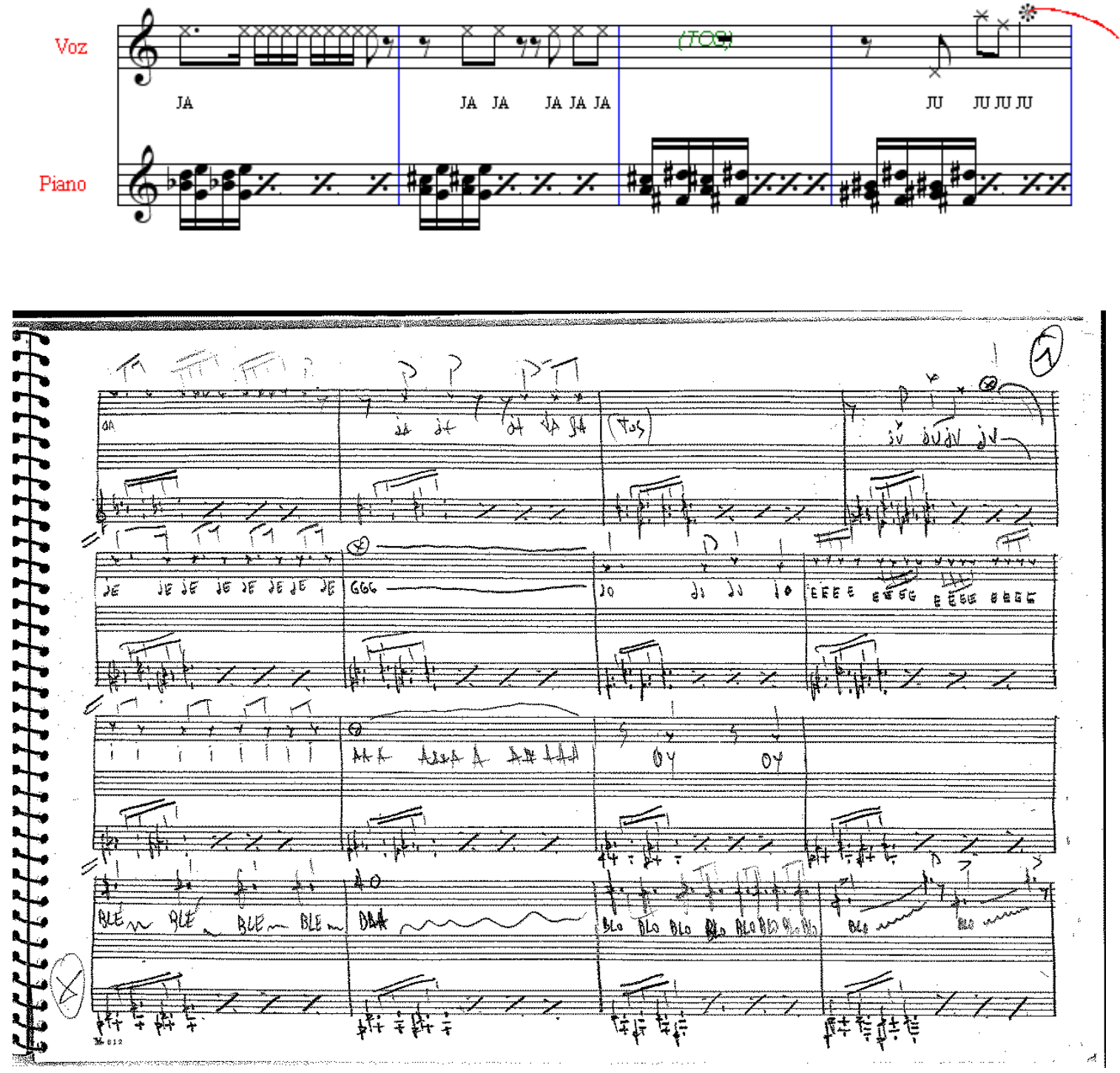

La voz es una soprano.

Estrenada el 12 abril de 1991 al Teatre Adrià Gual (Institut del Teatre), de Barcelona, en la IV Setmana de Música Contemporània. 
Existe un vídeo ${ }^{75}$ incluido en el listado "Vídeos Archivo Artea", que están disponibles para su consulta y visualización en Matadero Madrid. Centro de Creación Contemporánea (Paseo de la chopera, 14. 28045 Madrid. www.mataderomadrid.com).

\section{MATERIAL TOTAL:}

- Obra incompleta. Partitura manuscrita y fotocopiada del autor.

- Existen 2 papeles sueltos que no parecen de la misma obra.

- Partes: No existen partes

- No consta relación de originales y copias.

${ }^{75}$ Archivo virtual Artes Escénicas. (sin fecha). La grenya de Pascual Picanya, assesor juridicadministratiu. S. reg.. S. reg. Recuperado de:

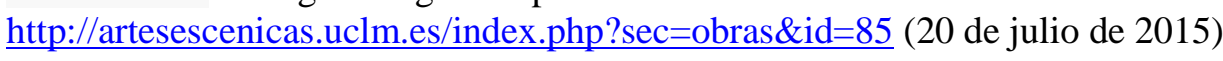


15.- LA MEUA FILLA SOC JO, Ópera, politonal, Solistas vocales, Piano, Orquesta de viento, Violín y Percusión, con partitura, 2005, Arc. 6.
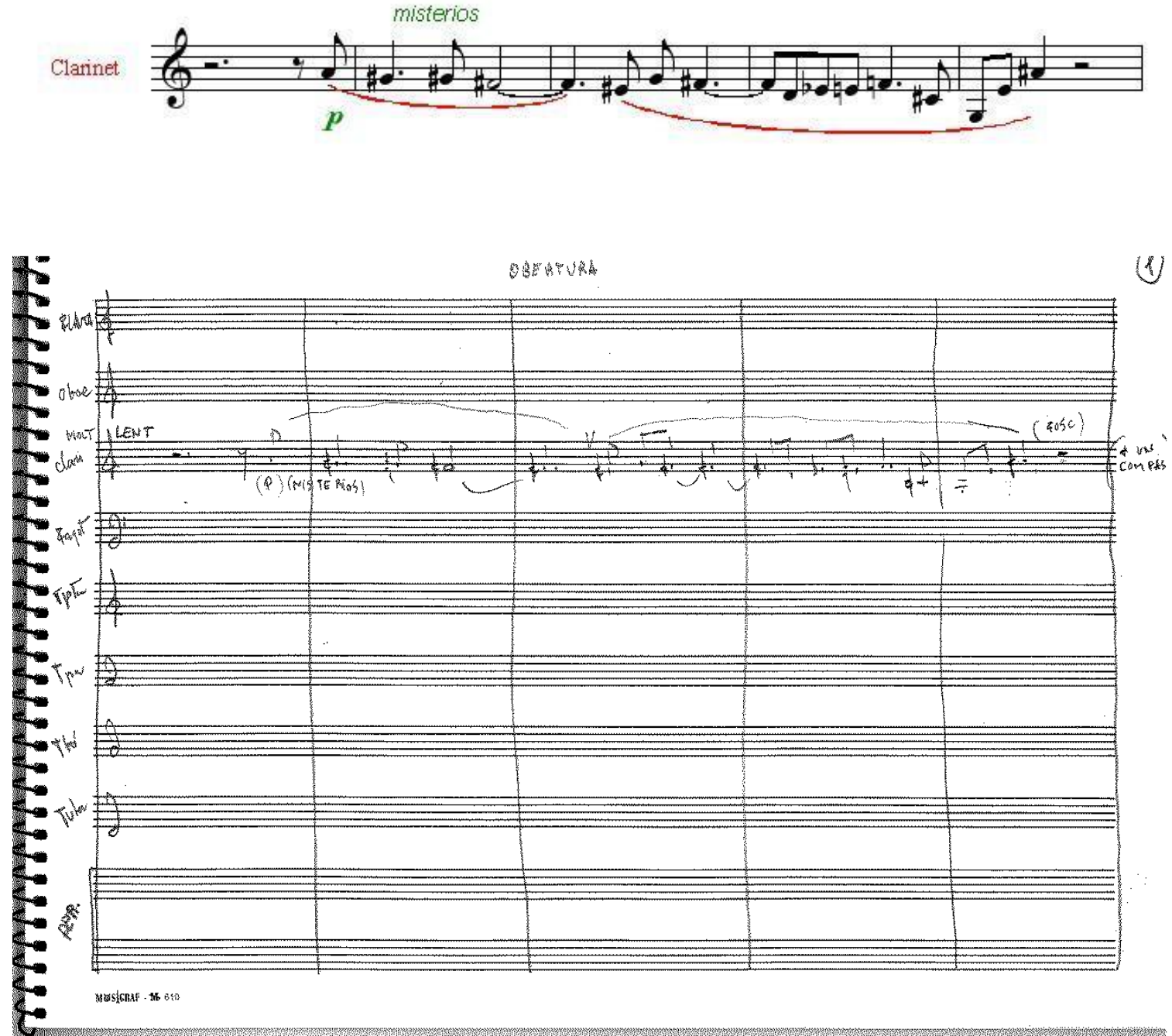

Las voces son: 3 sopranos, 2 mezzos, Contratenor, tenor, barítono, bajo.

Estrenada el 19 de mayo de 2005 al Teatre Lluire de Barcelona.

\section{MATERIAL TOTAL:}

- Partitura manuscrita y original del autor. Consta de 6 blocs de escritura musical, que no contienen la totalidad de la obra, con los siguientes títulos:

○ " $1^{\mathrm{a}}$ La Filla (Obertura). $2^{\mathrm{a}}$ Feto" en el exterior (inicio de la obra) con $21+$ 10 páginas numeradas y manuscritas;

○ " $4^{\circ}$ Joc (4 sopranos + musics)" en el exterior con 28 páginas numeradas y manuscritas; 
○ "L'adolescencia" en el exterior con 10 páginas numeradas y manuscritas;

○ "Orgasmes (1er)" en el exterior con 21 páginas numeradas y manuscritas;

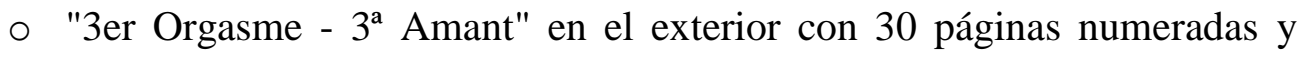
manuscritas;

○ "3er Orgasme - $3^{\mathrm{a}}$ Amant (continuació)" en el exterior con 9 páginas numeradas y manuscritas. El bloc contiene el original manuscrito de la siguiente escena, "Boda” (15 pág.);

- Partitura impresa de todo el material (2 unidades), una con anotaciones y la otra el original impreso. Manuscrito fotocopiado del autor, de todo el material, excepto de la parte "Bressol", que es original (Partes instrumentales).

- Además, se ha encontrado el resto del material que consta de 3 blocs de escritura musical, con los siguientes títulos:

○ "1r Joc (Comas)" en el exterior con 7 páginas numeradas y manuscritas a las que siguen 1 hoja sin numerar con la anotación "solo flautí (1r joc)" y 8 páginas numeradas con la anotación "elements musicals (Bressol)". En la parte trasera de la portada existen anotaciones que se corresponden con la escenografía;

○ "3r Joc (baix cor infantil)" en el exterior con 23 páginas numeradas y manuscritas;

○ "2ºrgasme" en el exterior con 28 páginas numeradas y manuscritas; Existen 15 páginas con el texto de la obra (2 copias).

- Asimismo, existe un bloc con detalles de la escenografía de la obra, de puño y letra del autor, que consta de 18 hojas numeradas, escritas tanto a una como a dos caras.

- Partes: No existen partes

- No consta relación de originales y copias. 
16.- LA PANTERA IMPERIAL, Ópera, politonal, Solistas vocales, Coro, 3 Pianos y Violín, con guion, 1997, Arc. 3.

El espectáculo contempla música original de J. S. Bach y de Carles Santos.
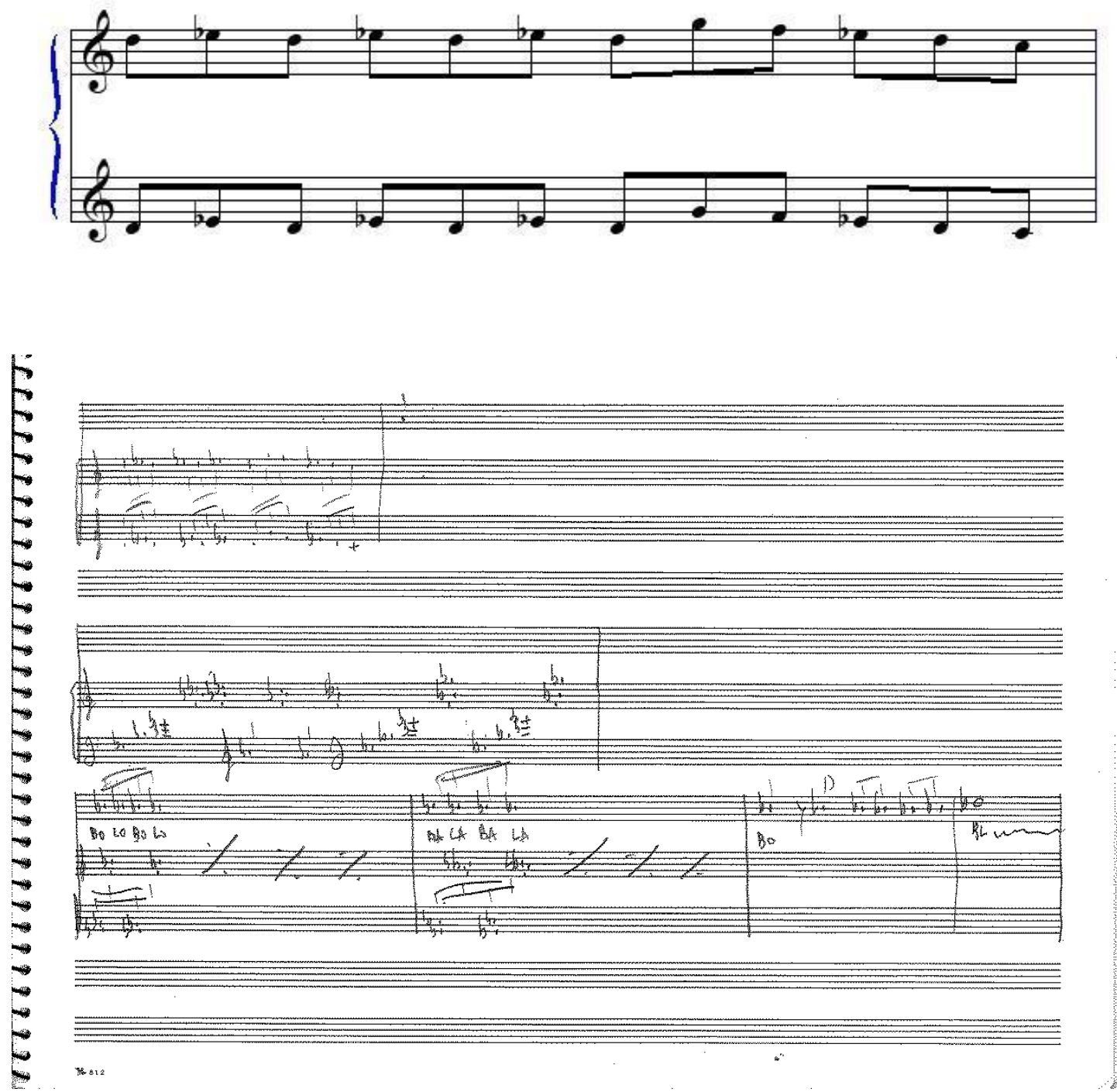

Existen fragmentos dedicados a una pianola móvil, conocida como La Lligotaria.

Estrenada el 30 mayo de 1997 en el Mousonturm - Künstlerhaus, Frankfurt.

\section{MATERIAL TOTAL:}

- Material manuscrito y original del autor. Consta de 2 blocs de escritura musical, con los títulos

○ La Pantera Imperial (1) en el exterior y 7 páginas de escritura musical, el primero, $\mathrm{y}$ 
- La Pantera en el exterior y 4 páginas de escritura musical, el segundo. En este bloc se encuentra música de Belmonte, de una obra para piano y música utilizada en la musicalización de imagines, que el autor no recuerda.

- Existen 6 páginas fotocopiadas que pertenecen a un arreglo de la fuga en La menor, BWV 543, para ser interpretada por el violín. El resto de la música utilizada en el espectáculo es original de J. S. Bach.

- Partes: No existen partes

- No consta relación de originales y copias. 
17.- L'ADEU DE LUCRECIA BORGIA, Cantata/Ópera/Obra escénica, politonal, 4 solistas vocales, Coro y Orquesta y Dulzainas, con guion y partitura original, 2001, Grande 5 y Arc. 5.

Obra dividida en las siguientes partes: Prólogo, Obertura, Escena 1, Corte 1, Escena 2, Corte 2, Escena 3, Corte 3, Escena 4, Aparición de Joan, Corte 4, Final.
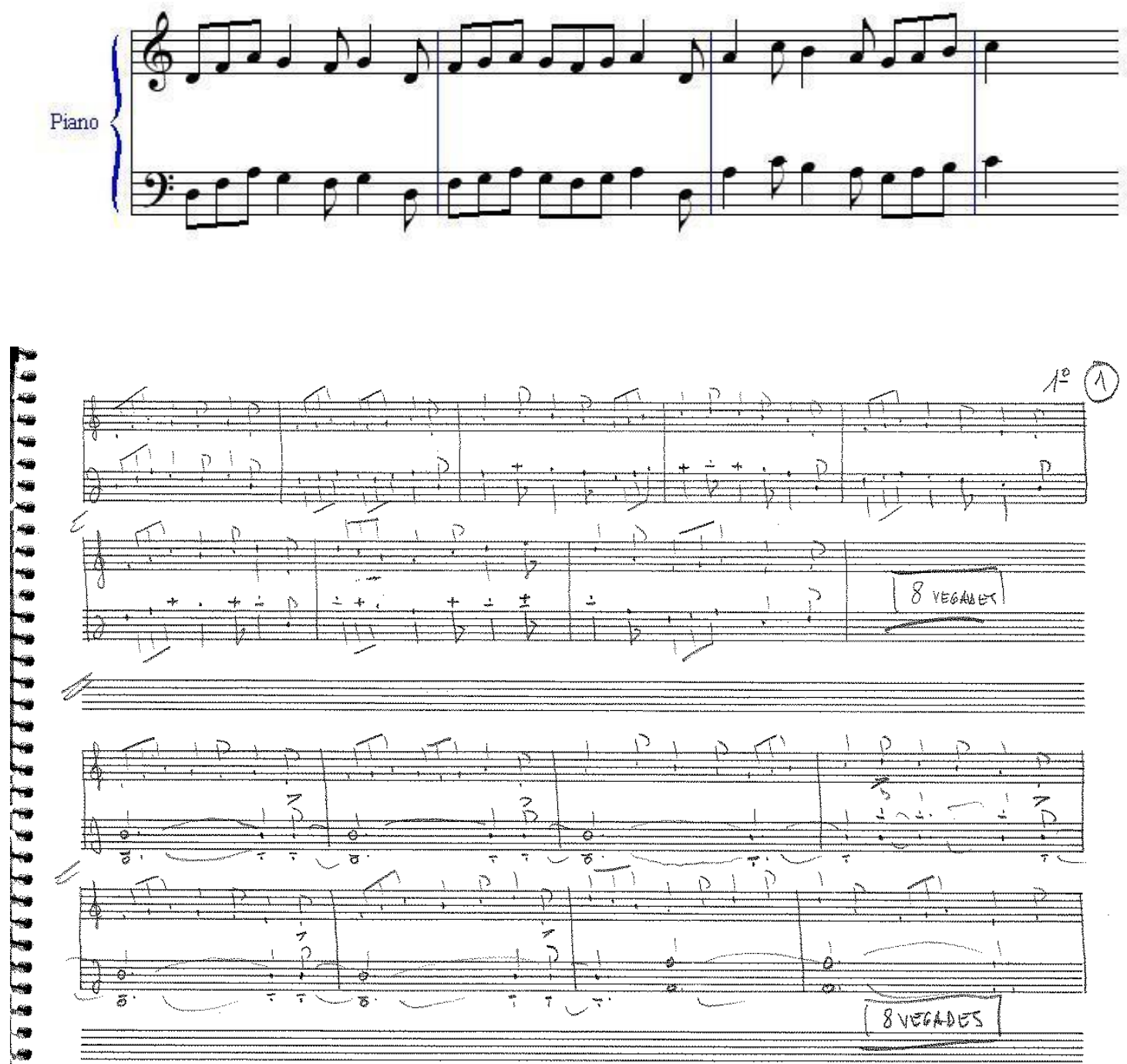

Estrenada el 3/02/2001 al Palau de la Música de València, en el 500 aniversario de la Universidad de València. Textos de Joan F. Mira.

Orquestación de Pere Josep Puértolas.

La versión Cantata omite el Prólogo.

La versión Ópera fue estrenada el 22/11/2001 en el Teatre Lliure de Barcelona. 


\section{MATERIAL TOTAL:}

- Partitura manuscrita y original del autor. Consta de 10 blocs de escritura musical, con los siguientes títulos:

○ "Borja (1)" en el exterior (inicio de la obra) con 28 páginas numeradas y manuscritas;

○ "Borja (2)" en el exterior con 30 páginas numeradas y manuscritas;

○ "Borja (3)" en el exterior con 30 páginas numeradas (de la 31 a la 60) y manuscritas;

○ "Borja (4)" en el exterior con 30 páginas numeradas (de la 61 a la 90) y manuscritas;

○ "Borja (5)" en el exterior con 30 páginas numeradas (de la 91 a la 120) y manuscritas;

○ "Borja (6)" en el exterior con 30 páginas numeradas (de la 121 a la 150) y manuscritas;

○ "Borja (7)" en el exterior con 30 páginas numeradas (de la 151 a la 180) y manuscritas;

○ "Borja (8)" en el exterior con 30 páginas numeradas (de la 181 a la 210) y manuscritas;

○ "Borja (9)" en el exterior con 9 páginas numeradas (de la 211 a la 219) y manuscritas;

○ "Borja Piano" en el exterior con 3 páginas numeradas y manuscritas;

- Asimismo, del material impreso, existen 3 copias de la partitura de orquesta en formato A3 y encuadernadas y dos en tamaño A4, una sin encuadernar, así como 2 reducciones de la obra a piano y otra reducción para piano.

- Existe una copia del material manuscrito en Grande 5.

- Los personajes principales son los siguientes:

○ Lucrècia Borja: Soprano.

○ Adriana del Milá: Mezosoprano.

○ Vannozza: Mezosoprano.

○ Cesar Borja: Tenor.

○ Joan Borja: Baritono.

○ Joana de Montcada: Actriz.

○ El Papa Alexandre VI: Baritono. 
- Ambaixador de Ferrara: Actor.

○ Cardenal Joan de Borgia: Actor.

- Partes: Existen partes del coro y los solistas. No así de los instrumentos.

- Existen libretos de la obra.

- No consta relación de originales y copias. 
18.- L'ESPLÈNDIDA VERGONYA DEL FET MAL FET, Obra escénica, politonal, Solistas vocales, Piano, Orquesta de viento, Violín y Percusión, con partitura original, 1995, Arc. 4 y 5.
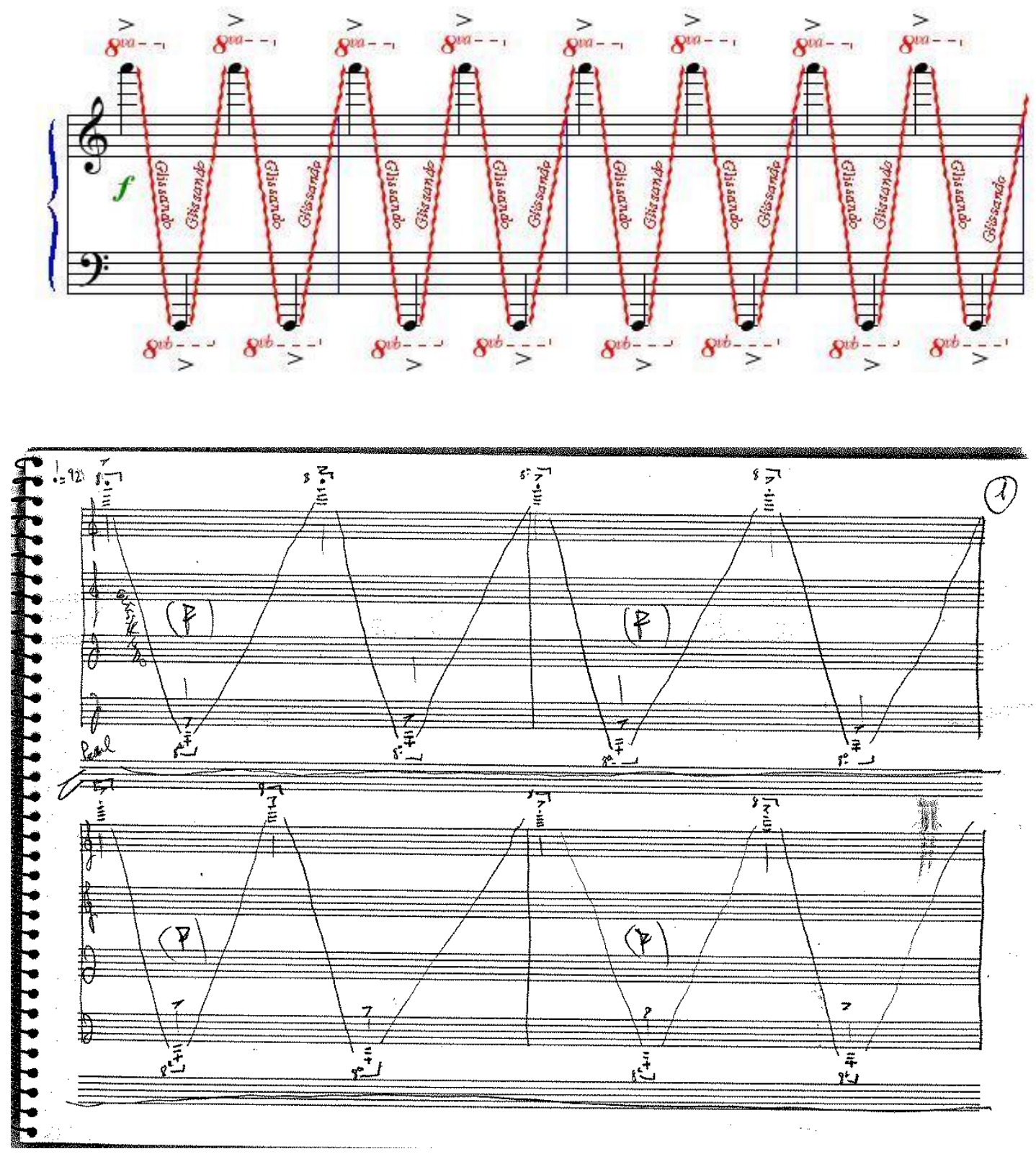

Estrenada el 4 de abril de 1995 en el Mercat de les Flors de Barcelona. La obertura está fechada en agosto de 1998. El autor desconoce el motivo.

MATERIAL TOTAL:

- Partitura manuscrita y original del autor. Consta de 4 blocs de escritura musical, con los siguientes títulos: 
○ "Vergonya Obertura" en el exterior, y música escrita en 12 páginas numeradas y fechadas en agosto de 1998;

○ "Final $\left(1^{\circ}\right)$ " en el exterior (título "Truenke" tachado), y música escrita en 18 páginas numeradas, de la 0 a la 17 , y fechadas en agosto de 1998;

○ "Ball de 'La Lligotaria'" en el interior y música escrita en 20 páginas numeradas en 3 grupos ( 1 a 13; 1 a 5 y 1 a 2 con el título "Albert");

○ "La" en el interior y música escrita en 34 páginas numeradas en 8 grupos (1 a 3; 1 a 7 "Coral", 1 a 5 sin numerar "Tenedors", 1 a 7 sin numerar "Tenedors 2", 1 a 4 sin numerar "Tenedors 3", 1 a 3 sin numerar "Tenedors 4", 1 a 4 sin numerar "Tenedors 5" y 1 sin numerar "Tenedors 6");

- Existen páginas sueltas numeradas de 1 a 7 y de 16 a 20 que se corresponden con la misma obra. Asimismo existe más material que consta de 3 blocs de escritura musical con las siguientes características:

○ $1^{\text {a }}$, "La esplendida... , $1^{\text {a }}$, Uma-Principe, Toni-Taula, Duo" en el exterior, y música escrita en 38 páginas numeradas de la siguiente manera: 1a a 9a con el título "1r solo" al principio; 1b a 10b con el título "1r solo Uma" al principio; 1c a 19c con el título "Duo" al principio.

$\circ 2^{\mathrm{a}}$, "L'esplendida (2)" en el exterior, y música escrita en 10 páginas numeradas.

$\circ 3^{\text {a }}$, "Vergonya...., Solo $2^{\circ}$, Final" en el exterior, y música escrita en 5 páginas numeradas.

- Partes: No existen partes

- No consta relación de originales y copias. 
19.- LISISTRATA, Ópera libre/Obra escénica, politonal, 5 solistas vocales, 8 violines, 8 guitarras eléctricas, 5 percusionistas, 2 pilotos de moto y Coro (12 hombres y 12 mujeres); con partitura original, 2003, Arc. 7 y 7Bis.
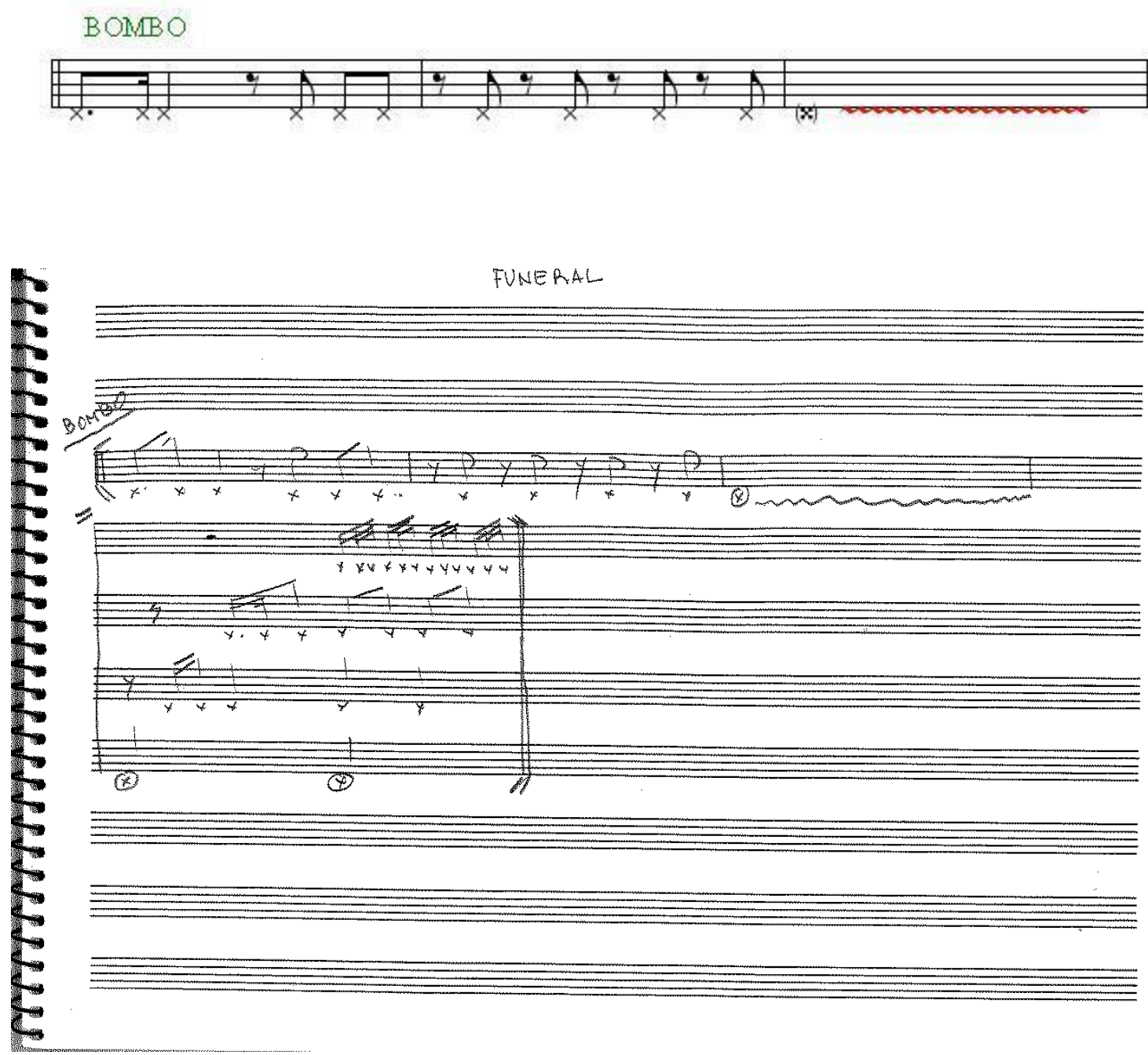

Estrenada el 7 de junio de 2003 en la II Bienal de València, en la Nave Sagunto.

\section{MATERIAL TOTAL:}

- Partitura manuscrita y original del autor. Consta de 13 blocs de escritura musical, con los siguientes títulos:

- Lisistrata 1- "(Cor). Funeral. Cerco de da Acrópolis" en el exterior (inicio de la obra) con 7 páginas numeradas y manuscritas ("Funeral”) y 28 páginas numeradas y manuscritas (de la 8 a la 25) (“Cerco de la Acrópolis"); 
- Lisistrata 2- "continuación Cerco de da Acrópolis" en el exterior y con 11 páginas numeradas y manuscritas (de la 26 a la 36);

○ "Pericles (Funeral), Muerte de Pericles, Escena erótica" en el exterior, y música escrita en 17 páginas numeradas $(7+4+6)$;

○ Lisistrata 1- "Conjura " en el exterior y música escrita en 29 páginas numeradas;

○ Lisistrata 2- “Conjura " en el exterior y música escrita en 22 páginas numeradas (de la 30 a la 51);

○ Lisistrata "(Jurament)" en el exterior y música escrita en 29 páginas numeradas;

○ "Acusaciones 1" en el exterior y música escrita en 30 páginas numeradas y manuscritas;

○ "Acusaciones 2" en el exterior y música escrita en 8 páginas numeradas, (de la 31 a la 38 );

○ "Sospecha " en el exterior y música escrita en 13 páginas numeradas (5 $+8)$

○ "Rendez vous" con 25 páginas numeradas y manuscritas.

○ "Asamblea popular" en el exterior y música escrita en 7 páginas numeradas;

○ "Reconciliació" con 16 páginas numeradas y manuscritas;

○ "Banquete" en el exterior y música escrita en 26 páginas numeradas;

- Existe material fotocopiado con anotaciones del autor.

- Asimismo existe partitura impresa de toda la obra con el orden de la obra que es el siguiente: Funeral, Escena erótica, Conjura, Jurament, Muerte de Pericles, Cerco de la Acrópolis, Acusacions, Sospecha, Enfrentamiento, Rendez-vous, Asamblea popular, Reconciliació, Banquete (1), Banquete (coro), Banquete (final). El mismo material impreso está separado por escenas.

- Los personajes principales son los siguientes:

○ Lisistrata: Soprano.

○ Pericles: Bajo.

○ Cleónica: Mezzosoprano.

○ Mirrina: Soprano.

○ Lampitó: Contralto. 
- Partes: No existen partes

- No consta relación de originales y copias. 
20.- MINIMALET MINIMALOT, concierto-espectáculo escénico, politonal, Piano y voces, con guion, 1982, Arc. 34 .
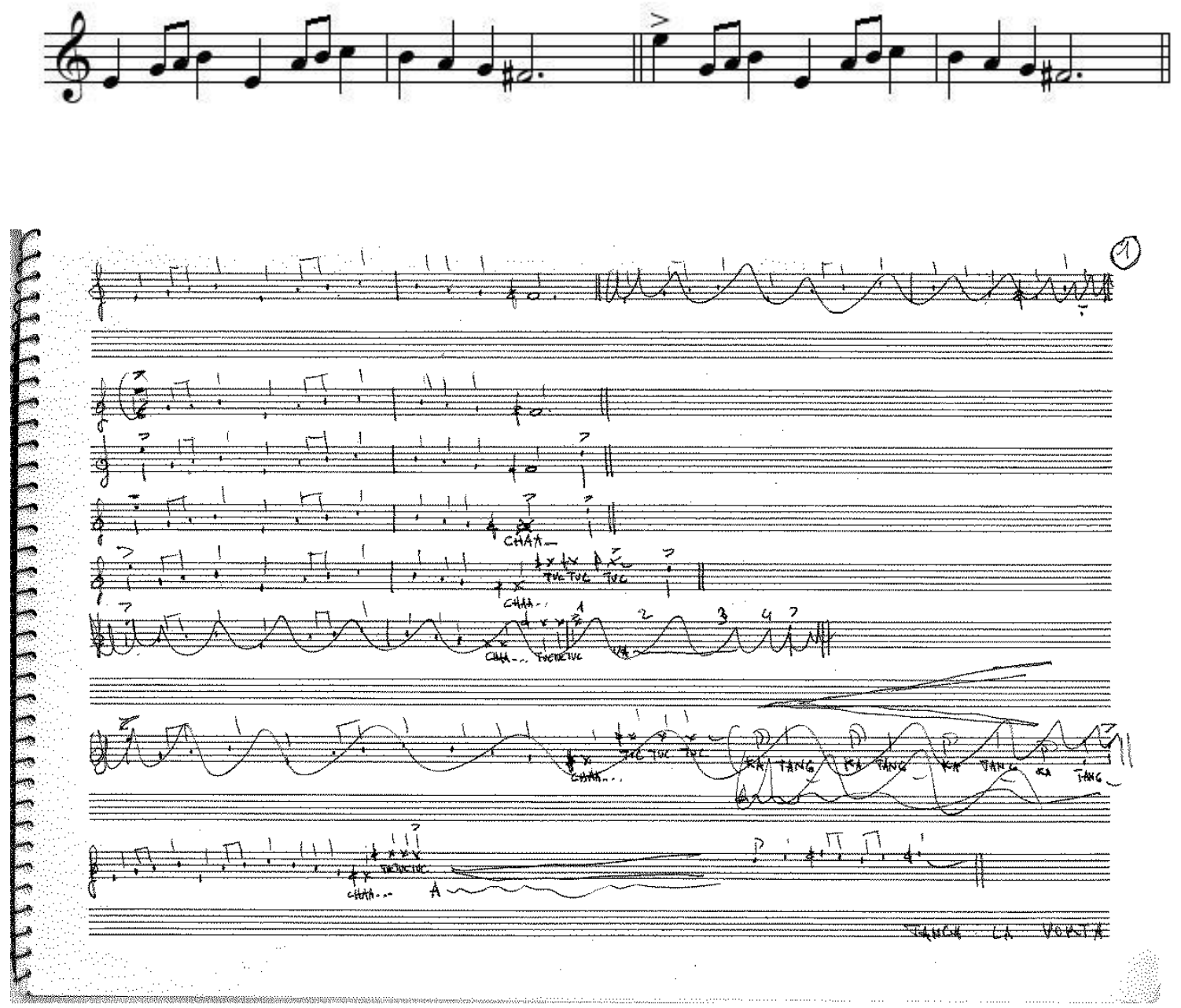

Estrenada al Centre George Pompidou de Paris el 29 de octubre de 1982.

\section{MATERIAL TOTAL:}

- Material manuscrito y original del autor. Consta de 1 bloc de escritura musical, sin título en el exterior. Páginas numeradas del 14 al 26. En el reverso se encuentran las páginas numeradas de 1 a 7 . En otro bloc, sin título en el exterior, se encuentran las páginas numeradas del 8 al 13, de la obra. La página numerada como 12 de este bloc, contiene textos que hacen referencia a la obra Te xina la fina petxina de Xina, lo que nos hace pensar que ambas obras son la misma. 
Dado que la obra registrada en la SGAE es Te xina la fina petxina de Xina, damos a esta la titularidad formal de la misma.

- Partes: No existen partes.

- No consta relación de originales y copias. 
21.- RICARD I ELENA, Ópera, politonal, Solistas vocales, Coro, Piano, Órgano, Orquesta y Percusión, con guion, 2000, Arc. 13.
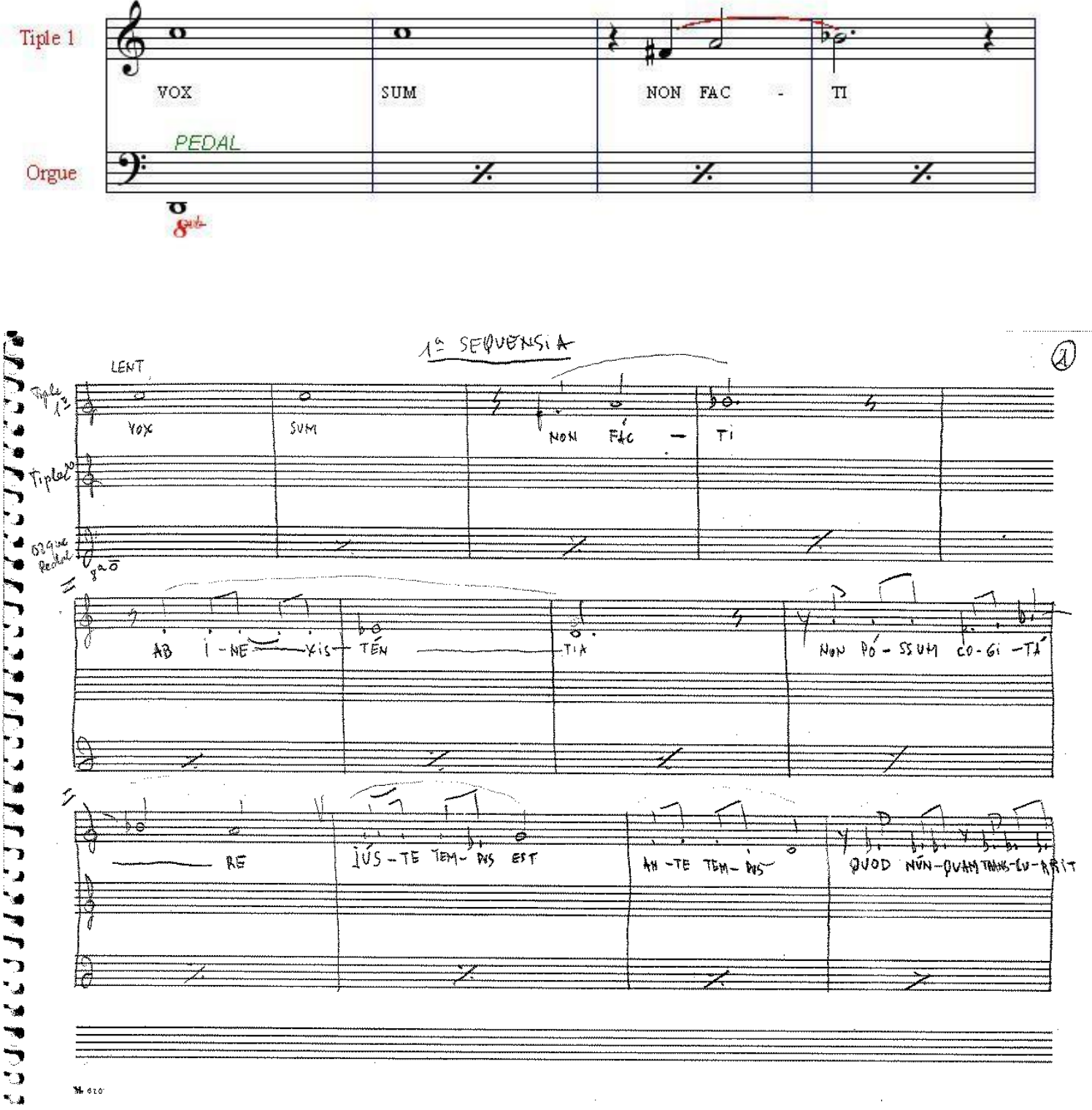

Orquestación de Pere Josep Puértolas. Ópera cantada en latín.

Estrenada al Teatre Nacional de Catalunya el 15 de marzo de 2000.

\section{MATERIAL TOTAL:}

- Partitura manuscrita y fotocopiada del autor. Consta de 6 secuencias $\left(1^{\mathrm{a}}, 2^{\mathrm{a}}, 3^{\mathrm{a}}\right.$, $4^{\mathrm{a}}, 7^{\mathrm{a}}$ y $10^{\mathrm{a}}$ ), un fragmento sin identificar i 2 finales. Existen partes originales. 
La disposición, en páginas, de las distintas secuencias, es la siguiente:

○ “ 1 a secuencia”, 4 páginas numeradas, de la 1 a la 4 ;

○ "2 ${ }^{\mathrm{a}}$ secuencia", 17 páginas numeradas, de la 4 a la 20;

○ “ 3 a secuencia", 40 páginas numeradas, de la 21 a la 60;

○ " 4 a secuencia", 7 páginas numeradas, de la 61 a la 69 (faltan la 64 y 65);

○ “7 $7^{\text {a }}$ secuencia”, 9 páginas numeradas, de la 1 a la 9 a las que siguen 30 páginas numeradas, de la 2 a la 31 ;

○ " $10^{\mathrm{a}}$ secuencia”, 20 páginas numeradas, de la 1 a la 20 con la anotación "acords baixada cuadros" en la $1^{\text {a }}$ página;

○ "Final 1", 13 páginas numeradas, de la 1 a la 13;

○ "Final 2", 8 páginas numeradas, de la 14 a la 21;

Existen otro material con 7 páginas numeradas de la 1 a la 7 con música para Donachona y coro.

- Asimismo existe el libreto de la obra, en latín y en catalán, de 8 páginas cada uno.

- Los personajes principales son los siguientes:

○ Ricard: Tenor.

○ Elena: Soprano.

○ Donachona (mujer): Contralto.

○ Cinta Esbrí: Bailarina.

○ Badobar: Funambulista.

○ Virila: Trapecista.

○ Jo mateix (Carles Santos): Pianista.

- Partes: Existen partes instrumentales.

- No consta relación de originales y copias. 
22.- RONI, Acción musical, politonal, Piano, violín, Voz y Percusión, con guion, 1994, Arc. 28.

Ver: OLVIDO (Otras agrupaciones)
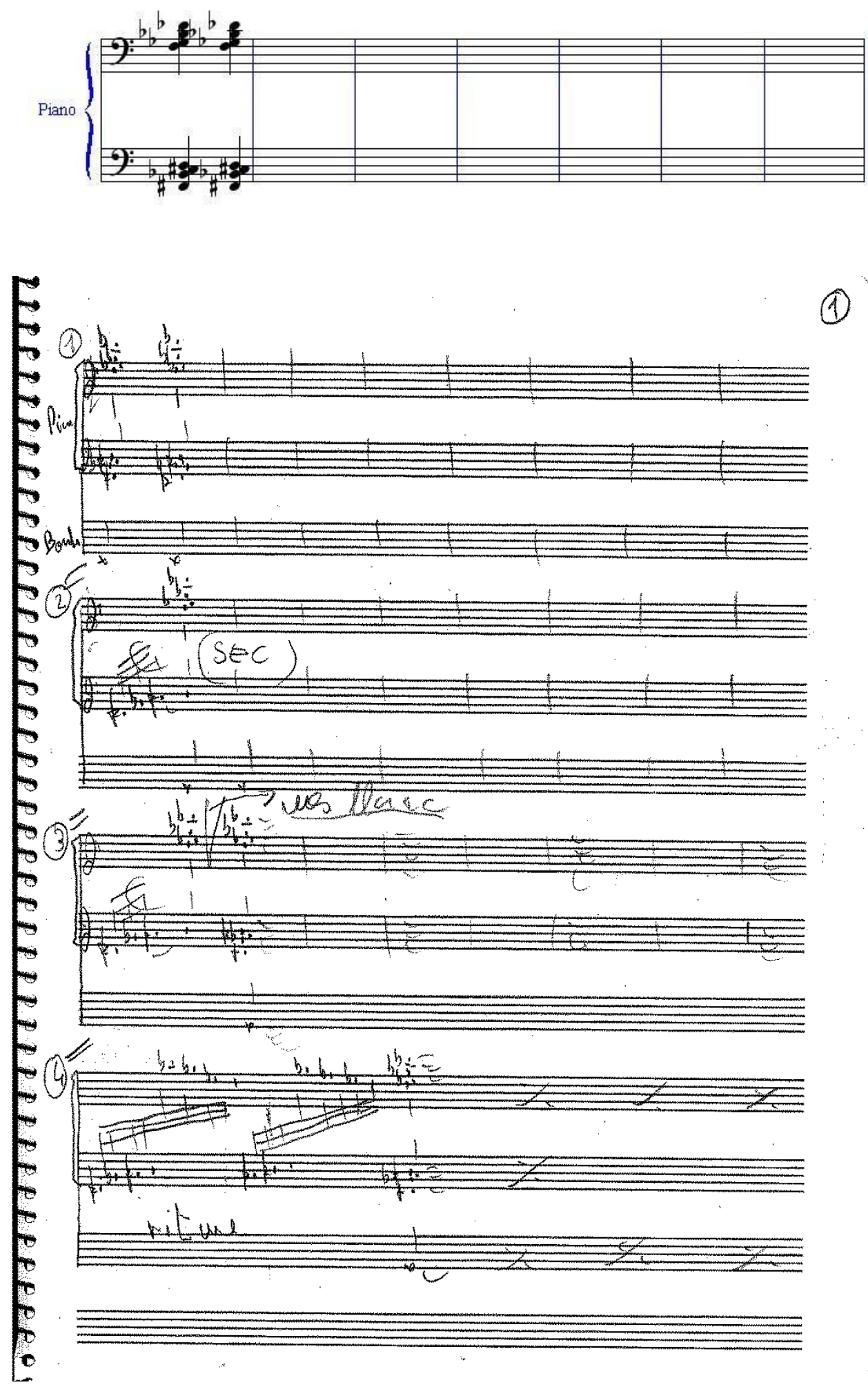

(1) 
Estrenada el 7 de julio de 1994 con motivo de la inauguración de la exposición Despulles inoxidables de Marialena Roqué. Fundación Joan Miró.

\section{MATERIAL TOTAL:}

- Material manuscrito y original del autor. Se encuentra en el bloc de escritura musical titulado Roni. Consta de 34 páginas escritas y numeradas. Asimismo existe otro material que consta de 5 páginas manuscritas y fotocopiadas del autor, numeradas de la 1 a la 5, sin título. Corresponde a un fragmento del bloc anterior, exactamente el correspondiente a las páginas 5 a 8 del mismo. Este material es posterior a la fecha de estreno (1994), lo que hace pensar que existió un material original, anterior a este, del que están sacadas las fotocopias del fragmento de 5 páginas, expuesto anteriormente.

- Existe un material bajo el título Olvido, que contiene la parte de violín de esta obra (ver: Otras agrupaciones)

- Partes: No existen partes.

- No consta relación de originales y copias. 
23.- SAMA SAMARUCK, SAMARUCK SUCK SUCK, Ópera, politonal, Solistas vocales, Coro, Piano, Orquesta y Percusión, con partitura impresa, 2002, Grande 7.
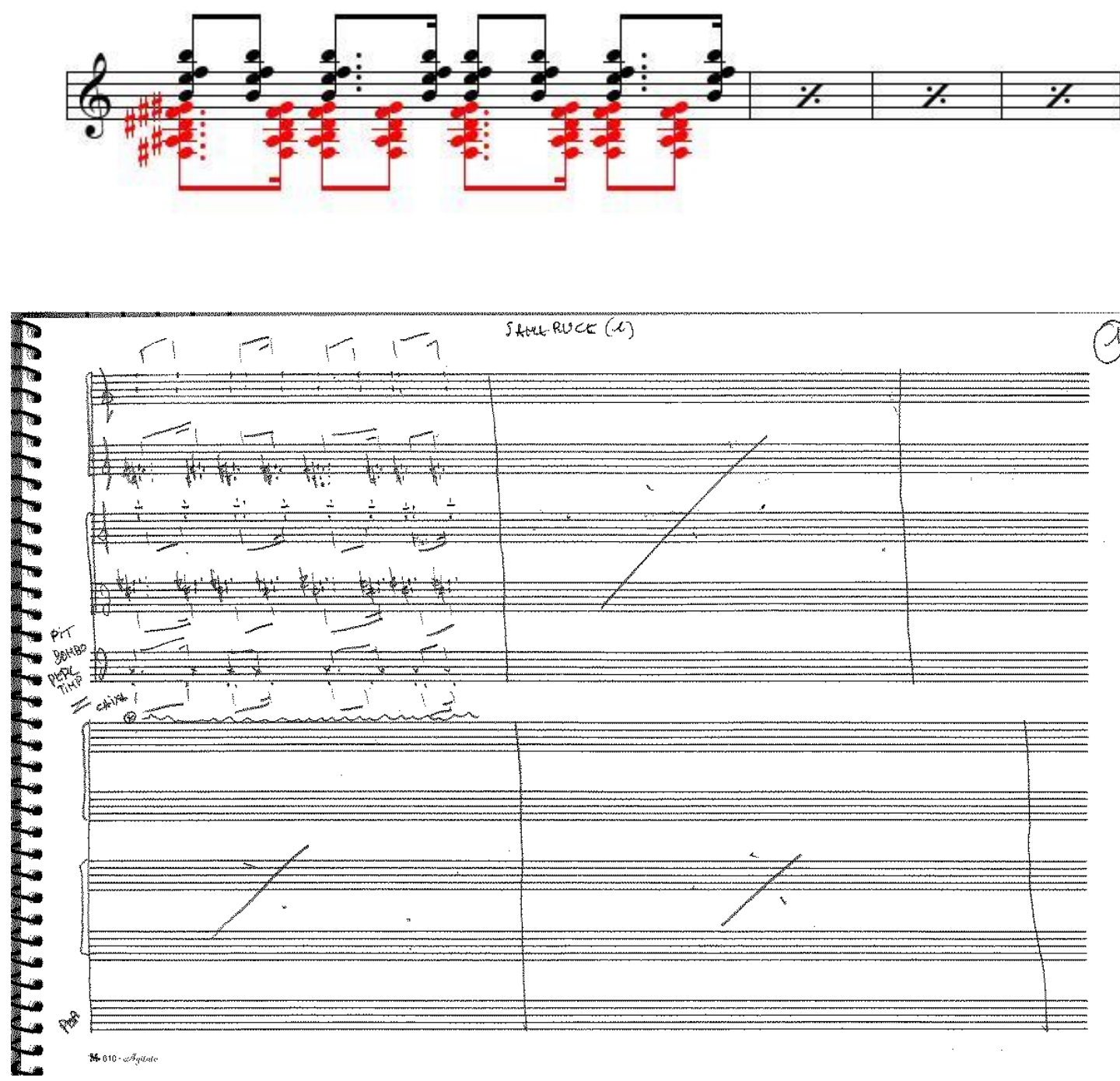

Orquestación de Pere Josep Puértolas. Ópera cantada en francés.

Estrenada en La Villete París el 26 de abril de 2002.

Existe material en software Sibelius, realizado por Xavier Piquer.

MATERIAL TOTAL:

- Partitura manuscrita y original del autor. Consta de 5 blocs de escritura musical, que no contienen la totalidad de la obra, con los siguientes títulos: 
- Samaruck (1) en el exterior (inicio de la obra) con 30 páginas numeradas y manuscritas;

- Samaruck (2) en el exterior con 28 páginas numeradas y manuscritas (de la 31 a la 58$)$;

- Samaruck (4) en el exterior con 30 páginas numeradas y manuscritas (de la 85 a la 114$)$;

- Samaruck (5) en el exterior con 30 páginas numeradas y manuscritas (de la 115 a la 144);

- Samaruck (6) en el exterior con 12 páginas numeradas y manuscritas (de la 145 a la 156);

- Fotocopia del material anterior, con anotaciones del autor, sobre la orquestación a realizar, que está completa. El material que corresponde al bloc Samaruck (3), contiene 19 páginas numeradas y manuscritas (de la 59 a la 84), faltando las páginas 73 a 78 ;

- Partitura de sofware, de 135 páginas (2 unidades). 2 partituras que contienen las 83 primeras páginas. Anotaciones manuscritas del autor. Todas ellas en formato DIN A3. Existen cuatro partituras iguales en formato A4, sin encuadernar, y otra encuadernada, distribuida en 87 páginas, a las que faltan anotaciones que existen en las anteriores (p. e. en pág. 40 ó 43). Existen, asimismo, 1 partitura exacta a la de A3 de 135 pág. (sin encuadernar) y siete semejantes de 83 pág. en formato A4, (una sin encuadernar y seis encuadernadas). Asimismo existe la partitura entera, en formato pdf, dividida en 3 partes.

- Asimismo existe guion del texto, con la personalidad de los personajes, en catalán y en francés.

- Los personajes principales son los siguientes:
- Adonala-Naladona: Presentadora.
○ Ressorgit: Presentador.
- Duranga (Dur.): Mezzosoprano.
○ Docteur Rumball (D.R.): Soprano.
○ Culatre (Cul): Tenor.
○ Robafina: Artista de circo.
- Chacota: Artista de circo.
○ Virulat: Artista de circo. 
- Deu: Artista de circo.

○ Samaruck:

- Partes: Existen partes de los instrumentos, en papel, de formato impreso, y en pdf, distribuidas en los siguientes grupos:

○ Madera (1) y (2).

- Metal y Percusión (1) y (2) (que contienen también las partes de Piano e instrumentos de Cuerda).

○ Solistas y Coro

- No consta relación de originales y copias. 
24.- SCHUBERTNACLES HUMITS, espectáculo escénico, Politonal, Violín, dos voces y Piano, con guion, 2012, Arc 34.

Ver: SCHUBERT 8 - 10 1⁄2 (sección otras agrupaciones)
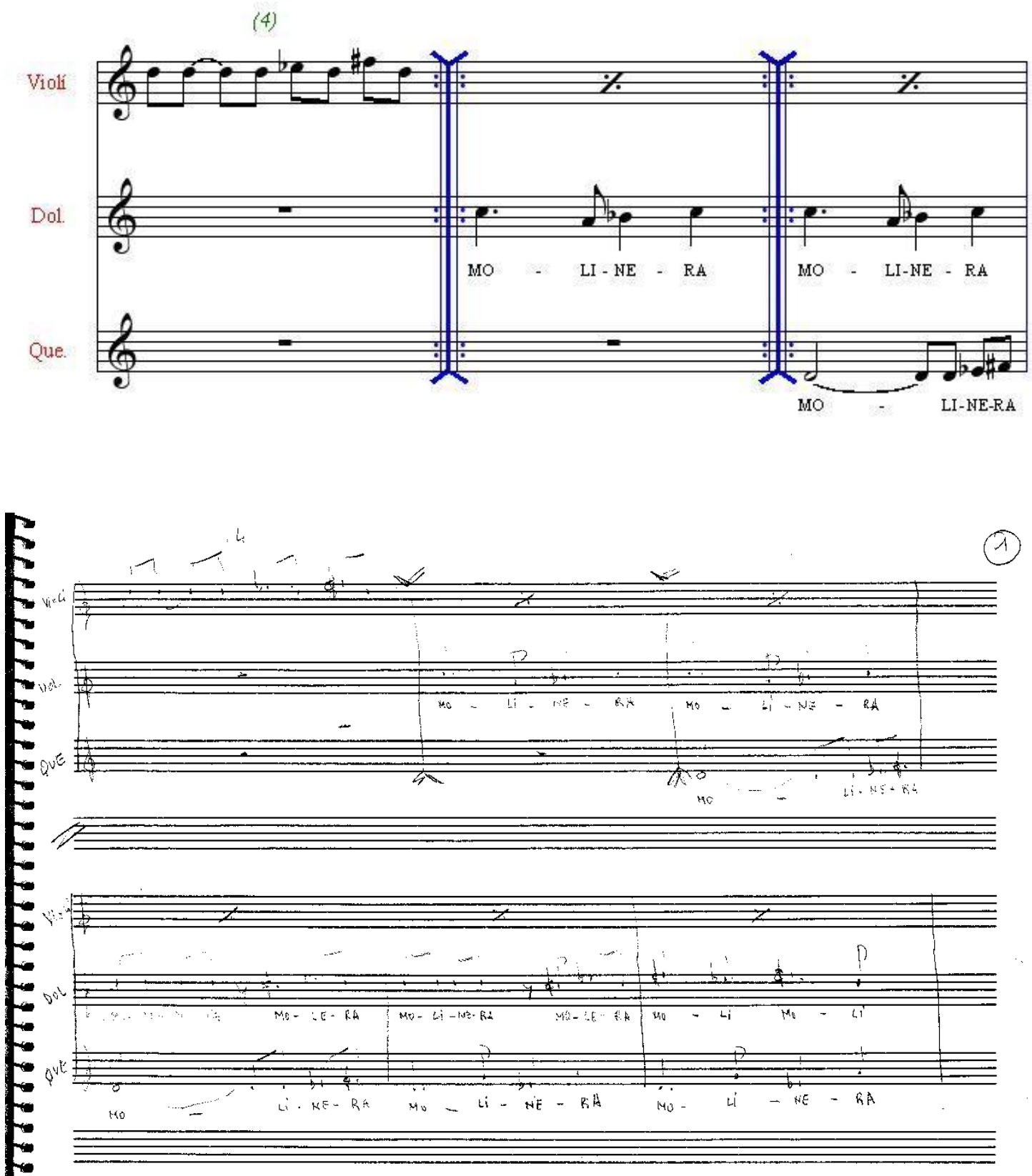

Estrenada en el Festival Temporada Alta. El montaje, al principio iba a llamarse 'Els urinaris públics europeus'. Santos está acompañado en escena por Queralt Albiñana (actriz), Josep Ferrer (la voz de un personaje ausente), Cati Reus (violinista) y Dolors Ricart (una directora de orquesta sin orquesta) y un altavoz de $3 \times 3$ metros. La mayor 
parte de las piezas musicales que interpretan son de Schubert, como es el caso de la Sinfonía Inacabada, con la que se inicia la obra, la sonata número 2 para piano y La Bella Molinera, aunque también hay temas de Paganini y Mompou, así como "alguna

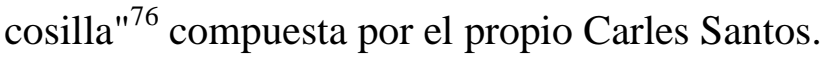

\section{MATERIAL TOTAL:}

- Partitura manuscrita y original del autor. Se encuentra en el bloc de escritura musical titulado Schubert 8 - 10 1/2. Consta de 5 páginas escritas y numeradas. Da la sensación de estar inconclusa.

- Partes: No existen partes.

- No consta relación de originales y copias.

${ }^{76}$ Testimonio oral del autor. 
25.- TÉ XINA LA FINA PETXINA DE XINA, Obra escénica, politonal, Solistas vocales, actrices, bailarines y Piano, con guion, 1983, Arc. 34.

BI RI BI RI BAM BAM BI RI BI RI BAM BAM BI RI BI RI BI RI BI RI BA
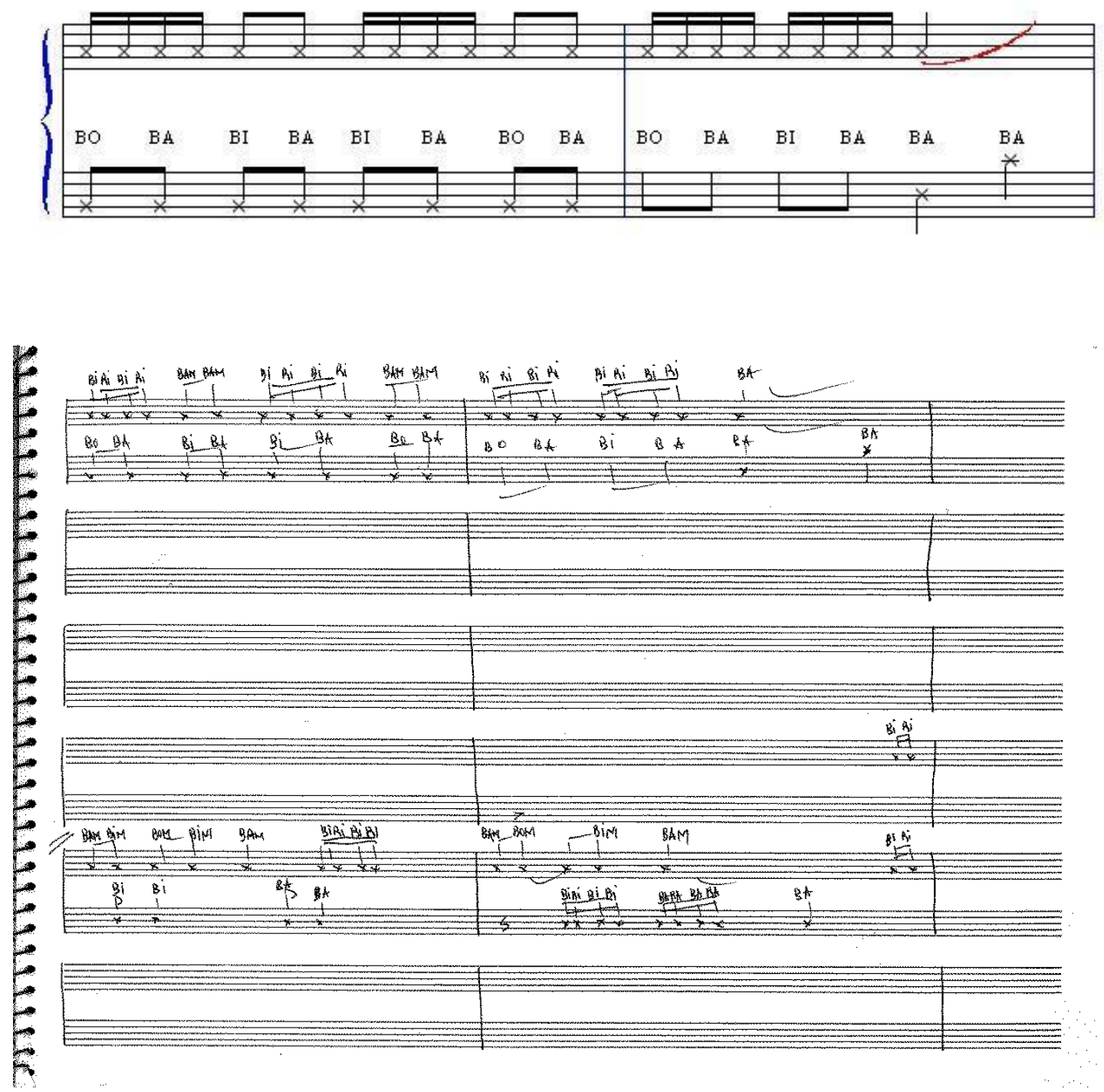

La obra contiene material bajo los títulos: Té xina la fina petxina de Xina, Minimalet y Si que té lo que té.

Estrenado al Teatre Regina de Barcelona, el 24 de abril de 1984.

\section{MATERIAL TOTAL:}

- El material es diverso:

- Material manuscrito y original del autor. Consta de 1 bloc de escritura musical, con el título Té xina la fina petxina de Xina en el exterior. Páginas sin numerar. 
○ Existe otro bloc con el título Te xina ... y la letra $\mathrm{T}$ encercada en el exterior, que contiene los textos de la obra.

- Asimismo existen apuntes de esta obra en el bloc con el título Boqueta amplificada en el exterior (hoja $\mathrm{n}^{\circ} 11$ y 12 ).

- Material manuscrito y original del autor. Consta de 1 bloc de escritura musical, sin título en el exterior. Páginas numeradas del 14 al 26. En el reverso se encuentran las páginas numeradas de 1 a 7 . En otro bloc, sin título en el exterior, se encuentran las páginas numeradas del 8 al 13, de la obra. La página numerada como 12 de este bloc, contiene textos que hacen referencia a la obra Té xina la fina petxina de Xina, lo que nos hace pensar que ambas obras son la misma. Dado que la obra registrada en la SGAE es Té xina la fina petxina de Xina, damos a esta la titularidad formal de la misma. No existen partes.

- De la obra Si que té lo que té, material manuscrito y original del autor. En la hoja octava, del bloc con el título Té xina la fina petxina de Xina en el exterior, se encuentra el texto de esta obra. Da la sensación de formar parte de la obra más extensa Té xina la fina petxina de Xina. Dado que la obra registrada en la SGAE es Té xina la fina petxina de Xina, damos a esta la titularidad formal de la misma.

- Partes: No existen partes.

- No consta relación de originales y copias. 
26.- TIRANT LO BLANC, Obra escénica, politonal, Solistas vocales, Coro de actrices, Órgano, Piano, Orquesta y Dulzainas, con guion, 2007, Arc. 31.
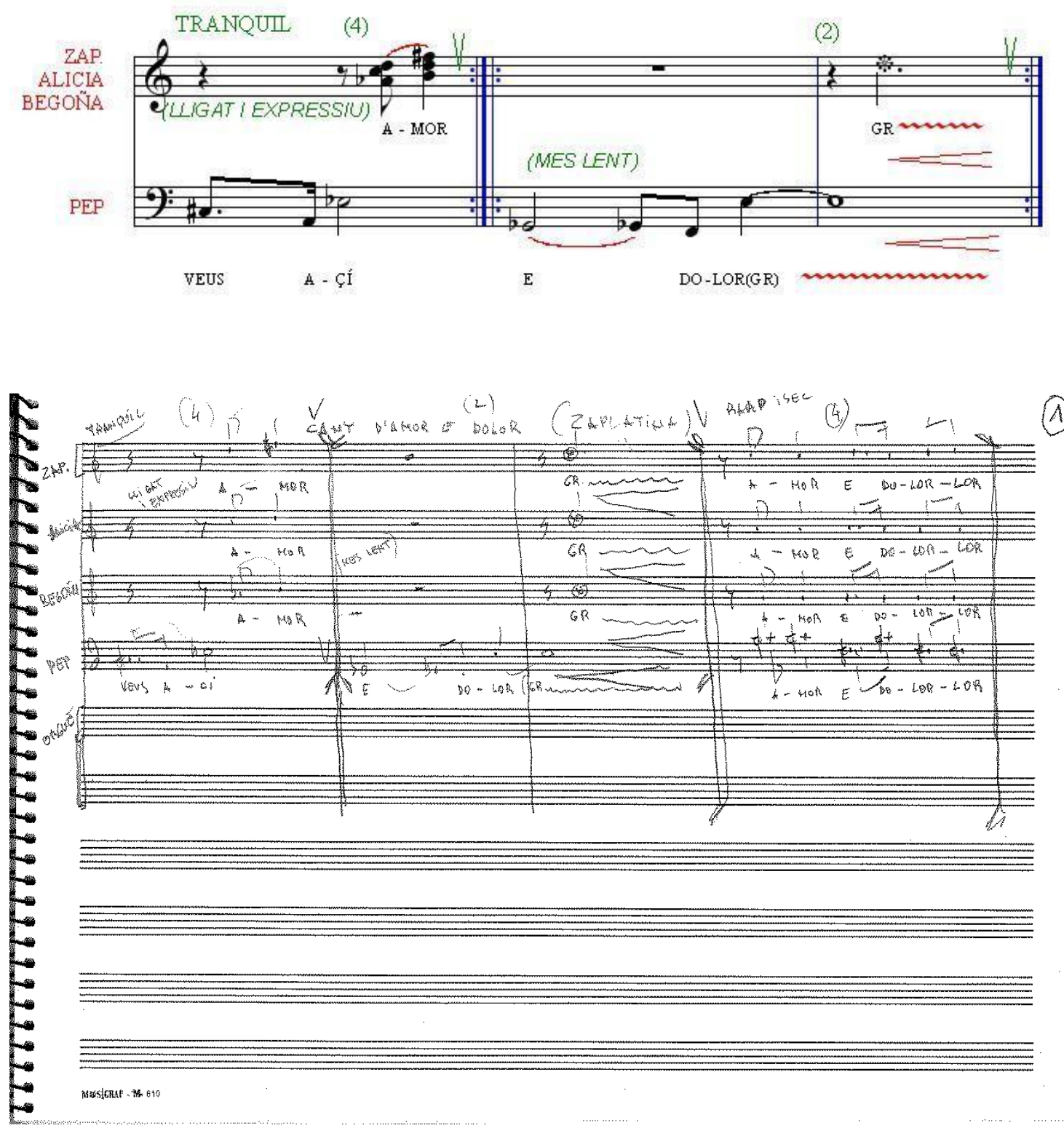

Existen 2 copias del libreto. En ellas consta que la dramaturgia es de Calixto Bieito y Marc Rosich.

Estrenada en la Feria de Fráncfort (Alemania).

La música en directo corre a cargo de los mismos actores y está interpretado por una quincena de intérpretes. En su estreno, los de la compañía estable del Romea, teatro que dirige Bieito, a los que se suma el personaje de Tirant lo Blanc. 
Nominada a 7 categorías, fue ganadora del Premio MAX a la "Mejor Dirección Musical" y del Premio MAX a la "Mejor Composición Musical para Espectáculo Escénico", en 2009, en la persona de Carles Santos.

\section{MATERIAL TOTAL:}

- Partitura manuscrita y original del autor. Consta de 4 blocs de escritura musical, con los siguientes títulos:

- Tirant (1) en el exterior (inicio de la obra) con 27 páginas manuscritas;

○ Tirant (2) "Cant d'amor (Eliseu)" en el exterior con 9 páginas numeradas y manuscritas;

○ "(4) Cançó de guerra + Coit (1R) + Coit $\left(2^{\circ}\right) "$ en el exterior con 32 páginas numeradas y manuscritas, divididas en las siguientes partes:

- " Cançó de guerra ", 5 páginas;

- "Coit $\mathrm{n}^{\circ} 1$ ", 1 página;

- " Coit no 2", 2 páginas;

- "Carmesina", 4 páginas;

- "Gent argent e for ment", 1 página;

- "Rebuda de les doncelles al camp", 6 páginas;

- "Cançó de bodes sordes", 2 páginas;

- "Rituals secrets", 2 páginas;

- "El miracle dels morts", 9 páginas.

- "Requiem" en el exterior con 17 páginas manuscritas;

- Al parecer, y según numeración, falta el bloc $n^{\circ} 3$.

- Partes: No existen partes.

- No consta relación de originales y copias. 
27.- TRAMUNTANA TREMENS, Obra escénica, politonal, Coro y Piano, sin guion ni partitura, 1989, Arc. 8 .
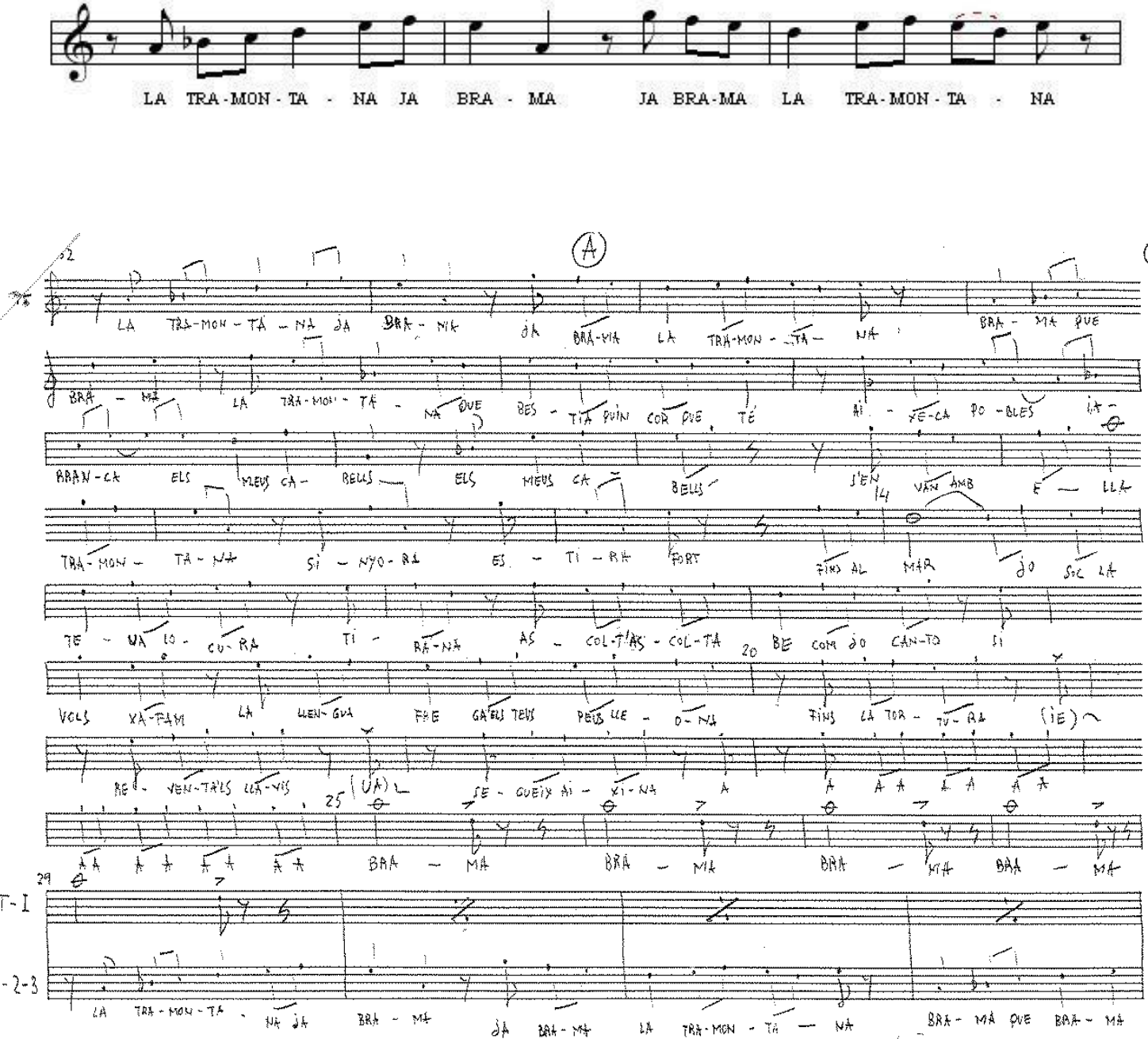

Estrenada al Mercat de les Flors de Barcelona en 1989 (30 noviembre - 1 diciembre 1989)

\section{MATERIAL TOTAL:}

- Partes de coro (Manuscrito fotocopiado de las partes de coro de la obra). Consta de 14 facsímiles grapados, con el siguiente orden y contenido:

○ 1.- 9 páginas fotocopiadas y numeradas con los títulos "Escena $\mathrm{n}^{\mathrm{o}} 1$ " y "A" en la tapa.

○ 2.- 13 páginas fotocopiadas y numeradas con el título "A" en la $1^{a}$ página. 
○ 3.- 7 páginas fotocopiadas y numeradas con el título "B" en la $1^{a}$ página.

○ 4.- 8 páginas fotocopiadas y numeradas con el título "C" en la $1^{a}$ página. Existen 2 juegos más de este material.

○ 5.- 14 páginas fotocopiadas y numeradas con el título "D $2^{\mathrm{a} \text { " en }}$ la $1^{\mathrm{a}}$ página.

○ 6.- 5 páginas fotocopiadas y numeradas con los títulos "Cor femení" y "E" en la tapa.

○ 7.- 4 páginas fotocopiadas y numeradas, sin título en la $1^{\text {a }}$ página, que corresponden a la obra Tocatico-Tocatá, versión coro.

○ 8.- 8 páginas fotocopiadas y numeradas, sin título en la $1^{a}$ página, que corresponden a la obra Tocatico-Tocatá, versión coro. Es una versión ampliada de la anterior.

○ 9.- 11 páginas fotocopiadas y numeradas con el título "Vals" en la $1^{\mathrm{a}}$ página. Existen 2 juegos de este material.

- 10.- 13 páginas fotocopiadas y numeradas (del 11 al 23) con el título "Nacho" en la $1^{\text {a }}$ página y que son continuación del material anterior, con el que comparten la página 11.

- 11.- 2 páginas fotocopiadas y numeradas, sin título en la $1^{\mathrm{a}}$ página.

- 12.-3 páginas fotocopiadas y numeradas, sin título en la $1^{\mathrm{a}}$ página.

○ 13.- 4 páginas fotocopiadas y numeradas, sin título en la $1^{\text {a }}$ página.

○ 14.- 6 páginas fotocopiadas y numeradas con los títulos "Cor femení i solista amb aigua" y Tramuntana Tremens en la tapa.

- Partes: Las expuestas anteriormente.

- No consta relación de originales y copias. 
3.2.8.1. ACCIONES MUSICALES 
Como Acciones Musicales se entienden espectáculos con o sin puesta en escena, que no cuentan solamente con el contenido musical, sino que se plantea, junto a este, alguna representación artística conjunta (danza, filmografía, exposición, performance, etc.). Por tanto, la música empleada ya está catalogada pero, al ser un hecho diferenciador de la obra de Santos, se cree conveniente incluirlas en este trabajo, como un apéndice de su obra escénica.

ALÉ VINAROÇENC, Libre, en Mi, banda, con guion, 2007, Arc. 27 (pág. 259)

Compuesta para la Acción musical realizada en Vinaròs, el 30 de junio de 2007 con motivo de la entrega del Premio "Alé Vinaroçenc" a la Banda de Vinaròs, por parte de la Caixa Rural de Vinaròs (Mecenas de la Fundación). La interpretación se realiza subiendo los intérpretes de uno en uno (o por grupos instrumentales) al escenario y una vez en el mismo, comienzan la ejecución escrita. Poco a poco el escenario va llenándose de músicos hasta que el director ocupa su lugar en última posición. En su estreno no se interpretó la totalidad de la obra. Por el momento no existe el estreno en su versión actual, acabada.

ANEM, ANEM, ANEM, ANEM A VOLAR, Libre, politonal, 2 voces mixtas y piano, con partitura, 1982, Arc. 16.

(pág. 223)

Música escrita para la acción musical desarrollada por Las Ramblas de Barcelona en 1982, empujando el autor un piano por la calle al tiempo que una cantante, se mantenía encima del instrumento. Al llegar al punto de destino, se interpretó la música escrita.

CARRER, Libre, Politonal, Cobla, metal y percusión, con partitura y partes, 2008. Arc.20.

Ver: sección otras agrupaciones.

(pág. 435) 
Compuesta para la Acción musical estrenada en Agramunt el 13 de diciembre de 2008, como homenaje a Guinovat.

CONCERT IRREGULAR, Libre, politonal, voz solista (sin determinar) y piano, con partitura, 1967, Arc. 19.

(pág. 230)

Para festejar el 75 aniversario de Joan Miró. Estrenada a la Fundación Maeght de Sant Pau de Vença. Carles Santos y Anna Ricci.

MAQUINOFOBIA PIANOLERA, Libre, politonal, Piano e Instrumento mecánico, con guion, 2011. Arc.28.

(Pág. 457)

Compuesta para la Acción musical estrenada en Barcelona el 23 de julio de 2011, junto al Grupo Cabo San Roque, dentro del Festival de Verano de Sant Feliu de Guíxols.

MINIMALET SÛR MER, Libre, politonal, piano, con partitura, 1988, arc. 34.

Ver: PEÇA A LA MAR (sección Obra piano)

(pág. 118)

Música para acción musical realizada en Vinaròs en 1988 en la que el compositor realiza la interpretación sobre una plataforma flotante, al mismo tiempo que una soprano canta desde una superficie elevada en el puerto.

MORELLAR MORELLA (desfile), Libre, en La, coro mix to a 2 voces, con partitura, 2011, Arc. 20.

Ver: MORELLAR MORELLA (Sección Obra Banda)

(pág. 192) 
Compuesta para la Acción musical representada en el evento "Com sona l'ESO" de 2011, celebrado en Morella (11 a 14 de mayo) En concreto para el desfile del día 12. En el mismo, 4 grupos de alumnos de secundaria de diversos Institutos de la Comunidad Valenciana, Cataluña y Baleares, recorrieron las calles de la localidad, por 4 recorridos diferentes, portando antorchas, al mismo tiempo que cantaban la pieza catalogada. Las salidas de los 4 grupos se realizó desde las 4 puertas que dan acceso a la ciudad desde sus murallas, finalizando este recorrido en la Plaza de la iglesia de Morella, el lugar más elevado de la localidad.

\section{PECATAMONICATISMARMOLLA TUA TUA (2009)}

s. reg. puesto que se desconoce la música interpretada por el autor.

Acción realizada en las calles de Barcelona el 1 de abril de 2009. Santos toca el piano encima de una plataforma arrastrada manualmente a lo largo de las Ramblas, al mismo tiempo que dos artistas, danzan sobre el piano. Inauguración de Arts Santa Mónica, temporada 2009.

https://www.youtube.com/watch?v=pGA8P8YtkRQ

VI SONOR, libre, politonal, coro, con partitura, 2011, Arc. 23

Ver: CONILL AMB CARAGOLS

(pág. 214)

Compuesta para la Acción musical realizada en Pobla de Gervoles (cerca de Agramunt) el 2 de julio de 2011, como homenaje a los vinos de la bodega Celler Mas Blanch i Jové, que creó la denominada La Vinya dels Artistes. La acción transcurría en los viñedos. Mediante un paseo, los invitados degustaban comida típica de los periodos clásico, romántico, impresionismo, siglo XX y la actualidad, al mismo tiempo que un pianista interpretaba música propia del periodo al que se hace referencia. Los camareros vestían de acuerdo con la época. En total participan 5 pianistas (Oscar Campos, Inés Borrás, Albert Giménez, Miquel Villalva y Carles Santos) con 5 pianos colocados en puntos estratégicos del recorrido, un coro (que interpreta la música al tiempo que los invitados recorren el espacio que separa una época de la siguiente) y una violinista, Katy Reus, encima de una grúa. Encima de los pianos se depositaros productos típicos 
de cada periodo. La acción comenzó con la interpretación de la obra a cargo de El Cor Eurídice de les Borges Blanques dirigido por la compositora Dolors Ricart. El mismo coro fue el encargado de interpretar las 3 obras corales de Santos ("Saó Blanc", "Saó Expressiu" i "Saó Rosat") en los paseos de transición de un lugar a otro de las viñas de la bodega.

VIDEO BANYERA, Libre, en Sol, voz solista, con partitura, 1980 aproximadamente, Arc. 23

(pág. 216)

Puede formar parte de la musicalización de algunas imágenes o film. "Imágenes rodadas en Madrid, para un documental de TVE, en las cuales se paseó, por las calles de Madrid, una plataforma, encima de la cual se encontraba una bañera llena de agua con una modelo dentro. El autor, también encima de la plataforma, iba cantando, al tiempo que sumergía a la actriz en la bañera" (Carles Santos Ventura). Se desconoce si alguien tocaba el piano al mismo tiempo. 
3.2.9. INTEGRALES 
1.- CREDIT TONAL, espectáculo escénico, politonal, varias agrupaciones, 1986, Arc. 34

Consta de los siguientes materiales:

Título

Peça veu amb Cesc

Gelabert

Demana-ho

Credit tonal

\section{Instrumentación}

Piano y voz $(\sin$
identificar).

2.- EL PONT DE VARSOVIA, B. S. O., politonal, varias agrupaciones, 1989? Arc. 29.

Consta de los siguientes materiales:

\begin{tabular}{lll} 
Título & Instrumentación & Catálogo \\
\hline El pont de Varsovia & $\begin{array}{l}\text { Piano, 4 voces femeninas, } \\
\text { cuarteto de cuerda, } \\
\text { quinteto de cuerda y } \\
\text { percusión. }\end{array}$ & Grupos de cuerda \\
& Orquesta & \\
\hline Delta & Cuarteto de cuerda & Obra orquestal \\
\hline $\begin{array}{l}\text { El pont de Varsovia } \\
\text { "Berlin (mare)" }\end{array}$ & & \\
\hline $\begin{array}{l}\text { Quintet de corda. } \\
\text { Portabella }\end{array}$ & Quinteto de cuerda & Grupos de cuerda \\
\hline $\begin{array}{l}\text { El pont de Varsovia, } \\
\text { Quintet de corda. }\end{array}$ & Quinteto de cuerda & Grupos de cuerda \\
\hline $\begin{array}{l}\text { El pont de Varsovia, } \\
\text { Metro. }\end{array}$ & Grupo de percusión & Grupos de cuerda \\
\hline $\begin{array}{l}\text { El pont de Varsovia, } \\
\text { Piano, 4 voces femeninas) }\end{array}$ & Piano y 4 voces femeninas & Grupos de cuerda \\
\hline Portaferrisa & Cuerda, metal, Piano y & Otras agrupaciones \\
\hline & Percusión & \\
\hline & & \\
\hline
\end{tabular}


3.- JJ. OO. BARCELONA '92, Evento deportivo, politonal, varias agrupaciones, 1992, G 8.

Consta de los siguientes materiales:

\begin{tabular}{lll} 
Título & Instrumentación & Catálogo \\
\hline Medalles (promenade), & Oquesta & Orquesta \\
\hline Piromusical & Banda y coro & Banda \\
\hline Comedians & Banda y coro & Banda \\
\hline Promenade (Banda) & Banda & Banda \\
\hline Medalles (fanfàrria), & Fanfarria & Fanfarria \\
\hline Piromusical & sexteto vocal (sin & Voz y piano \\
& especificar) y piano & \\
\hline
\end{tabular}

4.- LA VINYA DELS ARTISTES, Acción musical, politonal, varias agrupaciones, 2011, Arc. 23

Consta de los siguientes materiales:

\begin{tabular}{lll} 
Título & Instrumentación & Catálogo \\
\hline Conill amb caragols & coro & Obra vocal \\
\hline "Saó blanc" & coro & Obra vocal \\
\hline "Saó expressiu" & coro & Obra vocal \\
\hline "Saó rosat" & coro & Obra vocal \\
\hline
\end{tabular}


5.- MEDITERRANEA '09, Evento musical, politonal, varias agrupaciones, 2009, Arc. 12.

Consta de los siguientes materiales:

\begin{tabular}{lll} 
Título & Instrumentación & Catálogo \\
\hline 6 tenoras i piano & 6 tenoras i piano & Otras agrupaciones \\
\hline Tenora i piano & 1 Tenora y piano & Otras agrupaciones \\
\hline Tenores (anyadit), & 12 Tenoras y Piano & Otras agrupaciones \\
\hline Soprano i tenora & 1 Soprano i 1 tenora & Obra vocal \\
\hline Cantata (manresa), & Voces solistas y coro & Obra vocal \\
\hline Els monts & Voces solistas y coro & Obra vocal
\end{tabular}

6.- MORELLAR MORELLA, Evento musico-pedagógico “Com sona l'ESO” de 2011, politonal, varias agrupaciones, 2011, Arc. 11.

Consta de los siguientes materiales:

\begin{tabular}{lll} 
Título & Instrumentación & Catálogo \\
\hline Morellar morella & $\begin{array}{l}\text { banda, órgano, coro y } \\
\text { soprano solista, }\end{array}$ & Banda \\
\hline Morellar Morella (desfile) & coro mixto a 2 voces & Obra vocal \\
\hline
\end{tabular}


3.2.10. OTRAS AGRUPACIONES 
1.- 6 TENORAS I PIANO, libre, politonal, 6 tenoras y piano, con partitura y partes, 2009, Arc.12.

La plantilla a la que está dedicada es la de 6 tenoras y piano.
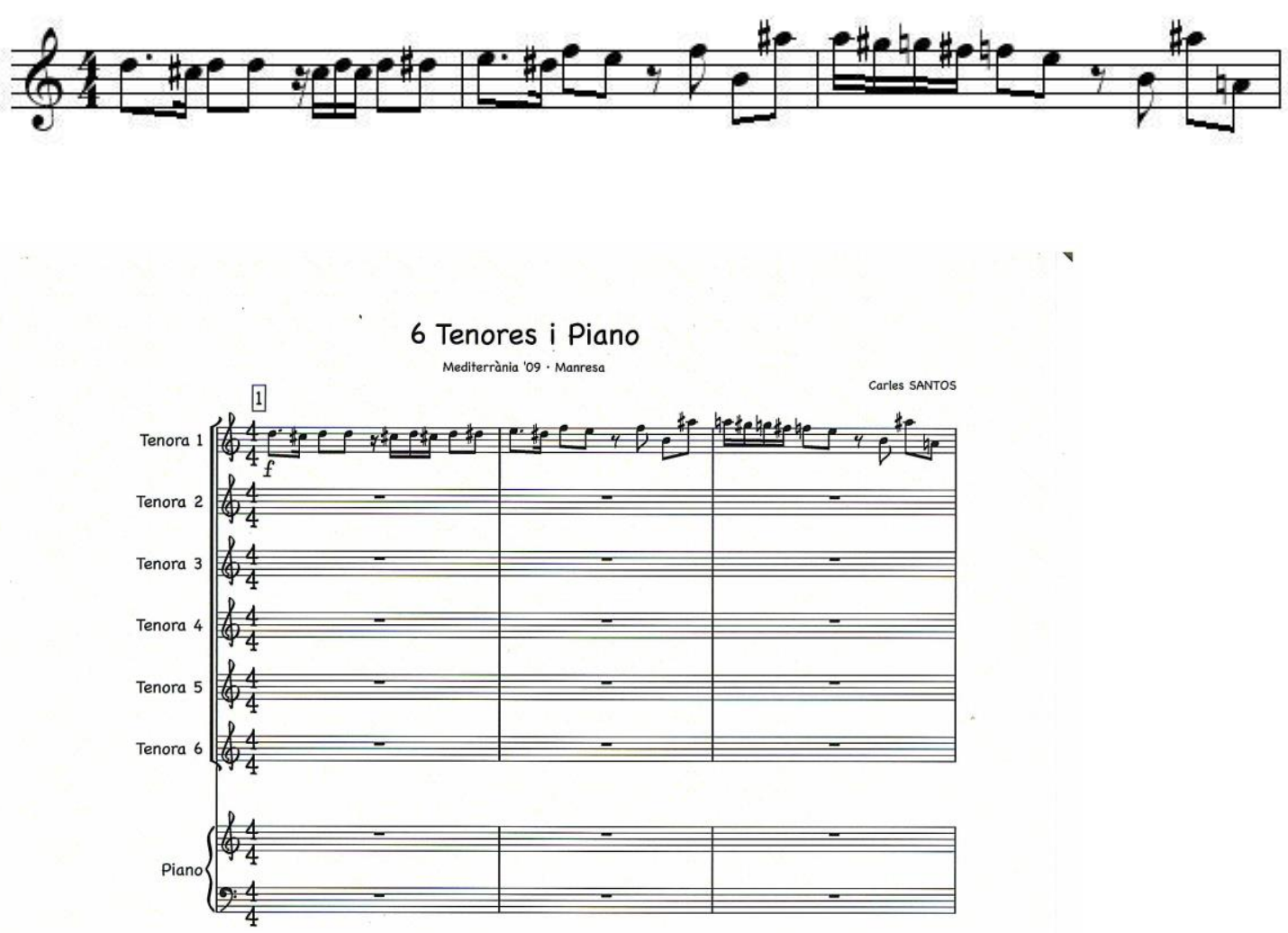

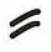

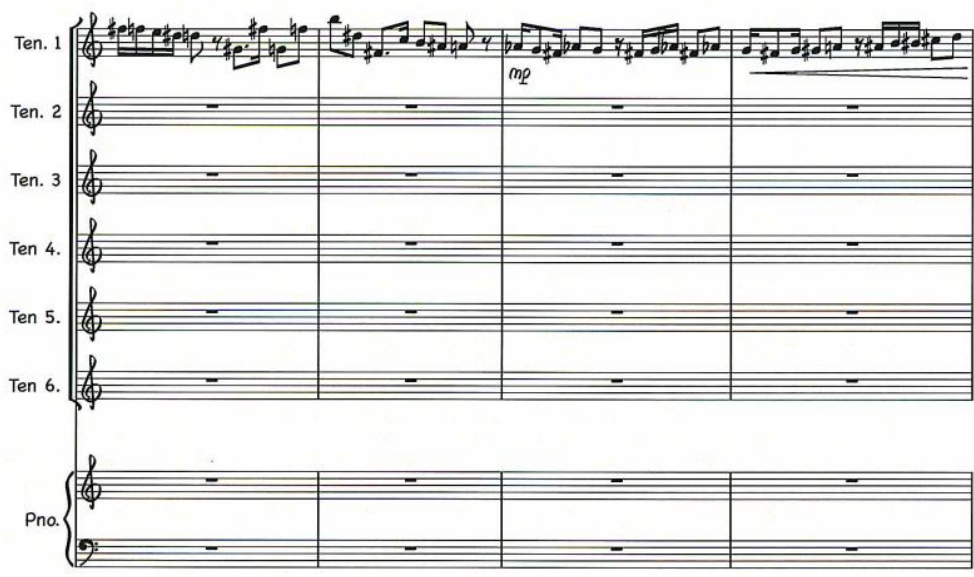


Obra escrita para el evento "Mediterranea '09" celebrado en Manresa en 2009. Texto de Pere Jaume.

\section{MATERIAL TOTAL:}

- Material manuscrito del autor, original, en dos blocs de escritura musical, numerados en el exterior y con los títulos "Manresa (6 Tenores) (1)" Y "Tenores (2)". Páginas numeradas de la 1 a la 30 , en el $1^{\circ}$, y de la 28 a la 47 , en el $2^{\circ}$.

- Partitura impresa de software, de 31 páginas, sin encuadernar. PDF realizado por Xavier Piquer con software Sibelius (Mac).

- Partes: Existen partes de software y originales.

- No consta relación de originales y copias. 
2.- 682-3133 BUFALO MINNESOTA, libre, en Re m, Flauta, con partitura y guion, 1977, Arc.24.

La plantilla a la que está dedicada es la de una flauta.
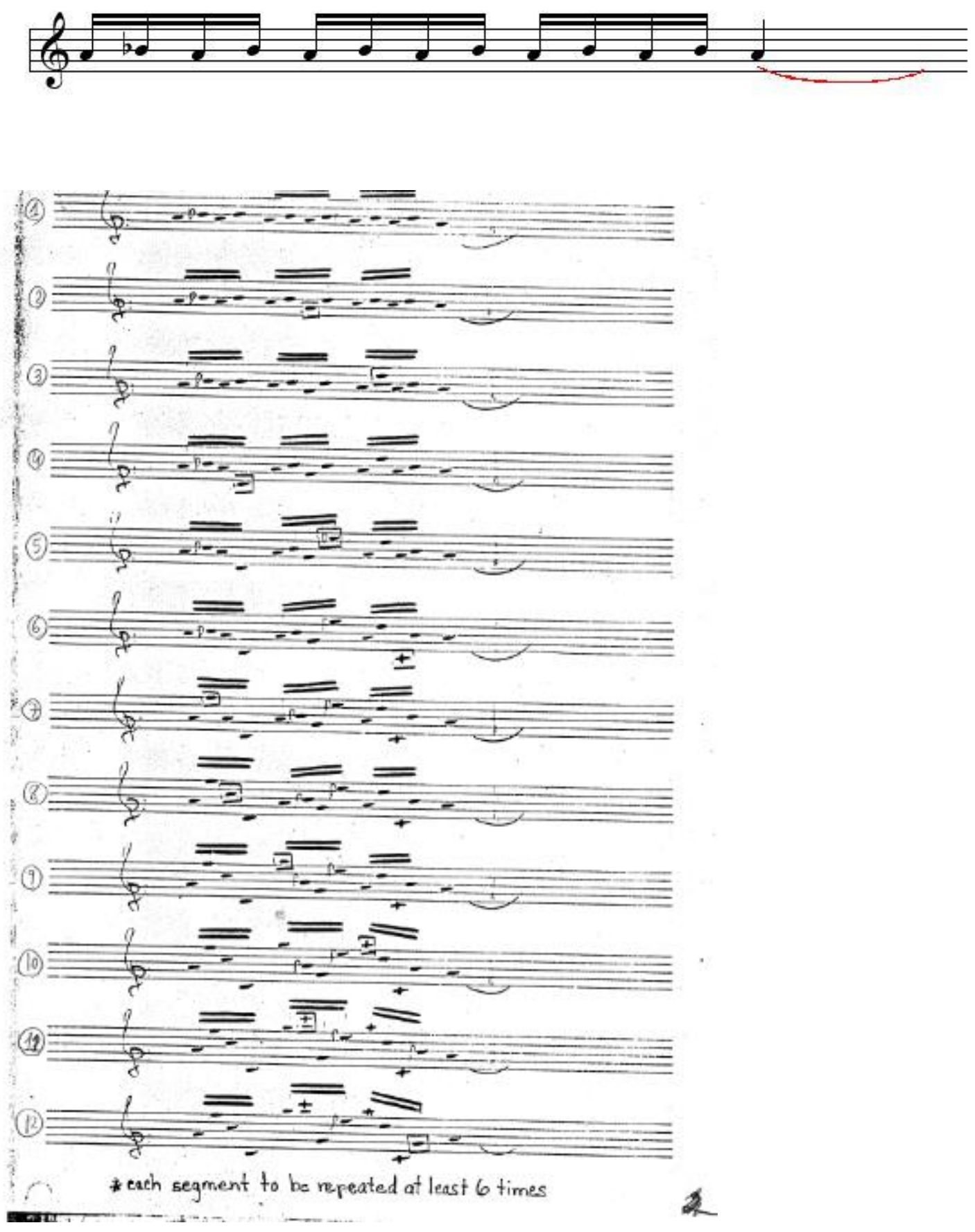
La melodía de la flauta es semejante a la de la obra Flauta.

Existe una grabación del film. Los vídeos incluidos en el listado "Vídeos Archivo Artea" están disponibles para su consulta y visualización en Matadero Madrid. Centro de Creación Contemporánea (Paseo de la chopera, 14. 28045 Madrid. www.mataderomadrid.com)

Compuesta para la musicalización de un Corto, del que Santos es el Realizador.

\section{MATERIAL TOTAL:}

- Partitura manuscrita y fotocopiada del autor. Consta de dos páginas numeradas de escritura musical, con el título 682-3133 Buffalo-Minnesota en la segunda página y la indicación "Intimate, very tranquil" en la primera. Existe otra indicación que informa que cada fragmento ha de interpretarse 6 veces (en inglés), así como la fecha y lugar de composición: MEXIC-JULIOL-1977

- Partes: No existen partes.

- No consta relación de originales y copias. 


\section{3.- ACCIÓ AMB ESTUDIANTS DE TOULOUSE I L'INSTITUT DE TEATRE}

DE BARCELONA, Libre, politonal, clarinete y voz (mezzo-soprano), con partitura, 2004, Arc.28.

La plantilla a la que está dedicada es la de un clarinete y una mezzo-soprano.

Ver: PENTAGRAMA O ESPERMA (Obra vocal)
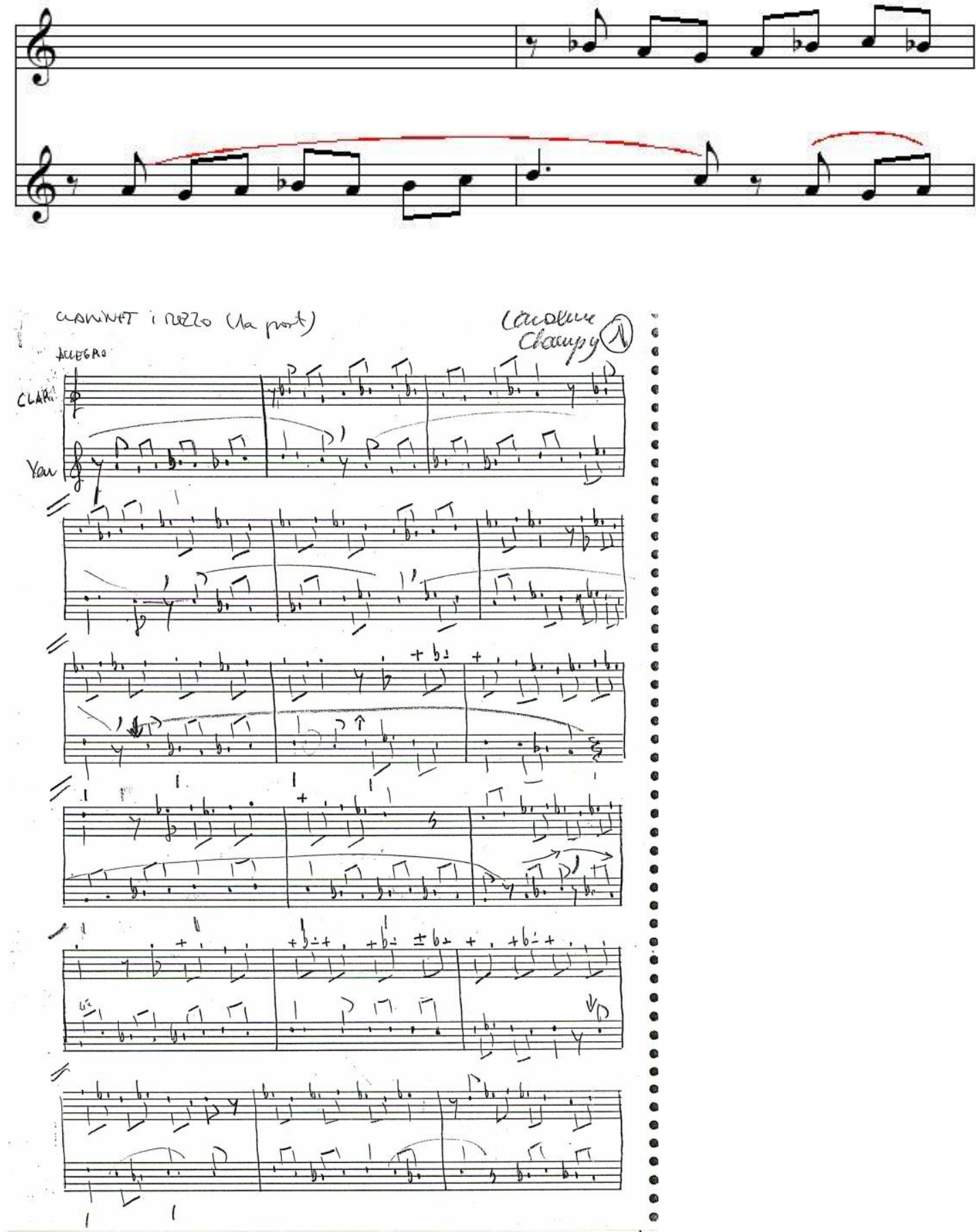
El material se encuentra en un sobre con matasellos de Toulouse y con fecha de 26/04/04. Existe una nota de la Secretaria del Director del Teatro Nacional de Toulouse, devolviendo las partituras que Santos les pidió.

Forma parte del material utilizado por el compositor, para las clases que tuvieron lugar en Toulousse, entre enero y marzo de 2004, en el evento "Pentagrama o Esperma".

\section{MATERIAL TOTAL:}

- Partitura de la obra: Partitura manuscrita y fotocopiada del autor. Consta de 2 hojas escritas, sueltas y numeradas.

- Partes: No existen partes.

- No consta relación de originales y copias. 
4.- ANGELS, Libre, politonal, grupo instrumental, voz y piano, con partitura, s. d., Arc.14.

La plantilla a la que está dedicada es la de una orquesta reducida y Piano. Los instrumentos que constan son: 3 voces distintas, Violín, 2 Cellos, Trompeta, Trompa, Bombardino, Tuba y Piano. Existe también la intervención de perros. Algunas partes vocales se encuentran sin texto.
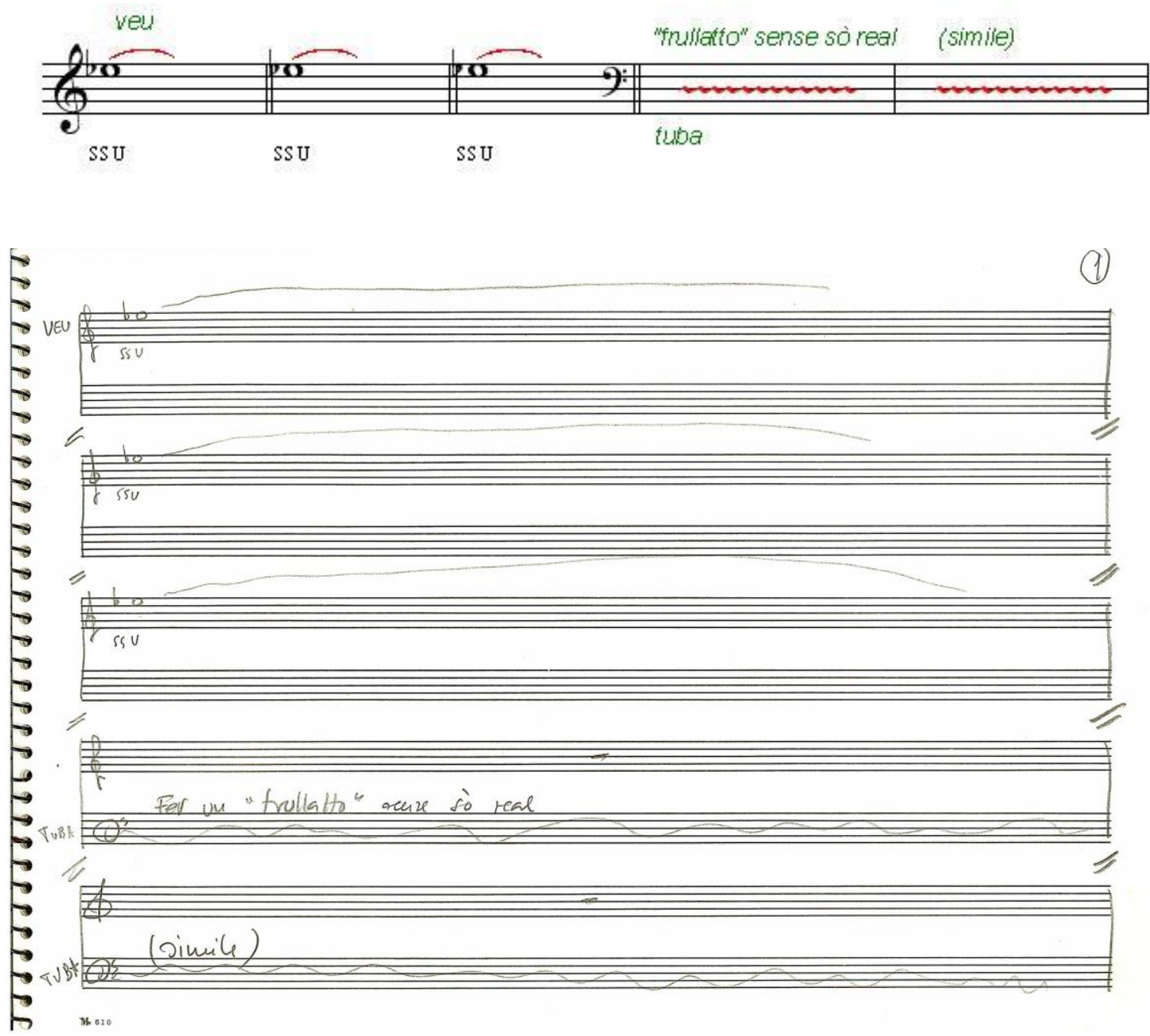

\section{MATERIAL TOTAL:}

- Partitura de la obra: Manuscrito original del autor en tres blocs de escritura musical, numerados en el exterior y numeradas sus páginas (1 a 29, 30 a 58 y 59 a 87).

- Partes: No existen partes.

- No consta relación de originales y copias. 
5.- BARBY FLUTE, Libre, politonal, viento, guitarras eléctricas y piano, con partitura y partes, s. d., Arc.15.

La plantilla a la que está dedicada es la de un grupo de viento, guitarras eléctricas y piano.
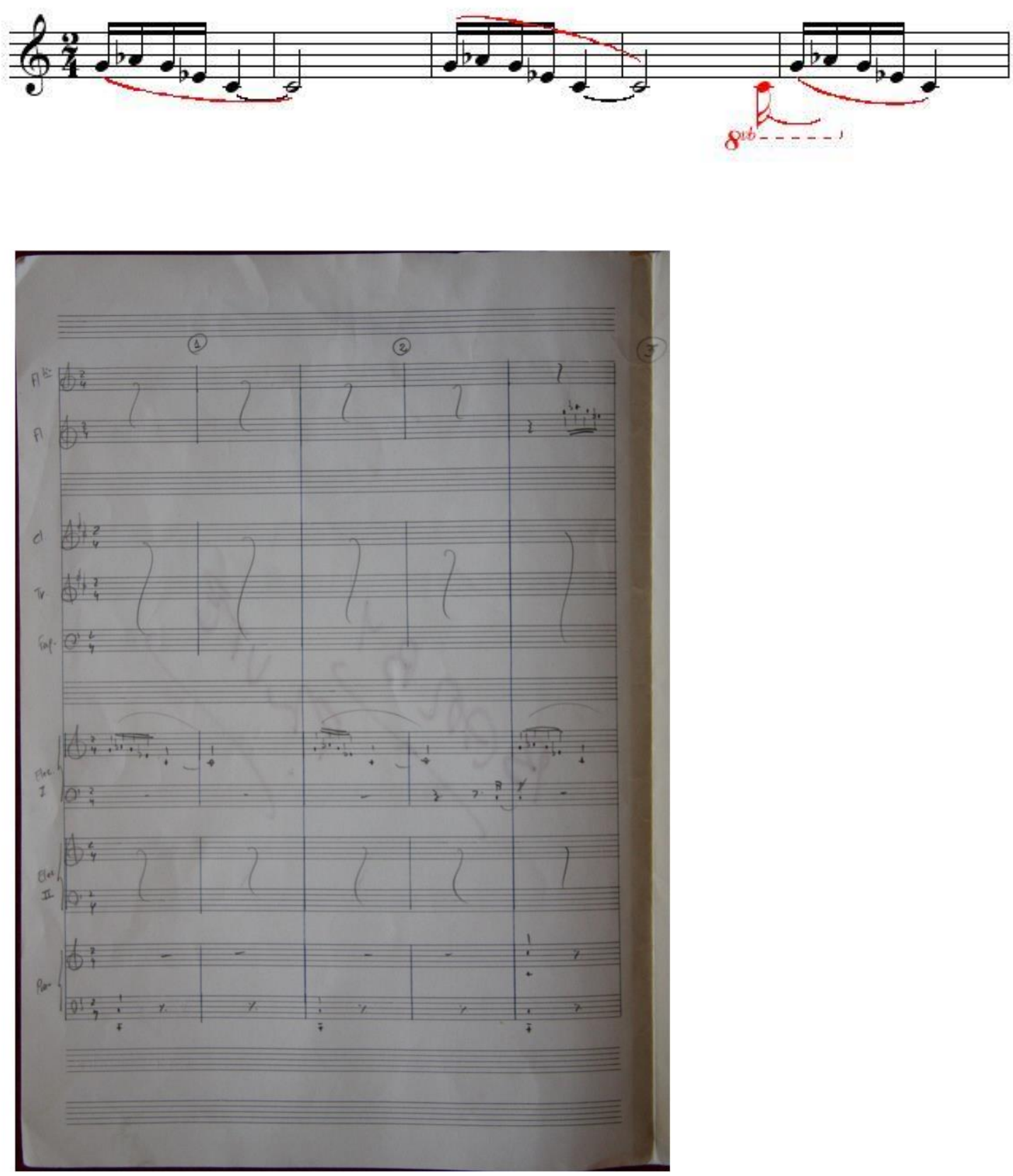


\section{MATERIAL TOTAL:}

- Partitura de la obra: Partitura manuscrita y original del autor. Consta de un facsímile con 7 hojas escritas y numeradas. Existe una copia de la partitura.

- Partes: Existen partes originales y manuscritas de cada instrumento.

- No consta relación de originales y copias.

Existe indicación que cada fragmento o grupo debe repetirse 8 veces. 
6.- BROSSA, Libre, politonal, 4 partes, con guión, s. d., archivador 15.

No existe una plantilla determinada a la que va destinada la obra ya que constan 4 partes distintas, pero sin especificar a que voces o instrumentos van destinadas. Existen anotaciones manuscritas del autor que sí hacen referencia, en momentos determinados, a formas de interpretación (pizz.).
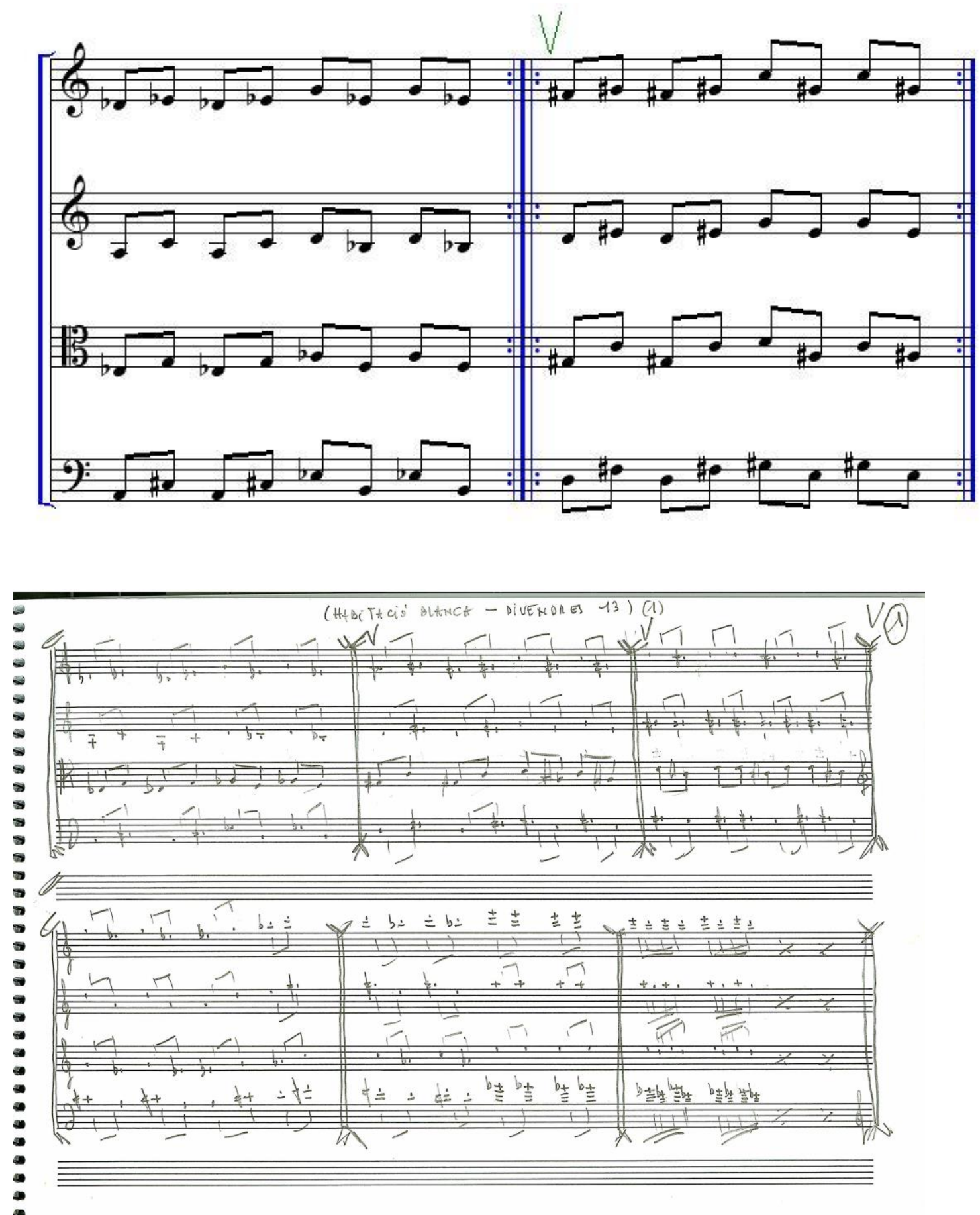
Da la impresión de ser anotaciones o guión de la obra.

Al parecer, música escrita para la ambientación musical de alguna novela de Brossa. Constan anotaciones del autor que hacen referencia a diversos momentos de la acción o personajes que intervienen (Habitació blanca, llansol, escenari apuntado, talla ungles, hab. blanca homes projecció, noia bosc, andana tren, actor smoking, fumera cara d'actor, noia al tren, noia cos mascaret, clava clau, cap de pulcinella, botiga buida, noia carrer, violí xafat, la noia entra a casa, terrat geperut, bosc cabana, final).

\section{MATERIAL TOTAL:}

- Partitura de la obra: Manuscrito original del autor en dos blocs de escritura musical, numerados en el exterior y numeradas sus páginas (1 a 30 y 31 a 40).

- Partes: No existen partes.

- No consta relación de originales y copias. 
7.- CANTATA, Cantata, Politonal, voz solista, coro de niños, piano y percusión, con partitura, 2007. Arc.18.

La plantilla a la que está dedicada es la de una voz solista, coro de niños, piano y percusión (Timbales, Xilófono y Marimba). Sobre texto de Albert Roig.

Ver: FLOR D'ESCARABAT (sección Obra voz y piano)
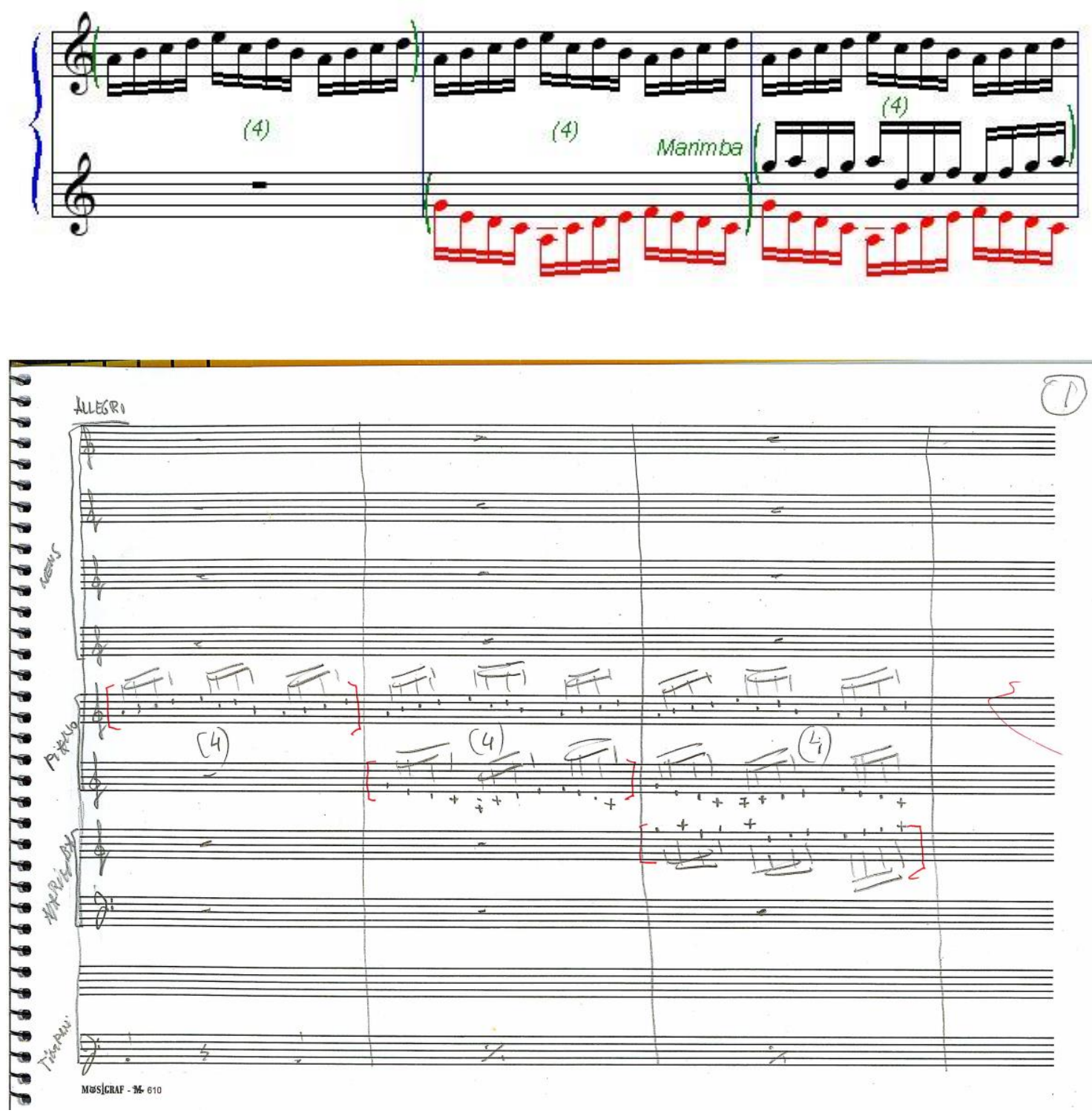

Estrenada en el Palau San Jordi en 2007. Coro de 3000 niños. Encargo del Secretariat de Corals Infantils de Catalunya. 
Existe otra versión de esta obra con el título Flor d'escarabat, impresa por DINSIC PUBLICACIONS MUSICALS, S.L. Es la obra es la misma pero con otro título.

\section{MATERIAL TOTAL:}

- Partitura manuscrita y original del autor. Consta de 4 blocs de escritura musical, con 116 páginas manuscritas, con los siguientes títulos:

- Cantata (1) en el exterior con 29 páginas numeradas y manuscritas.

- Cantata (2) en el exterior con 30 páginas numeradas y manuscritas (de la 30 a la 59).

- Cantata (3) en el exterior con 30 páginas numeradas y manuscritas (de la 60 a la 89$)$.

- Cantata (4) en el exterior con 27 páginas numeradas y manuscritas (de la 90 a la 116).

- Partitura impresa. Constan solamente los 343 primeros compases que se corresponden con los 2 primeros cuadernos manuscritos.

- Partes: No existen.

- No consta relación de originales y copias. 
8.- CARRER, Libre, Politonal, Cobla, metal y percusión, con partitura y partes, 2008. Arc.20.

La plantilla a la que está dedicada es la de una Cobla, metal y percusión.

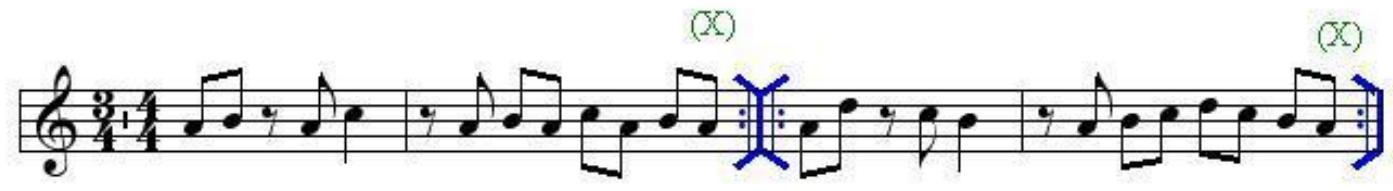

CARRER

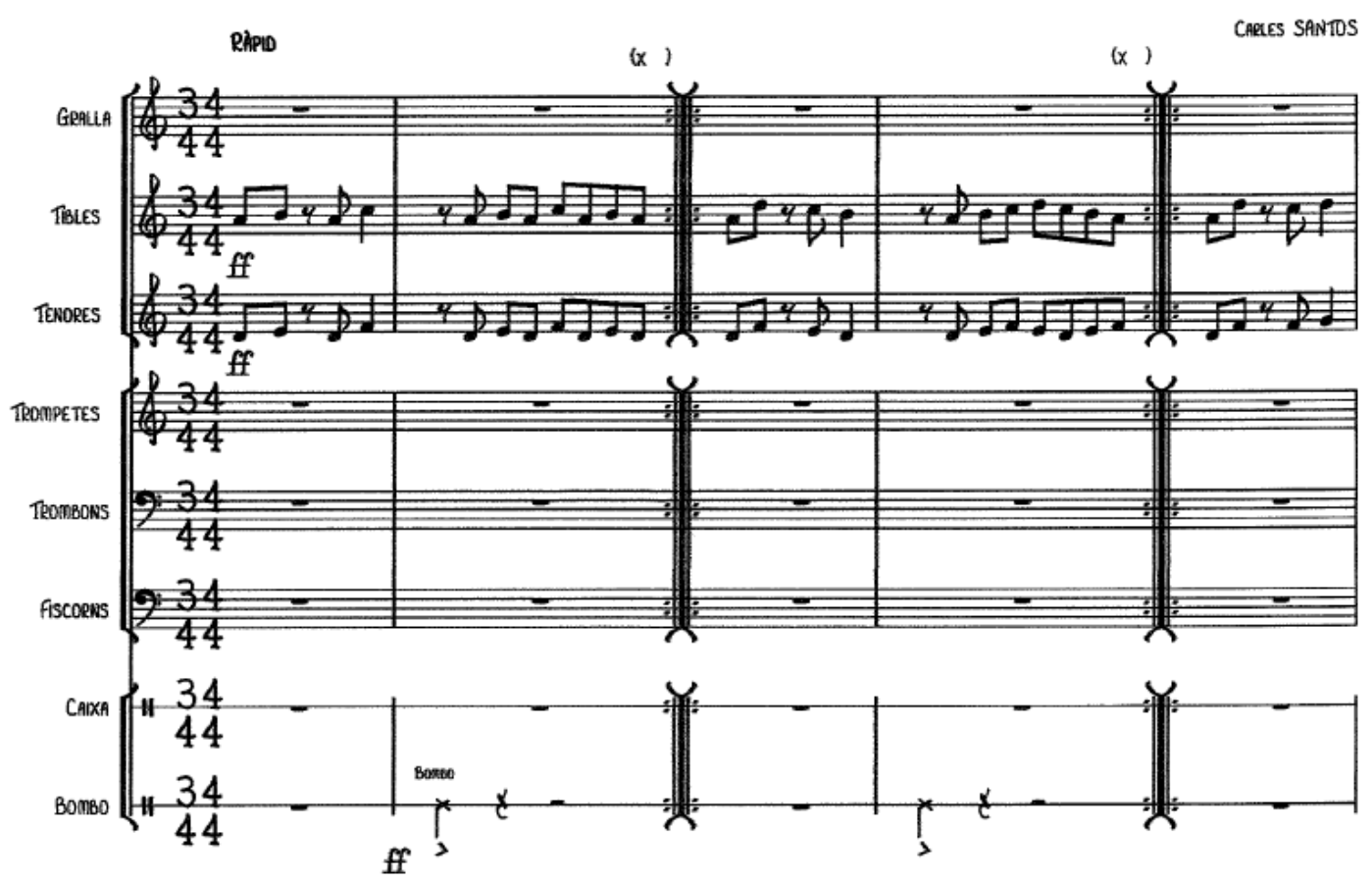

Compuesta para la Acción musical estrenada en Agramunt el 13 de diciembre de 2008, como homenaje a Guinovat.

Existen imágenes por internet.

\section{MATERIAL TOTAL:}

- Escanéo de partitura en sofware Sibelius. Todo el material se encuentra en papel en archivador 20 .

- Partes: Existen partes en pdf, no impresas.

- No consta relación de originales y copias. 
9.- CASTELLÓ '99, Libre, politonal, muy variable, con partitura y partes, 1999, Arc. 15 .

La plantilla es muy variable.
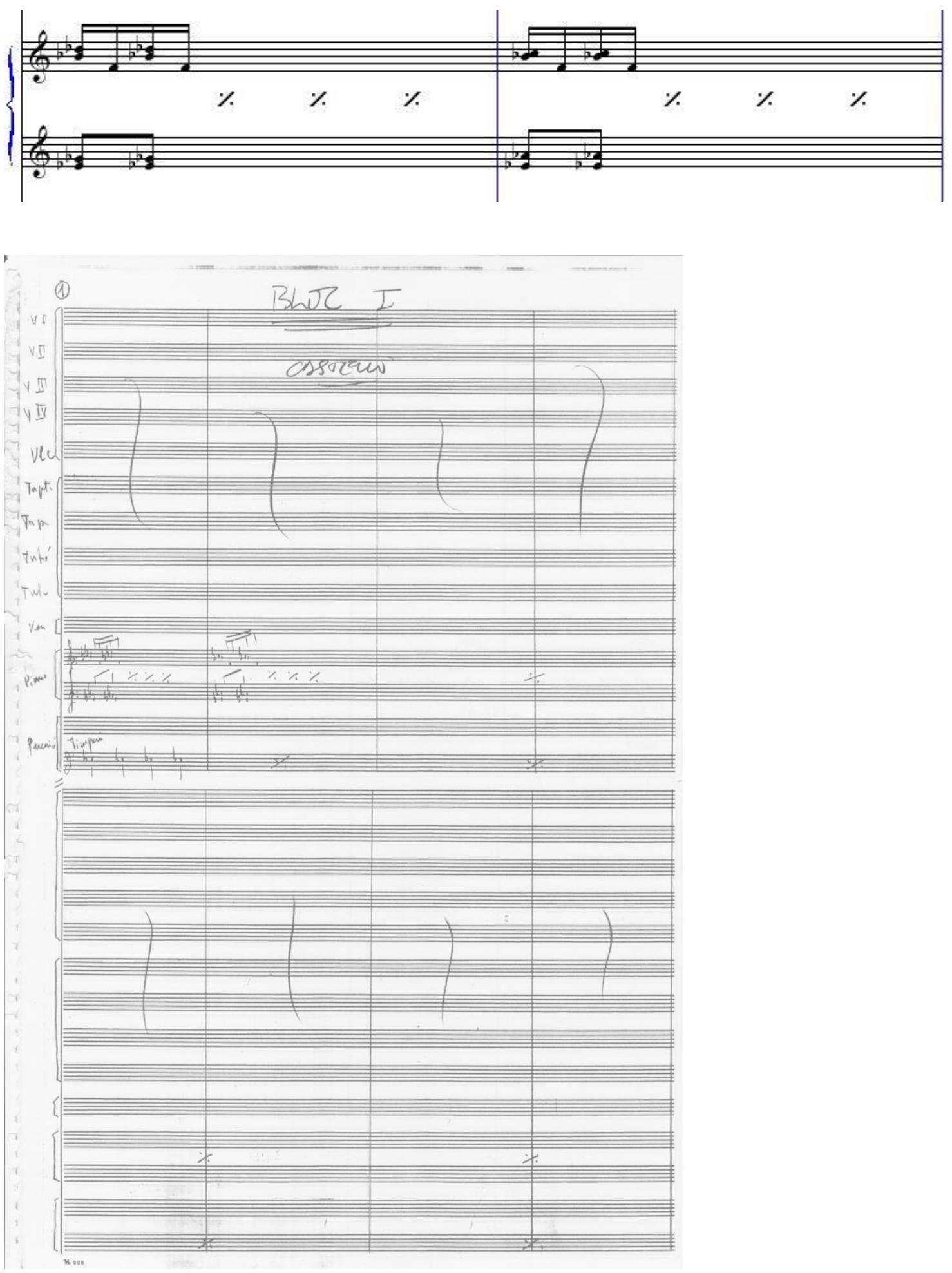
Recopilación de material ya escrito, utilizado para la inauguración del Espai d'Art Contemporani de Castelló. A la misma acudió Consuelo Ciscar.

\section{MATERIAL TOTAL:}

- Partitura de la obra: Partitura manuscrita y original del autor. Consta de un facsímile con 7 hojas escritas y numeradas. Existen partes. Existe una copia de la partitura.

- Partes: Existen partes originales y manuscritas de cada instrumento.

- No consta relación de originales y copias. 
10.- CONCERT TONI MIRA, Libre, politonal, grupo instrumental, piano y percusión, con partitura, s. d., Arc. 14.

La plantilla a la que está dedicada es la de un grupo instrumental con percusión y Piano. No constan qué instrumentos deben interpretar las partes que no sean de Piano o Percusión.
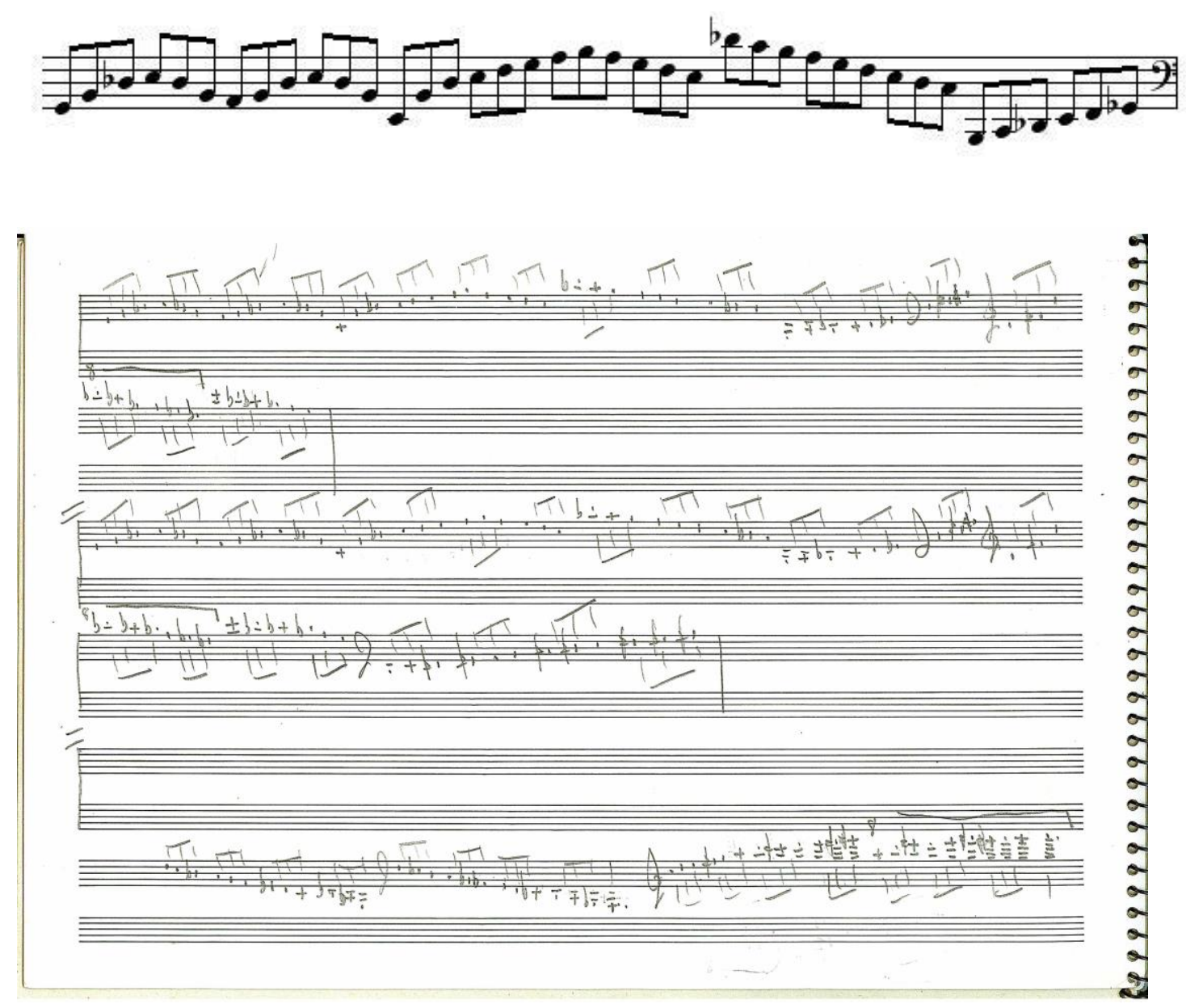

Música compuesta para el espectáculo de danza titulado "Blanc i negre", representado por primera vez por la Compañía de Danza Nats Nus.

\section{MATERIAL TOTAL:}

- Partitura de la obra: Manuscrito original del autor en un bloc de escritura musical.

- Partes: No existen partes.

- No consta relación de originales y copias. 
11.- CRITS DE CRIST, Libre, politonal, Coro, Fanfarria y Percusión, con guion, partitura y partes, 2010, Arc. 33.

La plantilla a la que está dedicada es la de un Coro mixto, Fanfarria y Percusión.

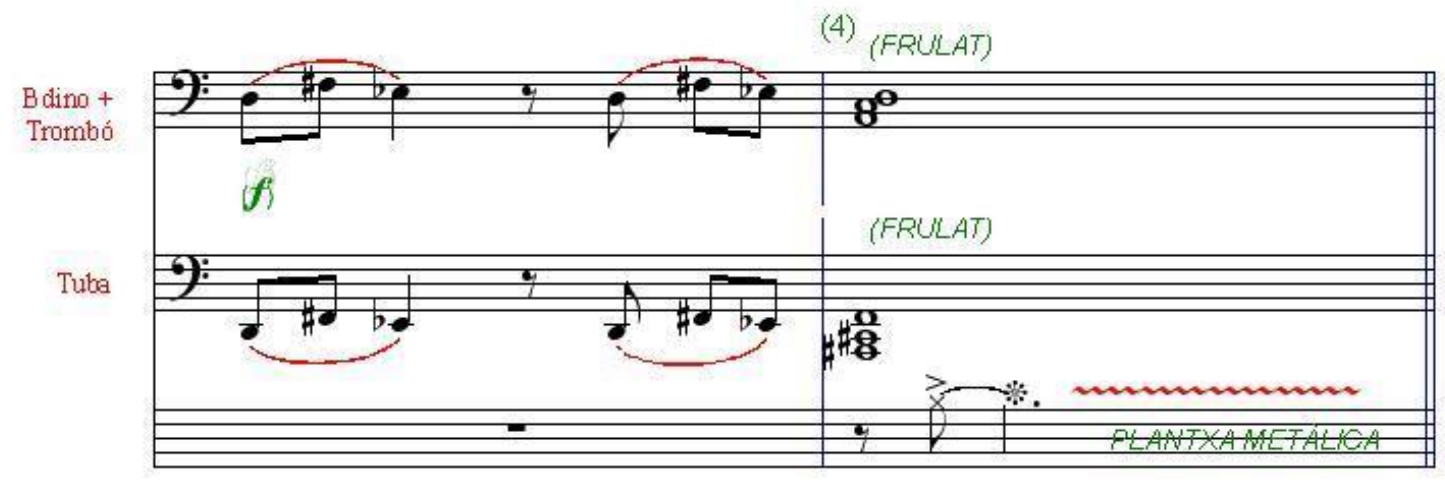

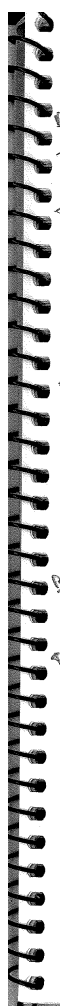

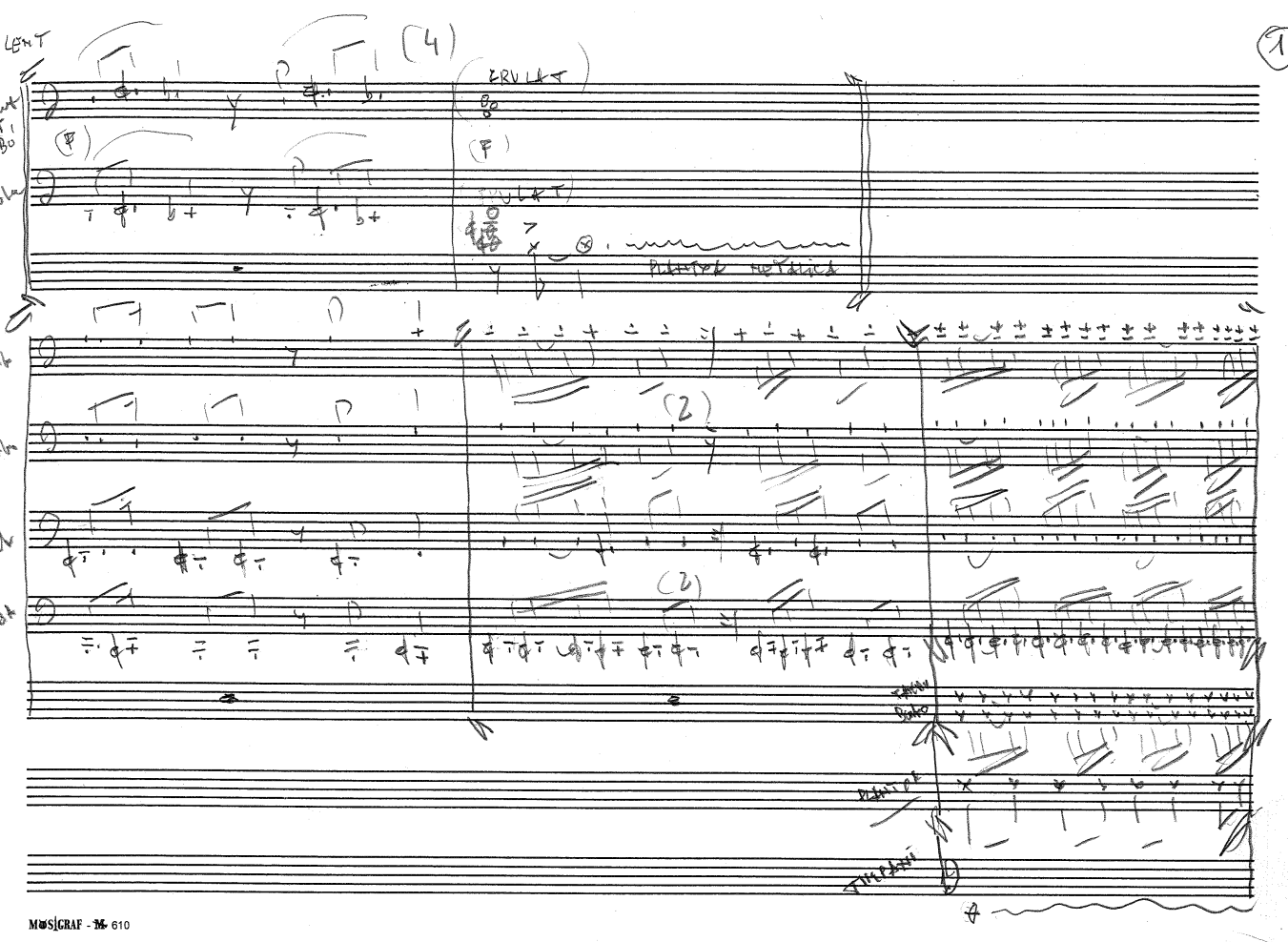

Estrenada por la Societat musical "La Alianza" de Vinaròs. Compuesta para la cofradía de Semana Santa: "Jesús Natzarè i Sant Sepulcre" de Vinaròs. La música contempla la procesión por las calles de la localidad, que se celebra el miércoles santo y que comienza a las 5:30 de la madrugada. Esta procesión se recuperó después de 80 años sin 
celebrarse, el 31 de marzo de 2010, al ritmo de la música de Santos. En 2014 se realiza un proyecto mappingy en el que se utilizan proyecciones audiovisuales, sobre la fachada del auditorio municipal con música de Santos. Realizado por el joven creativo David Inlines, incorporará fotografías de Pedro Vidal y la pieza Crits de Crist.

Bajo el título "Crits de Crist al Crist de Crits", en el año 1997, se realiza una Exposición fotográfica, estrenada en Lleida, del 20 de desembre de 2007 al 10 de febrero de 2008. Sala Gòtica de 1'IEI (Institut d'Estudis Ilerdencs). Los títulos de ambas obras, aunque semejantes, no tienen conexión aparente. El autor, como en otras ocasiones, ha podido titular la obra musical como referencia a una obra anterior, como es el caso de esta exposición fotográfica.

\section{MATERIAL TOTAL:}

- Material manuscrito y original del autor. Consta de 1 bloc de escritura musical, con el título Crits de Crist en el exterior. Páginas numeradas de la 1 a la 15. Existe partitura y partes instrumentales en formato impreso realizado con el sofware Sibelius.

- Partes: Existen partes en formato impreso.

- No consta relación de originales y copias. 
12.- CUINA, Libre, en Sol, Coro y Piano, con guion, 1995, Arc. 12.

La plantilla a la que está dedicada es la de un Coro mixto, y Piano.

Ver: CUINA CATALANA (sección obra banda).
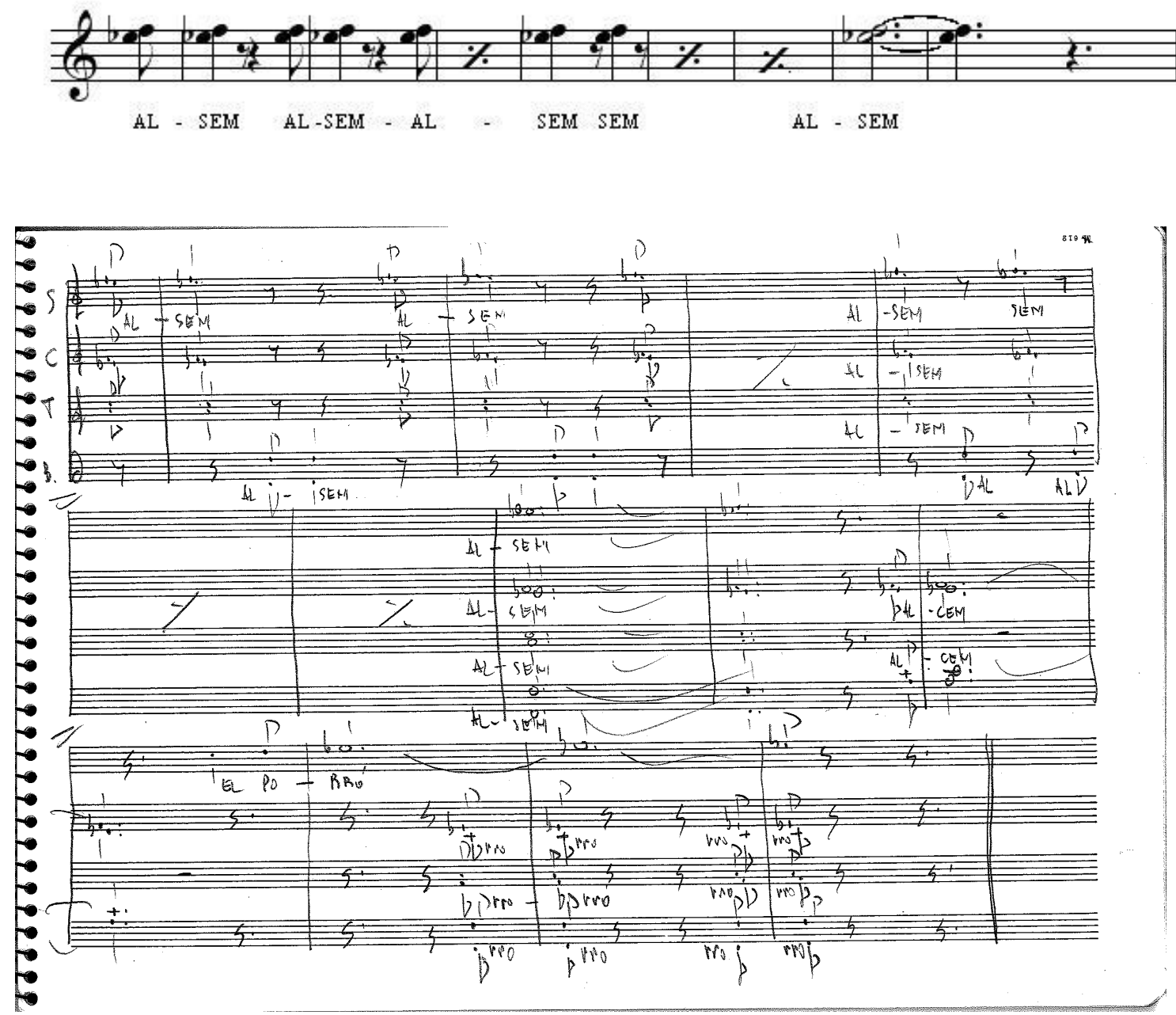

\section{MATERIAL TOTAL:}

- Material manuscrito del autor, original, en un bloc de escritura musical con los títulos Cuina y Reflex en la tapa. La obra Cuina ocupa 23 páginas y en ella se encuentran los apuntes de la obra Cuina catalana, incluida en el CD Himne, grabado por K-Industria Cultural, en 1995, a modo de guion, y la parte del coro, sin desarrollar. En el mismo bloc, por la parte posterior se encuentra la obra Reflex.

- Partes: No existen partes.

- No consta relación de originales y copias. 
13.- DOLÇAINERS CARNAVAL 2001, Libre, politonal, Dulzainas y Percusión, con guion, 2001, Arc. 25.

La plantilla a la que está dedicada es la de un grupo de Dulzainas y Percusión.
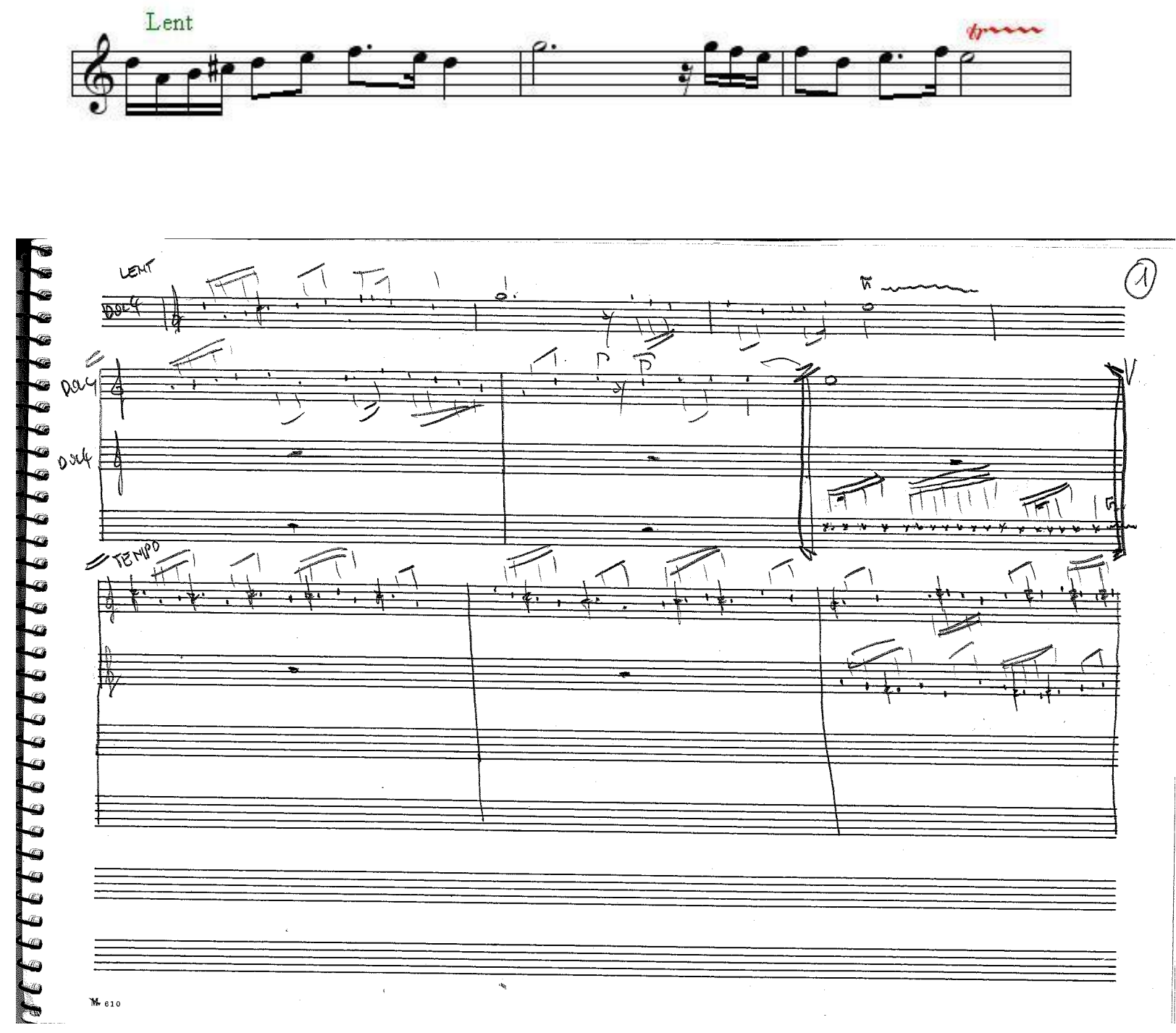

MATERIAL TOTAL:

- Partitura manuscrita y original del autor. Consta de un bloc de escritura musical con 6 páginas escritas y numeradas.

- Partes: No existen partes.

- No consta relación de originales y copias. 
14.- EL CANT DEL DUC, Libre, politonal, Soprano y Bajo solista, Coro de niños, Coro mixto y Banda, con partitura, 2010, Arc.27.

La plantilla a la que está dedicada es la de dos voces solistas (Soprano y Bajo), Coro de niños, Coro mixto y Banda.

Ver: GANDÍA (Sección Otras agrupaciones).

Compuesta para la conmemoración del 500 aniversario del nacimiento de Francesc de Borja i d'Aragó. Encargo del Ayuntamiento de Gandía y estrenada en la localidad. La obra se conoce bajo el nombre de El Cant del Duc aunque en los originales del autor consta el título Gandía. 
15.- FLAUTA, Libre, en Sol, Flauta, Soprano, Viento metal, Contrabajo, Percusión y Piano, con partitura y partes, 1982, Arc.25.

La plantilla a la que está dedicada es la de una flauta solista, una soprano solista, trompas, trombones, tuba, contrabajo, percusión y piano.
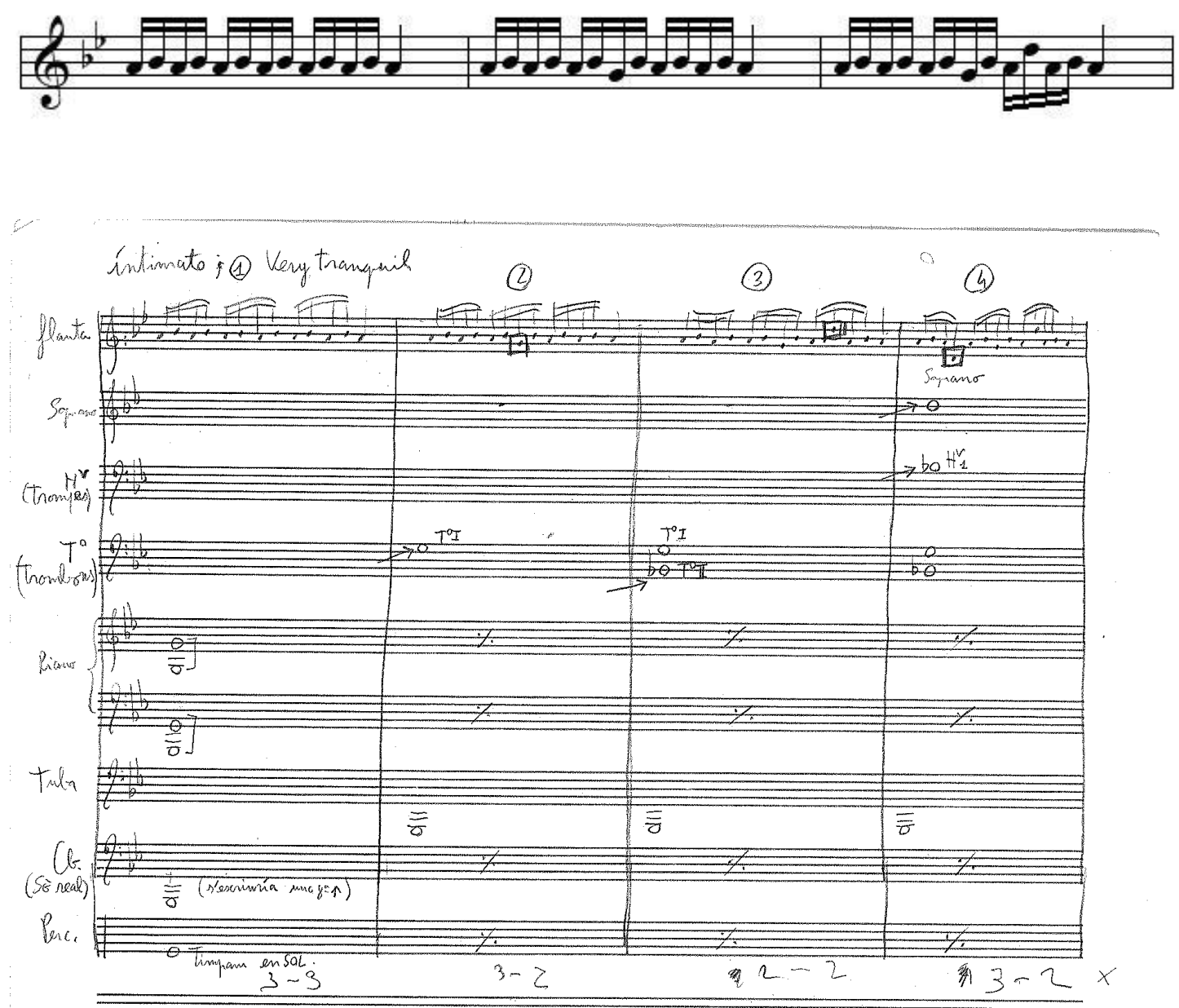

La partitura está numerada como 39 por el autor.

La melodía de la flauta es semejante a la de la obra 682-3133 Buffalo, Minnesota.

\section{MATERIAL TOTAL:}

- Partitura manuscrita y original del autor. Consta de un libreto de escritura musical con 2 páginas escritas con el título "Flauta (1982?)", y las anotaciones "Partitura per a flauta solista", "Música de la discografia d'un soci de l'A. A. G. 1986" y el número 39 encercado, en la $1^{\text {a }}$ página.

- Partes: Existen partes de todos los instrumentos, excepto de la flauta.

- No consta relación de originales y copias. 
16.- FOC AL CANTIR, Libre, politonal, voz, orquesta y percusión, con partitura, 2000, Arc. 15 .

La plantilla a la que está dedicada es la de una voz solista, orquesta y percusión.

Ver: BROSSA (Sección Otras agrupaciones)
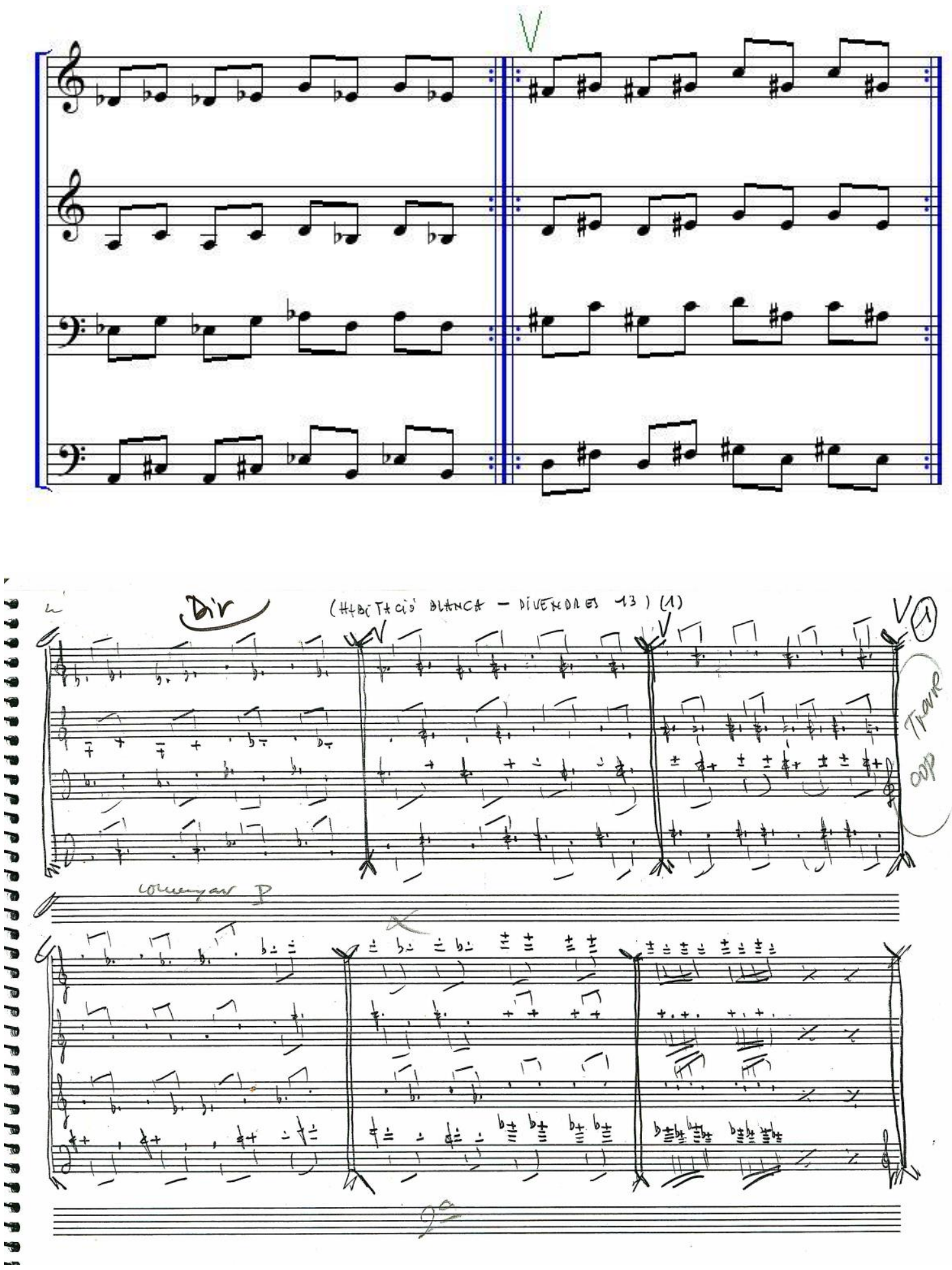
En la carpeta consta el material de Brossa, fotocopiado, aunque se ha modificado la clave del tenor a clave de fa. Parece anterior a la música de Brossa ya que en el material de Brossa se observa que se modificó la clave y la posición de las notas a clave de Do en $3^{\mathrm{a}}$.

\section{MATERIAL TOTAL:}

- Partitura de la obra: Partitura manuscrita y fotocopiada del autor. Consta de 1 hojas escrita y suelta, numerada, aunque no se observa el número.

- Partes: No existen partes.

- No consta relación de originales y copias.

Material incompleto. 
17.- GANDÍA, Libre, politonal, Soprano y Bajo solista, Coro de niños, Coro mixto y Banda, con partitura, 2010, Arc.27.

La plantilla a la que está dedicada es la de dos voces solistas (Soprano y Bajo), Coro de niños, Coro mixto y Banda.

Ver: EL CANT DEL DUC (Sección Otras agrupaciones)
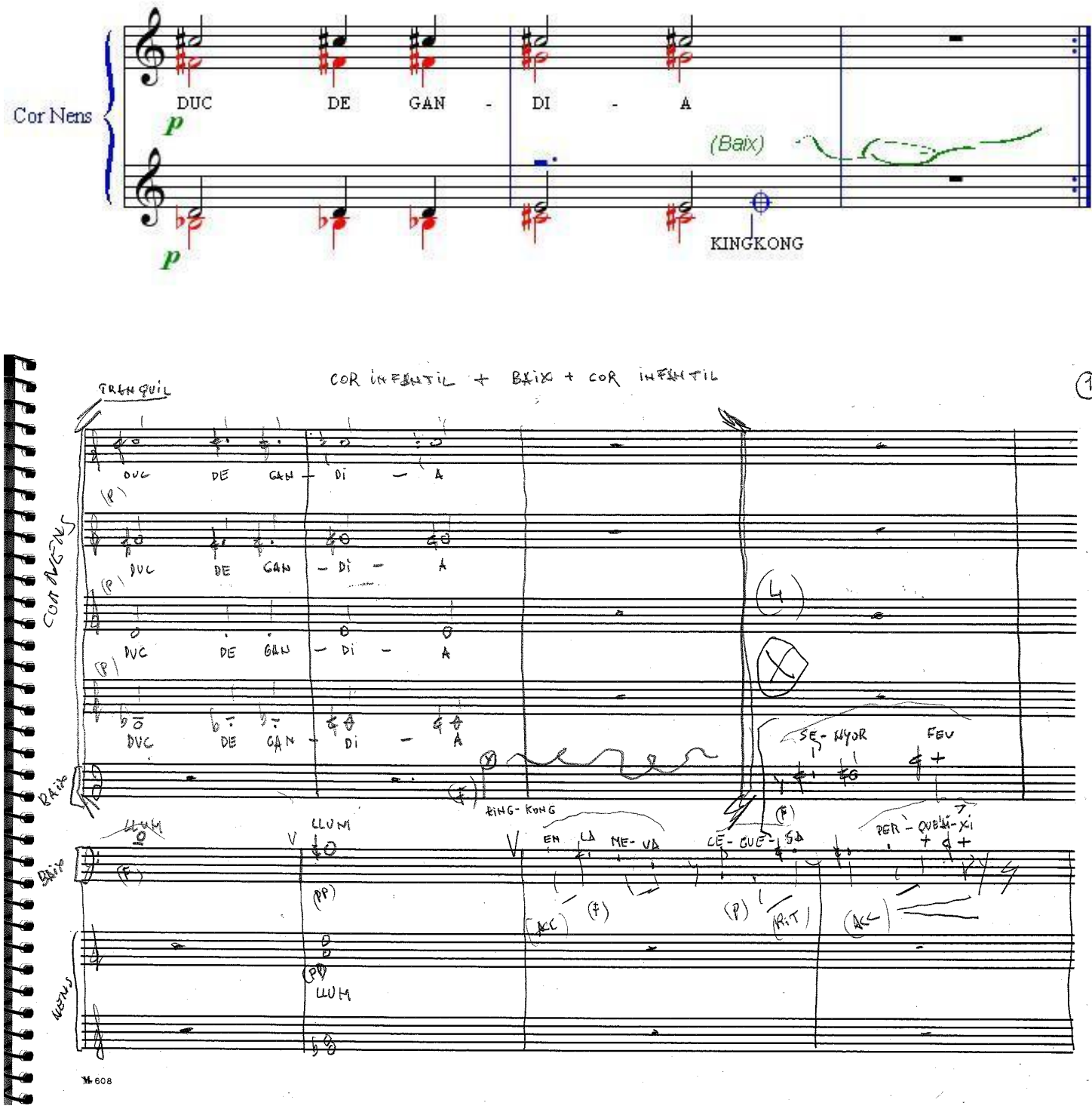

Compuesta para la conmemoración del 500 aniversario del nacimiento de Francesc de Borja i d'Aragó. Encargo del Ayuntamiento de Gandía y estrenada en la localidad. La obra se conoce bajo el nombre de El Cant del Duc. 


\section{MATERIAL TOTAL:}

- Partitura manuscrita y original del autor. Consta de 5 blocs de escritura musical, con los siguientes títulos:

- A.- Gandía (1) en el exterior (inicio de la obra) con 29 páginas numeradas y manuscritas (de la 1 a la 29 );

- B.- Gandía (2) en el exterior con 24 páginas numeradas y manuscritas (de la 1 a la 24);

- C.- Gandía (3) + “(4) Final" en el exterior con 9 páginas numeradas (de la 1 a la 9 ) y manuscritas con el título G-3 a las que siguen 20 páginas numeradas y manuscritas (de la 1 a la 20 ) con el título G-4;

- D.- Gandía (4) en el exterior con 30 páginas numeradas y manuscritas (de la 21 a la 50);

- E.- Gandía (5) en el exterior con 26 páginas numeradas y manuscritas (de la 51 a la 76). Partitura impresa. Consta de una partitura de 102 páginas.

- Partes: No existen partes.

- No consta relación de originales y copias. 
18.- HAMLET, Libre, politonal, metal, voces y percusión, con partitura y algunas partes, 1999, Arc.10.

La plantilla a la que está dedicada es la de voces, metales y percusión sinfónica.
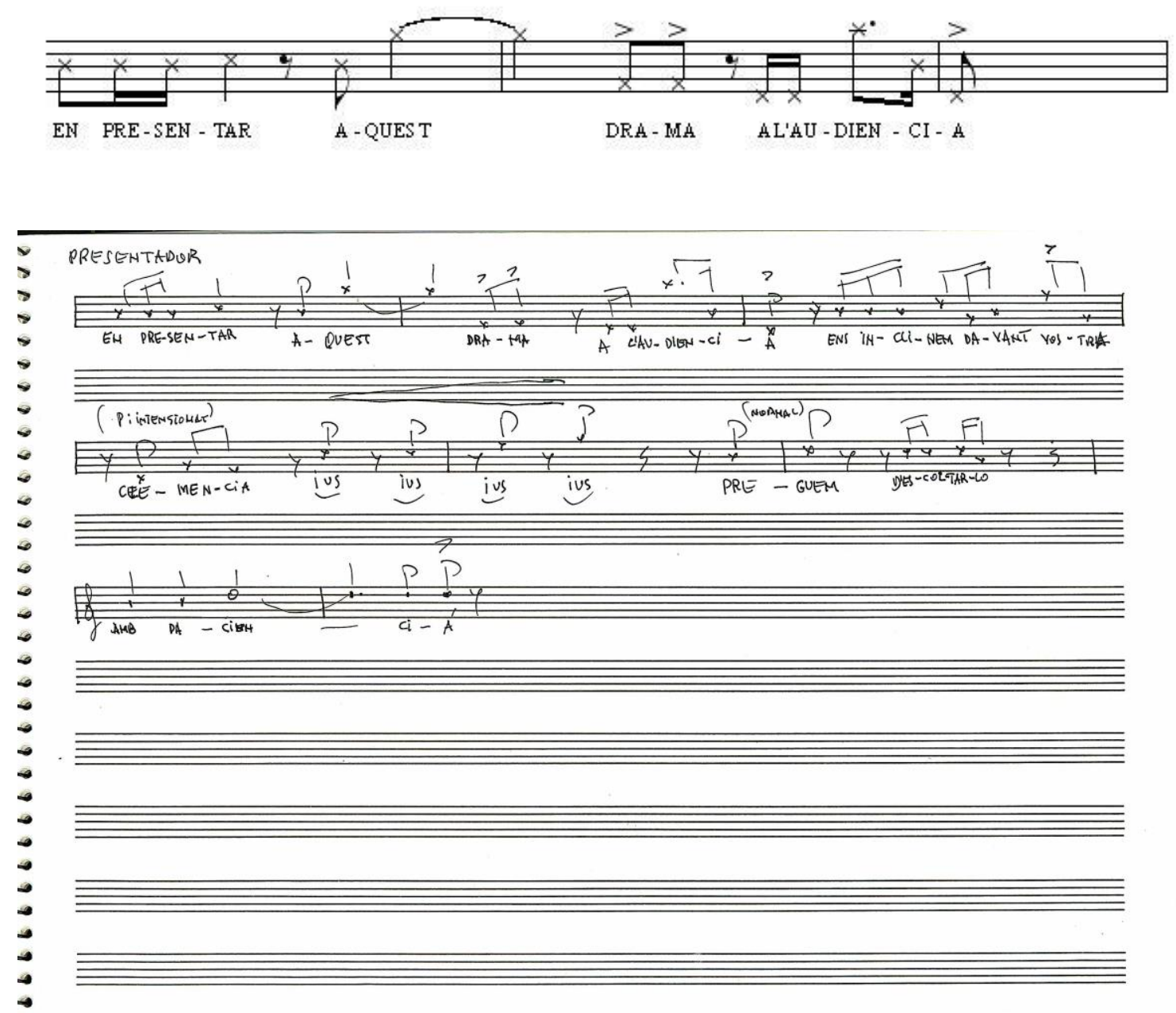

Estrenada el 27 de julio de 1999 en el Teatre Grec en Barcelona.

\section{MATERIAL TOTAL:}

- Partitura de la obra: Material manuscrito del autor, original, en 1 bloc de escritura musical, con título en el exterior, escrito en sentido inverso. Consta de fragmentos musicales a interpretar en momentos concretos y de una duración determinada, algunos cronometrados. Asimismo existe un libreto de 3 páginas con el texto y algunas anotaciones de medida. 
- Partes: Existen partes de trompas en otro bloc de escritura musical manuscrito y original del autor. No existen más partes. Existe una copia de cada uno de los dos materiales.

- No consta relación de originales y copias.

Obra, al parecer, para la ambientación musical del drama griego. 
19.- JJ. OO. BARCELONA 92', Libre, politonal, varias agrupaciones, con guion y partitura, 1992. G 8 .

La plantilla a la que está dedicada es variada, constando las algunas piezas de plantillas al uso, en sus respectivas secciones.

Ver: MEDALLES (FANFARRIA) (Sección Fanfarria), INAUGURACIÓ y MEDALLES (PROMENADE) (Sección Orquesta) y PROMENADE (Sección Banda)
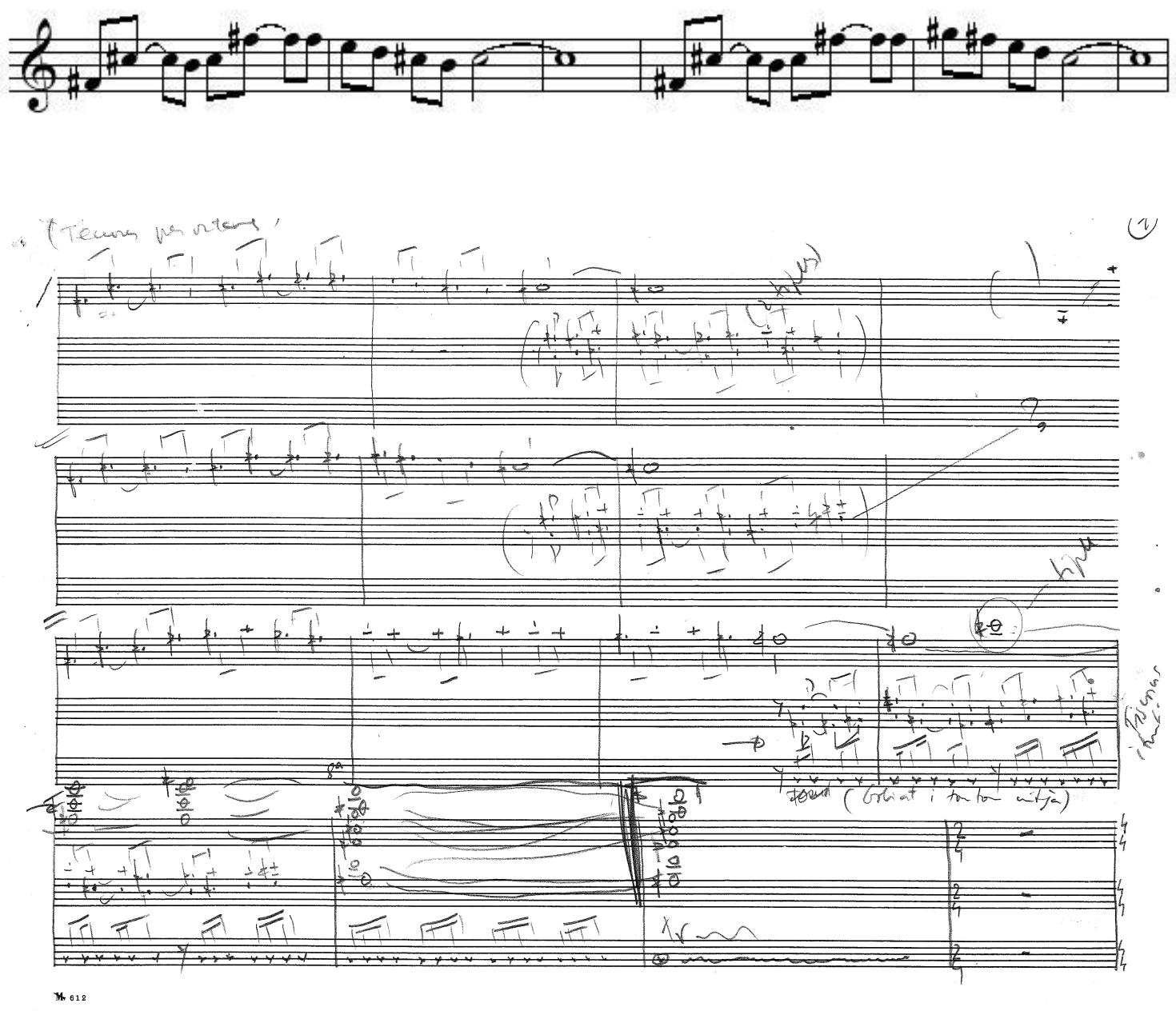

Música compuesta para los Juegos Olímpicos celebrados en Barcelona en 1992.

Existe un CD con toda la música de los Juegos, bajo el título Música para las Ceremonias Olímpicas Barcelona '92, grabado por On the Rocks en 1992. El mismo contiene la música compuesta por Santos para la Expo de Sevilla '92. 
Del material expuesto a continuación, solamente una parte ha sido catalogado tal y como consta en el CD. El resto no ha sido encontrado. Puestos en contacto con el Comité Olímpico Español, con la finalidad de encontrar dicho material, hasta el momento no se ha recibido contestación por parte del mismo.

\section{MATERIAL TOTAL:}

El material es muy diverso. Aquel que está perfectamente analizado se encuentra catalogado en sus respectivas secciones. El resto, que se corresponden a apuntes del autor sin instrumentar, es el que pasamos a desarrollar.

- Guion compuesto por 16 hojas sueltas con apuntes manuscritos y originales del autor. De este material se extraen las siguientes piezas:

○ La totalidad se corresponde a la pista 1, "Obertura Hola” del disco.

○ Las páginas 2 y 3 se corresponde a la pista 11, "Fanfarra Marató", del disco.

○ Las páginas 1 a 4 se corresponde a la pista 12, "Fanfarra Clausura", del disco.

- Un bloc con apuntes de la música y un cuaderno con dos facsímiles.

- Guion manuscrito del autor, original, en 19 hojas sueltas grapadas. Forma parte de la música utilizada en varias ceremonias de los Juegos. Algunas de estas hojas son fotocopiadas aunque las originales (4 páginas), se encuentran junto al planning escrito de la ceremonia y un pequeño guion de piano con el título "Obertura" en la tapa. Existen partes de los instrumentos utilizados. De este material se extraen las siguientes piezas:

- La página 8 se corresponde a la pista 3, "Fanfarra Atletes", del disco.

○ Las páginas 9 y 10 se corresponden a la pista 8, "Fanfarra Montjuic", del disco.

○ La página 12 se corresponde a la pista 10, "Fanfarra del Rei”, del disco.

○ La página 13 se corresponde a la pista 7, "Fanfarra Jurament", del disco.

○ La página 13 se corresponde a la pista 9, "Fanfarra Torxa”, del disco.

○ La página 14 se corresponde a la pista 5, "Fanfarra Medieval”, del disco.

○ Las páginas 15 y 16 se corresponden a las pistas 4 y 6, "Fanfarra Maragall" y "Fanfarra Coob", del disco. 
- 4 partituras (2 encuadernadas) que contienen la música de la inauguración de los JJ. OO. De Barcelona 92'. Existe el original en Grande 2.

- 2 partituras iguales, fotocopiadas y manuscritas del autor, que parecen apuntes del material musical utilizado posteriormente. Pueden contener las partes de piano.

- Asimismo existe una partitura incompleta (pág. 20 a 45) manuscrita del autor y original, con desarrollo orquestal de la expuesta anteriormente.

- Partitura de la obra: Partitura manuscrita y fotocopiada del autor. Consta de 6 hojas escritas, sueltas y numeradas. Existe un segundo material con las 4 primeras hojas.

- 1 partitura que contiene la Obertura, la Clausura y a continuación "Desfilada atletes" (B) + "Baixada Samaranch" (C + "Baixada Naraga", cada una con diferentes instrumentaciones pero siempre dentro de la plantilla de la fanfarria.

- El material que consta en las siguientes obras también forma parte de la música de los JJ. OO.
○ MEDALLES (FANFARRIA) (Sección Fanfarria)
○ MEDALLES (PROMENADE) (Sección Orquesta)
○ PROMENADE (Sección Banda)
- COMEDIANS (Sección Banda)
○ INAUGURACIÓ (Sección Orquesta)

- Partes: Existen partes de algunos materiales.

- No consta relación de originales y copias. 
20.- KATRALLA, Libre, politonal, violín, piano, clarinete y voz (mezzo-soprano), con partitura, 2004?. Arc.16.

La plantilla a la que está dedicada es la de una mezzo-soprano, un violín, un clarinete y un piano.
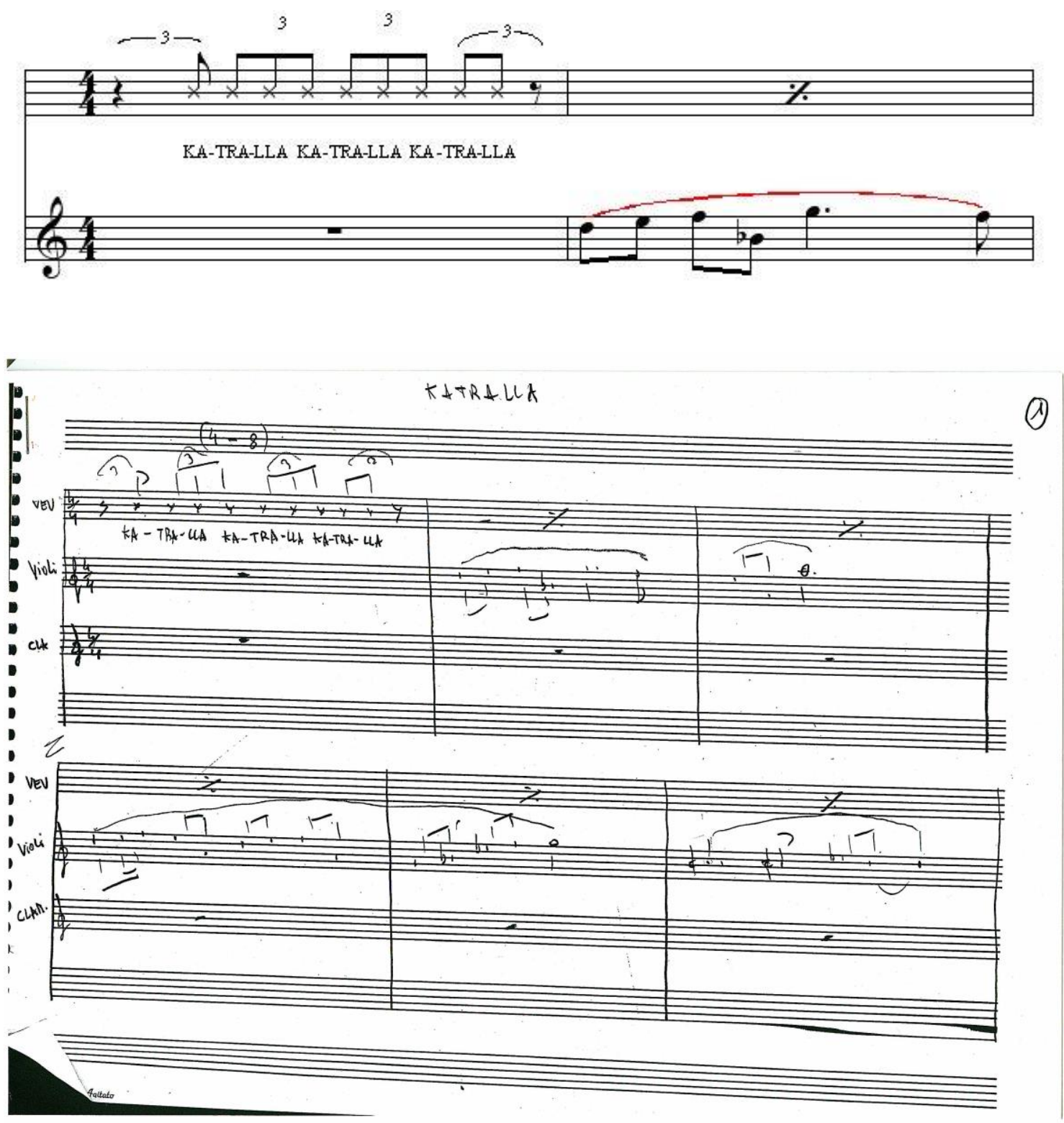

El original consta en el bloc con título Pentagrama o Esperma?. 


\section{MATERIAL TOTAL:}

- Partitura de la obra: Partitura manuscrita y fotocopiada del autor. Consta de 6 hojas escritas, sueltas y numeradas. Existe un segundo material con las 4 primeras hojas.

- Partes: No existen partes.

- No consta relación de originales y copias. 
20.- LIRIA (BEETWEEN, LIRIA I LA BISBAL), Libre, Sol m, Metal, Percusión, Flauta, Contrabajo y Piano, con partitura, s. d. Arc. 25.

La plantilla a la que está dedicada es un grupo de Metal, Percusión, Flauta, Contrabajo y Piano.
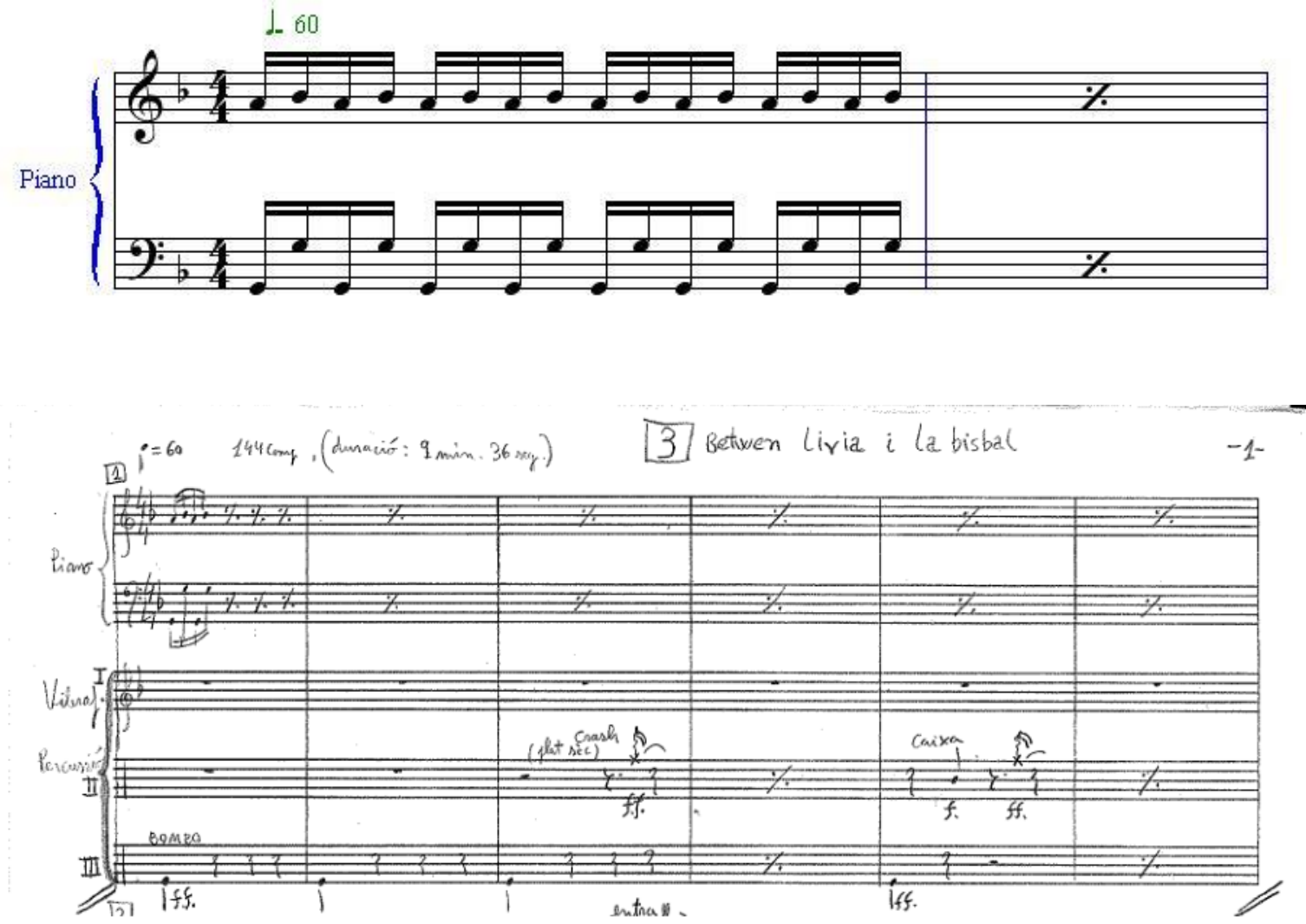

La obra tiene una estructura en forma de espejo.

\section{MATERIAL TOTAL:}

- Partitura manuscrita y original del autor. Consta de un libreto de 18 páginas numeradas de escritura musical. En la tapa constan los títulos Beetween, Liria I La Bisbal i Liria. En la $1^{\circ}$ página constan indicaciones de duración (9 m. 36") e interpretación (obra dividida en 3 partes a lo largo de la partitura).

- Partes: No existen partes.

- No consta relación de originales y copias. 
21.- LLUÏS-ANAÏS, Libre, politonal, Voz y Clarinete, con guion, s. d. Arc.28.

La plantilla a la que está dedicada es la de una Voz (sin determinar) y Clarinete.

Ver: PENTAGRAMA O ESPERMA (Obra voz y piano)

(4)

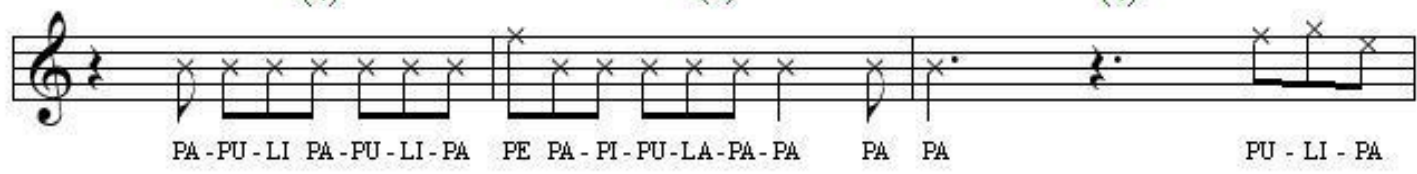

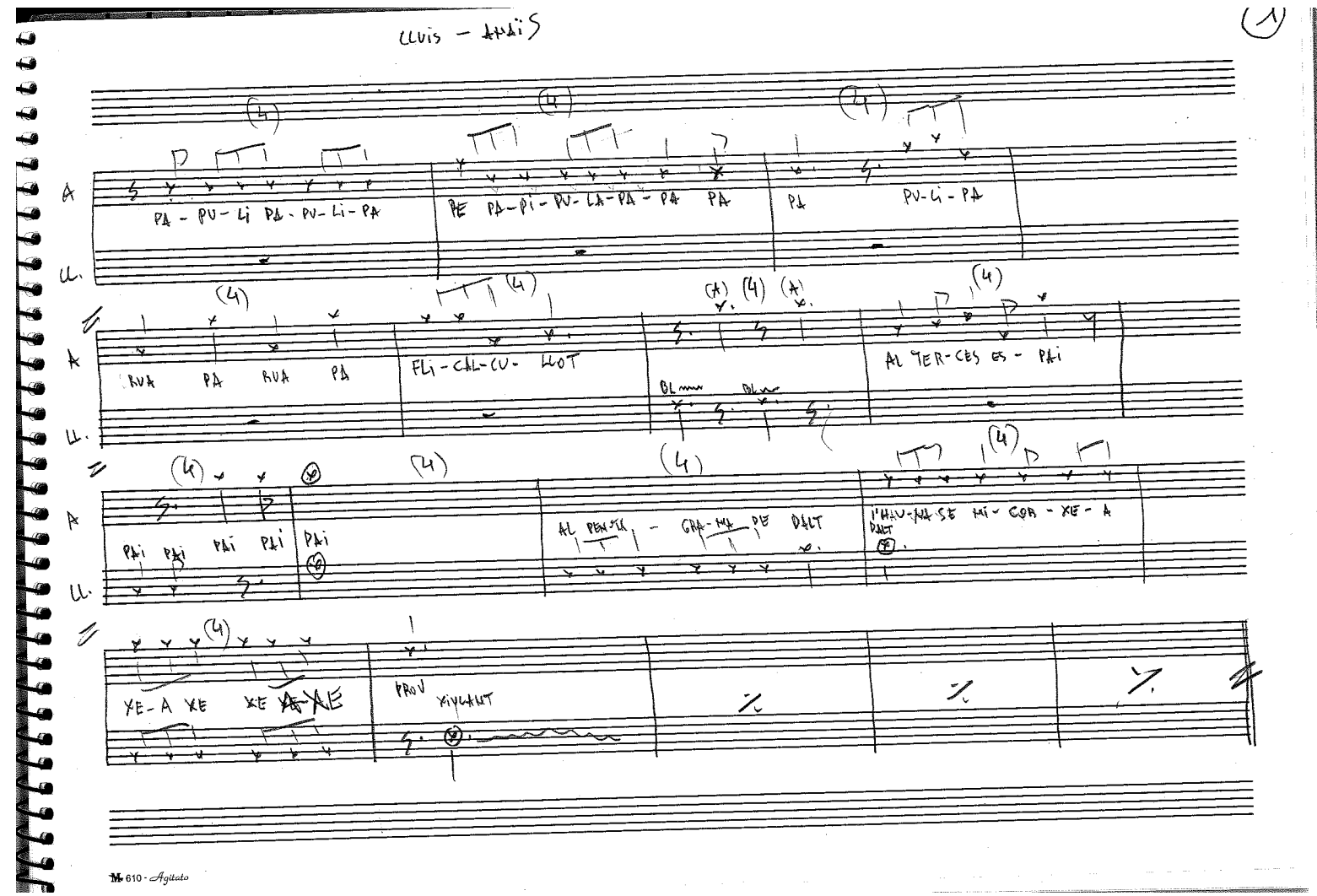

Puede tratarse de un fragmento de la obra escénica Pentagrama o Esperma?.

\section{MATERIAL TOTAL:}

- Partitura manuscrita y original del autor. Se encuentra en el bloc de escritura musical titulado Pentagrama o Esperma?. Consta de 4 páginas escritas y numeradas, llevando el título de "Lluis-Anaïs" al principio.

- Partes: No existen partes.

- No consta relación de originales y copias. 
22.- LLUR METALS, Libre, politonal, cuarteto (sin determinar), con guion y partitura, s. d. Arc.30.

La plantilla a la que está dedicada es la de un cuarteto (sin determinar).

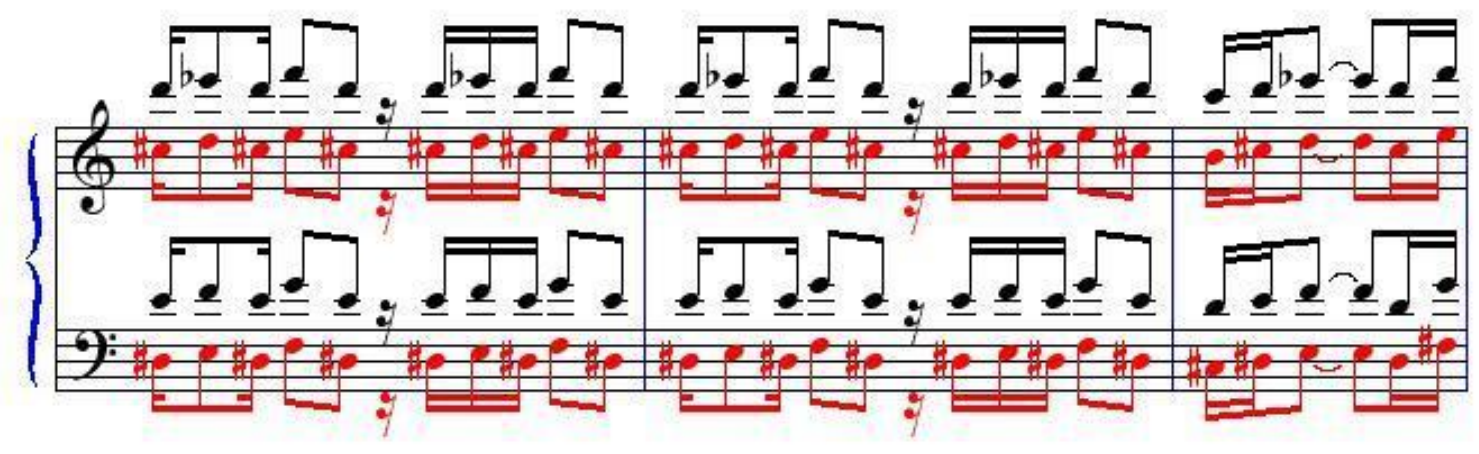

5
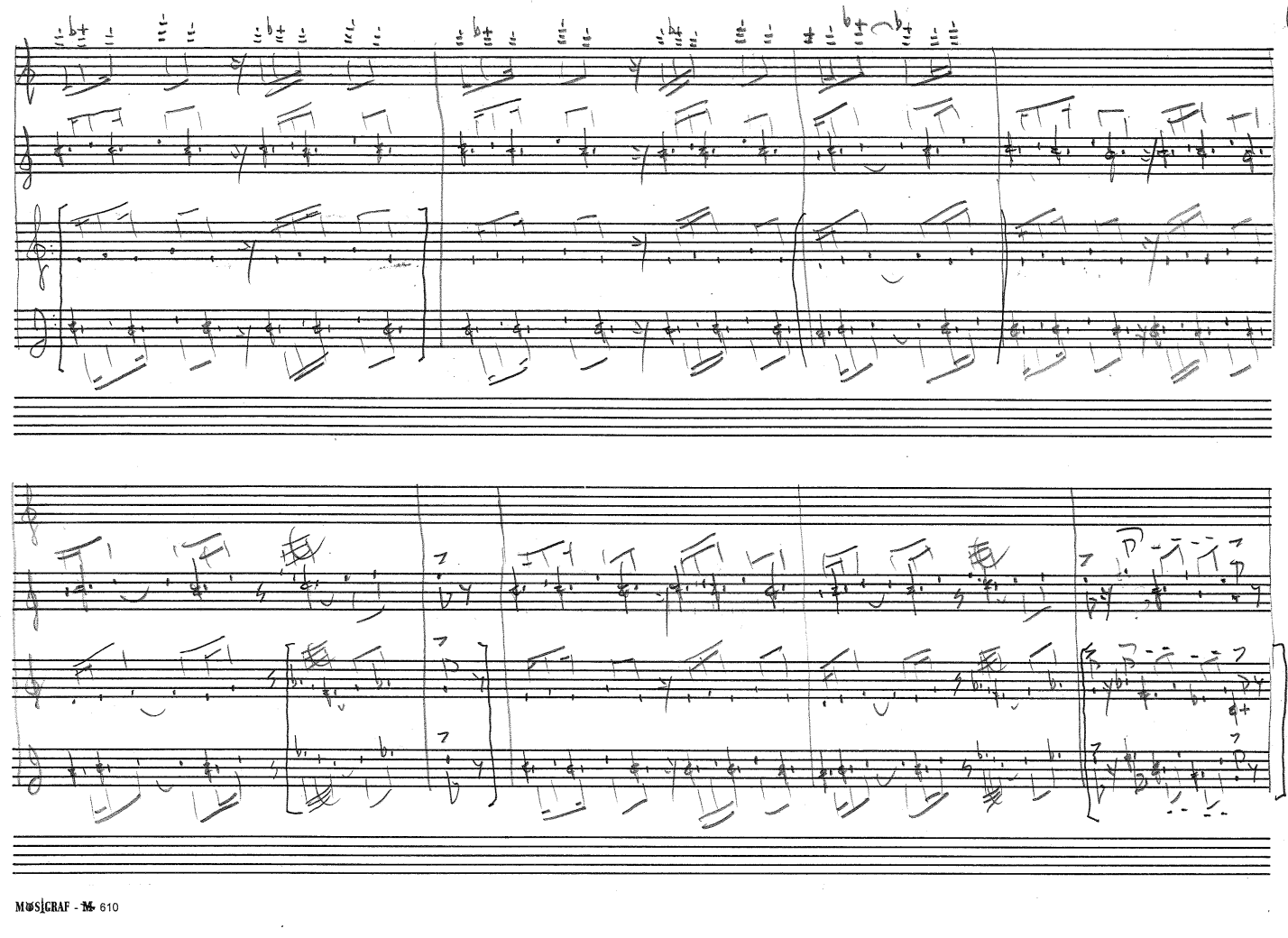


\section{MATERIAL TOTAL:}

- Partitura manuscrita y original del autor. Consta de un bloc de escritura musical, con el título Llur Metals y el título tachado Kronos en el exterior y 12 páginas manuscritas y originales, numeradas. La voz superior está incompleta. Existen 4 páginas sueltas que son apuntes de esta obra.

- Partes: No existen partes.

- No consta relación de originales y copias. 
23.- MAQUINOFOBIA PIANOLERA, Libre, politonal, Piano e Instrumento mecánico, con guion, 2011. Arc.28.

La plantilla a la que está dedicada es la de un piano y un instrumento mecánico.
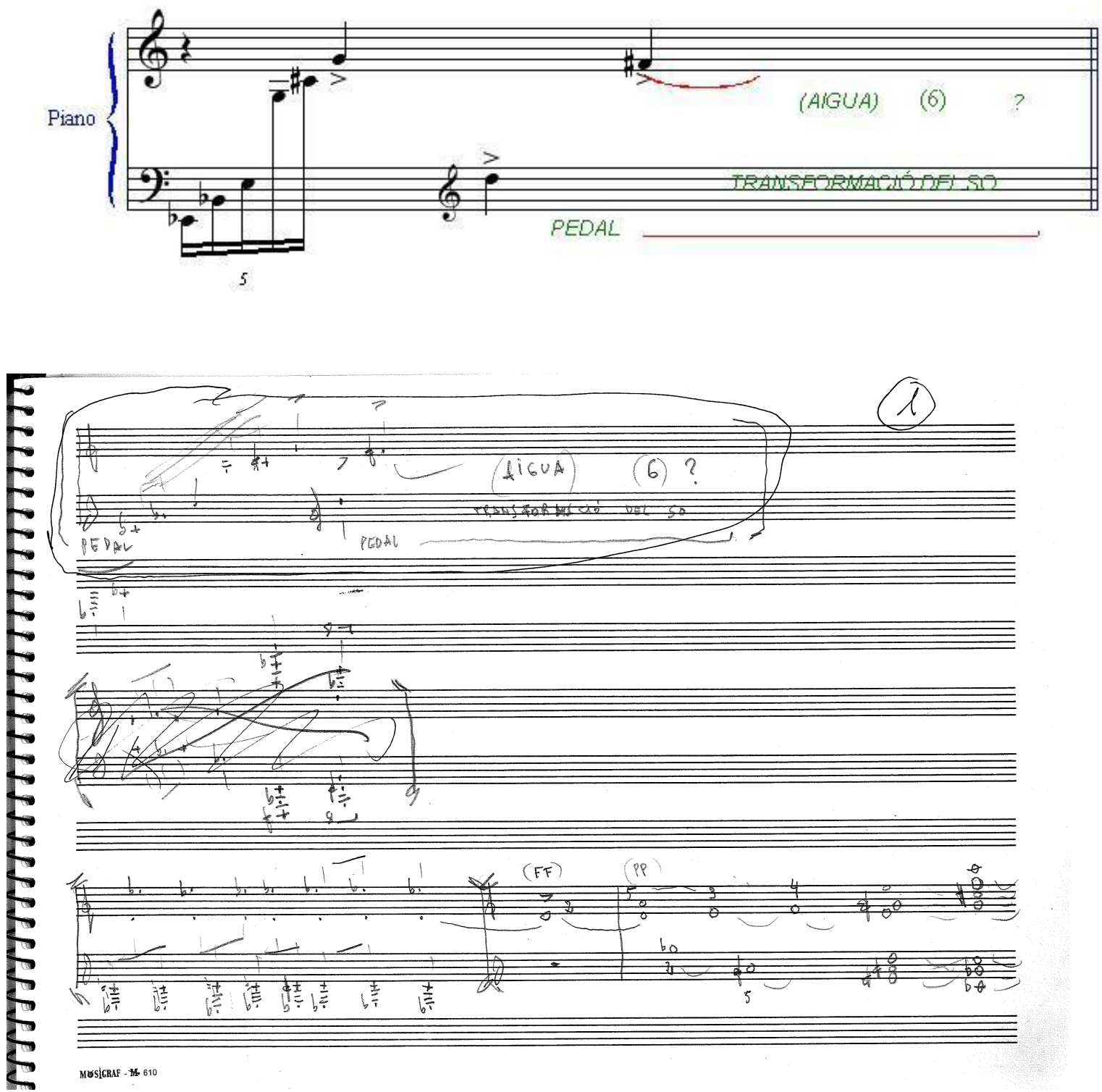

Compuesta para la Acción musical estrenada en Barcelona el 23 de julio de 2011, junto al Grupo Cabo San Roque, dentro del Festival de Verano de Sant Feliu de Guíxols. 


\section{MATERIAL TOTAL:}

- Partitura manuscrita y original del autor. Consta de 3 blocs de escritura musical, con los siguientes títulos:

○ "Cabo (1)" en el exterior (inicio de la obra) con 31 páginas manuscritas. Asimismo, existen 2 obras más en este bloc:

- la $1^{\mathrm{a}}$ consta de 3 páginas manuscritas, para 4 voces, con el texto BO-NA-BA en la $1^{\mathrm{a}}$ al inicio de la obra.

- La $2^{\mathrm{a}}$, escrita en el reverso del bloc, es el manuscrito de la obra Morellar Morella (Desfile), $\mathrm{n}^{\mathrm{o}}$ de orden 62, escrita para coro y que consta de 3 páginas manuscritas;

○ "Cabo (2)" en el exterior con 13 páginas numeradas y manuscritas. La 4 primeras páginas no forman parte de la obra ;

○ "Cabo (3)" en el exterior con 3 páginas numeradas y manuscritas.

- Partes: No existen partes.

- No consta relación de originales y copias. 
24.- MATAR-HO, Libre, politonal, diversas, con guion y partitura, 1987. Arc.25.

La plantilla a la que está dedicada es diversa.

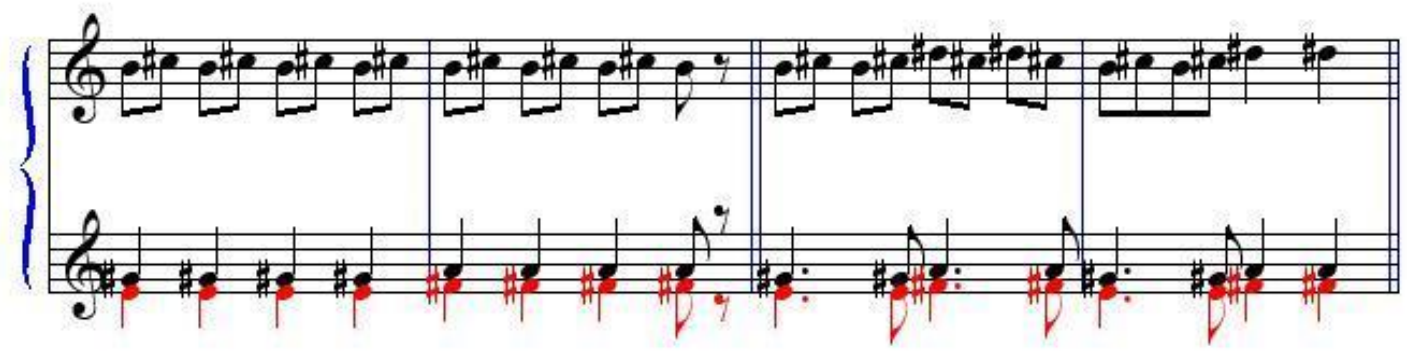

particle Wotor-to
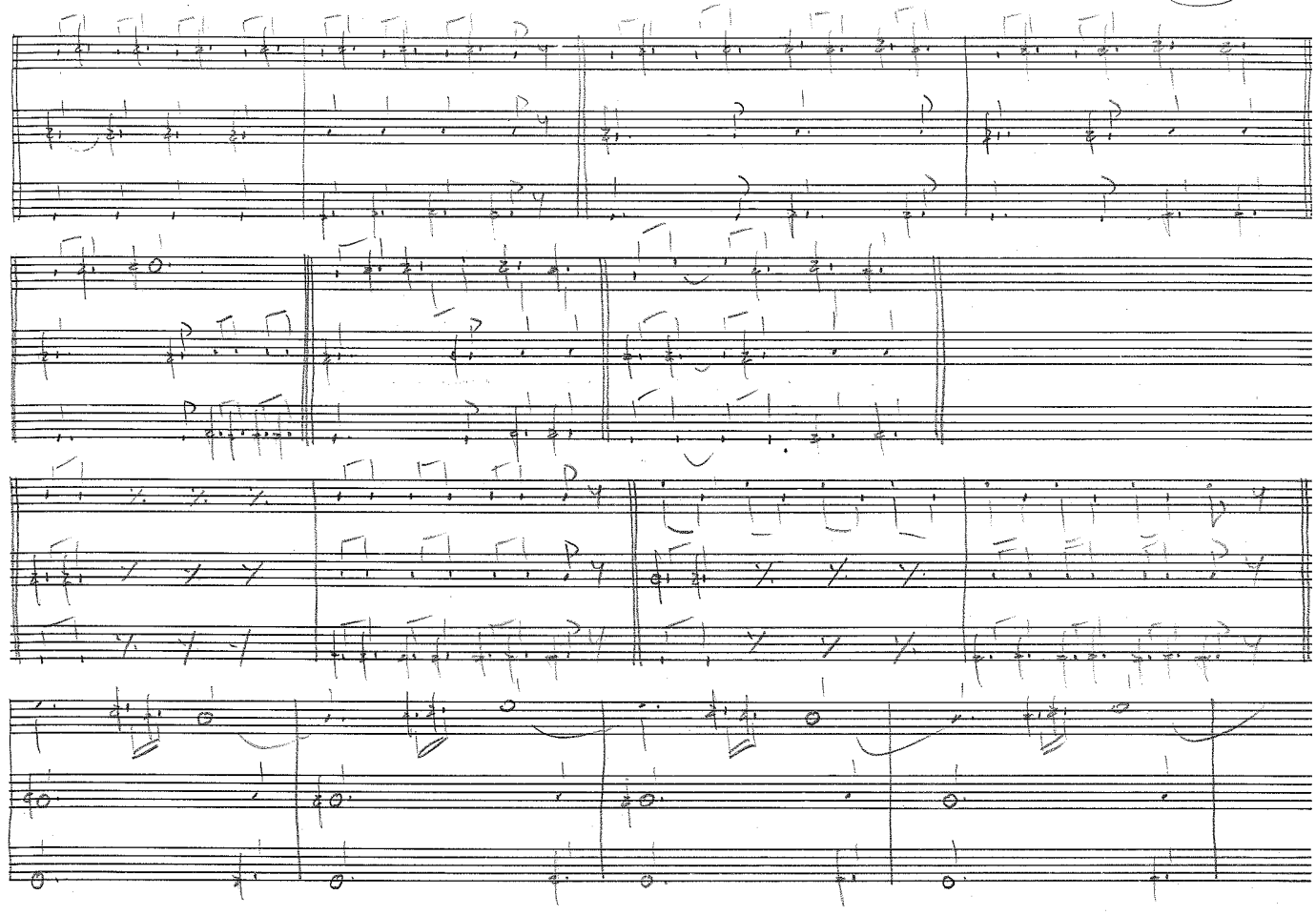

Las partituras están numeradas como 19 por el autor. 


\section{MATERIAL TOTAL:}

- El material existente es muy variado y en algunas ocasiones existen coincidencias entre partituras y partes de otras.

- A.- Partitura manuscrita y original del autor (más 3 fotocopias) que consta de un libreto de escritura musical apaisado con 3 páginas escritas con el título "Particel·les Matar-ho" y el número 19 encercado.

- B.- Otra partitura manuscrita y original del autor, que consta de 4 libretos de escritura musical apaisados con 8 páginas escritas (de 1 a 4bis) con el título "Matar-ho! 1987", la anotación "Tres veus", y el número 8 encercado. Las 4 últimas páginas coinciden con la partitura $\mathrm{A}$.

- C.- Partitura manuscrita y fotocopiada del autor (4 copias), que consta de 2 páginas de escritura musical con el título "Matar-ho! FRAGMENT", la anotación "Versió quartet de corda", y el número 17 encercado. No existe coincidencia con la música escrita en esta partitura con otras aquí expuestas.

- D.-Partitura manuscrita y original del autor (más 3 fotocopias), que consta de 1 libreto de escritura musical apaisado con 2 páginas escritas con el título "Particel·les Matar-ho" y el número 19 encercado.

- E.- Partitura manuscrita y original del autor (mas 3 fotocopias), que consta de 1 libreto de escritura musical con 2 páginas escritas con el título "Particel·les Matar-ho".

- F.- Partitura manuscrita y original del autor (mas 3 fotocopias), que consta de 2 libretos de escritura musical con 3 páginas escritas con el título " Matar-ho. Versió Trio de Corda" y el número 19 encercado.

- Partes: No existen partes.

- No consta relación de originales y copias. 
25.- MIRAME, Libre, politonal, Piano, voz y 1 instrumento, con guion, s. d., Arc. 22.

La plantilla a la que está dedicada es la de un Piano, voz (sin determinar) y 1 instrumento (sin determinar).
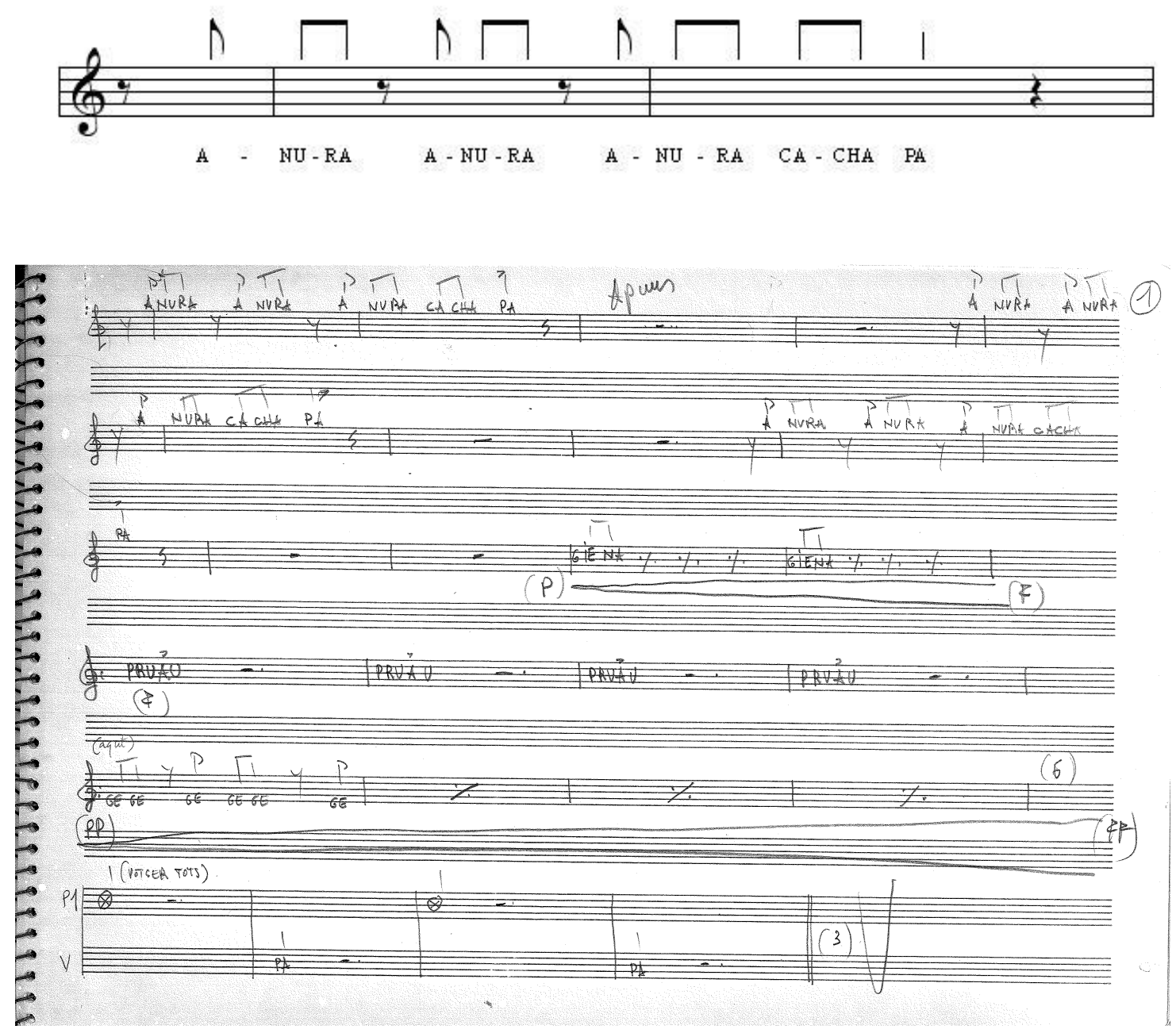

MATERIAL TOTAL:

- Partitura manuscrita y original del autor. Consta de un bloc de escritura musical con 3 páginas escritas y numeradas, en el que consta el título Mirame y el número 6 encercado. Asimismo existe un facsímil de papel pautado con el título "fragment Mirame " y el número 6 encercado en la $1^{\mathrm{a}}$ página. En el reverso del bloc anterior existen 13 páginas escritas y numeradas, originales, que son de la misma obra puesto que el texto "ANURA" coincide en ambas partes del bloc.

- Partes: No existen partes.

- No consta relación de originales y copias. 
26.- MIRÓ '93, Libre, politonal, metal, cuerda, percusión, voz y piano, con partitura, guion y partes, 1993, G. 8 .

La plantilla a la que está dedicada es la siguiente: Trompetas, Trompas, Trombones, Tuba (I y II), Percusión, Voz, Violines (solista, I y II), Violoncelo y Piano.

Ver: PROMENADE CONCERT (Sección Otras agrupaciones)
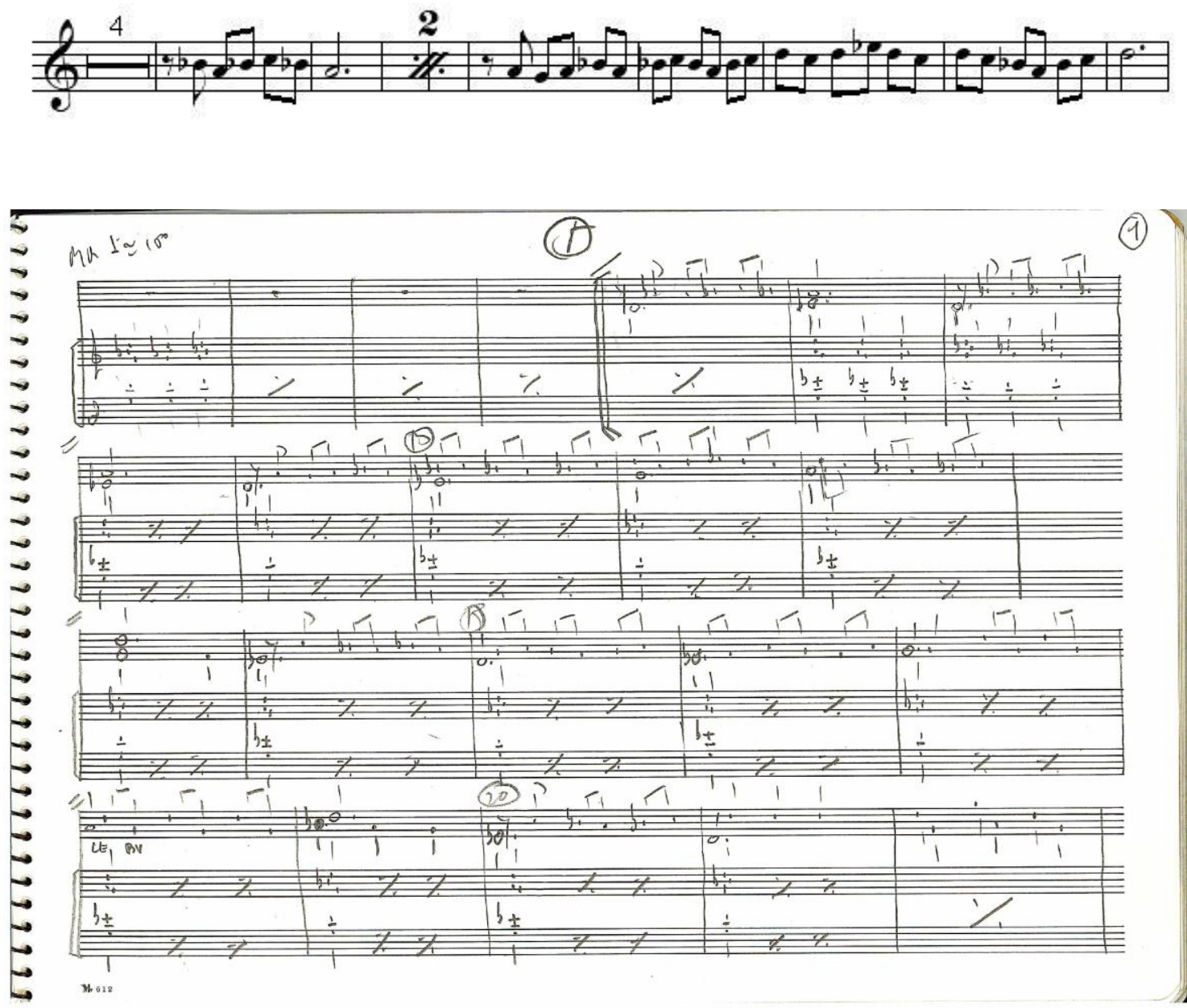

Estructura: del inicio al c. 198, repitiendo 3 veces. La tercera vez que se va D.C. finaliza en el FIN del c. 172, siguiendo en el Moderato 4/4 (solo de Trompa) y de aquí se enlaza con "Portaferrissa". Al finalizar, D.C. al inicio de la obra hasta la señal W (c. 198).

Se trata del material utilizado en el espectáculo Promenade Concert, estrenado en la Fundación Miró en 1993 y del que existe material grabado en directo, en un CD del mismo título. 


\section{MATERIAL TOTAL:}

- Partitura de la obra: Guion manuscrito y original del autor en un bloc de escritura musical con el título Miró en el exterior y 36 páginas manuscritas y originales, numeradas las 9 primeras y el resto sin numerar. Existe otro guion que consta de 6 hojas sueltas y numeradas. En el reverso de las 3 últimas existen fragmentos de partes instrumentales de cuerda. Asimismo existen 3 hojas sueltas y numeradas que pertenecen a este material. Partitura manuscrita y fotocopiada del autor (2 materiales grapados).

- Partes: Partes manuscritas y originales de copista (desconocido). Sobrantes fotocopiados. Existe parte de Piano del último fragmento ("Final"), manuscrita y original, aunque no del autor. La parte de Piano se encuentra aparte.

- Consta relación de originales aunque incompleto. Faltan las partes de la Voz y de Trompas. 
27.- NOVELA, Libre, politonal, orquesta reducida, percusión, voz y piano, con guion, s. d., Arc.15.

La plantilla a la que está dedicada es la de una orquesta reducida y Piano. Los instrumentos que constan son: voz (soprano), 4 Violines, Cellos, Trompetas, Trompas, Tuba, Percusión y Piano.

\section{Ver: CASTELLÓ '99 y PORTABELLA}
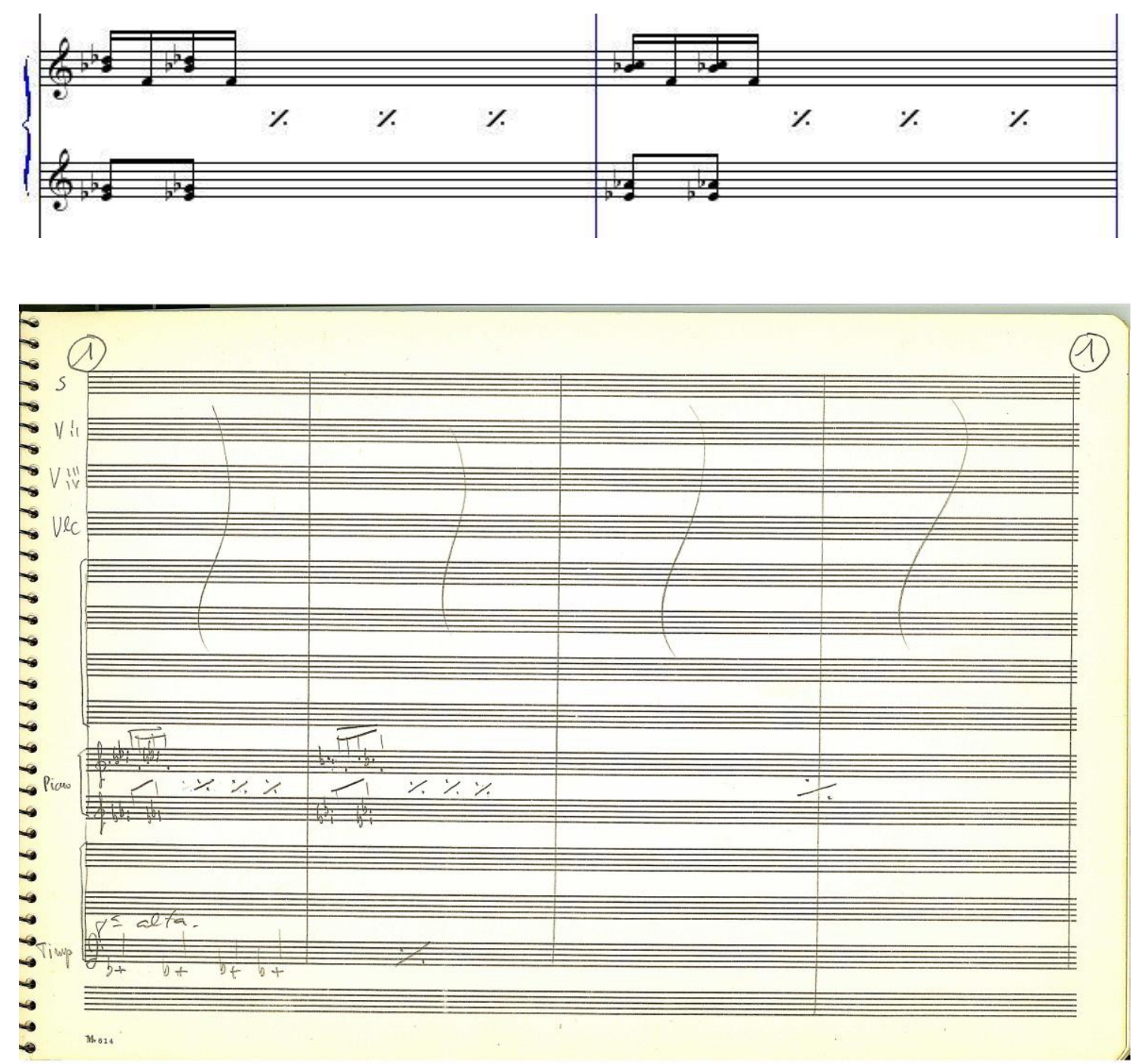

Al parecer, música escrita para la ambientación musical de alguna novela. 


\section{MATERIAL TOTAL:}

- Partitura de la obra: Manuscrito original del autor en cuatro blocs de escritura musical, numerados en el exterior y numeradas sus páginas de la 1 a la 97 (1 a 38, 39 a 78, 79 a 92 y 93 a97).

- Partes: No existen partes.

- No consta relación de originales y copias. 
28.- OLVIDO, Libre, Politonal, violín, piano, bombo y voz, con partitura, s. d., Arc.18.

La plantilla a la que está dedicada es la de Violín, Piano, Bombo y algunas intervenciones de la voz, sin determinar su tipo.

Ver: RONI (Obra escénica)
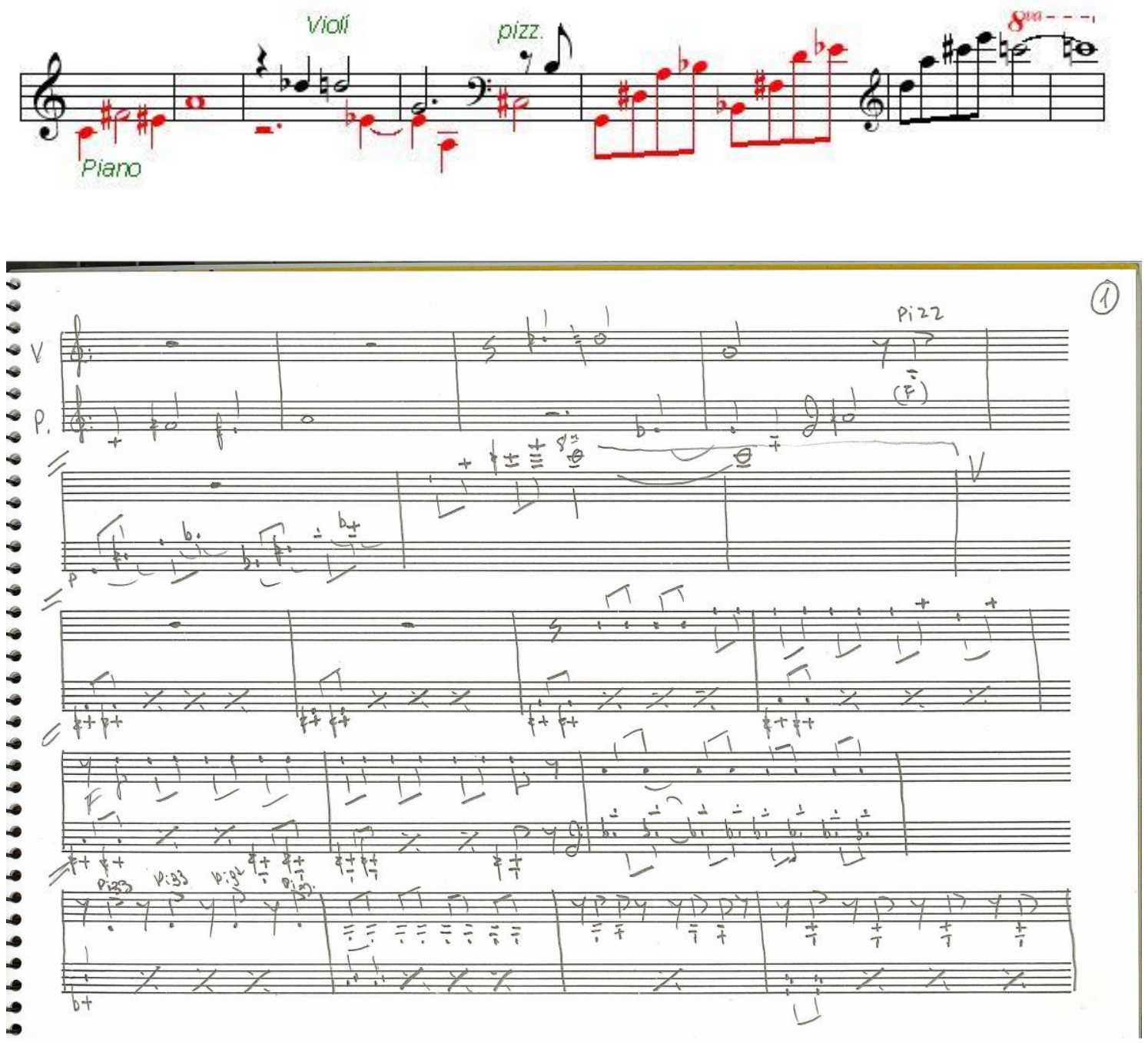

Escrita para la violinista Olvido Lánza.

\section{MATERIAL TOTAL:}

- Partitura manuscrita y original del autor. Consta de 1 bloc de escritura musical, con el título Olvido en el exterior con 18 páginas numeradas y manuscritas y un 
cuaderno manuscrito de 6 páginas que contiene música para violín. En el nombre del pentagrama consta "Olvido". La música es igual a la de la obra Roni. Da la sensación de estar inconclusa.

- Partes: No existen.

- No consta relación de originales y copias. 
29.- ONA, Concierto Clarinete, Politonal, Clarinete solista, Piano y Percusión, con guion, 2006, Arc.24.

La plantilla a la que está dedicada es la de un Clarinete solista, Piano y Percusión.
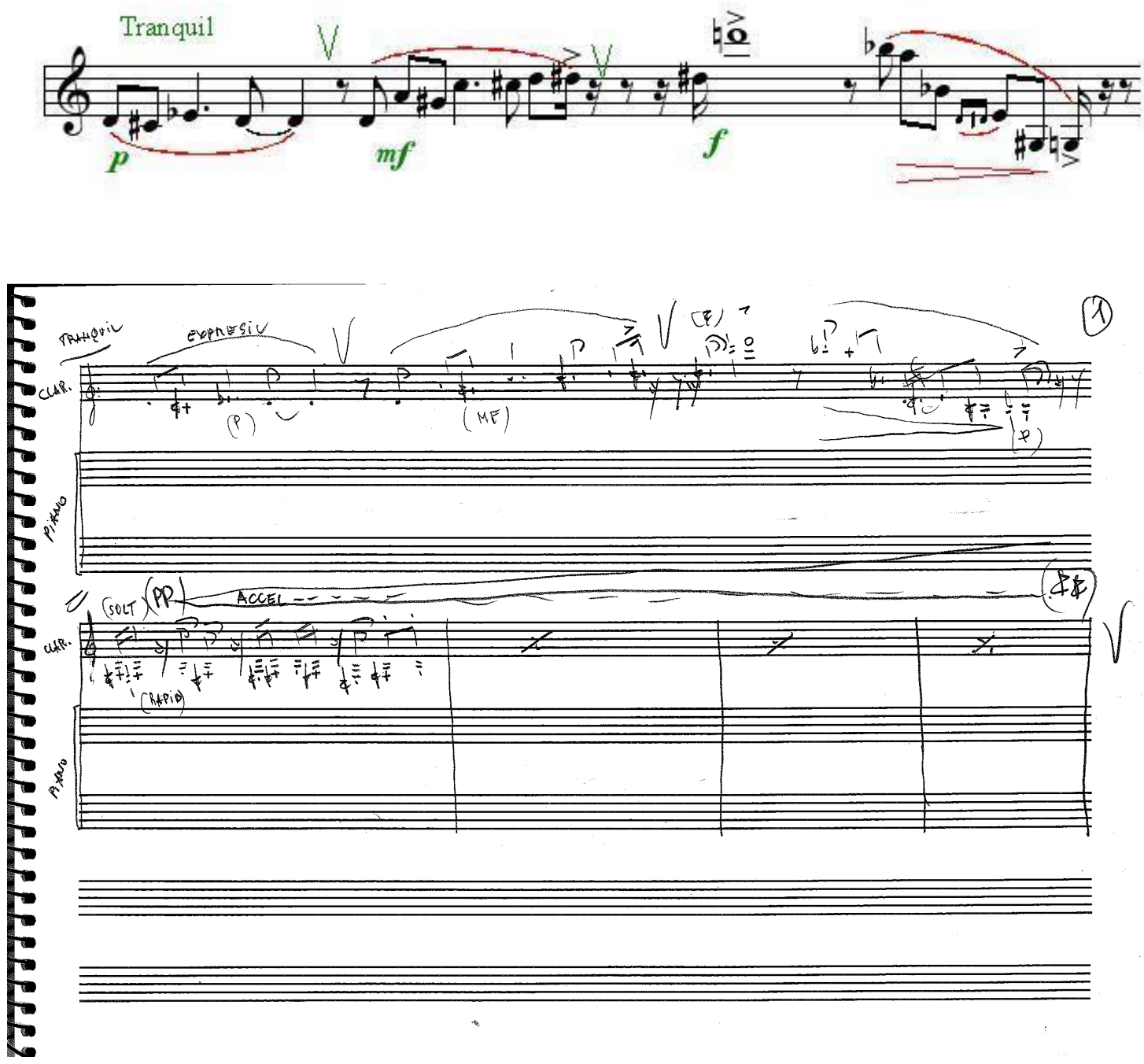

Compuesta para la clarinetista Ona Carbonell y estrenada para su Concierto Fin de Carrera.

\section{MATERIAL TOTAL:}

- Partitura manuscrita y original del autor. Consta de un bloc de escritura musical con 17 páginas escritas y numeradas.

- Partes: No existen.

- No consta relación de originales y copias. 
30.- PITURRINO FA DE MÚSIC, Concierto, politonal, percusión, piano, instrumentos de metal, 2 violines y violonchelo, con partitura y partes, 2009, Arc.20.

La plantilla a la que está dedicada es la de un grupo formado por Piano, instrumentos de viento-metal, percusión, 2 violines y cello.
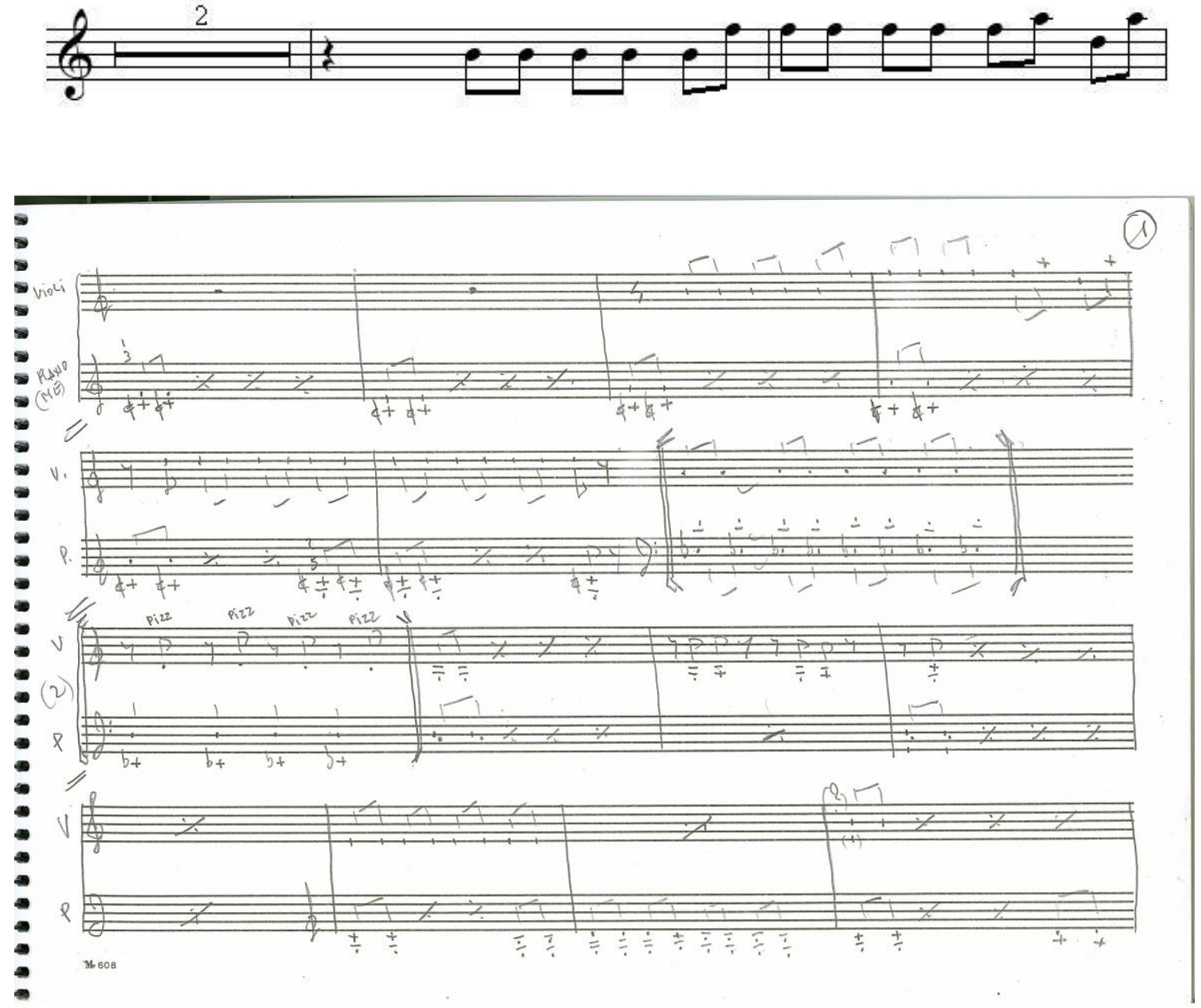

“Tocamos durante una hora sin parar, puro concierto, no tiene ninguna pretensión teatral"*

\section{MATERIAL TOTAL:}

- Partitura manuscrita y original del autor. Consta de 5 blocs de escritura musical, con los siguientes títulos:

* Testimonio oral del autor. 
- Piturrino (1) en el exterior (inicio de la obra) con 28 páginas numeradas y manuscritas;

○ Piturrino (2) “(Continuació) $1^{\text {a" }}$ en el exterior con 20 páginas numeradas y manuscritas en 3 grupos: 29 - continuación del bloc anterior-, de la 25 a la 30 y de la 36 a la 47 ;

○ Piturrino 1 "(Continuació) $2^{\mathrm{a}}$ " en el exterior con 25 páginas numeradas y manuscritas en 3 grupos: de la 1 a la 10, de la 1 a la 10, y de la 1 a la 5;

○ Piturrino (2) "Piano-Cello" en el exterior con 8 páginas numeradas y manuscritas;

○ Piturrino "(Trombó) + (Piano)" en el exterior con 5 páginas numeradas y manuscritas.

○ "Piano i Tuba + Bombardino" en el exterior con 6 páginas numeradas y manuscritas.

- Partitura y partes impresas del tutti final y partitura y partes de las partes solistas con piano que corresponden a los instrumentos: Bombardino, Violoncelo, Tuba, Trompeta, Trompa, Violín 1, Violín 2 y Trombón.

- Asimismo existe material, que el autor lo considera como los primeros apuntes de la obra, que consta de 1 libreto con música de piano escrita en 3 páginas con fragmentos numerados del 1 al 6, manuscrita y original del autor. Otro material consta de un libreto con 2 cuadernos y 5 páginas manuscritas y originales. Este material está duplicado con otro que consta de un libreto con 2 cuadernos y 4 páginas manuscritas y originales, copiadas con rotulador. Otro material consta de 5 páginas manuscritas y originales, con apuntes de la posterior instrumentación de la obra. Otro material, de la parte de piano, consta de un libreto con 2 cuadernos y 4 páginas manuscritas y originales, copiadas con rotulador.

- Partes: Existe parte de piano impresa, en poder de Carles Santos. En ella constan los datos del estreno.

- PDF realizado por Xavier Piquer con software Sibelius (Mac)

- No consta relación de originales y copias. 
31.- PORTADA, Libre, La M, Violín, Piano, Percusión y Contrabajo, con partitura, s. d., Arc.25.

La plantilla a la que está dedicada es la de un grupo formado por Violín, Piano, Percusión y Contrabajo.
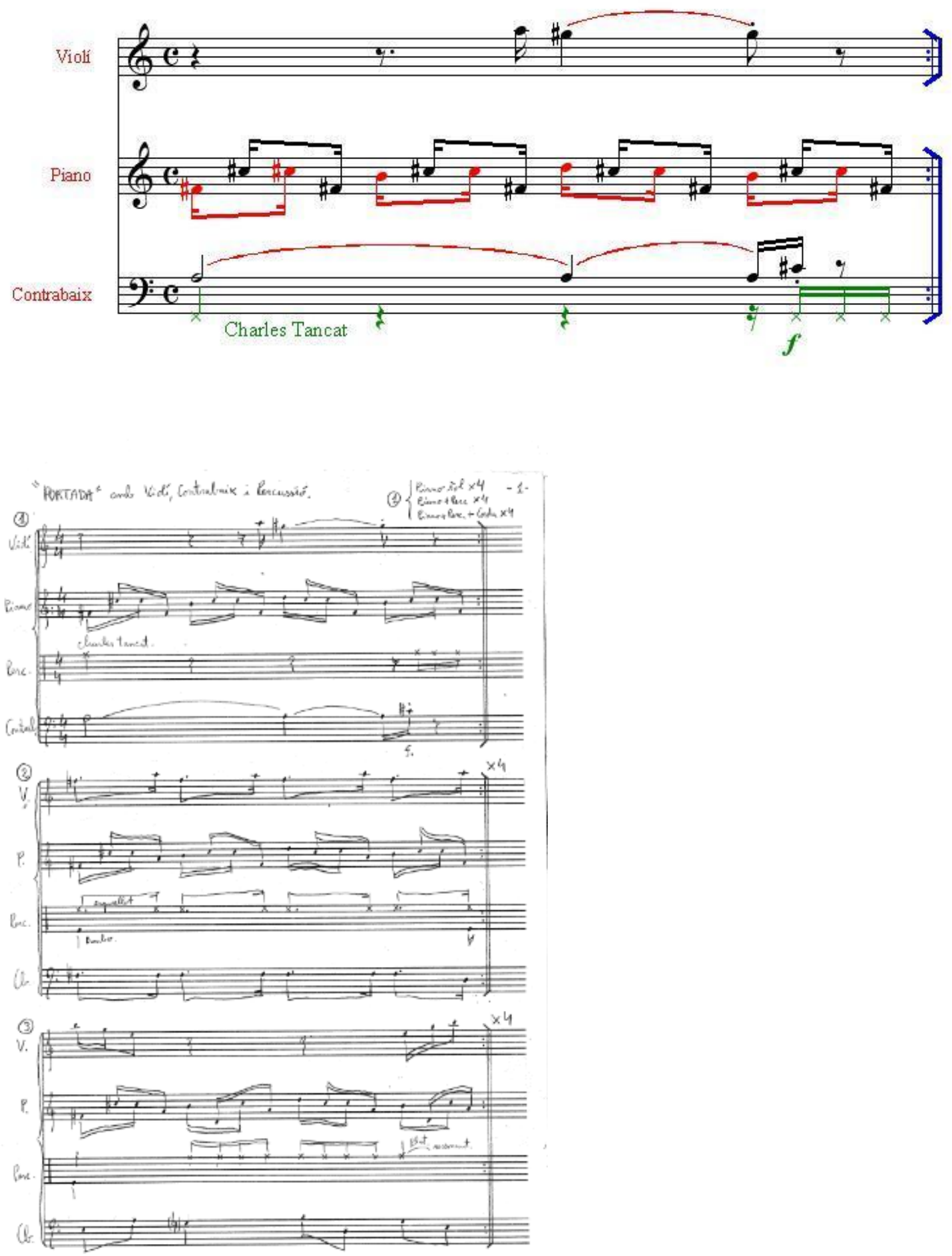
La parte de piano es semejante a la obra Portada en Swing lent, aunque en esta ocasión está escrita en compás 4/4, por lo que existe una variación estructural. El resto de instrumentos nada tienen que ver con la obra antes citada.

"Es música que forma parte de alguna película de cine" (Carles Santos Ventura).

\section{MATERIAL TOTAL:}

- Partitura manuscrita y original del autor. Consta de un libreto de 3 páginas numeradas de escritura musical. En el interior consta el título Portada e indicaciones de interpretación.

- Partes: No existen partes.

- No consta relación de originales y copias. 
32.- PORTADA EN SWING LENT, Libre, La M, Flauta, Violín, Piano, Batería y Contrabaix, con partitura, guion y partes, s. d., Arc.25.

La plantilla a la que está dedicada es la de un grupo formado por Flauta, Violín, Piano, Batería y Contrabaix.
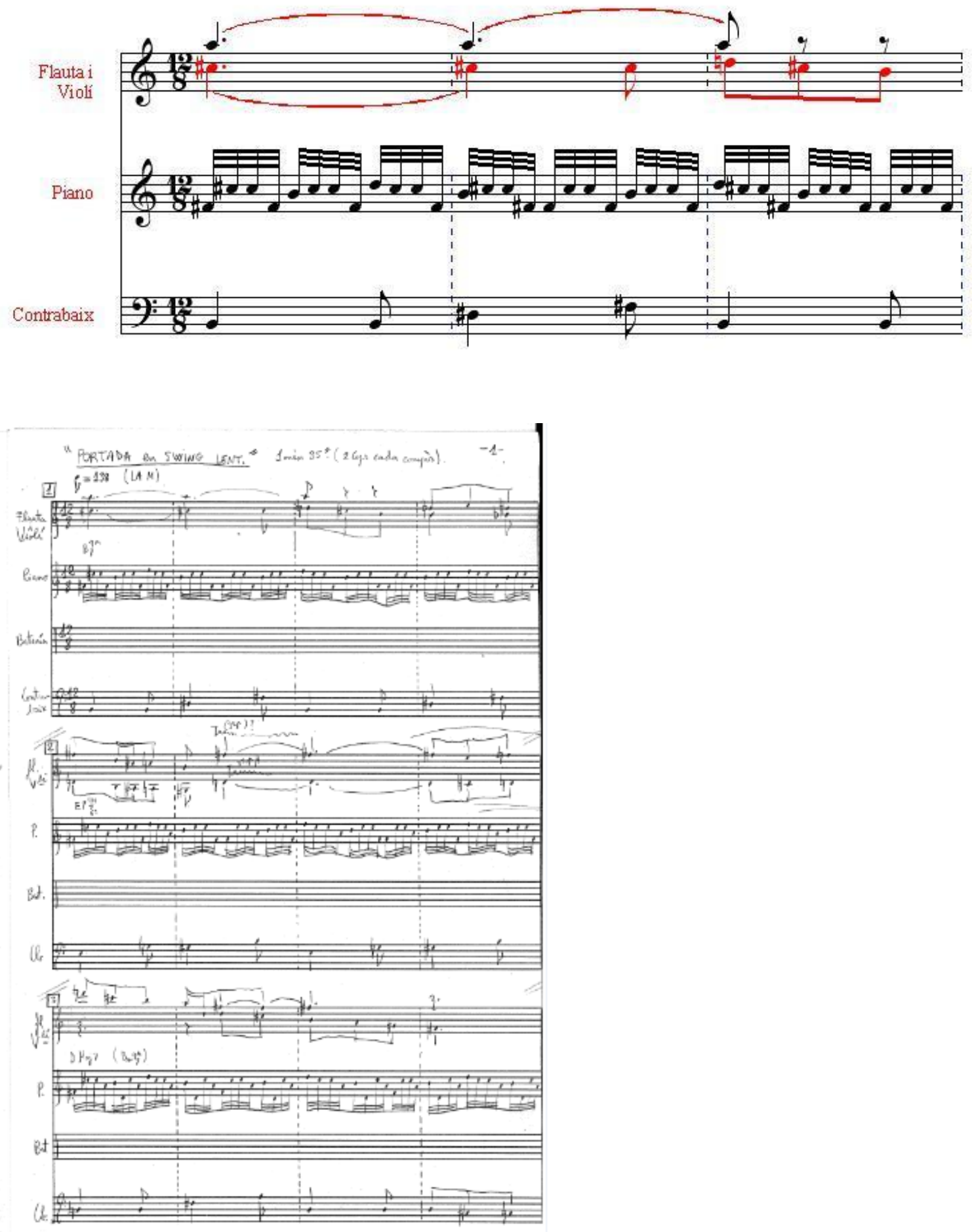
Compás de 12/8. "Es música que forma parte de alguna película de cine" (Carles Santos Ventura)

\section{MATERIAL TOTAL:}

- Partitura manuscrita y original del autor. Consta de un libreto de 6 páginas numeradas de escritura musical. En la tapa consta la parte de Piano. En el interior consta el título Portada en swing lent e indicaciones de duración e interpretación ( 1 m. 35" y 2 cops cada compàs). No existe la parte de batería ni la de piano desarrollada.

- Partes: Existe partes de algunos instrumentos.

- No consta relación de originales y copias. 
33.- PORTAFERRISSA, Libre, politonal, Cuerda, metal, Piano y Percusión, con partitura, 1989, archivador 29.

La plantilla a la que está dedicada es la de tres instrumentos de cuerda (dos violines y un violonchelo), grupo de metales (fanfarria), piano y percusión.
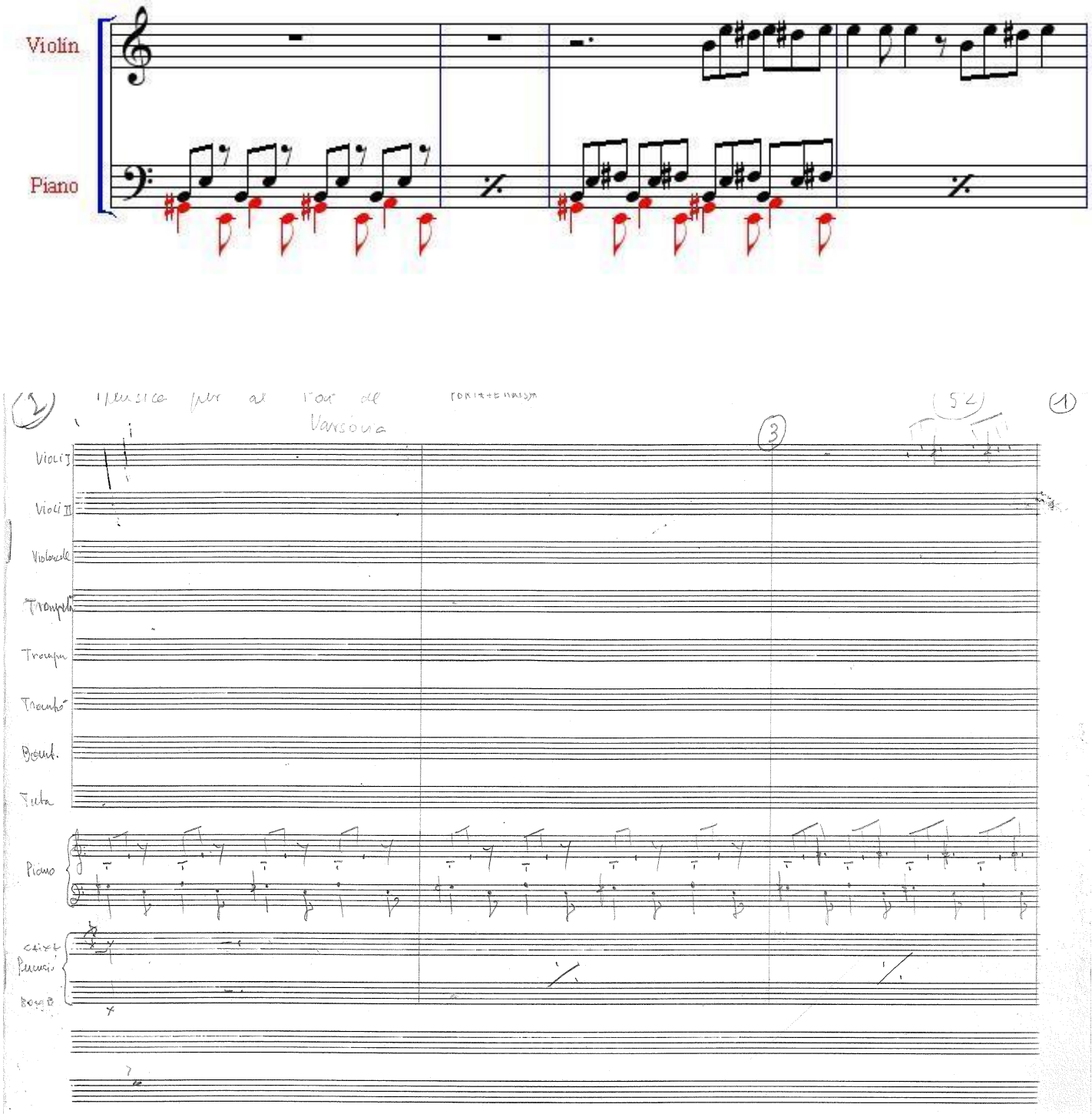

Portaferrissa forma parte de la obra El Pont de Varsovia.

Las partituras están numeradas como 52 por el autor. 


\section{MATERIAL TOTAL:}

- Material manuscrito y original del autor. Consta de un libreto manuscrito y original, de 24 páginas, como partitura, con el título "Musica per al Pont de Varsovia" y Portaferrissa en el exterior y con el n ${ }^{\circ} 52$ encercado.

- Partes: No existen partes instrumentales de la misma. Sólo consta el solo de 2 tubas fotocopiado (3 materiales), y un fragmento del papel de tuba.

- No consta relación de originales y copias. 
34.- RIERADA MUSICAL, Libre, politonal, banda, coro, orquesta sinfónica, tibles y gralles, con partitura y partes, 1999, Arc.11.

La plantilla a la que está dedicada es múltiple, admitiendo otras formaciones diversas.

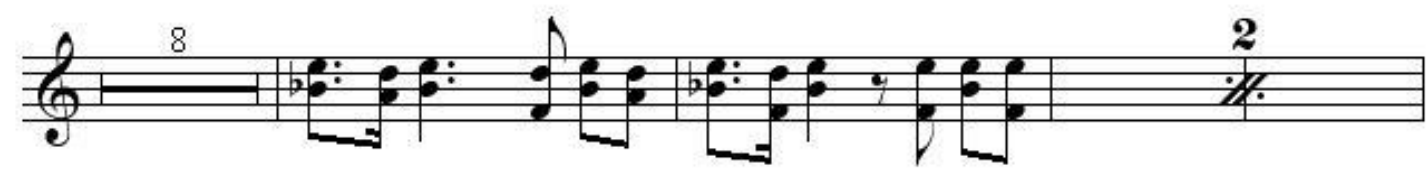

$R_{i}$
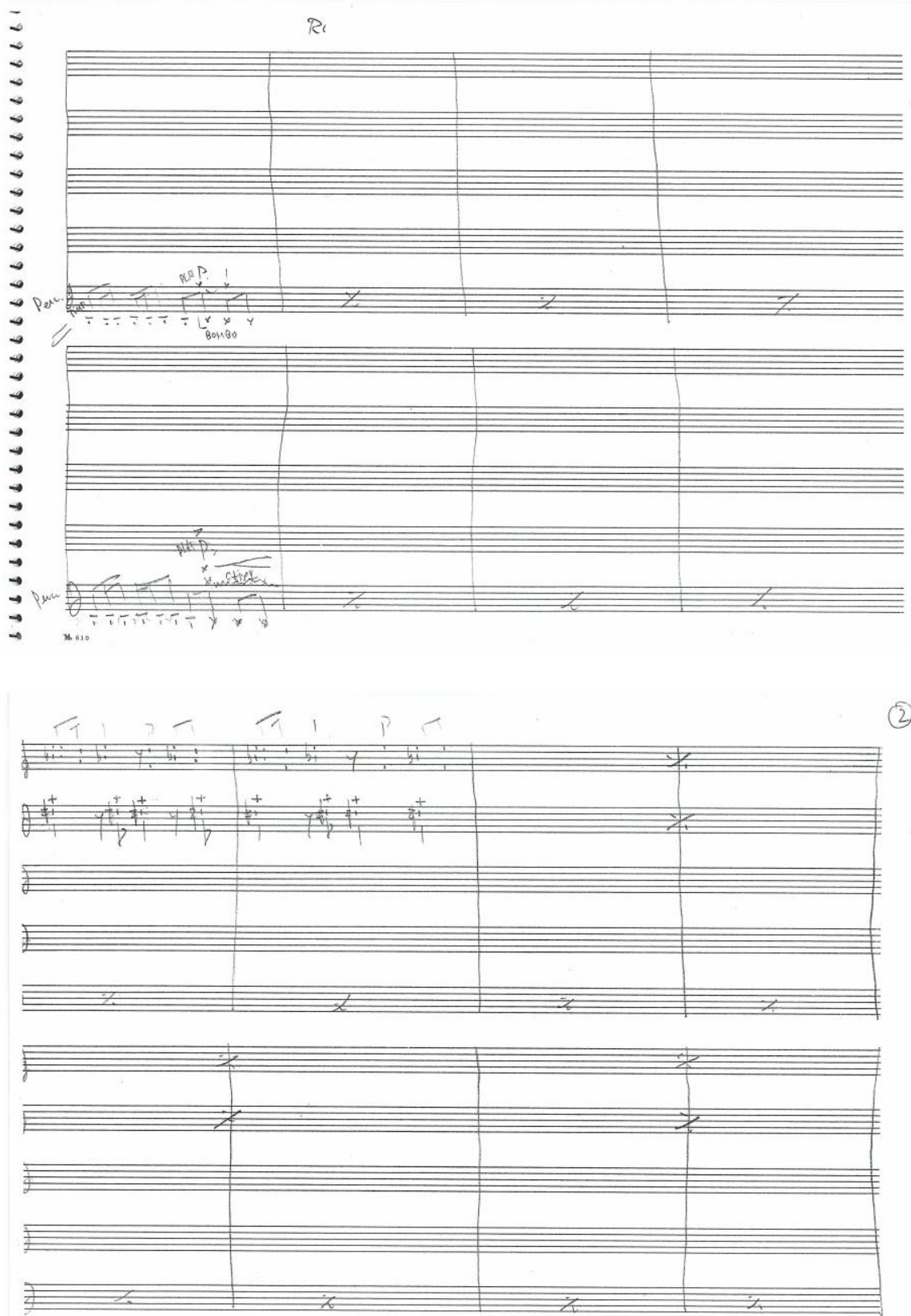
Estrenada el 26 de junio de 1999 en Reus. Existe guión escrito de su interpretación. La interpretación de la misma se desarrolla desde distintos puntos de la población, desde donde van saliendo cada grupo musical móvil, realizando un recorrido preestablecido y confluyendo todos ellos en un único punto final donde se encontrará la Orquesta Sinfónica. Dependiendo de la población donde tenga lugar la interpretación, el recorrido, el número de componentes de cada formación y el montaje escénico variará. Asimismo las representaciones admiten elementos típicos de cada lugar (gigantes, cabezudos, animales, etc.)

\section{MATERIAL TOTAL:}

- Partitura de la obra: partitura manuscrita y original del autor. Consta de un bloc de escritura musical, con el título Reus en el exterior, y música escrita en 10 páginas numeradas que se corresponden con la versión impresa destinada a la Orquesta Sinfónica. Existe un material fotocopiado de este original en el que constan rasgos de la posterior instrumentación.

- Partitura impresa y partes de la versión de Orquesta, en el que consta que la instrumentación es de P. J. Puértolas.

- Partitura impresa y partes de la $1^{\text {a }}$ versión para Banda.

- Partitura impresa y partes de la $2^{\mathrm{a}}$ versión para Banda.

- Partitura impresa y partes de la versión para Coro.

Las versiones de banda poseen modificaciones estructurales, con respecto a la partitura de Orquesta. Existe material impreso de toda la obra, en el que consta que la instrumentación es de P. J. Puértolas. Existe material popular típico de la población de Reus, impreso y destinado a una Cobla. Se desconoce si es de Carles Santos.

- Partes: Existen partes de todas las versiones impresas.

- No consta relación de originales y copias.

- Existe guion escrito de su interpretación. 
35.- SARDANA GELABERT, Sardana, politonal, banda y Cobla, con partitura y partes, 2011, Arc 28.

La plantilla a la que está dedicada es múltiple, admitiendo otras formaciones diversas. Ver: SARDANA GELABERT (sección Obra banda)
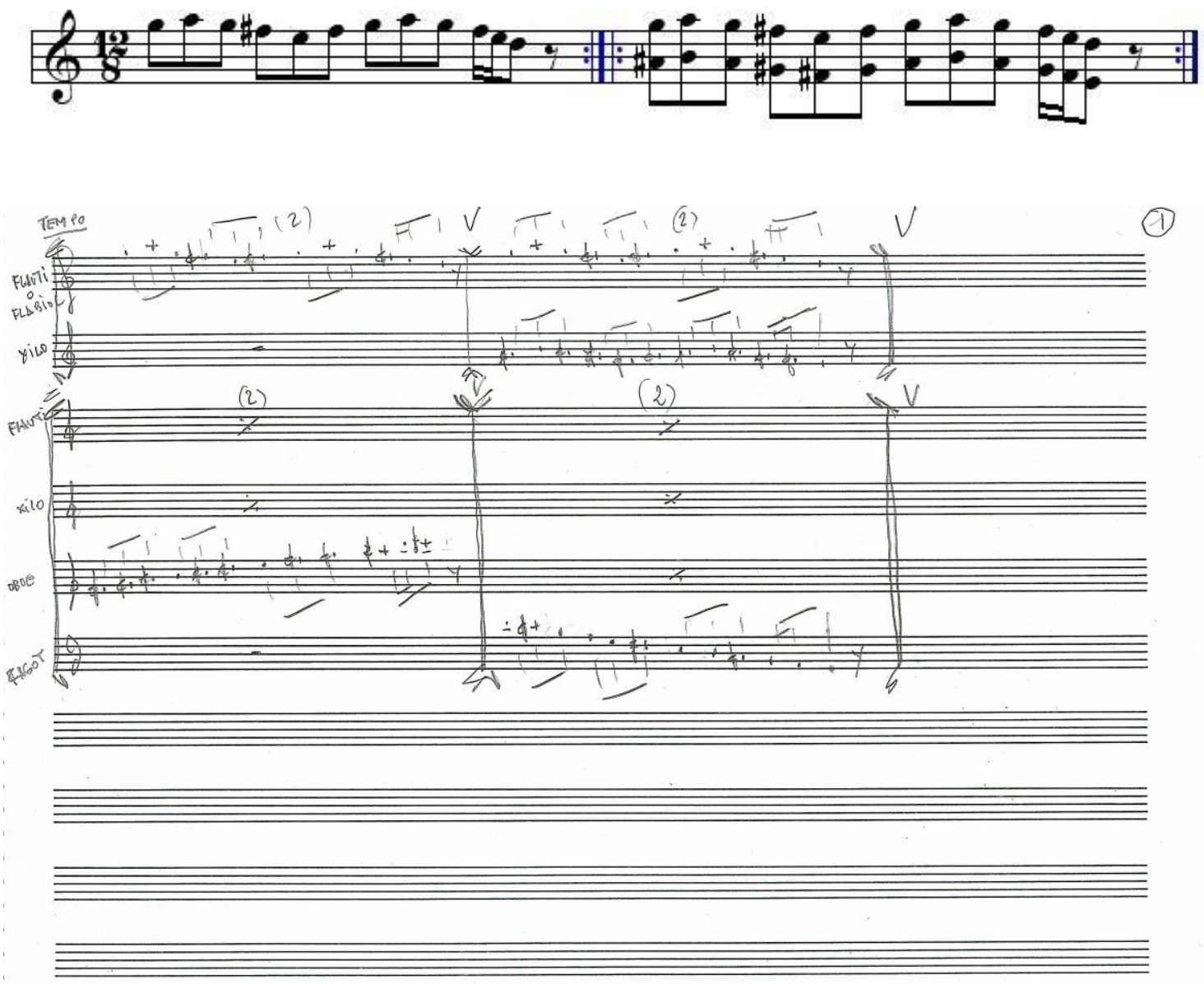

MøSichaf - Mo 610

Compuesta para inaugurar el Grec 2011 en Barcelona. El bailarín Cesc Gelabert será el encargado, junto a 12 bailarines de su compañía. Será interpretada en directo por los músicos de la Banda Municipal de Barcelona.

Se corresponde a la pista 10, "Sardana Gelabert" del disco La muntanya al teu voltant grabado en 2011 por el Festival Grec 2011. 


\section{MATERIAL TOTAL:}

- Partitura manuscrita y original del autor. Consta de un bloc de escritura musical, tamaño A4 apaisado de 30 hojas, con el título Sardana en el exterior y 32 páginas manuscritas y originales. Existe partitura impresa y partes impresas.

- Partes: Existen partes de software y originales.

- No consta relación de originales y copias. 
36.- SARDANA RUSA, Sardana, Sol m, Voz, Metal, Percusión, Flautín y Piano, con partitura, 1992 aprox., Arc 25.

La plantilla a la que está dedicada es: Voz femenina, Metal, Percusión, Flautín y Piano. Ver: MIRÓ 93' o PROMENADE CONCERT (Sección Otras agrupaciones)
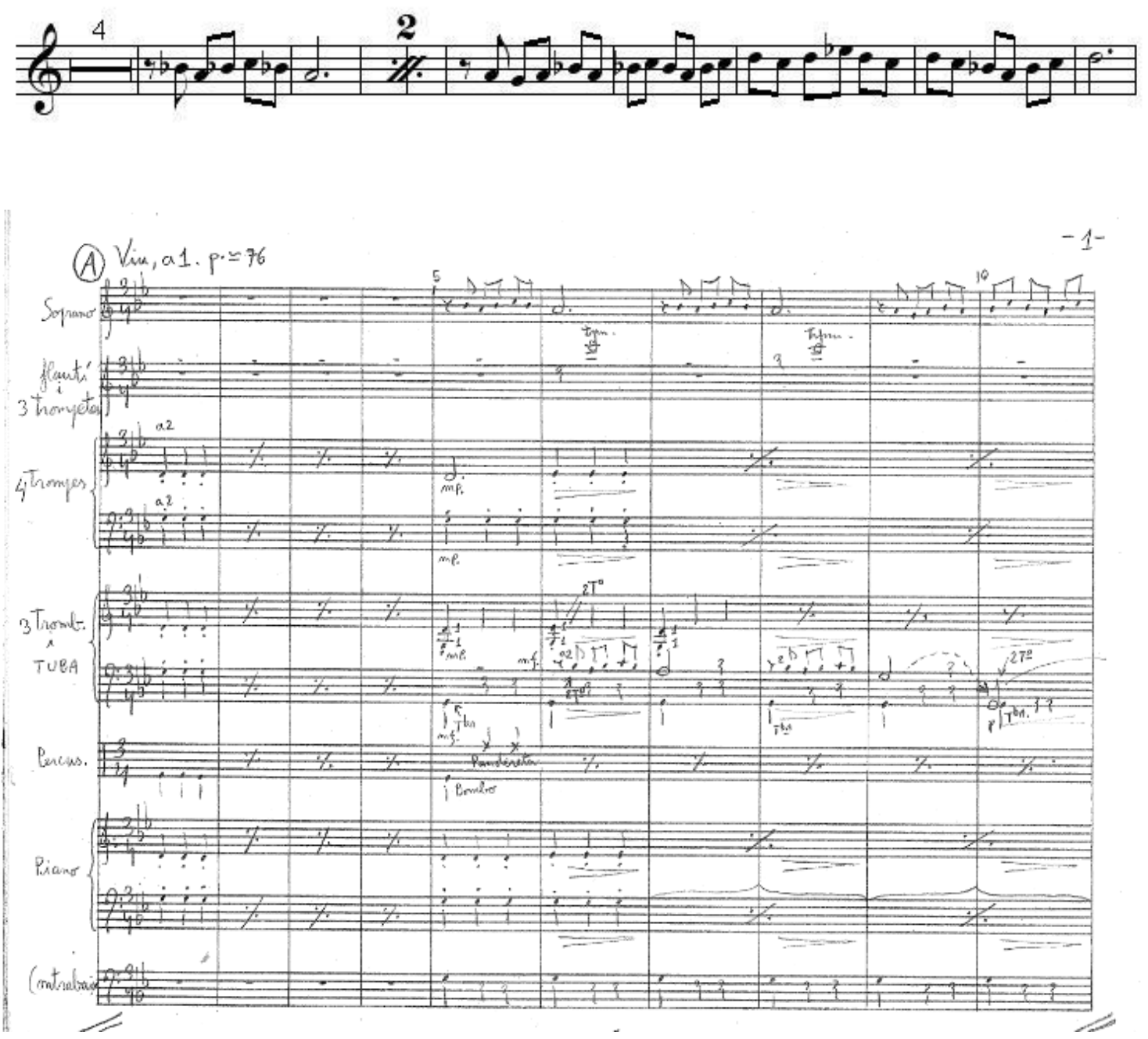

Se trata de un fragmento de Promenade Concert.

\section{MATERIAL TOTAL:}

- Partitura manuscrita y original del autor. Consta de un libreto de 6 páginas numeradas de escritura musical. En la tapa consta el título Sard. Rusa.

- Partes: No existen partes.

- No consta relación de originales y copias. 
37.- SCHUBERT 8 - 10 1/2, Concierto escénico, Politonal, Violín, dos voces y Piano, con guion, 2012, Arc 34.

La plantilla a la que está dedicada es: Violín, dos voces (sin determinar) y Piano.

Ver: SCHUBERTNACLES HUMITS (sección Obra escénica)

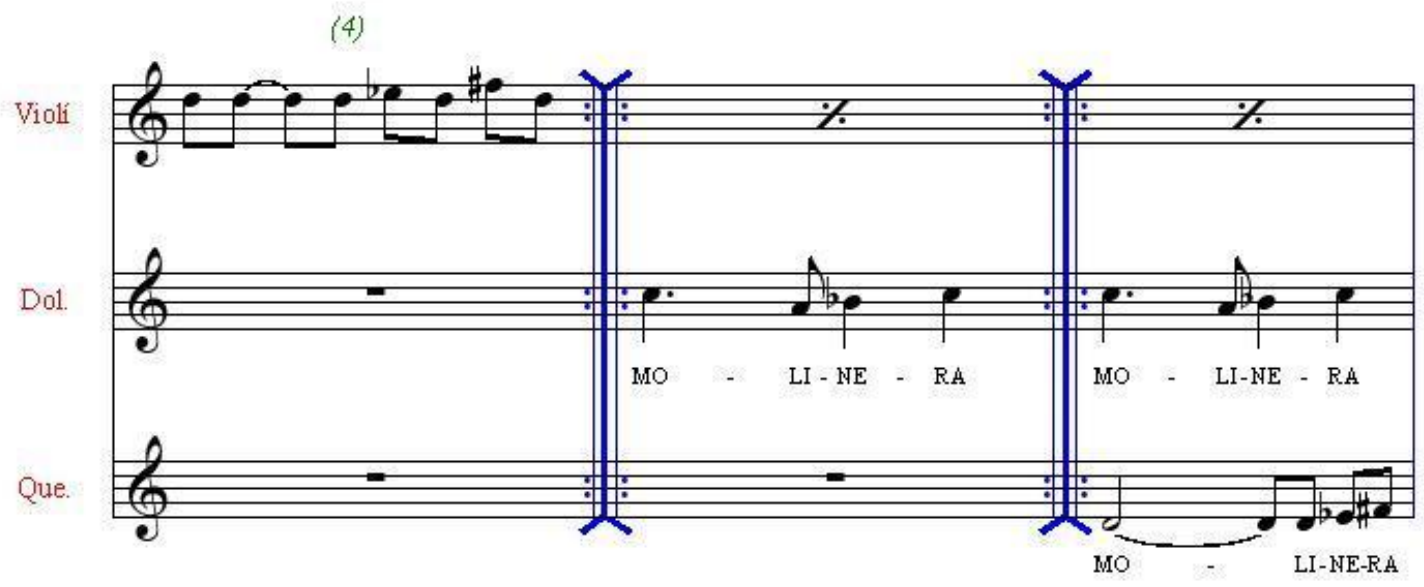



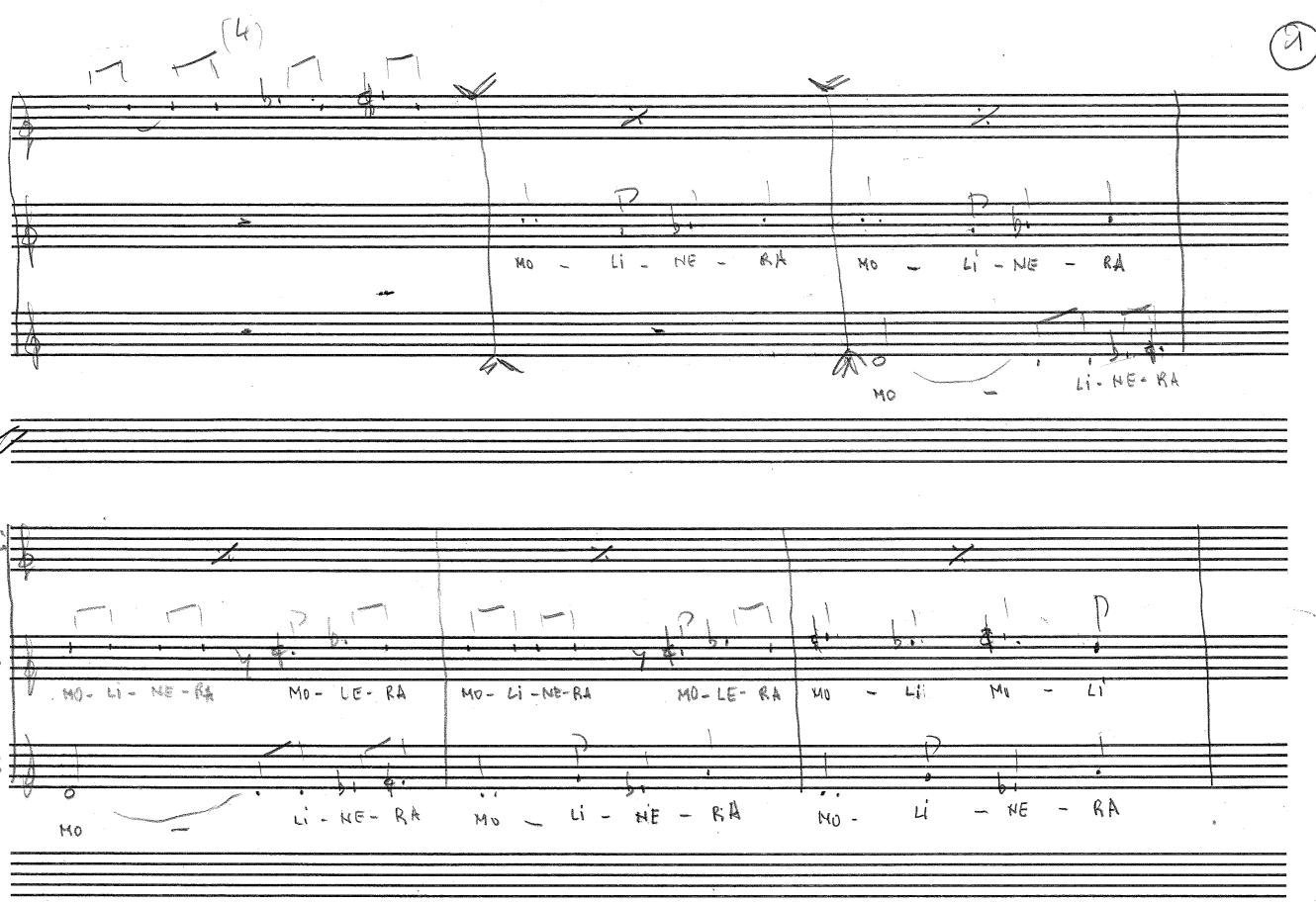


Forma parte del espectáculo Schubertnacles humits, estrenado en el Festival Temporada Alta. El montaje, al principio iba a llamarse Els urinaris públics europeus. Santos está acompañado en escena por Queralt Albiñana (actriz), Josep Ferrer (la voz de un personaje ausente), Cati Reus (violinista) y Dolors Ricart (una directora de orquesta sin orquesta) y un altavoz de $3 \times 3$ metros. La mayor parte de las piezas musicales que interpretan son de Schubert, como es el caso de la Sinfonía Inacabada, con la que se inicia la obra, la sonata número 2 para piano y La Bella Molinera, aunque también hay temas de Paganini y Mompou, así como "alguna cosilla"77 compuesta por el propio Carles Santos.

\section{MATERIAL TOTAL:}

- Partitura manuscrita y original del autor. Se encuentra en el bloc de escritura musical titulado Schubert 8 - 10 1/2. Consta de 5 páginas escritas y numeradas. Da la sensación de estar inconclusa.

- Partes: No existen partes.

- No consta relación de originales y copias.

\footnotetext{
${ }^{77}$ Testimonio oral del autor.
} 
38.- SEVILLA (2), libre, politonal, Coro infantil y Guitarra, con guion, s. d., Arc 25.

La plantilla a la que está dedicada es Coro infantil y Guitarra.
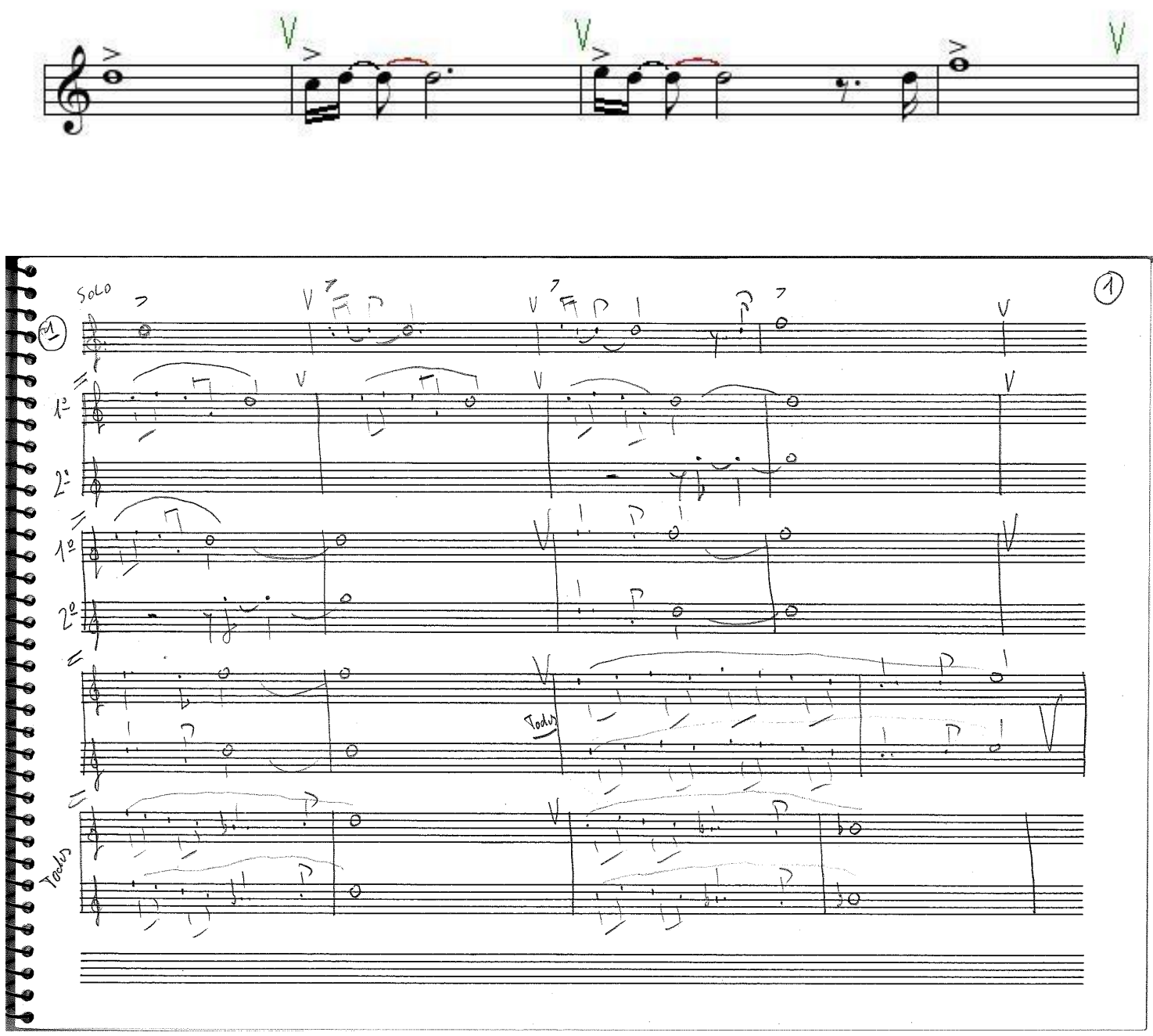

Esta obra no tiene ninguna conexión con el pasodoble del mismo título.

\section{MATERIAL TOTAL:}

- Partitura manuscrita y original del autor. Consta de un bloc de escritura musical con 8 páginas escritas y numeradas.

- Partes: No existen partes.

- No consta relación de originales y copias. 
39.- TENORA I PIANO, libre, politonal, tenora y piano, con partitura, 2009, Arc.12.

La plantilla a la que está dedicada es la de 1 tenora y piano.

Tenora

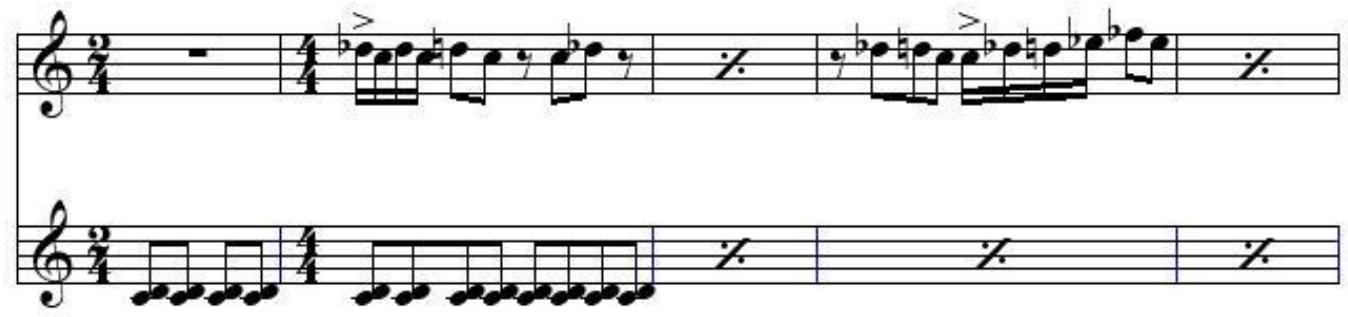

Tenora i Piano

Mediterrània '09 · Manresa

Carles SANTOS
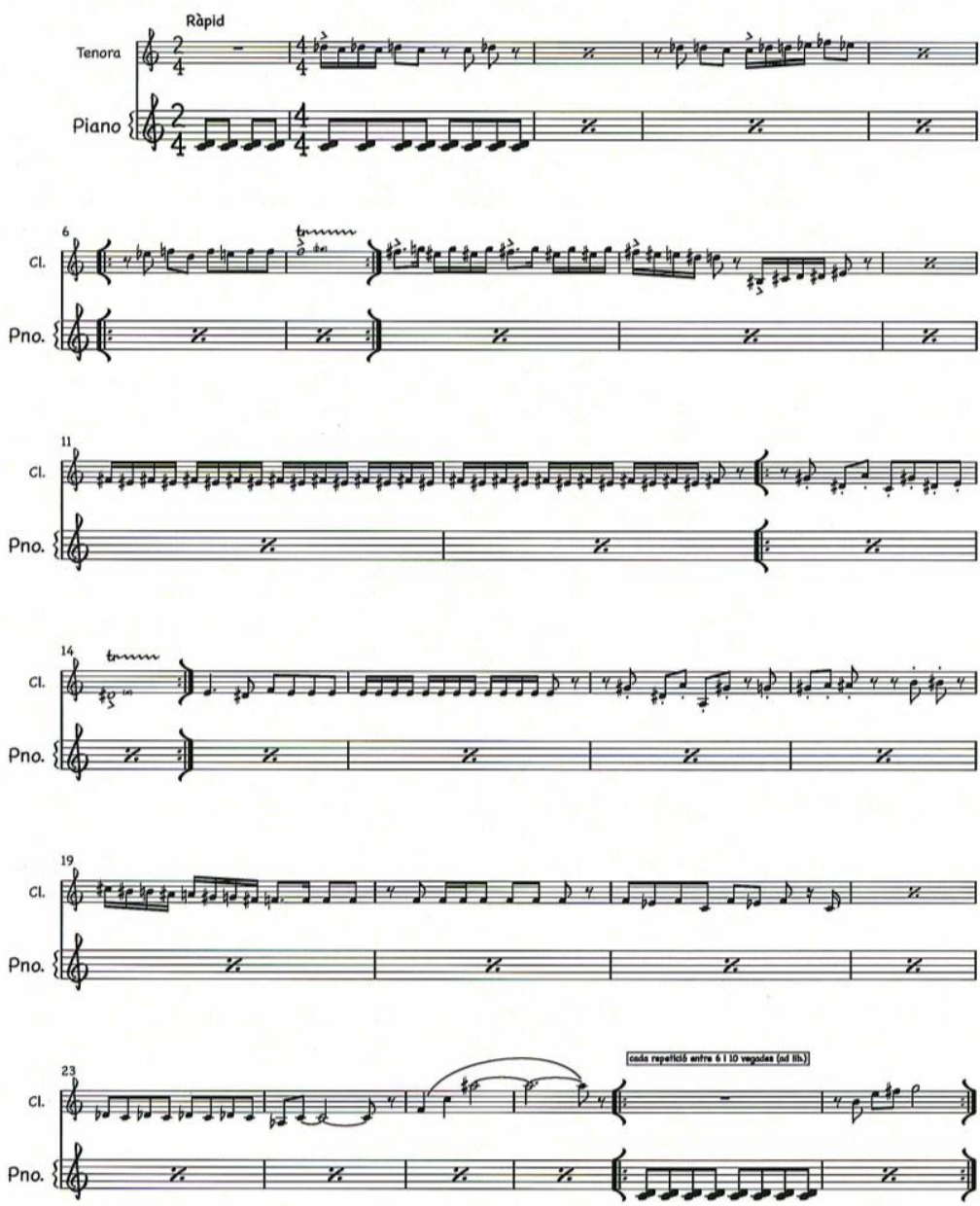
Obra escrita para el evento "Mediterranea '09" celebrado en Manresa en 2009. Texto de Pere Jaume

\section{MATERIAL TOTAL:}

- Partitura impresa de software, de 2 páginas, sin encuadernar. PDF realizado por Xavier Piquer con software Sibelius (Mac). No existen manuscritos.

- Partes: Existen partes de software y originales.

- No consta relación de originales y copias. 
40.- TENORES (ANYADIT), libre, en La, Soprano, 12 Tenoras y Piano, con guion, 2011, Arc.34.

La plantilla a la que está dedicada es la de una soprano, 12 tenoras y piano.
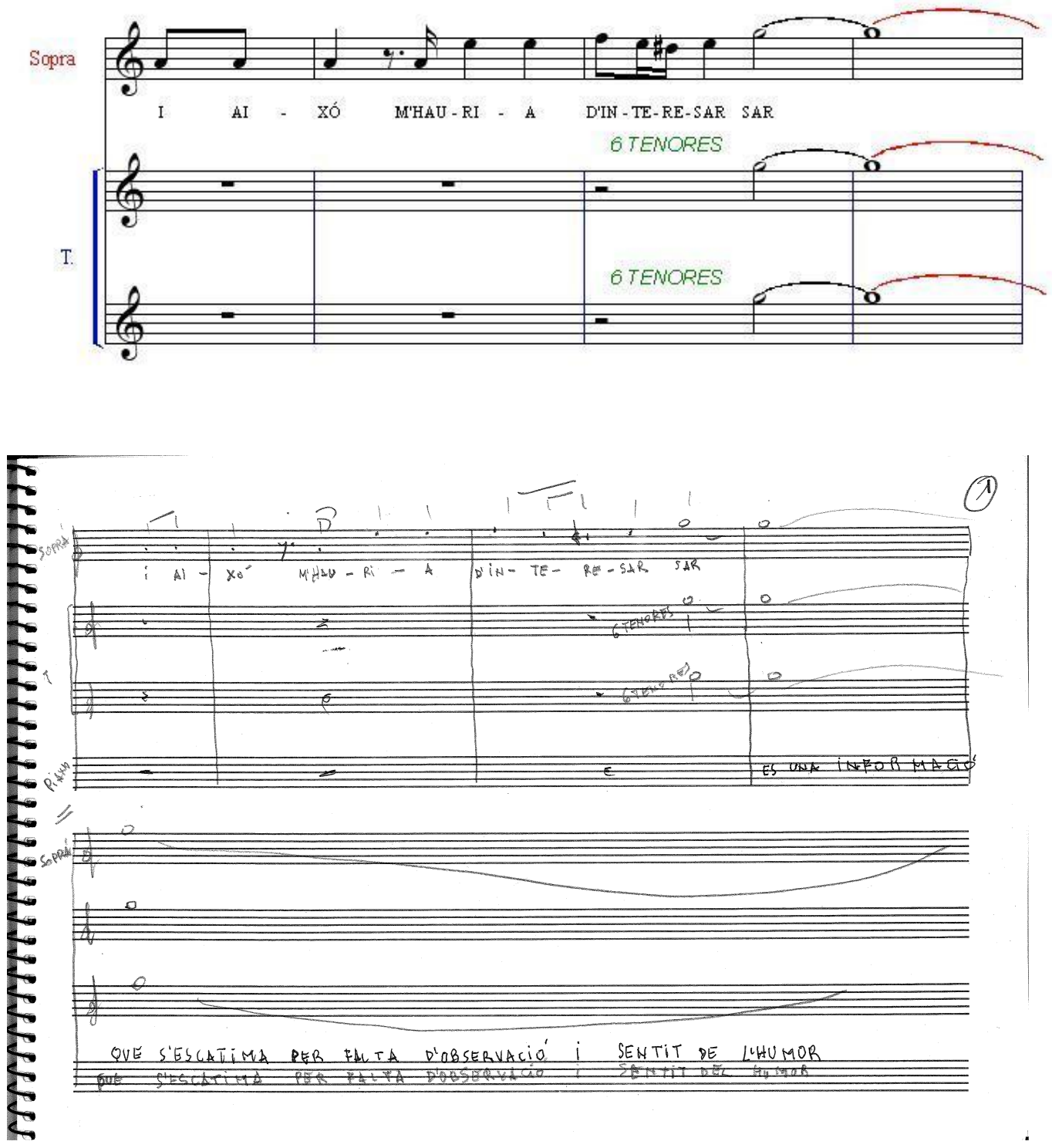

Obra escrita para el evento "Mediterranea '09" celebrado en Manresa en 2009. Texto de Pere Jaume

Personajes: Jaume y Maite. 


\section{MATERIAL TOTAL:}

- Partitura manuscrita y original del autor. Consta de un bloc de escritura musical, tamaño A4 apaisado de tapa amarilla de 30 hojas, con el título Tenores (anyadit) en el exterior y 22 páginas manuscritas y originales. Existe una copia del texto en el interior del bloc.

- Partes: No existen partes.

- No consta relación de originales y copias. 
41.- TRES NOTES, libre, politonal, Cuerda, Viento metal, Percusión y Piano, con guion y partitura, s. d., Arc.30.

La plantilla a la que está dedicada es la de un grupo de instrumentos de cuerda, instrumentos de viento metal, Percusión y piano.

Ver: $\mathbf{8 8} \mathbf{-} \mathbf{3}=\mathbf{8 5}$ (Obra piano)
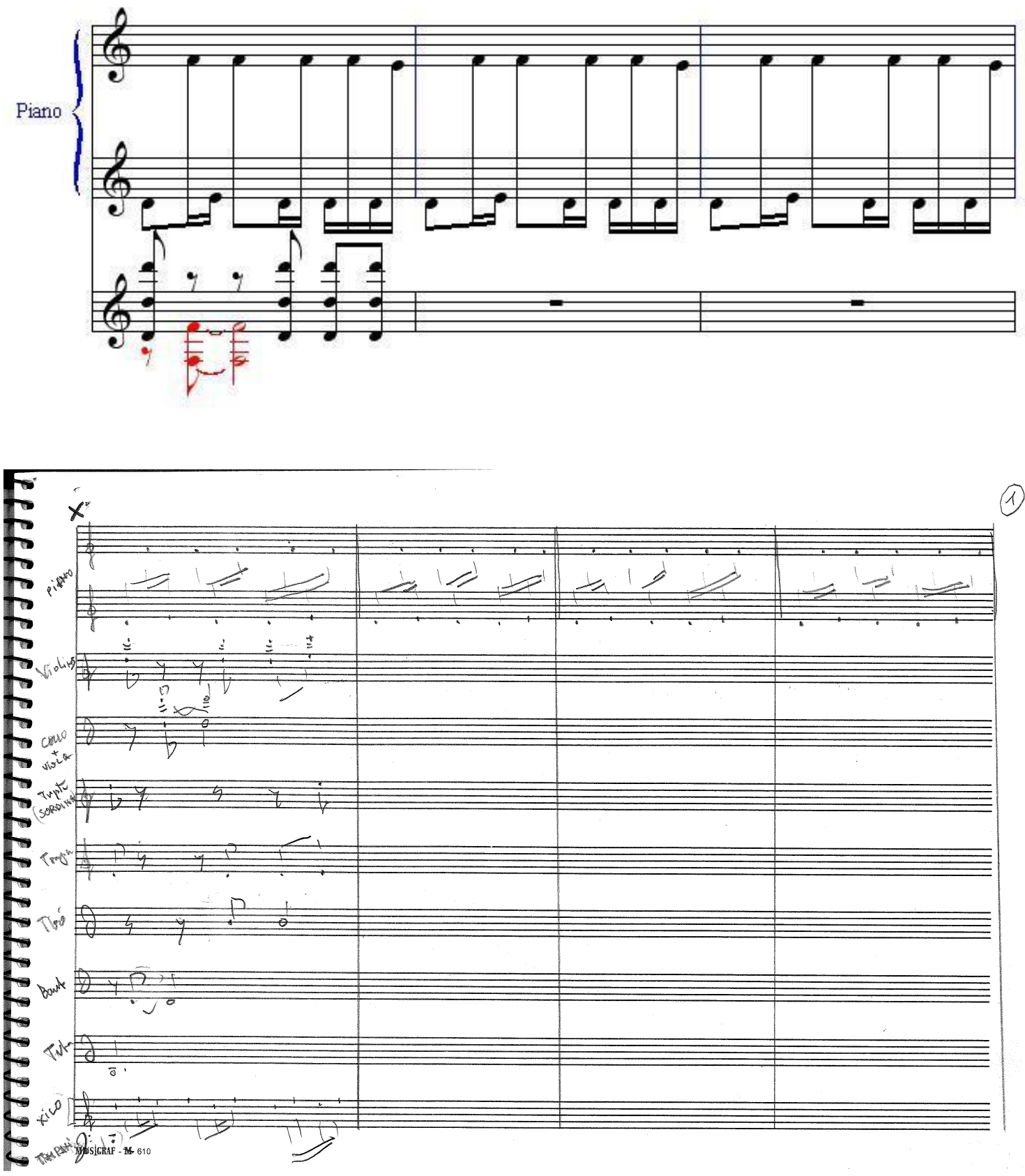

Tres notes es la instrumentación de $88-3=85$, a partir de la primera idea de la obra. 


\section{MATERIAL TOTAL:}

- Partitura manuscrita y original del autor. Consta de un bloc de escritura musical, con el título Tres notes en el exterior y 20 páginas manuscritas y originales, numeradas. Da la sensación de estar inacabada.

- Partes: No existen partes.

- No consta relación de originales y copias. 
42.- TRIO INSTRUMENTAL, libre, politonal, 3 instrumentos, con guion, 1985, Arc.26.

La plantilla a la que está dedicada es la de un trio instrumental, sin determinar.

Ver: LA BOQUETA AMPLIFICADA (Obra escénica)
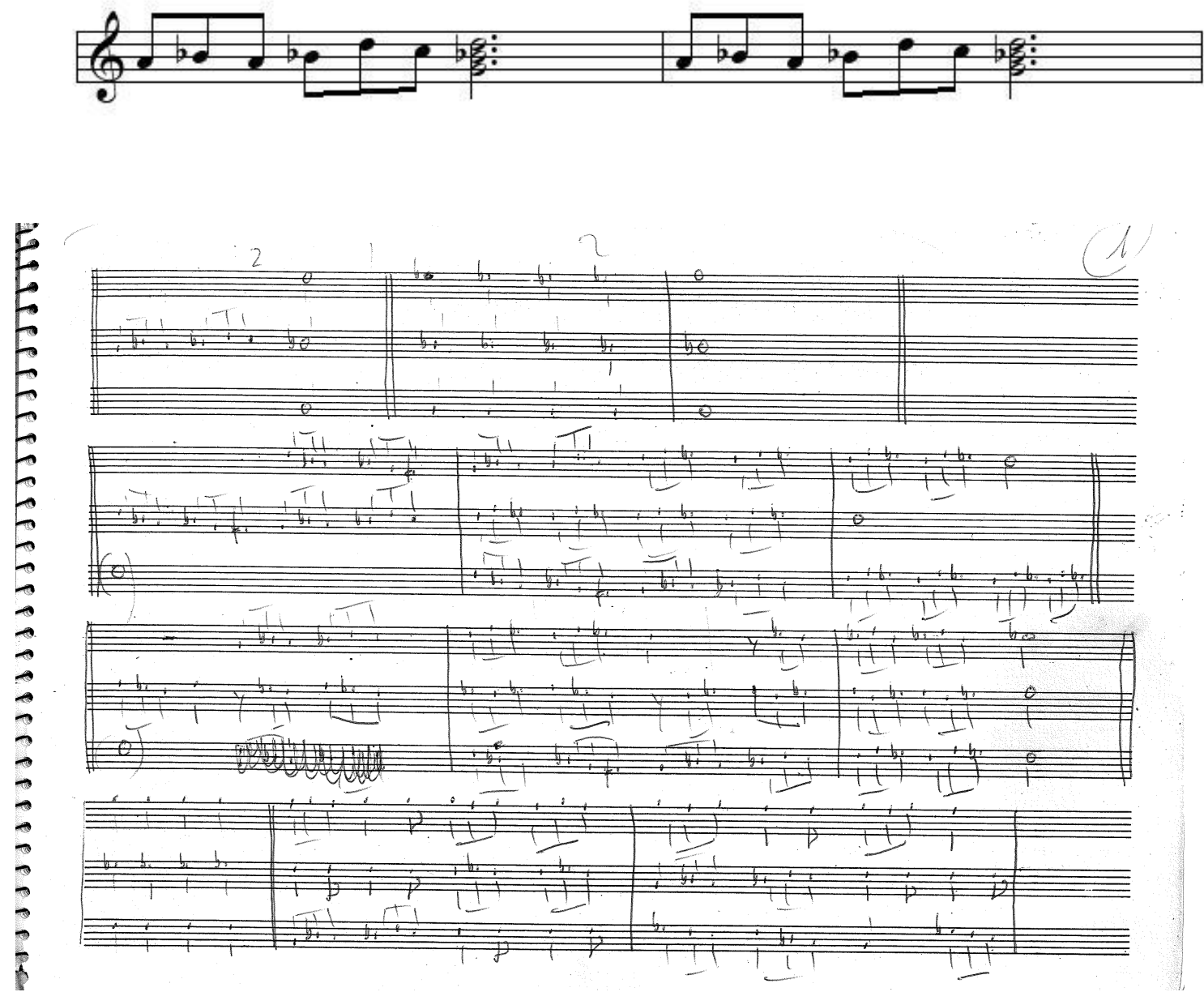

\section{MATERIAL TOTAL:}

- Material manuscrito y original del autor. Consta de 1 bloc de escritura musical, con el título Boqueta amplificada en el exterior. La obra comienza en hoja $\mathrm{n}^{\circ} 15$. Páginas numeradas de la 1 a la 7 y la última sin numerar. Posiblemente sea un fragmento de otra obra.

- Partes: No existen partes.

- No consta relación de originales y copias. 
43.- TUTTI, libre, politonal, Cuerda, Viento metal, Percusión y Piano, con guion y partitura, s. d., Arc.30.

La plantilla a la que está dedicada es la de un grupo de instrumentos de cuerda, instrumentos de viento metal, Percusión y piano.

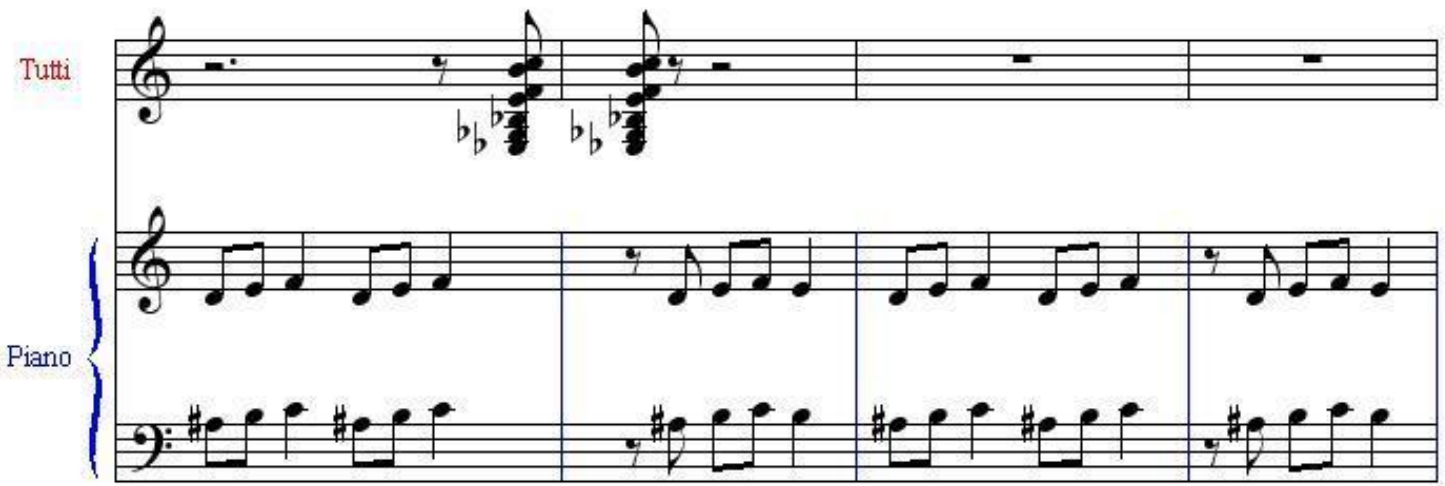

$E^{f}$

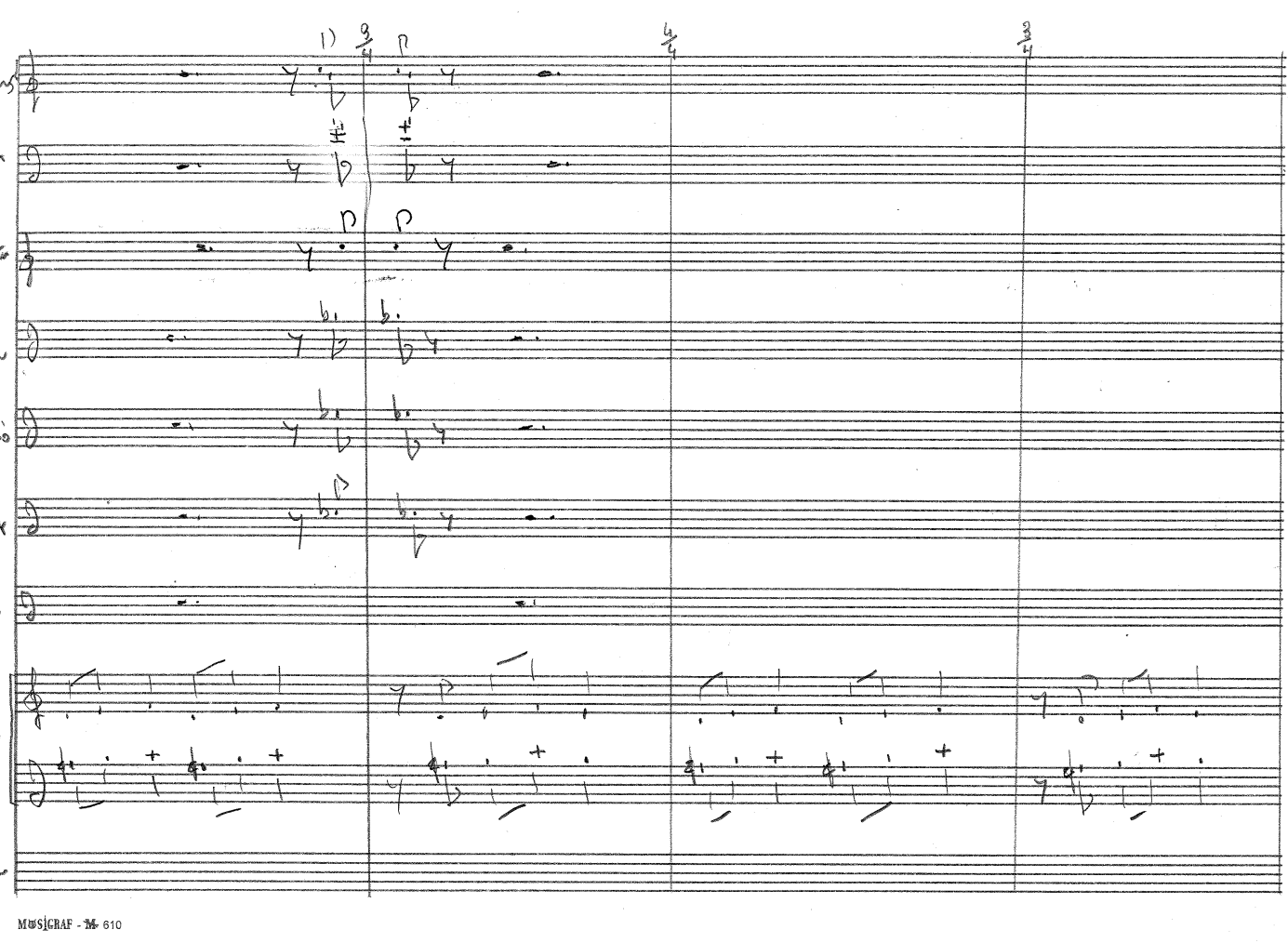




\section{MATERIAL TOTAL:}

- Partitura manuscrita y original del autor. Consta de un bloc de escritura musical, con el título Tutti en el exterior y 24 páginas manuscritas y originales, numeradas. Da la sensación de estar inacabada. Existe solo de Piano.

- Partes: No existen partes.

- No consta relación de originales y copias. 
44.- UN CRANC ES UN CRANC, Libre, fa\# M, cuerda, metal y percusión, con fragmento de partitura y partes, 1991, G. 2

La plantilla a la que está dedicada es una plantilla poco usual: Violines I, II, III y IV, Violoncelo, Trompetas, Trompas, Trombones, Tubas y Percusión.
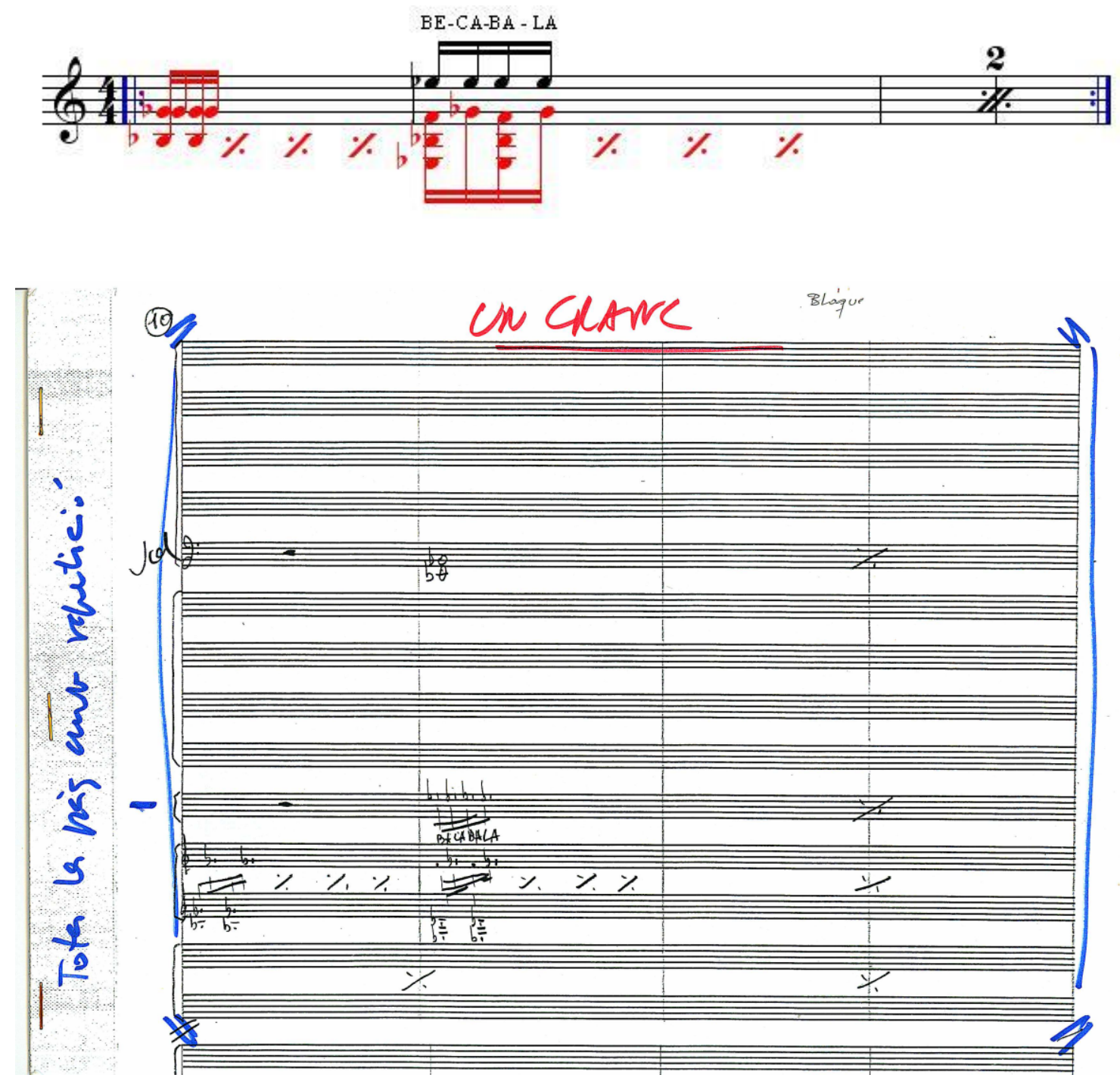

Obra dividida en 2 partes, ligada a otras 3, Miró 93, Asdrúbila y Portaferrissa. La estructura total es: "Cranc I", “Cranc II”, "Miró 93”” y "Portaferrissa".

Estructura:

"Cranc I": 140 cc.

"Cranc II": 21 grupos de 8 cc. cada uno, al que siguen $360 \mathrm{cc}$.

"Miró 93"”: 


\section{MATERIAL TOTAL:}

- Partitura de la obra o guión: no existe. Tan solo un fragmento fotocopiado (bloques 10 a 21 de la II parte).

- Partes: manuscritas y originales de los instrumentos citados con anterioridad. Existen unas partes adjuntas de "Cranc II" que contienen música del c. 262 al 320 (Violines I y II, Viola, Violoncelo, Trompetas, Trompas, Trombones y Tubas). Título: Un cranc es un cranc. No existe el nombre del autor en las partes. Existe papel de Piano por indicación del autor, pero está extraviado. Existe un fragmento manuscrito del autor para las Tubas, del que se desconoce su ubicación exacta en la obra.

- Asimismo existe un material compuesto por 14 hojas sueltas numeradas, manuscritas y originales del autor, que contienen la parte de piano (las 8 primeras) y la parte de la voz con su texto e indicaciones de una posible orquestación, las 6 restantes.

- No consta relación de originales y copias. 
3.2.11. OBRA EXTRAVIADA 


\section{OBRA EXTRAVIADA}

Aquí se exponen los títulos de obras musicales de Carles Santos, de los cuales existen referencias en artículos, libros o discografía, pero de los cuales se desconoce su paradero actual, en lo que respecta a la música empleada.

\begin{tabular}{|c|c|c|}
\hline TÍTULO & FORMA O GÉNERO & AÑO \\
\hline Visca el Piano & Espectacle & 1981 \\
\hline L'àpat & Film (Corto) & 1967 \\
\hline La cadira & Film (Corto. Realizador) & 1968 \\
\hline Playback & Film (Corto. Realizador) & 1970 \\
\hline Acció Santos & Film (Corto. Realizador) & 1972 \\
\hline La Re Mi La & Film (Corto. Realizador) & 1979 \\
\hline Noctturn 29 & $\mathrm{BSO}$ & 1968 \\
\hline Miró l'altre & BSO (Corto) & 1969 \\
\hline Poetes catalans & BSO (Corto) & 1970 \\
\hline Semejante a Pedro & $\mathrm{BSO}$ (Corto) & 1971 \\
\hline Calidoscopi & BSO (Corto) & 1971 \\
\hline Umbracle & BSO (Corto) & 1972 \\
\hline Cantants 72 & BSO (Corto) & 1972 \\
\hline Advocats laboralistes & BSO (Corto) & 1973 \\
\hline El barri del Besós & BSO (Corto) & 1978 \\
\hline Laberint & BSO (Corto) & 1979 \\
\hline La delinqüència & BSO (Corto) & 1979 \\
\hline Setmana de la sanitat & BSO (Corto) & 1979 \\
\hline L'Ajuntament & BSO (Corto) & 1979 \\
\hline L'agressió quotidiana & BSO (Corto) & 1979 \\
\hline L'assemblea de Catalunya & BSO (Corto) & 1981 \\
\hline Eleccions a Las Cortes 28-10-82 & BSO (Corto) & 1982 \\
\hline Romàntic & $\mathrm{BSO}$ (Corto) & 1989 \\
\hline Clara foc & BSO (Corto) & 1991 \\
\hline Art a Catalunya & BSO (Video) & 1992 \\
\hline $\begin{array}{l}\text { L'espectador. Habitació amb rellotge. La } \\
\text { llum. Conversa }\end{array}$ & $\begin{array}{l}\text { BSO (Corto. Realizador) } \\
\text { (parcialmente) }\end{array}$ & 1967 \\
\hline
\end{tabular}




\begin{tabular}{|c|c|c|}
\hline Preludi de Chopin, Opus $28 n^{\circ} 7$. & BSO (Corto. Realizador) & 1969 \\
\hline Preludi de Chopin, Opus $28 n^{\circ} 18$ & BSO (Corto. Realizador) & 1974 \\
\hline El pianista i el conservatori & BSO TV (Corto. Realizador) & 1977 \\
\hline Peça per a quatre pianos & BSO TV (Corto. Realizador) & 1978 \\
\hline Vampir-Cuadecuc & $\mathrm{BSO}$ & 1970 \\
\hline \multicolumn{3}{|l|}{ Informe general sobre algunas cuestiones } \\
\hline para una proyección pública & BSO & 1975-1976 \\
\hline Informe General & BSO & 1977 \\
\hline L'obscura història de la cosina Montse & BSO & 1977 \\
\hline Vértigo en Mahattan & BSO & 1981 \\
\hline Barcelona Sud & BSO & 1981 \\
\hline Pa d'àngel & BSO & 1984 \\
\hline És quan dormo que hi veig clar & BSO & 1988 \\
\hline El pianista & BSO & 1997 \\
\hline Las variaciones Goldbergh & $\mathrm{BSO}$ & 2007 \\
\hline Alfombra voladora & Piano & \\
\hline Astukaplau & Voz & \\
\hline
\end{tabular}

"El meu llit, teu llit" (de Carles Santos

\begin{tabular}{lll} 
Piano) & Piano (Parcialmente) & \\
\hline "La sargantaneta" (de Voicetracks) & Vocal & 1981 \\
\hline $\begin{array}{l}\text { "Fragment del Properdisc" (de } \\
\text { Pianotrack) }\end{array}$ & Piano & \\
\hline "Autoretrat" (de Voicetracks) & Vocal & 1981 \\
\hline "La notaria de Utrera" (de Música para & & 1992 \\
las Ceremonias Olímpicas) & Vocal & 1982 \\
\hline Beethoven... si tanco la tapa, que passa? & Escénico (parcialmente) & 1985 \\
\hline Roma & Escénico & 1996 \\
\hline Saó & Escénico & 2012 \\
\hline Retrovisor musical. 1+1 & Escénico & 2009 \\
\hline Pecatamonicatismarmolla Tua Tua, & Piano & 1979 \\
\hline Divertiment N" 1 en Re mayor & Piano & 2005 \\
\hline Transfer & Piano & 1968
\end{tabular}


"Squelette músical" (de Concert

\begin{tabular}{lll} 
Irregular) & Piano y voz & 1968 \\
\hline "L’écho" (de Concert Irregular) & Piano y voz & 1968 \\
\hline "Figures en cire" (de Concert Irregular) & Piano y voz & 1968 \\
\hline "La momie" (de Concert Irregular) & Piano y voz & 1968 \\
\hline "Hommage au vietcong" (de Concert & Piano y voz & 1968 \\
Irregular) & Piano y voz & 1966 \\
\hline "Suite Bufa" & Violin y Piano & 2010 \\
\hline
\end{tabular}


3.2.12. COINCIDENCIAS 
Debido a las características particulares, ya expuestas, de la obra de Carles Santos, en lo referente a sus títulos, incluyo una relación de obras, los cuales, pueden aparecer de formas distintas

TÍTULO

11.509 notes per a 2.001 músics

$88-3=85$

Acció amb estudiants de Toulouse $i$

l'Institut del Teatre de BCN

Agramunt

Alé vinaroçenc

Amb 2 dits

Amb 2 dits

Armandino 77

Barbylet o el silenci de la Nit Americana

Bienal Valencia (Fanfarria)

Brosa (Pel-licula)

Cabo

Cal-de-rón

Cantata

Cantata (Manresa)

Cantata (Manresa)

Carrer

Comediants

Conill amb caragols

Ebrofalia copulativa

El cant del duc

El fervor de la persevarencia

El gran teatro del Mundo

Els Monts

Entreacte

Es quan dormo...

Espectacle per a dança, veu i piano

\section{TÍTULO ALTERNATIVO}

Valencia (1) 2001

Tres notes

Pentagrama o esperma?

Carrer

Fanfarria

Piano moto

Ebrofalia copulativa

L'Aperitiu

La nit americana

Fanfàrria Biennal

Foc al cantir

Maquinofobia Pianolera

El gran teatro del Mundo

Flor d'escarabat

Els Monts

La veu assumpte/a

Agramunt

Piromusical

Vi Sonor

Piano moto

Gandía

Fervor

Cal-de-rón

Cantata (Manresa)

Tinc que ser castigat

X

Música per a dansa 
Fanfarria

Fanfàrria Biennal

Fervor

Flagelació e inmobiliaries

Flauta

Flor d'escarabat

Foc al cantir

Gandía

La nit americana

La veu assumpte/a

L'Aperitiu

Liria (Beetween, Liria i La Bisbal)

Lliria-Vinaròs

Maquinofobia Pianolera

Marrajo

Minimalet

Minimalet sur mer

Miro 93'

Música per a Cesc Gelabert

Música per a dansa

Música per a dansa

Música piano 2005

No al no

No al no

No al no

No al no

Obra conjunta

Olvido

Pasodoble-2

Peça a la mar

Pentagrama o esperma?
Alé vinaroçenc

Bienal Valencia (Fanfarria)

El fervor de la persevarencia

Flagelació e inmobiliaries

Liria (Beetween, Liria i La Bisbal)

Cantata

Brosa (Pel-licula)

El cant del duc

Barbylet o el silenci de la Nit Americana

Cantata (Manresa)

Armandino 77

Lliria-Vinaròs

Liria (Beetween, Liria i La Bisbal)

Cabo

Sevilla

Té fina la fina petxina de Xina?

Peça a la mar

Promenade Concert

No al no

No al no

Música per a Cesc Gelabert

Premis octubre '05

Obra conjunta

Música per a Cesc Gelabert

Música per a dansa

Sin título (bloc $\left.n^{\circ} 31\right)$

No al no

Roni

Sevilla

Minimalet sur mer

Acció amb estudiants de Toulouse $i$

l'Institut del Teatre de BCN

Ebrofalia copulativa 


\begin{tabular}{ll} 
Piano moto & Amb 2 dits \\
\hline Piromusical & Comediants \\
\hline Premis octubre '05 & Música piano 2005 \\
\hline Promenade Concert & Miro 93' \\
\hline Roni & Olvido \\
\hline Sardana Rusa & Miró 93' o Promenade Concert \\
\hline Schubert 8 - 10 1/2 & Schubertnacles humits' \\
\hline Schubertnacles humits' & Schubert 8 - 10 1/2 \\
\hline Sevilla & Pasodoble-2 \\
\hline Sevilla & Marrajo \\
\hline Somnis Marmolencs & Ulldecona \\
\hline Tinc que ser castigat & Entreacte \\
\hline Tres notes & 88 - 3 $=85$ \\
\hline Ulldecona & Somnis Marmolencs \\
\hline Valencia (1) 2001 & 11.509 notes per a 2.001 músics \\
\hline Vi Sonor & Conill amb caragols \\
\hline$X$ & Es quan dormo... \\
\hline & \\
\hline &
\end{tabular}


3.3. CATALOGACIÓN POR ORDEN ALFABÉTICO 
TÍTULO

CATALOGACIÓN VER TAMBIÉN

11.509 notes per a 2.001 músics

Fanfarria

\begin{tabular}{ll}
\hline 2 Pianos & Piano \\
\hline 3 Notes & Piano \\
\hline $58-57$ & Voz y Piano \\
\hline 6 Tenoras i Piano & Otras agrupaciones \\
\hline $682-3133$ Bufalo Minnesota & Otras agrupaciones \\
\hline $88-3=85$ & Piano \\
\hline A la Piscina Misericordia & Piano
\end{tabular}

Acció amb estudiants de Toulouse $i$

l'Institut del Teatre de BCN

Otras agrupaciones

Alé vinaroçenc Banda

Anem, anem, anem, anem a volar

Voz y Piano

Angels

Otras agrupaciones

Aquesta Es La Història Que Mai Podré

Oblidar; Una Trista Història D'Amor,

D'Un Amor Que Mai, Mai, Mai Podrà

Acabar

Voz y Piano

Argamchulla

Obra escénica

Argamchulla, Percussió

Obra escénica

Armandino 77

Piano

Arrosegant el Piano

Voz y Piano

Asdrubila

Obra escénica

Avigno 79

Voz

Barby Flute

Otras agrupaciones

Barbylet o el silenci de la Nit

Americana

Piano

Beethoven... si tanco la tapa, que passa?

(apunts)

Voz

Belmonte

Banda

Bloc de Progrès 6 de maig

Banda 
Boqueta amplificada

\begin{tabular}{|c|c|c|}
\hline Brosa (Pel·licula) & Otras agrupaciones & \\
\hline Brossalobrossotdebrossat & Obra escénica & \\
\hline Bujaraloz by night & Piano & \\
\hline Busca la Perdiu & Voz & \\
\hline Cal De Rón & Obra escénica & \\
\hline Calixa & Voz & \\
\hline Cant energetic & Voz & \\
\hline Cant i dança & Voz & \\
\hline Cantata & Otras agrupaciones & \\
\hline Cantata (Manresa) & Voz & \\
\hline Capitol 2 (Salut) & Piano & \\
\hline Capitol 6 (Comunió) & Voz & \\
\hline Carles Mor & Voz y Piano & \\
\hline Carrer & Otras agrupaciones & \\
\hline Castelló '99 & Otras agrupaciones & \\
\hline Chicha Montenegro & Obra escénica & \\
\hline Codi o estigma? & Piano & \\
\hline Comediants & Banda & \\
\hline Concert Irregular & Voz y Piano & Obra escénica \\
\hline Concert Toni Mira & Otras agrupaciones & \\
\hline Congrés de Cuina Catalana & Banda & \\
\hline Conill amb caragols & Voz & \\
\hline Conversa & Voz & \\
\hline Cosimans & Piano & \\
\hline Credit tonal & Obra escénica & Integrales \\
\hline Crits de Crist & Otras agrupaciones & \\
\hline Crits de Crist al Crist de Crits & & Exposición fotográfica \\
\hline Cuina & Voz y Piano & Otras agrupaciones \\
\hline Cuina catalana & Banda & \\
\hline Delta & Orquesta & \\
\hline Demana-ho & Voz & Voz y Piano \\
\hline
\end{tabular}


Desig

Dolçainers Carnaval 2001

Dorema-domare

Ebrofalia copulativa

El barbero de Sevilla

El Cant del Duc
Grupos cuerda

Otras agrupaciones

Voz

Piano

Obra escénica

Otras agrupaciones

El Compositor, la Cantant, el Cuiner $i$

la Pecadora

Obra escénica

El Fervor de la perseverància

Obra escénica

El Gran Teatro del Mundo

Obra escénica

El pont de Varsovia

Grupos cuerda

Integrales

El teu llit

Piano

Els Monts

Voz

Entreacte

Piano

Espectacle per a dança, veu i piano

Voz y Piano

F.N.A.C.

Banda

Fanfarria

Banda

Fanfàrria Biennal

Fanfarria

El Fervor de la

Fervor

Obra escénica

perseverància

Figasantos Fagotrop

Obra escénica

Fins l'últim llangostí (Peça 51)

Piano

Flagelació e inmobiliaries

Piano

Flauta

Otras agrupaciones

Flor d'escarabat

Voz y Piano

Foc al cantir

Otras agrupaciones

Fuga en la menor

Piano

Gandía

Banda

Otras agrupaciones

Hamlet

Otras agrupaciones

Inauguració

Orquesta

Inauguració

JJ. OO. Barcelona 92'

Otras agrupaciones Integrales

Katralla

Otras agrupaciones 
La Boqueta Amplificada

Obra escénica

La convalidació o la cançó del tremall Piano

La grenya de Pasqual Picanya

Obra escénica

La meua filla soc jo

Obra escénica

La moto

$\mathrm{Voz}$

La nit americana

Piano

La Pantera Imperial

Obra escénica

La porca $i$ vibràtica tecluria

Piano

La Primavera del Disseny

Voz y Piano

La si la la

Voz

La veu de la terra

Banda

La vinya dels artistes

Integrales

L'adeu de Lucrecia Borgia

Obra escénica

L'aperitiu

Piano

Laura

Voz y Piano

L'esplèndida vergonya

Obra escénica

Liria (Beetween, Liria i La Bisbal)

Otras agrupaciones

Lisistrata

Obra escénica

Lliria-Vinaròs

Banda

Lliure (Obra de Piano a considerar)

Piano

Lluïs-Anaïs

Otras agrupaciones

Llur Metals

Otras agrupaciones

Maquinofobia Pianolera

Otras agrupaciones

Marid relexionant al despatx

Grupos cuerda

Matar-ho

Otras agrupaciones

Medalles (Fanfarra)

Fanfarria

Medalles (Promenade)

Orquesta

Banda (Promenade)

Mediterranea 09'

Integrales

Minimalet Minimalot

Obra escénica

Minimalet sûr mer

Piano

Mirame

Otras agrupaciones

Miró 93'

Otras agrupaciones

Misa

Voz 


\begin{tabular}{lll} 
Misteri d'Elx & Banda & Integrales \\
\hline Morellar Morella & Banda & Voz \\
\hline Morellar Morella (Desfile) & Piano \\
\hline Música per a Cesc Gelabert & Piano \\
\hline Música per a dansa & Voz y Piano
\end{tabular}

Música per al IV centenari de

l'arribada de la relíquia de St. Sebastià

a Vinaròs

Voz

Musica per les victimes de la

intolerancia Banda

\begin{tabular}{|c|c|}
\hline Música Piano 2005 & Piano \\
\hline No al no & Piano \\
\hline Novela & Otras agrupaciones \\
\hline Obra conjunta & Piano \\
\hline Obra per a piano i cello & Grupos cuerda \\
\hline Octavi i Lidia & Piano \\
\hline Olvido & Otras agrupaciones \\
\hline Ona & Otras agrupaciones \\
\hline Pasodoble-2 & Banda \\
\hline Peça a la mar & Piano \\
\hline Peça Mexic 1979 -рeça 56- & Voz y Piano \\
\hline Peça per a Piano (I) & Piano \\
\hline Peça per a Piano (II) & Piano \\
\hline Peça per a Piano (III) & Piano \\
\hline Peça per a Piano (IV) & Piano \\
\hline Peça per a Piano (IX) & Piano \\
\hline Peça per a Piano $(V)$ & Piano \\
\hline Peça per a Piano (VII) & Piano \\
\hline Peça per a Piano (VIII) & Piano \\
\hline Peça per a Piano $(X)$ & Piano \\
\hline Peça per a Piano (XI) & Piano \\
\hline Peça per a Piano (VI) & Piano \\
\hline
\end{tabular}




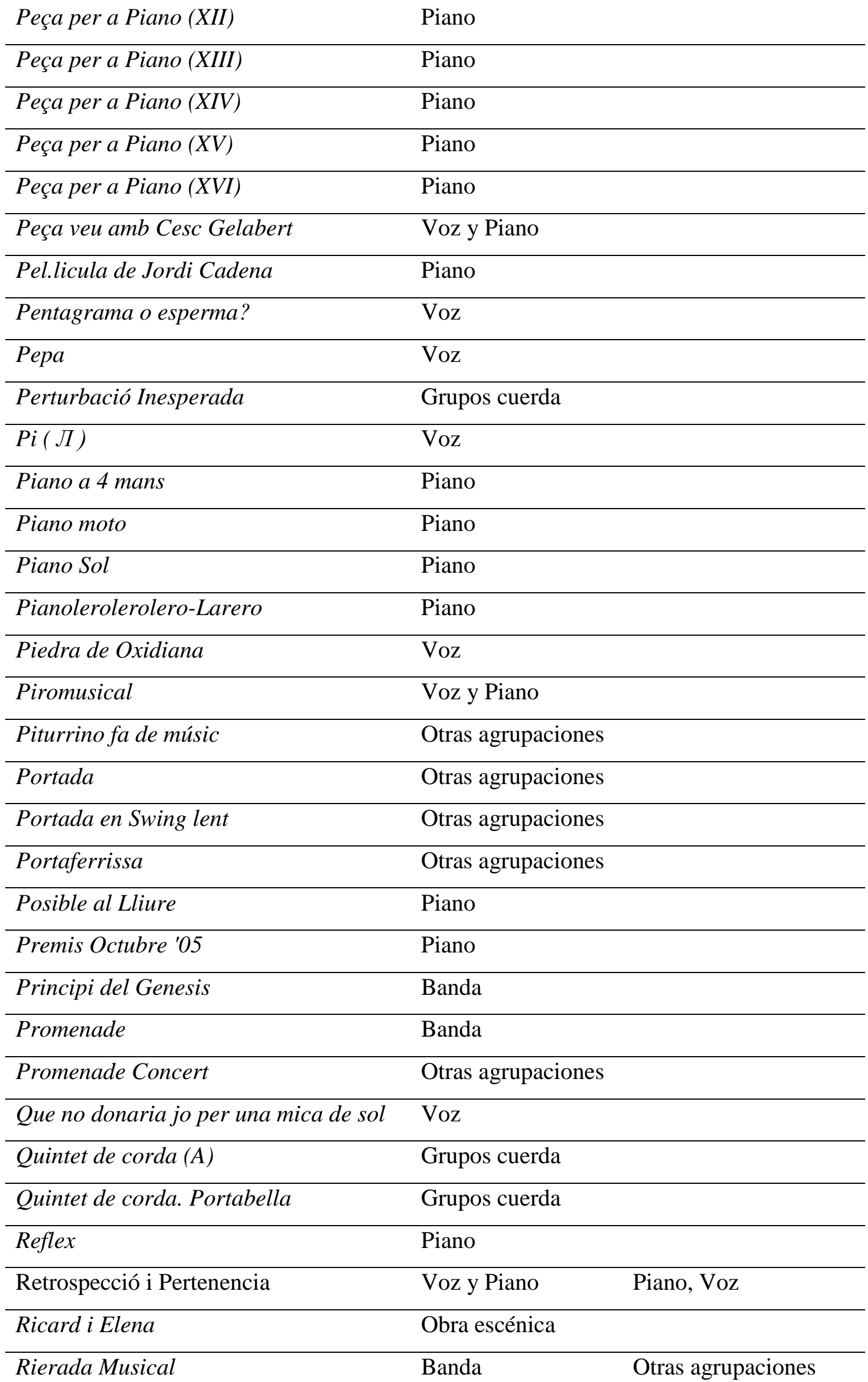




\begin{tabular}{|c|c|}
\hline Roni & Obra escénica \\
\hline Sama Samaruck, Samaruck Suck Suck & Obra escénica \\
\hline Sardana Gelabert & Otras agrupaciones \\
\hline Sardana Rusa & Otras agrupaciones \\
\hline Sauna de la Boqueta & Voz \\
\hline Schubert $8-101 / 2$ & Otras agrupaciones \\
\hline Schubertnacles humits & Obra escénica \\
\hline Segadors (versió Frankfurt) & Piano \\
\hline Serie 3-C & Piano \\
\hline Sevilla & Banda \\
\hline Sevilla (2) & Otras agrupaciones \\
\hline Si que té lo que té & Voz y Piano \\
\hline Somnis marmolencs & Banda \\
\hline Soprano i Tenora & Voz \\
\hline Sound Fight & Voz y Piano \\
\hline Té xina la fina petxina de Xina? & Obra escénica \\
\hline Tenora i Piano & Otras agrupaciones \\
\hline Tenores (anyadit) & Otras agrupaciones \\
\hline Textos escabetxats & Exposición fotográfica \\
\hline Tinc que ser castigat & Piano \\
\hline Tinc que tinc & Voz y Piano \\
\hline Tirant lo Blanc & Obra escénica \\
\hline Tocaticotocatá & Voz \\
\hline Tot queda en familia & Grupos cuerda \\
\hline Tramuntana Tremens & Obra escénica \\
\hline Tres notes & Otras agrupaciones \\
\hline Trio de corda & Grupos cuerda \\
\hline Trio instrumental & Otras agrupaciones \\
\hline Tutti & Otras agrupaciones \\
\hline Ulldecona & Banda \\
\hline Un cranc es un cranc (i y II parte) & Otras agrupaciones \\
\hline Un gat es un gat & Voz \\
\hline
\end{tabular}


Valencia premis octubre-95

Banda

\begin{tabular}{lll}
\hline Vi Sonor & Voz & \\
\hline Video Banyera & Voz & \\
\hline Violí sobre fons de trémolos & Grupos cuerda & \\
\hline & & $\begin{array}{l}\text { Piano (Pelicula de } \\
X\end{array}$ \\
\hline Xavier Riba & Grupos cuerda & Jordi Cadena) \\
\hline & Grupos cuerda & \\
\hline & & Piano (A la piscina \\
& Grupos cuerda & Misericordia Ubach) \\
\hline
\end{tabular}


3.4. CATALOGACIÓN CRONOLÓGICA 
Se expone a continuación la catalogación cronológica de la obra del autor, atendiendo a la información descubierta. Se debe tener en cuenta que esta catalogación, como se apuntaba anteriormente, es incompleta, complicada y puede resultar inexacta por las razones esgrimidas:

- Los originales son, en muchas ocasiones, copias manuscritas de una primera versión, hoy en día desaparecida.

- El poco apego que el autor tuvo, en un principio, por registrar sus obras o guardar sus originales.

- Los cambios existentes en la titulación de sus obras.

- La indeterminación y/o revisión de sus obras a lo largo del tiempo.

Es por ello que ante piezas con distinto título y misma música, se ha referenciado la fecha de su estreno con el título correspondiente. Así pues piezas como Armandino '77 o L'aperitiu, que son idénticas, constan 2 fechas diferentes que se corresponden a su estreno como tales.

Con todo ello, la catalogación resultante sería la siguiente.

S. d.

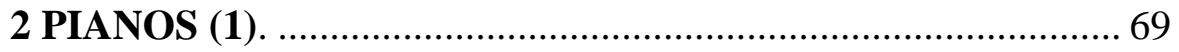

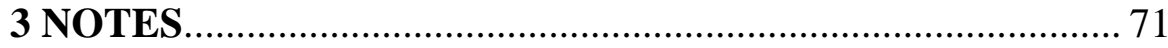

88 - 3 = 85

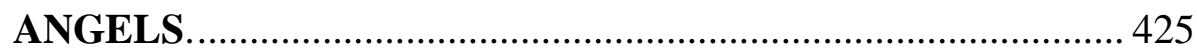

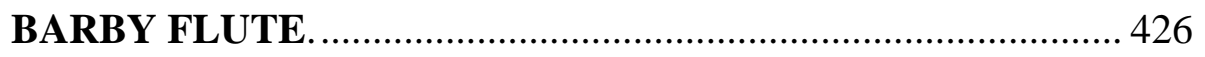

BLOC DE PROGRÈS 6 DE MAIG. .......................................... 270

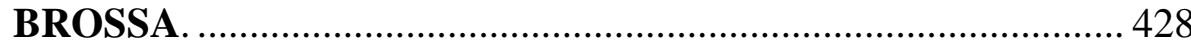

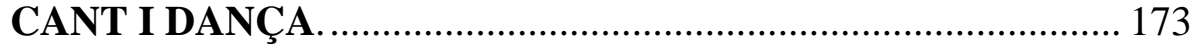

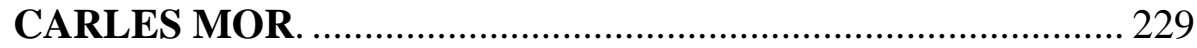

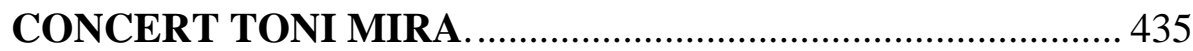

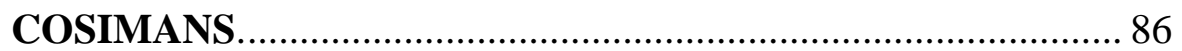

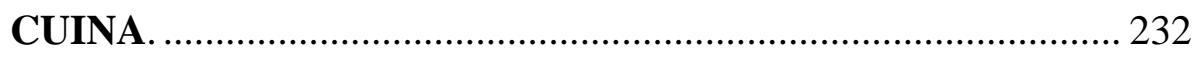

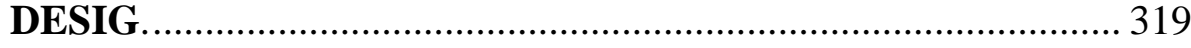

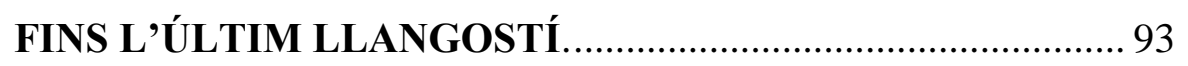

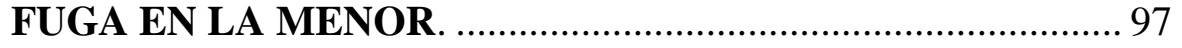

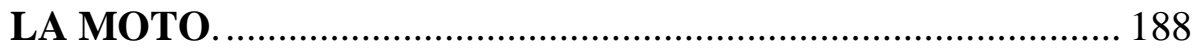




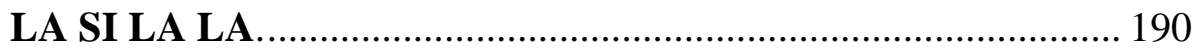

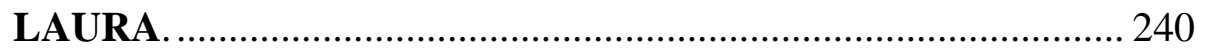

LIRIA (BEETWEEN, LIRIA I LA BISBAL) .............................. 453

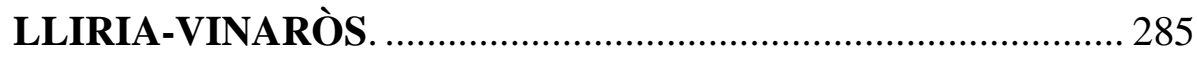

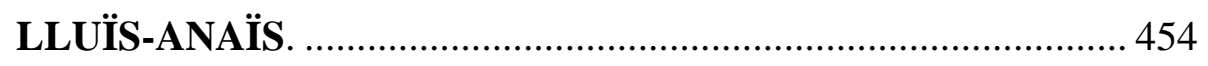

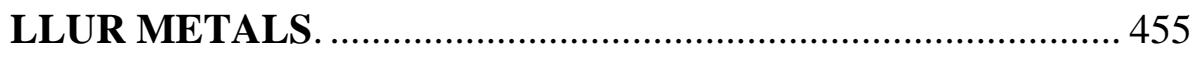

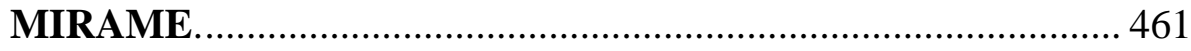

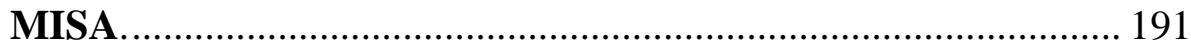

MÚSICA PER A CESC GELABERT ........................................ 107

MÚSICA PER A LA DANSA..................................................... 109

MÚSICA PER A VEU SOLA..................................................... 242

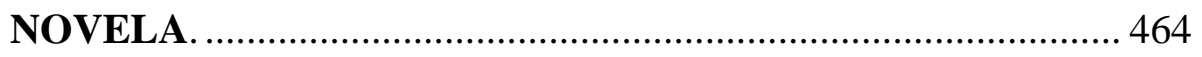

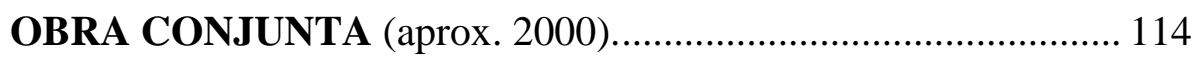

OBRA PER A PIANO I CELLO ............................................ 322

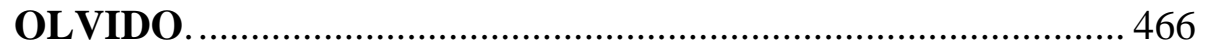

PEÇA PER A PIANO (I) ......................................................... 120

PEÇA PER A PIANO (II) ..................................................... 122

PEÇA PER A PIANO (III) ................................................... 123

PEÇA PER A PIANO (IV) . .................................................... 124

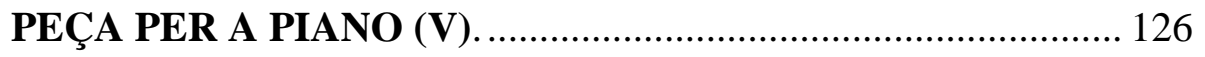

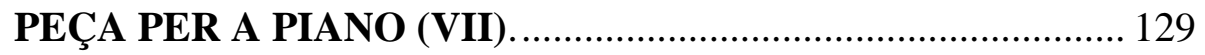

PEÇA PER A PIANO (VIII). .................................................... 130

PEÇA PER A PIANO (IX). .......................................................... 131

PELICULA DE JORDI CADENA. ............................................ 143

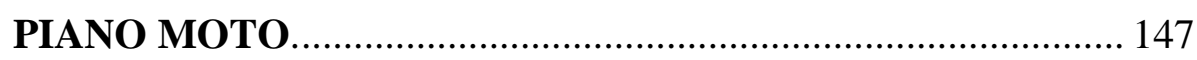

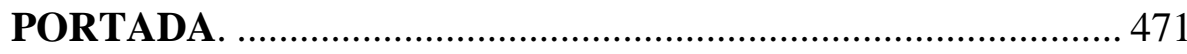

PORTADA EN SWING LENT. ............................................. 473

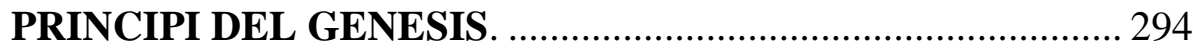

QUINTET DE CORDA. PORTABELLA.................................. 339

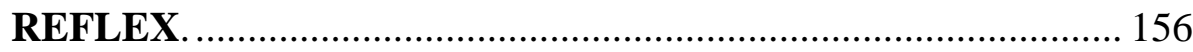

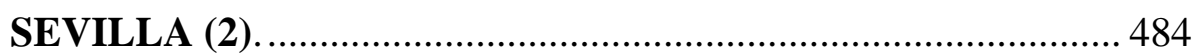

TOT QUEDA EN FAMILIA ................................................. 210

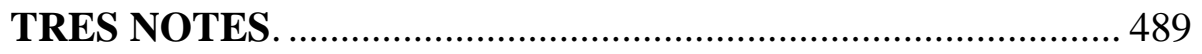

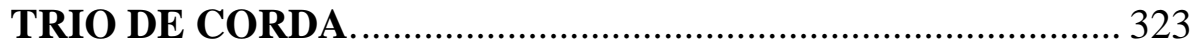




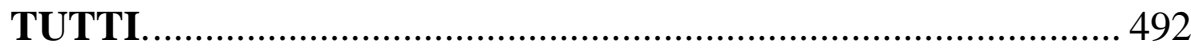

VIOLÍ SOBRE FONS DE TRÉMOLOS. .................................... 333

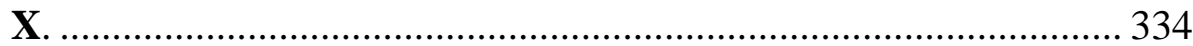

Y

1967

CONCERT IRREGULAR. $230,355,408$

1970

PIANO SOL (aprox.). 149

1975

CALIXA. (aprox.) 171

PEÇA PER A PIANO (VI) (aprox.)........................................... 128

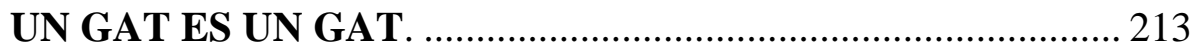

1977

682-3133 BUFALO MINNESOTA............................................ 421

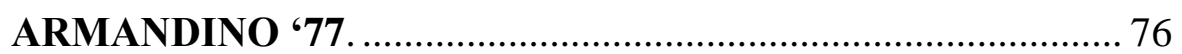

1978

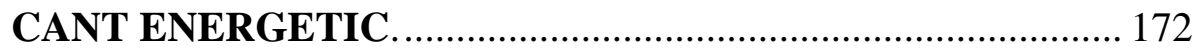

DOREMA-DOMARE (aprox.)..................................................... 184

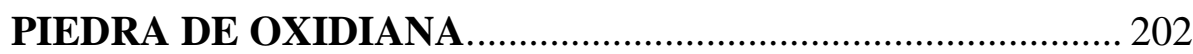

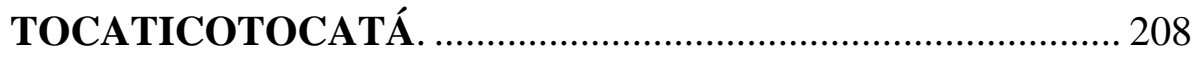

1979

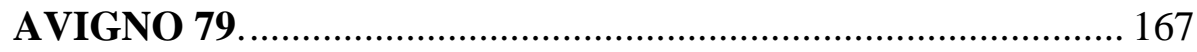

OCTAVI I LIDIA (FRAGMENT DE BEETHOVEN) .............. 116

PEÇA MEXIC 1979 -PEÇA 56-..................................................... 244

1980

ARROSEGANT EL PIANO_................................................... 227

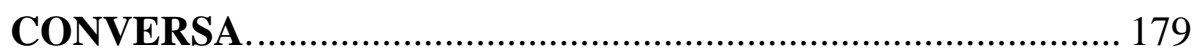




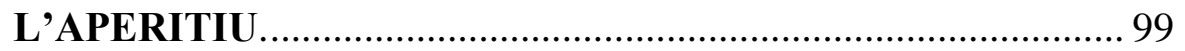

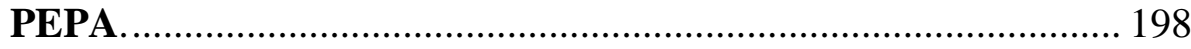

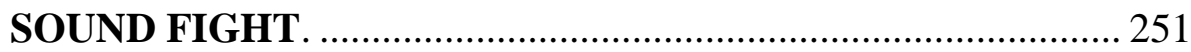

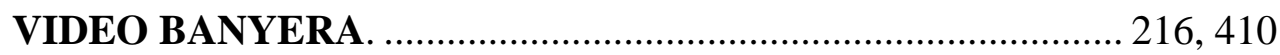

1981

58-57 221

BARBYLET O EL SILENCI DE LA NIT AMERICANA......... 78

LA NIT AMERICANA 103

1982

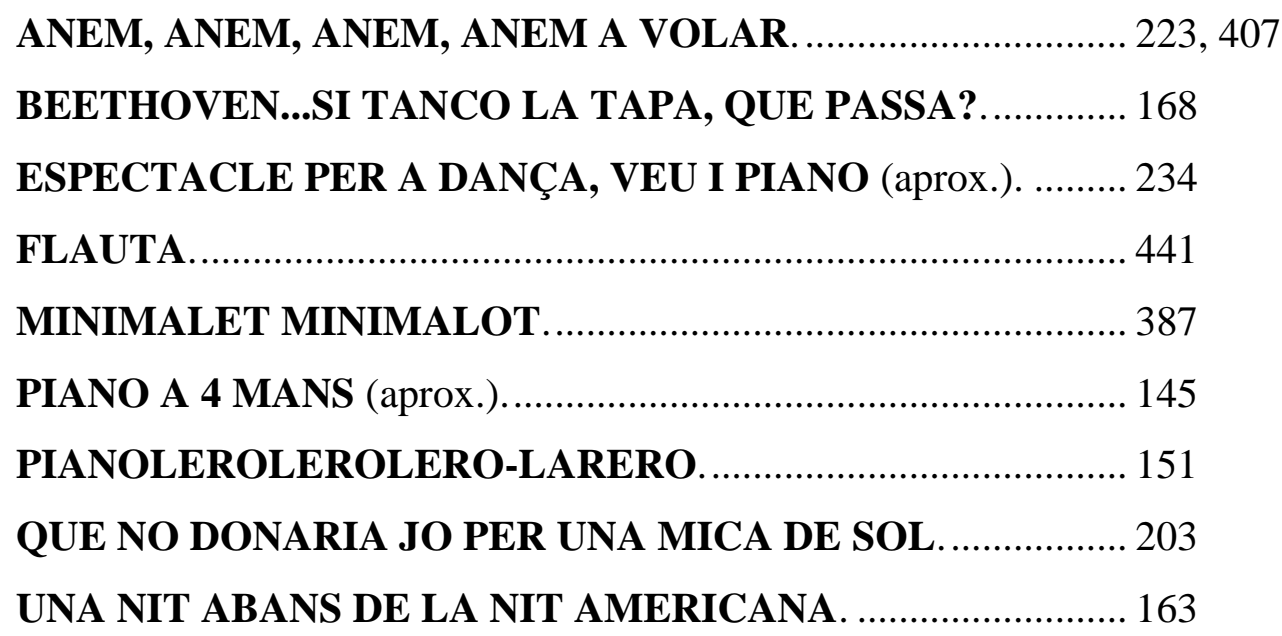

1983

LA CONVALIDACIÓ O LA CANÇÓ DEL TREMALL............ 101

SI QUE TÉ LO QUE TÉ........................................................... 249

TÉ XINA LA FINA PETXINA DE XINA. ................................ 398

1984

AQUESTA ES LA HISTÒRIA QUE MAI PODRÉ OBLIDAR; UNA TRISTA HISTÒRIA D'AMOR, D'UN AMOR QUE MAI, MAI, MAI PODRÀ ACABAR. 225

BUJARALOZ BY NIGHT. 80

1985

ARGANCHULLA, ARGANCHULLA-GALLAC 343 
DEMANA-HO (aprox.).................................................... 180, 233

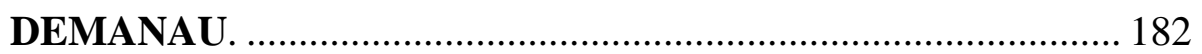

LA BOQUETA AMPLIFICADA................................................ 371

PEÇA PER A PIANO (XI) (aprox.)............................................ 134

PEÇA PER A PIANO (XII) (aprox.)........................................... 136

PEÇA PER A PIANO (XIII) (aprox.). ......................................... 137

PEÇA PER A PIANO (XIV) (aprox.).......................................... 138

PEÇA PER A PIANO (XV) (aprox.). ............................................ 140

PEÇA PER A PIANO (XVI) (aprox.)........................................... 142

SAUNA DE LA BOQUETA. ...................................................... 204

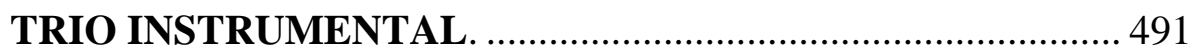

1986

BUSCA LA PERDIU (aprox.)................................................... 170

CREDIT TONAL. ............................................................ 357, 413

MARID RELEXIONANT AL DESPATX................................. 329

PEÇA PER A PIANO (X) (aprox.)........................................... 132

PEÇA VEU AMB CESC GELABERT ...................................... 246

PERTURBACIÓ INESPERADA............................................. 335

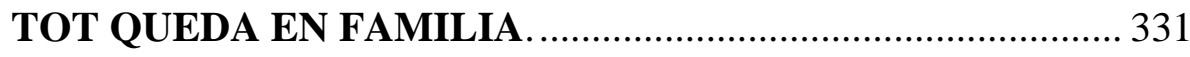

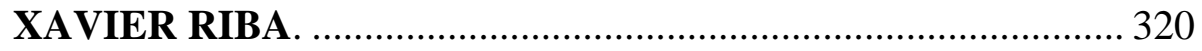

1987

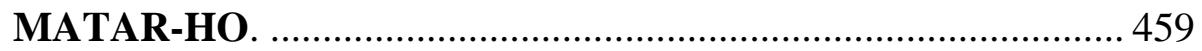

1988

A LA PISCINA MISERICORDIA........................................ 74

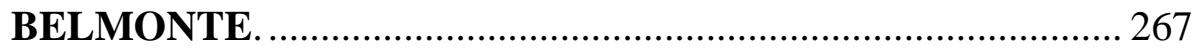

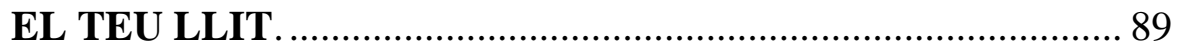

FLAGELACIÓ E INMOBILIARIES ........................................ 95

MINIMALET SÛR MER. .................................................... 106, 408

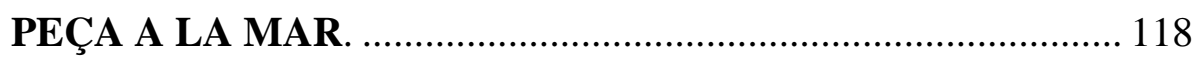

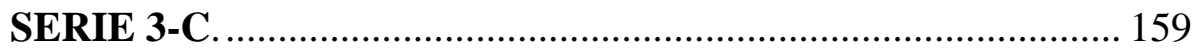


1989

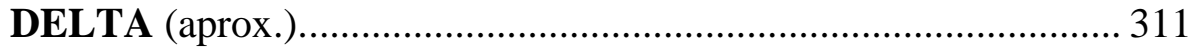

EL PONT DE VARSOVIA .................................................. 327, 337, 413

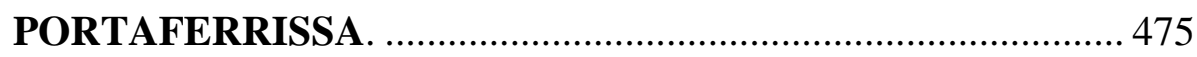

TRAMUNTANA TREMENS ................................................... 402

1990

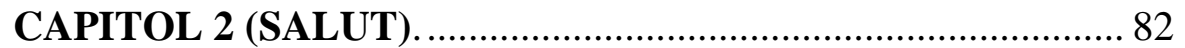

CAPITOL 6 (COMUNIÓ) (aprox.). .............................................. 176

1991

LA GRENYA DE PASQUAL PICANYA............................... 373

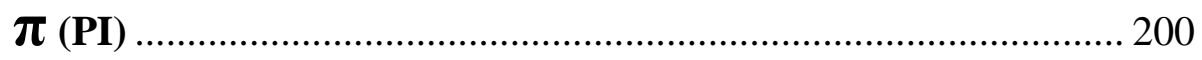

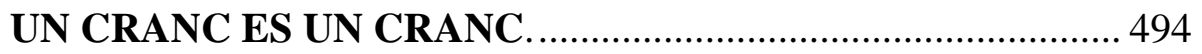

1992

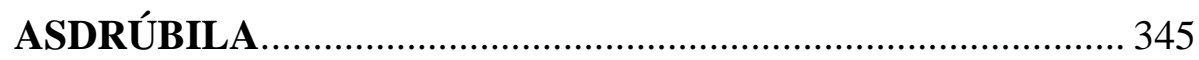

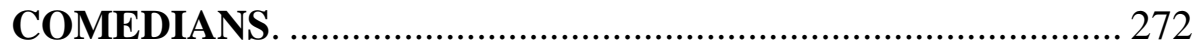

JJ. OO. BARCELONA '92 ................................................. 414, 448

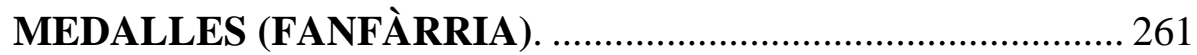

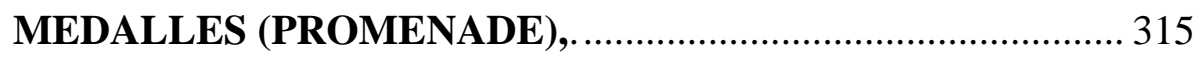

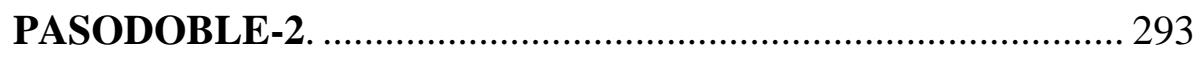

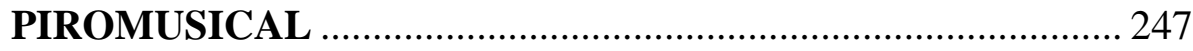

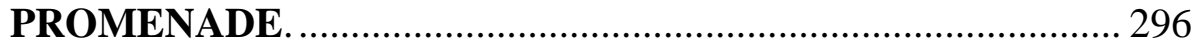

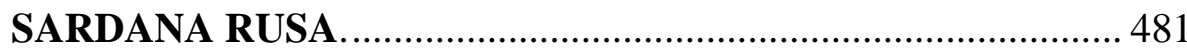

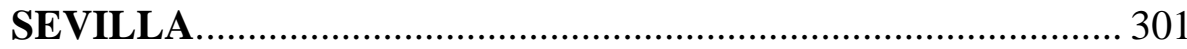

1993

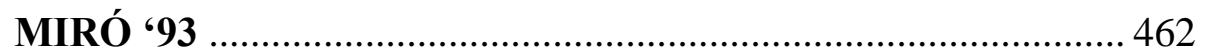

1994

LA PORCA I VIBRÀTICA TECLURIA ….................................. 104

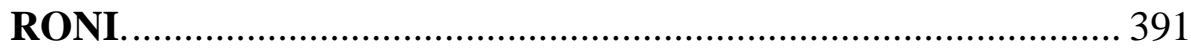


1995

CONGRÉS DE CUINA CATALANA …....................................... 274

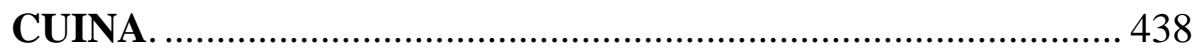

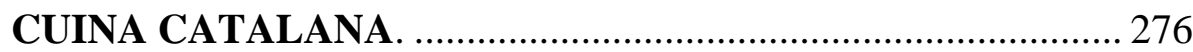

L'ESPLÈNDIDA VERGONYA DEL FET MAL FET. .............. 382

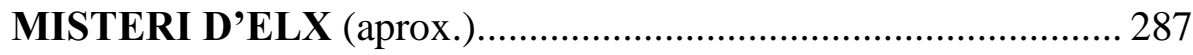

MUSICA PER LES VICTIMES... (aprox.). ............................... 291

VALENCIA PREMIS OCTUBRE ‘95 ..................................... 307

1996

FIGASANTOS FAGOTROP: missatge ................................. 368

1997

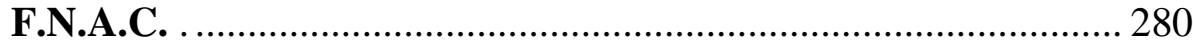

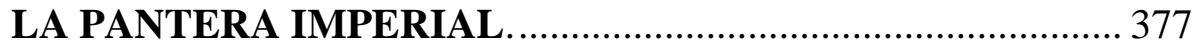

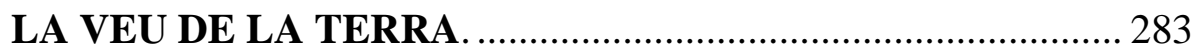

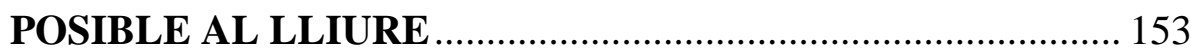

1998

CODI O ESTIGMA? 84

1999

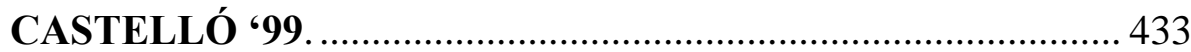

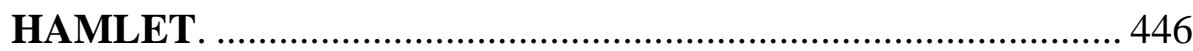

LA PRIMAVERA DEL DISSENY ......................................... 238

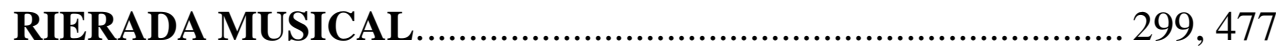

2000

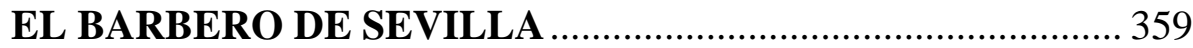

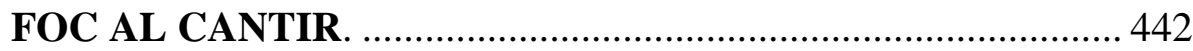

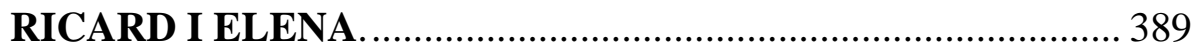


2001

11.509 NOTES PER A 2.001 MÚSICS ….................................... 257

DOLÇAINERS CARNAVAL 2001.............................................. 439

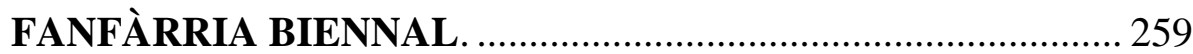

L'ADEU DE LUCRECIA BORGIA.......................................... 379

2002

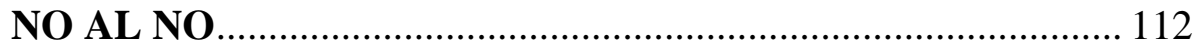

SAMA SAMARUCK, SAMARUCK SUCK SUCK. ................... 393

2003

EL COMPOSITOR, LA CANTANT, EL CUINER I ............... 361

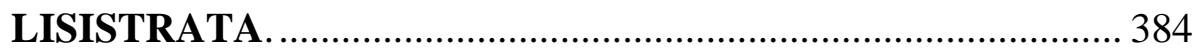

PENTAGRAMA O ESPERMA？ ................................................ 196

2004

ACCIÓ AMB ESTUDIANTS DE TOULOUSE I L'INSTITUT DE TEATRE

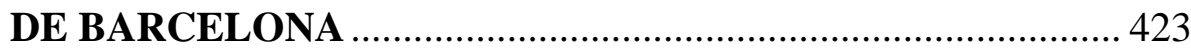

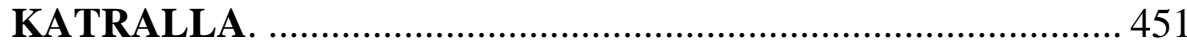

2005

LA MEUA FILLA SOC JO_................................................. 375

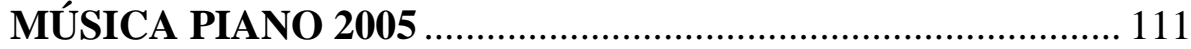

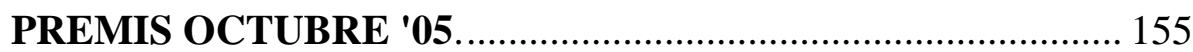

2006

EL FERVOR DE LA PERSEVERÈNCIA.................................. 364

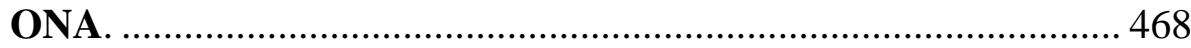

2007

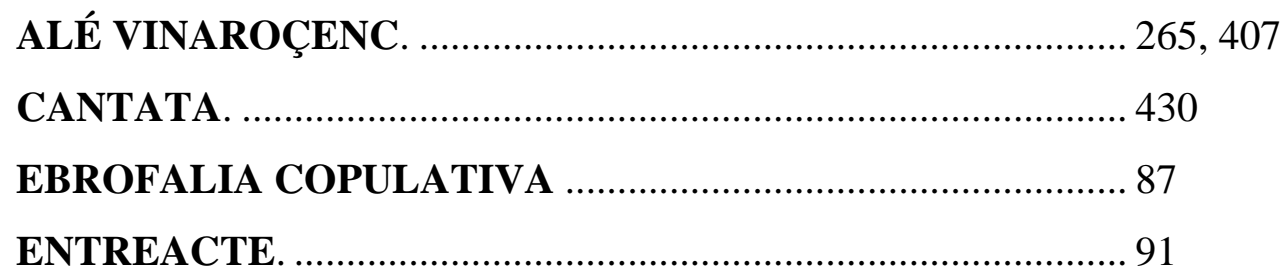




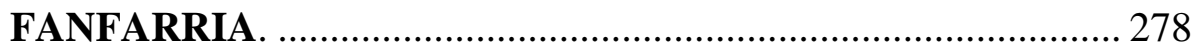

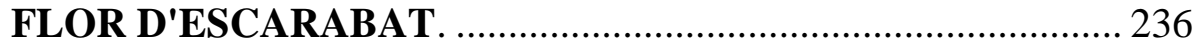

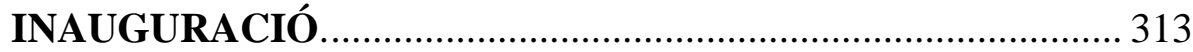

SEGADORS (VERSIÓ FRANKFURT) ................................... 157

TINC QUE SER CASTIGAT PER NO HAVER.... .................. 161

TINC QUE TINC.... ........................................................ 253

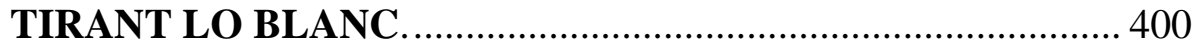

2008

BROSSALOBROSSOTDEBROSSAT . ..................................... 350

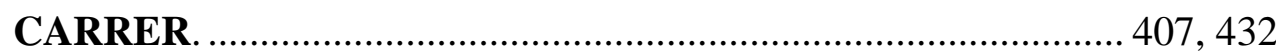

2009

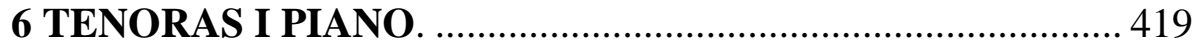

CANTATA (MANRESA) ........................................................... 174

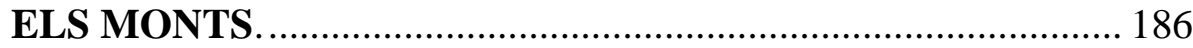

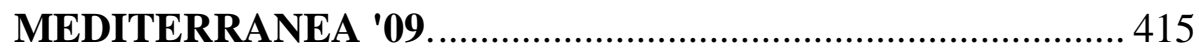

PECATAMONICATISMARMOLLA TUA TUA....................... 409

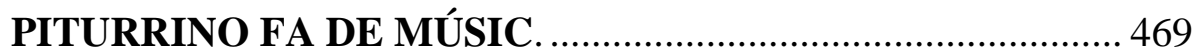

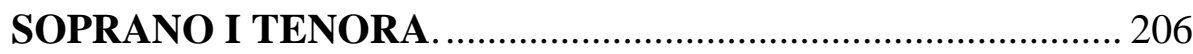

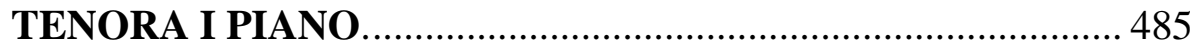

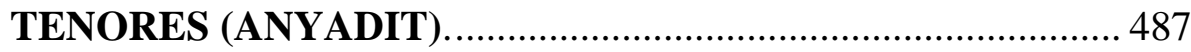

2010

CHICHA MONTENEGRO GALLERY .................................... 353

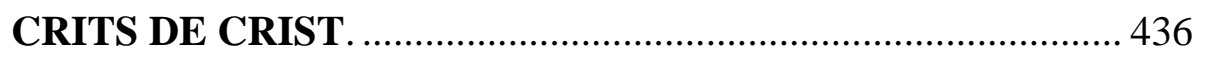

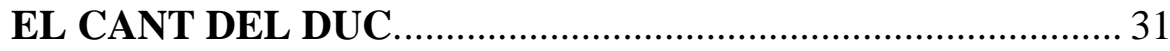

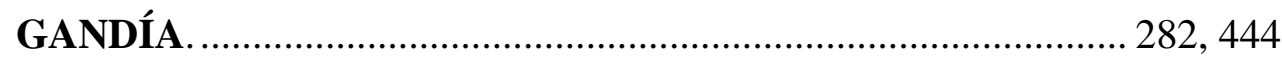

MÚSICA PER AL IV CENTENARI DE L'ARRIBADA DE LA RELÍQUIA

DE ST. SEBASTIÀ A VINARÒS.................................................. 194

SOMNIS MARMOLENCS ..................................................... 304

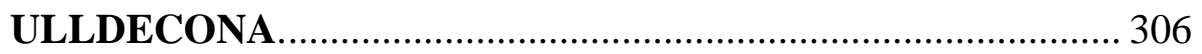


2011

CONILL AMB CARAGOLS 177

LA VINYA DELS ARTISTES. ....................................................... 414

MAQUINOFOBIA PIANOLERA. 408,457

MORELLAR MORELLA (desfile). 192,408

MORELLAR MORELLA. 289,415

SARDANA GELABERT. 300,479

VI SONOR. 214,409

2012

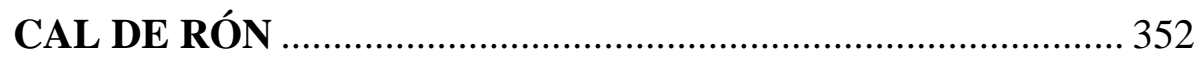

EL GRAN TEATRO DEL MUNDO. .......................................... 366

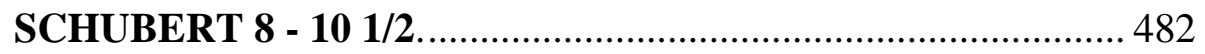

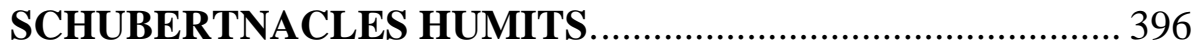




\section{4.- Discografía}




\section{DISCOGRAFÍA}

Carles Santos: Piano (Edigsa, 1977)

Voicetracks (R.A. Taylor, 1981)

○ To-ca-ti-co-to-ca-tà

○ Cant enegètic

○ Pepa

- La sargantaneta

- Conversa

○ Autoretrat

Pianotrack (L. Música, 1984)

- Bujaraloz By Night

- Pianolerolerolero-Larero

- Armandino 77

- Una Nit Abans De La Nit Americana

- La Nit Americana

- La Convalidació O La Cançó Del Tremall

- Fragment Del Properdisc

Pertorbació Inesperada (L. Música, 1986)

- Aquesta Es La Història Que Mai Podré Oblidar; Una Trista Història D'Amor, D'Un Amor Que Mai, Mai, Mai Podrà Acabar

○ Sauna

- La Boqueta Amplificada

- Xavier Riba

○ Marit Reflexionant Al Despatx

- Pertorbació Inesperada

Carles Santos piano (Grabaciones Accidentales, 1988)

> Five Voices - Greetje Bijma/Shelley Hirsch/Anna Homler/David Moss/Carles Santos (Intakt Records, 1989)

$>$ Belmonte (Virgin, 1990)

○ Unisono

○ Empeño

○ Tres Mujeres 
○ El Toro

○ Esplendor del Miedo y la Violencia

- Primer Toque y Estructura de la Arrogancia

- Segundo Toque y Solo de Aliento con Banderillas

○ Pre-pasodoble

- Pasodoble

○ Tercer Toque

○ Muerte

Música para las Ceremonia Olímpicas (OTR, 1993)

- Obertura ¡Hola!

- Fanfarria Promenade (Entrega De Medallas)

- Fanfarria Atletas

- Fanfarria Maragall

- Fanfarria Medieval

- Fanfarria Coob

- Fanfarria Juramento

○ Fanfarria Montjuïc

- Fanfarria Antorcha

- Fanfarria del Rey

- Fanfarria Maratón

- Fanfarria Clausura

- Marrajo

- La Notaria De Utrera

○ Piromusical

Promenade Concert (E. Privada, 1993)

La porca i vibriàtica tecluria (Plusmusic, 1994)

Himne (K-Industria Cultural, 1995)

> Un dit és un dit, (CD inclós en el número 9 de la revista "Cave Canis", Barcelona 1999).

> Obertura Musical Para Una Bienal (2001)

○ Fanfàrria musical

○ 11.509 notes per a 2001 músics

L'adéu de Lucrècia Borja (Universitat de València, 2001) 
Sama Samaruck Suck Suck (Ópera-Circ de Carles Santos) (K. Indústria Cultural, 2002)

Lo bo ve per baix ${ }^{78}$ (Fundació Caixa Vinaròs, 2014)

En el Anexo 9.2.3., Audios, en disco compacto, se encuentran las grabaciones de los siguientes trabajos:

Voicetracks (R.A. Taylor, 1981)

Pianotrack (L. Música, 1984)

Pertorbació Inesperada (L. Música, 1986)

Carles Santos piano (Grabaciones Accidentales, 1988)

$>$ Belmonte (Virgin, 1990)

> Música para las Ceremonia Olímpicas (OTR, 1993)

$>$ Himne (K-Industria Cultural, 1995)

>bertura Musical Para Una Bienal (2001)

El resto de trabajos del autor no han podido ser incluidos en la presente tesis por el carácter comercial de los mismos.

\footnotetext{
${ }^{78}$ Trabajo compuesto por 4 CD's, con 25 pistas de audio y $2 \mathrm{~h}$. 55 ' de música “de piano de Santos per Santos", tal y como consta en la portada. Solamente 2 de las 25 piezas tiene título. Según consta en la contraportada y en palabras del autor, "Els títols de les obres han anant desapareixent entre 1971 i 2014. L'ordre dels temes és rigorosament aproximatiu".
} 
5.- Filmografía 


\section{FILMOGRAFÍA}

Se presenta, por orden cronológico, la filmografía del autor, de la cual es autor de la música de la misma, siendo, en muchas ocasiones, asimismo el intérprete.

\section{1.- Largometrajes cine}

$>$ s. reg. (productor) y s. reg. (director). (1967): L'apat. [cinta cinematográfica]. España. Films 59.

$>$ s. reg. (productor) y Portabella, P. (director). (1967): No compteu amb els dits. [cinta cinematográfica]. España. Films 59.

$>$ s. reg. (productor) y Portabella, P. (director). (1968): Nocturn 29*. [cinta cinematográfica]. España. Films 59.

$>$ s. reg. (productor) y Portabella, P. (director). (1970): Vampir cuadecuc. [cinta cinematográfica]. España. Films 59

$>$ s. reg. (productor) y Portabella, P. (director). (1975): Informe general. [cinta cinematográfica]. España. s. reg.

$>$ s. reg. (productor) y Cadena, J. (director). (1977): L'obscura història de la cosina Montse. [cinta cinematográfica]. España. Ona Films.

$>$ s. reg. (productor) y Brossa, J. (director). (1978): El pianista y la flautista. [cinta cinematográfica]. España. s. reg.

$>$ s. reg. (productor) y Herralde, G. (director). (1981): Vértigo en Manhattan (Jet Lag). [cinta cinematográfica]. España. Figaro Films.

s. reg. (productor) y Cadena, J. (director). (1981): Barcelona Sud. [cinta cinematográfica]. España. Figaro Films.

$>$ Pérez Giner, J. A. (productor) y Bellmunt, F. (director). (1984): Pa d'àngel. [cinta cinematográfica]. España. Ópalo Films.

$>$ s. reg. (productor) y Cadena, J. (director). (1988): És quan dormo que hi veig clar. [cinta cinematográfica]. España. Septimània Films.

$>$ González, J. A. (productor) y Portabella, P. (director). (1989): Pont de Varsovia. [cinta cinematográfica]. España. Films 59.

$>$ Herrero, G. (productor) y Gas, M. (director). (1998): El pianista. [cinta cinematográfica]. España. Tornasol Films. 
*La música fue compuesta por Josep Maria Mestres Quadreny; pero se da por sentado (así lo han declarado siempre Santos y Portabella) que las aportaciones y sugerencias de Santos fueron importantes.

\section{2.- Cortometrajes}

Maeght, A. (productor) y Portabella, P. (director). (1969): Miró l'altre. [cinta cinematográfica]. Francia. s. reg.

$>$ Maeght, A. (productor) y Prévost, C. (director). (1969): Tàpies. [cinta cinematográfica]. Francia. Ed. Fondation Maeght

$>$ Maeght, A. (productor) y Prévost, C. (director). (1969): Gaudí. [cinta cinematográfica]. Francia. Ed. Fondation Maeght

$>$ s. reg. (productor) y Portabella, P. (director). (1970): Poetes catalans. [cinta cinematográfica]. España. s. reg.

$>$ s. reg. (productor) y Prévost, C. (director). (1971): Miró, litographie d'une affiche. [cinta cinematográfica]. Francia. Ed. Fondation Maeght

$>$ s. reg. (productor) y Bury, P y Prévost, C. (directores). (1971): 8500 tonnes de fer. [cinta cinematográfica]. Francia. s. reg.

$>$ s. reg. (productor) Bellmunt, F. (directores). (1971): Semejante a Pedro. [cinta cinematográfica]. España. Vertigo P. C..

$>$ s. reg. (productor) Rossell, B. (directores). (1971): Calidoscopi. [cinta cinematográfica]. España. s. reg.

> s. reg. (productor) y Portabella, P. (director). (1972): Umbracle. [cinta cinematográfica]. España. s. reg.

$>$ s. reg. (productor) y Leure, C. y Lecca, F. (directores). (1972): Ubac, un portrait. [cinta cinematográfica]. Francia. s. reg.

$>$ Portabella, P. (productor) y Portabella, P. (director). (1972): Cantants 72. [cinta cinematográfica]. España. s. reg.

> 1973.- Advocats laboralistes (Pere Portabella)

$>$ Portabella, P. (productor) y Portabella, P. (director). (1974): Art a Catalunya. [cinta cinematográfica]. España. Films 59.

$>$ s. reg. (productor) y Prévost, C. (director). (1974): Miró parle. [cinta cinematográfica]. Francia. Ed. Fondation Maeght 
Maeght, A. (productor) y Prévost, C. (director). (1975): L'aròme du chemin: Eduardo Chillida. [cinta cinematográfica]. Francia. Ed. Fondation Maeght

$>$ s. reg. (productor) y Durán, C. (director). (1978): El barri del Besós. [cinta cinematográfica]. España. Institut de Cinema Catalá.

s. reg. (productor) y Villaronga, A. (director). (1979): Laberint. [cinta cinematográfica]. España. Anta Films.

$>$ s. reg. (productor) y Codina, J. (director). (1979): La delinqüència. [documental]. España. Institut de Cinema Catalá.

$>$ s. reg. (productor) y Codina, J. y Güell, J. (directores). (1979): Setmana de la sanitat. [documental]. España. Institut de Cinema Catalá.

s. reg. (productor) y Cisquella, G. y Ventura, P. (directores). (1979): L'Ajuntament (de Barcelona). [documental]. España. Institut de Cinema Catalá.

$>$ s. reg. (productor) y Durán, C. (director). (1979): L'agressió quotidiana. [cinta cinematográfica]. España. Institut de Cinema Catalá.

$>$ s. reg. (productor) y Durán, C. (director). (1981): L'assemblea de Catalunya. [cinta cinematográfica]. España. Institut de Cinema Catalá.

$>$ s. reg. (productor) y Passola, I. (director). (1982): Eleccions a Las Cortes 28-1082. [documental]. España. s. reg.

$>$ s. reg. (productor) y Roqué, M. E. (director). (1985): Piedraperla. [cinta cinematográfica]. España. s. reg.

$>$ s. reg. (productor) y Corominas, A. (directora). (1989): Romàntic. [cinta cinematográfica]. España. Lateco S. A.

$>$ s. reg. (productor) y Colell, J. (directora). (1991): Clara foc. [cinta cinematográfica]. España. Septimània Films.

$>$ Martí, J. (productor) y Portabella, P. (director). (1992): Art a Catalunya. [documental]. España. Institut de Cinema Catalá.

$>$ s. reg. (productor) y Amat, F. (director). (2000): Foc al Cantir. [cinta cinematográfica]. España. Ovideo TV S. A. 
5.3.- Filmografía como realizador (todo son cortos)

s. reg. (productor) y Santos, C. (director). (1967): L'apat. [cinta cinematográfica]. España. Films 59.

$>$ s. reg. (productor) y Santos, C. (director). (1967): L'espectador. Habitació amb rellotge. La llum. Conversa. [cinta cinematográfica]. España. Films 59

$>$ s. reg. (productor) y Santos, C. (director). (1968): La cadira. [cinta cinematográfica]. España. s. reg.

$>$ s. reg. (productor) y Santos, C y Portabella, P. (directores). (1969): Preludi de Chopin, Opus $28 n^{\circ} 7$. [cinta cinematográfica]. España. s. reg.

$>$ s. reg. (productor) y Santos, C y Portabella, P. (directores). (1970): Play-back. [cinta cinematográfica]. España. s. reg.

$>$ s. reg. (productor) y Santos, C y Portabella, P. (directores). (1970): Acció Santos. [cinta cinematográfica]. España. s. reg.

> Maeght, A. (productor) y Santos, C y Prévost, C. (directores). (1973): Miró sculpteur. [cinta cinematográfica]. Francia. s. reg.

$>$ Maeght, A. (productor) y Santos, C y Prévost, C. (directores). (1973): Miró, un portrait. [cinta cinematográfica]. Francia. s. reg.

$>$ s. reg. (productor) y Santos, C y Portabella, P. (directores). (1974): Preludi de Chopin, Opus $28 n^{o} 18$. [cinta cinematográfica]. España. s. reg.

$>$ s. reg. (productor) y Santos, C. (director). (1977): El pianista i el conservatori. [cinta cinematográfica]. España. TVE.

$>$ s. reg. (productor) y Santos, C. (director). (1977): 682-3133 Bufalo Minnesota. [cinta cinematográfica]. España. s. reg.

$>$ s. reg. (productor) y Santos, C. (director). (1978): Peça per a quatre pianos. [cinta cinematográfica]. España. TVE.

$>$ Corominas, P. (productor) y Santos, C. (director). (1979): La Re Mi La. [cinta cinematográfica]. España. s. reg.

$>$ s. reg. (productor) y Santos, C. (director). (1979): Divertimento $n^{o} 1$ en Re Mayor. [cinta cinematográfica]. España. s. reg. 


\section{4.- Videos}

Se pueden encontrar algunos videos de obras de Santos en la siguiente dirección:

http://artesescenicas.uclm.es/index.php?sec=video previa licencia del autor.

Asimismo y en otras plataformas (http://www.imdb.com/, http://www.filmoteca.org/, youtube, etc), existen fragmentos de representaciones escénicas o acciones musicales de Santos, algunas de ellas catalogadas en esta filmografía. De entre todos los trabajos audiovisuales de Santos realizamos un extracto en formato video, a continuación. Dado que no es parte fundamental de este trabajo, no nos adentraremos más en ellos, dejando esta parte como una propuesta de futuras investigaciones. De la mayoría de ellos, los no catalogados según las normas APA, existe solamente referencia.

Fundació Caixa Vinaròs [fundaciocaixavinaros] (1981, s. d., s. d) To-ca-ti-co-to$c a$-ta. [archivo de video]. Recuperado de: https://www.youtube.com/watch?v=fGCisW5y_pU

> 1981.- Música en viu (María Muxart)

$>$ 1982.- Que no donaría jo per una miqueta de sol (Lluís M. Güell)

Archivo Artea [mataderomadrid] (1982, s. d., s. d.), Anem, anem, anem a volar. [archivo de video]. Recuperado de https://www.youtube.com/watch?v=VYZepfjRshA y de http://www.rtve.es/alacarta/videos/imprescindibles/imprescindibles-carlessantos/2787834/.

$>$ 1985.- Cabaret Voltaire. Homenatge a Marcel Duchamp.

> Radio Televisión Española [rtve] (1987, s. d., s. d.), Buenos días, Madrid. [archivo de video]. Recuperado de http://www.rtve.es/alacarta/videos/imprescindibles/imprescindibles-carlessantos/2787834/ (fragmento)

$>$ Huerga, M. [manuelhuerga] $(1984,6,15)$, Minimalet sur mer, [archivo de video]. Recuperado de: http://www.dailymotion.com/video/xkuefd_estoc-depop-carles-santos-minimalet-sur-mer-ep-22-15-06-84_tv

> Arts Santa Mónica [artssantamonica] (2009, abril, 1), y Pecatamonicatismarmolla tua tua. [archivo de video]. Recuperado de https://www.youtube.com/watch?v=pGA8P8YtkRQ. 
Asimismo existen videos promocionales de varios de sus espectáculos escénicos, o videos promocionados por el autor, con fragmentos de estos espectáculos. También, y dentro de estos espectáculos escénicos, el autor ha utilizado videos para las representaciones en directo de estos espectáculos.

Por otra parte, existen gran cantidad de grabaciones audiovisuales del autor en la Fundació Caixa Vinaròs. Dejamos como una propuesta de futura investigación, el análisis y catalogación de estos trabajos.

En el Anexo 9.2.4., Videos, en disco compacto, se encuentran las grabaciones de los siguientes trabajos:

Fundació Caixa Vinaròs [fundaciocaixavinaros] (1981, s. d., s. d) To-ca-ti-co-to$c a$-ta. [archivo de video]. Recuperado de: https://www.youtube.com/watch?v=fGCisW5y_pU

$>$ Corominas, P. (productor) y Santos, C. (director). (1979): La Re Mi La. [cinta cinematográfica]. España. s. reg.

Archivo Artea [mataderomadrid] (1982, s. d., s. d.), Anem, anem, anem a volar. [archivo de video]. Recuperado de https://www.youtube.com/watch?v=VYZepfjRshA y de http://www.rtve.es/alacarta/videos/imprescindibles/imprescindibles-carlessantos/2787834/.

$>$ Huerga, M. [manuelhuerga] $(1984,6,15)$, Minimalet sur mer, [archivo de video]. Recuperado de: http://www.dailymotion.com/video/xkuefd_estoc-depop-carles-santos-minimalet-sur-mer-ep-22-15-06-84_tv 
6.- Exposiciones 


\section{EXPOSICIONES}

Dentro de la dilatada carrera artística de Santos y de sus incursiones en otros campos artísticos, el autor ha realizado varias exposiciones gráficas. A continuación enumeramos aquellas de las que se ha tenido conocimiento. De las no referenciadas según las normas APA, existe solamente referencia

$>$ Finestra Santos (1984)

> La polpa de Santa Percínia de Clavicònia (1994)

$>$ Grup de Treball (1999)

$>$ Caligaverot (1999)

> Inauguracuión del Espai d'Art de Castelló (1999)

> Musipotàmia (2001)

> Cicle Fotòpsia, en Castellbisbal (2005)

$>$ Els ulls dels fills de Bach (2006)

$>$ Santos, C. (junio - noviembre, 2006): Carles Santos: Visca el Piano. Fundació Joan Miró. Fundació Joan Miró. Barcelona.

> Santos, C. (junio - noviembre, 2006): Pianos intervenidos. Fundació Joan Miró. Fundació Joan Miró. Barcelona.

$>$ Santos, C. y Mariaelena Roqué (junio - niviembre, 2006): Mariaelena desviste Carles Santos. Museo Téxtil y de Indumentaria de Barcelona. S. reg. Barcelona.

$>$ Santos, C. (diciembre, 2007 - febrero, 2008): Crits de Crist al Crist de crits. Sala Gótica de l'Institut d'Estudis Ilerdencs. Institut d'Estudis Ilerdencs. Lerida.

> Santos, C. (noviembre, 2012 - enero, 2013): Anatomías imposibles. Palacio de la Escuela de Medicina Mexicana. Mexico.

$>$ Santos, C. (mayo-agosto, 2015): UNIVERSO SANTOS. El fervor de la perseverancia en Carles Santos. Centre Cultural La Nau. Universidad de Valencia. Valencia. 


\section{7.- Conclusiones}




\section{CONCLUSIONES}

La catalogación de la obra instrumental de Carles Santos difiere de las catalogaciones al uso, realizadas con otros compositores. Varias son las causas que permiten realizar esta afirmación:

La indeterminación o considerar su obra abierta (sin número de opus específico). Esto permite que una misma música pueda ser utilizada en distintas escenografías musicales, o bien como obra entera o bien como fragmentos de una obra total.

La reutilización de los materiales compuestos, para acciones musicales distintas, con la consiguiente modificación de las estructuras, elementos o instrumentaciones utilizadas.

$>$ La utilización de distintos títulos para una misma obra (o fragmentos de la misma) o de títulos en sus manuscritos que no tienen que ver con el título por la que es conocida en el registro de la SGAE o en sus actuaciones.

$>$ La desaparición de los títulos de sus obras ${ }^{79}$.

D El autor titula sus conciertos, espectáculos y exposiciones pero suele omitir los títulos de las obras utilizadas en ellos. Con ello, buscar un título de un concierto, no lleva a encontrar los títulos de sus obras, hecho que confunde entre espectáculos y obras.

$>$ La conservación de sus manuscritos pero no de las instrumentaciones de las mismas, parte de las cuales corresponden a Josep Puertotas.

$>$ La realización de collage con fragmentos de obras distintas.

El trabajo continuo del autor sobre su obra (sobre todo de la pianística) que hace de esta un elemento en proceso constante de evolución.

Por otra parte la reticencia del autor a las grabaciones de sus actuaciones en directo así como el poco apego a las cosas materiales (léase partituras) en sus inicios, ha dado como resultado el extravío de gran parte de su obra.

\footnotetext{
79 "Els títols de les obres han anant desapareixent entre 1971 i 2014". Nota del autor en su trabajo Lo bo ve per baix.
} 
De la personalidad de su obra hablan sus manuscritos. En ellos se encuentran detalles que hacen de su obra un caso singular. Después de analizar su obra instrumental, se pueden adelantar los siguientes rasgos de identidad y las siguientes ideas:

- En general, el autor no utiliza signos de escritura musical al uso. Deja de utilizar las claves al inicio de sus obras (en cuyo caso se entiende que la música está escrita en clave de sol) así como el compás. Se debe observar la métrica de la música escrita para sacar las conclusiones pertinentes.

No utiliza, en muchos casos, signos de repetición. Los fragmentos o motivos a repetir se encuentran entre signos de doble línea divisoria o bien escritos en un mismo sistema o pentagrama. En su obra pianística la cantidad de repeticiones del fragmento suele ser a gusto del intérprete, atendiendo a factores como la acústica de la sala, la expresividad del mismo en ese momento o la respuesta del público. En su obra instrumental no pianística, sí suele indicar el número de repeticiones que deben ejecutarse, detrás de la doble barra, siendo estas, habitualmente, 4 o en algunas ocasiones 6 u 8 .

$>$ Este factor da a su obra una estructura formal muy consistente, propia del periodo clásico.

> Las indicaciones dinámicas tampoco son habituales en los manuscritos. Sobre todo en los de su obra pianística. Más extensas en sus obras para conjunto (banda, fanfarria, orquesta $\mathrm{u}$ otras agrupaciones), el ámbito utilizado se encuentra en una tesitura entre $p p$ y ff. Como signos de articulación solamente utiliza acentos y $s f z$. Las ligaduras de expresión tampoco son habituales.

$>$ Las tonalidades o notas utilizadas están pensadas para la tesitura de la voz o para la sonoridad del grupo. Este detalle hace que se encuentren bastantes alteraciones en sus manuscritos y que no estén pensados para la comodidad de los ejecutantes (recordar que existen dos versiones del pasodoble "Marrajo" o "Sevilla", una de las cuales está transportada una segunda menor ascendente en Sol- y que el autor desconoce el motivo de esta transposición y de hecho no la considera válida para su interpretación).

$>$ Estas tonalidades, utilizadas en la mayoría de sus obras, giran alrededor de una tónica o nota fundamental, que les otorga un sentido tonal, pero no pueden considerarse tonales. Utiliza a menudo escalas modales. 
En cuanto a las modificaciones que realiza en sus obras para posteriores interpretaciones, estas la realiza en fotocopias de los originales y nunca sobre el mismo.

$>$ La armonía utilizada raramente está construida sobre acordes mayores o menores. Puesto que el autor utiliza la armonía con fines expresivos, esta, igual está formada por acordes de 3 ó 4 sonidos, como por notas añadidas a acordes mayores o menores, como utiliza clusters (racimos de notas).

$>$ Es habitual la presentación de fragmentos contrapuntísticos en sus obras.

$>$ Existe una medida que se puede considerar como la firma del autor. Esta es la

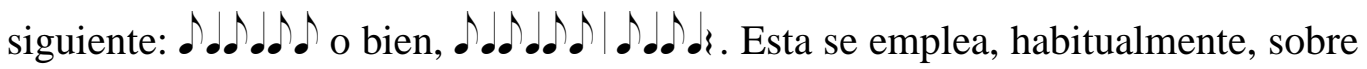
el mismo sonido o grupo de sonidos.

> Las instrumentaciones más utilizadas son: piano, voz, piano y voz, banda, fanfarria, orquesta y coro. Suele utilizar, asimismo, fanfarrias mezcladas con instrumentos de cuerda frotada o bien instrumentos típicos de la Cobla catalana.

L Los textos son muy personales, atendiendo a la utilización de palabras inventadas que busca la fuerza de la palabra, con gran carga expresiva y mucha musicalidad, en fragmentos recitados, o bien, utilizar las vocales de las notas utilizadas antecedidas de la consonante 1 (lo, le, li, la, lol, la, li), en los fragmentos cantados. En este caso, el texto se omite en los manuscritos.

$>$ En su obra pianística suele omitir la medida requerida de sus fragmentos. Solamente está indicada la línea melódica a través de las cabezas de las notas (observar No al no o Bujaraloz by night).

$>$ La mayoría de sus originales son copiados en blocs de escritura musical, con tapas amarillas, en formato A4, apaisado, de 30 hojas, en las que escribe su música en las impares, dejando las pares para apuntes o para modificar el original, en cuyo caso numera la página como bis.

$>$ Los títulos expuestos en estos blocs no coinciden con el nombre por el que es conocida la obra. Este hace referencia a un personaje, lugar o contenido contextual de la obra (Ebrofagia Copulativa consta en la tapa como Piano-moto en la tapa, o Maquinofobia Pianolera consta como Cabo, por ejemplo).

$>$ La memoria del autor le permite reproducir la partitura de su obra incluso varios años después de ser ejecutada por última vez. De este modo se han podido recuperar obras que se encuentran extraviadas en sus primeros originales. Es por 
ello que en algunas ocasiones, la fecha en la que están datadas es anterior al bloc en que están escritas, debido al cambiante diseño de la tapa de los mismos.

La extensa obra de Carles Santos, su producción que a día de hoy todavía continúa, la aparición de nuevas partituras hasta el momento desaparecidas y, como he dicho con anterioridad, la reutilización de sus materiales para otras acciones musicales, hacen de ella un elemento vivo, cuya catalogación no se puede considerar acabada. Es por ello que, a partir de este trabajo, queda todavía un gran camino por recorrer hasta completar esta clasificación y análisis. 
8.- Futuras líneas de investigación. 


\section{FUTURAS LÍNEAS DE INVESTIGACIÓN}

En el transcurso de la realización de este trabajo han ido apareciendo nuevos caminos sin explorar, relacionados con la obra de Carles Santos. Cada uno de ellos lleva a una nueva perspectiva y pueden dar paso a futuras líneas de investigación. Pasamos a continuación a argumentar algunas de ellas:

Dado que el autor sigue en activo, esta obra no puede considerarse cerrada. Las nuevas creaciones futuras darán paso a la ampliación de este trabajo.

$>$ La gran cantidad de obra extraviada conduce a una búsqueda exhaustiva de la misma por caminos no explorados o bien continuando por los caminos ya recorridos, aunque con más intensidad, si cabe (léase las instrumentaciones de la música de los JJ. OO. de Barcelona, por ejemplo).

- Existen grabaciones de la obra del autor, tanto en audio como en video, que podrían dar luz sobre aquellos manuscritos que no han podido ser catalogados. Al mismo tiempo, ampliarían el patrimonio de la Fundació Caixa Vinaròs, donde se encuentra la obra de Santos.

Teniendo en cuenta estas grabaciones dispersas, realizar una catalogación de las mismas, tanto de las ya expuestas en este trabajo como de las que se pueden encontrar en distintas plataformas en la web. Se han podido encontrar más de 140 entre documentos de sus obras o entrevistas y reportajes al propio autor o a personas vinculadas con Santos que realizan comentarios sobre su persona o su obra.

$>$ Analizar y catalogar las grabaciones de audio y video que se encuentran en la Fundació Caixa Vinaròs y que han sido recopiladas a lo largo del tiempo. Muchas de ellas son de carácter particular y han sido recogidas gracias al trabajo de Nati Romeu. Entre ellas se encuentran reportajes de sus exposiciones, grabaciones de sus conciertos, entrevistas y otras.

$>$ La edición de la obra de Santos, respetando en todo momento sus particularidades y personales connotaciones, queda pendiente.

$>$ Como se ha detallado en el apartado "Lenguaje", y después del experimento realizado con los alumnos del Conservatorio de Castellón, el trabajo pedagógico que puede realizarse a través de la obra de Santos, queda patente, aunque inexplorado. 
9.- Anexos 


\subsection{ENTREVISTAS PERSONALES Y TESTIMONIOS DE CARLES SANTOS}

A lo largo de todo este periodo, muchas han sido las dudas que han surgido en la realización de este trabajo. Gran cantidad de estas dudas, han ido clarificándose a través de los contactos continuados que he tenido al placer de mantener con Carles Santos. La privilegiada memoria del autor ante sus partituras, sean estas del periodo que sean o estén o no instrumentadas, ha sido de vital ayuda para concretar muchas de las catalogaciones. La falta o el exceso de títulos en los manuscritos, me han llevado a muchas confusiones. Y gran parte de estas confusiones han sido clarificadas por Santos. A continuación paso a detallar algunas de estas conversaciones, datando las mismas.

Mayo de 2011

Ante las dudas surgidas en una primera toma de contacto con los manuscritos de Carles Santos, en el Auditorio que lleva su nombre en la Fundación Caixa Vinaròs, y en el que se encuentra custodiada su obra, le presenté algunos manuscritos y pasé a preguntarle algunos detalles mostrándole los mismos.

Pregunta: La obra Concert Toni Mira, ¿Dónde comienza exactamente?

Carles Santos: No lo sé a ciencia cierta. Formó parte de un espectáculo titulado Blanc $i$ negre en el cual la música servía para acompañar un espectáculo de danza, realizado por la Compañía Nats Nous.

P.: En la obra Castelló '99, ¿existe algún fragmento original, compuesto para el evento? C. S.: No. Es una recopilación de música ya escrita. Se ejecutó en la inauguración de 1'Espai d'Art Contemporani de Castelló, inauguración realizada por Consuelo Ciscar.

P.: Sobre el material de las Olimpiadas del 92, ¿Piromusical forma parte de este material?

C. S.: Si.

P.: ¿Y Promenade?

C. S.: También. Se interpretaba en la entrega de medallas a los atletas.

P.: Y Promenade concert, ¿existe?

C. S.: Si. La música se encuentra en la libreta que lleva como título "Miró".

P.: La obra que titulas "Brossa" ¿forma parte de Brossalobrossotdebrossat?.

C. S.: Si. Es un espectáculo escénico.

P.: Y la obra que titulas Foc al cantir ¿es un espectáculo escénico? 
C. S.: Creo recordar que sí. La música utilizada es la misma que la de "Brossa".

P.: ¿Recuerdas la fecha en que se estrenó la obra Congrés de Cuina Catalana?

C. S.: No.

P.: La obra que titulas Piano moto ¿es la misma que se ha titulado Ebrofagia copulativa?

C. S.: Si, aunque la música utilizada en esta última comienza en la página 9 del manuscrito. Esta música también se ha utilizado en Piturrino fa de músic y sale de una obra anterior que yo llamo "Musica en tres notes".

P.: La obra que titulas Obra conjunta ¿es la misma que se ha titulado No al no?

C. S.: Si, es la primera versión del No al no. El orden de ejecución de los fragmentos que la forman, según los títulos del manuscrito, es libre.

P.: La obra que titulas Fervor ¿forma parte de la que se ha titulado El fervor de la perseverancia?

C. S.: Si, lo que está titulado como "Claudia" y la música escrita detrás. No, lo de piano. El espectáculo comenzaba con esta música.

P.: ¿Recuerdas la fecha en que se estrenó la obra que titulas Cantata?

C. S.: Si, en 2008. Se estrenó en el Palau Sant Jordi de Barcelona y fue un encargo de la Asociació de Corals Catalanes. Había cerca de 3000 niños cantando.

P.: La obra que titulas Tinc que tinc ¿forma parte de la que has titulado Tinc que ser castigat?

C. S.: Si, forma parte de la misma obra.

P.: Es conocida también como Tinc que ser castigat per no haber estimat mai ningú?

C. S.: Si.

P.: La obra que interpretas de Bach, ¿Cuál es?

C. S.: Es una fuga en la menor, a partir de un arreglo de Listz. La he utilizado en $L a$ Pantera Imperial. En La vinya dels artistas se interpretó por un violín solo.

P.: ¿Qué es la obra que titulas Olvido?

C. S.: Olvido hace referencia a la violinista Olvido Lanza. Fue escrito para ella. 
Abril de 2012

Carles me informó que en su domicilio particular tenía bastantes manuscritos aunque no los tenía "controlados del todo". Un sábado de abril de 2012, acordamos que sería interesante recopilar estos manuscritos y catalogarlos.

En la entrada de su domicilio existen 3 estanterías que se encontraban repletas de partituras. Algunas eran manuscritos suyos, originales y copias. Existías, asimismo, partituras musicales para piano de diversos autores.

C. S.: Muchas de estas obras las adquirí en New York. Algunas de ellas las poseo desde hace más de 40 años y no recordaba que las tenía. Son, sobre todo, piezas del siglo XX. También tengo manuscritos de varios compositores, que me mandaron personalmente por amistad para con ellos.

Junio de 2013

Después de catalogar lo encontrado en su domicilio, Carles me informó que tenía más obras suyas en diversas dependencias de su casa particular. En junio de 2013, acordamos continuar con la recopilación de estos manuscritos y catalogarlos.

Lo encontrado en estas dependencias fue muy interesante.

P.: Estas fotografías en blanco y negro, ¿a que corresponden?

C. S.: Esto es de la acción musical Sound Figh ${ }^{80}$ t.que realicé en New York. Se ve el ring donde se realizó el espectáculo y parte de los asistentes.

P.: Se ven instrumentos a un lado del ring. ¿La acción musical tenía música instrumental? No he encontrado nada de este espectáculo.

C. S.: Si que tenía. Fue uno de mis primeros espectáculos.

Al poco tiempo encontré una libreta muy antigua, con las tapas amarillas y referencias en inglés. En su interior había música escrita, que en algunas ocasiones hacía referencia a Charly y en el interior de la misma existía una plantilla instrumental. Al enseñársela a Carles, certificó que se trataba de la música que escribió para el espectáculo. Visionando las fotografías anteriores, en las que se apreciaba la formación instrumental que se utilizó, y comparándola con la que constaba en la libreta, se observa que coincide.

\footnotetext{
${ }^{80}$ Las fotografías se incluyen en el punto 11, Anexo fotografías.
} 


\subsection{APÉNDICE DOCUMENTAL}

En $\mathrm{X}$ discos compactos se presentan ejemplos, fragmentos o la totalidad, de distintas facetas de la obra de Carles Santos. Se pasa a enumerar el apéndice documental:

9.2.1. Partituras: En disco compacto se incluyen todos los manuscritos del autor, reflejados en esta tesis.

9.2.2. Carteles, fotografías y programas: En disco compacto se incluyen algunos de los carteles promocionales de los espectáculos del autor.

9.2.3. Audios: En disco compacto se incluyen todas las grabaciones del autor, que no estén sometidas al carácter comercial de las mismas, en formato mp3.

9.2.4. Videos: En disco de video digital (DVD) se incluyen algunos cortometrajes representativos del autor.

9.2.5. Videos Experimento pedagógico: En disco de video digital (DVD) se incluyen las grabaciones realizadas a los alumnos que realizaron el experimento pedagógico al que hace referencia esta tesis. 
10.- Anexo partituras 
10.1. PIANO SOL (1970)
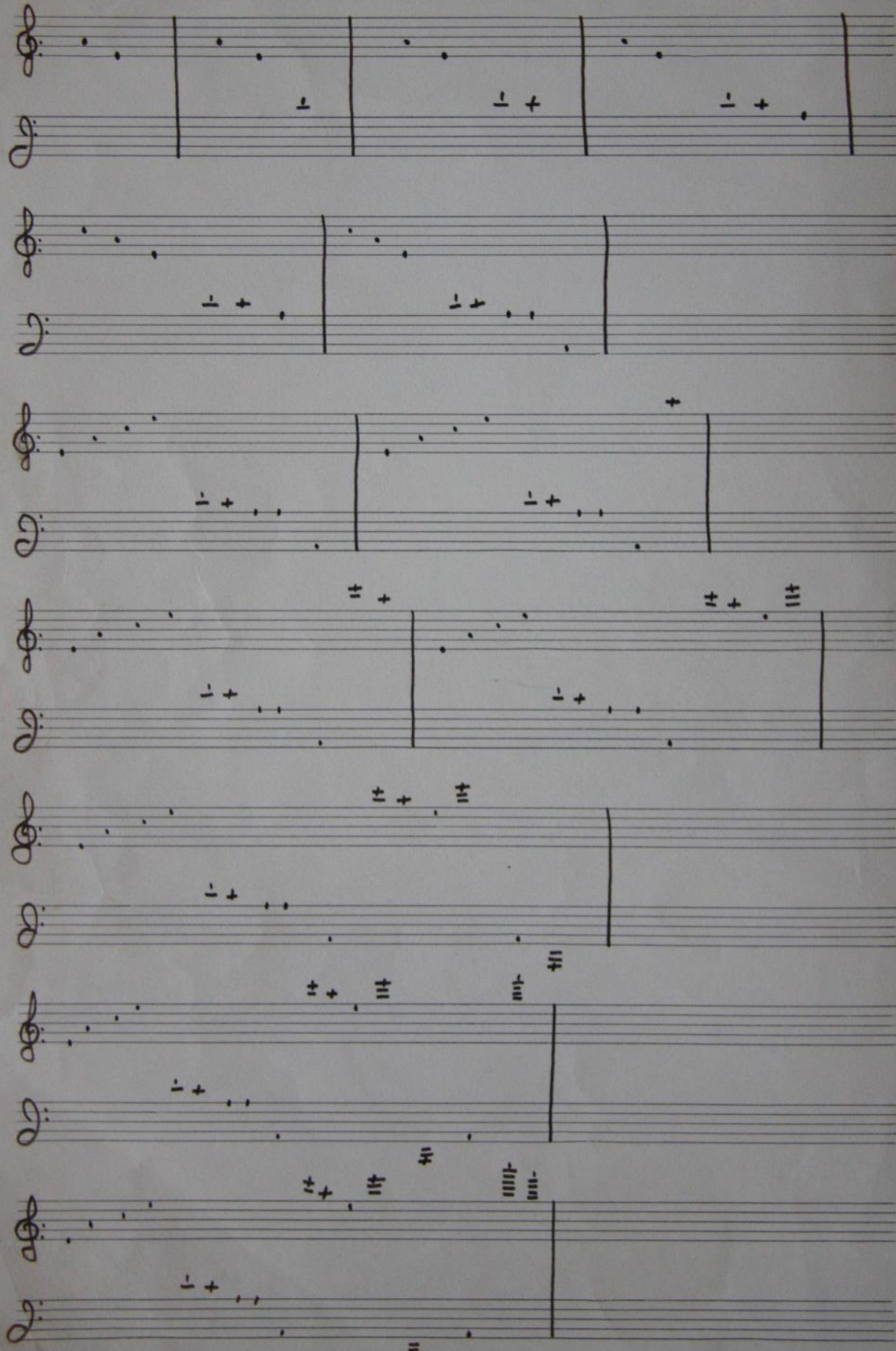

$\frac{0}{2}$ 


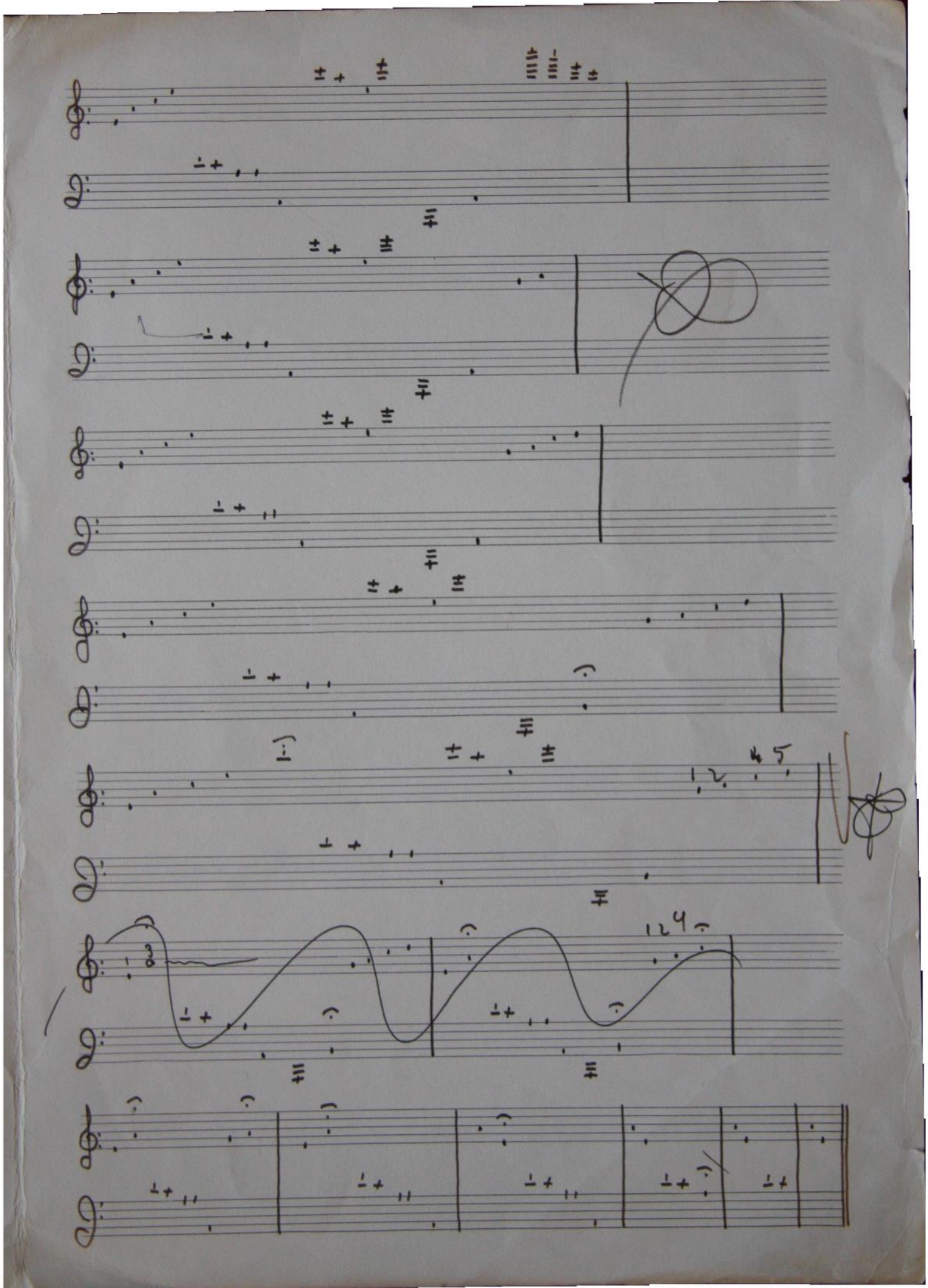


10.2. ARMANDINO 77 (1977)

\section{Carles Santos - Armandino 77}

Música original de l'espectacle "L'aperitiu" d'Albert Vidal.
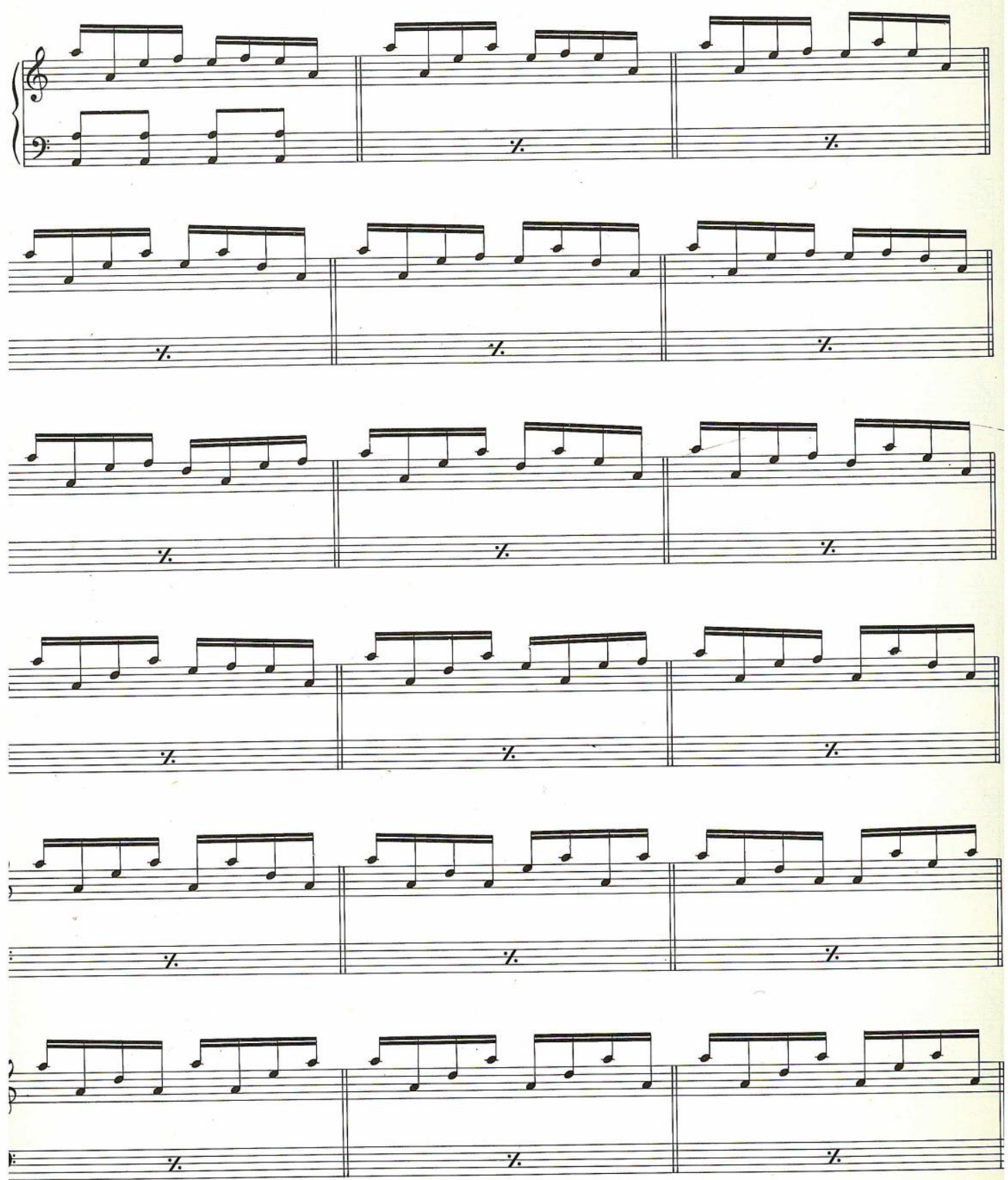

Cal repetir cada seqüència entre 15 i 20 vegades. Respecteu l'ordre de les seqüències. La dinàmica pot variar dins del (f) Repetir cada secuencia entre 15 y 20 veces. Respetar el orden de las secuencias. La dinámica puede variar dentro del (f).

aquest és el final de l'obra.

este es el final de la obra. 
Joaquín Ortells Agramunt

326

(2) Carles Santos - Armandino 77
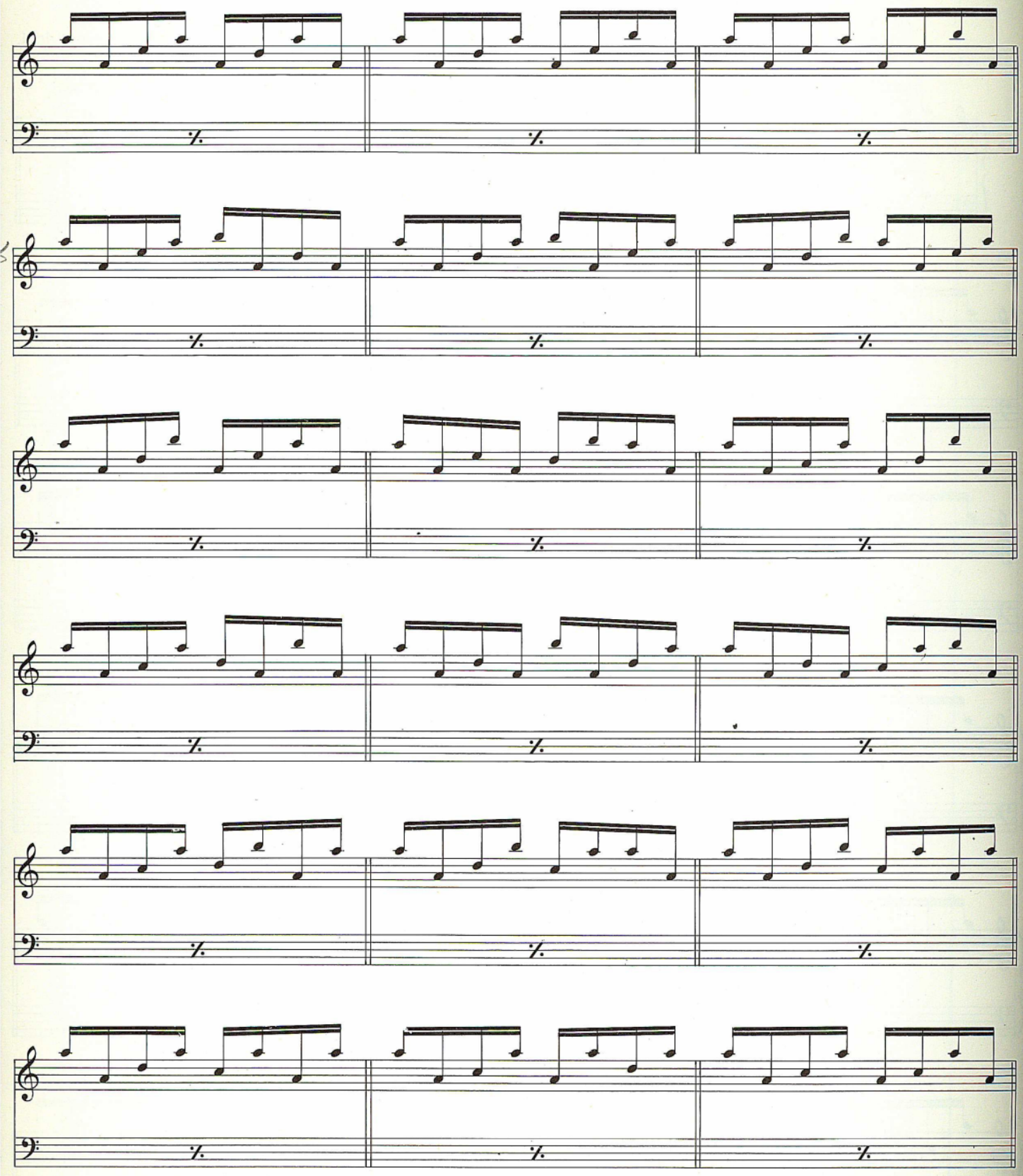

570 
10.3. TO-CA-TI-CO-TO-TA-TA (1978)
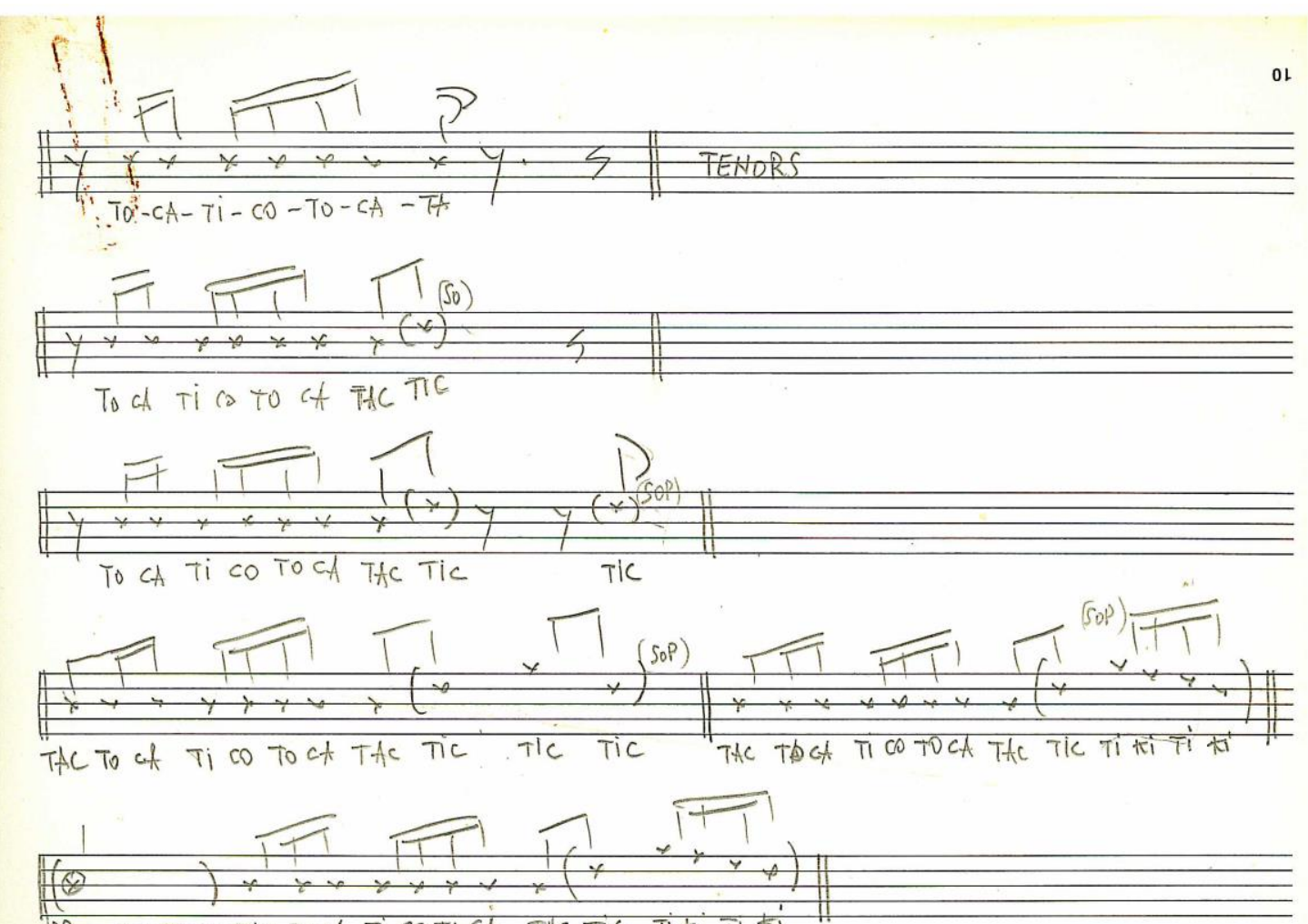

(B)

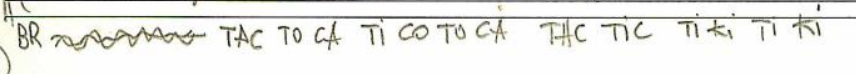

(B) BR

BR 2000000

PiM Tiki Tiki
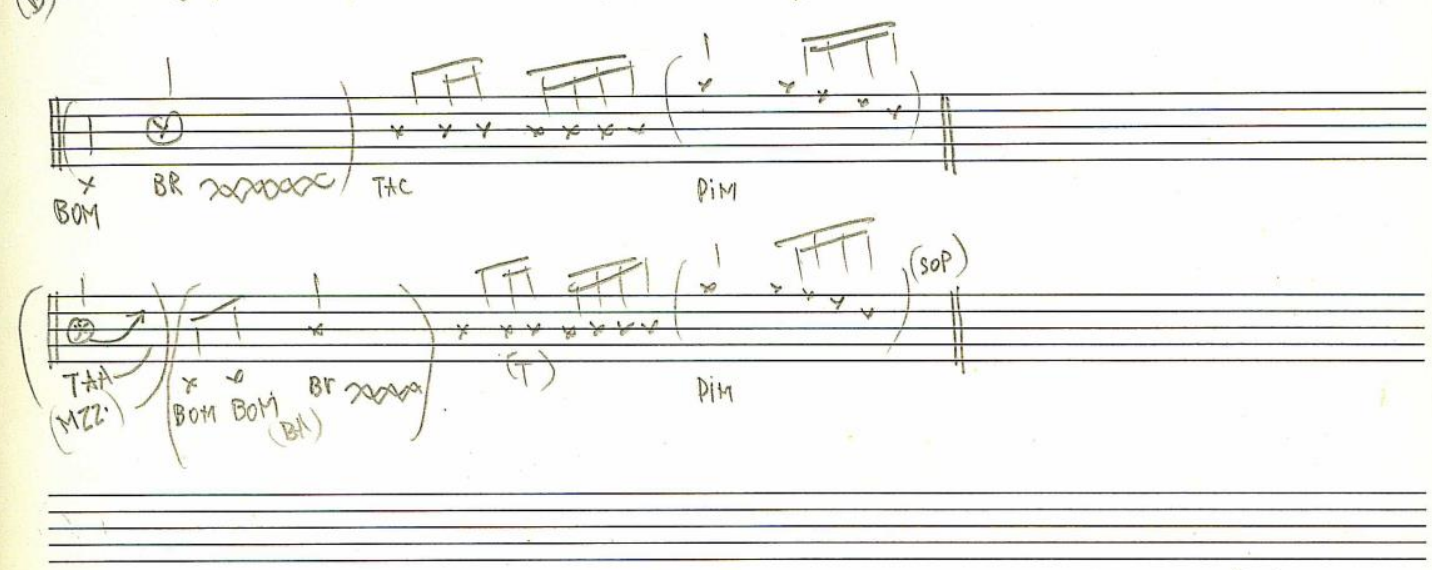

(so)

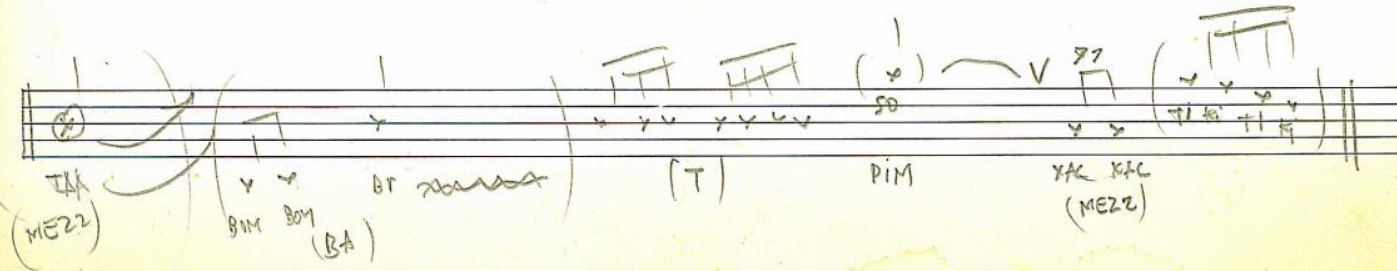



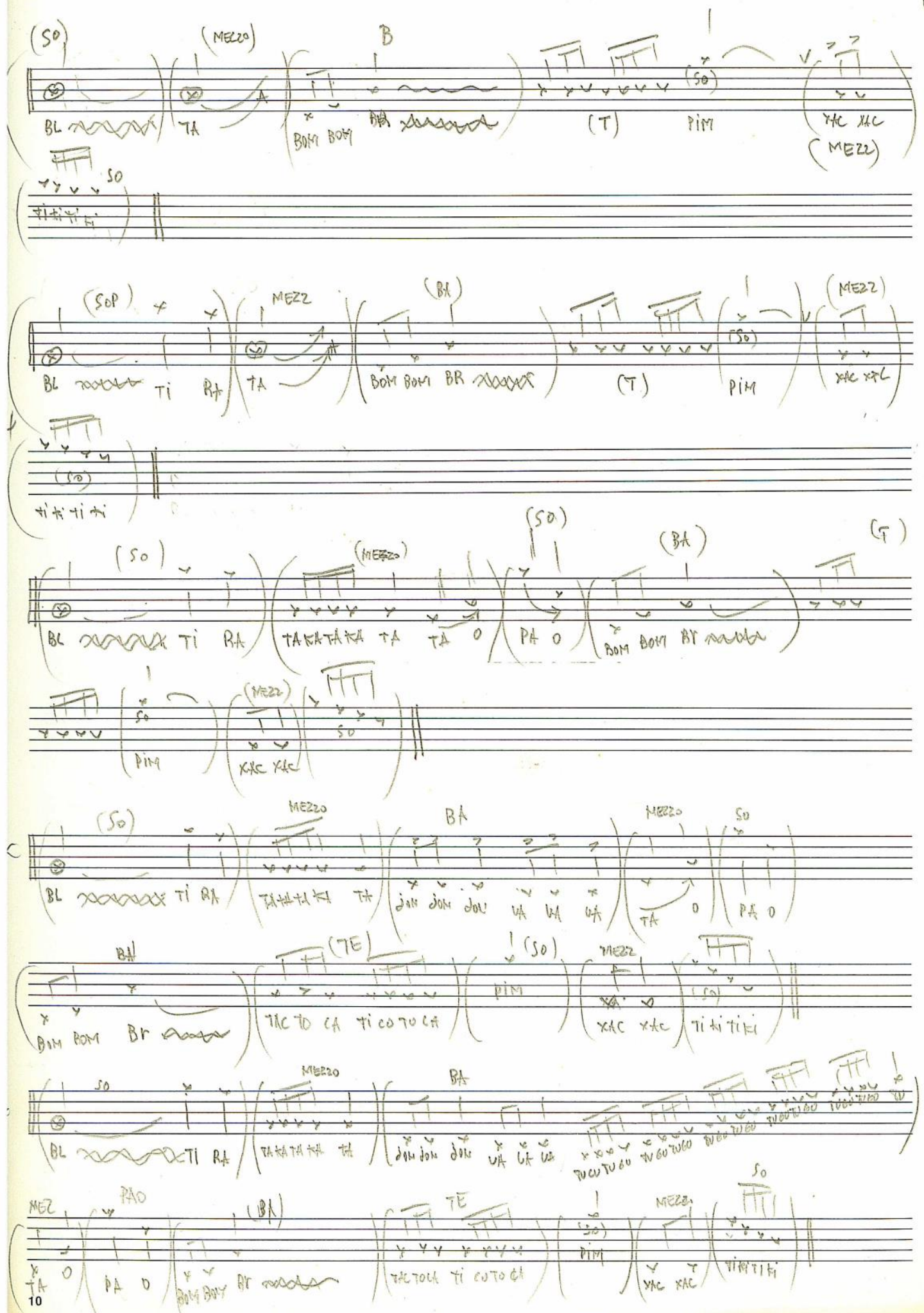
10.4. OCTAVI I LIDIA (1979)

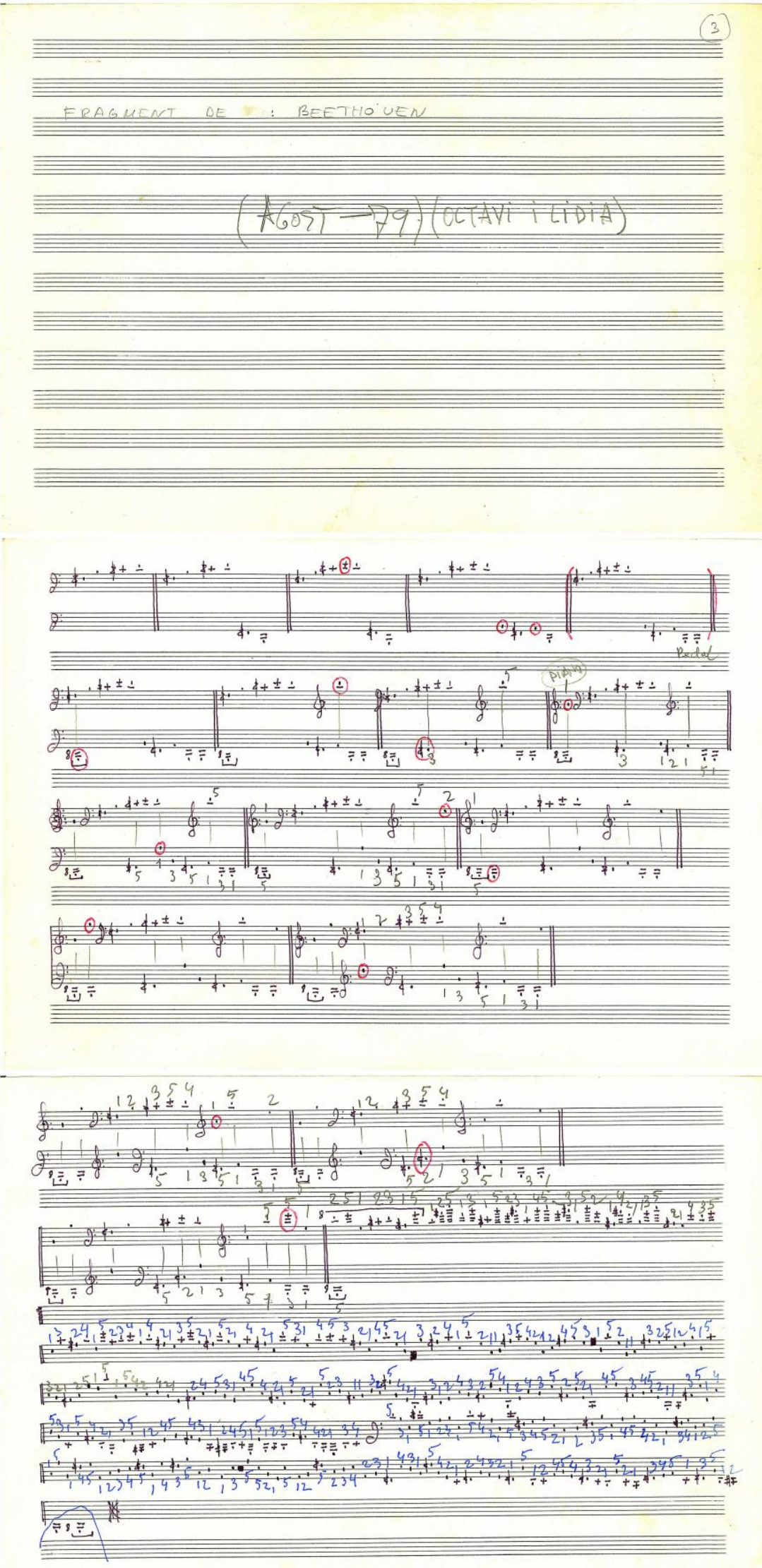


10.5. ARROSEGANT EL PIANO (1980)

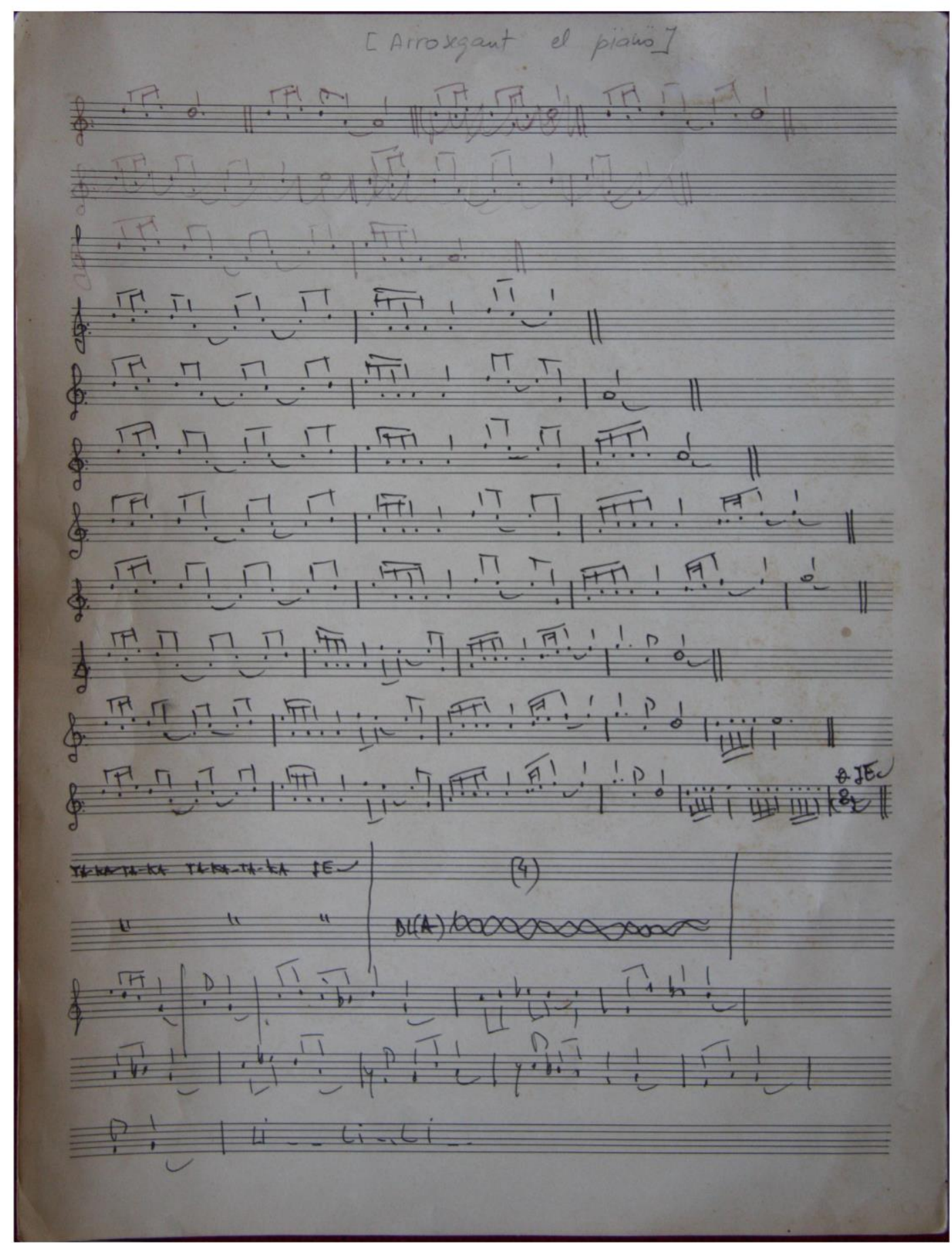


10.6. PEPA (1980)

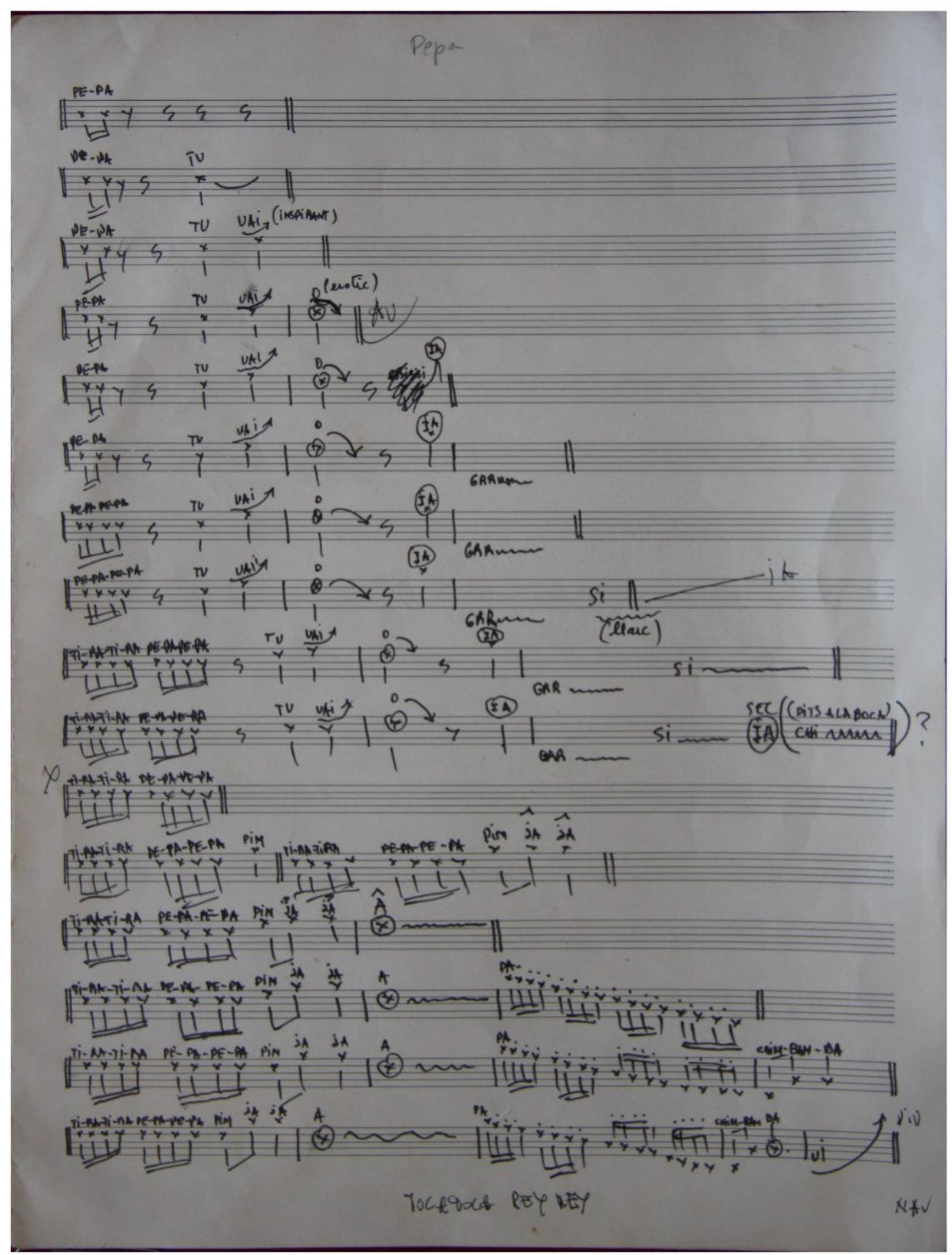


10.7. PEÇA PER A PIANO (I) (s. d.)

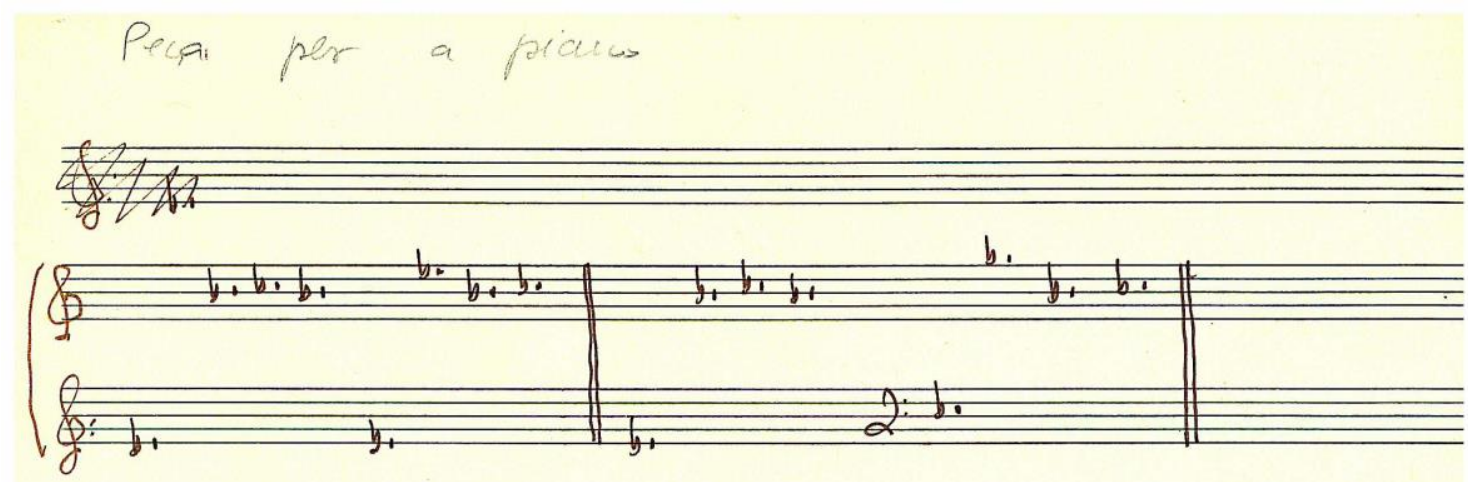

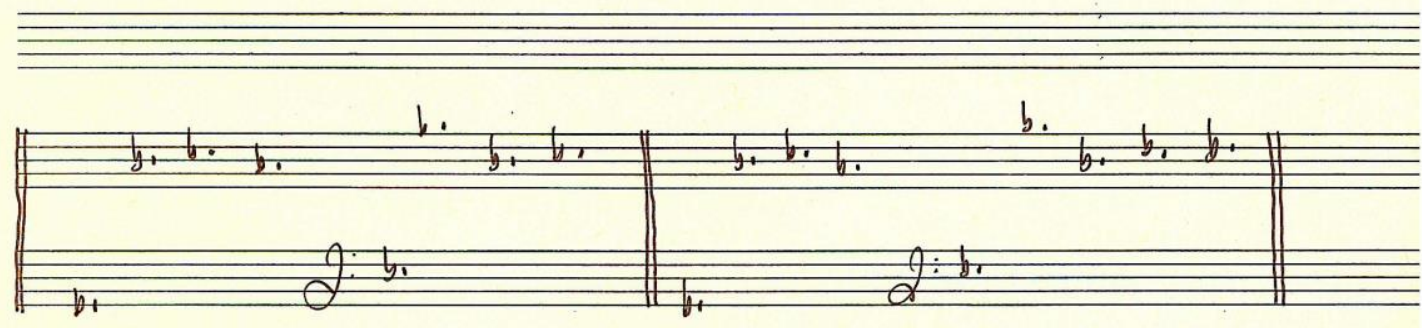
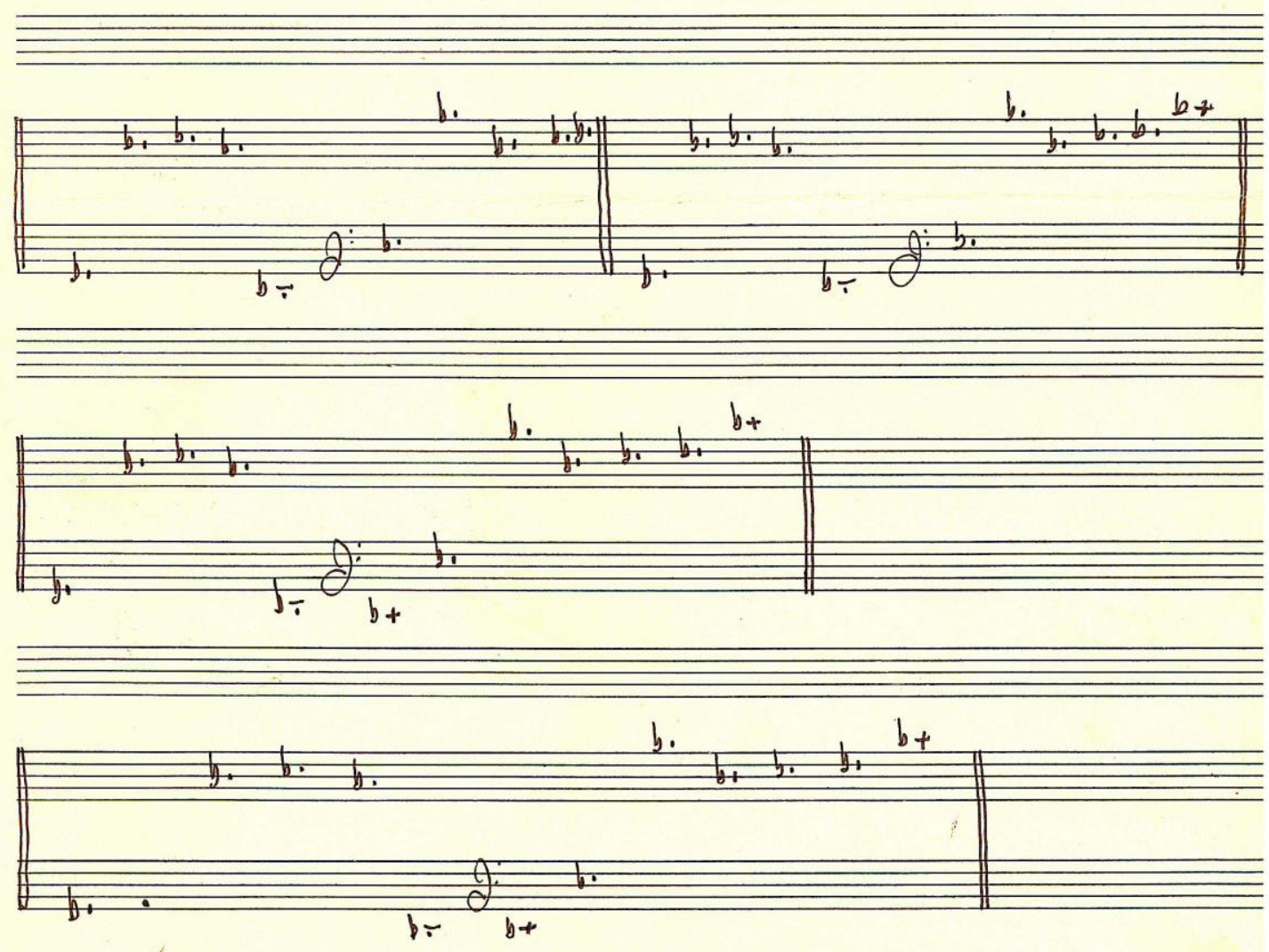

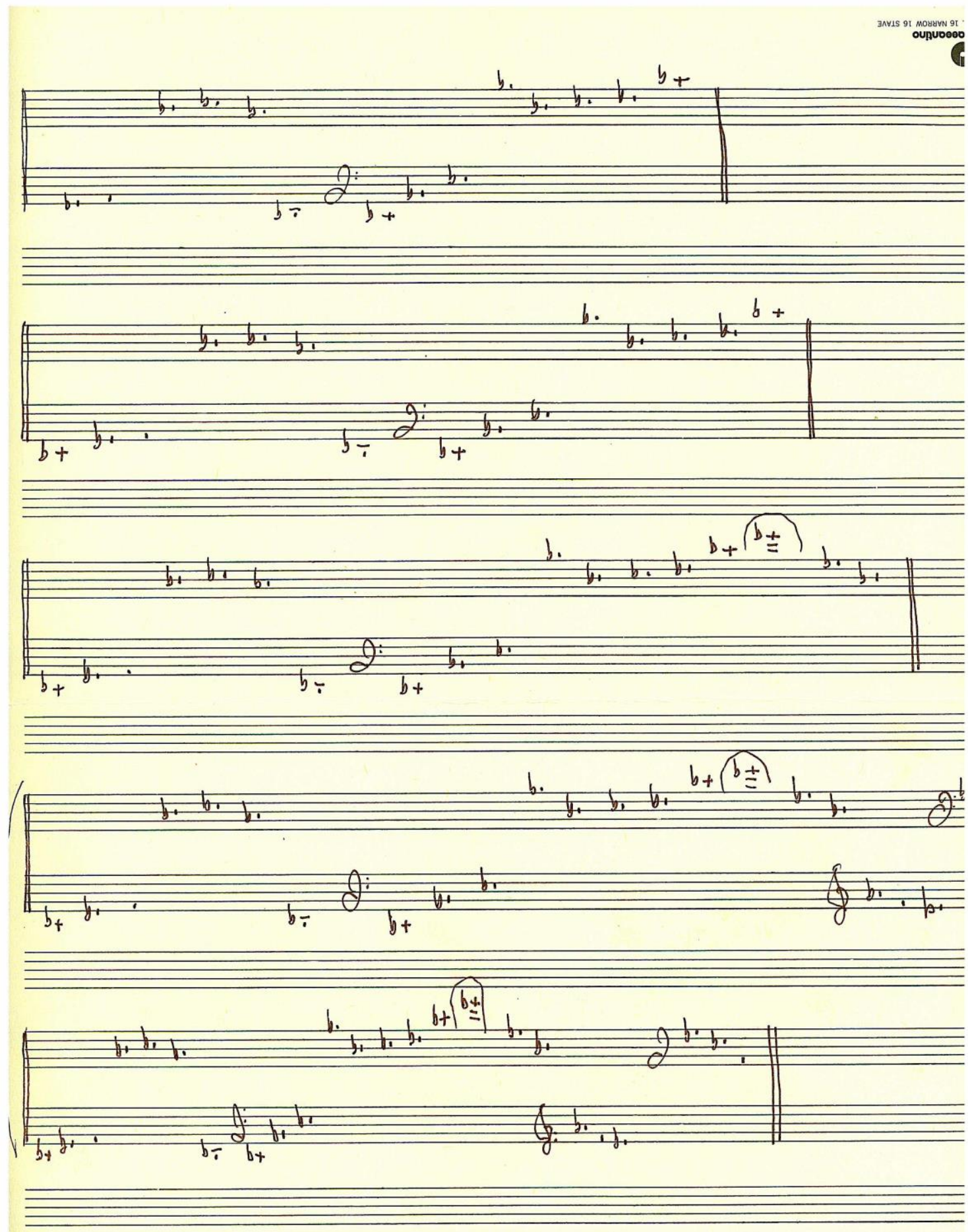

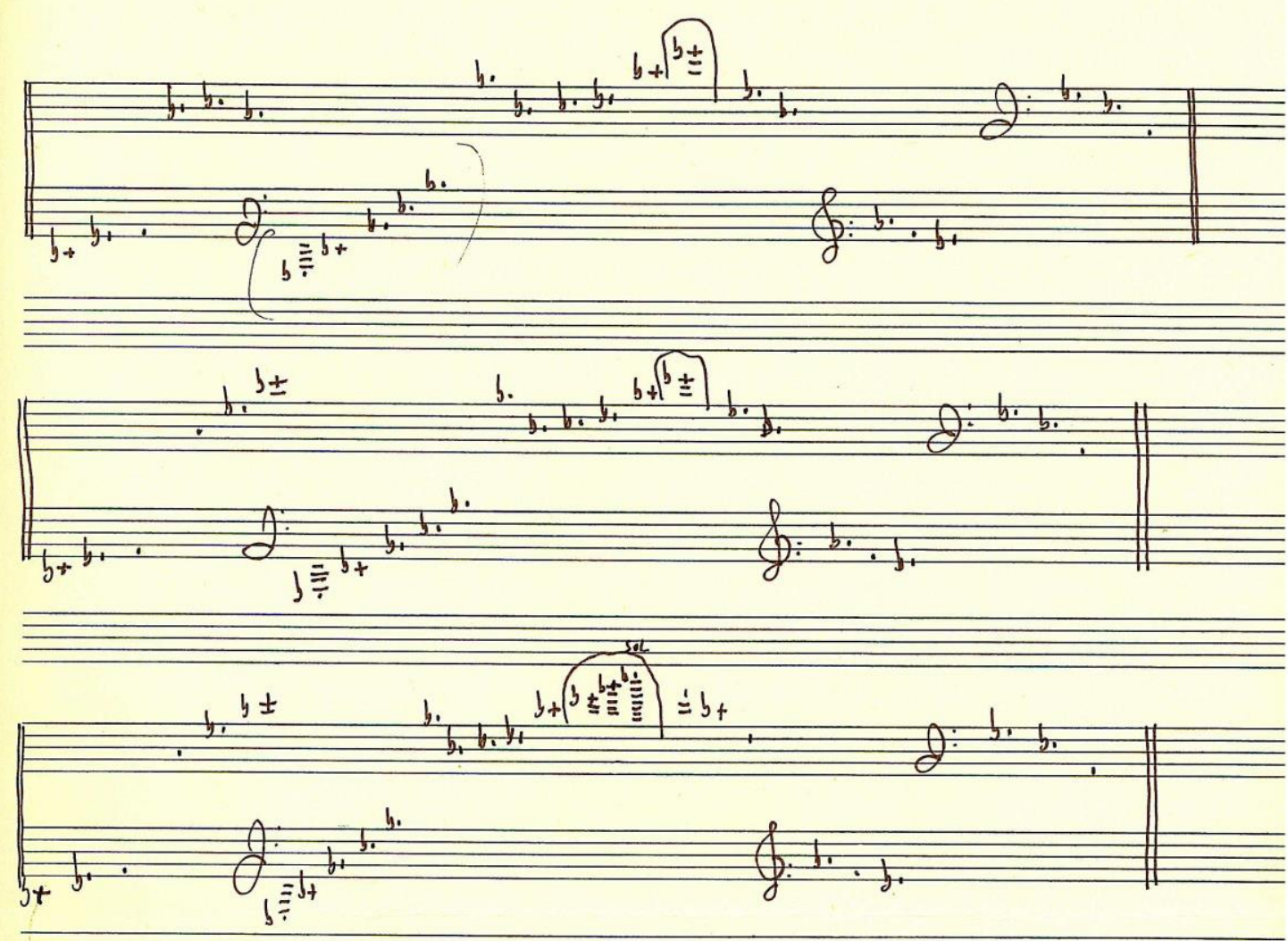
10.8. BUJARALOZ BY NIGHT (1984)

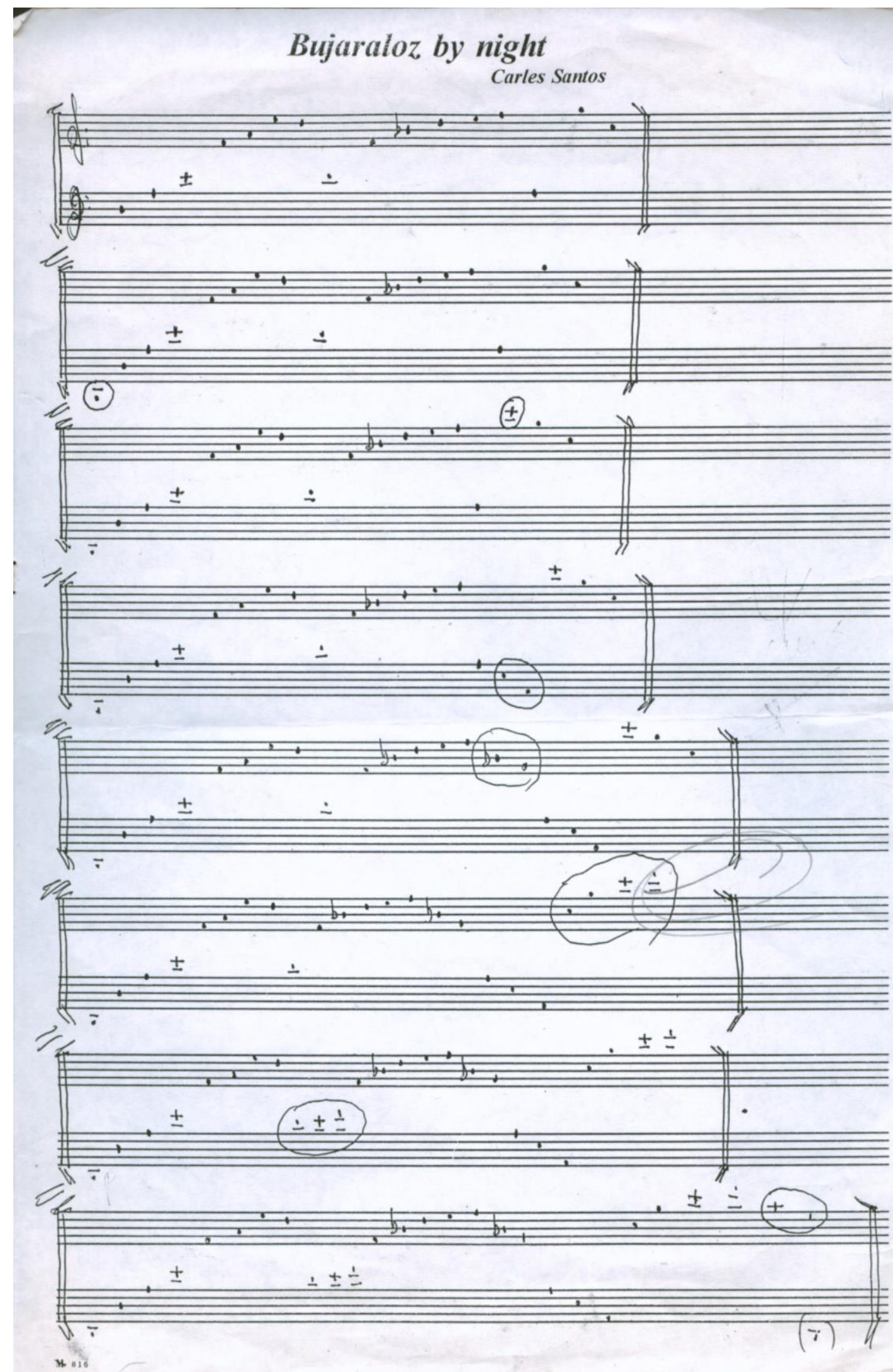




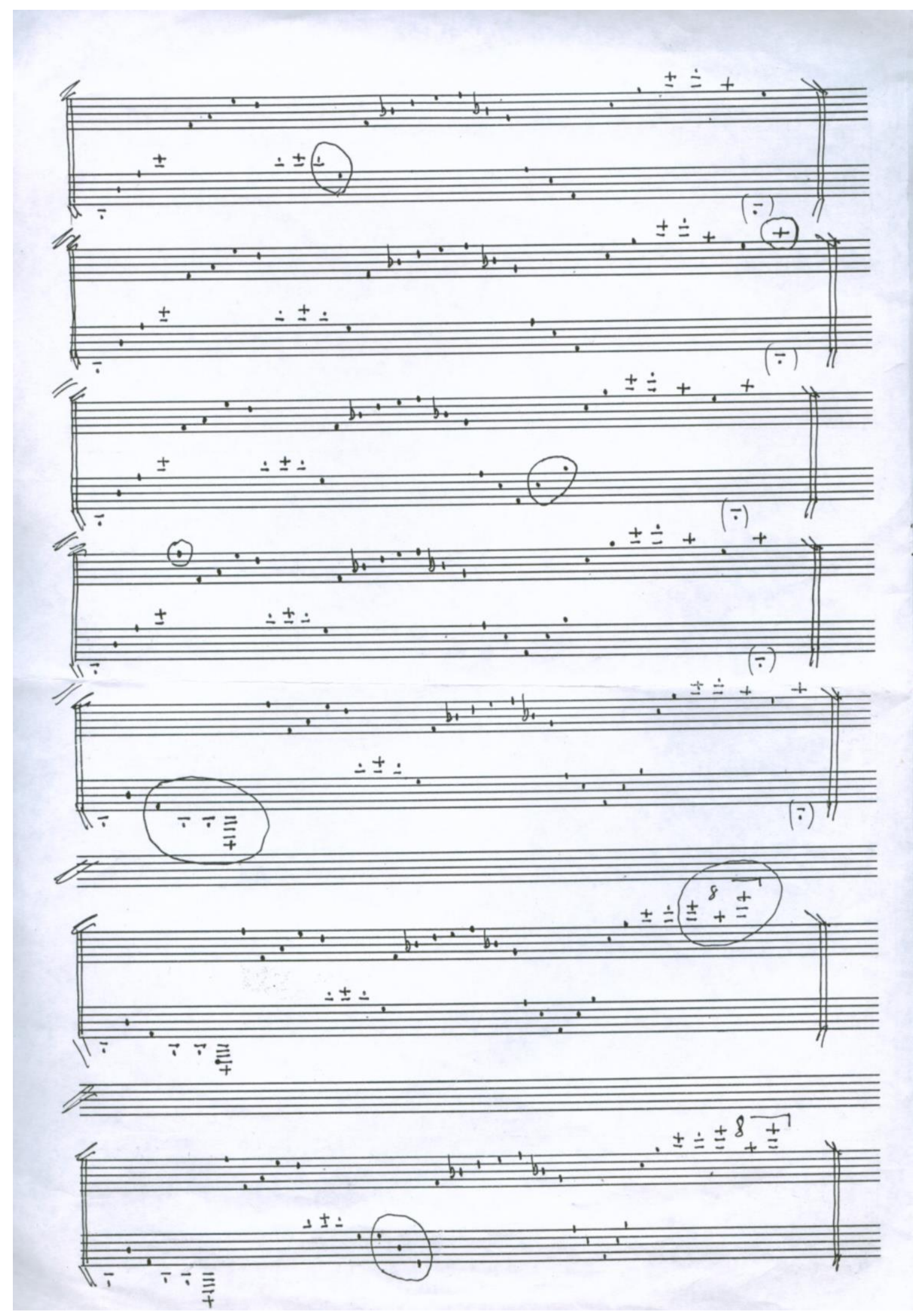


10.9. BARBY FLUTE (s. d.)

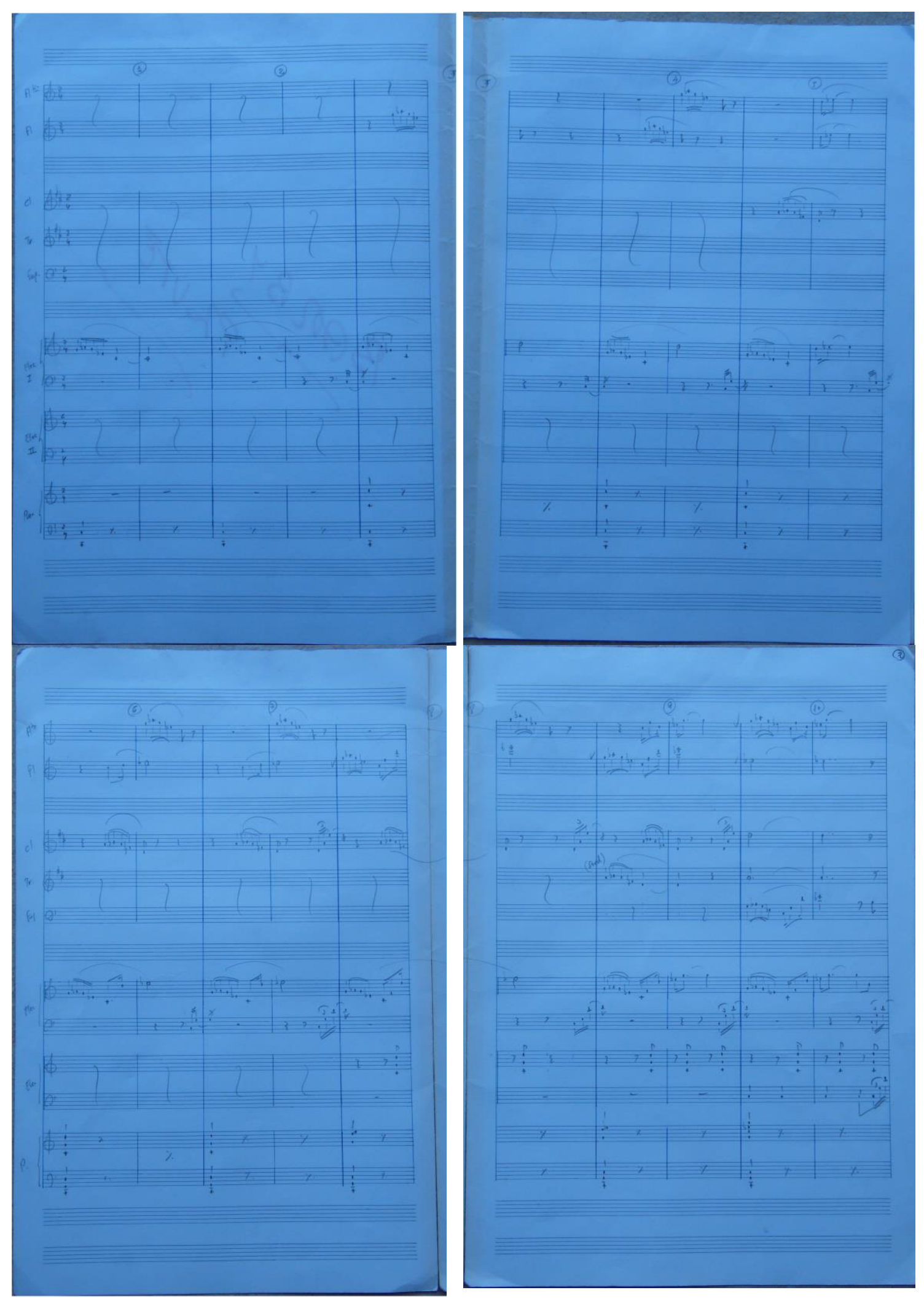




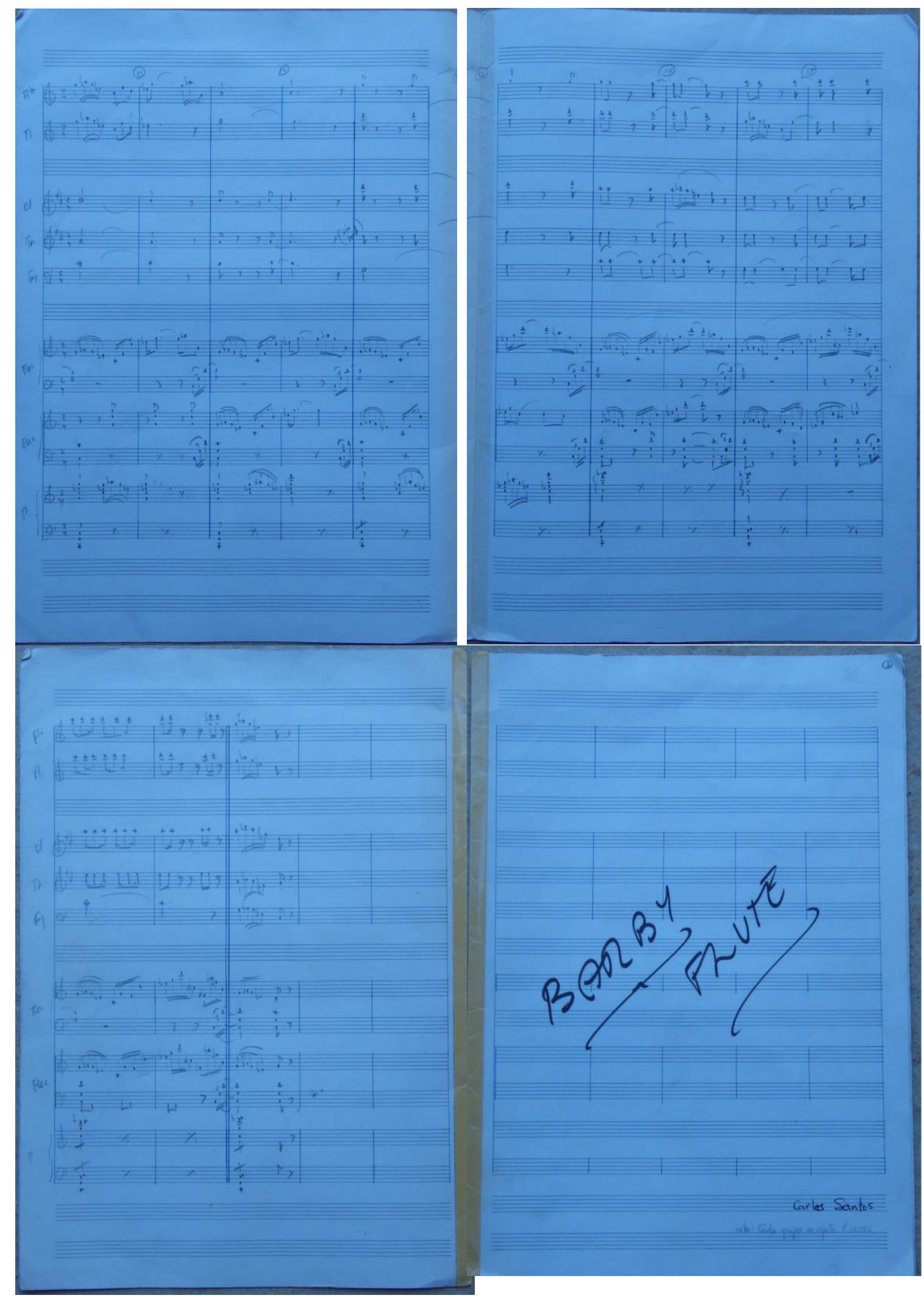


10.10. BUSCA LA PERDIU (1986?)

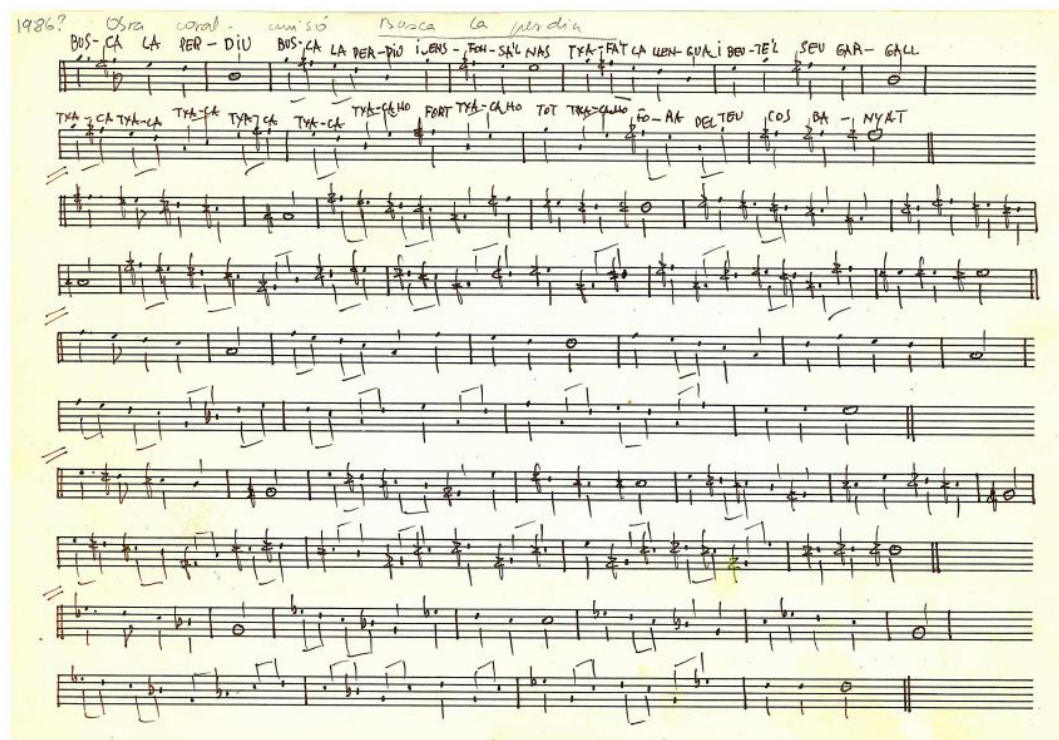

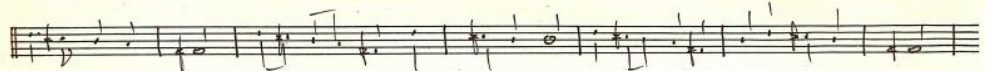
W W W

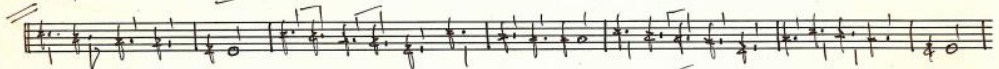

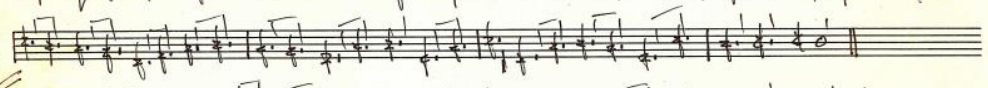

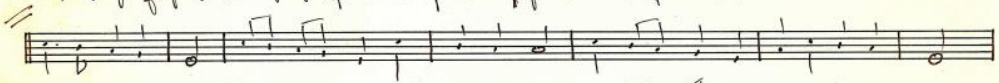

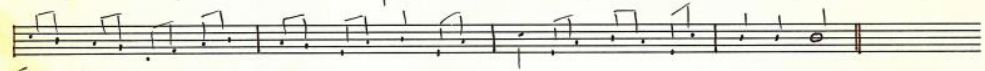
$11 \%$
1
1

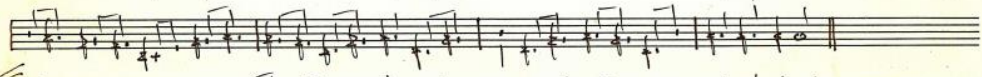
! ! ! ! ! !

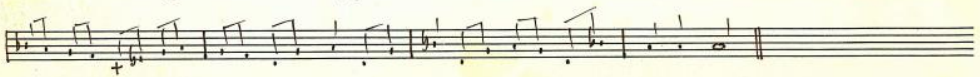
w wo

1.

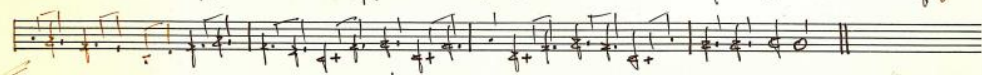
W

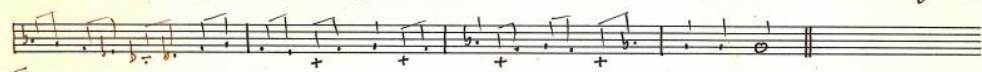

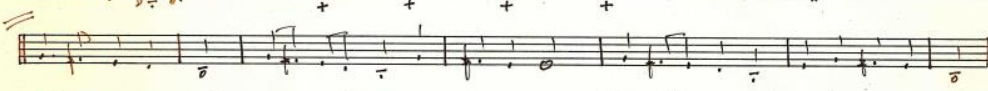
1.

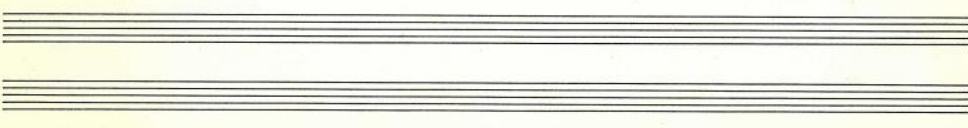

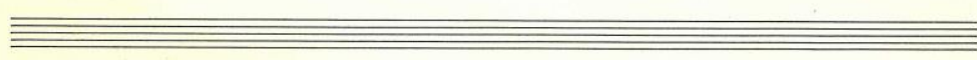

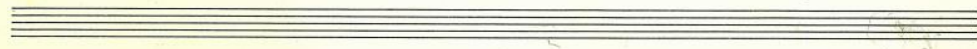


10.11. PIANO A 4 MANS (s. d.)
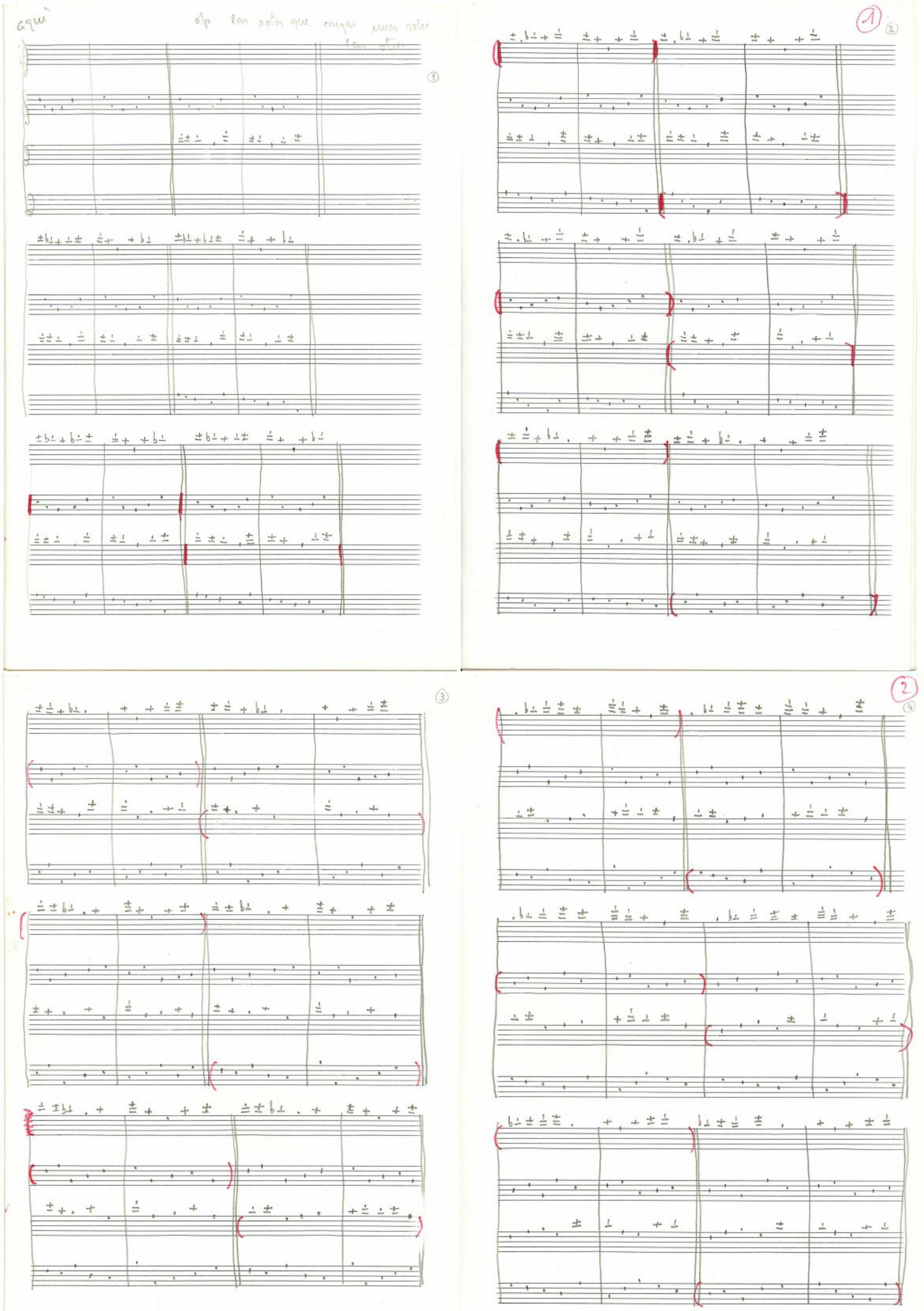

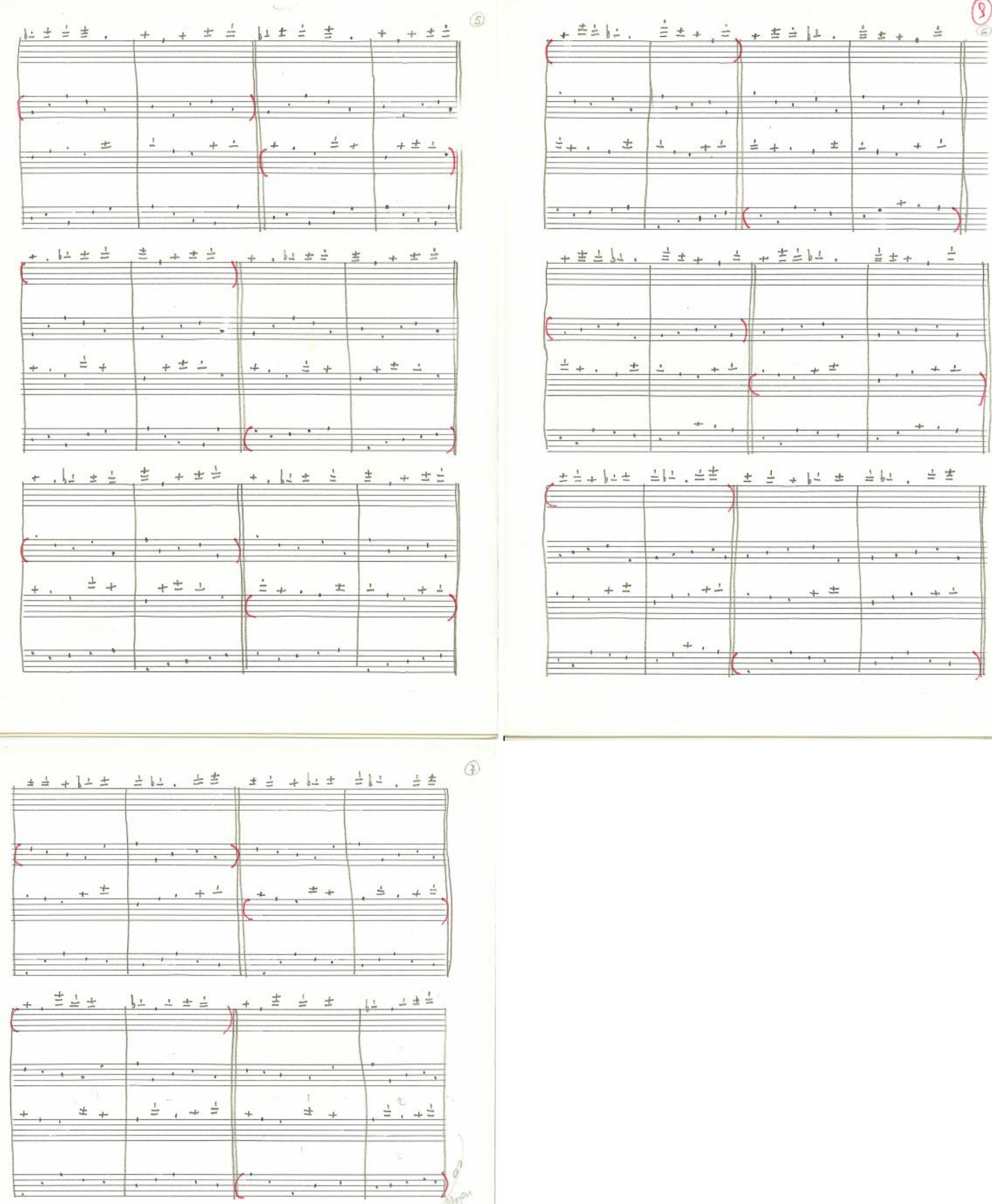

\section{(7)}

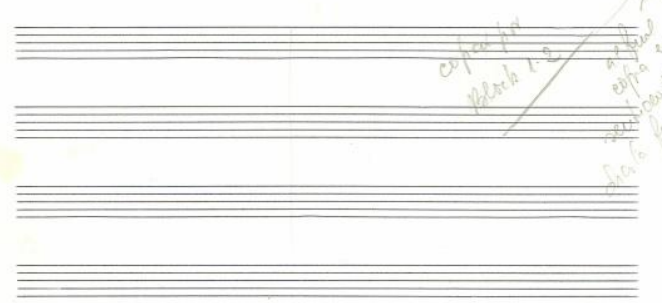


10.12. MORELLAR MORELLA (Desfile) (2011)
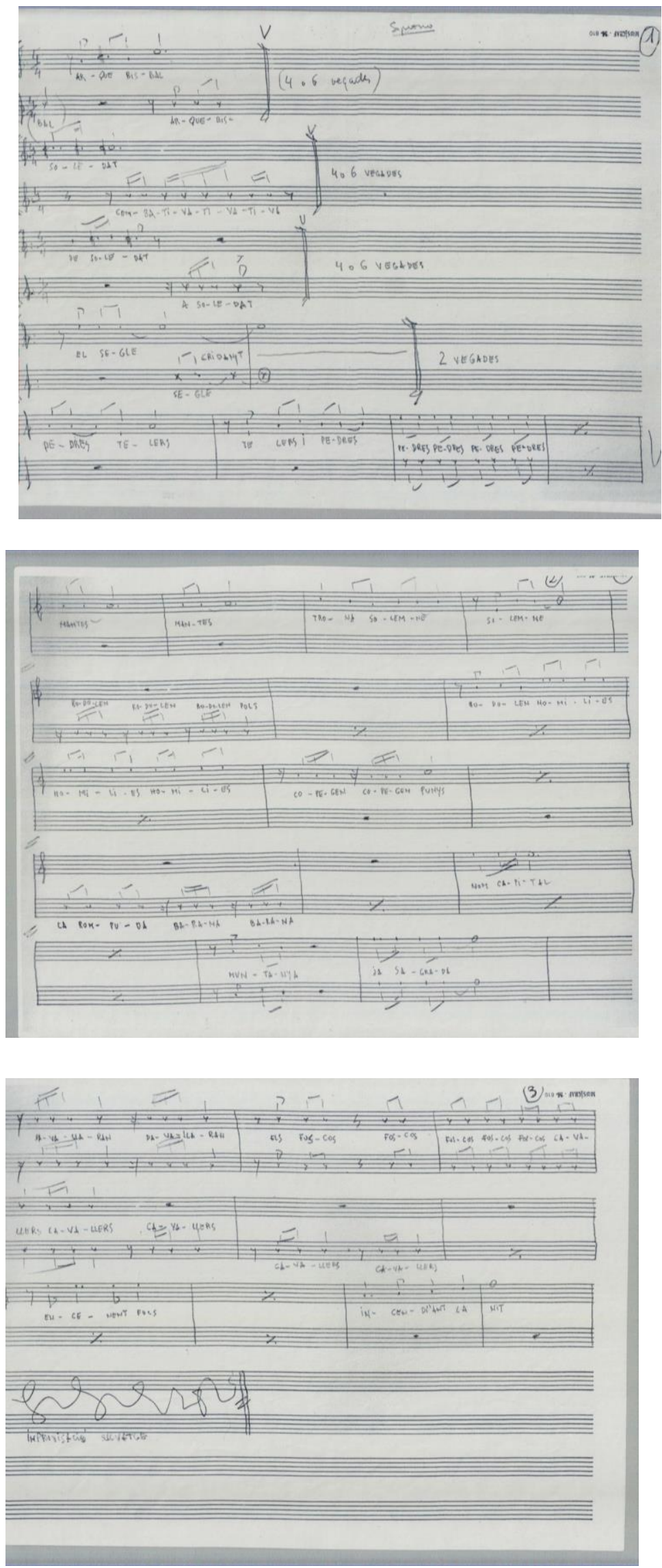
11.- Anexo fotografías 
11.1. SOUND FIHGT (1981)
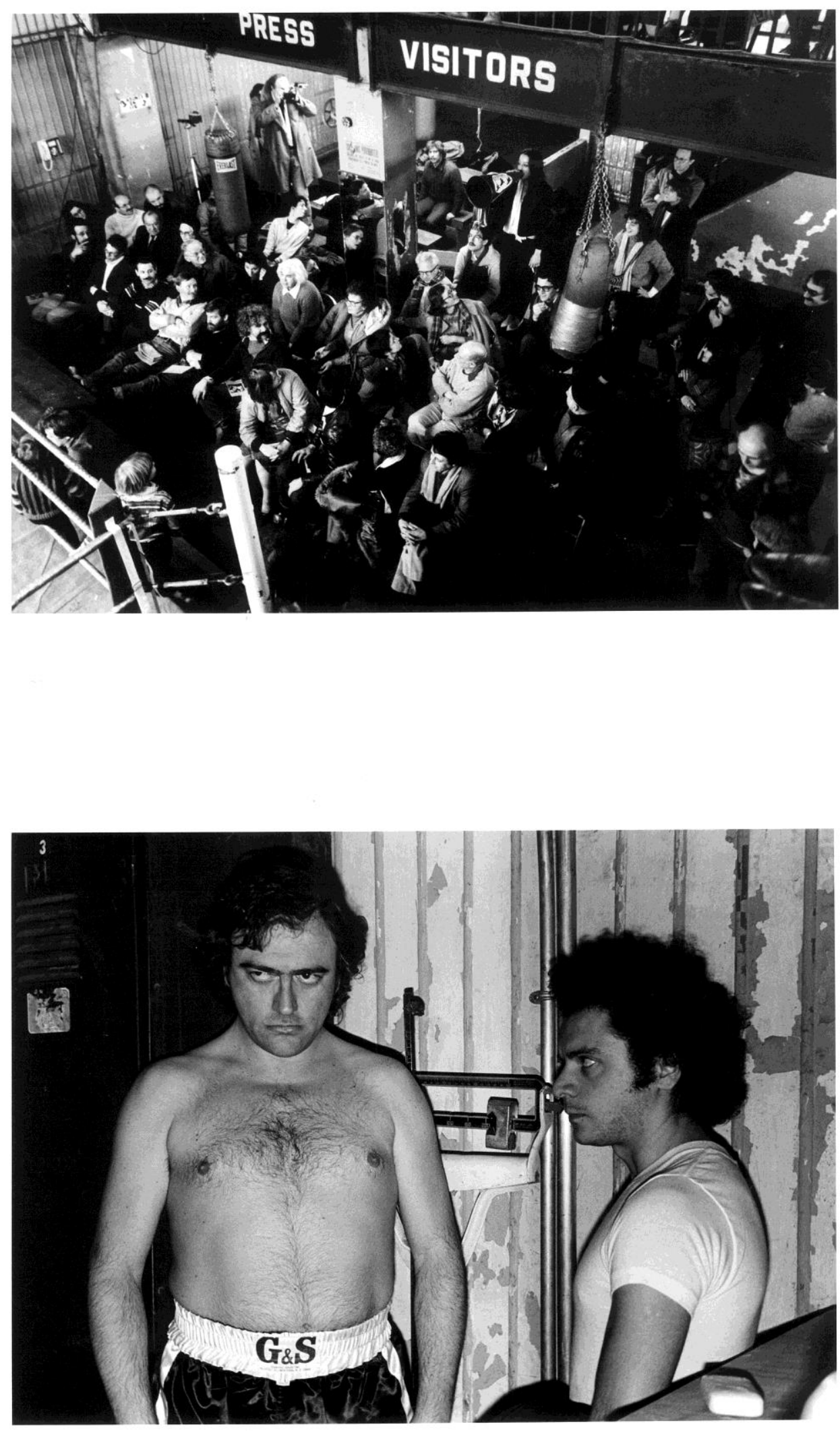

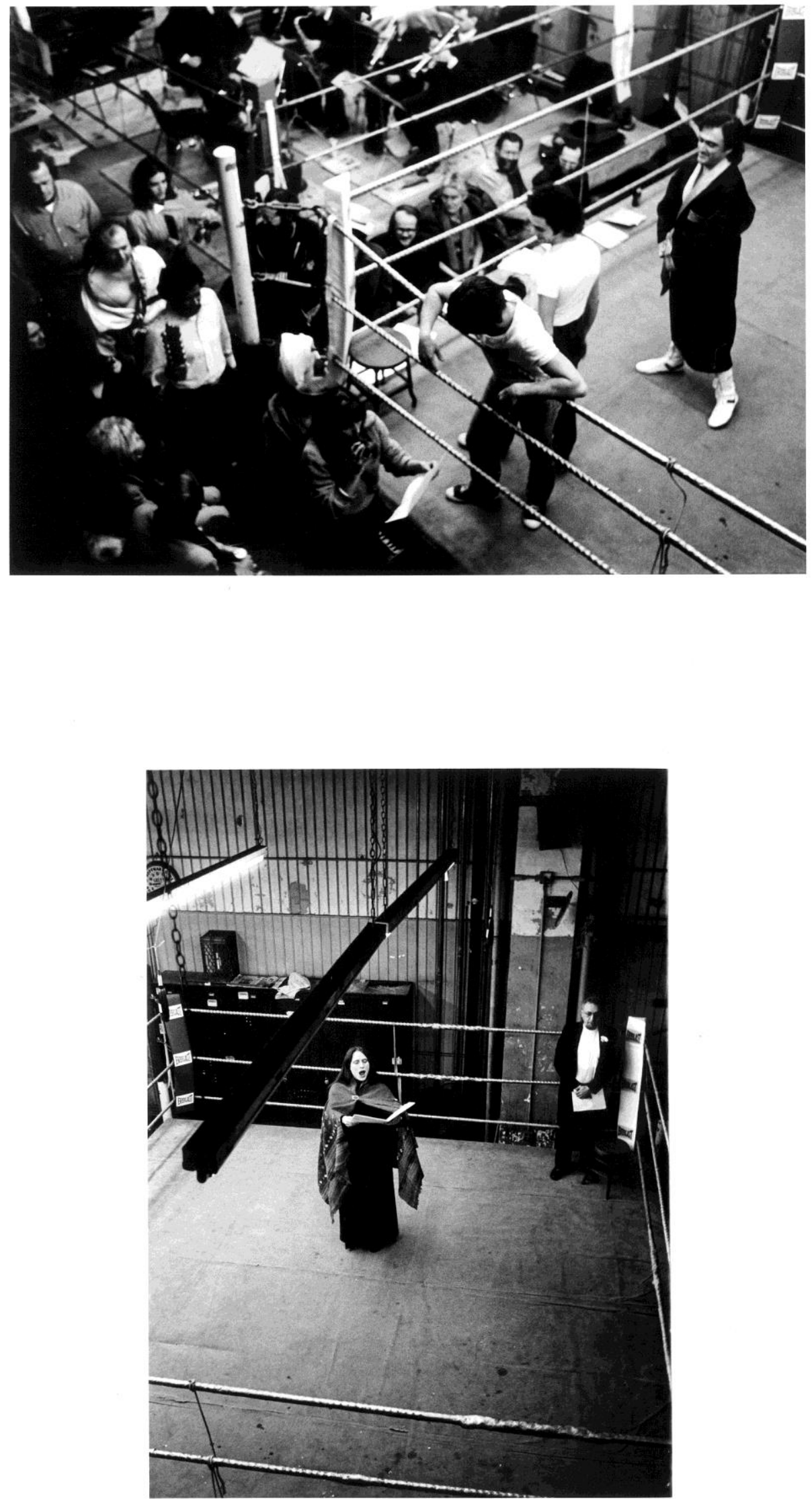

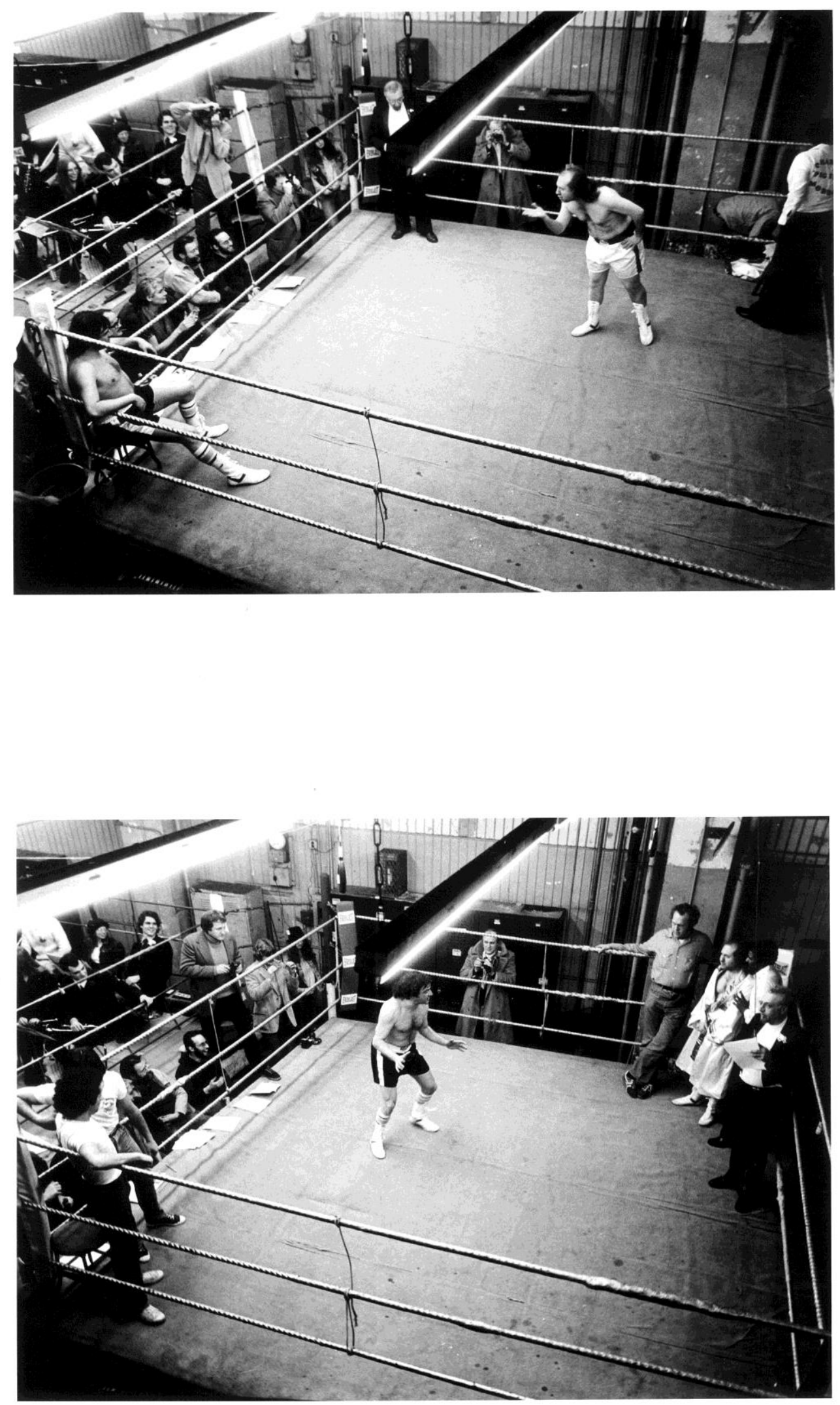

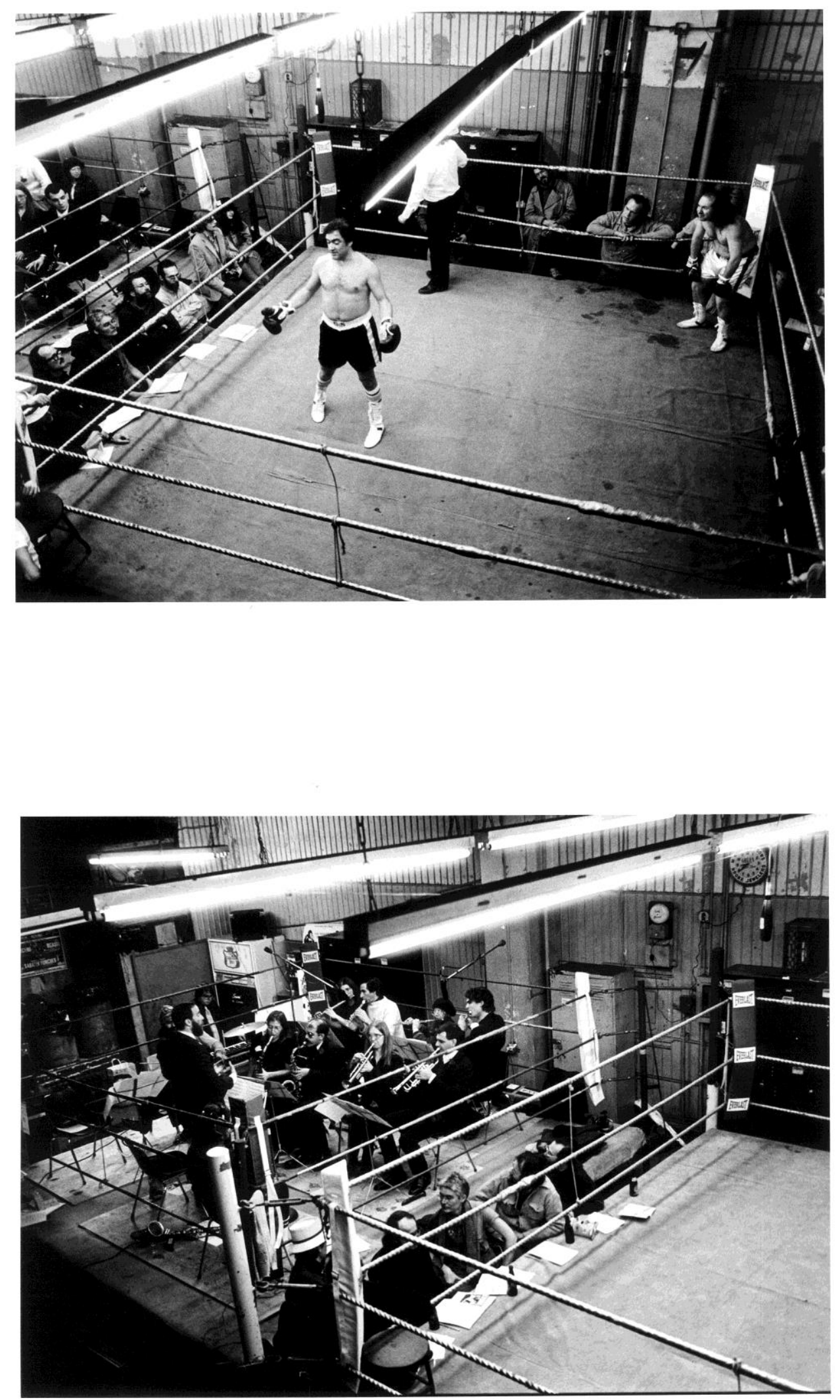

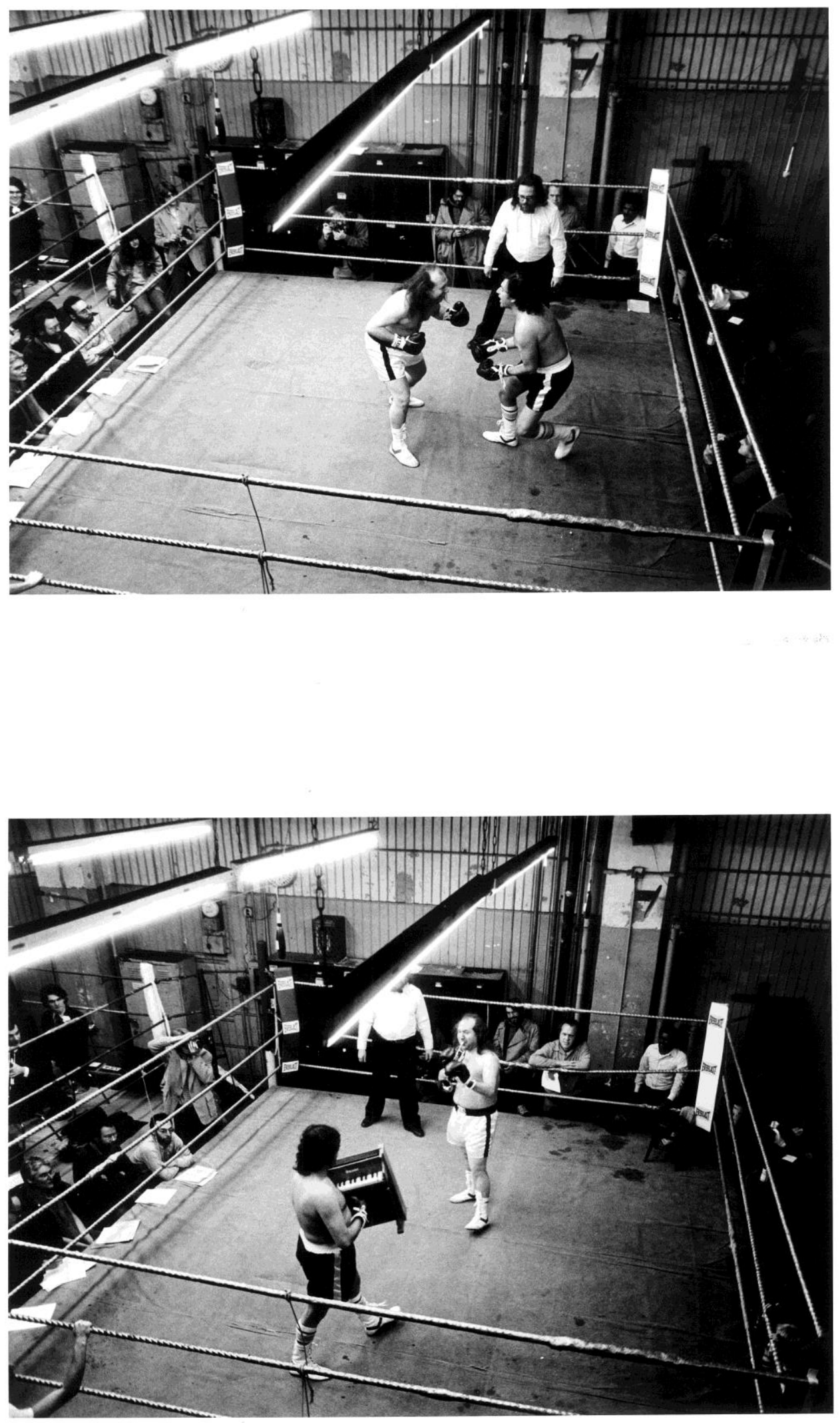

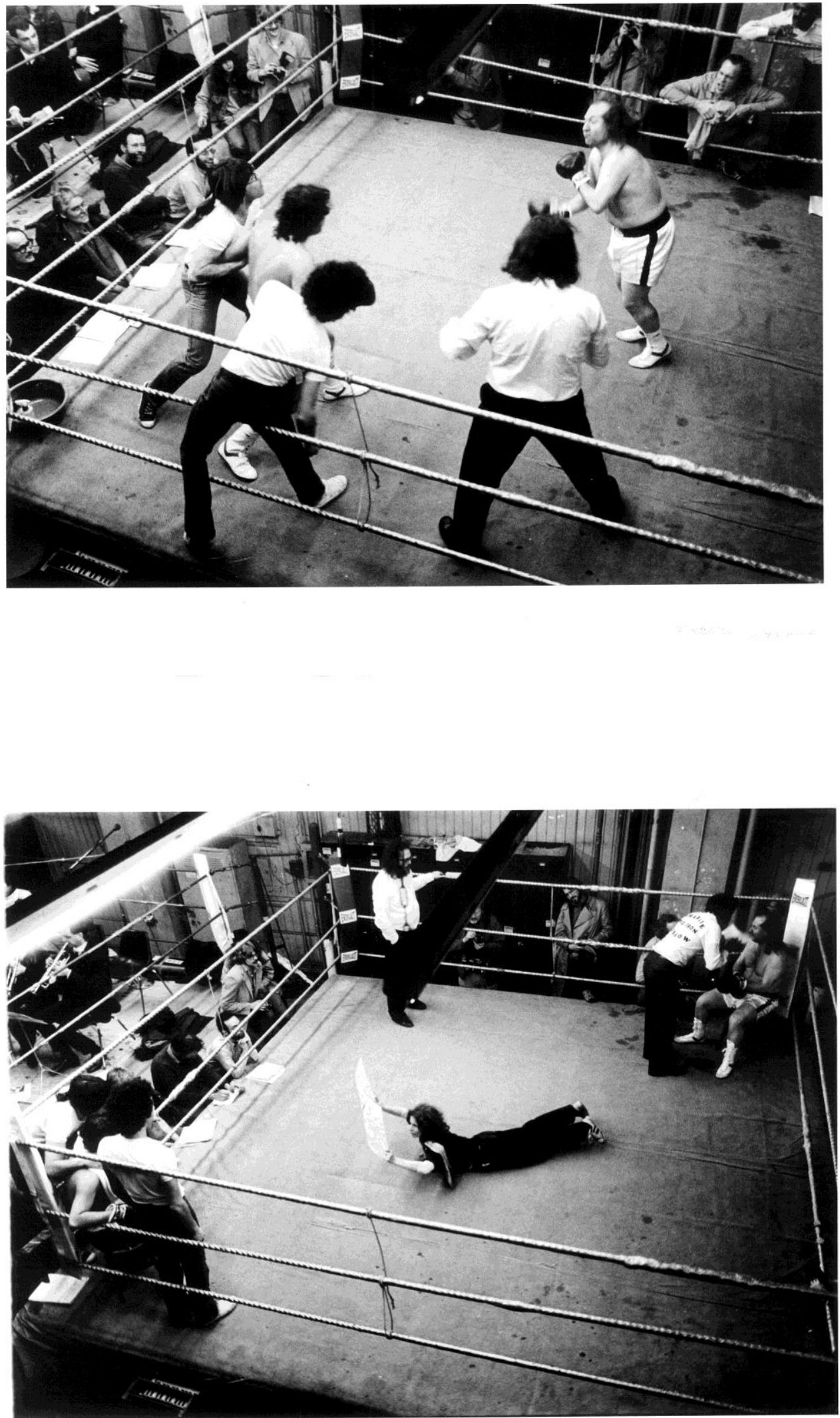

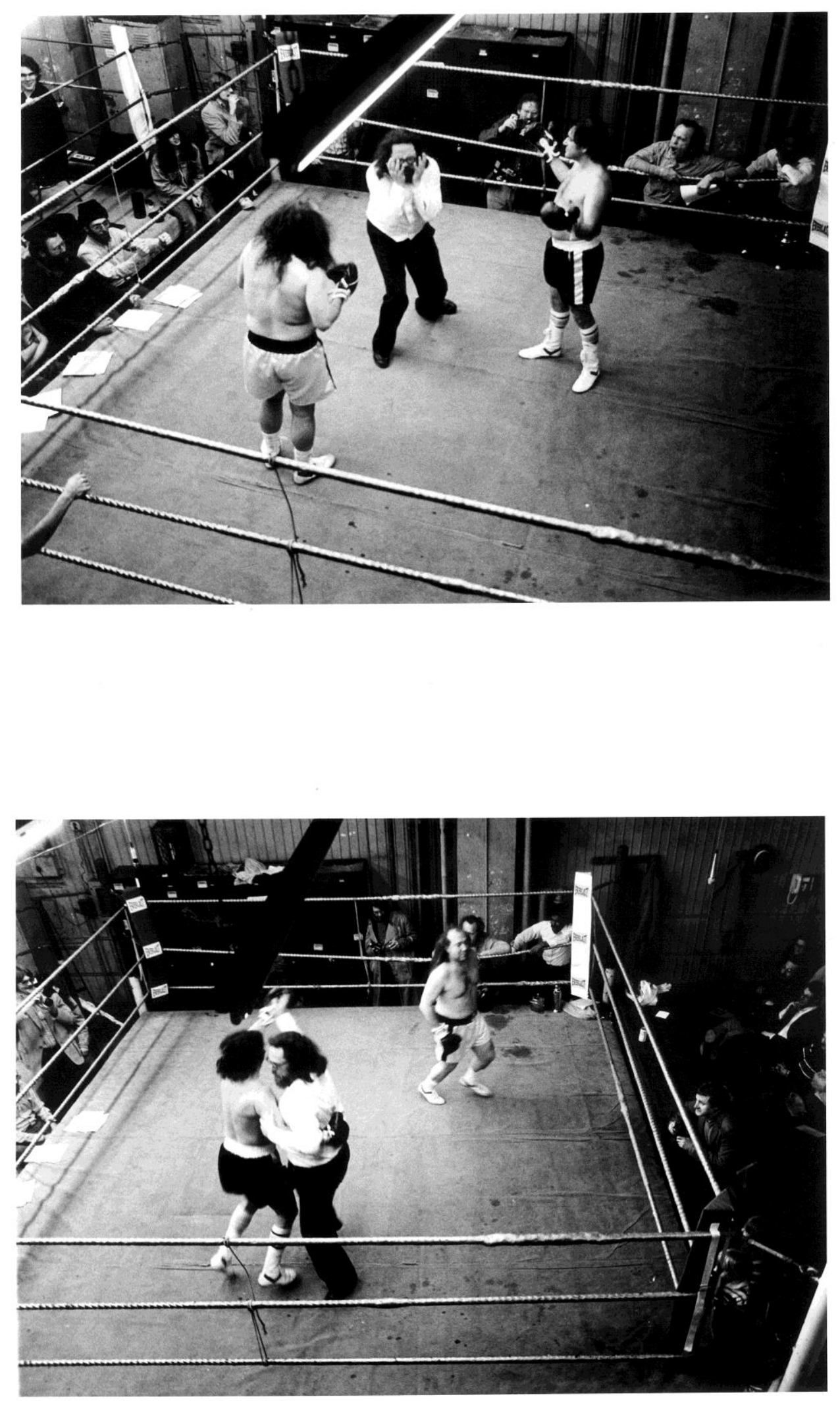

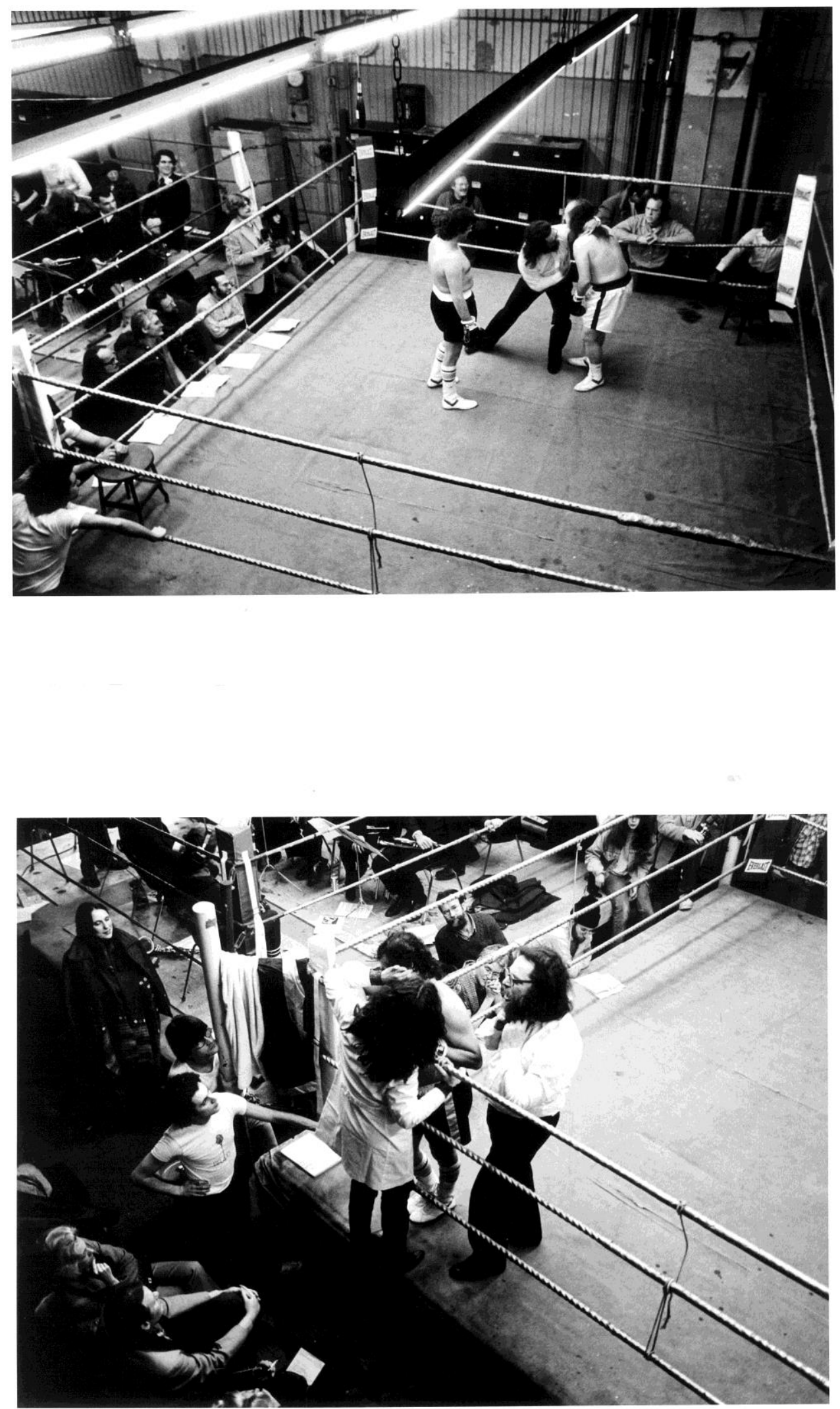

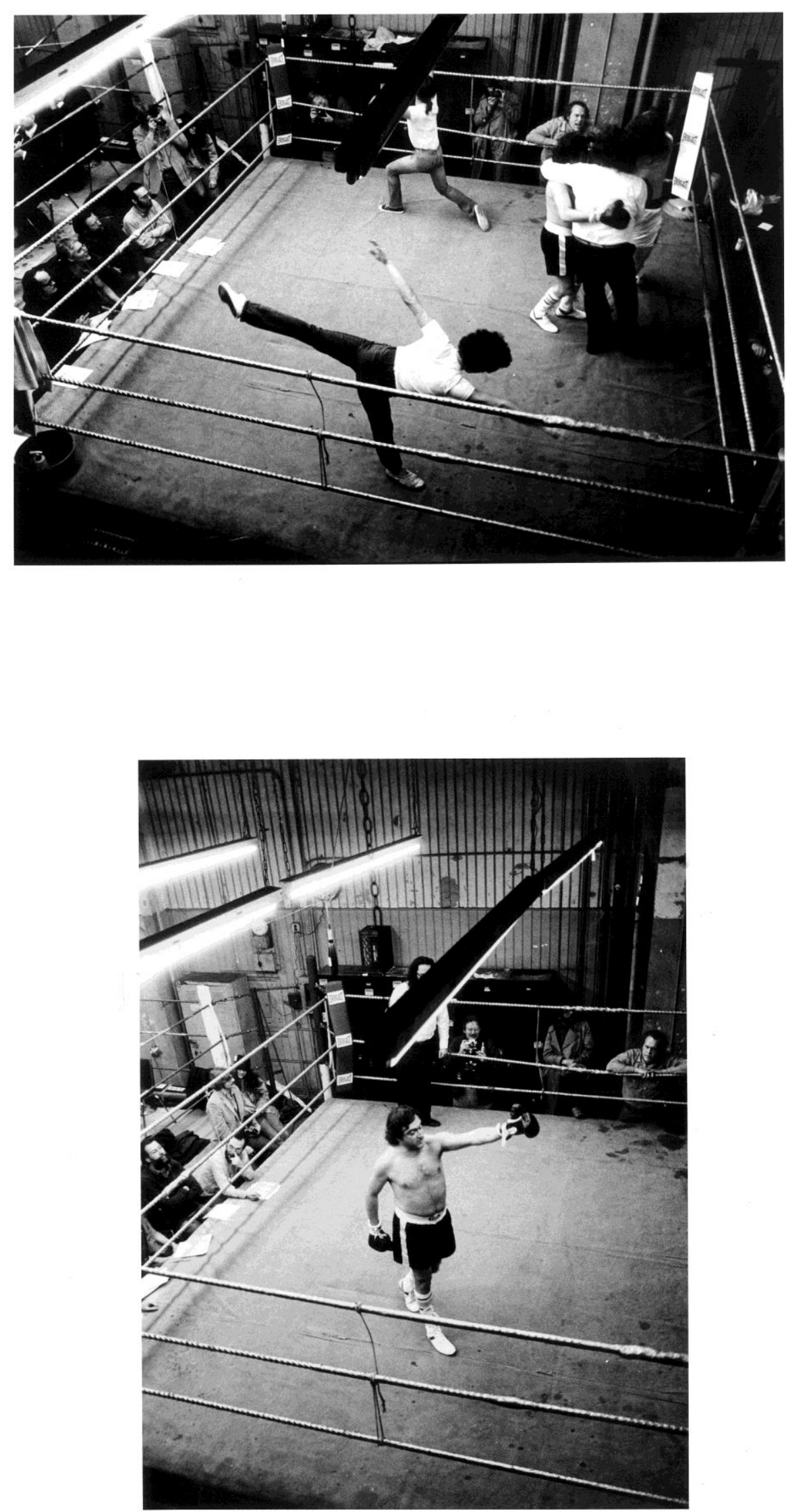
11.2. CANTURIA CANTADA (2014)

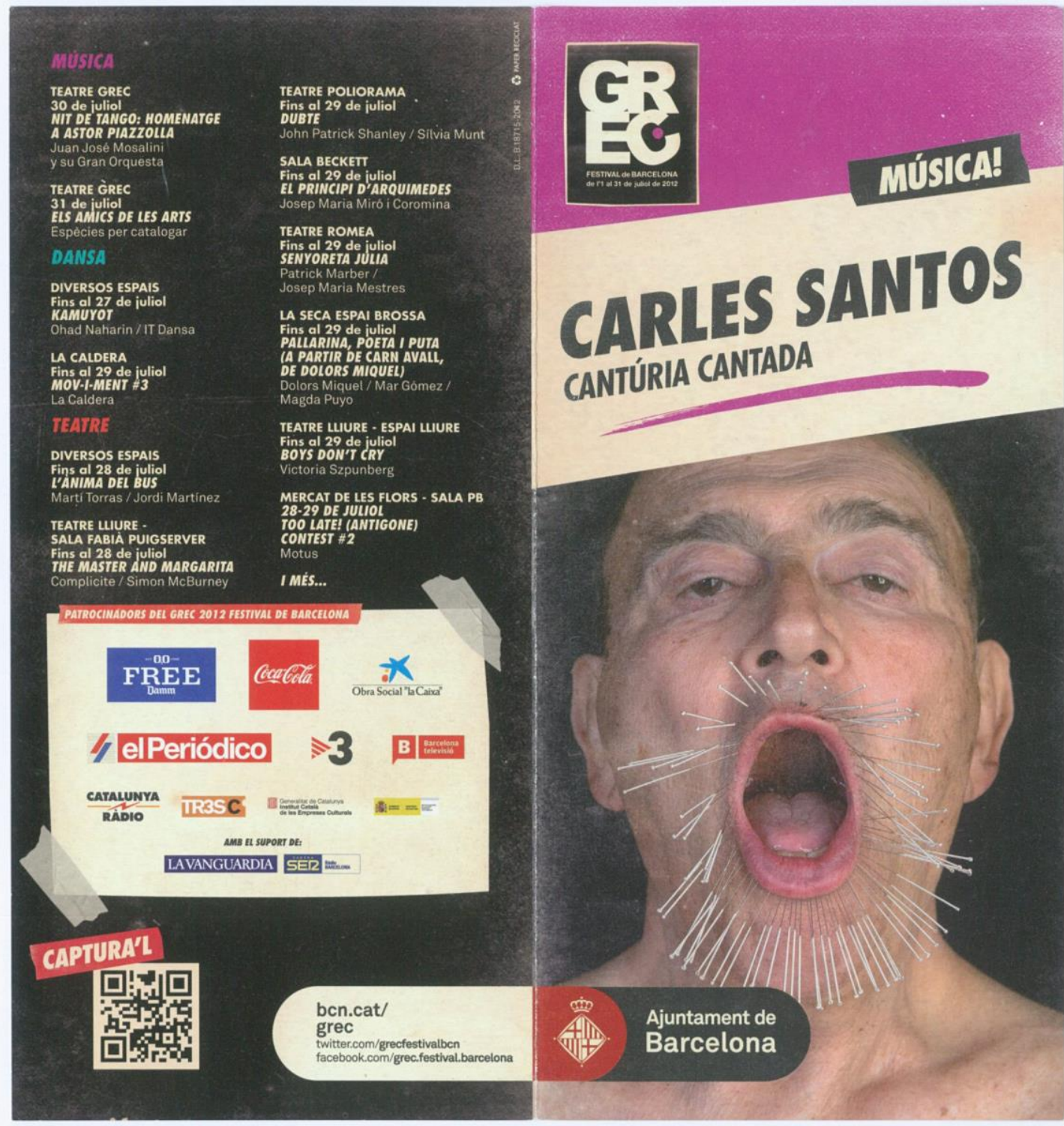




\section{MÜSICA CORAL CONTEMPORÁNIA}

MERCAT DE LES FLORS -

SALA OUIDI MOWTLOR

\section{I 27 DE JULIOL}

\section{CARLES SANTOS}

COR DE CAMBRA DEL PALAU DE LA MÚsICA CatalaNA CANTÚRIA CANTADA

La música per la boca

per la boca de la memòria

de la memòria a la pròpia realitat,

realitat del so

del so sol.

Això és lo que passarà

quan la veu se cante

iprou.

Prou de cristos rebentats.

Vòmits de bona escriptura.

Llets diverses.

Famities mortes.

Pits peluts.

Desesperació.

Taló d'agulla - forat tapat.

Xiquets masturbadors.

Cantar i orinar al mateix temps.

Escatologia divina.

Idees mortes.

Vestits de ventolera.

Vevols de ventolera.

Revolcons xonats.

Contorsió de cervells esgarranyats.

Pauses, moltes pauses.

Pauses de coses que tots hem vist.

Que tots hem vist cantant.

Cantant no hem vist lo que estem veient.

No cal veure-ho.

Amb una sola llum esperem

el moment del silenci moderat,

prenyat de ràbia i cantat per

si mateix.

Fes lo que tingues que fer

tot està penetrat per tu

fins que les arestes s'acoblen.

Regalima'm per dins.

Per dins.

\section{PROGRAMA}

AUTORETRAT (Voicetracks, 1981)

LA TRAMUNTANA JA BRAMA (Tramuntana Tremens, 1989)

GERMINACIÓ (Tramuntana Tremens, 1989)

CINTURÓ DE CASTEDAT (Chicha Montenegro Gallery, 2010)

3er JOC: PATINS (La meua filla sóc jo, 2005)

OBERTURA (L'adéu de Lucrècia Borja, 2001)

GUI-NO-VART (Homenatge a Josep Guinovart, 2008)

LLET HUMANA (Chicha Montenegro Gallery, 2010)

OBERTURA (La Pantera Imperial, 1997)

PLOR DE LES VERGES (L'adéu de Lucrècia Borja, 2001)

SANG (Chicha Montenegro Gallery, 2010)

SEMPRE ESTARÀS PROP (L'adéu de Lucrècia Borja, 2001)

KI-KI-RI-KI (La meua filla sóc jo, 2005)

TO-CA-TI-CO TO-CA-TÀ (Voicetracks, 1978)

COMPOSICIÓ MUSICAL

CARLES SANTOS

DIRECCIÓ

DOLORS RICARTIAMANÓS

INTERPRETACIÓ MUSICAL

COR DE CAMBRA DEL PALAU DE LA MÚSICA CATALANA

DIRECTOR TITULAR DEL COR

JOSEP VILAI CASANAS

IL. LUMINACIÓ

SAMANTHA LEE

MOVIMENT

MONTSE COLOMÉ I TONI JODAR

FOTOGRAFIA

CARLES SANTOS

Una coproducció del Grec 2012 Festival de Barcelona,

Carles Santos i M.O.M. / EI Vivero (Marta Oliveres).

Amb la col-laboració de la Fundació Caixa de Vinaròs.

$$
\text { (2) } \mathrm{FunDaCO}
$$


11.3. LO BO BE PER BAIX (2014)
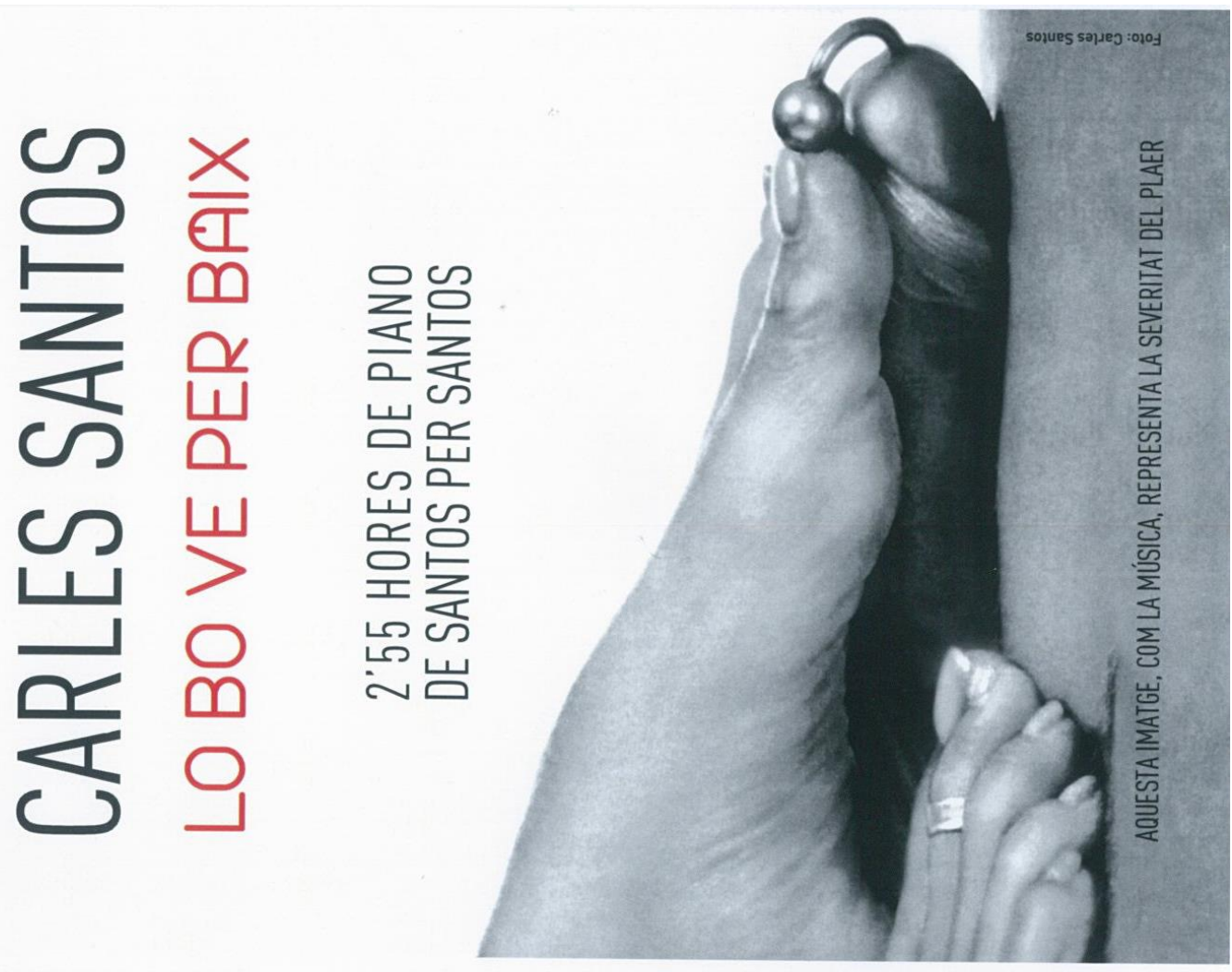

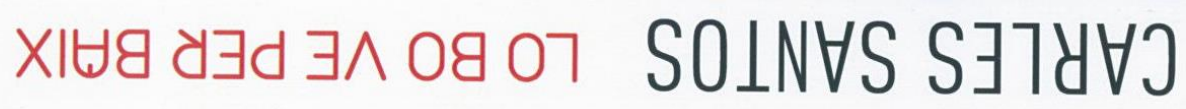

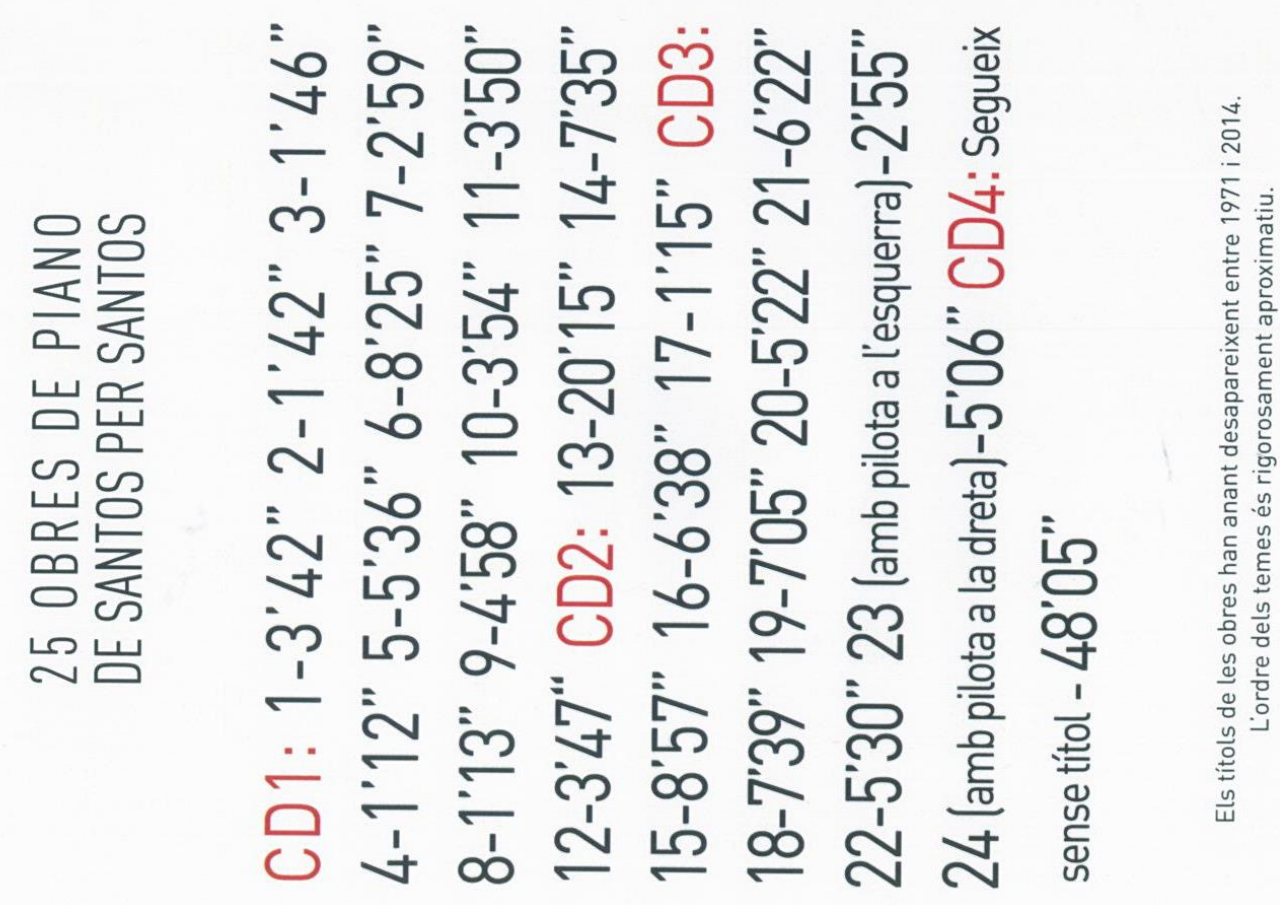




\section{2.- Bibliografía}




\section{2.- BIBLIOGRAFÍA}

\subsection{LIBROS}

Aviñoa, X. (2003): Història de la Música Catalana, Valenciana i Balear (Vol. X). Barcelona. Edicions 62. ISBN 84-297-5329-X.

> Balló, J., Espelt, R., Lorente, J. (1990): Els músics, Cinema català 1975-1986. Barcelona: Columna, 1990, p. 187-195.

Beltrán Moner, R. (1984): La ambientación musical. Selección, montaje y sonorización. Madrid: Instituto Oficial de radio y Televisión, [2ª edición 1991].

> Fundación Autor-ICCMU-Institut Valencià de la Música (Ed.), (2006): Diccionario de la Música Valenciana (II). Valencia. España. ISBN 84-8048706-2.

$>$ Fundació Miró. (Ed.) (2006): Carles Santos. Long Live the Piano. Generalitat de Catalunya, Departament de Cultura. Barcelona. ISBN 84-96540-40-5. Edición en catalán.

> Galbis López, V. (2006): Diccionario de la Música Valenciana. (Vol. II). Iberautor Promociones Culturales S. R. L. Madrid. ISBN 84-8048-707-0, p. 414418.

> García, J. M. y Rom, M. (1982): Finestra Santos. Ed. Cine-Club Assiciació d’Enginyers Industrials de Catalunya. Barcelona.

> González García, A. (2007): Esto es una silla. LOCVS AMENVS 9, 20072008, p. $385-391$

Guerrero, M. (2006): Carles Santos. Visca el Piano!. Fundació Joan Miró. Barcelona. 
Jay Grout, D. (1984): Historia de la Música Occidental, 2. Alianza Editorial, Madrid.

Johnson, Tom (1992): Vocabulaire de la musique contemporaine. Ed. Minerva, París.

Locatelli de Pergamo, A. Ma . (1973): La notación de la música contemporánea. Buenos Aires, Ricordi Americana S.A.E.C.

> Lluís I Falcó, J. (2001): El cinema, Història de la Música Catalana, Valenciana i Balear. Vol. VII. Música de participació i de noves tecnologies. Barcelona: Edicions 62.

MacMillan Publishers Ltd. (Ed.) (2000): The New Grove Dictionary of Music and Musicians. (Vol. XXII). Reino Unido.

Michels, U. (1992): Atlas de Música, 2. Vol. 2. Alianza Editorial. Madrid.

Ruvira, J. (1987): Compositores contemporáneos valencianos. Valencia, Alfond el Magnànim.

Ruvira, J. (1996): El caso Santos. Valencia, Mà d'obra.

Ruvira, J. (2008): Los desafíos artísticos de Carles Santos. Valencia, Institució Alfons el Magnànim.

\subsection{COMUNICACIONES Y TESIS DOCTORALES}

> Fraile Prieto, T. (2008): La creación musical en el cine español contemporáneo. (Tesis Doctoral). Universidad de Salamanca, España. pp. 1-3.

> Kaiero Claver, A. (2007): Creación musical e ideologías: la estética de la postmodernidad frente a la estética moderna. (Tesis Doctoral). Universidat Autònoma de Barcelona, España. pp. 298-340. Recuperado de: http://www.tdx.cat/bitstream/handle/10803/5197/akc1de1.pdf?sequence=1 
Marín Sánchez, E. J. (2013): La poética del fragmento y del intervalo en la poesía experimental sonora de Bartolomé Ferrando. (Tesis Doctoral). Universidad Miguel Hernández de Alicante, España. pp. 145-146, 155-156, 427431.

\subsection{REVISTAS Y CATÁLOGOS IMPRESOS}

> AA.VV. (junio 2015): UNIVERSO SANTOS. El fervor de la perseverancia en Carles Santos. (catálogo de la exposición en el Centre Cultural La Nau. Universidad de Valencia). Valencia.

$>$ Badiou, M. (septiembre 1987): Carles Santo, veinte años de riesgos. El Público, núm. 48, pp. 15-16.

> Blasi, E.; Herreros, R. (1979): Música i cinema: parlant amb Carles Santos, Arc Voltaic. Full de cinema, núm. 5, primavera 1979, pp. 1-3.

Cureses, M. (1996): Claves de comunicación en la música contemporánea: la fascinación interpretativa de Carles Santos. Eufonía, 5,X-1996.

Diago, N. (mayo-junio 1990): Tramuntana tremens. Canto acuático de Carles Santos. El Público, núm. 78, p. 50.

Dluís I Falcó, J. (octubre 2007): Música i audiovisual a Catalunya, Carles Santos. Secuencias de Música de cine. Número extraordinario. pp. 14-15.

Mac Low, J. (1981): Voice Tracks, New York.

Ponce, Vicente (1999), "El cuerpo sonoro (Acerca de Carles Santos)", en Santos, Carles (1999), Carles Santos (catálogo de la exposición en el Espai de Art Contemporani de Castellón), Catellón, pp. 104-123.

Ruvira, J. (1999), "Les dimensions artístiques de Carles Santos", en Santos, Carles (1999), Carles Santos (catálogo de la exposición en el Espai de Art Contemporani de Castellón), Catellón, pp. 40-72. 
$>$ Sánchez, J. A. (s. f.) El pensamiento y la carne. Revista Digital ARTEA. En disponibilidad

Web: http://artesescenicas.uclm.es/archivos_subidos/textos/288/pensamientoycarne_ja sanchez.pdf

> Teatre Lliure (mayo 2008), Brossalobrossotdebrossat, Carles Santos (catálogo del espectáculo en el Teatre Lliure de Montjuic), Barcelona.

> Teatre Lliure (octubre 2010), Chicha Montenegro Gallery, Carles Santos (catálogo del espectáculo en el Teatre Lliure de Montjuic), Barcelona.

Teatre Lliure (febrero 2010), La Pantera Imperial, Carles Santos (catálogo del espectáculo en la Sala Fabià Puigserver de Montjuic), Barcelona.

Teatre Lliure (mayo 2009), Piturrino fa de músic, Carles Santos (catálogo del espectáculo en la Sala Fabià Puigserver de Montjuic), Barcelona.

Teatre Lliure (noviembre 2011), Shubertnacles humits, Carles Santos (catálogo del espectáculo en la Sala Fabià Puigserver de Montjuic), Barcelona. 
13.- Webgrafía 


\section{WEBGRAFÍA}

Ajuntament de Viladecamps (2009): "Tirant lo Blanc" rep vuit nominacions als Premis Max de les Arts Escèniques. S. reg. Recuperado de: http://www.ajviladecans.es/Plantilles/noticia/_JNJtGAWc42b7NrmOUzSiUD2R2BWP1oTGRJNIM5 qMnRVYHr2nPvsrSmSnJleNndoc. (20 de julio de 2015)

Archivo Artea [mataderomadrid] (1982, s. d., s. d.), Anem, anem, anem a volar. [archivo de video]. Recuperado de https://www.youtube.com/watch?v=VYZepfjRshA y de http://www.rtve.es/alacarta/videos/imprescindibles/imprescindibles-carles-

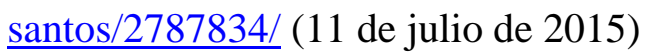

Archivo virtual Artes Escénicas. (sin fecha). La grenya de Pascual Picanya, assesor $\begin{array}{lllll}\text { juridic-administratiu. } & \text { S. } & \text { reg.. } & \text { S. } & \text { reg. }\end{array}$ http://artesescenicas.uclm.es/index.php?sec=obras\&id=85 (20 de julio de 2015)

[Arganchulla, Argan chulla, GaIlac, abre el Grec '87]. (4 de agosto de 1987). El periódico de Cataluña. Recuperado de: (http://archivo.elperiodico.com/ed/19870804/pag_029.html). (20 de julio de 2015)

Arts Santa Mónica [artssantamonica] (2009, abril, 1), y Pecatamonicatismarmolla tua tua. [archivo de video]. Recuperado de https://www.youtube.com/watch?v=pGA8P8YtkRQ (11 de julio de 2015)

Balló, J. (19.09.07): El silencio antes de Bach. La Vanguardia. Recuperado de: http://www.societatbach.org/drupal_antic/node/284 (20 de julio de 2015)

Boix, A. (1 de febrero de 2011): Documentales sobre Joan Miró. Blog. Recuperado de: http://artcontemporanigeneral.blogspot.com.es/2011/02/documentales-sobre-joanmiro.html (11 de julio de 2015)

Carles Santos Ventura, (1 de junio de 2015). En Wikipedia. Recuperado el 20 de julio de 2015 de http://ca.wikipedia.org/wiki/Carles_Santos_Ventura. (20 de julio de 2015) 
Catalan Deus, J. (9 de noviembre de 2007): Estreno: 'El fervor de la perseverancia' de Carles Santos. Recuperado de:

http://blogs.periodistadigital.com/arte.php/2007/11/09/p125913 (20 de julio de 2015)

Centre Pompidou (sin fecha): 8500 tonnes de fer. Recuperado de: https://www.centrepompidou.fr/id/cR5bLdq/rxAd64e/fr (11 de julio de 2015)

Díaz Sande, J. R. (sin fecha): La meua filla sóc jo (mi hija soy yo) un no argumento sin final, sino diversos comportamientos de hijas y madres en una ópera de pequeño formato. Madrid. Recuperado de:

http://www.madridteatro.eu/teatr/entrevistas/entrevista059.htm . (20 de julio de 2015)

Divx Clásico (sin fecha): foro. Recuperado de: http://www.divxclasico.com/foro/viewtopic.php?t=25753. (4 de septiembre de 2011)

Experimentaclub. (sin fecha). Carles Santos. Madrid. S. reg. Recuperado de: http://www.experimentaclub.com/data/carles_santos/index.htm. (20 de julio de 2015)

Filmoteca.org (sin fecha) La dekinqüencia. Recuperado de: http://www.filmoteca.org/pelicula-la-delincuencia.htm (11 de julio de 2015)

Filmaffinity (sin fecha): El pianista. Recuperado de: http://www.filmaffinity.com/es/film979188.html (11 de julio de 2015)

Fundació Caixa Vinaròs [fundaciocaixavinaros] (1981, s. d., s. d) To-ca-ti-co-to-ca-ta. [archivo de video]. Recuperado de: https://www.youtube.com/watch?v=fGCisW5y_pU (11 de julio de 2015)

González García, A. (2007). Esto es una silla. LOCVS AMENVS, págs.. 385-391. Recuperado de: http://www.raco.cat/index.php/locus/article/viewFile/137407/188027 (11 de julio de 2015) 
González García, A. (diciembre 2009). El piano, ¿mueble inútil?: Carles Santos y el cine. Recuperado

de: http://www.academia.edu/2163033/_El_piano_mueble_in\%C3\%BAtil_Carles_Santos y_el_cine_Blogs_and_Docs_diciembre_2009 (20 de julio de 2015)

Hirsch, Sonia (abril de 2011): Carles Santos: El cine experimental hace sus deberes. S. reg. Recuperado de: http://www.inventodeldemonio.es/2011/04/carles-santos-el-cineexperimental-hace-sus-deberes.html. (20 de julio de 2015)

Huerga, M. [manuelhuerga]. (2 de septiembre de 2011). Estoc de pop: Carles Santos "Minimalet Sur Mer" ep.22 [archivo de video]. Recuperado de:

(http://www.dailymotion.com/video/xkuefd_estoc-de-pop-carles-santos-minimaletsur-mer-ep-22-15-06-84_tv (11 de julio de 2015)

Huerga, M. [manuelhuerga] (1984, 6, 15), Minimalet sur mer, [archivo de video]. Recuperado de: http://www.dailymotion.com/video/xkuefd_estoc-de-pop-carles-santosminimalet-sur-mer-ep-22-15-06-84_tv (11 de julio de 2015)

Imdb (sin fecha): Vértigo en Manhattan. Recuperado de:

http://www.imdb.com/title/tt0080955/ (11 de julio de 2015)

Imdb (sin fecha): L'agressió quotidiana. . Recuperado de:

http://www.imdb.com/title/tt1127285/?ref_=nm_flmg_dr_3 (11 de julio de 2015)

Imdb (sin fecha): L'Assemblea de Catalunya. . Recuperado de:

http://www.imdb.com/title/tt1127288/?ref_=rvi_tt (11 de julio de 2015)

Imdb (sin fecha): El barri del Besós. . Recuperado de: http://www.imdb.com/title/tt1127291/?ref_=rvi_tt (11 de julio de 2015)

Imdb (sin fecha): $\quad \mathrm{Pa}$ d'àngel. Recuperado de: http://www.imdb.com/title/tt0086076/?ref_=rvi_tt (11 de julio de 2015) 
Imdb (sin fecha): Cantants '72. Recuperado de:

http://www.imdb.com/title/tt0182867/?ref_=rvi_tt (11 de julio de 2015)

Imdb (sin fecha): Barcelona sur. Recuperado de:

http://www.imdb.com/title/tt0082047/?ref_=rvi_tt (11 de julio de 2015)

Imdb (sin fecha): La delinqüència. Recuperado de: http://www.imdb.com/title/tt1356743/?ref_=nm_flmg_dr_2 (11 de julio de 2015)

Imdb (sin fecha): Setmana de la sanitat. Recuperado de: http://www.imdb.com/title/tt1356840/?ref_=nm_flmg_dr_21 (11 de julio de 2015)

Imdb (sin fecha): L'ajuntament de Barcelona. Recuperado de: http://www.imdb.com/title/tt1356700/ (11 de julio de 2015)

Imdb (sin fecha): Aurora Corominas. Recuperado de: http://www.imdb.com/name/nm0180533/ (11 de julio de 2015)

Imdb (sin fecha): Clara foc. Recuperado de: http://www.imdb.com/title/tt0447898/ (11 de julio de 2015)

Imdb (sin fecha): Foc al càntir. Recuperado de: http://www.imdb.com/title/tt0336452/combined (11 de julio de 2015)

Instituto Cervantes (2008). Cortometrajes de Carles Santos (Hanóver). Bremen:. Instituto Cervantes. Recuperado de:

http://bremen.cervantes.es/FichasCultura/Ficha50149_46_1.htm. (11 de julio de 2015)

La información (17/06/2011): Cesc Gelabert bailará sardanas "sin folclorismos" para inaugurar el Grec 2011.[ lainformacion.com]. Recuperado de: http://noticias.lainformacion.com/arte-cultura-y-espectaculos/danza/cesc-gelabertbailara-sardanas-sin-folclorismos-para-inaugurar-el-grec2011_n5BWdFS9xwLxtUXneUCVd6/. (20 de julio de 2015) 
Lluís i Falcó, J. (2011): Carles Santos. S. reg. s. reg. Recuperado de: http://usuarios.multimania.es/compositores/csantos00.html (4 de septiembre de 2011)

Lluís i Falcó, J. (2011): Carles Santos. S. reg. s. reg. Recuperado de: http://usuarios.multimania.es/compositores/csantos01.html. (4 de septiembre de 2011)

Lluís i Falcó, J. (2011): Carles Santos. S. reg. s. reg. Recuperado de: http://usuarios.multimania.es/compositores/csantos04.html. (4 de septiembre de 2011)

Lluís i Falcó, J. (2011): Josep Lluís Falcó. S. reg. s. reg. Recuperado de: http://usuarios.multimania.es/compositores/JLLF.html. (4 de septiembre de 2011)

López Mozo, J. (sin fecha): La meua filla sóc jo. Mi hija soy yo (o vaya usted a saber). Madrid. Recuperado de: http://www.madridteatro.eu/teatr/musica/musica003.htm. (20 de julio de 2015)

Madridteatro (sin fecha): La meua filla sóc jo (Mi hija soy yo). Madrid. Recuperado de: http://www.madridteatro.eu/teatr/informacion/informacion105.htm. (20 de julio de 2015)

Mariaelena Roqué (sin fecha): [cia santos]. Recuperado de: http://www.mariaelenaroque.com/ciasantos.html (20 de julio de 2015)

Matadero Madrid (sin fecha). Matadero Madrid. Madrid. S. reg. Recuperado de: www.mataderomadrid.com (11 de julio de 2015)

Moreno, J. (4 de septiembre de 2008): Carles Santos. Recuperado de: http://ozurret.blogspot.com/2008_09_01_archive.html. (20 de julio de 2015)

Morgades, L. (02/04/ 09): El amante del piano. El País. Recuperado de: http://www.geifco.org/actionart/actionart01/nmP/espectaculo/santos/santos.htm (20 de julio de 2015) 
Música minimalista (5 de junio de 2015). En Wikipedia. Recuperado el 20 de julio de 2015 de: http://es.wikipedia.org/wiki/M\%C3\%BAsica_minimalista (20 de julio de 2015)

Oliveres, M. (2011): [Manager artística/Carles Santos]. S. reg. s. reg. Recuperado de: http://www.martaoliveres.com/pagina.asp?0=3\&1=371838\&3=47366 (4 de septiembre de 2011)

Pascual, J. A. (7 de marzo de 2013): El WhatsApp no daña la lengua, es un formato distinto. . La Vanguardia. Recuperado de:

http://www.lavanguardia.com/cultura/20130307/54368078967/entrevista-jose-antoniopascual-rae-whatsapp.html (20 de julio de 2015)

Perales, L. (15 de octubre de 2010): Carles Santos "Mi interés por visualizar la música me llevó al teatro". S. reg. Recuperado de: http://www.elcultural.es/version_papel/ESCENARIOS/27999/Carles_Santos. (20 de julio de 2015)

Pere Portabella (sin fecha). Pont de Varsovia. Barcelona. Films 59. Recuperado de: http://www.pereportabella.com/es/largometrajes/largometrajes/pont-de-varsovia-es (11 de julio de 2015)

Pere Portabella (sin fecha). Concert Irregular. Barcelona. Films 59. Recuperado de: http://www.pereportabella.com/es/direccionescenica/direcci\%C3\%B3n\%20esc\%C3\%A9nica/concert-irregular (20 de julio de 2015)

Pere Portabella (sin fecha). Asdrubila. Barcelona. Films 59. Recuperado de: http://www.pereportabella.com/es/direccionescenica/direcci\%C3\%B3n\%20esc\%C3\%A9nica/asdrbila (20 de julio de 2015)

Pere Portabella (sin fecha). Informe General. Barcelona. Films 59. Recuperado de: http://www.pereportabella.com/es/largometrajes/largometrajes/informe-general-es (20 de julio de 2015) 
Pere Portabella (sin fecha). Umbracle. Barcelona. Films 59. Recuperado de: http://www.pereportabella.com/es/largometrajes/largometrajes/umbracle-es (20 de julio de 2015)

Pere Portabella (sin fecha). Vampir-Cuadecuc. Barcelona. Films 59. Recuperado de: http://www.pereportabella.com/es/largometrajes/largometrajes/vampir-cuadecuc-es (20 de julio de 2015)

Pere Portabella (sin fecha). Nocturn-29. Barcelona. Films 59. Recuperado de: http://www.pereportabella.com/es/largometrajes/largometrajes/nocturn-29-es $\quad(20$ de julio de 2015)

Pere Portabella (sin fecha). No compteu amb els dits. Barcelona. Films 59. Recuperado de: http://www.pereportabella.com/es/largometrajes/largometrajes/no-compteu-amb-elsdits-es (20 de julio de 2015)

Pere Portabella (sin fecha). No al no. Barcelona. Films 59. Recuperado de: http://www.pereportabella.com/es/cortometrajes/cortometrajes/no-al-no-es (20 de julio de 2015)

Pere Portabella (sin fecha). Art a Catalunya. Barcelona. Films 59. Recuperado de: http://www.pereportabella.com/es/cortometrajes/cortometrajes/art-a-catalunya-es (20 de julio de 2015)

Pere Portabella (sin fecha). Acció Santos. Barcelona. Films 59. Recuperado de: http://www.pereportabella.com/es/cortometrajes/cortometrajes/accio-santos (20 de julio de 2015)

Pere Portabella (sin fecha). Miró l’altre. Barcelona. Films 59. Recuperado de: http://www.pereportabella.com/es/cortometrajes/cortometrajes/miro-laltre-es $\quad(20$ de julio de 2015) 
Play.me (sin fecha): Pianotrack. Recuperado de: http://www.playme.com/carlessantos/pianotrack_2011043a.html. (4 de septiembre de 2011)

Play.me (sin fecha): Belmonte. Recuperado de: http://www.playme.com/carlessantos_bandasinfonicauniomusicaldelliria/belmonte_416 8172a.html. (4 de septiembre de 2011)

Play.me (sin fecha): Obertura Musical para una Bienal. Recuperado de: http://www.playme.com/carlessantos/obertura-musical-para-una-bienal_4786677a.html. (4 de septiembre de 2011)

Play.me (sin fecha): Fanfarria medieval. Recuperado de: http://www.playme.com/carlessantos/fanfarria-medieval_1628400m.html. $\quad$ (4 de septiembre de 2011)

Play.me (sin fecha): Perturbació Inesperada. Recuperado de: http://www.playme.com/carlessantos/perturbaci\%C3\%B3n-inesperada_1291605a.html. (4 de septiembre de 2011)

Play.me $\quad(\sin$ fecha): Album. Recuperado de: http://www.playme.com/carlessantos/album/. (4 de septiembre de 2011)

Pliego de Andrés, V. (2002): El circo de la ópera. Filomúsica, $\mathrm{N}^{\circ} 35$. Recuperado de: http://www.filomusica.com/filo35/v3.html (20 de julio de 2015)

Portabella, P. [pereportabellavideos]. (6 de marzo de 2013). Trailer Pont de Varsovia [archivo de video]. Recuperado de: https://www.youtube.com/watch?v=KjKQA7FG_fA (11 de julio de 2015)

Radio Televisión Española [rtve] (1987, s. d., s. d.), Buenos días, Madrid. [archivo de video]. Recuperado de http://www.rtve.es/alacarta/videos/imprescindibles/imprescindibles-carlessantos/2787834/ (fragmento) (11 de julio de 2015) 
Rateyourmusic (sin fecha): La oscura historia de la prima Montse. Recuperado de: http://rateyourmusic.com/film/la_oscura_historia_de_la_prima_montse/ (11 de julio de 2015)

Rtve (sin fecha) [Carles Santoss y el piano]. Recuperado de: http://www.geifco.org/actionart/actionart01/nmP/espectaculo/santos/santos.htm. (20 de julio de 2015)

Sánchez, J. (2/11/2005): Carles Santos. S. reg.. S. reg. Recuperado de: http://artesescenicas.uclm.es/index.php?sec=texto\&id=24 (20 de julio de 2015)

Teatre Lliure (2010): Chicha Montenegra Gallery. S. reg. Recuperado de: http://www.teatrelliure.com/documents/temp1011/chicha_montenegro_cas.pdf (20 de julio de 2015)

Tower Records. (sin fecha): Un dit es un dit (CD). Recuperado de: http://www.tower.com/un-dit-s-carles-santos-cd/wapi/117311615. (20 de julio de 2015)

Tradevit (sin fecha): s. reg. Recuperado de: http://www.tradebit.com/mp3artist/902038/carles-santos-agrupacion-musical-rapitenca. (20 de julio de 2015)

Tradevit (sin fecha): Voice-tracks. Recuperado de: http://www.tradebit.com/filedetail.php/119346993-voice-tracks. (20 de julio de 2015)

Vazquez Gómez, P. (2002): Nuevas tendencias: el Minimalismo. Filomúsica, № 25. Recuperado de: www.filomusica.com/filo25/grana.html (20 de julio de 2015)

Archivo Sonoro

Ars Sonora. (3 de julio de 2010). Publicado por admin el 3, julio 2010 en Programas: Monográfico: Carles Santos, setenta años (I). Recuperado de: http://www.rtve.es/buscador/GoogleServlet?q=Monogr\%E1fico\%3A+Carles+Santos\%2 
$\underline{\mathrm{C}+\text { setenta}+\mathrm{a} \% \mathrm{~F} 1 \mathrm{os}+\% 28 \mathrm{I} \% 29 \& \mathrm{btnG}=\text { Buscar\&site=RTVE\&client=RTVE\&lr=lang_es }}$ $\underline{\text { \&hostfrom }=\text { www.rtve.es\&hl=es\&oe=latin1\&ie=latin1\&getfields }=* \text { \&output }=x m l \_n o \_d t}$

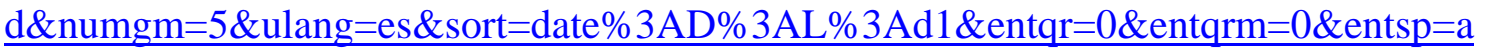
_PL_Fase_0\&wc $=200 \& w c \_m c=1$ (20 de julio de 2015) 
